\title{
In Need of a Better Framework for Success
}

An evaluation of the Norwegian participation in the EU $6^{\text {th }}$ Framework Programme (2003-2006) and the first part of the EU $7^{\text {th }}$ Framework Programme (2007-2008)

Helge Godø, Liv Langfeldt, Aris Kaloudis, et al.
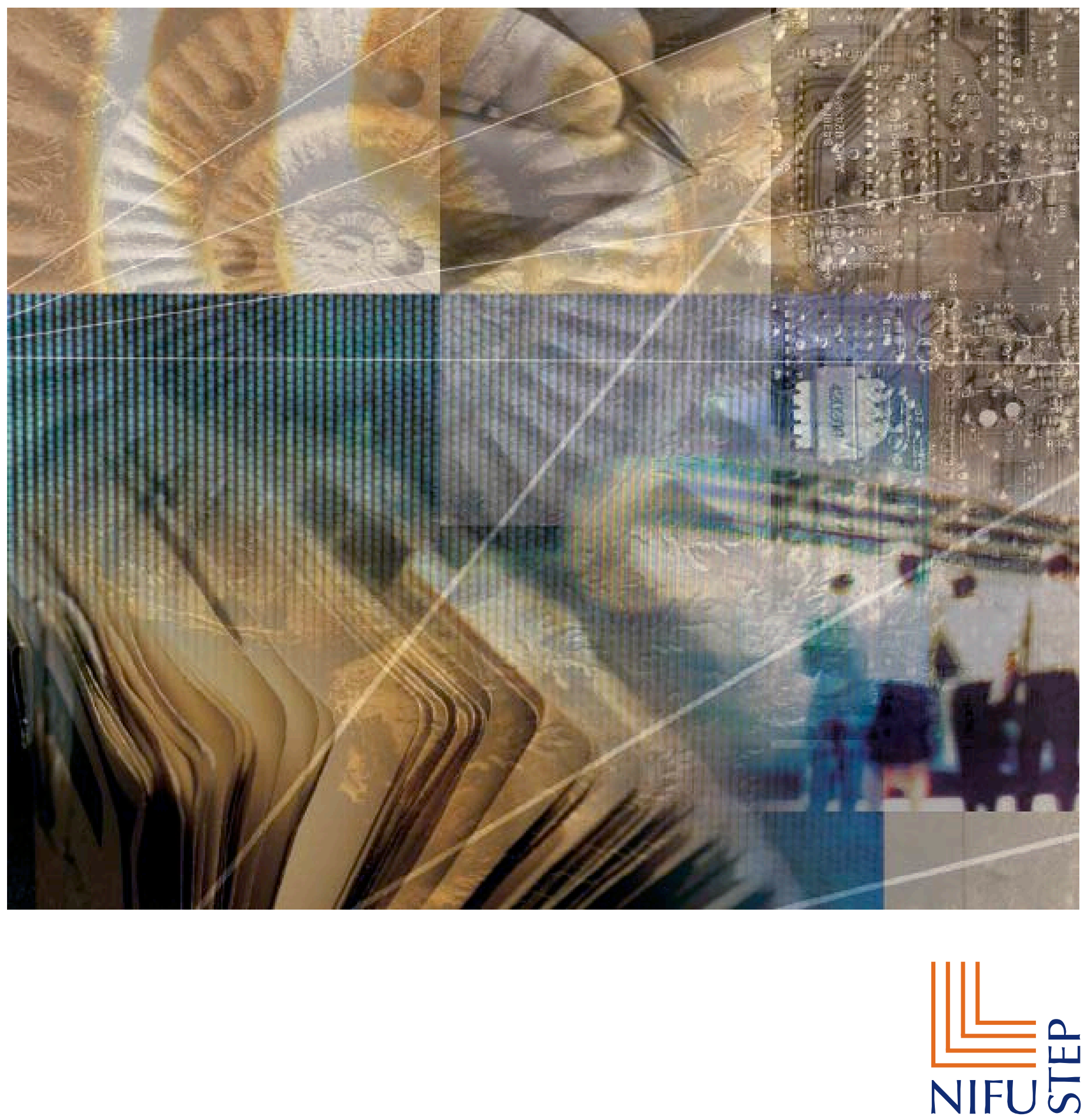
(C) NIFU STEP Norsk institutt for studier av innovasjon, forskning og utdanning Wergelandsveien 7, 0167 Oslo

Rapport 22/2009

ISBN 978-82-7218-629-5

ISSN 1504-1824

The publications of NIFU STEP are available at www.nifustep.no

Norsk institutt for studier av innovasjon, forskning og utdanning Norwegian Institute for Studies in Innovation, Research and Education Wergelandsveien 7, 0167 Oslo

NIFU心 Tlf. +4722595100 • www.nifustep.no 
RAPPORT 22/2009

Helge Godø, Liv Langfeldt, Aris Kaloudis, et al.

\section{In Need of a Better Framework for Success}

An evaluation of the Norwegian participation in the EU $6^{\text {th }}$ Framework Programme (2003-2006) and the first part of the EU $7^{\text {th }}$ Framework Programme (2007-2008)

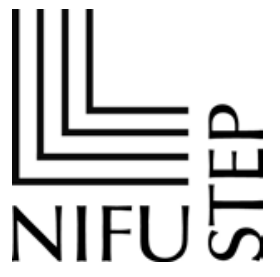





\section{Preface}

This report presents the main findings and recommendations from the evaluation of Norwegian participation in the $6^{\text {th }}$ Framework Programme for research, technological development and demonstration activities of EU (FP6) implemented in the period 20032006, and the first two years of the $7^{\text {th }}$ Framework Programme (2007-2008). The evaluation was undertaken by a team of researchers at NIFU STEP with assistance of three external researchers according to terms of reference in the contract with the Norwegian Ministry of Education and Research. Chapter 1 of this report describes how the evaluation was done. However, the main emphasis in the evaluation is on the following topics:

- Results and effects for the participants and Norwegian society,

- The EU Framework Programme and ERA as policy measure in Norwegian research and innovation policy,

- National policy measures for participation in the EU research.

The work with the evaluation commenced in January 2009, and a final draft of the evaluation report was submitted 13 November 2009. In March 2009, NIFU STEP submitted an interim report to the Ministry of Education and Research of the preliminary findings based on an analysis of the Norwegian participation in the $6^{\text {th }}$ Framework Programme, a bibliometric analysis and an analysis of Norwegian R\&D data on EU funding of Norwegian research. As work with the evaluation progressed, results and various drafts of the evaluation were presented to an advisory group established by the Ministry of Education and Research, chaired by Karen Nossum Bie. The other members of this group were:

- Simen Ensby, Research Council of Norway

- Dag Gustafson and Pål Gretland, Ministry of Trade and Industry

- Gunnar Jordfald, NILU - Norwegian Institute for Air Research

- Tore Li, NHO - Confederation of Norwegian Enterprise

- Mette Lending, Ministry of Education and Research

- $\quad$ Astrid Lægreid, NTNU - Norwegian University of Science and Technology

- Hjørdis Møller Sandborg, Ministry of Health and Care Services

- Sveinung Skule, University College of Oslo

- Erik Yssen, Ministry of Education and Research.

The evaluation was organized as a project in NIFU STEP under the leadership of Aris Kaloudis of NIFU STEP. As usual in teamwork, the final report is based on contributions from many people; however, the core of the evaluation team under Aris Kaloudis' leadership was:

- Helge Godø

- Liv Langfeldt

- Åse Gornitzka 
- $\quad$ Ernst Kristiansen (SINTEF)

- Dag Aksnes

- Hebe Gunnes

- Trond Einar Pedersen

- Tore Sandven

- $\quad$ Stig Slipersæter

- Nils Henrik Solum.

In addition to this team, Dr. Erik Arnold of Technopolis and Professor Irwin Feller of Pennsylvania State University served as advisors and commented on drafts.

Needless to say, an evaluation of this type is not possible without considerable contribution of facts, opinions, insights and data from a large number of sources. Whenever possible and where appropriate, this report pays credit to these sources in the text. We also express thanks to the EU RTD Department in the Research Council of Norway for providing the evaluation with data and analyses that were important. In addition, we express our gratitude to all those who used valuable time to providing data, information and insight in support of this report.

Oslo, December 2009

Per Hetland

Director

Magnus Gulbrandsen

Head of Research 


\section{Contents}

Sammendrag

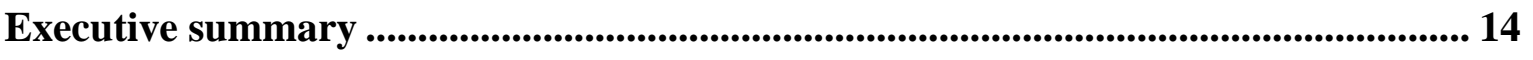

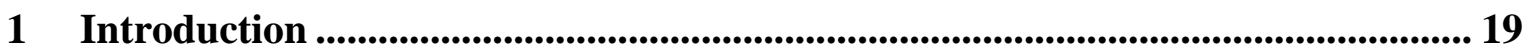

1.1 The main objectives of this evaluation............................................................ 19

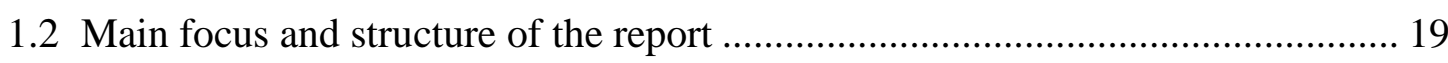

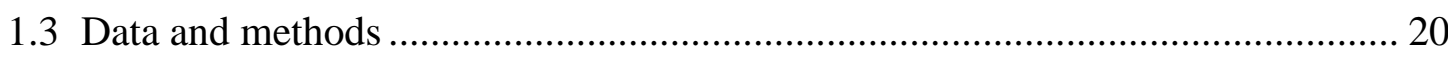

1.3.1 CORDA-data on Norwegian participation.............................................. 21

1.3.2 Surveys of Norwegian participants in FP6 projects and Norwegian participants in FP7 project proposals ................................................... 21

1.3.3 Interviews with key actors in Norway's participation in EU FP6 and FP7 23

1.3.4 Case studies of four thematic areas....................................................... 23

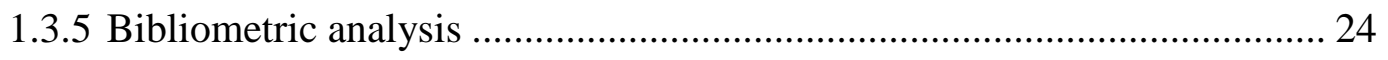

1.3.6 Analysis of Norwegian R\&D statistics ................................................... 24

1.3.7 Analyses of relevant documents on research policy, research strategy and evaluations done in other countries and organisations on EU's FPs .......... 25

2 The Framework Programmes, ERA and the Norwegian strategy......................... 26

2.1 The structure of the Framework Programmes and ERA …................................. 26

2.1.1 ERA and the Lisbon strategy ................................................................. 26

2.1.2 The $6^{\text {th }}$ Framework Programme $(2003-2006)$........................................... 28

2.1.3 The $7^{\text {th }}$ Framework Programme (2007-2013) .......................................... 30

2.2 The overall development of EU research policy ................................................ 32

2.3 Norway's research policy and participation in EU FPs .................................... 36

2.3.1 Norway's research strategy for participation in EU FPs .......................... 38

2.4 Factors influencing Norwegian participation and implications for the

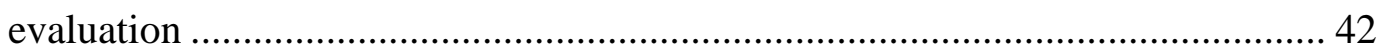

3 Norwegian FP6 and FP7 participation profile................................................... 45

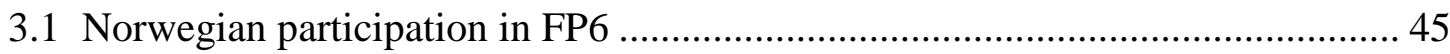

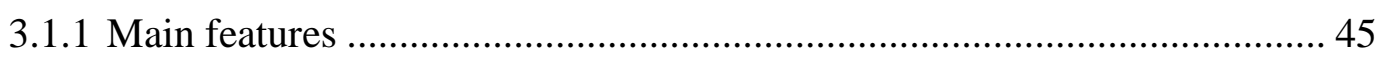

3.1.2 National participation performance in FP6 - comparison with other participating nations ........................................................................... 49

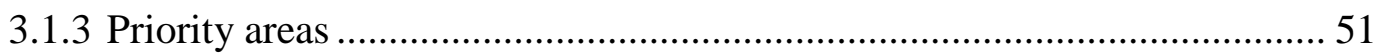

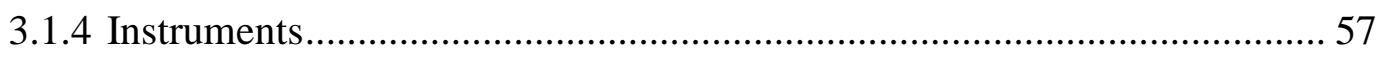

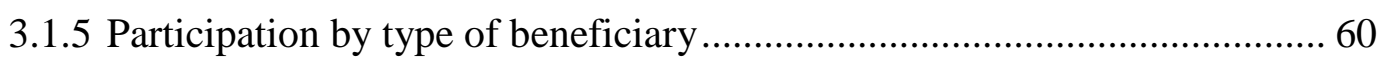

3.1.6 Geographical distribution of participation ................................................ 64

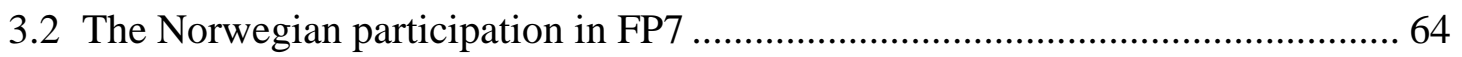

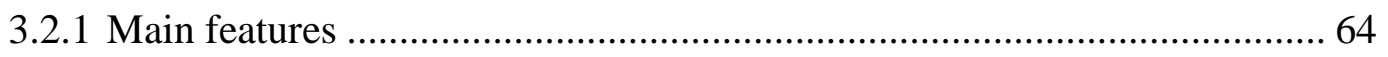

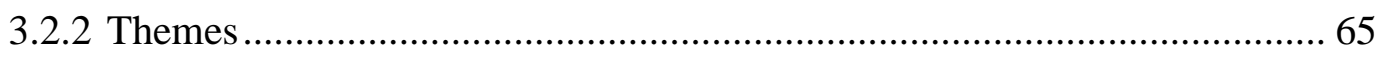




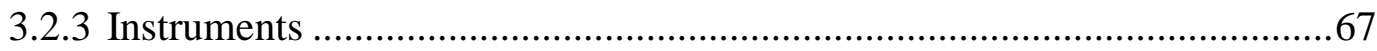

3.2.4 Participation by type of organisation .....................................................68

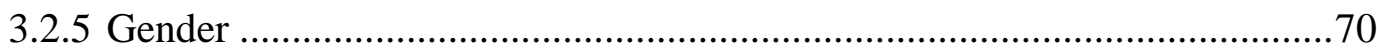

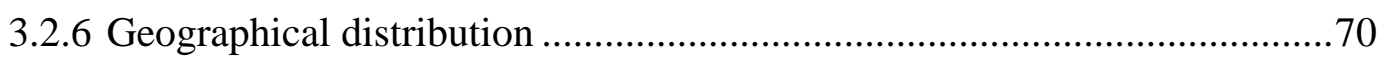

3.3 Comparing Norwegian participation in FP5, FP6 and FP7 …..........................71

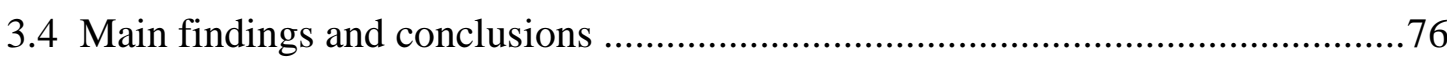

4 Results and impacts for Norwegian participants and society ................................79

4.1 Partners, project responsibilities and involved researchers .................................79

4.2 Project results: costs, strategies, quality and collaboration..................................83

4.2.1 Participants aims, involvement and priorities...........................................86

4.2.2 The qualities of the EU projects ..........................................................94

4.2.3 Proposal costs, obstacles and strengths .................................................96

4.2.4 Benefits for participants: Collaboration and networks .............................104

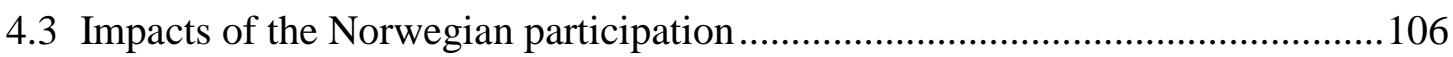

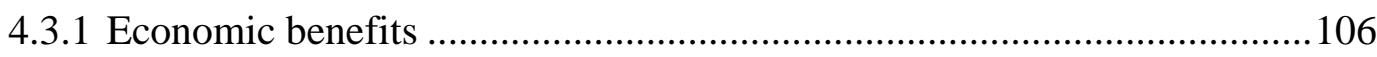

4.3.2 New knowledge and innovation: Expected and achieved project results..107

4.3.3 Long-term effects on knowledge production..........................................108

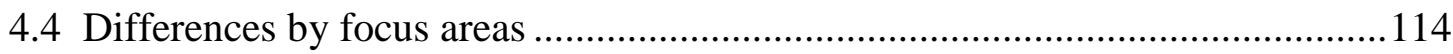

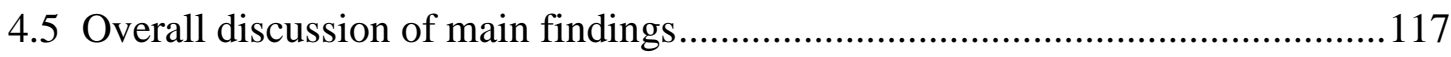

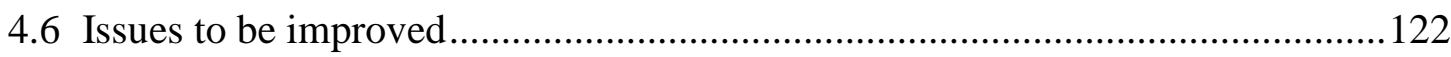

5 The role of the Framework Programmes in the Norwegian research and

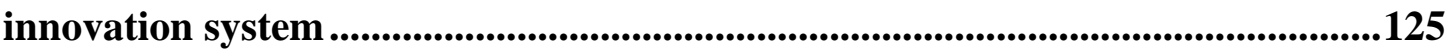

5.1 The significance of the Norwegian participation in the Framework Programmes compared to national research activities .........................................................126

5.1.1 The significance of FPs as a vehicle of internationalisation of the

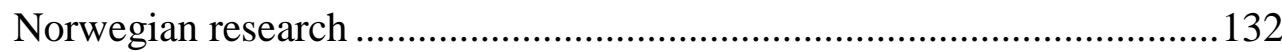

5.1.2 Geographical range of internationalisation activities ..............................135

5.1.3 Norwegian national thematic and technology priorities...........................136

5.1.4 Assessment of the role of FPs in the national research system .................138

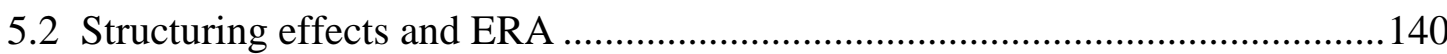

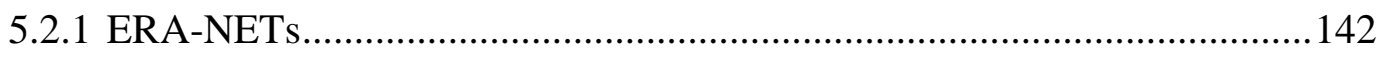

5.2.2 Integrated projects and Network of Excellence......................................143

5.2.3 European research Council (ERC) ........................................................144

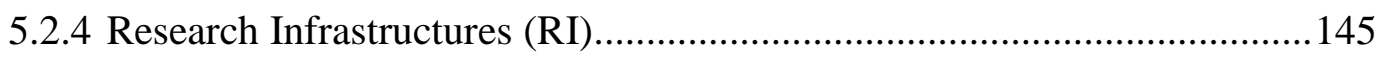

5.2.5 European Technology Platforms (ETP), Joint Technology Initiatives

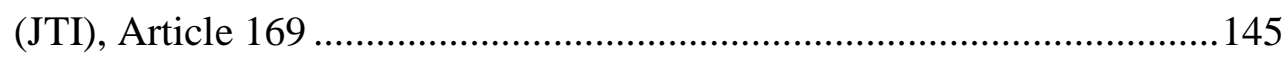

5.2.6 Participation of Small and Medium Enterprises (SMEs) ........................147

5.3 Prospects of Norwegian participation in FP7 and national research

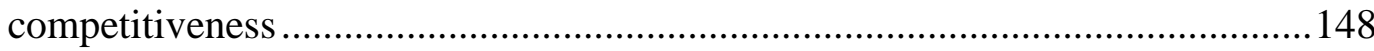

5.3.1 Prospective of Norwegian participation in FP7 .......................................148

5.3.2 Competitiveness of the Norwegian research system in FPs .....................150 
5.4 Strategic aspects of the Norwegian participation in FPs .................................. 153

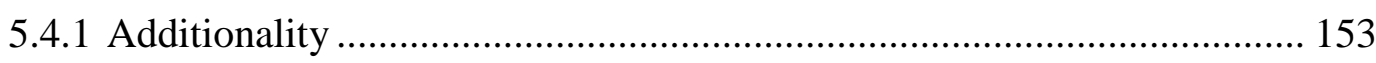

5.4.2 Strengthening national administrative infrastructures ............................ 155

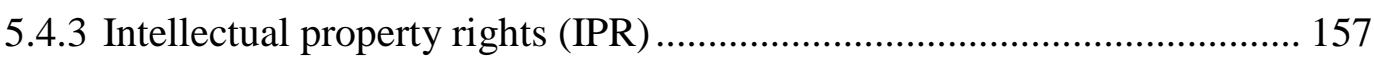

5.4.4 National absorptive capacity .............................................................. 158

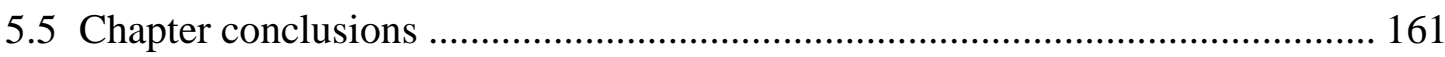

6 In-depth analysis of Norway's participation in four important thematic priorities in EU Cooperation ............................................................................ 164

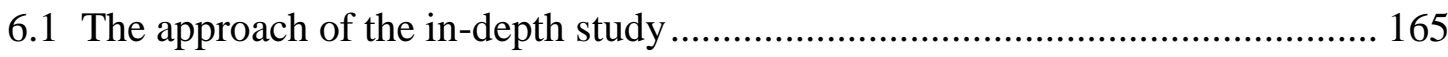

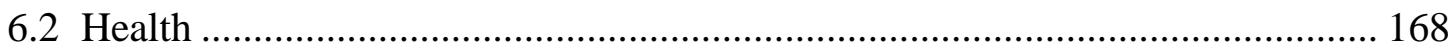

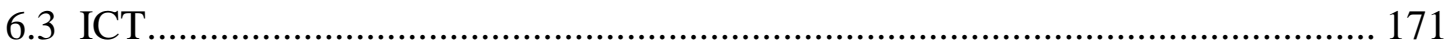

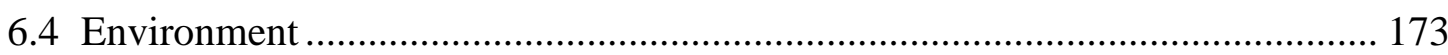

6.5 Nanoscience, nanotechnology and new materials ........................................... 175

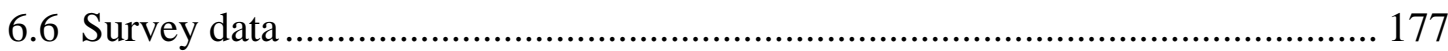

6.7 General observations and discussion ............................................................. 177

7 National policy measures and the governance of EU research ............................. 181

7.1 Analyses of effects of the national system for information and counselling and related economic incentives ......................................................................... 181

7.1.1 The national system for information and counselling............................. 182

7.1.2 Effects of national information and consultation services and financial

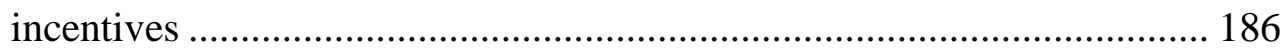

7.1.3 Instruments and incentives for increasing participation .......................... 191

7.2 Norway's influence on EU research priorities and participation in programme

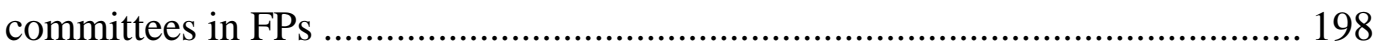

7.3 National governance processes and coordination of Norway's participation in

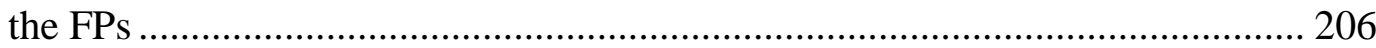

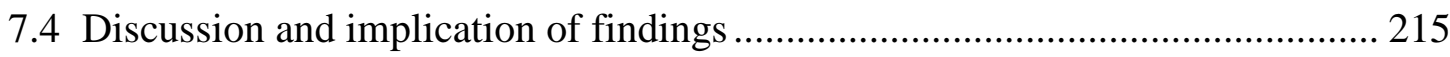

8 Overall assessments of Norwegian participation and future strategies ............. 220

8.1 Norwegian participation and results versus resources spent ............................ 221

8.2 The role of the Framework Programme and the ERA in Norwegian research and innovation policy ................................................................................ 224

8.3 National policy measures and the governance of EU research .......................... 226

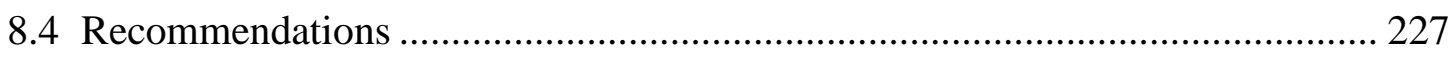

8.5 Looking forward for a better framework......................................................... 231

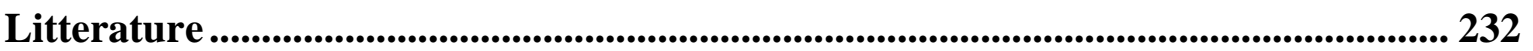

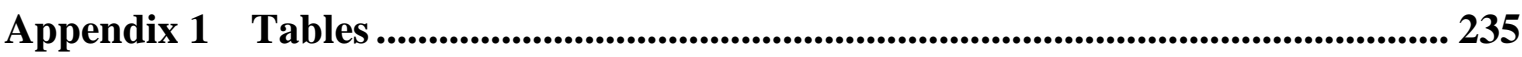

Appendix 2 List of Abbreviations ......................................................................... 245 
Appendix 3 Informants in the evaluation

Appendix 4 Terms of Reference for the evaluation ...............................................2251

Appendix 5 Bibliometric analysis of Norwegian R\&D ...........................................256

Appendix 6 Questionnaires used in the surveys of participants in EU FP6 and 7

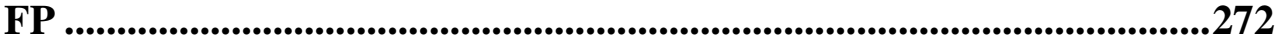




\section{Sammendrag}

Evalueringens hovedanbefaling er at Norge fortsatt bør delta i EUs rammeprogrammer for forskning, teknologisk utvikling og demonstrasjonsaktiviteter. Dette fordi deltakelsen hittil har vært klart vellykket og tegner til å fortsette å gi godt utbytte for norsk forskning. Deltakelsen samsvarer også med målene i norsk forskningspolitikk om internasjonalisering av norsk forskning. Men mye kan gjøres for å forbedre den fremtidige deltakelsen, særlig gjelder dette forhold knyttet til utviklingen av ERA - det europeiske forskningsområdet. Nedenfor utdypes først disse anbefalingene. Deretter oppsummeres evalueringens resultater og konklusjoner.

Denne rapporten fremlegger evalueringen av norsk deltakelse i EUs 6. rammeprogram for forskning, teknologisk utvikling og demonstrasjonsaktiviteter (FP6) og første del av EUs 7. rammeprogram (FP7). Evalueringen er utført som oppdrag for Kunnskapsdepartementet. Hensikten med evalueringen er å tilveiebringe et kunnskapsgrunnlag for de utfordringene som Norge står overfor i deltakelsen i EUs rammeprogrammer, og et grunnlag for politikkog strategiutvikling for denne delen av norsk forskning. Evalueringen bygger på en rekke kilder og har brukt mange forskjellige metoder og tilnærminger mht kartlegging av resultater og virkninger av den norske deltakelsen og virkemidler som er benyttet (jfr kapittel 1). Dette sammendraget bygger i det vesentlige på siste kapittel i denne rapporten, der evalueringens konklusjoner og anbefalinger er fremlagt (kapittel 8).

\section{Anbefalinger}

Internasjonalisering som en helhetlig norsk forskningsstrategi

Norske beslutningstakere og forskningsinstitusjoner bør ha sterkere oppmerksomhet og forpliktelse til internasjonalisering av norsk FoU, særlig gjelder dette EUs rammeprogrammer. I overskuelig fremtid vil EUs rammeprogrammer fortsatt være Norges viktigste brohode for internasjonalisering av norsk FoU. Norske forskningsinstitusjoner og -bedrifter må bli mer systematiske og målrettede mht internasjonalt FoU-samarbeid i sine strategier. Dette gir grunnlag for å anbefale følgende:

- Beslutningstakere i styrer, utvalg og programkomiteer i Norges forskningsråd må prioritere internasjonalt forskningssamarbeid og prosjekter i sine beslutninger og tildelinger. De må tenke hvordan internasjonal forskningssamarbeid kan berike norsk forskning og hvordan norsk forskning skal bli mer konkurransedyktig internasjonalt.

- $\quad$ Det må skapes sterkere og mer direkte koblinger mellom norske representanter i styringssystemet for EU-forskningen og beslutningstakere i det norske forskningssystemet, spesielt innen Norge forskningsråd.

- Departementer som er interessenter i forskningen som foregår i EU bør inngå et tett samarbeid med Norges forskningsråd om utvikling av strategier og forpliktende 
mål for deltakelsen i EU-forskningen, og, på lengre sikt, også deltakelsen i ERAaktivitetene som ventelig vil øke i omfang de nærmeste årene.

- Utviklingen i ERA vil kreve utforming av en norsk strategi for deltakelse og beslutningsmekanismer knyttet til dette. Her har Kunnskapsdepartementet i første omgang et spesielt ansvar.

- Det må utvikles incentiver som oppmuntrer til større norsk deltakelse i de tidlige, formative fasene i utvikling av nye rammeprogram og andre forskningspolitiske initiativ i EU. EU er relativt åpen og påvirkbar på slike stadier, men for å få gjennomslag er det viktig med faglig tyngde og evne til faglig argumentasjon. Dette gjelder deltakelse av fagpersoner med høy kompetanse og reputasjon fra norske forskningsmiljøer. Kunnskapsdepartementet og Norges forskningsråd bør samarbeide om utvikling av konkrete tiltak.

\section{Avhjelpe administrative og økonomiske byrder}

EU-prosjekter er generelt underfinansierte og meget krevende mht administrative forpliktelser; rammeprogrammenes administrasjon, finansielle regler og oppfølging av disse vurderes som ineffektive av forskere. Denne oppfatningen er nærmest unison, dvs. en oppfatning som deles av forskere i alle land som deltar i EU-forskningen - og er en kritikk som har vært fremsatt over lang tid. Dette er klart uholdbart og virker demotiverende for fremtidig deltakelse. En rekke tiltak anbefales for å avbøte disse forholdene:

- Medfinansiering: Norges forskningsråd må finne frem til nye nasjonale finansieringsformer som kompenserer fullt ut for de prosjektkostnadene som ikke dekkes av EU. EU dekker i dag inntil 75 prosent av de samlede prosjektkostnadene. Vanskeligheter med å skaffe medfinansiering utgjør et betydelig hinder for økt deltakelse av især norsk instituttsektor.

- Overheadkostnader for oppdragsprosjekter for EU: Norges forskningsråd må finne frem til nye nasjonale finansieringsformer som dekker de reelle overheadkostnadene i forskningsbaserte oppdrag, Coordination and Support Actions (CSA), som norske institusjoner utfører for EU. EU godtgjør nå bare et overheadpåslag på 7 prosent, noe som gjør denne type oppdrag til tapsprosjekter.

- EUs definisjon og beregning av prosjektkostnader (“eligible costs”) må revideres og samsvare med reelle kostnader for utføring av forskning og utvikling. Norges forskningsråd bør arbeide for dette og ellers utvikle en kompetent rådgivingstjeneste om slike forhold for norske deltakere i EU-forskningen.

- Norges forskningsråd, gjerne i samarbeid med Kunnskapsdepartementet, må ta et initiativ for standardisering av regnskap og revisjonsberetninger knyttet til prosjekter. I dag skaper dette mye forvirring og frustrasjon blant norske deltakere i EU-prosjekter. Når selv store og internasjonalt meget erfarne, anerkjente organisasjoner opplever vanskeligheter med å få godkjent sine prosjektregnskaper av EU er noe galt.

- Kunnskapsdepartementet, som sektoransvarlig for Norges forhold til EU mht deltakelsen i EUs rammeprogrammer, må ta et politisk initiativ for å igangsette 
reformer av rammeprogrammenes administrasjon og finansielle regler, samt oppfølging av disse, fordi dette er en form for byråkrati som i økende grad fremstår som lite effektivt, ressurskrevende og sløsing med forskningstid.

\section{Sikre økt deltakelse av store bedrifter}

Utfordringen for mange store bedrifter som utfører egen FoU er å finne utlysninger i EUforskningen som passer til deres interesser. Her er det behov for bedre informasjonsformidling, men også behov for å trekke dem inn i arbeidet med utvikling av nye programmer. Norges forskningsråd og systemet av NCP'er (National Contact Points) som de forvalter bør intensivere sitt arbeid på dette området. I likhet med andre norske deltakere opplever store norske bedrifter at de administrative byrdene som deltakelse medfører i økende grad virker demotiverende for deres interesser i å delta i EUforskningen.

\section{Bedre betingelser og økt deltakelse av SMBer - bedre spredning av resultater}

Flere små- og mellomstore bedrifter (SMB) bør oppmuntres til å delta i de ordinære forskningsprogrammene i rammeprogrammet, ikke bare i SME-programmen. Også blant SMBene som deltar er det misnøye mht støtte og veiledning i forbindelse med søknadsarbeid og med prosjektadministrasjon. Innovasjon Norge har et primæransvar for å bedre spredning av resultater fra SMBenes deltakelse i EUs rammeprogrammer. Norges forskningsråd bør være en naturlig samarbeidspartner i dette.

\section{Læringsoverføring fra de som lykkes - og fra norske eksperter}

Norges forskningsråd, i sær EU-kontoret, må utvikle et opplæringstilbud - inklusive webbaserte løsninger - som sørger for at ferdigheter og innsikter overføres fra norske deltakere i EU-forskningen som har lykkes, til fremtidige søkere. Ulike økonomiske incentiver, samt styrking av nettverket av EU-rådgivere i UoH-sektoren vil være relevant i denne sammenheng. Det er også naturlig å trekke inn norske eksperter som utfører fagfellevurderinger i regi av EU-kommisjonen. Samtidig er det klart at institusjonene selv har et ansvar for å styrke sitt administrative støtteapparat.

I rapporten er disse anbefalinger og utdypinger av disse nærmere begrunnet og spesifisert.

\section{Resultater og konklusjoner}

Suksessrater: Hittil i FP7 (EUs 7. rammeprogram for forskning, teknologisk utvikling og demonstrasjonsaktiviteter) har Norge oppnådd en suksessrate på 22 prosent, noe som ligger over EU-gjennonsnittet på 16 prosent. Suksessraten er beregnet ut fra antall prosjekter med norsk deltakelse som oppnår støtte fra EU i forhold til total antall søknader med norsk deltakelse. I FP6 var suksessraten 25 prosent, som også var over EU-gjennomsnittet på 18 prosent. Når det gjelder finansiering av norske prosjekter så viser tallene at Norge betaler 
mer til EU enn det som kommer tilbake til norske deltakere i form av prosjektstøtte. Dette “underskuddet” har økt noe fra FP5 til FP6 og ser ut til å øke ytterligere (men svakt) hittil i FP7. Dette kan tolkes som en mulighet til økt norsk deltakelse.

Resultater og måloppnåelse av prosjektene: Det store flertall av forskere som har deltatt i FP6 mener at prosjektene har vært vellykkede, særlig mht utvikling av nettverk. De mener også at prosjektene har vært vellykkede mht gjennomføring, måloppnåelse og som grunnlag for videreføring i nye FoU-prosjekter. 38 prosent av norske bedrifter som deltok sier at de forventer umiddelbar økonomisk gevinst av prosjektene de deltok i; flertallet mener at prosjektene gir dem tilgang til nye kunder og styrker deres konkurranseevne.

Virkninger av prosjektene: De norske deltakerne oppgir omfattende virkninger av deres prosjekter mht FoU-kompetanse og aktiviteter - og betydelige langsiktige virkninger. Dette fordi EU-prosjektene går inn i nye forskningsområder som de mener er viktig for deres fremtidige forsknings- og innovasjonsvirksomhet. En stor andel av prosjektene har hatt positiv effekt mht utvikling av forsknings- og innovasjonsferdigheter og langsiktige samarbeidsrelasjoner. Som følge av dette har de norske deltakerne blitt mer samarbeidsorienterte, internasjonaliserte og i økende grad har deltakelse i store prosjekter som arbeidsform. Dette tyder på at deltakernes måte å utføre forskning på er blitt endret. I tillegg har deltakelsen ført til økt forskningssamarbeid i prosjekter utenom EUs rammeprogrammer. Alt dette tyder på at deltakelsen har ført til høy grad av adferdsaddisjonalitet.

\section{Begrenset synergi med nasjonale forskningsprioriteringer: Deltakelsen i EUs} rammeprogrammer utgjør bare 1,3 prosent av Norges FoU-kostnader. Følgelig kan man ikke forvente at denne lille andelen vil påvirke norsk forskning i nevneverdig grad. Men norsk medfinansiering fører til at denne andelen er større og den binder dessuten opp andre ressurser. Et høyt antall norske forskere deltar i EUs rammeprogrammer, ca. 5.000 forskere bare i FP6. Av disse er 18 prosent doktorgradsstudenter, noe som også gir grunnlag for langsiktige og integrerende virkinger. I tillegg sa 72 prosent av søkerne til FP7 at deres prosjekt var en integrert del av internasjonaliseringsstrategien til deres institusjon. På overordnet og tematisk nivå er det samsvar mellom EUs rammeprogrammer og tematiske prioriteringer i norsk forskningspolitikk, noe som tilsier muligheter for synergi. Det er imidlertid vanskelig å finne slike former for samspill på det forskningsutførende nivået i Norge. Bare i liten grad foregår det koordinering av søknader til EU med norsk deltakelse, med beslutninger om støtte til tilsvarende og komplementære norske prosjekter. Mye tyder på at det er muligheter for en sterkere kobling av norske prioriteringer (og finansiering) med deltakelse i EUs rammeprogrammer - noe som primært gir muligheter for økt gevinst og forsterking av norsk forskning. Dette gjelder især norsk deltakelse i EUs rammeprogrammer innen ICT og Health, men også Ideas og People. 
Rammeprogrammene og ERAs rolle i norsk forsknings- og innovasjonspolitikk: I norsk forskningspolitikk er det uttrykt en klar målsetning om at norsk forskning skal internasjonaliseres og at deltakelse i EUs rammeprogrammer er viktig i denne sammenheng fordi det tjener Norges interesser. Utviklingen av ERA, særlig fremveksten av mange nye tiltak og virkemidler kan få større følger for fremtidig norsk forsknings- og innovasjonspolitikk og bør sees i sammenheng med utviklingen i FP7 og FP8, som ventelig vil etterfølge FP7. I evalueringen ble det klart at det ligger betydelige utfordringer knyttet til overvåkning, analyse og forståelse av utviklingen innen ERA, noe som i første omgang berører norske politikkutviklere og interessenter. Kunnskapsdepartementet må her ta et lederskap mht utvikling av en norsk strategi for deltakelsen i ERA.

Norske tiltak: Norsk deltakelse i EUs forskning omfatter mange organisasjoner og tiltak. For det norske forskersamfunn er det to forhold som er viktige for deres deltakelse og som må forbedres: Bedre rådgiving om hvordan man kan oppnå sammenkobling av nasjonal FoU-støtte i forbindelse med deltakelse i EU-forskningen, og dernest, avhjelpende tiltak som reduserer byrdene knyttet til EUs byråkrati, spesielt mht regelverket for finansiering, regnskapsrevisjon og økonomisk rapportering.

Forvaltning av EU-forskningen: Kunnskapsdepartementets utøvelse av sitt sektoransvar for EU-forskningen kan karakteriseres som indikativ og indirekte, noe som preger styringsdialogen i forvaltningen. Kunnskapsdepartementet har delegert mye av ansvaret for implementering av strategi og forvaltningen av EU-forskningen til Norges forskningsråd. Kunnskapsdepartements overordnede strategi mht EU-forskningen er tydelig og velbegrunnet, men i norsk forskning er det sektorprinsippet som gjelder. I sektordepartementenes forskningspolitikk og -strategi, slik de kommer til uttrykk i de årlige statsbudsjettdokumentene, har EU-forskningen og ERA generelt sett liten, ofte ingen, plass, med unntak av Nærings- og handelsdepartementet, hvor dette får en bred omtale og analyse. 


\section{Executive summary}

The main recommendation from this evaluation is that Norway should continue its participation in the EU Framework Programme for Research, Technological Development and Demonstration Activities (EU FP). So far, the participation has been clearly successful and is likely to continue to do so, for the benefit of Norwegian research. Moreover, the participation serves goals set in Norway's research policy. However, there are a number of issues and measures that should be taken in order to improve future participation in the Framework Programme and the associated development of ERA. These are specified in the recommendations below. Subsequently, main results and conclusions are presented.

This evaluation of Norway's participation in EU $6^{\text {th }}$ Framework Programme (FP6) and first part of EU $7^{\text {th }}$ Framework Programme (FP7) was commissioned by the Norwegian Ministry of Education and Research in order to provide an improved knowledge foundation for meeting the challenges of participating in EU-research and EU research policy. It is based on a multitude of data sources and methods for studying the results and effects of Norwegian participation, as well as the Norwegian policy measures for participation (see Chapter 1). This executive summary provides an overview of the main recommendations and conclusions (Chapter 8).

\section{Recommendations}

Internationalisation as a comprehensive national research strategy

Norwegian research decision makers and research institutions need to have a strong focus and dedication to the importance of internationalisation of $R \& D$, and in particular the Framework Programme. In the foreseeable future this will continue to be Norway's most important internationalisation channel of national R\&D activities. At the institutional level there is also a need to become more systematic and goal-oriented in terms of research strategy and orientation towards international R\&D collaboration. For these reasons, we recommend the following actions:

- Decision makers that serve various boards and committees in the Research Council of Norway must be required to make priorities in terms of international research collaboration and innovation arenas. How to create synergies with national research and how to become more internationally competitive should guide their decisions.

- The relationship between the EU RTD-system, national delegations and research decision makers, in particular decision makers that serve the Research Council of Norway, needs to become more coupled and strengthened.

- Many stakeholder ministries responsible for the sectors relevant for the research done in the EU FPs should work with the Research Council of Norway in developing strategies and goals for participation in EUs FP - and, increasingly, also participation in ERA-related activities. 
- The development of ERA should be given attention in terms of strategy and level of decision making.

- In order to influence and increase our understanding of EU's research system, the Ministry of Education and Research and the Research Council of Norway should develop incentives and encourage experts from the Norwegian research community to participate in activities that are strategic for the planning and formation of EU FPs.

\section{Ease the administrative and economic burdens}

EU projects are not adequately funded and they are very demanding in terms of administration, i.e. the EU RTD system's administrative and financial rules and control of these are considered as inefficient by many of the respondents. This point has been made in almost all evaluations of EU FPs. This situation is clearly unsustainable and may discourage future participation. A number of specific actions related to these points should be taken:

- National co-funding: Because EU funding schemes for research projects cover as a maximum 75 per cent of the total cost, there is a need for better mechanisms for national co-funding. This is a major barrier for especially research organisations, for expanding their EU funded research activities. The Research Council of Norway should explore in an innovative manner possible ways of improving national co-funding.

- The maximum threshold of 7 per cent of actual personnel costs in claiming overhead expenses for Coordination and Support Actions (CSAs) represent for the majority of Norwegian participants a clear obstacle to participate in these types of projects. The Research Council of Norway should explore in an innovative manner possible ways of improving funding of CSAs.

- The definition and computation of "eligible costs" needs to be revised and harmonised with real costs of doing R\&D. In this, RCN should provide assistance and advice.

- Audits of costs statements is a major source of confusion among the Norwegian participants. When the largest and most experienced Norwegian research organisation reports difficulties in getting the ECs financial services to accept its financial statements it is clear that there is a need for radical reforms. The RCN should develop a plan and strategy for this, in cooperation with other national research funding agencies. This matter is also urgent.

- Norway should take initiatives for a reform of EU FP administrative and financial rules and control, which is increasingly recognized as inefficient and a drain on resources and human talent. 


\section{Ensure increased participation of the large enterprises}

The major challenge for many of the large enterprises is to find Framework Programme calls that match their research interests. Ways should be found to improve communication opportunities to the large enterprises, as well as better promoting their interests when calls are formulated. This is a task for the NCPs of the Research Council of Norway. In addition, private firms doing R\&D are also discouraged by the bureaucracy of EU FPs.

\section{Improving conditions and participation of SMEs - improve dissemination of results}

More SMEs should be encouraged to apply for participation in the ordinary programmes in the FP, not just the SME programme. Many are still not satisfied with the external support for applications and administration of projects, and demand more efficient assistance. Improving working conditions for SMEs in this context is primarily a responsibility of Innovation Norway ${ }^{1}$. Innovation Norway should in particular improve its system for utilisation of results from the SME participations.

\section{Transferring the skills of successful participation and experts}

A system of learning and skills development should be instituted in order to transfer knowledge and skills from successful applicants to future applicants. Economic incentives, as well as strengthening the network of EU advisers in the higher education sector are relevant measures for skill transferring. Moreover, the insight of expert reviewers who work for the EU DG RTD in doing ex-ante assessments of research proposals to FPs should be used as advisors for the Norwegian research community. To reduce the time and costs of participating in RCN seminars and courses, web-based participation and tutorials should be developed and offered. This should be a responsibility of the EU RTD Department of the Research Council of Norway. The research performing institutions themselves are still responsible for strengthening their administrative support.

\section{Results and conclusions}

Rate of success. So far in FP7, the Norwegian rate of success is approximately 22 per cent of the applications, which is above the EU average of 16 per cent. In FP6, the rate of success was 25 per cent, which also was above the EU average of 18 per cent. In terms of funds, the Norwegian rate of success is less impressive and Norway pays more for the FPs than is returned to Norwegian participants (in pure financial terms). The implication of these hard figures is that there is a potential for increased participation in the EU FP.

Project success and impacts. The large majority of the Norwegian participants characterise their FP6 projects as successful and particularly in terms of network building. The projects are also regarded as successful in terms of research performance, achieving project

1 Innovation Norway is an agency under the Ministry of Trade and Industry, whereas the Research Council of Norway is an agency under the Ministry of Education and Research. 
objectives, and as basis for acquiring and participating in new R\&D projects. Thirty-eight per cent of the participating Norwegian enterprises expect direct economic benefits from their project, and a large part of the enterprises indicate that the project represents a gateway to new customers and will strengthen their position vis-à-vis competitors.

Project impacts. The FP6 participants report extensive impact of their projects on their R\&D capabilities and activities, and significant long-term effects are found. The EU projects explore new research areas of significant importance for the participants' future research/innovation activities. A substantial proportion of the projects have had positive effects on research and innovation capabilities, and long-term cooperation links. The FP6 participants' research activities are becoming more collaborative, international and organised in larger projects. This is an indication that the participating organisations' way of doing research has changed. Moreover, Norwegian researchers participate in more European collaboration also outside the FPs. In other words, the behavioural additionality of participation in the Framework Programme is high.

Limited synergies with national priorities. Accounting for only1.3 per cent of Norway's total R\&D expenditure, the Framework Programme would not normally be expected to have large impact on Norwegian research. However, national and institutional co-funding of the Framework Programme co-opts substantially more research resources than the EU contribution to the FP projects. At the overall policy level there is a good match between the Framework Programme priorities and Norwegian research priorities, and apparently a good basis for synergies. It is however, hard to discover these synergies at the researchperforming level. The larger part of both FP6 participations as well as FP7 applications are not closely related to nationally financed research, and the data indicate limited coordination with national priorities and funding. The data suggest a potential for increasing the alignment of national research with participation in the Framework Programme, in particular within the thematic priorities of Health and ICT, and also Ideas and People. There are indications of substantial synergies and integration of Norwegian research with the Framework Programme: a high number of Norwegian researchers are involved in the Framework Programmes (the FP6 survey alone, accounting for 42 per cent of the Norwegian participations, report 2499 involved researchers). About 18 per cent are $\mathrm{PhD}$ students indicating potential for long-term synergies and integration. Moreover, 72 per cent of FP7 applicants report that the project was an integrated part of their organisation's internationalisation strategy.

The role of the Framework Programme and ERA in Norwegian research and innovation policy. Norwegian research policy and priorities are clearly stated: internationalisation and - as an extension of this - participation in EU FPs is important because this is perceived as beneficial for Norway. The development of ERA, in particular the emergence of numerous initiatives and new instruments, may have a more profound and far-reaching structuring effect on Norwegian research and innovation policy in the future than the development of 
FP7 or the anticipated FP8. In the evaluation, it became clear that an important challenge related to ERA is to observe, understand and "translate" the dynamics and direction of this development to Norwegian policy-makers and stakeholders. The Ministry of Education and Research should take a strong initiative and leadership in developing a national strategy for Norway's participation in ERA.

National policy measures. Norway's participation in EU research involves a number of organisations and measures. For the Norwegian research community, two issues are critical for their participation and for this reason need to be improved: better advice on how to combine national R\&D funding with FP activities, and more assistance with financial rules and regulations, audits and financial reporting.

The governance of EU research. The role of the Ministry of Education and Research (MER) in coordinating Norway's participation in Framework Programme is generally loose and indirect. MER has delegated and assigned much of the responsibility for coordinating Norway's research strategy on participation in the Framework Programme to the Research Council of Norway. The strategy of the MER on this point is clear and has a sound logic, being based on the principle of sector responsibility in Norwegian research policy. However, in the research policy and strategy of "sector" ministries, participation in the Framework Programme and ERA is generally given little attention with the exception of the Ministry for Trade and Industry. 


\section{Introduction}

\subsection{The main objectives of this evaluation}

This evaluation was commissioned by the Norwegian Ministry of Education and Research in order to provide an improved basis for meeting the challenges of participating in EUresearch and EU research policy. The general purpose of the evaluation is an improved knowledge base for Norwegian research and innovation policy, and knowledge about the internationalisation of Norwegian research. The Framework Programme (FP) is the largest international research cooperation initiative in which Norway participates, and accounts for 80 per cent of Norwegian public expenditures on participation in international research. Knowledge about the Framework Programme is consequently important for Norwegian research policy.

More specifically the evaluation is intended to give input to the Ministry of Education and Research's EU Research Strategy for the period 2010-2013 (the last part of the $7^{\text {th }}$ Framework Programme), as well as to the EU research policy and strategy of other Ministries, the Research Council of Norway, and to the research performing institutions. It is also intended to form part of the basis for a more active Norwegian policy for the participation in the European Research Area (ERA), and for Norwegian participation and priorities concerning a future $8^{\text {th }}$ Framework Programme. An interim report was delivered February 2009 to provide input to the 2009 White Paper on Norwegian research policy (St.meld.nr. 30 2008-2009).

The Terms of Reference for the evaluation (“oppdragsspesifikasjon”) ask for independent analyses of the Norwegian participation in the EU Framework Programmes 2002-2008 regarding:

1. the results and effects of the Norwegian participation

2. the Framework Programme and ERA as instruments in Norwegian research and innovation policy

3. the national policy measures for participation in the EU-research

They also stipulate that as far as possible, the findings should be related to prior evaluations of Norwegian participation in the Framework Programmes, and to analysis of other countries' participation in the Framework Programmes. The full text of the Terms of reference is found in Appendix 4.

\subsection{Main focus and structure of the report}

How should Norway organise and support its participation in the Framework Programme in order to better achieve the objectives in Norwegian research and innovation policy? This 
is the main challenge for Norwegian EU research policy and the main question considered in this evaluation. In order to address this challenge, the focus of the evaluation is on:

1. The scope and results of the Norwegian participation in the EU-research compared to the overall ambitions and priorities in Norwegian research policy,

2. The use and impact of Norwegian resources spent on the Framework Programme and ERA activities compared to other Norwegian public research expenditures, and

3. The efficiency of the national policy measures for participation in the EU research and how they may be improved.

A multitude of data sources and methods have been used in the evaluation. These are presented in Section 1.3 of this chapter. As a backdrop to the evaluation, Chapter 2 provides a short introduction to the Framework Programmes and EU research policy developments. Chapter 3 provides key information on Norwegian participation in the $6^{\text {th }}$ and $7^{\text {th }}$ Framework Programme, including comparisons between the programmes and with other countries. Results and impacts of the Norwegian participation are analysed in Chapter 4. Chapter 5 analyses the role of the Framework Programme in Norwegian research and innovation policy. Chapter 6 provides an analysis of Norway's FP participation in four important thematic priorities. Chapter 7 addresses the national policy measures and the management of EU research. Finally, Chapter 8 provides overall assessments and recommendations for future strategies.

\subsection{Data and methods}

This research based evaluation combines quantitative and qualitative analyses to provide a solid basis for studying the results and effects of Norwegian participation, as well as Norwegian policy measures for the participation. The plan for data collection and analyses was in accordance with the terms of reference for the evaluation. The sources of data and methods used for analyses were mainly:

- CORDA-data on Norwegian participation (see 1.3.1),

- Surveys of the Norwegian participants in FP6 projects and Norwegian participants in FP7 project proposals,

- Interviews with key actors in Norway's participation in FP6 and FP7,

- Case studies of four thematic areas,

- Bibliometric analyses,

- Analyses of Norwegian R\&D statistics,

- Analyses of relevant documents on research policy, research strategy and evaluations undertaken in other countries and organisations on EU FPs.

There is now an abundance of data on EU Framework Programmes. Compared to earlier FPs, a number of databases provide more detailed information on the projects, such as who participates, budgets, project plans, deliveries, goals, and so forth. Much of this 
information is accessible on the Internet. In addition, national research agencies, such as the Research Council of Norway, publish excellent overviews and analyses in annual reports, strategy documents, and others on the national participation and performance in EU FPs. Some of this information is presented in the evaluation. However, the main focus in terms of data collection has been to elicit insights and undertake analyses that have not been provided by others in terms of topics relevant for Norway's research strategy and policy. In particular, the evaluation has focused on obtaining attitudes, reflections and insights from a broad range of stakeholders in Norway. The particulars of this approach are explained below.

\subsubsection{CORDA-data on Norwegian participation}

The Research Council of Norway has provided the evaluation team with data on the Norwegian participation in EU FPs extracted from the EU data base CORDA. The FP6 data cover all Norwegian participation recorded at the end of 2008. The data on the Norwegian participation in FP7 were generated in April 2009. This data set also includes information on all Norwegian proposals to FP7 which had been evaluated, and the outcomes of these as of April 2009. In the data sets, the participations are classified into organisation types (sectors) as shown in Table 1.1. Although comprising a small set of participants, the university hospitals have been classified as a separate organisation type. The analyses of these data are presented in Chapter 3 of this report.

Table 1.1 Definitions of the organisation types (acronyms) for participation used in the evaluation

\begin{tabular}{|l|l|l|}
\hline $\begin{array}{l}\text { Organisation } \\
\text { type FP6 }\end{array}$ & $\begin{array}{l}\text { Organisation } \\
\text { type FP7 }\end{array}$ & Explanation \\
\hline HES & HES & Higher or secondary education, i.e. Universities and colleges \\
\hline REC & REC & $\begin{array}{l}\text { Research Centres, only including organisations with research as } \\
\text { their primary focus }\end{array}$ \\
\hline IND & PRC & Private for profit (excluding education) \\
\hline & PUB & Public body (excluding research and education) \\
\hline OTH & OTH & Other, including PUB in FP6 \\
\hline HOS & HOS & $\begin{array}{l}\text { University Hospitals, originally either HES, PUB or OTH, not } \\
\text { defined in CORDA }\end{array}$ \\
\hline
\end{tabular}

\subsubsection{Surveys of Norwegian participants in FP6 projects and Norwegian participants in FP7 project proposals}

The major data sources for studying the Norwegian experiences with - and results of - the EU Framework Programme, are surveys of the Norwegian participants. In order to obtain comparable data and data for time series analysis, the present evaluation used several questions posed in surveys of previous evaluations of the Norwegian participation in $4^{\text {th }}$ and $5^{\text {th }}$ Framework Programmes. However, in order to address new issues in FP6 and FP7, and new issues specified in the Terms of Reference, additional questions were introduced. 
These are particularly concerned with the characteristics of the EU projects compared to participants' other R\&D projects (scientific quality, importance etc), the funding of participants' related research, communication within the project, and the impact on other research activities of the participating organisations.

\section{Data and response rates}

As part of the evaluation, two separate web-based Internet surveys were carried out. In the first, the questionnaire was sent to all Norwegian participants in FP6 projects; in the second, a different questionnaire was sent all Norwegian participants who were involved in FP7 project proposals. The data consequently cover only successful applicants to FP6, but both successful and unsuccessful applicants to FP7.

The web-based questionnaires were sent to all Norwegian participants/applicants where we were able to obtain an e-mail address. (More precisely one questionnaire per “participation”, i.e. to each institution/organisation/firm participating in the project/proposal.)

The FP6 questionnaire was sent to 1246 participations. Of these 36 generated an error message (incorrect address) or where the addressee replied that he/she had no knowledge of or involvement in the project. Of the remaining 1210 participations, 522 completed the survey (43 per cent). Several more completed parts of the survey and the response rates for the different questions varied from 43 to 50 per cent (Table 1.2). ${ }^{2}$

\section{Table 1.2 FP6 participant survey, response rates}

\begin{tabular}{lrr}
\hline Sample & N & $\begin{array}{r}\text { Response } \\
\text { rate (\%) }\end{array}$ \\
\hline Population: Registered Norwegian participations in FP6 projects & 1285 \\
Requested sample: Participations with e-mail address & 1246 \\
Obtainable sample: Presumably informed participations with correct e-mail & \\
address (no automatic rejection notes or messages of no knowledge of the project) & 1210 \\
\hline Obtained incomplete sample: Participations accessing the survey & 610 & 50,4 \\
Obtained complete sample: Participations completing the survey & 522 & $\mathbf{4 3 , 1}$ \\
\hline Note: There are differences in response rates between the different groups of participants and FP6 programmes (tables in \\
Appendix 1:Table A 1; Table A 2).
\end{tabular}

The FP7 questionnaire was sent to 2261 Norwegian applicants. Of these, 244 generated an error message (incorrect address) or where the addressee replied that he/she had no knowledge of or involvement in the project. Of the remaining 2017 applicants, 919 completed the survey (46 per cent). Several more completed parts of the survey and the response rates for the different questions varied from 46 to 56 per cent (Table 1.3).

2 Persons registered as responsible for several participations received one questionnaire for each participation, but they often chose to reply only to one of them. Hence, one may assume that the response rate calculated as a percentage of the net amount of different participants, would be higher. This interpretation also applies for the FP7 survey. 


\begin{tabular}{lrr}
\hline Sample & N & $\begin{array}{r}\text { Response } \\
\text { rate (\%) }\end{array}$ \\
\hline Population: Registered Norwegian participations in FP7 proposals & 2282 \\
Requested sample: Applicants with e-mail address & 2261 \\
Obtainable sample: Presumably informed applicants with correct e-mail address & \\
(no automatic rejection notes or messages of no knowledge of the proposal) & 2017 \\
\hline Obtained incomplete sample: Applicants accessing the survey & 1134 & 56,2 \\
Obtained complete sample: Applicants completing the survey & 919 & $\mathbf{4 5 , 6}$ \\
\hline Note: There are differences in response rates between the different groups of applicants and FP7 programmes (tables in \\
Appendix 1: Table A 3; Table A 4; Table A 5).
\end{tabular}

In both the FP6 and the FP7 surveys, the response rate varied between different groups of participants (cf. Appendix 1, Tables A1-A5). There was a sufficient number of responses in all major categories to analyse differences between the groups. For instance, the response rate of successful applicants was somewhat higher than the response rate of unsuccessful applicants (FP7), but as the number of unsuccessful applicants was high, we have a good data set also for unsuccessful applicants (Table A 3). The response rate also varied between the FP6 and FP7 priority areas (Table A 2, Table A 5). Moreover, both for FP6 and FP7 the response rate for enterprises is somewhat lower than for higher education institutions and research institutes (Table A 1, Table A 4). The presentation in Chapter 4 is largely based on data obtained from these surveys. Copies of the questionnaires used in the surveys are given in Appendix 6.

\subsubsection{Interviews with key actors in Norway's participation in EU FP6 and FP7}

In the evaluation, as input to the analyses on Norway's participation in EU FP in terms of its national research strategy and policy, 49 key actors relevant for these issues were interviewed. Appendix 3 in this report includes a list of the persons interviewed. The interviews were undertaken using a semi-structured interview guide, adjusted for each category of informants according to their field of expertise and role in the Norwegian R\&D community, and their institutions and organisations. In particular, the information and insights from these interviews has provided the evaluation with inputs for the analyses presented in Chapter 6 and 7 of this report. The information and data obtained in the interviews were used in the thematic case studies that are presented in Chapter 6.

In addition to the interviews, the evaluation team participated in a number of meetings with key Norwegian actors engaged with EU research (Appendix 3).

\subsubsection{Case studies of four thematic areas}

In accordance with the terms of reference for the evaluation, in-depth analyses were undertaken on four thematic areas in EU FP6 and FP7 on Norway's participation in the thematic priorities: 
- Health,

- ICT,

- Environment,

- Nanoscience, nanotechnology and new materials.

The purpose of these analyses was to obtain a better understanding of the diversity and rationale of Norway's pattern of participation and performance in various thematic priorities in EU FPs, and simultaneously to analyse this within the framework and goals of Norwegian research policy and strategy. The latter provided the evaluation with a starting point, i.e. Norway's research policy and strategy, in general - and in terms of internationalisation and the rationale for participating in EU FPs. Based on this, the evaluation analysed national research programmes ("Large-scale Programmes”) which have been established specifically to boost research which has received high priority in the national policy; more specifically, research that is complementary to Norway's participation in the abovementioned four thematic priorities in EU FP. In the evaluation, the focus is on how these national priorities are related to participation in EU FPs, and the governance and management of these national priorities. Many of the interviews (cf. Section 1.3.3 above) served as input to these case studies. The findings of the case studies are presented in Chapter 6. Moreover, Section 4.4 summarises survey results for the four focus areas.

\subsubsection{Bibliometric analysis}

As part of the evaluation, a bibliometric study was undertaken in order to analyse whether Norway's participation in EU FPs has had an impact on Norwegian R\&D, and to what extent. The study analysed the 20-year period 1988-2007, with a main focus is on the most recent five year period 2003-2007, which is the most relevant period for the evaluation of the participation in EU FP6 and FP7. The 20 year period analysed also covers years prior to the first Norwegian participation in the Framework Programme in 1994 (1988-1993). In this way we were able to assess the situation before Norwegian researchers prior to their participation in the Framework Programme. Major findings from the bibliometric analysis are presented in Section 4.4.3; more detailed information is found in Appendix 5.

\subsubsection{Analysis of Norwegian R\&D statistics}

In order to analyse and assess the role of EU FPs as an instrument in Norwegian research and innovation, the evaluation team has analysed data from Norwegian R\&D statistics. These analyses are presented in Chapter 5.1 of this report, but also elsewhere. Norwegian $\mathrm{R} \& \mathrm{D}$ statistics are compiled in accordance with international guidelines proposed by the OECD in the "Frascati Manual" (OECD 2002). R\&D statistics for Norway are based on administrative databases and questionnaires sent to the R\&D performing units in each sector. In Norwegian R\&D statistics, resources are classified in three performing sectors: the Industrial sector, the Higher Education sector, and the Institute sector. The OECD 
Higher Education sector corresponds to the Norwegian definition. The OECD's Business Enterprise sector includes the Industrial sector as well as non-profit research institutes serving enterprises. In Norwegian statistics, these business-oriented research institutes are included in the Institute sector which also covers the Government sector and Private NonProfit sector (PNP). The PNP sector is rather small in Norway, and is therefore merged with the Government sector in international statistics.

\subsubsection{Analyses of relevant documents on research policy, research strategy and evaluations done in other countries and organisations on EU's FPs}

In the evaluation, various documents and literature were used as sources of information and assessment. Needless to say, official Norwegian and EU documents on research policy played an important role for the analyses presented in the evaluation, in particular for Chapters 5 and 6, but they have also been used as a framework for the recommendations that are presented by the evaluation. In addition, we have studied a number of evaluations and strategic analyses made by various national agencies and by the EU on FP6. Regarding Norway, documents from the Ministry of Education and Research and the Research Council of Norway on Norway's participation in EU FPs have played an important role in the evaluation. References to these sources are given in the text. The literature list at the end of the report provides details on the sources. 


\section{The Framework Programmes, ERA and the Norwegian strategy}

As a background for analysing Norwegian participation in EU research, this chapter outlines the structure and main elements of the two most recent Framework Programmes and the European Research Area (ERA), and the Norwegian policy for participating in EU research. Emphasis is placed on recent changes and issues that provide an important framework for Norway’s present and future participation in international research.

\subsection{The structure of the Framework Programmes and ERA}

Following the 1984 decision to establish the Framework Programme (FP), this has been the centrepiece of EU policy and involvement in $R \& D$. The overall objective of the Framework Programmes as stated in the Treaty is to strengthen "the scientific and technological bases of Community industry and encouraging it to become more competitive at international level” (Treaty of European Union, Article 163, European Union 2006). Since the commencement of the first FP, the programme has gradually evolved to encompass a range of different instruments and a considerable widening of the scope of research areas, and in this process new goals have been added. When the decision to work towards establishing the European Research Area (ERA) was made in 2000, it was decided to incorporate the FP as an instrument into this wider European ambition. Needless to say, this implied changes within and outside the FPs. This section outlines the structure and main elements of the two last FPs, i.e. FP6 and FP7, as well as the European Research Area (ERA), and place these within the research policy context that has undergone considerable changes in the first decade of the present century.

\subsubsection{ERA and the Lisbon strategy}

The European Research Area (ERA) was initiated in 2000 to meet challenges in European research, and since has been a central concept and mission in European research policy. The major aims of ERA include an "internal market" in research with free movement of knowledge, researchers and technology, increasing cooperation, stimulating competition, and achieving a better allocation of resources, improved coordination of national research activities and policies, and the development of a European research policy "which not only addresses the funding of research activities, but also takes account of all relevant aspects of other EU and national policies”. ${ }^{3}$

The turn of the century implied a change in the political ambitions of the EU in the area of research and innovation policy. The Commission’s communication, “Towards a European

3 Cf.: http://cordis.europa.eu/era/concept_en.html 
Research Area” from January $2000^{4}$, was a landmark in this respect. The European Research Area (ERA) communication argued that Europe lagged behind the USA and Japan in industrial competitiveness and the ability to make social and economic use of research. It was presented as an initiative to address the problem of fragmentation in European research efforts: "This fragmentation, isolation and compartmentalisation of national research efforts and systems and the disparity of regulatory and administrative systems only serve to compound the impact of lower global investment in knowledge” 5 . The communication called for overall investment in R\&D, and efforts to increase networking and the building of critical mass in European R\&D, as well as increased mobility of researchers within the ERA. The problem of fragmentation was also identified in Europe's research policy landscape, i.e. the ' $15+1$ '-problem. This fragmented landscape thus consisted of 15 uncoordinated research policies of the member states with the European research policy added to it. This was the argument both for coordination between member states and between the European research policy and national governments. The general concept of the ERA was endorsed by the European Parliament and Council in 2001, and was incorporated into the text of the Lisbon treaty enhancing it as an official and long-term declaration of EU involvement in research and development.

In March 2000, only two months after the ERA communication, the EU heads of state and government met in Lisbon and formulated a strategy whereby Europe could become "the most competitive knowledge-based economy in the world, capable of sustained economic growth with more and better jobs and greater social cohesion”. This placed the triangle of research, education and innovation at the heart of the competitiveness agenda for the EU, linking "knowledge policies" to macro-economic, competition, regional policy, etc., of the EU. It is, however, debatable how central the ERA was to the overall Lisbon process in practice. Larédo (2008), for instance, argues that the concept of ERA was by and large absent as a self-standing objective in the first seven years of the Lisbon strategy.

The ERA concept and the Lisbon process were core elements in framing the reform of the FP (see below). The ERA concept did not stop at reforming the FP as the main instrument; it went beyond what the FP could be used to accomplish. The Lisbon Conclusions specifically encouraged the development of a process based on the Open Method of Coordination (OMC) ${ }^{6}$ for R\&D policies. By so doing, the idea of policy coordination reappeared as an ambition of European research policy (Kaiser and Prange 2004). First, it addressed the issue of the funding base of R\&D in Europe. The Commission's ERA Communication harboured ambitions to fill the gap in research investments in Europe, an area where the EU, of course, had little impact but would rely on the efforts at the national

4 Commission 2000 COM(2006)6 final, Brussels, 18.1.2000.

5 Commission 2000 COM(2006)6 final, Brussels, 18.1.2000, page 7.

6 OMC refers to a process that involves securing agreement in respect of joint policy objectives through agreed declarations and commitments and through institutionalising stocktaking mechanisms which monitor and benchmark achievements and report on best practice. 
level and on private investments in R\&D. An investment target set at three per cent of GDP was agreed by the Council two years later (the "Barcelona target") where the main instrument for working towards this target was the use of the OMC. Several of the other ERA issues also became subject to OMC-type processes such as that which culminated in the Commission's Recommendation on the European Charter for Researchers and a Code of Conduct for the Recruitment of Researchers. ${ }^{7}$

The implementation of the Lisbon strategy became a challenge also in the area of research and development, and the mid-term review of the strategy in 2004, the so-called Kokreport was highly critical of its achievements and of the effectiveness of its governance structure. In the revised Lisbon strategy the aim was to streamline and simplify the process and to achieve better horizontal and vertical coordination. The Lisbon Growth and Jobs strategy focused on two headline targets: total (public and private) investment of 3 per cent of Europe's GDP in research and development, and an employment rate of 70 per cent (the proportion of Europe's working-age population in employment). With the 2005 reform, the implementation of the strategy centred on Member States producing reports on the implementation of their National Reform Programmes. All Member States should appoint Lisbon Co-ordinators ("Mr or Mrs Lisbon”) charged with driving the strategy forward in their own Member State and involving stakeholders in its implementation. Research and development remained a core item in the Lisbon agenda, also after its relaunch. Notwithstanding, the disappointment of the first half of the Lisbon strategy, the Lisbon agenda had been instrumental in bringing about a small but significant shift in the overall budgetary priorities of the EU (see below). The EU financial perspectives for the period 2007-2013 proposed by the European Commission contained an increase in the role of knowledge and innovation in the EU budget. A broad range of funding tools were to be mobilised to help realise the knowledge economy.

\subsubsection{The $6^{\text {th }}$ Framework Programme (2003-2006)}

The FP6 became the first such programme to be developed within the framework of the ERA idea and the Lisbon strategy. It had a significantly larger budget than previous FPs (nominally about 30 per cent larger than the FP5 budget). It also introduced new instruments that were influenced by the ideas underpinning the ERA; Integrated Projects (IP), Network of Excellence (NoEs) and ERA-NETs. The purpose of IPs and NoEs was to build a "critical mass" by assembling larger networks and to enhance the integration of research within the Union's thematic priority areas. Further, the introduction of the ERANET scheme has its rationale in the ERA concept. This instrument aims at enhancing cooperation and coordination among R\&D funders within Europe, including joint calls for proposals and the mutual opening of national and regional research programmes. FP6 also facilitated the emergence of European Technology Platforms. 
Table 2.1 Structure of FP6 and its budget (€million)

\begin{tabular}{|c|c|c|}
\hline Programmes/priorities & * Euro mill & Per cent \\
\hline 1. Focusing and integrating Community research & 14682 & 76.3 \\
\hline A. Thematic priorities & 12438 & 64.7 \\
\hline 1. Life sciences, genomics and biotechnology for health (LIFE) & 2514 & 13.1 \\
\hline - Advanced genomics and its applications for health & 1209 & 6.3 \\
\hline - Combating major diseases & 1305 & 6.8 \\
\hline 2. Information society technologies (IST) & 3984 & 20.7 \\
\hline $\begin{array}{l}\text { 3. Nanotechnologies and nanosciences, knowledge-based multifunctional } \\
\text { materials, new production processes (NMP) }\end{array}$ & 1429 & 7.4 \\
\hline 4. Aeronautics and space (AERO) & 1182 & 6.1 \\
\hline 5. Food quality and safety (FOOD) & 753 & 3.9 \\
\hline 6. Sustainable development, global change and ecosystems (SUST) & 2329 & 12.1 \\
\hline - Sustainable energy systems (ENERGY) & 890 & 4.6 \\
\hline - Sustainable surface transport (TRANSPORT) & 670 & 3.5 \\
\hline - Global change and ecosystems (GLOBAL) & 769 & 4.0 \\
\hline 7. Citizens and governance in a knowledge-based society (CITIZEN) & 247 & 1.3 \\
\hline B. Specific activities covering a wider field of research & 1409 & 7.3 \\
\hline Policy support and anticipating scientific and technological needs (SSP + & & \\
\hline NEST) & 590 & 3.1 \\
\hline Horizontal research activities involving SMEs (SME) & 473 & 2.5 \\
\hline Specific measures in support of international cooperation (INCO) & 346 & 1.8 \\
\hline C. Non-nuclear activities of the Joint Research Centre (JRC) & 835 & 4.3 \\
\hline 2. Structuring the European Research Area & 2854 & 14.8 \\
\hline Research and innovation (INNOV) & 319 & 1.7 \\
\hline Human resources (MCA) & 1732 & 9.0 \\
\hline Research infrastructures (RI) & 715 & 3.7 \\
\hline Science and society (S\&S) & 88 & 0.5 \\
\hline 3. Strengthening the foundations of the European Research Area & 347 & 1.8 \\
\hline Support for the coordination of activities & 292 & 1.5 \\
\hline Support for the coherent development of policies & 55 & 0.3 \\
\hline Sixth Framework Programme for RTD and Demonstration Activities & & \\
\hline (excluding EURATOM) & 17883 & 93.0 \\
\hline Euratom Framework Programme (EUR million) & 1352 & 7.0 \\
\hline Total & 19235 & 100.0 \\
\hline
\end{tabular}

The budget of the FP6 (excluding EURATOM) ${ }^{8}$ was $€ 17.9$ billion (Table 2.1). Although this figure is substantial, the funding of FPs in the period 2002-2006 represented only about 4 per cent of the Member States' aggregate expenditures on R\&D. In an economic perspective, the FPs play a minor role in the EU. However, this figure does not reflect the strategic and political importance of EU FPs. Below, the budget categories, i.e. the activities of FP6, are briefly presented.

8 Though the general legal basis of the FP6 is as mentioned set out in Article 163 of the Treaty, the specific legal basis of FP6 is in five separate pieces of Council legislation comprising two distinct programmes, one under the EC treaty (see in particular Official Journal of the European Communities L232, 27 June 2002) and the other under the Euratom treaty. An additional €50m was voted in 2004 to fund the EURATOM Framework. 
Thematic priority areas comprise the largest block of FP6 (65 per cent of the overall budget). This represents a strong thematic continuity of the work of past FPs. The new FP6 instruments, NoEs and IPs, are deployed here. The IPs are transnational multi-partner projects where the aim is to generate knowledge in the priority thematic areas of FP6. IPs must include R\&D activities but can also include demonstrations, training and innovationrelated activities. The NoE specifically targets the fragmentation identified in the ERA communication. The underlying idea of NoE was that this instrument should contribute to the durable integration of the participants' activities and capacities (Muldur et al. 2006, p. 282).

Specific activities covering a wider field of research (7.3 per cent of the budget) is a blend of targeted policy-relevant research (SSP) - common with previous FPs - and the New and Emerging fields in Science and Technology (NEST) programme. The latter is a new form of activity intended to support leading edge research and activities related to gathering intelligence (information) about interesting future European research directions. Special activities for SMEs have been incorporated in the FPs since FP2 and continue under this heading. The "special measures in support of international cooperation" also further previous activities in support of the EU relationship with developing countries (INCO).

Structuring the European Research Area accounts for almost 15 per cent of the budget and also builds on previous FPs. Research and Innovation contains networking and information measures, such as linking the academic and industrial communities. The main mobility measures fall under the Human Resources heading where the Marie Curie Action (MCA) is best known. The major effort in research infrastructures is new to FP6, however, while the Science and Society programme scales up activities already present in FP5.

Strengthening the foundations of the European Research Area accounts for just under 2 per cent of the budget and is new in FP6. The purpose is to 'structure' the combined European RTD effort, coordinate national activities, and to undertake policy studies and benchmarking to encourage coordination and the development of an European research and innovation policy.

Euratom Framework Programme focuses on nuclear fusion, nuclear safety, waste storage and radiological protection. Norwegian researchers only participate in EURATOM on a project-to-project basis.

\subsubsection{The $7^{\text {th }}$ Framework Programme (2007-2013)}

The ambition of FP7 is to "contribute the Union becoming the world's leading research area”. ${ }^{9}$ This implies more emphasis on basic research and scientific excellence (European scientific competitiveness, more specifically, IDEAS and the European Research Council), 
as well as higher priority given to larger and more long-term activities in the Framework Programme. The total budget amounts to 50.5 billion Euro with a duration of seven years three years more than previous programmes. The structure and budget of FP7 is shown in Table 2.2.

FP7 is grouped into four specific programmes: COOPERATION, IDEAS, PEOPLE and CAPACITIES. COOPERATION represents the continuation of the thematic priorities of FP6 and accounts for the greater part of the budget (61 per cent). The relative size of the thematic priorities is much the same as in FP6 with ICT and Health as the two largest priorities. PEOPLE is the researcher mobility and research training programme (MCA Marie Curie Actions, 9 per cent of the total budget). CAPACITIES comprises activities aimed at promoting research capacities (about 8 per cent of the budget), with research infrastructure and research for the benefit of SMEs as the largest categories.

Relatively speaking, fundamental research has been a budget winner in FP7 with the launch of the European Research Council (ERC) under the heading of IDEAS. The idea of ERC has a long history. When introduced through the FP7 it was by and large met with support from the member states and research community in Europe. This happened even though it represented a considerable break with the principles of transnationality and collaborative research which were the guiding principles of the previous FPs and the bulk of the FP7. The proposal for establishing the Joint Technology Initiatives, primarily based on the European Technology Platforms, were more contentious than the ERC proposal (Muldur et al. 2006). The intention of IDEAS is to provide support to investigator-driven frontier research through the ERC and accounts for 14 per cent of the budget. It funds individual PIs as opposed to networks, and represents a redefinition of "European Added Value”, as previous Framework Programmes used transnational cooperation as a justification for EU-level intervention (following the subsidiarity principle). 
Table 2.2 Structure and budget of FP7

\begin{tabular}{|c|c|c|}
\hline Programmes/priorities & * Euro mill & Per cent \\
\hline \multicolumn{3}{|l|}{ COOPERATION } \\
\hline Health & 6100 & 11.5 \\
\hline Food, Agriculture and Fisheries, and Biotechnology & 1935 & 3.6 \\
\hline Information and Communication Technologies & 9050 & 17.0 \\
\hline \multicolumn{3}{|l|}{ Nanosciences, Nanotechnologies, Materials } \\
\hline and new Production Technologies & 3475 & 6.5 \\
\hline Energy & 2350 & 4.4 \\
\hline Environment (including Climate Change) & 1890 & 3.5 \\
\hline Transport (including Aeronautics) & 4160 & 7.8 \\
\hline Socio-economic Sciences and the Humanities & 623 & 1.2 \\
\hline Security and Space & 2830 & 5.3 \\
\hline Total COOPERATION & 32413 & 60.8 \\
\hline IDEAS - European Research Council & 7510 & 14.1 \\
\hline PEOPLE - Marie Curie Actions & 4750 & 8.9 \\
\hline \multicolumn{3}{|l|}{ CAPACITIES } \\
\hline Research Infrastructures & 1715 & 3.2 \\
\hline Research for the benefit of SMEs & 1336 & 2.5 \\
\hline Regions of Knowledge & 126 & 0.2 \\
\hline Research Potential & 340 & 0.6 \\
\hline Science in Society & 330 & 0.6 \\
\hline Coherent development of research policies & 70 & 0.1 \\
\hline Activities of International Co-operation & 180 & 0.3 \\
\hline Total CAPACITIES & 4097 & 7.7 \\
\hline Non-nuclear actions of the Joint Research Centre & 1751 & 3.3 \\
\hline Total FP7 (excluding Euratom) & 50521 & 94.8 \\
\hline Euratom for nuclear research and training activities & 2751 & 5.2 \\
\hline Total & 53272 & 100.0 \\
\hline
\end{tabular}

*Decision of the European Parliament and of the Council of 18 December 2006.

\subsection{The overall development of EU research policy}

In 2006, the EU heads of state together with EU Parliament decided to double the budget for the FP by shifting some of the funds from the budget for the Common Agricultural Policy. The average annual volume of the programme is nonetheless considerable for the FP7 (Figure 2.1) Prior to that the share of the FP in the overall EU budget had been increasing, from 2.1 per cent in 1984 (the year first FP was established) to 4.6 per cent in 2006. However, the FP7's share of EU's total budget is still small. The original increase proposed by the Commission was considerably larger, and the increase in the FP did not make much of an indent in the CAP budget. 
Figure 2.1 Annual average spending on EU Framework Programmes in R\&D, 1995 2013. In millions EURO

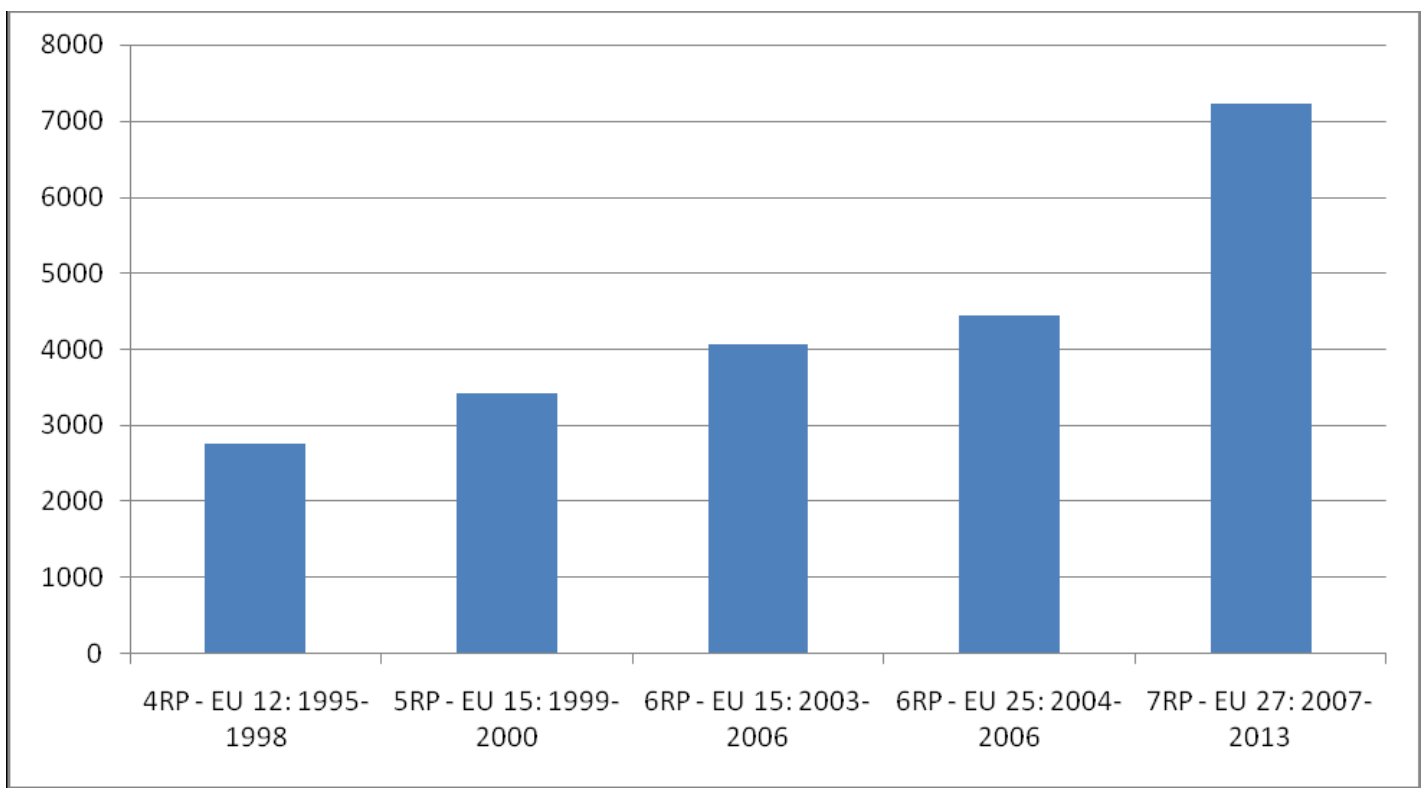

Source: European Court of Auditors 2008, page 4.

Along with the budget increase, new initiatives and instruments have also been introduced, both inside the Framework Programme and as a supplement. As shown in Figure 2.2, there is a trend that the newer EU R\&D initiatives and instruments are more policy-level oriented whereas the older initiatives and instruments are more at the project level. This should be linked to the ERA concept having attained - through the Lisbon Treaty - a formal and permanent position in EU research policy and in the overall integration process, putting R\&D policy on the political agenda, and entailing intensified focus on the need for national policy coordination and the use of softer policy instruments for such purposes. Moreover, new and old instruments have been mobilized and justified with reference to ERA.

The idea of the ERA was further emphasised and revised in the years following the reform of the Lisbon strategy. In 2007, the ERA concept also had its "relaunch" with the Green paper The European Research Area: New Perspectives ${ }^{10}$ emphasizing the ERA as an internal market for research. In a speech introducing the Green paper, Janez Potočnik, the European Commissioner for Research, spoke of his vision for a "fifth freedom" and a "United States of Research", ${ }^{11}$ a freedom that would make Europe an area "with excellent training and attractive prospects for researchers moving and interacting freely across Europe". ${ }^{12}$ The frame of reference for the Green Paper is the increasing globalization and the emergence of new scientific and technological centres, in particular in China and India. The paper clearly reaffirms the political vision for developing the ERA as a contribution to 
the Lisbon strategy. The main challenge are identified as ensuring the following characteristics of the ERA: Mobility not only between countries but also between institutions, disciplines and sectors; Integrated, networked research infrastructures; excellent research institutions engaged in public-private cooperation and attracting a critical mass of human and financial resources; effective knowledge-sharing between public research and industry, and with the public; well-coordinated research programmes and priorities. The enhanced ambitions of EU research policy underpin the relaunch of the ERA concept. The Green Paper underlines how the use of the FP alone cannot accomplish the ERA ambitions, and as with the reformed Lisbon strategy, a core message is to enhance ERA governance.

More specifically, the follow up to the ERA Green Paper shows how the EU R\&D policy in the ERA age has fanned out to include a spectrum of initiatives such as the following.

- Research Infrastructures. This initiative will consider providing a legal framework to assist Member States and other participating countries in the development and funding of pan-European research infrastructures which existing national, EU or international legal instruments might not be able to facilitate. The underlying rationale for this initiative is that although the Member States will remain central to the development and financing of major new infrastructures, the legal instruments are seen as unlikely to provide an adequate basis for establishing future panEuropean research infrastructures. The relevant infrastructures will primarily be based on a roadmap proposed by ESFRI (European Strategy Forum on Research Infrastructures), which also includes two Norwegian initiatives. The implementation of such infrastructures has therefore been facilitated by bringing forward a proposal to establish a legal framework for their construction and operation (cf. Council Regulation on the Community Legal Framework for an European Research Infrastructure (ERI) - COM (2008) 467).

- Joint programming as a new approach to address common grand societal challenges in a few key areas: making better use of Europe's public R\&D resources by pooling national research efforts. Joint programming is a voluntary and $a ̀ l a$ carte process aimed at fostering a structuring effect so as to increase the efficiency and impact of public research funding. Joint Programming will build upon experience gained from existing schemes coordinating national programmes, for example the ERA-NET scheme and initiatives based on Article 169 (and to some extent Article 171) of the Treaty, as well as from the agenda-setting practices of European Technology Platforms.

The Commission proposal entails a High Level Group consisting of nominees from Member States to identify suitable Joint Programming areas following consultation with stakeholders. Based on the result of this High Level Group, the Council, upon recommendation by the Commission, will select the few areas in which to launch the first Joint Programming Initiatives. The Green Paper further suggests that the EU should look 
into initiatives for strengthening the coordination of Community and member states' policies and programmes for international science and technology cooperation, i.e. constitute and enhance the EU as a collective actor on the international and global R\&D arena.

Other "non-FP" initiatives in the ERA relaunch address the issue of academic/researcher mobility where such mobility is impeded by lack of portability of social benefits and pension schemes for researchers, as well as the use of the Code of Good Conduct for handling intellectual property rights in research institutions. In spite of this development, the Framework Programme remains the main frame of reference for EU research policy, also after the introduction of ERA in 2000 and its relaunch seven years later. The development of FP6 and FP7 illustrates a layering process that adds new policy instruments both for market-close research and basic research. Alongside these developments the introduction of new measures for strengthening innovation in Europe such as the increasing use of Structural Funds for promoting research and innovation activities in Member States and the introduction of the Competitiveness and Innovation Framework Programme (CIP) represents a changing context for the FPs. These changes are discussed in Chapter 5.

As shown in Figure 2.2, the overall architecture of EU R\&D policy has been fanned out by the introduction of new instruments and the type of R\&D activities it addresses. Some of these instruments introduce decision-making procedures that are different from the modus operandi of the core of the FP instruments. At the end of the basic research, the decisionmaking criterion is "academic excellence" as the sole criterion, and at the spectrum of research closer to the market the concept of technology platforms (introduced under the FP6) is geared towards a better alignment of EU research priorities to industry's needs. The platforms bring together companies, research institutions, the financial world and regulating bodies at the European level under industrial leadership in order identify a common research agenda on strategic issues. European resources are then combined with public private partnerships (Muldur et al. 2006 pp.171-172). Such layering of new initiatives and instruments has created a complex architecture that constitutes the present EU research policy. 


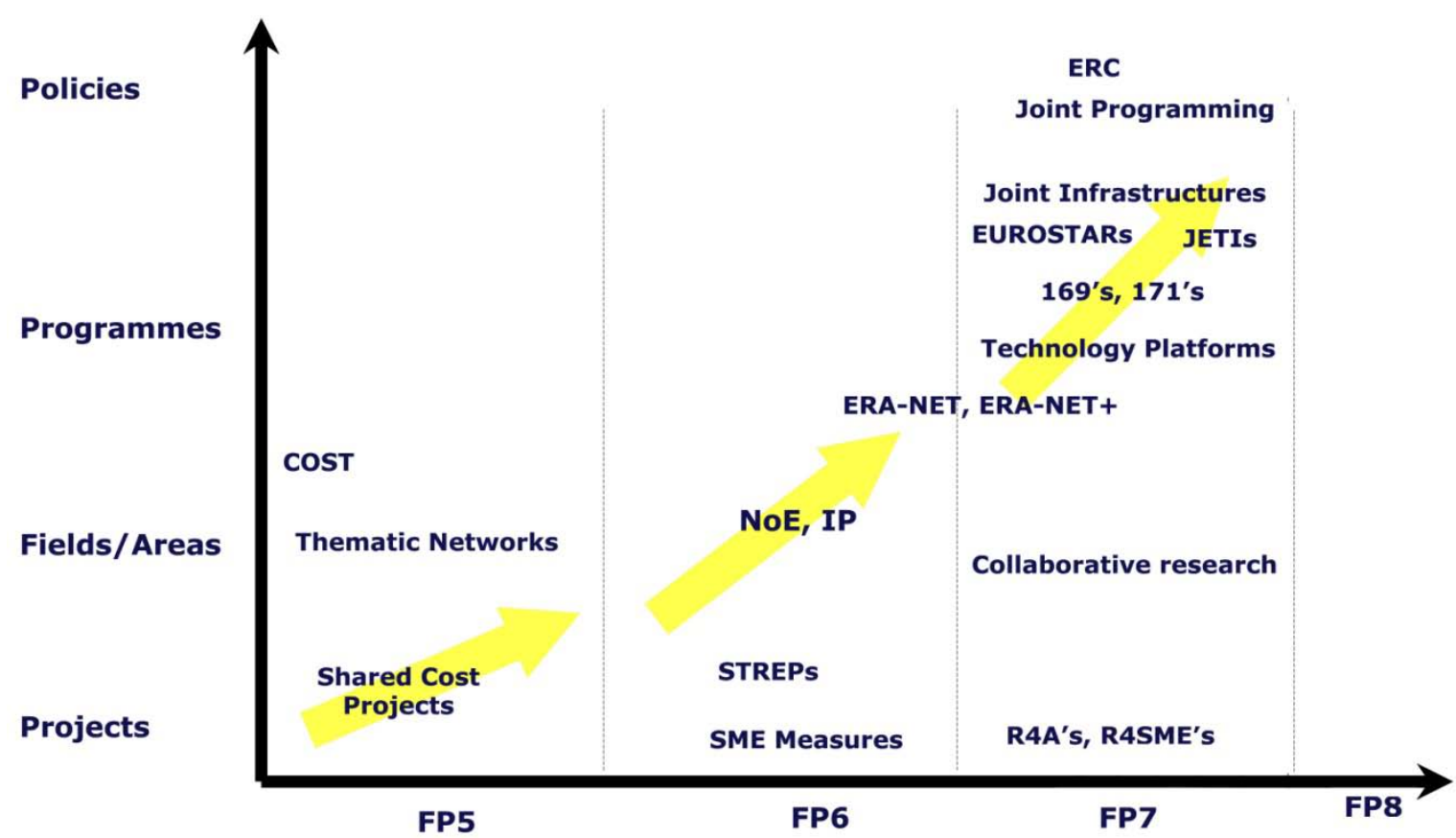

Source: L. Kaiser (2009): International Benchmark of Tech Transfer Organisations, Montpellier 18 June 2009, page 28. CJ Hull, EARTO undated Power Point. Source: http://crie-asso.org/IMG/pdf/LorentzKaiser.pdf.

\subsection{Norway's research policy and participation in EU FPs}

Internationalisation of Norwegian research has been a top priority in research policy for a long time. This is manifest in official documents that outline public research policy such as the White Paper on research policy presented to the Norwegian parliament (Stortinget) in 2005 where it is stated that: "Internationalisation of research must be a fundamental perspective in research policy with implications for specific priorities". ${ }^{13}$ This emphasis was reiterated in the next White Paper of 2009 on research policy, which expands on this theme: "Internationalisation of research is important in order to increase quality and strengthen relevance of Norwegian research, and in order to provide us with access to research done outside of Norway”. ${ }^{14}$ Similar reasons are given in other, and earlier, official documents on Norway's research policy. In these, Norway's participation in EU FPs are described and characterized, such as: "EU research and EU Framework Programmes is the largest formalized arena for collaboration between Norwegian and foreign researchers." 15 In the same White Paper, the following policy goal is given: "Norwegian research policy must contribute to a high degree of internationalisation of research". ${ }^{16}$ Further on in the

\footnotetext{
13 St meld nr 20 (2004-2005), ”Vilje til forskning”, p. 25, translated from Norwegian by the authors.

14 St meld nr 30 (2008-2009), ”Klima for forskning”, p 28, translated from Norwegian by the authors.

15 St meld nr 30 (2008-2009), "Klima for forskning”, p 28, translated from Norwegian by the authors.

16 St meld nr 30 (2008-2009), ”Klima for forskning”, p 107, translated from Norwegian by the authors.
} 
same 2009 White Paper, the priorities made in the preceding 2005 White Paper were reconfirmed, i.e. that research policy in terms of internationalisation aims at giving priority to four areas:

- Active participation in the European Research Area,

- Strengthening of bilateral research cooperation,

- Norway as an attractive host nation for research,

- Norway as a global partner in research.

In elaborating these goals, the latest (2009) White Paper on research policy states that in order to strengthen internationalisation of Norwegian research, the following general measures should be taken: ${ }^{17}$

1. Strengthening the national research capability is a prerequisite for coping with global challenges and the international competition for resources for research.

2. National priorities in research policy must be amplified by international research collaboration, and for this reason, more clear priorities for the total international collaboration must be made.

3. The rapid developments in the European Research Area and in EU's Framework Programmes require clear priorities and goal-oriented measures in order to increase Norway's benefit from its contribution.

4. Research institutions and firms must become capable of participation in international research collaboration, and they must take responsibility for developing this type of cooperation.

As seen, participation in EU research has significant importance and high priority in Norwegian research policy. More specifically, for EU FP7, the latest White Paper on research policy has translated these policy goals into three strategic aims for the period 2007-2010 ${ }^{18}$ :

1. To strengthen Norway's participation in EU FP7.

2. To develop an active policy for participation in the European Research Area, partly because the volume of research in this is expected to become so large that, due to limited resources, Norway cannot participate in all the progammes and projects, and must prioritize its participation.

3. To strengthen influence, coordination and knowledge.

17 St meld nr 30 (2008-2009), ”Klima for forskning”, p 108.

18 St meld nr 30 (2008-2009), ”Klima for forskning”, p 112. 


\subsubsection{Norway's research strategy for participation in EU FPs}

In May 2008, the Norwegian Ministry of Education and Research (MER) published a document on the strategy for Norway's cooperation with the EU on research and development. ${ }^{19}$ In the preface of this document, the minister of research, Ms. Tora Aasland, writes that Norway's participation in EU FP7 will require adjustments in the national research policy, in policy measures and funding of research, and that this is part of a broader effort for developing a new policy designed to strengthen internationalisation of Norwegian research. The document was thus given high level endorsement. In the strategy document, the focus is on how to achieve three policy goals which are essentially identical to the goals presented in the subsequent White Paper on research policy in 2009:

- Strengthening Norwegian participation in EU FP7 - policy priority no. 1

- Develop a proactive policy for participation in ERA - policy priority no. 2

- Influencing and follow-up of EU FP7 - policy priority no. 3

In this EU strategy document of the MER, the rationale for these policy goals were elaborated and justified with reference to a number of policy documents, specifically the policy statements and goals in the White Paper on research policy from 2005, as explained earlier. Based on these, the document suggests 24 specific measures, or actions. These actions are organized according to a number of strategic sub-goals derived from the three, general policy goals (policy priorities) stated above. These actions are briefly presented below. The strategy and actions are designed to meet three important challenges:

- Norway must respond actively to an increasingly ambitious and dynamic research and technology policy and related initiatives in the EU. ${ }^{20}$ Because of the magnitude and sheer size of the EU, based on its own national research and innovation policy priorities, Norway must develop priorities in terms of what parts of the EU R\&D system to participate. Furthermore, Norway must be capable of aligning this with the "sector principle" that governs Norwegian research policy and funding. ${ }^{21}$ The strategy suggests that the division of labour and responsibilities towards the EU should be made more explicit -and subject to MER's leadership role.

- Norway must strengthen its participation in, and use of outputs from EU FP7 and ERA. ${ }^{22}$ According to the strategy document, this is a clear responsibility for the Research Council of Norway.

- Norway should strive for an increase in EU funding of Norwegian participation. ${ }^{23}$ According to the document, Norway should attempt to increase its level of

19 Cf. "Strategi for Norges samarbeid med EU om forskning og utvikling”,[”Strategy for Norway’s cooperation with EU on research and development”], Ministry of Education and Research, Oslo, May 2008.

20 P. 21

21 P. 23

22 P. 24

23 P. 25 
participation, and by this, increase EU funding. Achieving parity between Norway's funding of EU FP7 and EU funding of Norwegian participation in FP7 (“just return”) will amount to an annual average of NOK 1.3 billion, an ambitious goal considering Norway’s present level of participation.

MER's strategy document provides a coherent and systematic approach to strategic aspects relevant for Norway's participation in EU FPs and ERA in general, and more specifically for FP7. By this, the document demonstrates MER's leadership role in developing a national strategy for Norway's participation in EU R\&D and innovation systems.

\section{Strengthening Norwegian participation in EU FP7 - policy priority no. 1}

A total of ten actions are suggested and elaborated in the MER strategy document for strengthening Norwegian participation in EU FP7 and increase activities that disseminates output from the research. ${ }^{24}$

Table 2.3 Actions in the policy priority 1 on strengthening Norwegian participation in EU'S FP7

\begin{tabular}{|l|l|l|}
\hline $\begin{array}{l}\text { Action } \\
\text { no. }\end{array}$ & Type of action & Implementation \\
\hline 1 & $\begin{array}{l}\text { Norway should use EU FP7 as a platform for internationalisation of } \\
\text { Norwegian research by aligning this closely with national R\&D and } \\
\text { innovation policy -and other international collaborations, including R\&D } \\
\text { related to global challenges and the North }\end{array}$ & Not stated \\
\hline 2 & $\begin{array}{l}\text { National R\&D programmes must be strengthened and developed in } \\
\text { order to create broad synergies with EU FP7 }\end{array}$ & RCN \\
\hline 3 & $\begin{array}{l}\text { Higher education institutions, including regional health institutions, } \\
\text { should develop goals and strategies for their participation in EU's FP7 }\end{array}$ & MER and RCN \\
\hline 4 & $\begin{array}{l}\text { RCN and Innovation Norway should strengthen coordination of their } \\
\text { information and counselling services, and develop web-based } \\
\text { information services on EU FP7 }\end{array}$ & RCN and Innovation \\
Norway
\end{tabular}

As seen in Table 2.3, the Research Council of Norway (RCN) has been designated responsibility for the implementation of seven of these ten actions alone (actions no. 2 and 7), together with Innovation Norway (actions no. 4 and 5), or with others such as the Ministry of Education and Research. However, the document has not designated 
implementation of the strategically most significant action, action no. 1, even though the importance of this action in the strategy is emphasised.

Develop a proactive policy for participation in ERA - policy priority no. 2

Altogether five actions are suggested and elaborated in the MER strategy document for development of a proactive policy for participation in ERA. ${ }^{25}$ Possibly because the ERA is not as well known as EU FPs, the strategy documents provide more information on the policy contexts and rationales for ERA, describing how the process of ERA has evolved from its ratification in Lisbon in 2000.

Table 2.4 Actions in the policy priority 2 on developing a proactive policy for participation in ERA

\begin{tabular}{|l|l|l|}
\hline $\begin{array}{l}\text { Action } \\
\text { no. }\end{array}$ & Type of action & Implementation \\
\hline 11 & $\begin{array}{l}\text { Coordinate and initiate active Norwegian advocacy related to measures } \\
\text { from the EU on the development of ERA - and contribute to making the } \\
\text { topic of marine research a cross-cutting priority in EU FP7 in } \\
\text { accordance with EU "blue book" on maritime policy. }\end{array}$ & MER \\
\hline 12 & $\begin{array}{l}\text { Develop a strategy for Norway's participation in ERA-NET and } \\
\text { measures proposed according to Articles 169 and 171, including plans } \\
\text { for national co-funding (budgets) - and submit these to MER and other } \\
\text { relevant ministries }\end{array}$ & RCN \\
\hline 13 & $\begin{array}{l}\text { Assess and determine Norwegian priorities related to development of } \\
\text { existing and future Norwegian and European research infrastructures } \\
\text { supported by EU FP7 }\end{array}$ & $\begin{array}{l}\text { MER, in cooperation } \\
\text { with other relevant } \\
\text { ministries and RCN }\end{array}$ \\
\hline 14 & $\begin{array}{l}\text { Map Norwegian participation in European Technology Platforms and } \\
\text { assess the potential for strengthened participation. Assess feasibility of } \\
\text { establishing and operating national technology platforms - and } \\
\text { measures proposed according to article 171 - Joint Technology } \\
\text { Initiatives }\end{array}$ & $\begin{array}{l}\text { RCN and Innovation } \\
\text { Norway, by the autumn } \\
\text { of 2008. }\end{array}$ \\
\hline 15 & $\begin{array}{l}\text { Assess the feasibility of establishing one or several agreements with the } \\
\text { European Investment Bank in order for Norwegian institutions and firms } \\
\text { to get access to "Risk-Sharing Finance Facility" (RSFF) }\end{array}$ & $\begin{array}{l}\text { MER and Ministry of } \\
\text { Industry and Trade }\end{array}$ \\
\hline
\end{tabular}

In this policy priority, the Ministry of Education and Research has a leading role in terms of implementation, because three of the five actions are assigned to this ministry.

\section{Influencing and follow-up of EU FP7 - policy priority no. 3}

This policy priority spells out the strategies for influencing the EU in terms of FP and ERA, the flow of information in Norway - and the topic of "sector responsibility," and coordination of the relationship between the ministries and the Research Council of Norway. ${ }^{26}$ The purpose of this is to improve Norway's efficiency in terms of achieving national goals in its relationship with the EU. A total of nine actions are suggested and elaborated in the MER strategy document related to these topics of which three are related to monitoring and analysis of Norway's participation in EU FPs.

\footnotetext{
25 Cf pp. 104-134

26 Cf pp. $135-151$
} 
Table 2.5 Actions in the policy priority 3 on influencing and follow-up of EU's FP7

\begin{tabular}{|c|c|c|}
\hline $\begin{array}{l}\text { Action } \\
\text { no. }\end{array}$ & Type of action & Implementation \\
\hline 16 & $\begin{array}{l}\text { Write draft strategy documents for participation in each FP programme, } \\
\text { stating Norway's main priorities and suggest, if necessary, possible } \\
\text { adjustments that will improve the programme. }\end{array}$ & $\begin{array}{l}\text { RCN in cooperation with } \\
\text { relevant R\&D institutions. } \\
\text { These documents must } \\
\text { be approved by the } \\
\text { relevant "sector" } \\
\text { ministries }\end{array}$ \\
\hline 17 & $\begin{array}{l}\text { Amplified responsibility for developing Norwegian positions and } \\
\text { priorities for participants in programme committees, in cooperation the } \\
\text { Norwegian R\&D community and Innovation Norway }\end{array}$ & $\mathrm{RCN}$ \\
\hline 18 & $\begin{array}{l}\text { Improve skills and increased learning and information exchange among } \\
\text { Norwegian delegates to EU programme committees. }\end{array}$ & MER \\
\hline 19 & $\begin{array}{l}\text { Dissemination of general, relevant information and strategic information } \\
\text { on EU research should be strengthened to cover target groups such as } \\
\text { Innovation Norway and "National Contact Points" }\end{array}$ & $\mathrm{RCN}$ \\
\hline 20 & $\begin{array}{l}\text { Ensure that as a minimum, eight Norwegian citizens work as national } \\
\text { experts within DG RTD and JTIs }\end{array}$ & $\begin{array}{l}\mathrm{RCN} \text { and relevant } \\
\text { "sector" ministries }\end{array}$ \\
\hline 21 & $\begin{array}{l}\text { Improved integration of EU research in relevant ministries, in their work } \\
\text { with national research policy - and on the agenda of the Research } \\
\text { Committee of the Ministries (DFU) }\end{array}$ & Not stated \\
\hline 22 & $\begin{array}{l}\text { An annual report on the development of Norway's participation in EU } \\
\text { FP7 - to be presented at the EEA Special Committee on Research and } \\
\text { the Research Committee of the Ministries }\end{array}$ & $\mathrm{RCN}$ \\
\hline 23 & $\begin{array}{l}\text { Analyses and evaluation of Norway's participation in EU FP7, in order } \\
\text { to provide information for various measures designed for improving } \\
\text { skills, learning and adjustments. }\end{array}$ & MER \\
\hline 24 & $\begin{array}{l}\text { Evaluation of Norway's participation in EU FP6 and the first part of EU } \\
\text { FP7. }\end{array}$ & MER \\
\hline
\end{tabular}

In this policy priority, the Research Council of Norway has been designated responsibility for implementation of five of the nine actions, either alone (actions no. 17, 19 and 22) or together with other organisations (actions no. 16 and 20). In a strategic perspective, actions no. 16 and 17 may be considered as crucial - and the Research Council of Norway has been given the main responsibility for implementing these. In particular, action no. 16, which requires approval of strategy documents from the relevant "sector" ministry may, however, raise the question of the MER's bilateral relationship and role vis à vis other ministries and the status of MER's leadership of Norway's EU-FP strategy. Is this an indication of weakness, or unwillingness of MER to "meddle" with the autonomy implied by the "sector responsibility"? According to informants, adhering to the "sector principle" has a sound, pragmatic rationale, but the implication of action no. 16 is that the burden of obtaining approval of Norway’s EU-strategy in the relevant stakeholder ministries is given to the Research Council of Norway, not to the ministry responsible for research policy and strategy in Norway.

Using the number of implementations shown in Table 2.3, Table 2.4 and Table 2.5 as a rough indicator, it is clear that the MER has assigned a major operational responsibility for implementation of Norway's research strategy to the Research Council of Norway. In November 2008, as a response to MER's strategy plan, the Research Council of Norway published a document on Norway's research cooperation with EU in FP7, more 
specifically, an action plan for $2009-2010 .{ }^{27}$ As an action plan, this document is explicit in term of goals and objectives because these are operationalised in a set of success criteria, the level of cooperation, financial objectives of projects that have Norwegian participations, and, finally, interaction with the EU Commission. The document also presents a plan for Norway's participation in EU FP7 and ERA. The specific responsibilities and roles of the Research Council of Norway's are defined and assigned to the various organisational entities within the Council and its system of governance and management. In the latter, emphasis is set on the role of programme committees: "In order to achieve desired synergies and added value, the programme committees must identify relevant overlap of their activities with FP7's priorities. In these 'interfaces' the programme committees must identify those parts of their programme where they require added value by participation in EU projects, irrespective of the type of cooperative mechanisms". ${ }^{28}$ The document then presents all the thematic priorities in Cooperation, Ideas, People and Capacities - and state specific, often quantified, targets for each of these and how they should be achieved. Finally, the document presents the action plans for:

- Information and counselling

- Financial support instruments for projects

- The Research Council's liaison office in Brussels

- Meeting places

- Representation and dialogue

- Analyses and reporting

- Organisation

- List of delegates and National Contact Points (NCPs).

The effects of these strategies and actions are discussed in Chapter 7.

\subsection{Factors influencing Norwegian participation and implications for the evaluation}

Norwegian participation in the FPs is the outcome of many different, interacting factors. Formally, Norway participates in EU FPs based on a provision in the agreement on the European Economic Area (EEA), which Norway is a part of. ${ }^{29}$ This treaty stipulates a number of conditions for Norway's participation, one of which is Norway's economic contribution to EU for its participation. However, in order to understand how Norway’s

27 Cf. Forskningsrådet (Research Council of Norway), "Forskningssamarbeidet Norge-EU. 7.

Rammeprogram 2007-2013. Forskningsrådets handlingsplan 2009-2010”, Oslo, November, 2008.

28 P. 8 - translated from Norwegian by the authors.

29 Cf. St.prp.nr. 48 (2006-2007), “Om samtykke til deltakelse i en beslutning i EØS-komiteen om innlemmelse i EØS-avtalen av EUs sjuende rammeprogram for forskning, teknologisk utvikling og demonstrasjonsaktiviteter (2007-2013)”. This bill was sanctioned by the Storting, Norwegian parliament, in a vote on April 16, 2007, based on a recommendation from the Storting's Education and Research Committee, cf. Innst. S. nr. 162 (2006-2007) 
pattern of participation is shaped, several different factors need to be taken into consideration. These have implications as a framework for the evaluation.

A first set of factors concerns the development at the European level within the Framework Programme and within realm of EU research and innovation policy more broadly, such as explained briefly earlier:

- Selection of topics and thematic priorities in the FPs and its overall implementation by the EU Commission, based on approval of the EU Parliament,

- Subsequently, development of new types of instruments and their orientation such as kinds of actors they address, and types of rules that apply to them. These processes are also initiated by the EU Commission, and afterwards executed and managed by mostly the Directorate General for Research Technology and Development (DG RTD). The emergence of ERA is the result of this type of process.

A second set of factors concerns how Norwegian research policy institutions organise and adapt to facilitate Norwegian participation:

- How the Norwegian government (i.e. ministries who are stakeholders in EU FP), the Research Council of Norway and other institutions at the research-strategic level organise their involvement with and attention to the FPs and EU research policy;

- How these institutions approach the implementation and management of the Norwegian participation in FPs, and the nature of the policy instruments that are developed and used to affect Norway's participation;

- How Norway's EU research policy blends with the overall national research policy priorities and development in terms of internationalisation of research.

The third set of factors concerns the research performing level:

- The overall characteristics and profile of Norwegian research, such as the distribution of human resources and thematic specialisations, the degree of internationalisation, as well as the overall framework conditions under which research institutes, industrial research, universities and colleges operate;

- Objectives, efficiency, effectiveness and experiences of the FP participants in particular.

These factors represent a confluence of aspects that are relevant for understanding what affects Norwegian participation in the FPs. That is, the development may be characterized as complex - and dynamic. Still, one may point to an "auspicious" confluence of three broad interests that gradually, if not particularly visibly, contribute to a general national consensus that Norway should, for its own benefit, give high priority to participation in EU FPs, regardless of its present status as non-member of the European Community: 
- Political-strategic, cultural and economic allegiance to the community of Western European nations, i.e. participation in EU research as an expression of political and cultural identity. This is the type of raison d'etre that justifies what Norwegian politicians term as a "broad consensus" on the importance of being a member of many international semi-political organisations and associations, such as NATO, OECD, etc. - and in terms of research, membership in organisations such as CERN, the ESA, EMBL, etc.

- Opportunities for funding and participation in international research communities and associated activities and networks - for which the Norwegian R\&D community is generally positive, regardless of its attitude towards the EU as a political system. Some disciplines have participated in international research collaboration for many decades, the most prominent among these being activities organized by international "big science” organisations such as CERN, ESA, EMBL, etc. However, for many members of the Norwegian R\&D community, participation in FPs represent opportunities and ways of carrying out research that are considered novel and promising. This positive attitude is discussed in Chapter 4.

- Opportunity for participation in, and surveillance of, technological development that has potential of high commercial and industrial impact. This specifically motivates advanced and high-tech Norwegian firms to participate. By providing these with access to knowledge benefits, industrial R\&D collaboration in EU may represent future business opportunities since participation expands their networks.

Many of the factors that may be paramount to Norwegian participation are beyond the control of FP administrators and research policy-makers. For instance, we can assume Norway's FP participation to be sensitive to short term changes in profile of the FP because of the path dependencies of the Norwegian research system. This implies that an underlying theme in the evaluation of Norway's participation is to identify the main factors that affect participation patterns, but also to discern between those aspects that are changeable and "controllable”, and those that are not. 


\section{$3 \quad$ Norwegian FP6 and FP7 participation profile}

This chapter presents information and analyses on a number of topics relevant for the evaluation of the Norwegian participation in the FP6 (excluding EURATOM) and the first two years of the FP7.

A frequently asked question in this context is: How much does Norway "get back" (retour) from its payment of the FP "participation fee" to Brussels? EU contribution to Norwegian researchers (Brussels $\rightarrow$ Norway) participating in FP6 amounted to $€ 284$ million. Norwegian government's funding of FP6 activities (“contingent”, i.e. payment flow Norway $\rightarrow$ Brussels) is estimated to $€ 365$ million. The funding “gap” between Norway's payment to EU and what Norwegian participants got back from the FP6 is €81 million, which at the current rate of exchange (September 2009) amounts to approximately NOK 700 million. However, it may plausibly be an effect of Norway's comparatively high GDP (which determines the size of Norway's FP contribution to the EU) - combined with Norway's comparatively low R\&D-intensity and size of R\&D community, i.e. its R\&D capacity. However, the total project value (cost) of the projects with Norwegian participants are close to $€ 4900$ million. This is an indicator that the Norwegian funding gives the Norwegian participants access to research and technology activities worth more than 13 times the Norwegian payment to EU.

\subsection{Norwegian participation in FP6}

\subsubsection{Main features}

EU contribution to Norwegian participants in FP6 amounted to $€ 284$ million compared with $€ 249$ million in FP5, an increase of 14 per cent ${ }^{30}$. Hence, one may conclude that the overall Norwegian participation in FP6 was greater than in FP5.

The total financial contribution from the Norwegian government to FP6 is estimated at $€ 365$ million $^{31}$ compared to $€ 274$ million in the FP5. The figure of $€ 365$ million also includes Norway's payment for EU administration costs, basic allowances to JRC funded through the FPs etc. For this reason, Norway's share of the contribution to the activities in FP6 which are open to competition from all participating countries is estimated to be about $€ 336$ million. In other words, in order for Norway to "break even”, it should have obtained $€ 336$ million in funding for its participation in EU FP6. Thus, the ratio between the EU contribution to Norwegian researchers and the Norwegian contribution to FP6 activities

30 Not adjusted for inflation and fluctuations in rates of exchange.

31 Referring to the St.prp. nr. 16 (2002-2003) page 4, the overall Norwegian contribution to FP\& is stipulated to be between $2.04-2.1$ per cent of the FP6 budget (excluding EURATOM, or about $€ 377$ million. The Norwegian contribution to the FP6-funding open to participants ("konkurranseutsatte midler”) is estimated to be about $€ 340$ million. 
open to competition - defined here as economic return ratio - is 0.84 (\$284 million Euro divided by $€ 336$ million). In FP5, the equivalent economic ratio was close to 1.

Another key indicator for assessing the importance of the Norwegian participation in the FPs is the total cost of the projects that had at least one Norwegian participant (hereafter mentioned as Norwegian EU-projects. This figure for all Norwegian FP6 projects was $€ 4,862$ million or approximately NOK 40 billion. The equivalent figure for FP5 was NOK 19 billion, i.e. a substantial increase in the total value of the $R \& D$ projects that had Norwegian participation in FP6, compared to FP5.

The main reasons why the total eligible costs of FP6 projects with Norwegian participants is far greater than the total eligible costs of Norwegian FP5 projects are:

- The total nominal budget of FP6 (excluding EURATOM ) is 30 per cent larger than the nominal budget of FP5,

- The total number of contracts (and participations) in FP6 is considerably lower than in FP5, and consequently the average FP6 project is much larger. The average EC financial contribution by participant in FP6 (excluding Marie Curie actions) was $€ 0.23 m i l l i o n$ compared with $€ 0.16$ million in FP5. Doubled EC financial contribution to FP6 participants implies also a significant increase (about 160 per cent) of total eligible costs by participants.

In other words, if the Norwegian participants are able to fully exploit the knowledge produced in their EU projects in terms of new abilities and skills, networks, market contacts and improved economic performance - EU research may be considered as a beneficial investment for Norway, even when the economic return ratio, as stated above, is lower than 1. In fact, one could claim the national contribution to the FP6 budget (i.e. the sum of annual contributions from the Norwegian State to FP6) was the "entry ticket" to R\&D activities costing $€ 4862$ million (the total eligible R\&D costs in the EU projects in which Norwegians participate).

Based on this observation, an important policy objective should be how to structure the Norwegian participation in such a way that it allows Norway to absorb and exploit scientifically and commercially the maximum of the total value (total eligible costs) of the Norwegian EU projects. 


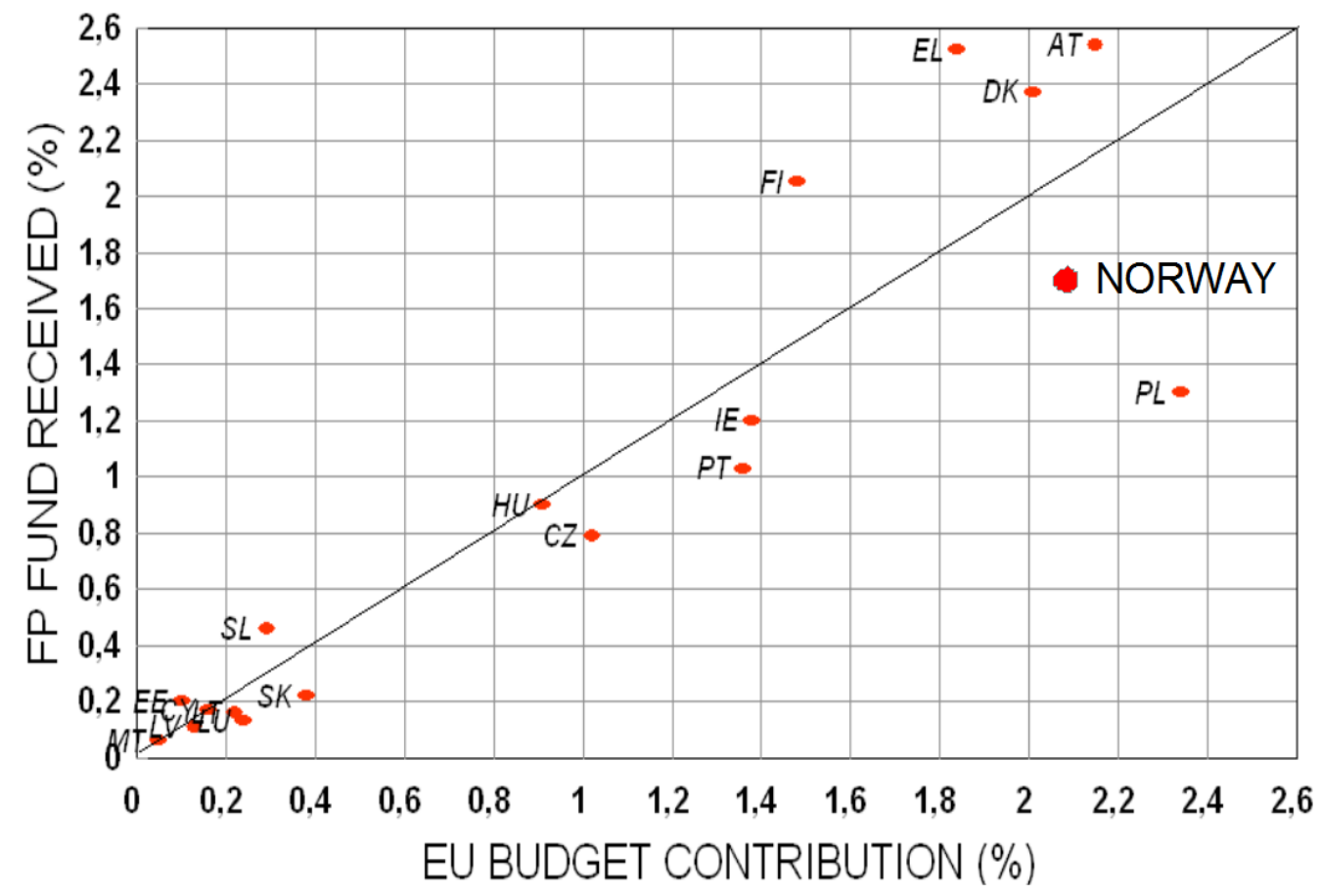

Figure 3.1 Shares of EU GDP (2005) and Retour in FP6 (smaller and medium Member States + Norway)

Source: DG-Research, FP6 Final Review: Subscription, Implementation, Participation, Brussels: European Commission, July 2008

Figure 3.1 compares Norway with other nations participating in FP6. Finland, Sweden, Denmark, Austria and Netherlands were able to obtain larger than break even EUcontributions to their participants, whereas Norway's “deficit” is on level with Portugal and Czech Republic. However, the reasons are not so obvious, and it may partly be explained by aspects not related to the quality of the Norwegian research system. As indicated in Figure 3.2, the factor of Gross Domestic Product (GDP) determines the size of national contributions ("participation fees") to FPs, which explains why Europe's "wealthiest" nations, Luxembourg and Norway are positioned to the far right in the diagram shown in Figure 3.2. In other words, if Norway's GDP per capita had been on the same level with that of the Netherlands, the economic return for Norway would have been positive. Further, Figure 3.4 shows that the overall success rate for projects with Norwegian participation in FP6 was higher than for nearly all other European countries, and Figure 3.3 indicates that the average EU-contribution per participant for Norway $(€ 223,000)$ is not far lower than the average for EU15 (€250,000). 


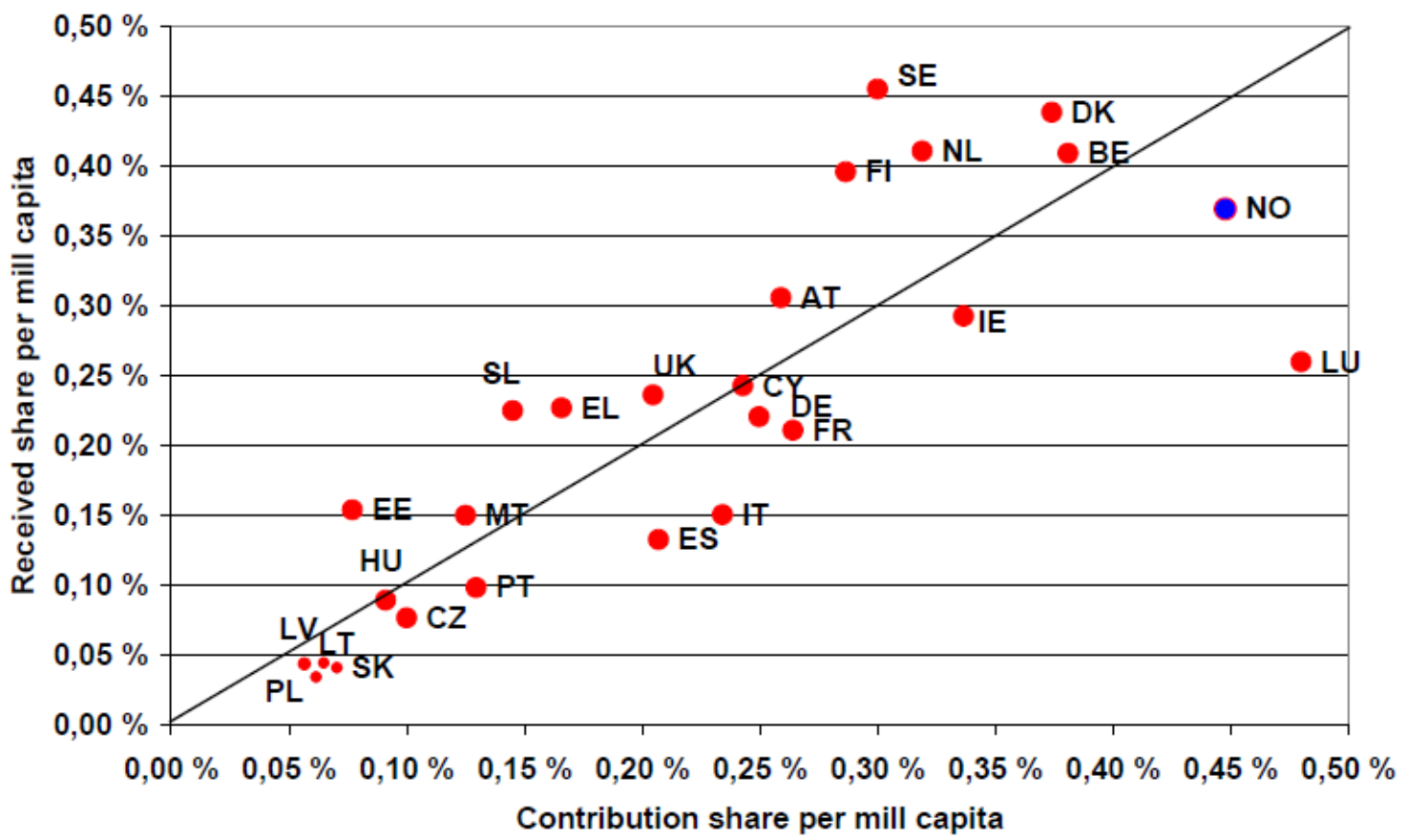

Figure 3.2 Contributions normalized to capita in each country

Source: Rietschel et al 2009/DG-Research, FP6 Final Review: Subscription, Implementation, Participation, Brussels: European Commission, July 2008/Eurostat.

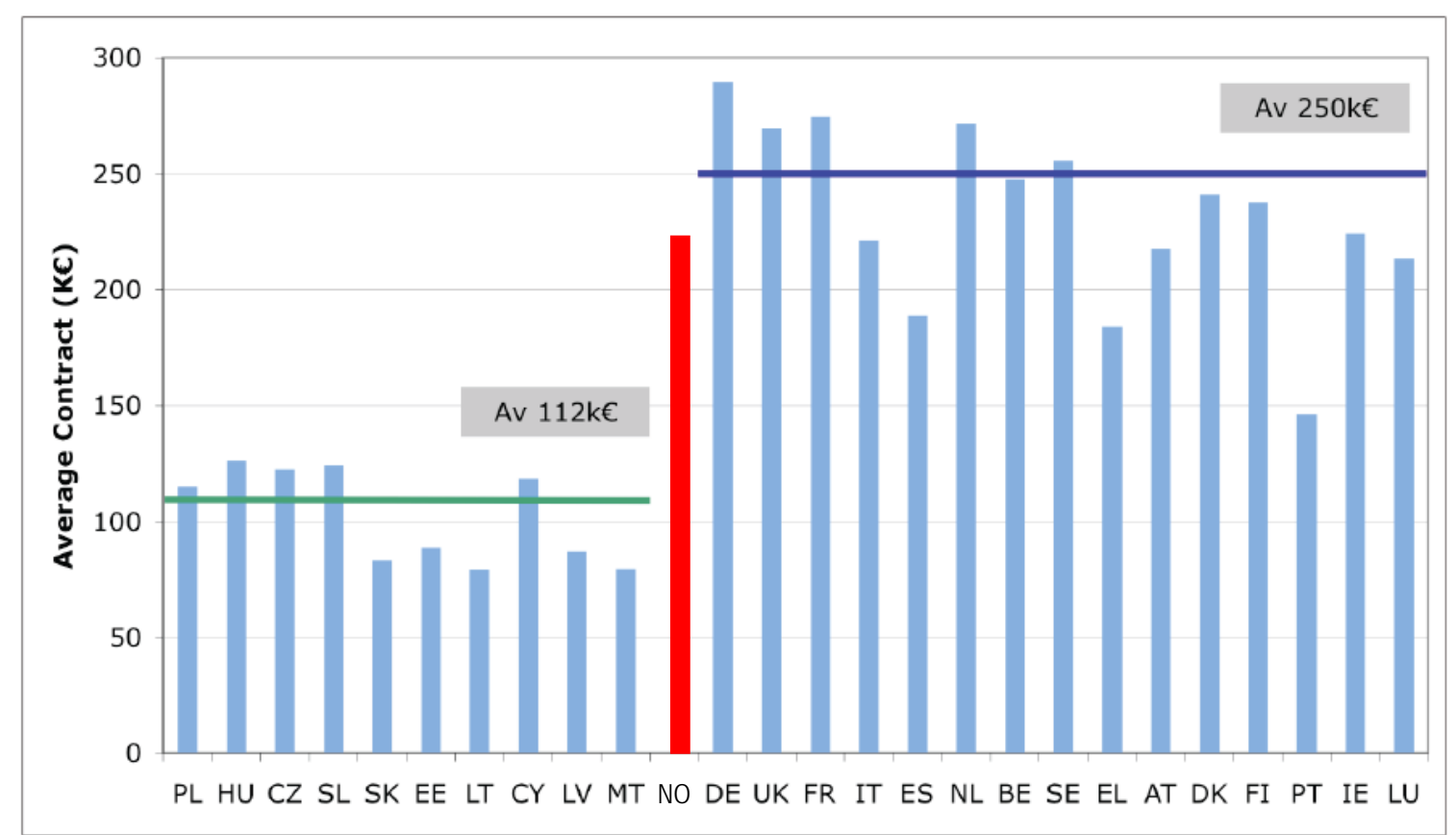

Source: EC DG RTD statistical paper

Figure 3.3 Average contribution per participant in FP6. EU27 and Norway. 


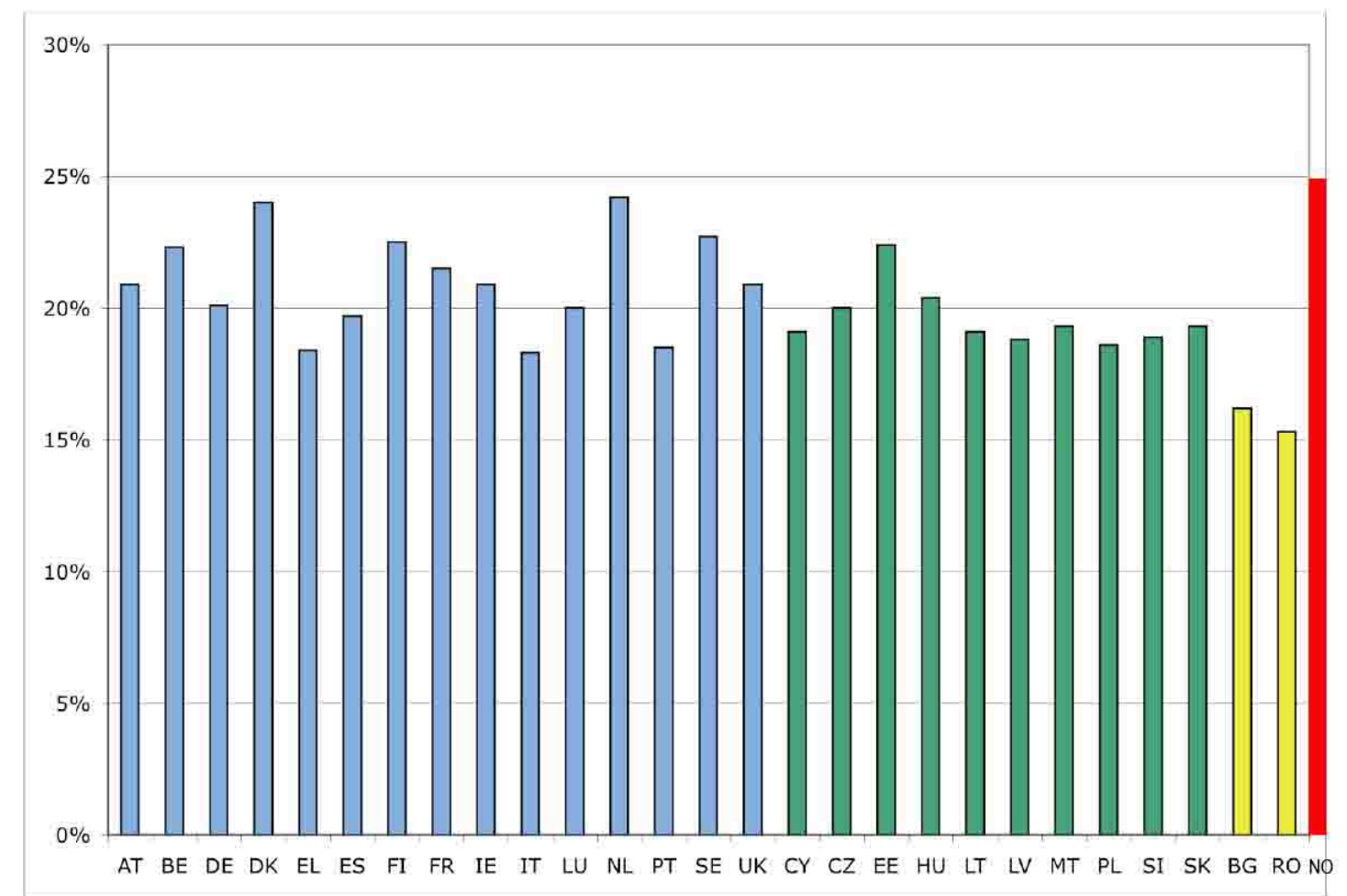

Source: DG-Research, FP6 Final Review: Subscription, Implementation, Participation, Brussels: European Commission, July 2008. EU-15 shown in blue. 2005 new Member States in green. Subsequent entrants in yellow.

Figure 3.4 Success rate for proposals to FP6. 27 Member States and Norway.

\subsubsection{National participation performance in FP6 - comparison with other participating nations}

Comparisons of Norway's participation in EU FP6 with other participating countries are of interest because this provides policy-makers with information on the competitiveness of the Norwegian research system. The histograms in Figure 3.4 compare Norwegian participation in FP6 with the participation of other Members States on a number of different parameters. 

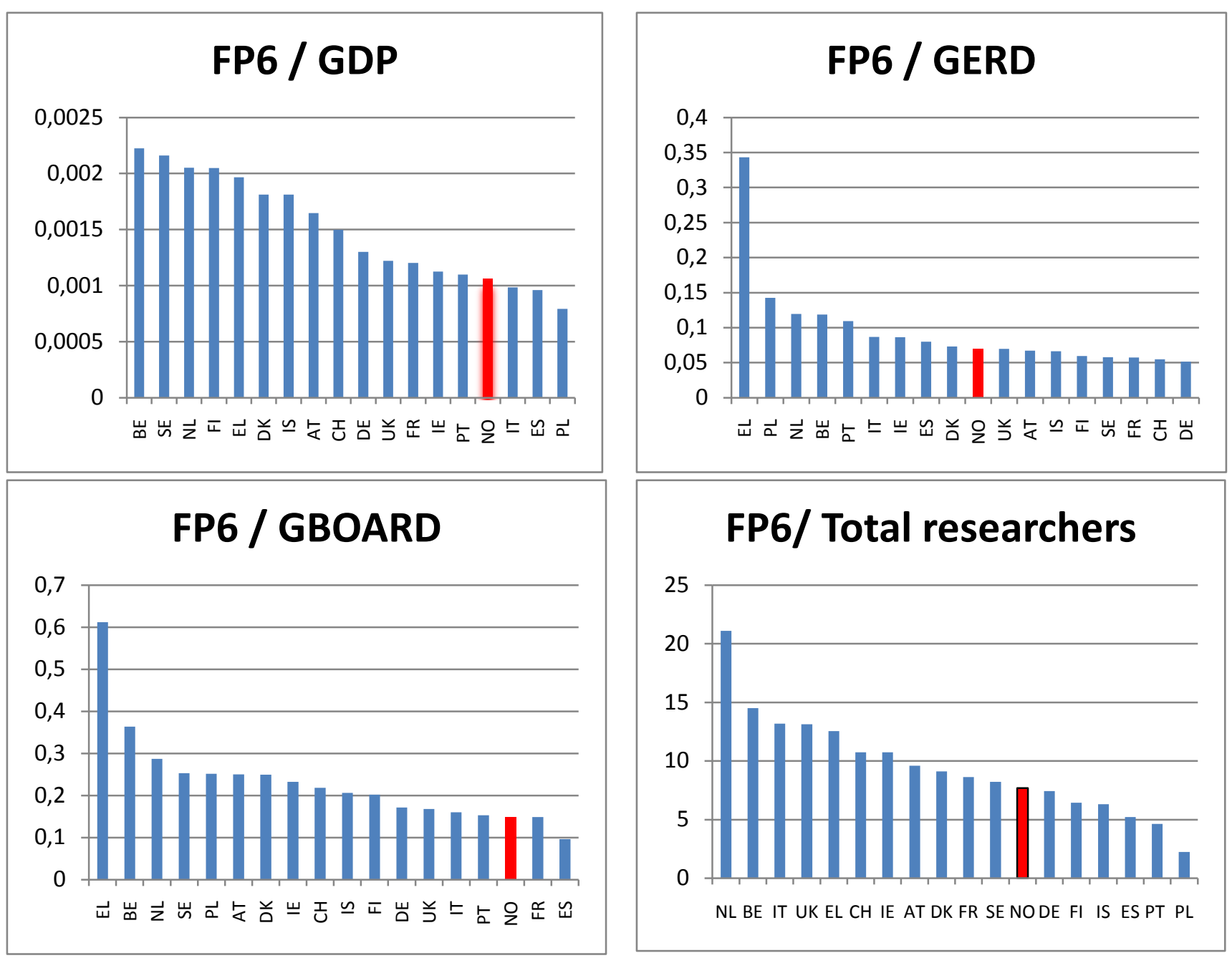

Note: GDP=Gross Domestic Product; GERD =Gross Expenditure on R\&D; GBOARD=Government Budget Appropriations or Outlays for R\&D. Scale in first 3 figures: billion Euro. Last figure shows average contribution measured in 10000 Euro by total number of researchers in the country (head count).

Figure 3.5 Performance indicators on participation in FP6. EU contribution to Norwegian researchers in €thousand (=FP6).

The histograms in the figure labelled "FP6/GDP" show a ranking of countries in terms of their economic return in FP6 (EU-contribution to the country divided by the GDP in 2006 of the country, measured in million Euros). National contributions to the Framework Programmes are largely determined by the national shares of EUs GDP. Norway had a lower EU-contribution per €million of GDP compared with many Member States and compared to Iceland and Switzerland which, similar to Norway, are associated members in the Framework Programmes.

The figure FP6/GERD shows a ranking of countries in terms of EU-contribution from the FP6 to the country, divided by the total intramural expenditures on R\&D in 2006 of the country measured in €millions. The figure demonstrates the role of FP6 in total research funding of the countries included. Norway is situated in an intermediary position. 
The figure FP6/GBOARD shows a ranking of countries in terms of EU-contribution from the FP6 to the country divided by the total government budget appropriation (or outlays) for R\&D measured in €millions. The figure demonstrates the role of FP6 compared to the total government R\&D funding, demonstrating that in terms of total Government R\&D funding funding FP6 plays a less significant role in Norway compared to many other countries.

The figure FP6/Total researchers shows a ranking of countries in terms of EU-contribution from the FP6 to the country divided by the total number of researchers ${ }^{32}$ in the country. The figure gives an indication of the FP6 funding available per researcher if evenly distributed.

All these graphs in Figure 3.5 indicate that compared to other countries Norway could have had a higher economic return ratio compared to other participating countries, given the fundamentals of the Norwegian research and economic system. In particular, the economic return in relation to total gross government outlays or appropriation on $R \& D$ (FP6/GBOARD) and also to the number of researchers (FP6/Total researchers) in Norway is considerably lower than those in many other Member States.

Hence, national mobilization and positioning strategies for enhanced participation in the Framework Programmes seem to still have a "raison d'être", as there are differences in how effectively the countries participate in FPs, and Norway seems to perform below its national potential. According to the indicators depicted in Figure 3.5, countries such as the Netherlands, Denmark and Sweden perform better than Norway.

\subsubsection{Priority areas}

In total, approximately 10000 projects (i.e. contracts) and 73000 participations ${ }^{33}$ have been registered in FP6 (excluding EURATOM), compared with about 16,000 projects and 77,145 participations in FP5. However, if the instrument "Human resources and mobility" contracts (basically Marie Curie actions - MCA) is excluded, the number of projects in the FP6 was about 5400, i.e. less than one third of the number of projects in FP5. Despite a significantly larger budget, the FP6 implemented considerably fewer and larger projects than FP5, with an average number of 12 participants per FP6 project. ${ }^{34}$ The structuring effect of the Integrated Projects (IPs) and Network of Excellence (NoEs) in terms of consolidation and concentration, introduced as new instruments in FP6, is evident.

32 Both public and private sector, head count.

33 One participation is registered when an organisation is registered as consortium partner (not subcontractor) in an FP6 contract. If the same organisation is participating in several FP6 projects, all these projects are counted as distinct participations for this organisation. A legal entity cannot participate more than once in the same EU-contract.

34 Here we consider all FP6 projects excluding Marie Curie Actions. 
The total number of FP6 projects involving at least one Norwegian participant (hereafter called Norwegian projects in FP6) is 834 and the total number of Norwegian participations in these projects was $1274^{35}$. Thus, the share of FP6 projects with Norwegian participation is 8.3 per cent (compared with 6.6 per cent in FP5) while the Norwegian share of participations in FP6 is 1.8 per cent. 579 of the projects (69 per cent) had only one Norwegian participation. This is 46 per cent of the participations. The remaining participations (54 per cent) were distributed among 255 projects with 2 to 10 Norwegian participations. Two projects had 10 Norwegian participations. Norwegian partners coordinated 149 projects (18 per cent of all EU-projects with Norwegian participation). These coordinators receive 22 per cent of the EU contribution to Norwegian participants, while the projects they run also include other Norwegian participations, representing altogether 29 per cent of the EU contribution to Norwegian participations.

Table 3.1 provides an overview of the distribution of these 834 projects and 1285 participations as well as EU contribution in €thousand according to priority areas.

35 After a cleaning of some duplicates among the 1285 in the CORDA database we are left with 1274 participations. 
Table 3.1 Norwegian participation in the FP6 by priority areas. Number of contracts, number of participations and EC financial contribution (in €thousand). EURATOM contracts are excluded.

\begin{tabular}{|c|c|c|c|c|}
\hline \multirow{3}{*}{ 西 } & \multirow{3}{*}{ Priority Area } & \multicolumn{3}{|c|}{ All Instruments - NORWAY FP6 } \\
\hline & & \multirow{2}{*}{$\begin{array}{l}\text { Contracts } \\
\text { No. }\end{array}$} & \multirow{2}{*}{$\begin{array}{l}\text { Participations } \\
\text { No. }\end{array}$} & \multirow{2}{*}{$\begin{array}{l}\text { EC financial } \\
\text { contribution to } \\
\text { participants } \\
\text { '000 Euros }\end{array}$} \\
\hline & & & & \\
\hline \multirow{12}{*}{ 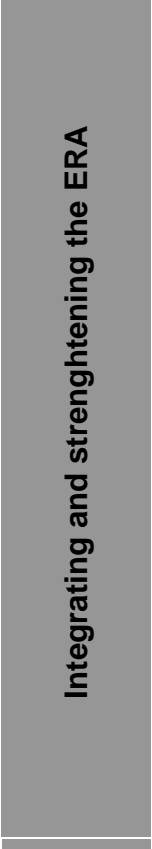 } & 1. Life sciences, genomics and biotechnology for health (LIFE) & 45 & 55 & 17544 \\
\hline & 2. Information society technologies (IST) & 117 & 176 & 54102 \\
\hline & $\begin{array}{l}\text { 3. Nanotechnologies and nanosciences, knowledge-based } \\
\text { multifunctional materials and new production processes (NMP) }\end{array}$ & 40 & 57 & 15468 \\
\hline & 4. Aeronautics and space (AERO) & 27 & 31 & 8637 \\
\hline & 5. Food quality and safety (FOOD) & 45 & 79 & 23099 \\
\hline & $\begin{array}{l}\text { 6. Sustainable development, global change and ecosystems } \\
\text { (SUST) }\end{array}$ & 161 & 324 & 78656 \\
\hline & $\begin{array}{l}\text { 7. Citizens and governance in a knowledge-based society } \\
\text { (CITIZEN) }\end{array}$ & 40 & 55 & 10701 \\
\hline & $\begin{array}{l}\text { Policy support and anticipating scientific and technological needs } \\
(\text { SSP+NEST) }\end{array}$ & 84 & 100 & 11896 \\
\hline & Horizontal research activities involving SMEs (SME) & 77 & 157 & 16682 \\
\hline & Specific measures in support of international cooperation (INCO) & 16 & 17 & 2431 \\
\hline & Support for the coordination of activities (ERANET) & 40 & 47 & 8679 \\
\hline & $\begin{array}{l}\text { Support for the coherent development of research \& innovation } \\
\text { policies }\end{array}$ & 2 & 6 & 164 \\
\hline \multirow{4}{*}{ 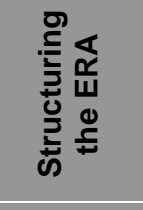 } & Research and innovation (INNO) & 21 & 38 & 4607 \\
\hline & Human resources and mobility (MCA) & 89 & 98 & 19949 \\
\hline & Research infrastructures (RI) & 20 & 24 & 10557 \\
\hline & Science and society (S\&S) & 10 & 10 & 722 \\
\hline Euratom & Euratom & (11) & (14) & (175) \\
\hline \multicolumn{2}{|l|}{ Total } & 834 & 1274 & 283897 \\
\hline
\end{tabular}

Source: European Commission and NIFU STEP. 


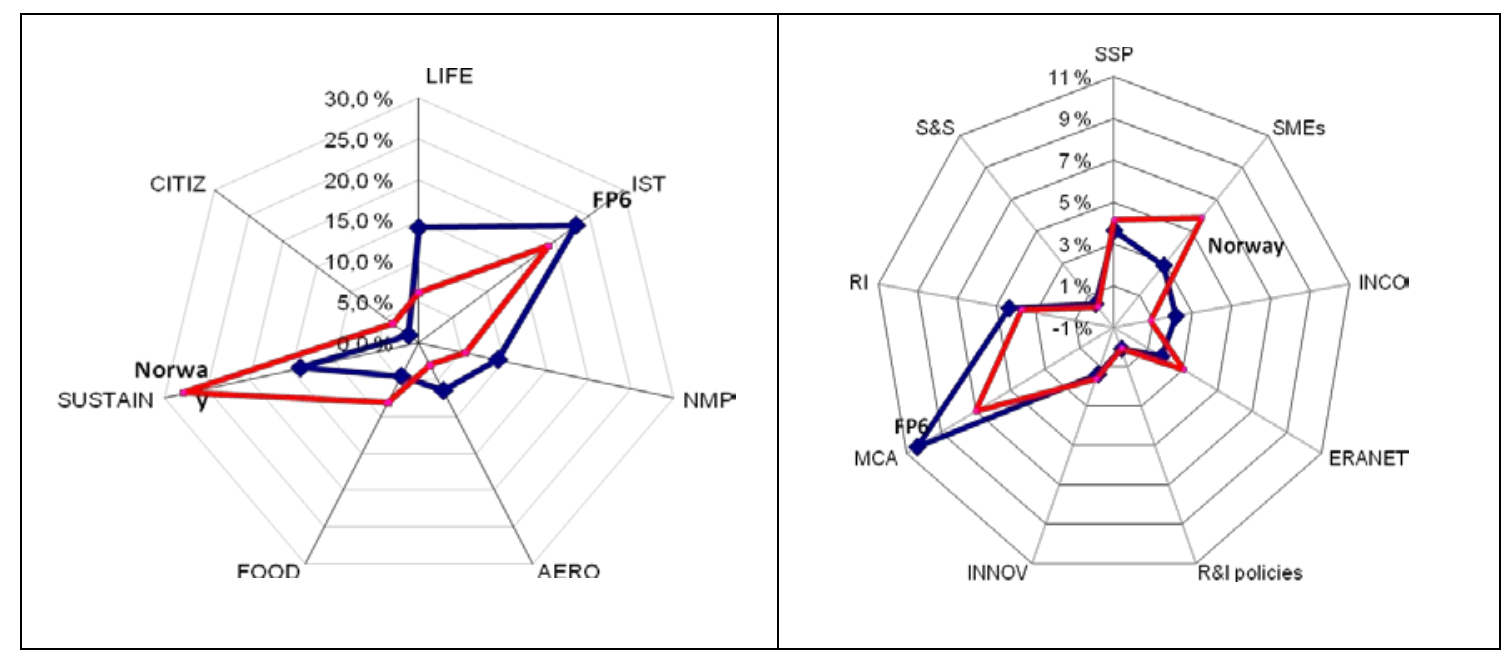

Figure 3.6 EU-contribution to FP6 (blue) and to Norwegian participants (red) by priority area. Percentages of total FP6-contribution to contracts.

Figure 3.6 shows the relative distribution of the EU-contribution by priority areas in FP6 (total) and for Norwegian participants. It is evident that Norwegian participation in the priority areas SUST, FOOD, SME and ERA-NET attracted a greater share of FP6 funding compared with the the distribution of the distribution of EU-contribution to priority areas in the entire FP6. Conversely, LIFE, IST, NMP, AERO, INCO and MCA attracted lower shares of FP6 funding than the break-even norm.

The break-even criterion or "juste retour" can be used as a yardstick to identify areas of strengths and weaknesses of the national research system, i.e. as an indicator of revealed strengths and weaknesses within the competitive environment of the Framework Programmes. This ultimately renders possible policy actions based on rational analysis. These analyses may lead to policies for the enhancement of national research activities within research fields with "low participation" and/or reinforcing national research activities in fields with "strong" participation.

With this as an important introductory clarification, Table 3.2 corroborates also these findings. In particular, LIFE, NMP and AERO thematic priority areas show considerably lower levels of participation than what is necessary for an economic return ratio close to 1.0. IST is also low in terms of Norwegian participation. It may also be mentioned that Norwegian participation in NEST - the programme which resembles in its design and organisation to the ERC activities in the FP7 - had only two Norwegian participations. 
Table 3.2 Norwegian shares of total EU-contribution in the FP6 by priority areas.

\begin{tabular}{|c|c|c|c|}
\hline \multicolumn{2}{|c|}{ Priority Area } & \multirow{2}{*}{$\begin{array}{c}\text { Norwegian } \\
\text { Participations } \\
\% \text { of all FP6 } \\
0.8 \%\end{array}$} & \multirow{2}{*}{$\begin{array}{c}\text { EC financial } \\
\text { contribution to } \\
\text { Norwegian } \\
\text { participants } \\
\% \text { of all FP6 } \\
0.8 \%\end{array}$} \\
\hline \multirow{12}{*}{ 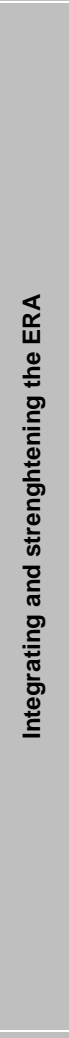 } & $\begin{array}{l}\text { 1. Life sciences, genomics and biotechnology } \\
\text { for health (LIFE) }\end{array}$ & & \\
\hline & 2. Information society technologies (IST) & $1.3 \%$ & $1.4 \%$ \\
\hline & $\begin{array}{l}\text { 3. Nanotechnologies and nanosciences, } \\
\text { knowledge-based multifunctional materials and } \\
\text { new production processes (NMP) }\end{array}$ & $1.0 \%$ & $1.0 \%$ \\
\hline & 4. Aeronautics and space (AERO) & $0.9 \%$ & $0.8 \%$ \\
\hline & 5. Food quality and safety (FOOD) & $2.5 \%$ & $3.1 \%$ \\
\hline & $\begin{array}{l}\text { 6. Sustainable development, global change } \\
\text { and ecosystems (SUST) }\end{array}$ & $3.1 \%$ & $3.4 \%$ \\
\hline & $\begin{array}{l}\text { 7. Citizens and governance in a knowledge- } \\
\text { based society (CITIZEN) }\end{array}$ & $2.8 \%$ & $4.4 \%$ \\
\hline & $\begin{array}{l}\text { Policy support and anticipating scientific and } \\
\text { technological needs (SSP+NEST) }\end{array}$ & $2.2 \%$ & $2.0 \%$ \\
\hline & $\begin{array}{l}\text { Horizontal research activities involving SMEs } \\
\text { (SME) }\end{array}$ & $2.9 \%$ & $3.5 \%$ \\
\hline & $\begin{array}{l}\text { Specific measures in support of international } \\
\text { cooperation (INCO) }\end{array}$ & $0.7 \%$ & $0.7 \%$ \\
\hline & $\begin{array}{l}\text { Support for the coordination of activities } \\
\text { (ERANET) }\end{array}$ & $3.9 \%$ & $3.0 \%$ \\
\hline & $\begin{array}{l}\text { Support for the coherent development of } \\
\text { research \& innovation policies }\end{array}$ & $3.6 \%$ & $1.2 \%$ \\
\hline \multirow{5}{*}{ 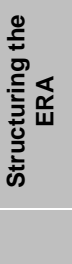 } & Research and innovation (INNO) & $2.1 \%$ & $2.0 \%$ \\
\hline & Human resources and mobility (MCA) & $1.2 \%$ & $1.2 \%$ \\
\hline & Research infrastructures (RI) & $1.4 \%$ & $1.5 \%$ \\
\hline & Science and society (S\&S) & $1.0 \%$ & $0.9 \%$ \\
\hline & Total & $1.8 \%$ & $1.7 \%$ \\
\hline
\end{tabular}

Note: The Norwegian government contributes to 2.04 -2.1 per cent of the total costs in FP6. Thus, Norwegian shares of EU-contribution lower than 2.04 -2.1 range indicate lower than "expected" levels of Norwegian participation. Conversely, shares higher than 2.04-2.1 indicate higher than "expected" participation levels. 
Table 3.3 Success rate for proposals with Norwegian participation in priority areas compared with the figures for the total FP6. Per cent.

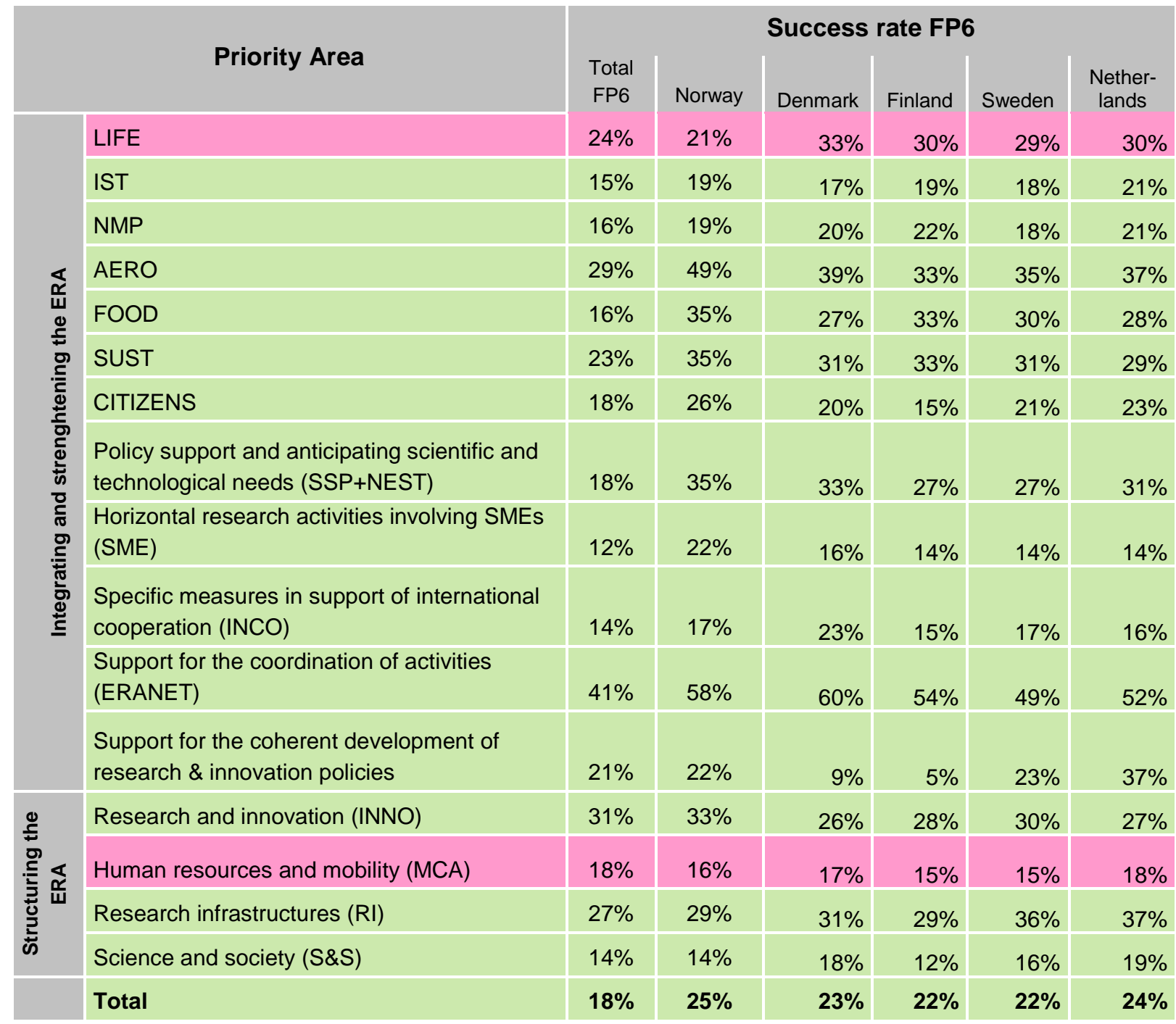

Source: European Commission, June 2008.

Note: Green indicates better Norwegian success rate than overall FP6 figures, pink lower Norwegian success rate.

Table 3.3 shows the success rates for the different priority areas. Projects with Norwegian partners had a higher success rate than the average overall success rate for FP6, and also slightly higher than countries as Finland, Sweden and Denmark. The success rate for Norwegian LIFE and MCA applications were, however, somewhat below the average.

Figure 3.7 presents the distribution of the number of Norwegian participations in FP6 by priority areas and by type of beneficiary. Figure 3.8 depicts the EU contribution to Norwegian participants by priority areas and types of beneficiaries in €million. Note that EU contribution to participants in MCA exceeded in total value that in LIFE. 


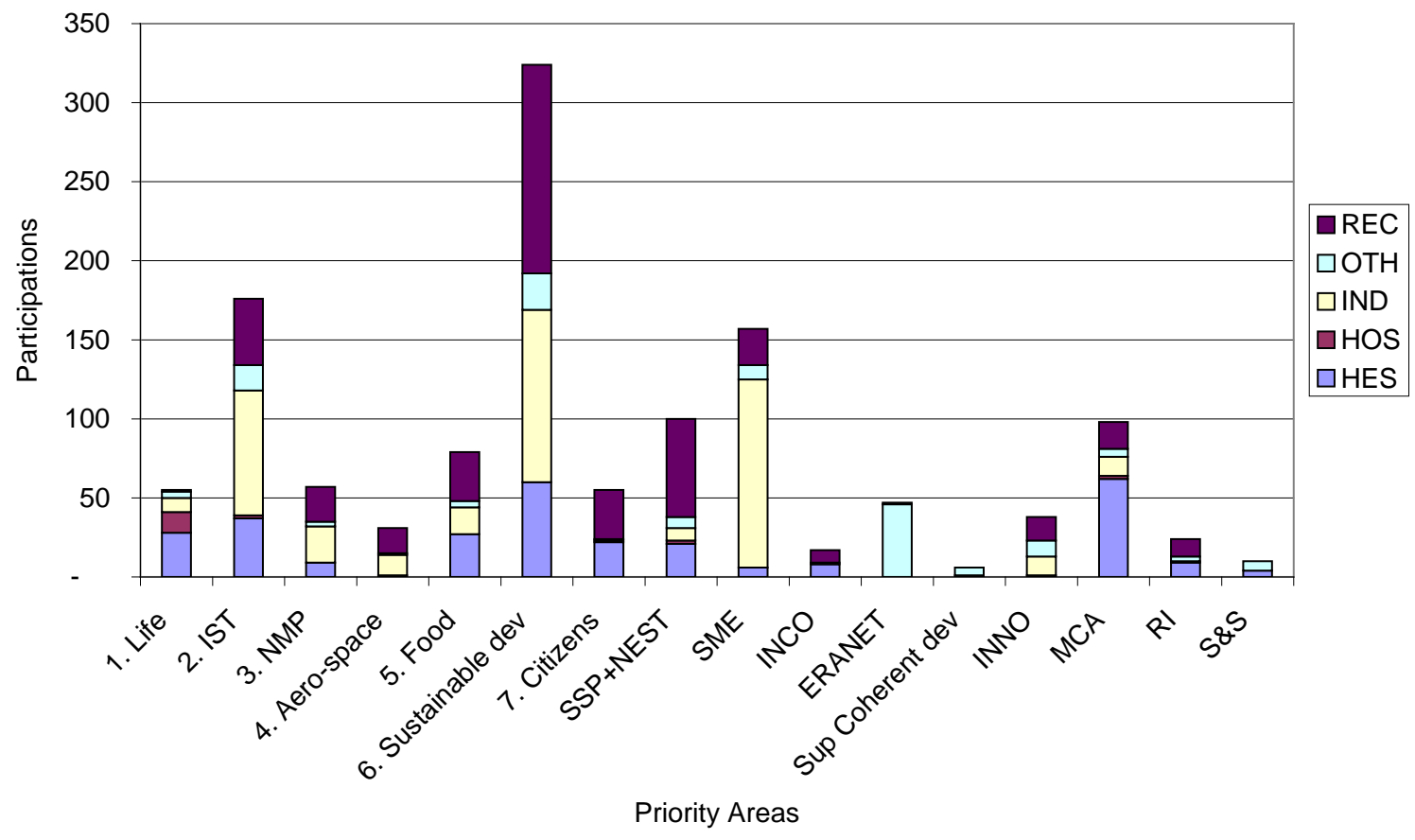

Figure 3.7 Number of Norwegian FP6 participations in priority areas.

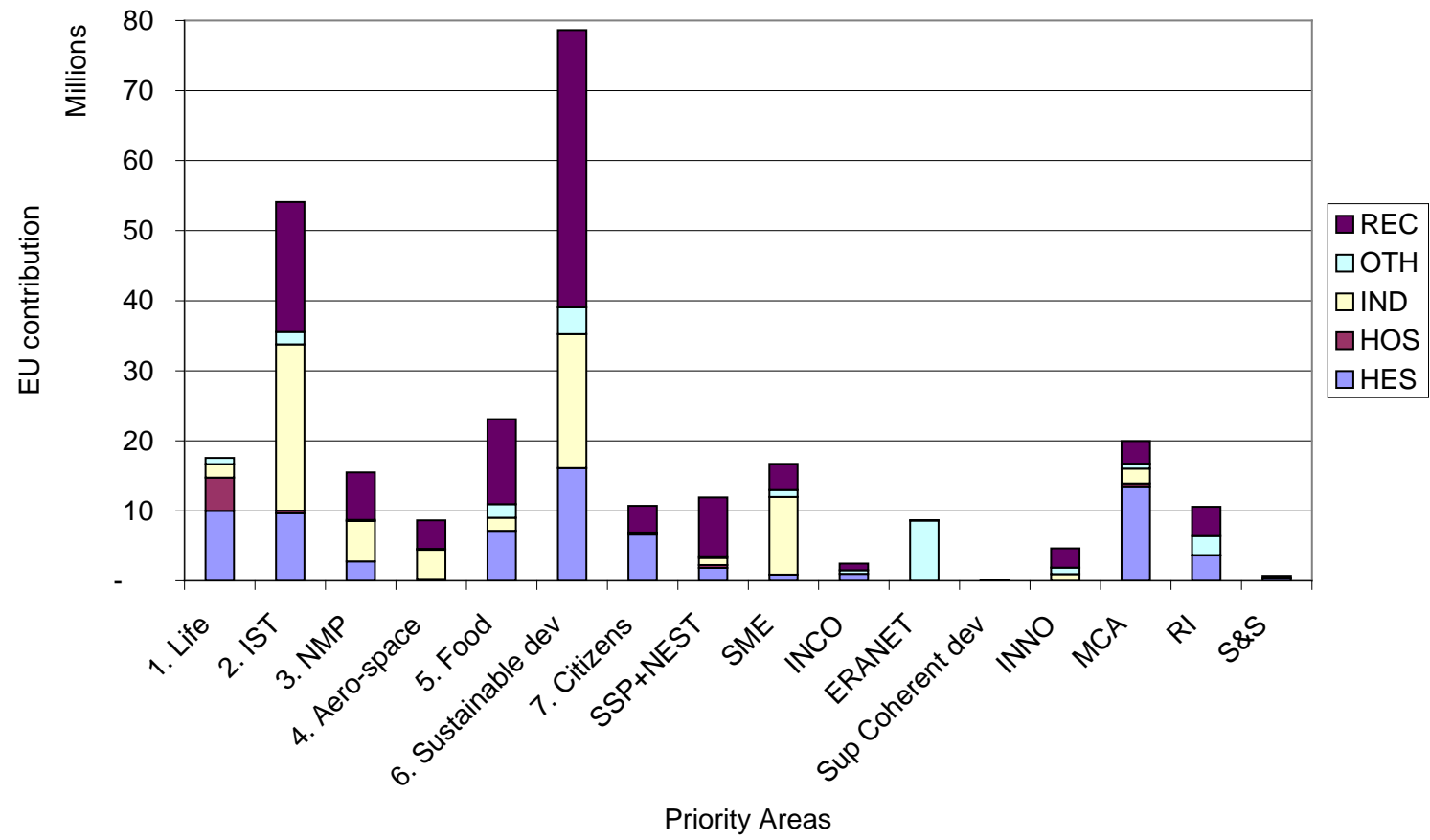

Figure 3.8 EU contribution to Norwegian participants in FP6 by priority areas. €Million.

\subsubsection{Instruments}

Table 3.4 shows the distribution of participations and EU contribution to FP6 and

Norwegian participants by types of instruments. In FP6, the lion's share of funding (40 per cent) was allocated to Integrated Projects, which was almost identical to what Norwegian 
participants obtained. For Network of Excellence, Norwegian participation and the share of funding was also close to the relative size of the instrument (7 per cent).

Table 3.4 EU-contribution and number of participations by type of instrument. Total FP6 and EU-contribution to Norwegian researchers in FP6

\begin{tabular}{|l|c|c|c|c|}
\hline \multicolumn{1}{|c|}{ Instrument } & \multicolumn{2}{|c|}{ FP6 } & \multicolumn{2}{c|}{ NORWAY - FP6 } \\
\hline \multicolumn{1}{|c|}{} & Participations & $\begin{array}{c}\text { EC financial } \\
\text { contribution to } \\
\text { participants }\end{array}$ & Participations & $\begin{array}{c}\text { EC financial } \\
\text { contribution to } \\
\text { participants }\end{array}$ \\
\hline IP - Integrated Projects & $24 \%$ & $40 \%$ & $26 \%$ & $41 \%$ \\
\hline NOE - Networks of Excellence & $7 \%$ & $8 \%$ & $7 \%$ & $7 \%$ \\
\hline STREP - Specific Targeted Research Projects & $29 \%$ & $27 \%$ & $25 \%$ & $25 \%$ \\
\hline CA - Coordination Actions & $10 \%$ & $4 \%$ & $12 \%$ & $7 \%$ \\
\hline SSA - Specific Support Actions & $11 \%$ & $6 \%$ & $8 \%$ & $4 \%$ \\
\hline CLR - Collective Research Projects & $2 \%$ & $1 \%$ & $3 \%$ & $2 \%$ \\
\hline CRAFT - Co-operative Research Projects & $5 \%$ & $2 \%$ & $9 \%$ & $4 \%$ \\
\hline MCA - Marie Curie Actions & $11 \%$ & $10 \%$ & $7 \%$ & $7 \%$ \\
\hline I3 - Specific Actions to Promote Research Infr. & $2 \%$ & $3 \%$ & $1 \%$ & $3 \%$ \\
\hline Total & $100 \%$ & $100 \%$ & $100 \%$ & $100 \%$ \\
\hline
\end{tabular}

On the other hand, the Norwegian participation in Marie Curie Actions (MCAs) and Specific Support Actions (SSA) was low. MCA accounted for 7 per cent of Norwegian participation, but 11 per cent of all participations in FP6. The similar figures for SSA are 8 per cent for Norway versus 11 per cent in FP6. Norwegian participation in Specific Targeted Research Projects (STREPs) is also slightly below average, whereas the participation in Co-operative Research Projects (CRAFT) and Coordination Actions (CA) was clearly above average.

Hence, we can conclude that the new integrating instruments (in particular the IPs) did not represent a significant obstacle to Norwegian participation in FP6, nor did they facilitate the Norwegian participation in any conspicuous way. Conversely, Cooperative research projects (CRAFT), Collective research projects (CRP) and Coordination actions (CA) are instruments which contribute to increasing the economic return for Norway. 


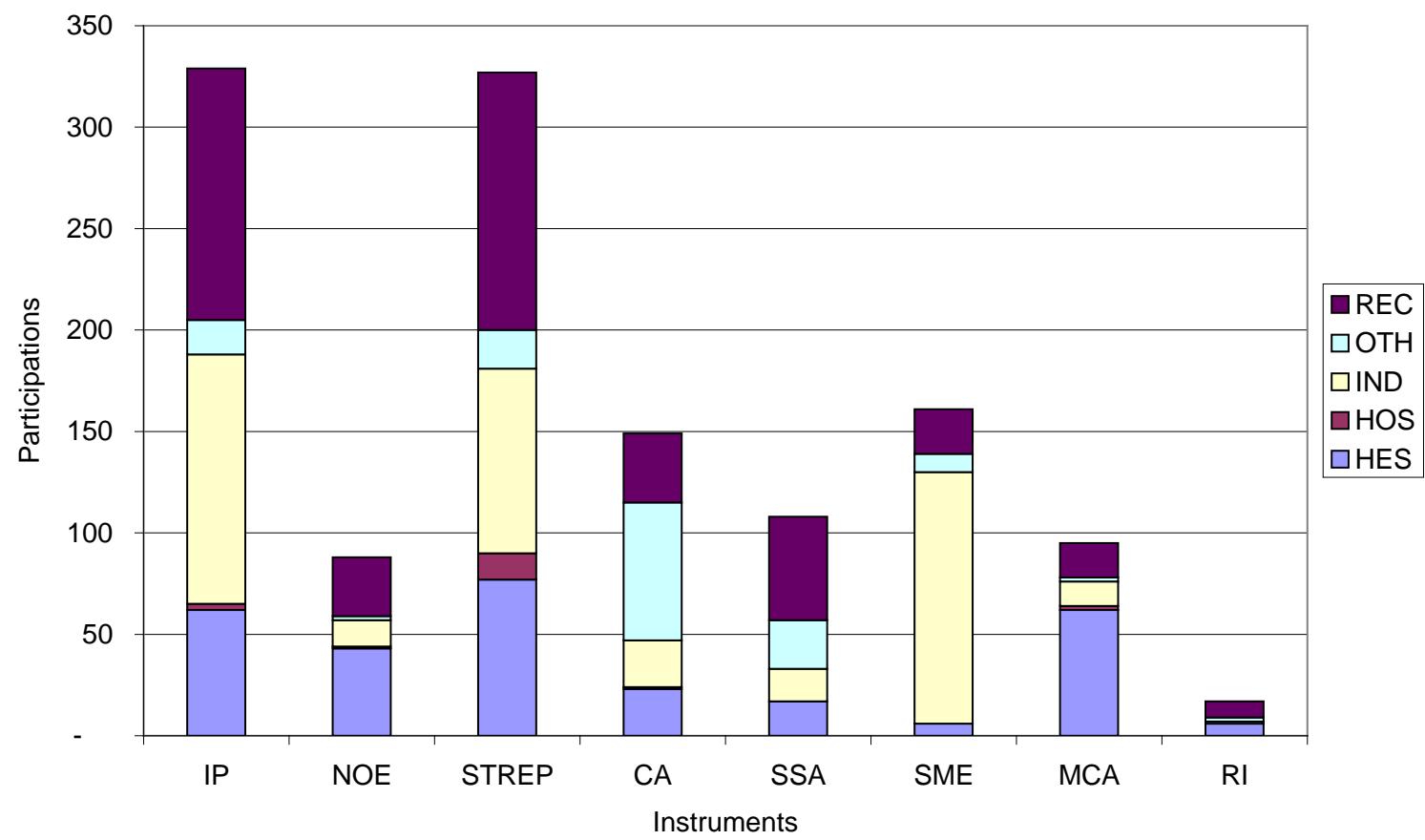

Figure 3.9 Distribution of Norwegian FP6 participations according to instruments and sectors

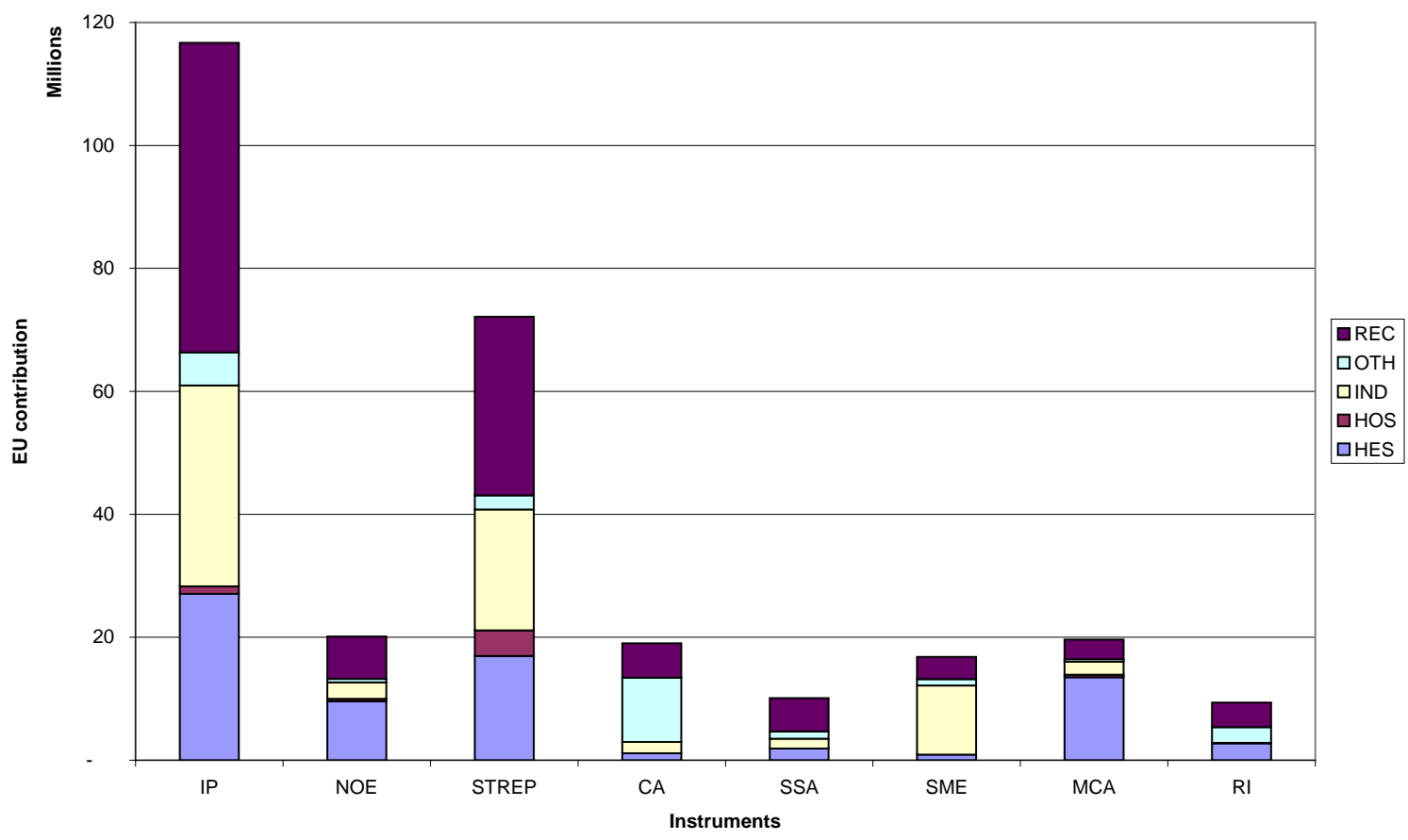

Figure 3.10 Distribution of EU-contributions to Norwegian FP6 participations according to instruments and sectors 


\subsubsection{Participation by type of beneficiary}

Norwegian research institutes (REC) received 38 per cent of the total EU contribution to Norway in FP6, as shown in Table 3.4. Norwegian participants from the business sector received less funding in nominal terms (€72 million) in FP6 compared to the EU-funding they received in FP5 (€73million). Norway was among the countries with the highest national EU contribution shares to the business sector both in FP5 also in FP6, Figure 3.12.

Norwegian higher education institutions (HES) received 28 per cent (€80 million) of EU contribution to Norway; two per cent of that (€6.1 million) went to university hospitals. It is worthwhile noting that Norwegian higher education institutions increased their number of participations and their EU contribution from FP5 to FP6 by the same proportional increase of the FPs budget compared to FP5 budget. This is not the case with the Norwegian research institutes or Norwegian industry. "Other types of beneficiaries” (OTH) received $€ 14$ million more in FP6 than in FP5. This chiefly reflects the fact that the Research Council of Norway (RCN) was the most active participant in this group of beneficiaries and one of the most active participants in ERA-NETs.

Table 3.5 EU funding by type of beneficiary. Total EU contribution in FP6 and EU contribution to Norwegian researchers in FP6 and in FP5 (€thousand).

\begin{tabular}{|c|c|c|c|c|c|c|}
\hline \multirow[b]{2}{*}{ Type of beneficiary } & \multicolumn{2}{|c|}{ Total FP6 } & \multicolumn{2}{|c|}{ NORWAY FP6 } & \multicolumn{2}{|c|}{ NORWAY FP5 } \\
\hline & Euros in 1000 & $\%$ & Euros in 1000 & $\%$ & Euros in 1000 & $\%$ \\
\hline HES - Higher Education & 6156380 & $37 \%$ & 80001 & $28 \%$ & 63117 & $25 \%$ \\
\hline IND - Industry & 3027373 & $18 \%$ & 71884 & $25 \%$ & 73117 & $29 \%$ \\
\hline REC - Research institutes & 5220463 & $31 \%$ & 108198 & $38 \%$ & 103293 & $42 \%$ \\
\hline OTH - Others & 2261049 & $14 \%$ & 23814 & $8 \%$ & 9094 & $4 \%$ \\
\hline Total & 16665265 & $100 \%$ & 284072 & $100 \%$ & 248621 & $100 \%$ \\
\hline
\end{tabular}

Note: The figures for total FP6 in this table include EURATOM-funding.

Source: European Commission and NIFU STEP 


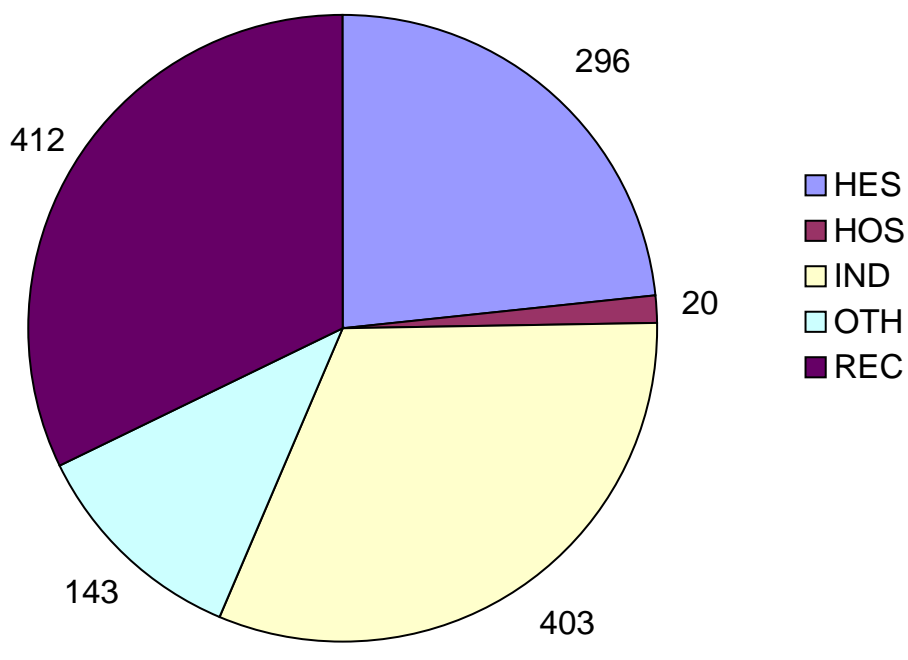

Figure 3.11 Number of participations in the FP6 by type of beneficiary.

Note: HES: Higher Education; HOS: University hospitals; IND: Business sector; OTH: Other type of beneficiaries; REC: Research institutes.

Source: European Commission and NIFU STEP

Figure 3.11 shows the distribution of the Norwegian participations by type of beneficiary in FP6. Norwegian Higher Education Sector (HES) had a significantly lower number of participations compared to both the research institute sector (REC) and the business sector (IND), while the Norwegian business sector had a fairly large number of participations (almost as many as the Norwegian RECs), but with considerably lower average EU contribution by participation than the Norwegian HESs. 


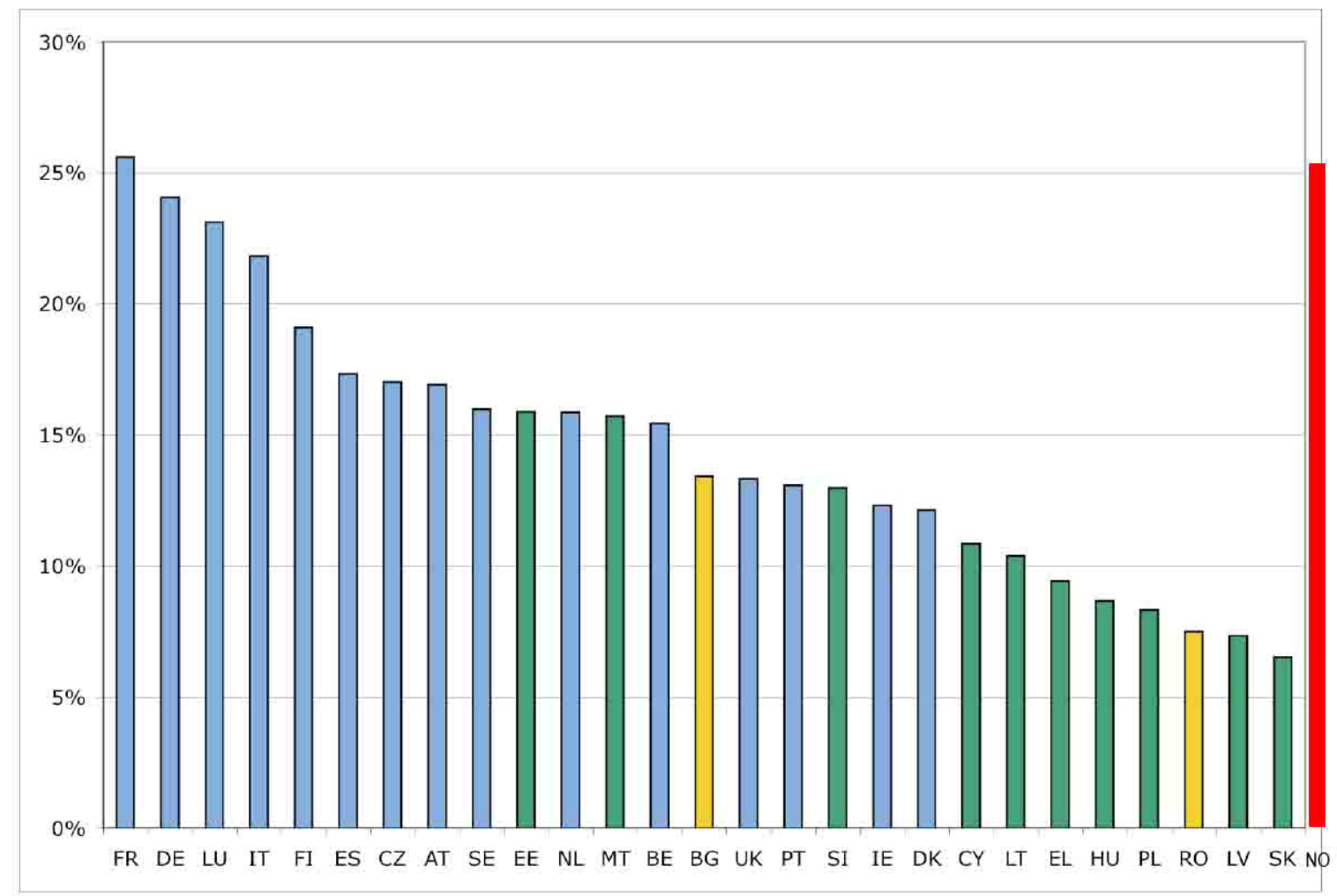

Source: Vonortas EU-15 shown in blue. 2005 new Member States in green.red. Subsequent entrants in yellow

Figure 3.12 Share of industrial participants. Percentages by country, FP6.

\section{International collaboration links in the FP6}

In total, Norwegian institutions had 23557 collaboration links (co-participations) with other R\&D-organisations in FP6, compared to 5,933 collaboration links in FP5. Based on this figure, it is evident that FP6 extended the networks and intensified international collaboration of the Norwegian researchers. Note that this was also an important goal for the Norwegian participation in FP6. About 13 per cent of these collaborative links represent collaborations with researcher organisations from UK, 12 per cent with German R\&D organisations, 11 per cent with French organisations, 8.5 per cent with Italian and 7 per cent with Dutch organisations.

\section{Institutional affiliation of Norwegian participants}

The research organisation SINTEF had the largest number of Norwegian participations in EU FP6. The second largest number of participations is found at the University of Oslo, followed by the University of Bergen and NTNU. These organisations are also the largest in Norway in terms of research, which shows that the size of R\&D activity as measured by the number of researchers and funding is a predictor for participation in EU FP6, as in preceding FPs. Hence, size seems to matter. The abbreviations in the figures are explained in Appendix 2. 

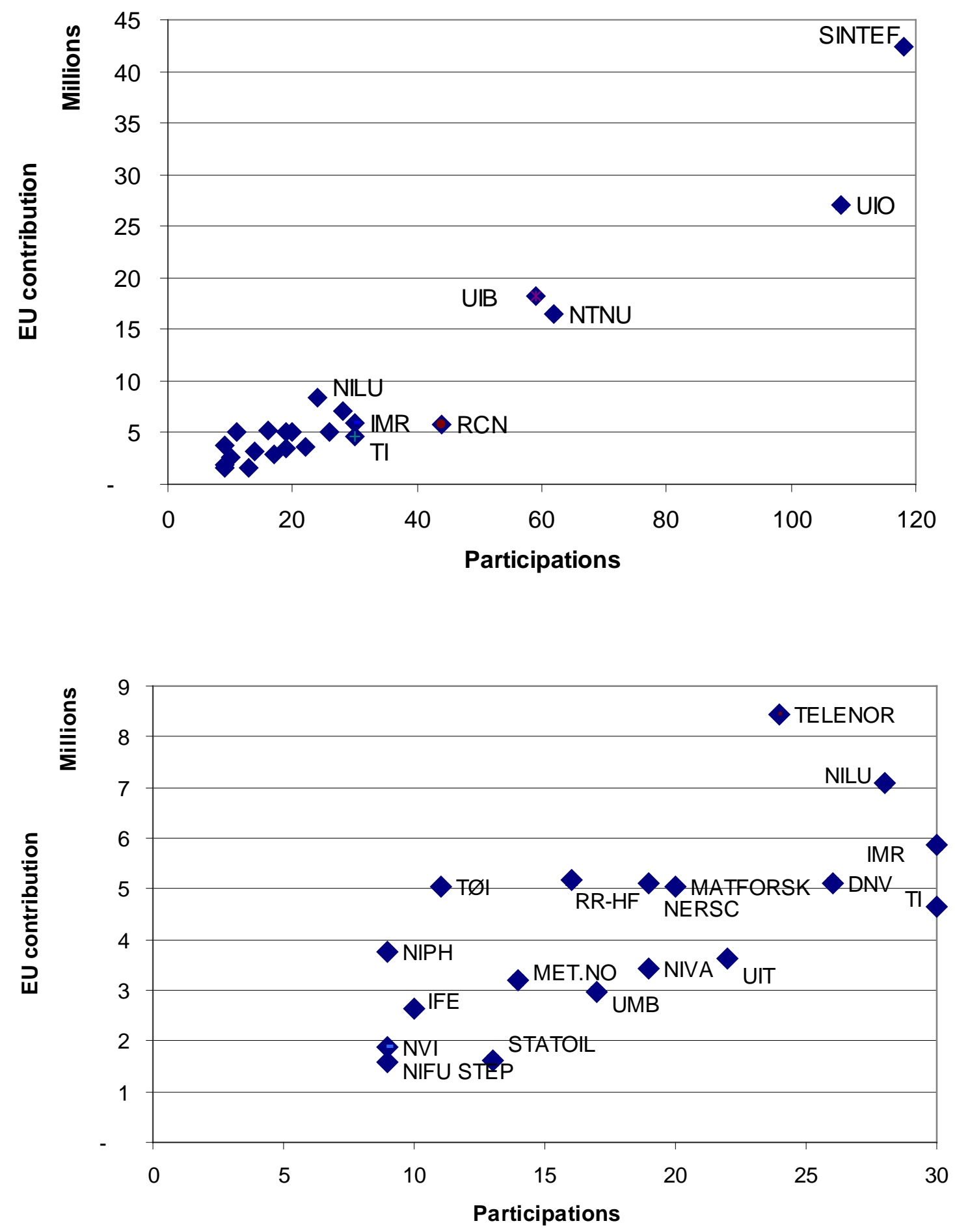

Figure 3.13 Number of participations and EU contribution in FP6. The upper figure shows the organisations with most participations, the lower organisations with participations between 9 and 30. 


\subsubsection{Geographical distribution of participation}

As mentioned above, the most important predictor for the level of Norwegian participation in FPs is the size of the participating organisations. Hence, the Norwegian geography of participation in FPs reflects where the largest R\&D organisations are located in Norway. The largest participation is found in the metropolitan region of Oslo and Akershus, which is where large $R \& D$ entities such as the University of Oslo, parts of the SINTEF group, Telenor R\&D, etc., are localized. This region accounts for 50 per cent of the Norwegian participations in FP7. The second largest region is Trøndelag (Trondheim region) where NTNU and parts of the SINTEF group are located - both large participants in EU FPs. Needless to say, this geographical distribution in Norway does not accord well with the national policy of "regional balance". However, the geographical distribution might become more balanced in the future as regional universities and colleges gain skills and experience in international research collaboration. The details of the regional distribution of FP7 participation in Norway are shown in Table 3.6.

Table 3.6 Norwegian FP6 participations by region and organisation type, per cent.

\begin{tabular}{|c|c|c|c|c|c|c|}
\hline Region & $\begin{array}{r}\text { Higher } \\
\text { education } \\
\text { institutions } \\
\text { (HES) }\end{array}$ & $\begin{array}{r}\text { Research institutes } \\
\text { (REC) }\end{array}$ & $\begin{array}{r}\text { University } \\
\text { hospitals } \\
\text { (HOS) }\end{array}$ & $\begin{array}{r}\text { Business } \\
\text { sector } \\
\text { (IND) }\end{array}$ & $\begin{array}{l}\text { Other } \\
(\mathrm{OTH})\end{array}$ & $\mathbf{N}$ \\
\hline Western Norway & 34.7 & 40.1 & 0.0 & 20.4 & 4.8 & 167 \\
\hline Oslo and Akershus & 20.7 & 30.3 & 3.0 & 31.1 & 15.0 & 628 \\
\hline Agder and Rogaland & 6.1 & 9.1 & 0.0 & 71.2 & 13.6 & 66 \\
\hline Trøndelag & 26.8 & 50.4 & 0.0 & 16.7 & 6.1 & 228 \\
\hline Svalbard & 33.3 & 0.0 & 0.0 & 66.7 & 0.0 & 3 \\
\hline South-Eastern Norway & 4.2 & 2.1 & 0.0 & 83.3 & 10.4 & 48 \\
\hline Northern Norway & 33.3 & 33.3 & 1.3 & 24.0 & 8.0 & 75 \\
\hline Hedmark and Oppland & 12.5 & 0.0 & 0.0 & 75.0 & 12.5 & 8 \\
\hline Info missing & 21.7 & 26.1 & 0.0 & 52.2 & 0.0 & 23 \\
\hline Total & 23.0 & 32.9 & 1.6 & 31.5 & 11.0 & 1246 \\
\hline
\end{tabular}

Note: In addition to the 1246 participations counted in this table there are 28 participations, in total 1274.

Source: ECORDA

\subsection{The Norwegian participation in FP7}

\subsubsection{Main features}

The total financial contribution ("participation fee" or "contingent") from the Norwegian government to FP7 will be approximately three times larger than the contribution to FP6. Although FP7 covers the period 2007-2013 (seven years), while FP6 covered 2003-2006 (four years), which explains some of this expected increase, the annual contribution to FP7 will increase significantly in the coming years. Whereas the level of financial contribution from Norway has increased incrementally compared to FP6 during the first years of FP7, it is expected to double by the end of FP7. 
Norway's annual financial contribution (contingent) to the EU for its participation in FP5 was $€ 62$ million. In FP6 and now at the first part of FP7, this contribution has risen to at least $€ 84$ million. The average EU contribution to Norwegian participants is now $€ 302,000$ (see also Table 3.12). However, within a project, a Norwegian coordinator will, on average, receive $€ 632,000$, whereas a partner (“ordinary project participant”), on average receives $€ 238,000$.

In the CORDA data for FP7 we identified 558 participations from Norway distributed to 389 projects (including projects from IDEAS and PEOPLE) of which 276 (71 per cent) had only one Norwegian participation. These 276 participations consist 49 per cent of the total number of all participations in the FP7 so far. The remaining participations (51 per cent) were distributed among 113 projects with 2 to 6 Norwegian participations each. There are Norwegian coordinator in 90 projects (23 per cent of projects). These coordinators receive 34 per cent of support for the Norwegian participation, while the projects they run also involve other Norwegian participations, in total representing 47 per cent of support to the Norwegian participations.

Figures published by the Research Council of Norway show that the success rate for FP7 applications with Norwegian participations is somewhat lower than comparable figures for Denmark and Sweden, but substantially higher than the total success rate for all countries (by August 2009). The Norwegian success rate was 22 per cent, the Swedish 23 per cent and the Danish 24 per cent, whereas the total success rate was only 16 per cent. Measured in financial resources, however, the Norwegian success is the same as the overall FP7 figures; the successful proposals cover 18 per cent of the applied amount. ${ }^{36}$

\subsubsection{Themes}

The highest number of Norwegian participations in FP7 so far has been in the SME programme. ENVIRONMENT is the theme in the Cooperation part of FP7 with the highest number of Norwegian participations. The details of Norway's pattern of participation in FP7 are shown in Figure 3.14 and Figure 3.15.

36 Similar figures for neighbour countries are higher: Denmark and Finland 22\% and Sweden 20\%. Source: Bladet Forskning 3/09, page 31.

(http://forskningsradet.ravn.no/bibliotek/forskning/200903/2009030019.html). 


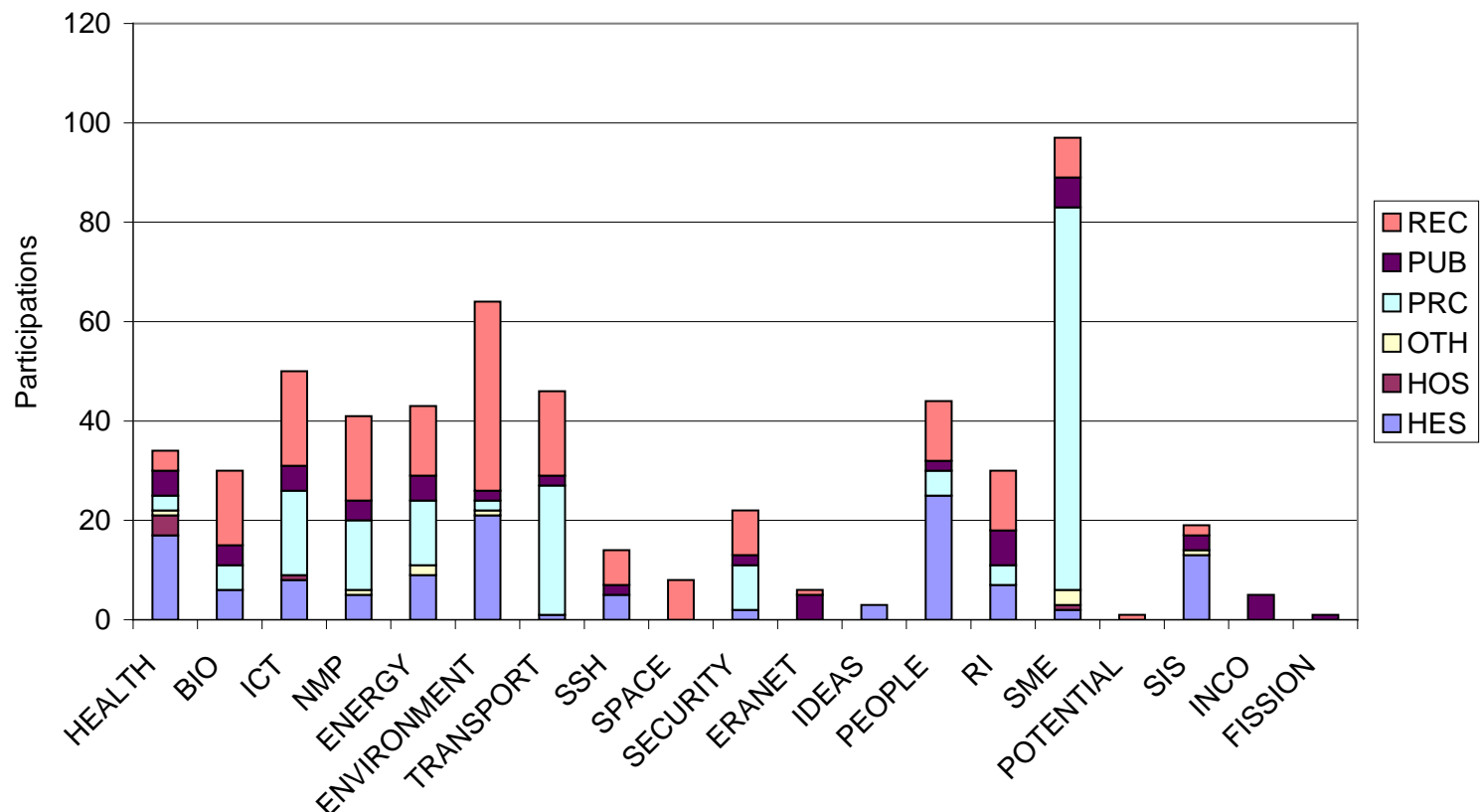

Sub-program

Figure 3.14 Number of Norwegian participations in FP7 by themes/programmes and by type of beneficiary. 2007-2008.

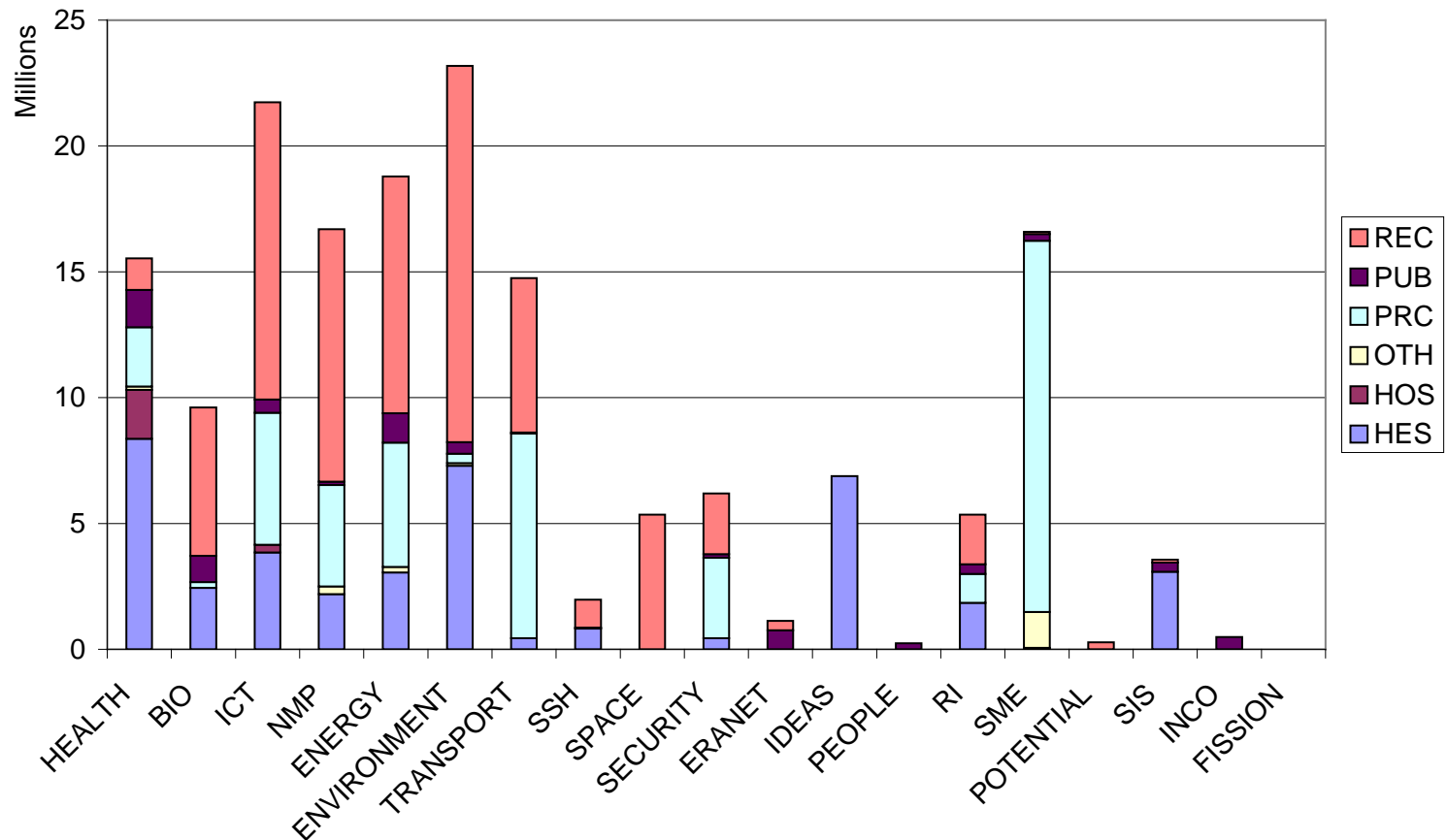

Figure 3.15 EU contribution to Norwegian participants in FP7 by themes/programmes and by type of beneficiary. 2007-2008.

Note: HES: Higher Education; HOS: University hospitals; PRC: Business sector; OTH: Other type of beneficiaries; REC: Research institutes. 
Table 3.7 Success rates by priority areas: Proposals with Norwegian participation compared to overall figures for FP7 (end of 2008). Per cent.

\begin{tabular}{|c|c|c|}
\hline Success rate by know result 31.12 .2008 & $\begin{array}{r}\text { Overall } \\
\text { success rate } \\
\text { FP7 }\end{array}$ & $\begin{array}{c}\text { Success rate } \\
\text { Norway FP7 }\end{array}$ \\
\hline HEALTH & $18 \%$ & $20 \%$ \\
\hline $\mathrm{BIO}$ & $15 \%$ & $18 \%$ \\
\hline ICT & $15 \%$ & $13 \%$ \\
\hline NMP & $11 \%$ & $25 \%$ \\
\hline ENERGY & $13 \%$ & $25 \%$ \\
\hline ENVIRONMENT & $14 \%$ & $24 \%$ \\
\hline TRANSPORT & $23 \%$ & $27 \%$ \\
\hline $\mathrm{SSH}$ & $11 \%$ & $13 \%$ \\
\hline SPACE & $28 \%$ & $40 \%$ \\
\hline SECURITY & $13 \%$ & $25 \%$ \\
\hline Total Cooperation & $15 \%$ & $20 \%$ \\
\hline $\mathrm{RI}$ & $38 \%$ & $42 \%$ \\
\hline SME & $16 \%$ & $24 \%$ \\
\hline POTENTIAL & $10 \%$ & $100 \%$ \\
\hline REGIONS & $18 \%$ & $0 \%$ \\
\hline Sis & $26 \%$ & $46 \%$ \\
\hline INCO & $22 \%$ & $63 \%$ \\
\hline Total Capacities & $18 \%$ & $30 \%$ \\
\hline ERA-NET & $57 \%$ & $50 \%$ \\
\hline Total excl. PEOPLE, IDEAS and EURATOM & $16 \%$ & $22 \%$ \\
\hline IDEAS & $2 \%$ & $1 \%$ \\
\hline PEOPLE/MCA & $30 \%$ & $18 \%$ \\
\hline Total PEOPLE, IDEAS & $12 \%$ & $10 \%$ \\
\hline Total & $14 \%$ & $20 \%$ \\
\hline
\end{tabular}

Source: Norwegian Research Council.

\subsubsection{Instruments}

In the FP7 the following funding schemes are in use:

1. Collaborative Projects, including combinations of Collaborative Projects and Coordination and Support Actions (CP/CP-CSA)

2. Networks of Excellence (NoE)

3. Coordination and Support Actions (CSA)

4. Research for the benefit of specific groups and Marie Curie Actions (Support for training and career development of researchers) (BSG/MC)

5. Support for frontier research (European Research Council), Risk sharing finance facilities and other minor types of instruments (ERC/RSFF/OTH)

Based on information from ECs Second Monitoring Report (October 2009), Collaborative Projects consist by far the largest part of FP7 in retained proposals both in terms of total numbers of applicants (52,7\%) and of requested EC contribution (72,8\%). The 1,349 retained proposals in BSG and Marie Curie Actions represent more than half (56,5\%) of 
the total number of all retained proposals in the FP7 (2007-2008). The Networks of Excellence funding scheme is almost of negligible size in terms of EU contribution. Figure how the instrument profile of the Norwegian participation in FP7. The Collaborative projects attracted the highest number of Norwegian participations (in retained proposals), both overall and for Norway. Norway has a higher share of retained proposals in the instruments CP/CP-CSA and CSA proposals and a lower share of Marie Curie Actions (BSG/MC) and ERC proposals compared to the FP7 (2007-2008) as a whole.

$\square$ CP,CP-CSA $\square$ NOE $\square$ CSA $\square$ BSG,MC $\square$ ERC

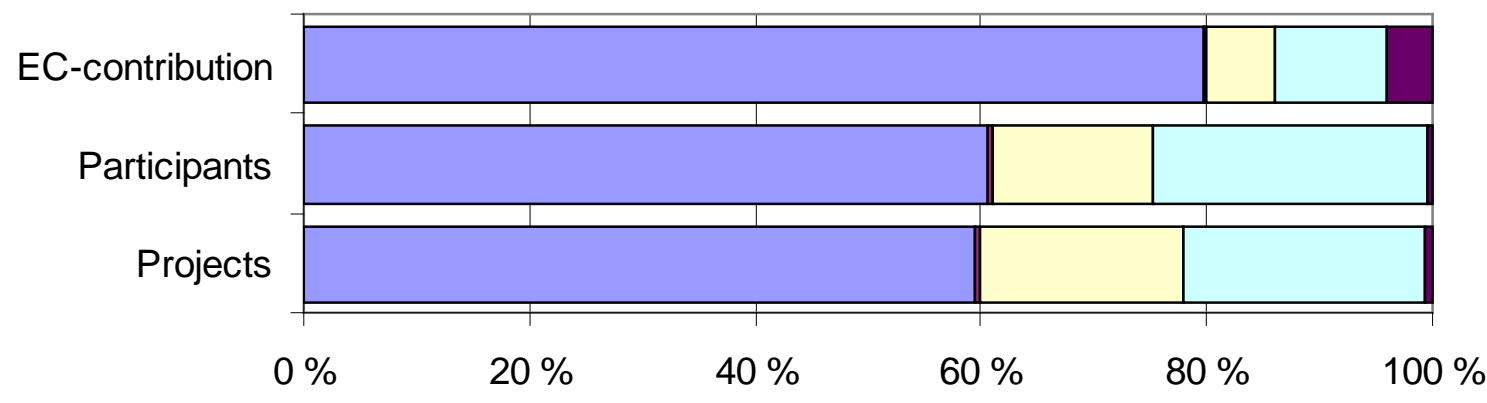

Source: CORDA data per April 2009

Figure 3.16 Norwegian FP participations by funding scheme: Requested EC contribution (EC-contribution), number of applicants (participants) and number of retained proposals (projects). Per cent.

\subsubsection{Participation by type of organisation}

Norway has a considerably lower proportion of participations from Higher education sector (HES) than the FP7. The participation of Norwegian research institutes on the other hand is higher than in the FP7 (33 per cent for Norway compared to 23 per cent in the FP7 (2007-2008)). 


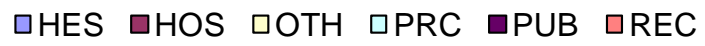

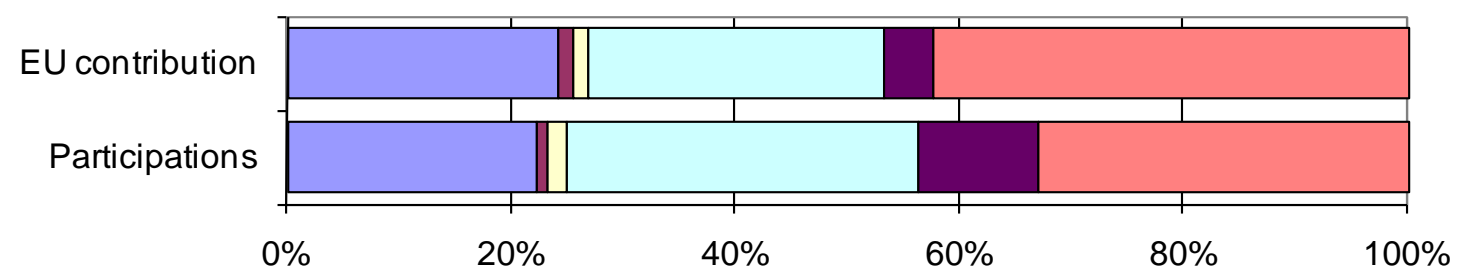

Source: CORDA data per April 2009.

Figure 3.17 Norwegian FP7 participations and requested EC contribution by organisation type.
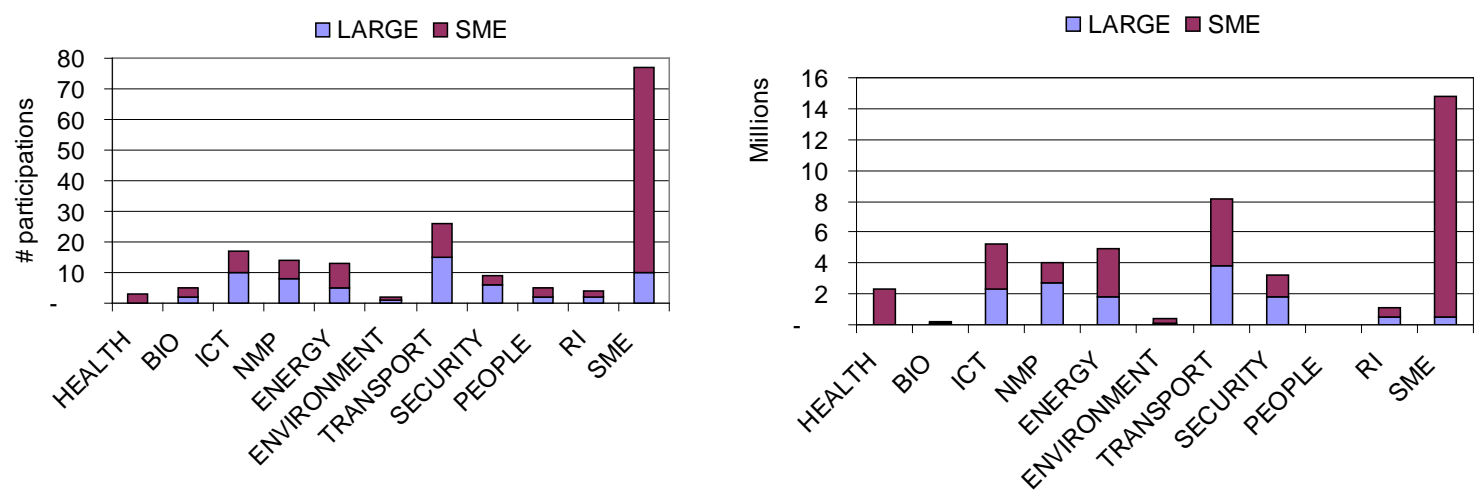

Figure 3.18 Norwegian FP7 participations (left) and requested EC contribution (right) by enterprise size. Source: CORDA data per April 2009.

Also the Norwegian business sector has a higher participation in FP7 compared with the business sectors in most other countries. Figure 3.18 shows that the large Norwegian enterprises have participations in ICT, NMP, ENERGY, TRANSPORT and SECURITY, but there is a quite large number of SME participations, particularly in the TRANSPORT and ICT themes. Though ECs statistics on SMEs are not fully reliable we note that 70 per cent of the SME in the FP7 participate in the Cooperation part of the FP7. The share of the Norwegian SMEs participating in the Cooperation part is much lower than 70 per cent, but of course, this is a direct consequence of the high participation of SMEs in the SME programme. It is difficult to assess the participation of Norwegian SMEs in the Cooperation part without a reliable benchmark, but the data suggest that there is potential for even higher SME participation in the Cooperation part of FP7 than the realised. Also, the EU contribution per SME participation in the Cooperation part of FP7 is on average larger than in the SME programme. TI and Nor-Tek (Norwegian office of PERA) have been especially active and 29 per cent of the contributions to Norwegian partners are in projects where these two partners are active. SINTEF is active in projects which give 19 per cent of contribution to the enterprises. 


\subsubsection{Gender}

The Second FP7 Monitoring Report reports that about 22 per cent of the contact persons for scientific aspects (project leaders) ${ }^{37}$ in FP7 (2007-2008) are women. For Norway, the figure is 19 per cent for both successful and unsuccessful applications. Both Norwegian research institutes and public bodies (REC and PUB) and higher education institutions (HES) have a somewhat higher share of female contact persons (23-35 per cent). For Norwegian enterprise participations, however, only 7 per cent of the contact persons are women (Figure 3.19).

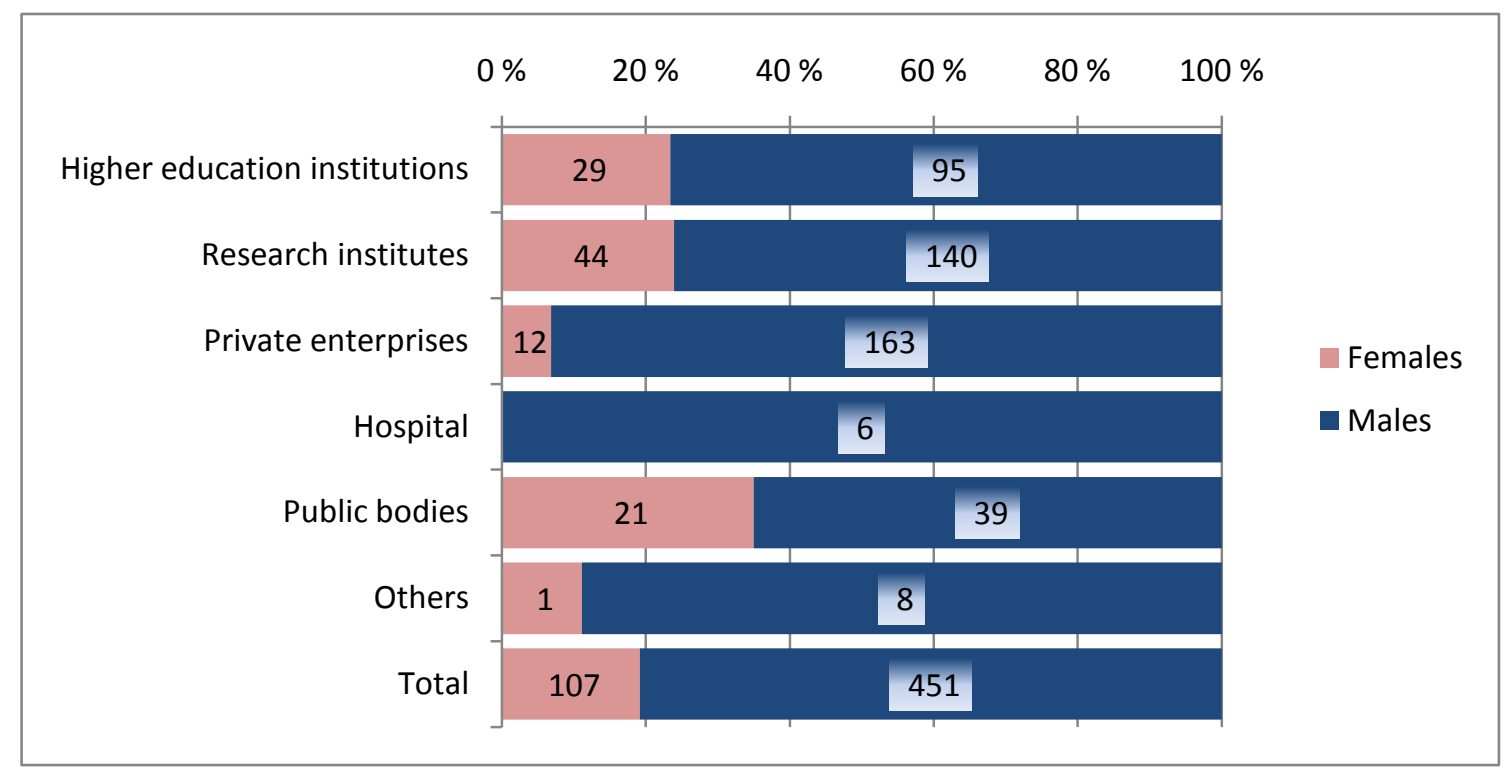

Figure 3.19 Norwegian participations in FP7 proposals by contact person's gender and type of organisation. Percentage and numbers.

\subsubsection{Geographical distribution}

Table 3.8 shows Norwegian participations in proposals by region and success rates. In FP7 so far the regional distribution of accepted applications with Norwegian participation is quite similar to the regional distribution of FP6 participations. As in FP6, the greater Oslo region accounts for about half of the participations, whereas Trøndelag and Western Norway are the other two major participating regions. Compared with FP6, Trøndelag has increased its proportion of Norwegian participations by 2.2 percentage points, and Northern and Western Norway have each decreased their proportion with 0.9 percentage point. Except for that, each region's (preliminary) FP7 proportion is fairly identical to their FP6 proportion. In conclusion, there is no indication of a more balanced regional distribution of Norwegian participation. It should however be noted that Agder and

37 The gender of the contact person for each participation is available information in the FP7 data base. In most cases, the contact persons are the project leaders at the participating organisations. 
Rogaland (with two newly established universities) prevail among the regions with the highest success rates for FP7 proposals.

Table $3.8 \quad$ Norwegian success rates FP7 by region, per cent.

\begin{tabular}{lrrrr|r}
\hline Region & MAINLIST & $\begin{array}{r}\text { RESERVE } \\
\text { LIST }\end{array}$ & REJECTED & $\mathbf{N}$ & $\begin{array}{r}\text { Region's per cent of } \\
\text { MAINLIST }\end{array}$ \\
\hline Vestlandet & 21.6 & 7.3 & 71.1 & 301 & 14.3 \\
Oslo and Akershus & 21.3 & 9.3 & 69.4 & 1061 & 49.9 \\
Agder and Rogaland & 21.2 & 9.7 & 69.0 & 113 & 5.3 \\
Trøndelag & 18.5 & 8.0 & 73.6 & 503 & 20.5 \\
Svalbard & 18.2 & 18.2 & 63.6 & 11 & 0.4 \\
Sør-Østlandet & 16.7 & 6.9 & 76.5 & 102 & 3.8 \\
Nord-Norge & 15.3 & 12.7 & 72.0 & 150 & 5.1 \\
Hedmark and Oppland & 9.4 & 18.8 & 71.9 & 32 & 0.7 \\
Info missing & 0.0 & 0.0 & 100.0 & 9 & 0.0 \\
\hline Total & $\mathbf{1 9 . 9}$ & $\mathbf{9 . 0}$ & $\mathbf{7 1 . 1}$ & $\mathbf{2 2 8 2}$ & $\mathbf{1 0 0 . 0}$ \\
\hline
\end{tabular}

\subsection{Comparing Norwegian participation in FP5, FP6 and FP7}

Overall participation results

Table 3.9 presents key indicators describing aspects of the Norwegian participation in the FP5, FP6 and the first two years of FP7.

Table 3.9 Key indicators for the Norwegian participation in the FP5, FP6 and FP7 (2007-2008).

\begin{tabular}{|l|c|c|c|}
\hline & FP5 & FP6 & FP7 (2007-2008) \\
\hline $\begin{array}{l}\text { 1. Share of all contracts with at least one } \\
\text { Norwegian participation }\end{array}$ & $7.0 \%$ & $8.3 \%$ & n.a. \\
\hline $\begin{array}{l}\text { 2. Share of all contracts with at least one } \\
\text { Norwegian participation (excluding Marie } \\
\text { Curie Actions) }\end{array}$ & $8.5 \%$ & $13.6 \%$ & $13 \%^{(1)}$ \\
\hline $\begin{array}{l}\text { 3.Norwegian coordinated contracts as } \\
\text { share of all contracts with at least one } \\
\text { Norwegian participation }\end{array}$ & $19.4 \%$ & $17.9 \%$ & $21 \%^{(4)}$ \\
\hline $\begin{array}{l}\text { 4. Overall share of Norwegian } \\
\text { participations }\end{array}$ & $1.9 \%{ }^{(2)}$ & $1.8 \%^{(2)}$ & $1.6 \%^{(3)}$ \\
\hline $\begin{array}{l}\text { 5. Overall share of EU-contribution to } \\
\text { Norwegians }\end{array}$ & close to $2 \%$ & $1.7 \%$ & $1.6 \%$ \\
\hline
\end{tabular}

(1) Only Co-operation and Capacity activities in FP7. The share of Norwegian contracts in IDEAS (and PEOPLE/Marie Curie) is very low.

(2) Source: European Commission (2008): FP6 Final Review: Subscription, Implementation,

Participation, Brussels and NIFU, STEP, Technopolis (2004) Tables 6.1 and 6.2.

(3) Source: Second Monitoring Report, Table B.1.

(4) Source: Forskningsrådet (2009): EU-kontorets halvårsrapport pr. 30.06.2009. 
The EU-contribution to Norwegian participants has in nominal terms increased from the FP5 to FP7 but in relative terms, i.e. as shares of the overall EU-contribution to all participants in the FPs, the Norwegian participation is stable or even slightly decreasing (see indicators 4 and 5 in Table 7.1). We discuss the logic behind this assertion in greater detail in 5.3 .

Meanwhile, Figure 3.20 depicts shares of Norwegian of EU contribution to Norwegian participants in the first two years of the FP7 by themes. We use this data as a base line for discussing trends in Norwegian participation by theme. In terms of thematic activities within the FPs we observe clear and stable participation patterns from the FP5 to FP7, but also some noteworthy changes. Norwegian participation in themes such as environment, food security and safety, energy and participation in the SME-programs have been high since FP5 and in some of them it keeps increasing. In particular, participation in the SMEprogram increased considerably from the FP5 to FP6 and it increased further from the FP6 to FP7. Conversely, Norwegian participation in HEALTH, ICT (IST), Research infrastructures (RI), Marie Curie Actions/PEOPLE and INCO was rather low in FP5 and remains low in FP7.

The EU-contribution to Norwegian participants in SSH and TRANSPORT themes in FP7 is lower than what it was in FP5 and FP6 and this is difficult to explain. Participation in SPACE, SECURITY (which is new areas of research in an FP context) and SiS is high. Participation in the NMP programme in the FP7 is higher compared to FP6.

ERC activities (IDEAS programme) and participation in the PEOPLE-programme in the FP7 represent a challenge for the Norwegian research system. The participation in these two programmes is very low. Together these two programmes receive close to 25 per cent of the total FP7 budget. Participation in Marie Curie Actions was always low since the FP4.

The INCO theme in the FP7 deserves more attention from the Norwegian policy makers compared to the rather low priority given to this programme in the past. This is because new instruments aiming to reinforce international research collaboration are under development (INCO-NETs and Specific International Coordination Actions - SICAS) are under development in the INCO theme. Further, the Science \& Technology agreements between the EC and a number of Third Countries, such as Japan, must be studied by the Norwegian delegates in the INCO programme and via the communication channels of RCN these agreements must be made known to Norwegian researchers. In general, collaboration with Third countries is a policy area - and one of the six pillars in the ERA policies - which currently attracts the energy and the attention of the DG RTD. 


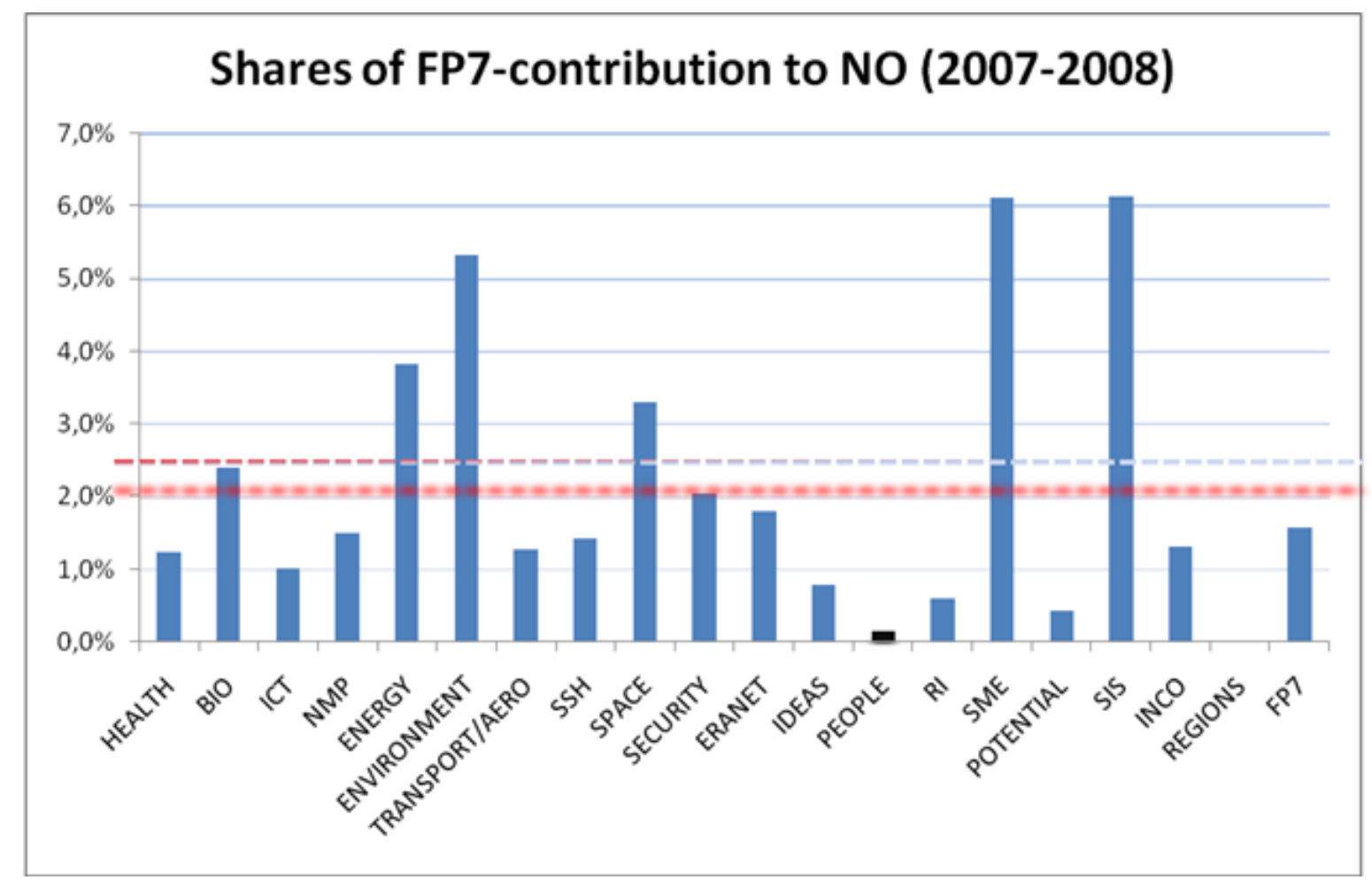

Source: CORDA and EC (2009: FP7 Subscription, Performance, Implementation during the first two years of operation 2007-2008.

Figure 3.20 Shares of EU contribution to Norwegian participants in the first two years of the FP7 by themes. Shares close to 2 percent or higher indicate that fair economic return is reached.

In terms of rates of success as measured by the number of retained proposals with at least one Norwegian participant (Norwegian proposals) as a percentage of the number of all project proposals, the figures show that so far in FP7, the overall Norwegian rate of success has been higher than the EU average in almost all thematic activities (except ICT).

For example, the success rates in NMP, ENERGY, ENVIRONMENT, TRANSPORT and SPACE varied from 24 to 40 per cent, In FP6, the rate of success was 25 per cent, which also was above the EU average (18 per cent). Statistics from RCN show also that the number of Norwegian proposals as a share of all proposals submitted in HEALTH, ICT, NMP, IDEAS, PEOPLE and to a lesser extend in TRANSPORT is low compared with the ten percent target set by the RCN, i.e. ten per cent of all proposals in Cooperation and Capacities parts of FP7 shall have at least one Norwegian applicant ${ }^{38}$.

The implication of these figures is that there is a potential for increased participation in FP7, in particular in the latter themes which also constitute large parts of the budget in FP7. In ICT there is a need also for increasing the quality of the Norwegian proposals.

38 See Forskningsrådet (2009): EU-kontorets halvårsrapport pr. 30.06.2009, p. 2. 
In terms of types of beneficiaries, we observe in Table 3.10 that the Higher education sector (HES) increased their EU-funding from the FP5 to FP6, but so far their participation in FP7 is lower to FP6, (i.e. lower funding). The EU-contribution to all type of beneficiaries has increased in FP6 compared to FP5,except EU contribution to the business sector (IND), and it will most likely increase in absolute terms from FP6 to FP7 (four year estimate based on data for the first two years). However, if we take into account that that the FP7 funds up to 75 per cent of project eligible costs while the FP6 funded only 50 per cent of project eligible costs, we need to calculate four year estimates which take into consideration this difference (four years adjusted estimates). Note that we calculated adjusted EU contribution estimates only for the research institutes (REC) and for the business sector (IND). The next to last raw in Table 3.10 presents the results of the four year adjusted estimates.

Table 3.11 and Table 3.12 show the number of Norwegian participations (Table 3.11) and average EU contribution per participation (Table 3.12) by type of beneficiary in FP5, FP6 and FP7.

Table 3.10. EU contribution by groups of beneficiaries in FP5, FP6 and FP7 (20072008). Million Euros.

\begin{tabular}{|l|c|c|c|c|c|}
\hline & HES & IND & OTH & REC & Total \\
\hline FP5 & 63 & 73 & 9 & 103 & 248 \\
\hline FP6 & 80 & 72 & 24 & 108 & 284 \\
\hline FP7 (adjusted four year estimate) ${ }^{(1)}$ & 86 & 59 & 13 & 95 & 253 \\
\hline FP7 (four year estimate) & 86 & 89 & 19 & 142 & 337 \\
\hline FP7 (2007-2008) & 43 & 44 & 10 & 71 & 168 \\
\hline Change FP5-FP6 & $27 \%$ & $-1 \%$ & $167 \%$ & $5 \%$ & $15 \%$ \\
\hline Change FP6-FP7 (four year adjusted) & $8 \%$ & $-18 \%$ & $-46 \%$ & $-12 \%$ & $-11 \%$ \\
\hline $\begin{array}{l}\text { Change FP6-FP7 (four year } \\
\text { unadjusted) }\end{array}$ & $8 \%$ & $23 \%$ & $-19 \%$ & $32 \%$ & $19 \%$ \\
\hline
\end{tabular}

Note: Estimate for four years and by taking into account the fact that the EU contribution in FP7 is $75 \%$ of the total costs while in FP6 this percent was 50\%. This adjustment is relevant only for the business sector (IND) and for research institutes (REC).

Table 3.11 Number of participations by type of beneficiaries in FP5, FP6 and FP7 (2007-2008).

\begin{tabular}{|l|c|c|c|c|c|}
\hline & HES & IND & OTH & REC & Total \\
\hline FP5 & 376 & 503 & 111 & 581 & 1571 \\
\hline FP6 & 316 & 403 & 143 & 412 & 1274 \\
\hline FP7 (four year estimate) & 260 & 350 & 138 & 368 & 1116 \\
\hline FP7 (2007-2008) & 130 & 175 & 69 & 184 & 558 \\
\hline Change FP5-FP6 & $-16 \%$ & $-20 \%$ & $29 \%$ & $-29 \%$ & $-19 \%$ \\
\hline Change FP6-FP7 (four year adjusted) & $-18 \%$ & $-13 \%$ & $-3 \%$ & $-11 \%$ & $-12 \%$ \\
\hline
\end{tabular}

Note: FP7 four year estimate is calculated as FP7 (2007-2008) multiplied by 2. 
Table 3.12 Average EU-contribution per participation and by type of beneficiaries in FP5, FP6 and FP7 (2007-2008). In €thousands.

\begin{tabular}{|l|c|c|c|c|c|}
\hline & HES & IND & OTH & REC & Total \\
\hline FP5 & 168 & 145 & 81 & 177 & 158 \\
\hline FP6 & 253 & 179 & 168 & 262 & 223 \\
\hline FP7 (2007-2008) & 331 & 254 & 141 & 387 & 302 \\
\hline Change FP5-FP6 & $51 \%$ & $23 \%$ & $107 \%$ & $48 \%$ & $41 \%$ \\
\hline Change FP6-FP7 & $31 \%$ & $42 \%$ & $-16 \%$ & $48 \%$ & $35 \%$ \\
\hline
\end{tabular}

Figure 3.21 shows the largest Norwegian $R \& D$ organisations in terms of number of participations in FP6 and FP7. Note that in the Appendix 2 we list all organisational abbreviations used in the figure.

The overall conclusion from the comparison of the Norwegian participation in FP5, FP6 and FP7 indicates that the larger the FPs the more difficult it is for Norway to increase proportionally its participation. This generally is true also for all types of beneficiaries, with the exception of universities which had a higher participation in FP6 than in FP5, but so far in FP7 they seem to losing ground (in relative terms) and the business sector which had a lower participation in FP6 than in FP5 and with a "steady state" level of participation between the FP6 and FP7.

Special policy attention must be given to mobilisation strategies in all R\&D performing sectors if the policy goal is to come closer to a "just retur" level of participation. In particular, special attention must be given to universities (including university hospitals) and to their participation in HEALTH, IDEAS and PEOPLE and to participations from large firms in the ICT theme and elsewhere in the COOPERATION programme in FP7. Norwegian SMEs seem to have the potential to increase their participation in COOPERATION, but on this point we have no solid data to substantiate this assertion.

We estimate that about 25 per cent of the overall budget of the FP7 has already been distributed after the first two years of the FP7. 

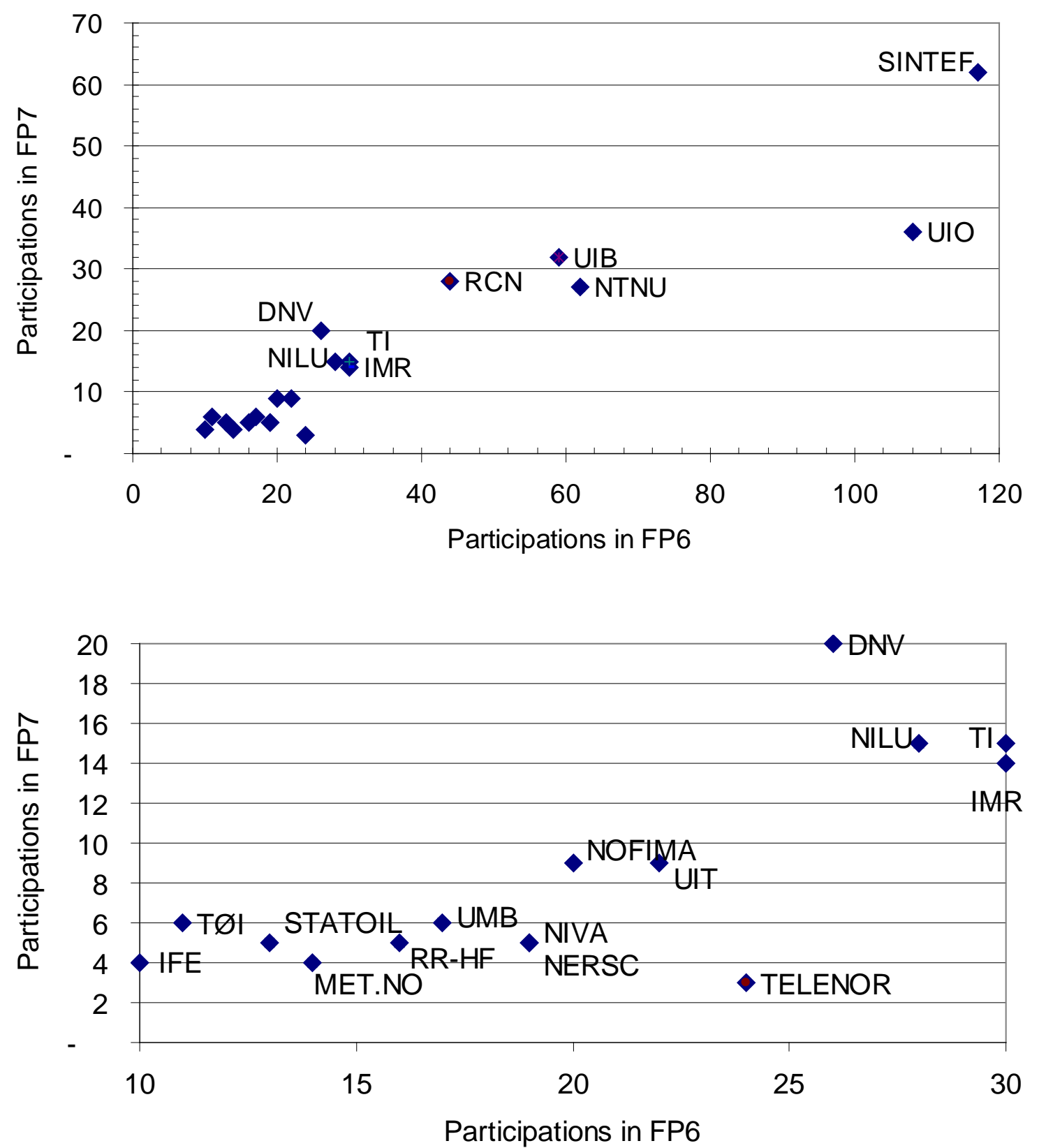

Figure 3.21 Participations in FP6 (x-axis) and FP7 (y-axis) for Norwegian organisations with the largest participations in FP6 and FP7

\subsection{Main findings and conclusions}

EUs contribution to Norwegian researchers (Brussels $\rightarrow$ Norway) participating in FP6 amounted to $€ 284$ million. The financial contribution of the Norwegian government to FP6 activities (“contingent”, i.e. payment flow Norway $\rightarrow$ Brussels) is estimated to $€ 365$ million. This funding “gap” between Norway’s payment to EU and what Norwegian participants got back from the FP6 is €81 million, which at the current rate of exchange (November 2009) amounts to approximately NOK 680 million. However, this gap is the effect of Norway's high GDP (which determines the size of Norway's FP contribution to 
the EU) - combined with Norway's comparatively low R\&D-intensity, i.e. its R\&D capacity.

Therefore, a more interesting indicator from a policy point of view is the total R\&D cost of all the FP6 projects with Norwegian participants. This value is close to $€ 4900$ million. This figures shows that the Norwegian state funding of FP6 is a ticket for the Norwegian participants to access research and technology activities worth more than 13 times the Norwegian contribution "contingent". The real strategic issue thus is how to better absorb and utilise nationally this large pool of international knowledge production.

In the first two years of the FP7 more than 2000 project proposals with at least one Norwegian applicant and 394 of these proposals have been retained for contract negotiations. We counted 558 Norwegian participations in these proposals, who all together requested 168 €million. The share of all projects with Norwegian participants in FP7 having Norwegian coordinator is high in FP7 (23 per cent), clearly higher than in FP6 (18 per cent) and FP5 (19 per cent). Also, the average EU contribution per participation increased in FP7 compared to FP6 and FP5, even if we control for the fact that in FP7 a participant can request for funding up to 75 per cent of total project eligible costs. In FP6e this per cent was only 50 per cent. If this trend continues throughout the entire FP7 it will only mean that the Norwegian participation gradually becomes more selective and concentrated and therefore probably more "strategic" than in earlier FPs.

Having said that, there are numerous challenges ahead for the Norwegian participants, the RCN and the Ministry of Education and Research. The overall conclusion from the comparison of the Norwegian participation in FP5, FP6 and FP7 indicates that the larger the FPs, the more difficult it is for Norway to increase proportionally its EU contributions from the FPs.

Further, Norwegian participation in themes such as environment, food security and safety, energy and participation in the SME-programs have been high since FP5 and in some of them it keeps increasing. Conversely, Norwegian participation in HEALTH, ICT (IST), Research infrastructures (RI), Marie Curie Actions/PEOPLE and INCO was rather low in FP5 and remains low in FP7. Further, the EU-contribution to Norwegian participants in SSH and TRANSPORT themes in FP7 is lower than what it was in FP5 and FP6. Participation in SPACE, SECURITY (which is new areas of research in an FP context) and SiS is high. Participation in NMP programme in the FP7 is higher compared to FP6.

ERC-activities (IDEAS programme) and participation in the PEOPLE programme in the FP7 represent a challenge for the Norwegian research system. The participation in these two programmes is very low. Together these two programmes receive close to 25 per cent of the total FP7 budget. Norwegian participation in Marie Curie Actions has been low in all FPs since the FP4 and remains low in the FP7. The INCO theme in the FP7 deserves 
also more attention from the Norwegian policy makers compared to the rather low priority given to this programme in the past. This is because new instruments aiming to reinforce international research collaboration are under development.

As a conclusion, special policy attention must be paid to mobilisation strategies in all R\&D performing sectors if the policy goal is to come closer to a "just retur" level of participation. In particular, special attention must be given to universities (including university hospitals) and to their participation in HEALTH, IDEAS and PEOPLE and to participations from large firms in the ICT theme and elsewhere in the co-operation part of FP7. Norwegian SMEs seem to have the potential to increase their participation in the Cooperation part of the FP7.

We estimate that about 25 per cent of the overall budget of the FP7 has already been distributed after the first two years of the FP7. 


\section{$4 \quad$ Results and impacts for Norwegian participants and society}

As with all research and development, a key dimension in Norway's participation in EU FPs is people, i.e. those who actually do the research and related work as participants in EU projects. Their insight, experience and views provide a knowledge base for an important issue related to Norway's participation in EU FPs. If, for strategic reasons, increased participation is seen as necessary, how can this be achieved? As explained in the evaluation in Chapter 1, two surveys were undertaken: one covering all Norwegian participants in FP6, and a second which was sent to all those who had participated in FP7 applications. The topics presented and analysed in this chapter are based on the information provided by respondents to these two surveys. More specifically, the topics are:

- Partners, project responsibilities and involved researchers (Section 4.1)

- Results: application and project costs, strengths, obstacles, project involvement and strategies, project quality and collaboration (Section 4.2)

- Impacts of the Norwegian participation: new knowledge and innovation, economic benefits, long-term effects (Section 4.3)

Finally, in summing up these findings, the chapter addresses issues the respondents believed to be important for their future participation in EU FPs (Section 4.6). A separate section (4.4) summarises results for the four focus areas (Health, ICT, Environment and NMP).

\subsection{Partners, project responsibilities and involved researchers}

In order to understand the response made in the survey, we need to understand the context in which research was undertaken, i.e. the number of partners in the project consortia, project coordination and work package responsibility by Norwegian partners, the number of researchers and $\mathrm{PhD}$ students involved in the Norwegian participations, and the gender distribution.

A large part of the respondents stated that their FP6 project had 10 to 19 partners (37 per cent, 225 of 610 participations, Table 4.1). About a quarter reported fewer than 10 partners, and another quarter reported between 20 and 39 partners; 13 per cent reported 40 or more partners. In particular, the participants in IP and NoE reported a high number of partners (Table 4.1). 
Table 4.1 Number of partners in the project by project type, FP6. Per cent.

\begin{tabular}{lrrrrrrrrrr}
\hline Number of partners & \multicolumn{1}{c}{ CA } & CLR & CRAFT & \multicolumn{1}{c}{ II } & \multicolumn{1}{c}{ IP } & MCA & NOE & SSA & STREP & N \\
\hline 1-9 & 4.8 & & 11.5 & 1.8 & 1.8 & 17.6 & & 23.6 & 38.8 & 165 \\
$10-19$ & 15.6 & 7.1 & 10.2 & .4 & 12.9 & 7.1 & 4.9 & 5.8 & 36.0 & 225 \\
20-39 & 20.6 & 3.7 & & 1.5 & 50.7 & & 8.8 & 5.1 & 9.6 & 136 \\
40 and above* & & & & 1.2 & 64.3 & & 33.3 & 1.2 & & 84 \\
\hline Total & 11.6 & 3.4 & 6.9 & 1.1 & 25.4 & 7.4 & 8.4 & 9.8 & 25.9 & 610 \\
\hline
\end{tabular}

*The projects have up to 95 partners

Source: Survey to Norwegian participants in FP6

The coordinator is legally the principal contractor of a Framework Programme project, but is in reality the chief project leader and responsible for coordinating both scientific and administrative tasks. For large projects these tasks can be extensive. Twenty per cent of the respondents coordinated their project. A far larger proportion of the smaller (1-9 partners) than larger projects has Norwegian coordinator (Table 4.2).

Table 4.2 Norwegian coordination by number of partners in the project, FP6, per cent.

\begin{tabular}{lrrr}
\hline Number of partners & Norwegian (respondent) & \\
coordinator & Other partner coordinate & N \\
\hline $1-9$ & 30.7 & 69.3 & 153 \\
$10-19$ & 19.8 & 80.2 & 202 \\
$20-39$ & 14.9 & 85.1 & 134 \\
40 and above (up to 95) & 6.3 & 93.8 & 80 \\
\hline Total & $* 19.7$ & 80.3 & 569 \\
\hline *Data from EC indicate the overall share of Norwegian coordinators is considerably lower, 12 per cent. The high share of \\
coordinators in this table is due to coordinators' higher survey response rate. \\
Source: Survey to Norwegian participants in FP6.
\end{tabular}

In addition to a coordinator, the projects (and especially the larger projects) may have a number of Work Package leaders (subproject leaders) and other leadership roles. Table 4.3 shows a higher proportion of Norwegian participations with a leading responsibility in FP7 than in FP6 (62 versus 58 per cent). Except for the higher education institutions, it also shows a higher share of Norwegian leading responsibility in rejected than in successful applications. This may be due to lower response rate among non-successful applicants without a leading responsibility than among non-successful applicants with a leading responsibility. ${ }^{39}$

39 The response rate is higher for successful than unsuccessful applicants (37 vs. 53 per cent, Table A 3). As we do not have information about leading responsibilities of applicants that did not reply to the survey we cannot calculate response rates for these groups. 
Table 4.3 Percentage of Norwegian participations with leading responsibility by respondent's sector/ type of organisation (per cent with leading responsibility within sector) FP6 and FP7.

\begin{tabular}{lrrrrrrrr}
\hline & \multicolumn{2}{c}{ FP6 } & \multicolumn{2}{c}{ FP7 } & \multicolumn{3}{c}{ FP7 not } \\
& \multicolumn{1}{c}{ participations } & \multicolumn{2}{c}{ participations } & FP7 rejected & \multicolumn{2}{c}{ concluded } \\
\cline { 2 - 10 } Type of organisation & $\star Y e s$ & $\mathrm{~N}$ & $*$ Yes & $\mathrm{N}$ & *Yes & $\mathrm{N}$ & *Yes & $\mathrm{N}$ \\
\hline a) Research Institute & 66.7 & 243 & 66.1 & 115 & 71.3 & 279 & 64.3 & 14 \\
b) Higher Education Institution & 57.8 & 128 & 78.0 & 59 & 76.5 & 204 & 75.0 & 4 \\
c) Enterprise & 51.4 & 111 & 47.9 & 71 & 56.8 & 111 & 17.6 & 17 \\
d) Other & 41.1 & 73 & 29.4 & 17 & 33.3 & 21 & 0 & 1 \\
\hline Total & $\mathbf{5 8 . 2}$ & $\mathbf{5 5 5}$ & $\mathbf{6 1 . 5}$ & $\mathbf{2 6 2}$ & $\mathbf{6 9 . 1}$ & $\mathbf{6 1 5}$ & $\mathbf{4 1 . 7}$ & $\mathbf{3 6}$ \\
\hline
\end{tabular}

${ }^{*}$ Reply to questions: Has your organisation had a leading responsibility (a work package for example) in the project? Sources: Surveys to Norwegian participants in FP6, and to Norwegian applicants to FP7.

\section{Involved researchers at participant's organisation, gender and PhD students}

In total, 2499 researchers are reported being involved in the EU projects at their organisation. Of these, 58 per cent are at research institutes, 24 per cent at HEIs, 13 per cent in enterprises, and 5 per cent in other kinds of organisations (e.g. government agencies such as the Research Council of Norway, Table 4.4). The majority of the PhD students are at the HEIs.

Table 4.4 Involved researchers, females and PhD students at participant's organisation, by type of organisation. Per cent.

\begin{tabular}{lrrr}
\hline Sector & Total number of researchers & PhD students & Women \\
\hline a) Research Institute* & 57.7 & 34.9 & 58.3 \\
b) Higher Education Institution & 23.8 & 56.0 & 27.0 \\
c) Enterprise & 13.0 & 7.5 & 9.1 \\
d) Other & 5.4 & 1.5 & 5.6 \\
\hline N & 2499 & 398 & 773 \\
(\#Replies) $^{\star \star}$ & $(536)$ & $(494)$ & $(510)$ \\
\hline
\end{tabular}

${ }^{*} \mathrm{~A}$ likely misinterpreted reply, reporting a very high number of involved researchers at a research institute, is included in the calculations. This respondent reported that 150 researchers were involved but did not give the figures for PhDs and females. The respondent might have misread the questions and reported the total number of researchers in the project, not only those involved at own organisation.

***The differences in number of replies indicate that some have not replied to question about PhDs and females, and that these figures may be underestimated. "No response" may indicate "None" or "Don't know".

Source: Survey to Norwegian participants in FP6.

Table 4.5 shows average number of researchers, $\mathrm{PhD}$ students and females per participation per sector. To obtain comparable figures only replies from the 493 respondents who reported on all three questions (total number, PhDs and females) are included. ${ }^{40}$ Thirty-four per cent of the 2219 involved researchers are female (746), and 18 per cent (392) are PhD students. The proportion of females involved is slightly above the overall figures for R\&D personnel in Norway at 32 per cent, ${ }^{41}$ but because replies from respondents who did not report the number of females are excluded, the figure is likely to be somewhat overestimated. When estimating the proportion of female researchers based

40 The total in table Table 4.5 is therefore lower than the totals in Table 4.4 which include all answers.

41 The R\&D Statistics Bank, http://www.nifustep.no. 
on the totals reported in Table 4.4 the percentage is however only slightly lower - 31 per cent (773 females of 2499 researchers).

The average number of researchers involved in the participating organisation is somewhat higher at the research institutes than in the other sectors. The participations at the research institute include on average 5.2 researchers, whereas the figure for the higher education institutions is 4.5, for the enterprises 3.3 and for the other organisations 2.9. Expect for the HEIs, there are cases where no researchers are reported as being involved at the organisation, indicating that the involved persons hold other positions. At one HEI as many as $24 \mathrm{PhD}$ students are reported to be involved. Somewhat surprisingly, one research institute reported to have $20 \mathrm{PhD}$ students involved in an EU project. This and other numbers shown in Table 4.5 reflect a large variety in EU research at the level of the participating organisations.

Table 4.5 Total number of involved researchers at participant's organisation, females and PhD students. Means by sector.

\begin{tabular}{|c|c|c|c|c|}
\hline Sector & & $\begin{array}{r}\text { Total number } \\
\text { of } \\
\text { researchers }\end{array}$ & PhD students & Women \\
\hline Research & Mean & 5.23 & .60 & 1.85 \\
\hline \multirow[t]{5}{*}{ Institute } & N (replies) & 233 & 233 & 233 \\
\hline & Sum researchers & 1219 & 139 & 430 \\
\hline & Minimum & 0 & 0 & 0 \\
\hline & Maximum & 34 & 20 & 29 \\
\hline & Std. Deviation & 4.660 & 1.576 & 2.631 \\
\hline Higher & Mean & 4.50 & 1.70 & 1.61 \\
\hline Education & N (replies) & 130 & 130 & 130 \\
\hline \multirow[t]{4}{*}{ Institution } & Sum researchers & 585 & 221 & 209 \\
\hline & Minimum & 1 & 0 & 0 \\
\hline & Maximum & 60 & 24 & 14 \\
\hline & Std. Deviation & 5.819 & 3.198 & 1.853 \\
\hline \multirow[t]{6}{*}{ Enterprise } & Mean & 3.31 & .30 & .77 \\
\hline & N (replies) & 87 & 87 & 87 \\
\hline & Sum researchers & 288 & 26 & 67 \\
\hline & Minimum & 0 & 0 & 0 \\
\hline & Maximum & 12 & 4 & 6 \\
\hline & Std. Deviation & 2.866 & .701 & 1.128 \\
\hline \multirow{6}{*}{ Other } & Mean & 2.95 & .14 & .93 \\
\hline & N (replies) & 43 & 43 & 43 \\
\hline & Sum researchers & 127 & 6 & 40 \\
\hline & Minimum & 0 & 0 & 0 \\
\hline & Maximum & 15 & 3 & 5 \\
\hline & Std. Deviation & 3.415 & .516 & 1.404 \\
\hline \multirow[t]{6}{*}{ Total } & Mean & 4.50 & .80 & 1.51 \\
\hline & $\mathrm{N}$ (replies)* & 493 & 493 & 493 \\
\hline & Sum researchers & 2219 & 392 & 746 \\
\hline & Minimum & 0 & 0 & 0 \\
\hline & Maximum ${ }^{\star \star}$ & 60 & 24 & 29 \\
\hline & Std. Deviation & 4.718 & 2.068 & 2.177 \\
\hline
\end{tabular}

*To obtain comparable figures only replies from the 493 respondents who responded to all three questions (total number, PhDs and females) are included in the table. Moreover, this excludes the reply from the respondent who stated that 150 researchers at his institute were involved. In a few cases where no reply obviously meant that there were no females/PhD students, "missing" was set to zero and the case was included in the calculations (e.g. when total number of researchers was 1, and the number of female researchers was 1, but the space for PhD students was not filled in).

Source: Survey to Norwegian participants in FP6. 
Total number of involved researchers at participant's organisation, females and PhD students by programme.

\begin{tabular}{|c|c|c|c|}
\hline Priority/programme & $\begin{array}{r}\text { Total } \\
\text { number of } \\
\text { researchers }\end{array}$ & $\begin{array}{r}\text { PhD } \\
\text { students }\end{array}$ & Women \\
\hline 1. Life sciences, genomics and biotechnology for health & 105 & 31 & 52 \\
\hline 2. Information society technologies & 366 & 81 & 83 \\
\hline $\begin{array}{l}\text { 3. Nanotechnologies and nanosciences, knowledge-based } \\
\text { multifunctional materials and new production processes and devices }\end{array}$ & 105 & 15 & 37 \\
\hline 4. Aeronautics and space & 62 & 8 & 13 \\
\hline 5. Food quality and safety & 217 & 53 & 103 \\
\hline 6. Sustainable development, global change and ecosystems & 646 & 40 & 205 \\
\hline 7. Citizens and governance in a knowledge-based society & 133 & 38 & 60 \\
\hline Horizontal research activities involving SMEs & 139 & 9 & 41 \\
\hline Human resources and mobility & 127 & 66 & 40 \\
\hline Policy support and anticipating scientific and technological needs & 160 & 17 & 72 \\
\hline Research and innovation & 39 & 1 & 9 \\
\hline Research infrastructures & 79 & 20 & 12 \\
\hline Science and society & 5 & 0 & 3 \\
\hline Specific measures in support of international cooperation & 25 & 9 & 11 \\
\hline $\begin{array}{l}\text { Support for the coherent development of research \& innovation } \\
\text { policies }\end{array}$ & 11 & 4 & 5 \\
\hline Total & 2219 & 392 & 746 \\
\hline Cross-programme: Marine & 476 & 43 & 135 \\
\hline
\end{tabular}

Source: Survey to Norwegian participants in FP6. To obtain comparable figures only replies from the 493 respondents who reply to all three questions (total number, PhDs and females) are included in the table.

*Includes 126 participations (across programmes) where respondents have reported that the project is expected to have positive impact on marine/maritime sector. See Table A 13, Appendix 1, for distribution by priority/programme.

\subsection{Project results: costs, strategies, quality and collaboration}

To what extent do the Norwegian participants succeed in their FP projects? How do they cover the application costs and link the FP projects to other projects, to what extent do they contribute to the collaborative projects? In what ways do the FP projects differ from participants' other projects? In the following, the participants' overall assessments of their projects are presented initially. The subsequent subsections analyse:

- participants' aims, involvement and priorities,

- participants' assessments of the qualities of the EU projects compared to their other R\&D projects,

- participation costs, and

- effects on collaboration and network.

All sections present results from the survey of Norwegian participants in FP6. The sections dealing with aims, priorities and costs also include results from the survey of Norwegian applicants to the FP7. Like the previous evaluations of Norwegian participation in the Framework Programmes, the units of analysis are Norwegian participations, that is organisations participating in projects/applications, and not the projects or individual participants. Even when the term participant is used, it refers to the participating organisations responding to the survey. 


\section{Participants' overall assessments}

The large majority of respondents characterise their projects as successful. Overall, 77 per cent of the participants stated that their project was "very successful" (17 per cent) or "successful" (60 per cent), and only 4 per cent stated that it was "unsuccessful" or "very unsuccessful”, which may be said to be a very satisfying result for the Norwegian participation (Table 4.7). ${ }^{42}$

Not surprisingly, the participants with coordinator responsibility are more positive than participants without coordinator responsibility. Eighty-four per cent of coordinators and 76 per cent of other respondents replied that the project was "successful” or "very successful”. Further, a somewhat higher proportion of coordinators characterised their project as "very unsuccessful” (3 per cent of coordinators versus 1 per cent of the other respondents), whereas a larger share of non-coordinators are uncertain whether the project was successful or unsuccessful (21 per cent of the other respondents versus 11 per cent of coordinators). This indicates that coordinators have been able to achieve their aims for the project to a greater extent. They are also better informed about the project and might also be somewhat more demanding concerning the outcome of the projects (a generally higher tendency to reply “very unsuccessful”).

Table 4.7 Overall assessment of the EU project: What is your total impression of the project (so far)? Participants' assessments. Per cent.

\begin{tabular}{lrrrrrr}
\hline $\begin{array}{l}\text { Respondent is } \\
\text { coordinator }\end{array}$ & $\begin{array}{r}\text { Very } \\
\text { unsuccessful }\end{array}$ & Unsuccessful & Uncertain & Successful & $\begin{array}{r}\text { Very } \\
\text { successful }\end{array}$ & N \\
\hline Yes & 3.2 & 2.1 & 10.6 & 63.8 & 20.2 & 94 \\
No & 0.8 & 2.8 & 20.8 & 58.5 & 17.2 & 390 \\
\hline Total & 1.2 & 2.7 & 18.8 & 59.5 & 17.8 & 484 \\
\hline
\end{tabular}

The participants were asked to assess the success of the projects along several dimensions. On all aspects, the proportion replying "successful" is higher than the proportion responding "unsuccessful” (Table 4.8 last column: "Positive balance”). The projects are assessed as particularly successful in terms of network building. Forty-seven per cent stated that the network building was very successful, and another 39 per cent that it was mostly successful.

The projects are also assessed as successful in terms of research performance (18 per cent "very successful” and 44 per cent "mostly successful”), achieving project objectives (28 per cent "very successful” and 51 per cent “mostly successful”), and as basis for acquiring new R\&D projects (22 per cent "very successful” and 33 per cent “mostly successful”).

42 See Section 4.4 for analyses of differences between thematic priorities. 


\begin{tabular}{|c|c|c|c|c|c|c|c|c|}
\hline $\begin{array}{l}\text { To what extent would } \\
\text { you say that the following } \\
\text { elements have been } \\
\text { unsuccessful/successful } \\
\text { within the project? }\end{array}$ & $\begin{array}{r}\text { Very } \\
\text { unsuccessful }\end{array}$ & $\begin{array}{r}\text { Mostly } \\
\text { unsuccessful }\end{array}$ & Uncertain & $\begin{array}{r}\text { Mostly } \\
\text { successful }\end{array}$ & $\begin{array}{r}\text { Very } \\
\text { successful }\end{array}$ & $\begin{array}{r}\text { Not } \\
\text { relevant }\end{array}$ & $\mathbf{N}$ & $\begin{array}{r}\text { *Positive } \\
\text { balance }\end{array}$ \\
\hline $\begin{array}{l}\text { Project objectives } \\
\text { achieved }\end{array}$ & 1.2 & 5.3 & 15.2 & 50.9 & 27.5 & & 513 & 71.9 \\
\hline Network building & 2.5 & 3.7 & 7.2 & 39.2 & 47.4 & & 515 & 80.4 \\
\hline $\begin{array}{l}\text { Basis for acquiring new } \\
\text { R\&D projects }\end{array}$ & 1.8 & 7.1 & 29.8 & 33.3 & 22.4 & 5.7 & 510 & 46.8 \\
\hline $\begin{array}{l}\text { Positive economic } \\
\text { results for the } \\
\text { organisation }\end{array}$ & 6.3 & 10.2 & 32.9 & 23.5 & 6.3 & 20.9 & 511 & 13.3 \\
\hline $\begin{array}{l}\text { Enhance market position } \\
\text { and/or develop customer } \\
\text { networks }\end{array}$ & 2.9 & 6.3 & 23.7 & 21.8 & 9.6 & 35.7 & 510 & 22.2 \\
\hline Research performance & 1.2 & 5.9 & 21.8 & 43.6 & 18.5 & 9.0 & 509 & 55.0 \\
\hline $\begin{array}{l}\text { Access to research } \\
\text { facilities abroad }\end{array}$ & 1.6 & 5.7 & 23.2 & 32.7 & 14.2 & 22.6 & 513 & 39.6 \\
\hline $\begin{array}{l}\text { Basis for new innovation } \\
\text { activities in own } \\
\text { organisation }\end{array}$ & 2.7 & 5.5 & 26.6 & 28.0 & 13.5 & 23.7 & 511 & 33.3 \\
\hline $\begin{array}{l}\text { Basis for new innovation } \\
\text { activities in Norway }\end{array}$ & 4.1 & 6.1 & 30.7 & 23.5 & 10.6 & 25.0 & 511 & 23.9 \\
\hline
\end{tabular}

*The column displays percentage points "Very successful" and "Mostly successful" minus percentage points "Very unsuccessful" and "Mostly unsuccessful".

Source: Survey to Norwegian participants in FP6. (Q 26: To what extent would you say that the following elements have been unsuccessful/successful within the project?) Appendix 1 contains figures by project type.

For the remaining issues in Table 4.8, many respondents answer "uncertain” or "not relevant”. Twenty-one per cent replied that positive economic results for their organisation are irrelevant, another 33 per cent state that they are uncertain about the economic results. Of those indicating success or lack of success on this issue, an equal number stated "very unsuccessful" and "very successful" (6 per cent each). A further 10 per cent answer that the project was mostly unsuccessful in terms of economic results for their organisation, whereas 24 per cent stated that is was mostly successful. In total, 13 per cent more respondents respond positively than negatively to the question of economic results of the project. However, the economic result is the issue where the participants are least positive (last column Table 4.8).

The second least positive result is obtained on enhancing market position/developing customer networks, with a positive balance of 22 percentage points. However, when we include only the enterprise respondents, for whom this is most relevant, the positive balance increases to 42 percentage points. ${ }^{43}$

Another issue with lower positive balance than on most of the other issues, is the basis for new innovation activities in own organisation. There are 33 percentage points more respondents who end up on the positive than the negative side on this issue. New

4320 per cent of enterprise respondents answer "Very successful" and 33 per cent answer "Mostly successful”, 6 per cent answer "Very unsuccessful" and 5 per cent answer "Mostly unsuccessful”. 
innovation activities are most relevant for the enterprises, and also here the balance is higher for the enterprise respondents -52 percentage points. ${ }^{44}$

Concerning basis for new innovation activities in Norway, the positive balance is lower and about the same for the enterprise respondents ( 25 percentage points) and the respondent group in general (24 percentage points). 17 per cent of enterprise respondents assess their project as "very successful" as basis for new innovation activities in Norway, and 25 per cent answer "mostly successful”, 12 per cent respond "mostly unsuccessful” and 5 per cent respond "very unsuccessful”.

There are notable differences between project types in participants' assessments (Appendix, Table A 8). Coordination Actions (CA) and Co-operative Research Projects (CRAFT) appear to be the most successful project types for giving basis for new innovation activities in Norway (21 to 23 per cent "very successful”). Collective Research Projects (CLR), Coordination Actions (CA) and Specific Targeted Research Projects (STREP) emerge as the most successful project types as basis for acquiring new $R \& D$ projects (26 to36 per cent "very successful”). Not surprisingly, Specific Actions to Promote Research Infrastructures (I3) are most successful in giving access to research facilities abroad (50 per cent "very successful”).

Specific Support Actions (SSA), Networks of Excellence (NoE) and Marie Curie Actions (MCA) are most successful in terms of achieving project objectives (33 to 37 per cent "very successful”). A likely explanation is that MCAs and SSAs might have more clear/concrete project aims which are both easier to achieve and to identify as achieved (the proportion answering "uncertain" is lower). The more general networking and collaboration goals of NoEs might be more easy to fulfil than ambitious aims of large Integrated Projects (22 per cent of Integrated Project respondents stated "very successful” on achieving project objectives).

Summing up, for Norwegian participants the EU projects seem most successful in terms of network-building and least successful in terms of economic results. The economy in the projects is further analysed in Sections 4.2.3 and 4.3.1, network building in Section 4.2.4.

\subsubsection{Participants' aims, involvement and priorities}

According to the surveys, access to research networks, expertise, scientific excellence and funding are the most important motivations for Norwegian participation in the Framework Programme. Among the FP6 participants, 76 per cent state that access to research networks was of large or very large significance in their motivation to participate, and more than 60 per cent stated that access to expertise (65 per cent), and to scientific excellence (63 per

4426 per cent of enterprise respondents answer "Very successful” and 35 per cent answer "Mostly successful”, 4 per cent answer "Very unsuccessful” and 6 per cent answer "Mostly unsuccessful”. 
cent) had large or very large significance (Table 4.9). For half of the FP6 participants, access to economic resources was of large or very large significance. Figures for the FP7 applicants are quite similar, with one notable difference: access to economic resources is more important (61 per cent stating large or very large significance, Table 4.10). Also access to scientific excellence is somewhat more important (5 percentage points more in FP7 stat that this was very important).

Also notable is that as many as 72 per cent state that one motivation (some, large or very large significance) for participation was that the project was considered as an integrated part of their organisation's internationalisation strategy, indicating that local policy and attitudes to international projects and collaboration are important and encourage participation (Table 4.10, response from FP7 applicants, this question was not posed to the FP6 participants). These findings are supported by information from interviews with research managers who state that opportunities for receiving funds according to the institution's research priorities is the most important driver, while establishing networks for future collaboration is another important driver.

Access to promising, talented young researchers is a motivation for a far smaller proportion of the participants. Twenty-four per cent of FP6 participants and 28 per cent of FP7 applicants answer that it had large or very large significance for their motivation to participate (Table 4.9 and Table 4.10). Notably, access to talented young researchers has higher significance for the higher education institutions than the other sectors (Table 4.11). Access to equipment and testing material is reported to be of large or very large significance only for 16 per cent of the FP6 participants, and 23 per cent of the FP7 applicants (Table 4.9 and Table 4.10).

Table 4.9 Motivations for participation in the FP6 projects. Per cent.

\begin{tabular}{|c|c|c|c|c|c|c|}
\hline $\begin{array}{l}\text { Please evaluate the significance } \\
\text { of the following as a motive for } \\
\text { your participation in the project? }\end{array}$ & $\begin{array}{r}1 \\
\text { No } \\
\text { significance } \\
\end{array}$ & $\begin{array}{r}2 \\
\text { Small } \\
\text { significance } \\
\end{array}$ & $\begin{array}{r}3 \\
\text { Some } \\
\text { significance } \\
\end{array}$ & $\begin{array}{r}4 \\
\text { Large } \\
\text { significance } \\
\end{array}$ & $\begin{array}{r}5 \\
\text { Very large } \\
\text { significance } \\
\end{array}$ & $\mathbf{N}$ \\
\hline a) Access to technology & 32.1 & 18.6 & 19.8 & 21.5 & 8.0 & 526 \\
\hline b) Access to expertise & 6.0 & 7.9 & 21.6 & 43.9 & 20.6 & 529 \\
\hline c) Access to market contacts & 39.6 & 19.4 & 17.7 & 17.9 & 5.3 & 525 \\
\hline d) Access to research networks & 2.3 & 4.5 & 17.2 & 36.8 & 39.2 & 530 \\
\hline e) Access to financial sources & 8.2 & 12.2 & 30.0 & 30.0 & 19.6 & 526 \\
\hline $\begin{array}{l}\text { f) Access to equipment and testing } \\
\text { material }\end{array}$ & 40.3 & 20.7 & 23.0 & 12.3 & 3.6 & 521 \\
\hline g) Access to scientific excellence & 5.7 & 9.5 & 21.3 & 38.1 & 25.3 & 525 \\
\hline $\begin{array}{l}\text { h) Access to promising/talented } \\
\text { young researchers }\end{array}$ & 25.2 & 25.2 & 25.6 & 14.8 & 9.1 & 527 \\
\hline $\begin{array}{l}\text { i) Encouragement from your } \\
\text { organisation }\end{array}$ & 11.9 & 18.2 & 33.8 & 26.0 & 10.1 & 523 \\
\hline 'j) Other, specify' & 66.7 & 1.9 & 5.0 & 12.0 & 14.3 & 258 \\
\hline
\end{tabular}

Source: Survey to Norwegian participants in FP6. 
Table 4.10 Motivations for participation in the FP7 projects. Per cent.

\begin{tabular}{|l|r|r|r|r|r|r|}
\hline $\begin{array}{l}\text { Please evaluate the significance } \\
\text { of the following as a motive for } \\
\text { your participation in the project? }\end{array}$ & $\begin{array}{r}\mathbf{1} \\
\text { No } \\
\text { significance }\end{array}$ & $\begin{array}{r}\text { Small } \\
\text { significance }\end{array}$ & $\begin{array}{r}\mathbf{3} \\
\text { Some } \\
\text { significance }\end{array}$ & $\begin{array}{r}\mathbf{4} \\
\text { significance }\end{array}$ & $\begin{array}{r}\text { Large } \\
\text { Very large } \\
\text { significance }\end{array}$ & $\begin{array}{r}\mathbf{5} \\
\mathbf{N}\end{array}$ \\
\hline a) Access to technology & 30.2 & 16.4 & 24.8 & 19.8 & 8.8 & 872 \\
\hline b) Access to expertise & 7.8 & 6.3 & 25.4 & 39.6 & $\mathbf{2 0 . 9}$ & 882 \\
\hline c) Access to market contacts & 4.3 & 17.4 & 19.5 & 18.7 & 7.0 & 866 \\
\hline d) Access to research networks & 7.1 & 9.1 & 22.9 & 32.5 & $\mathbf{3 6 . 4}$ & 881 \\
\hline e) Access to financial sources & 32.3 & 21.2 & 23.4 & 18.3 & 877 \\
\hline $\begin{array}{l}\text { f) Access to equipment and testing } \\
\text { material }\end{array}$ & 5.5 & 7.5 & 18.3 & 38.5 & 4.9 & 864 \\
\hline g) Access to scientific excellence & 21.4 & 22.6 & 28.1 & 19.5 & 30.3 & 879 \\
\hline $\begin{array}{l}\text { h) Access to promising/talented } \\
\text { young researchers }\end{array}$ & 12.0 & 17.5 & 32.3 & 29.1 & 8.4 & 872 \\
\hline $\begin{array}{l}\text { i) Encouragement from your } \\
\text { organisation }\end{array}$ & 12.8 & 15.2 & 25.7 & 30.1 & 9.1 & 880 \\
\hline $\begin{array}{l}\text { j) The project is an integrated part } \\
\text { of your organisation's } \\
\text { internationalisation strategy }\end{array}$ & 56.6 & 1.0 & 7.0 & 12.9 & 16.1 & 886 \\
\hline k) Other, specify' & & & 22.4 & 286 \\
\hline
\end{tabular}

Source: Survey to Norwegian applicants to FP7.

As expected, access to market contacts is most important as a motivation for the enterprises, whereas the project funding is more important for the research institutes and the higher education institutions (Table 4.11).

Table 4.11 Motivations for participation in the FP6 projects. Means* by sector.

\begin{tabular}{|c|c|c|c|c|c|c|c|c|c|c|}
\hline \multirow{2}{*}{$\begin{array}{l}\text { Please evaluate the significance of } \\
\text { the following as a motive for your } \\
\text { participation in the project? }\end{array}$} & \multicolumn{2}{|c|}{$\begin{array}{l}\text { Research } \\
\text { Institute }\end{array}$} & \multicolumn{2}{|c|}{$\begin{array}{l}\text { Higher } \\
\text { Education } \\
\text { Institution }\end{array}$} & \multicolumn{2}{|c|}{ Enterprise } & \multicolumn{2}{|c|}{ Other } & \multicolumn{2}{|c|}{ Total } \\
\hline & Mean & $\mathrm{N}$ & Mean & $\mathrm{N}$ & Mean & $\mathrm{N}$ & Mean & $\mathrm{N}$ & Mean & $\mathrm{N}$ \\
\hline a) Access to technology & 2.4 & 241 & 2.5 & 128 & 3.3 & 91 & 2.3 & 64 & 2.5 & 524 \\
\hline b) Access to expertise & 3.7 & 243 & 3.6 & 128 & 3.7 & 91 & 3.8 & 65 & 3.7 & 527 \\
\hline c) Access to market contacts & 2.3 & 244 & 1.7 & 125 & 3.1 & 91 & 2.2 & 63 & 2.3 & 523 \\
\hline d) Access to research networks & 4.3 & 243 & 4.2 & 130 & 3.7 & 90 & 3.7 & 65 & 4.1 & 528 \\
\hline e) Access to financial sources & 3.6 & 242 & 3.5 & 129 & 3.1 & 90 & 2.9 & 63 & 3.4 & 524 \\
\hline $\begin{array}{l}\text { f) Access to equipment and testing } \\
\text { material }\end{array}$ & 2.1 & 240 & 2.3 & 125 & 2.5 & 91 & 1.8 & 63 & 2.2 & 519 \\
\hline g) Access to scientific excellence & 3.7 & 239 & 4.0 & 128 & 3.5 & 91 & 3.2 & 65 & 3.7 & 523 \\
\hline $\begin{array}{l}\text { h) Access to promising/talented young } \\
\text { researchers }\end{array}$ & 2.5 & 241 & 3.1 & 129 & 2.5 & 91 & 2.0 & 64 & 2.6 & 525 \\
\hline i) Encouragement from your organisation & 3.2 & 240 & 2.8 & 128 & 3.0 & 90 & 3.1 & 63 & 3.0 & 521 \\
\hline
\end{tabular}

Source: Survey to Norwegian participants in FP6.

Several informants also listed other motivations for the projects (in an open reply box), including the opportunity to improve both their international and local recognition and standing, and positioning for future projects, or career development and ambition to become a leader in the field. Some also mentioned the specific research topic and personal research interest as the motivation; others that there was no interest for the topic in Norway and that international funding was the only option ("lack of decent national funding"). Continuation of previous FP projects and utilisation of data from other projects was also mentioned, as well as friendship with the partners, maintaining contact and that they were asked by colleagues to participate. Encouragement from the RCN was also mentioned. A more cynical respondent held that the main driver for the participation was to be politically 
correct, and that the science was not a driver since most of networking projects are highly inefficient. Another wrote that they decided to participate in order to keep good relations to the company that invited them to join the application.

Listed motives for ERA-NET projects include building network between funding organisations, collaboration between research programmes, contributing to the ERA, learning best practices and increasing skills. In an interview, a research manager at a research institute pointed to ERA-NETs as influential in the contents of later FP calls, implying that even if ERA-NETs are not a significant funding source, taking part in an ERA-NET may provide opportunities for influencing what is later to become major parts of the FP. Research managers at universities on the other hand are reluctant to engage in ERA-NETs, stating that the procedures are unclear, instruments in use vary between ERANETs, as well as unclear administrative procedures. Consequently, they did not encourage their staff to participate.

In summary, the Norwegian participants in general consider their participation in FP research as successful and important for their own research interests.

\section{Norwegian participants' involvement in project work}

There is a large variation in the participants' involvement in the EU projects (FP6, Table 4.12). Between 31 and 35 per cent report that they participated in the development of the project idea, the project formulation or the formulation of the application only to a small or very small extent. Eleven per cent were involved in the project execution to a small or very small extent. On the other hand, 45 per cent have been highly or very highly involved in the development of the project idea, and 65 per cent in the project execution. As expected, the coordinators are considerably more involved than other participants.

Table 4.12 Degree of involvement in the FP6 projects, per cent

\begin{tabular}{|c|c|c|c|c|c|c|}
\hline $\begin{array}{l}\text { To what extent did you (or } \\
\text { your EU project unit) } \\
\text { participate in the following } \\
\text { activities? }\end{array}$ & $\begin{array}{r}1 \\
\text { To a very } \\
\text { small } \\
\text { extent } \\
\end{array}$ & $\begin{array}{r}2 \\
\text { To a small } \\
\text { extent }\end{array}$ & $\begin{array}{r}3 \\
\text { To some } \\
\text { extent }\end{array}$ & $\begin{array}{r}4 \\
\text { To a high } \\
\text { extent } \\
\end{array}$ & $\begin{array}{r}5 \\
\text { To a very } \\
\text { high extent } \\
\end{array}$ & $\mathbf{N}$ \\
\hline $\begin{array}{l}\text { Development of project idea } \\
\text { (coordinators) }\end{array}$ & $\begin{array}{l}18.4 \\
(3.1)\end{array}$ & $\begin{array}{r}17.0 \\
(10.2) \\
\end{array}$ & $\begin{array}{l}19.9 \\
(8.2)\end{array}$ & $\begin{array}{r}20.8 \\
(17.3) \\
\end{array}$ & $\begin{array}{r}23.9 \\
(61.2) \\
\end{array}$ & $\begin{array}{l}523 \\
(98) \\
\end{array}$ \\
\hline $\begin{array}{l}\text { Project formulation } \\
\qquad \text { (coordinators) }\end{array}$ & $\begin{array}{l}14.9 \\
(6.2)\end{array}$ & $\begin{array}{r}16.5 \\
(10.3) \\
\end{array}$ & $\begin{array}{l}25.3 \\
(5.2) \\
\end{array}$ & $\begin{array}{r}21.1 \\
(19.6) \\
\end{array}$ & $\begin{array}{r}22.2 \\
(58.8) \\
\end{array}$ & $\begin{array}{l}522 \\
(97) \\
\end{array}$ \\
\hline $\begin{array}{l}\text { Formulation of application } \\
\qquad \text { (coordinators) }\end{array}$ & $\begin{array}{l}14.7 \\
(7.3) \\
\end{array}$ & $\begin{array}{r}16.4 \\
(11.5) \\
\end{array}$ & $\begin{array}{l}30.3 \\
(9.4) \\
\end{array}$ & $\begin{array}{r}18.5 \\
(15.6) \\
\end{array}$ & $\begin{array}{r}20.1 \\
(56.3) \\
\end{array}$ & $\begin{array}{l}518 \\
(96) \\
\end{array}$ \\
\hline $\begin{array}{l}\text { Project execution } \\
\qquad \text { (coordinators) }\end{array}$ & $\begin{array}{r}4.0 \\
(3.2)\end{array}$ & $\begin{array}{r}7.4 \\
(2.2)\end{array}$ & $\begin{array}{r}24.1 \\
(10.8)\end{array}$ & $\begin{array}{r}34.6 \\
(20.4)\end{array}$ & $\begin{array}{r}30.0 \\
(63.4)\end{array}$ & $\begin{array}{l}503 \\
(93)\end{array}$ \\
\hline
\end{tabular}


Table 4.13 shows the degree of involvement in FP7 applications by sector. The higher education institutions are the most active in the proposals, both in developing the project ideas and in formulating the projects and the proposals. Participants not belonging to any of the three research sectors ("Other") are the least involved. This corresponds to the sector differences in leading responsibility in the projects reported in Table 4.3. Within the enterprise sector large enterprises are the least involved in developing project ideas as well as in formulating projects and proposals for FP7.

Table 4.13 Degree of involvement in FP7 proposals by applicant sector. Per cent

\begin{tabular}{|c|c|c|c|c|}
\hline \multirow[b]{2}{*}{$\begin{array}{l}\text { To what extent did you (or your EU project } \\
\text { unit) participate in the following activities? }\end{array}$} & \multicolumn{3}{|c|}{$\begin{array}{c}\text { Percentage answering "to a high" or "very } \\
\text { high extent" }\end{array}$} & \multirow[b]{2}{*}{$\mathbf{N}$} \\
\hline & $\begin{array}{r}\text { Development of } \\
\text { project idea }\end{array}$ & $\begin{array}{c}\text { Project } \\
\text { formulation }\end{array}$ & $\begin{array}{l}\text { Formulation } \\
\text { of proposal }\end{array}$ & \\
\hline a) Research Institute & 49.0 & 49.4 & 51.3 & $400-405$ \\
\hline b) Higher Education Institution & 56.0 & 52.8 & 53.2 & $267-268$ \\
\hline \multicolumn{5}{|l|}{ c) Enterprise } \\
\hline Large enterprise & 25.0 & 25.3 & 18.7 & $72-75$ \\
\hline Medium enterprise & 35.0 & 30.0 & 28.6 & $20-21$ \\
\hline Small enterprise & 39.0 & 34.7 & 27.6 & $98-100$ \\
\hline d) Other & 28.6 & 19.0 & 21.4 & 42 \\
\hline Total & 46.8 & 45.0 & 44.6 & 903-907 \\
\hline
\end{tabular}

Overall, the project involvement seems slightly smaller in FP6 and FP7 than in FP5. In FP5, slightly more than half of the participants reported large involvement in developing the project idea (NIFU, STEP and Technopolis 2004, page 106), whereas in FP6 and FP7, 45 per cent report high or very high involvement (Table 4.12 and Table 4.13). Moreover, in the FP5 survey about 70 per cent reported large involvement in the project execution (NIFU, STEP and Technopolis 2004, page 106), whereas in FP6 64 per cent report high or very high involvement in project execution (Table 4.12).

Table 4.14 shows the FP7 applicants involvement in the proposal according to proposal success. Whereas the highest rejection rates are found among those who to a very small extent participated in the development of the project idea, highest success rates are found among those who to a very small extent participated in the project formulation and the formulation of the proposal. This indicates that formulating projects and proposals are not the Norwegian applicants' strongest qualification, and that collaborating with partners who are better at this, can be a successful strategy. ${ }^{45}$

45 The calculations do not include the ERC-applicants, for which the Norwegian success rate is particularly low at the same time as they normally will need to be play a central role in the formulation of the project and the proposal. 
Table 4.14 Proposal success FP7 by degree of involvement in the proposal. Per cent

\begin{tabular}{|c|c|c|c|c|c|c|}
\hline $\begin{array}{l}\text { To what extent did you (or } \\
\text { your EU project unit) } \\
\text { participate in the following } \\
\text { activities? }\end{array}$ & $\begin{array}{r}1 \\
\text { To a very } \\
\text { small extent }\end{array}$ & $\begin{array}{r}2 \\
\text { To a small } \\
\text { extent }\end{array}$ & $\begin{array}{r}3 \\
\text { To some } \\
\text { extent }\end{array}$ & $\begin{array}{r}4 \\
\text { To a high } \\
\text { extent }\end{array}$ & $\begin{array}{r}5 \\
\text { To a very } \\
\text { high extent } \\
\end{array}$ & Total \\
\hline \multicolumn{7}{|l|}{$\begin{array}{l}\text { Development of project } \\
\text { idea }\end{array}$} \\
\hline Proposal rejected & 70.2 & 61.1 & 68.6 & 66.5 & 67.0 & 66.7 \\
\hline Proposal funded & 24.0 & 36.1 & 27.5 & 31.6 & 31.3 & 30.2 \\
\hline Outcome uncertain & 5.8 & 2.8 & 3.9 & 1.9 & 1.8 & 3.0 \\
\hline $\mathrm{N}$ & 121 & 144 & 204 & 158 & 227 & 854 \\
\hline \multicolumn{7}{|l|}{ Project formulation } \\
\hline Proposal rejected & 60.8 & 65.2 & 66.3 & 67.7 & 69.3 & 66.6 \\
\hline Proposal funded & 32.9 & 29.6 & 31.1 & 31.1 & 28.7 & 30.5 \\
\hline Outcome uncertain & 6.3 & 5.2 & 2.6 & 1.2 & 2.0 & 2.9 \\
\hline $\mathrm{N}$ & 79 & 135 & 273 & 167 & 202 & 856 \\
\hline \multicolumn{7}{|l|}{ Formulation of application } \\
\hline Proposal rejected & 54.8 & 66.9 & 68.9 & 64.9 & 69.1 & 66.6 \\
\hline Proposal funded & 38.4 & 27.2 & 28.9 & 33.9 & 28.4 & 30.3 \\
\hline Outcome uncertain & 6.8 & 5.9 & 2.1 & 1.2 & 2.6 & 3.0 \\
\hline $\mathrm{N}$ & 73 & 136 & 280 & 171 & 194 & 854 \\
\hline
\end{tabular}

Source: Survey to Norwegian applicants to FP7. Replies from applicants to ERC-grants are not included in the table. See Table A 7 in Appendix for figures including also ERC-applicants.

The lower success of the more involved applicants is further corroborated in Table 4.15. On average, applicants who are not coordinators have 9 percentage points lower rejection rate than the coordinators. ${ }^{46}$ Moreover, applicants without a leading responsibility in the project have 11 percentage points lower rejection rate than the applicants with a leading responsibility.

Table 4.15 Proposal success FP7 by coordinator and leading responsibility. Per cent

\begin{tabular}{lcccc}
\hline & \multicolumn{2}{c}{ Coordinator } & \multicolumn{2}{c}{$\begin{array}{c}\text { Leading responsibility, } \\
\text { e.g. work package }\end{array}$} \\
\cline { 2 - 5 } Proposal outcome* & Yes & No & Yes & No \\
\hline Proposal rejected & 78.0 & 69.5 & 70.7 & 60.1 \\
Mainlist/Proposal funded & 15.4 & 20.9 & 26.8 & 32.0 \\
Reserve list/Outcome uncertain & 6.5 & 9.6 & 2.5 & 7.9 \\
\hline $\mathbf{N}$ & $\mathbf{4 2 8}$ & $\mathbf{1 8 5 4}$ & $\mathbf{6 0 1}$ & $\mathbf{3 1 6}$
\end{tabular}

*Rejection/success rates of "participations", not of the applications/projects.

Source: Data from EC (coordinator) and survey to Norwegian applicants to FP7 (leading responsibility). ERC-applicants are included. When excluding ERC-applicants, the difference is somewhat smaller: 73 per cent of coordinators' applications are rejected, whereas 69 per cent of other participants' applications are rejected $(\mathrm{N}=2171)$.

\section{Links to other projects and other funding sources}

Sixty-nine per cent of the projects are not an extension/follow up of another R\&D project (vs. 65 per cent in the FP5 survey). 17 per cent are extensions of previous EU projects,

$46 \quad$ See also Table A 14 and Section 4.4 for differences between priority areas. 
whereas only 6 per cent are extensions of nationally financed projects. These percentages differ between programmes (Table 4.16).

Table 4.16 Links to other projects: Is this project an extension/follow up of another $R \& D$ project? Replies by FP6 programme/priority. Per cent.

\begin{tabular}{|c|c|c|c|c|c|c|}
\hline Programme/priority & No & $\begin{array}{l}\text { Yes, } \\
\text { extension } \\
\text { of } \\
\text { internally } \\
\text { financed } \\
\text { project }\end{array}$ & $\begin{array}{l}\text { Yes, } \\
\text { extension } \\
\text { of } \\
\text { nationally } \\
\text { financed } \\
\text { R\&D } \\
\text { project }\end{array}$ & $\begin{array}{l}\text { Yes, } \\
\text { extension } \\
\text { of } \\
\text { previous } \\
\text { EU } \\
\text { project } \\
\end{array}$ & $\begin{array}{l}\text { Yes, extension } \\
\text { of another } \\
\text { internationally } \\
\text { financed R\&D } \\
\text { project }\end{array}$ & $\mathbf{N}$ \\
\hline $\begin{array}{l}\text { 1. Life sciences, genomics and biotechnology } \\
\text { for health }\end{array}$ & 44.0 & 8.0 & 24.0 & 24.0 & & 25 \\
\hline 2. Information society technologies & 68.3 & 1.2 & 11.0 & 19.5 & & 82 \\
\hline 3. Nanotechnologies and nanosciences & 60.0 & 25.0 & 5.0 & & 10.0 & 20 \\
\hline 4. Aeronautics and space & 64.3 & 7.1 & & 28.6 & & 14 \\
\hline 5. Food quality and safety & 69.6 & 2.2 & 15.2 & 8.7 & 4.3 & 46 \\
\hline $\begin{array}{l}\text { 6. Sustainable development, global change and } \\
\text { ecosystems }\end{array}$ & 65.1 & 9.3 & 3.1 & 18.6 & 3.9 & 129 \\
\hline $\begin{array}{l}\text { 7. Citizens and governance in a knowledge- } \\
\text { based society }\end{array}$ & 68.4 & & 5.3 & 23.7 & 2.6 & 38 \\
\hline Horizontal research activities involving SMEs & 76.5 & 7.8 & 5.9 & 7.8 & 2.0 & 51 \\
\hline Human resources and mobility & 79.1 & 2.3 & 4.7 & 11.6 & 2.3 & 43 \\
\hline $\begin{array}{l}\text { Policy support and anticipating scientific and } \\
\text { technological needs }\end{array}$ & 75.5 & & 1.9 & 20.8 & 1.9 & 53 \\
\hline Research and innovation & 64.7 & & 5.9 & 23.5 & 5.9 & 17 \\
\hline Research infrastructures & 90.0 & & & 10.0 & & 10 \\
\hline Science and society & 50.0 & & & 50.0 & & 4 \\
\hline $\begin{array}{l}\text { Specific measures in support of international } \\
\text { cooperation }\end{array}$ & 80.0 & & & 20.0 & & 5 \\
\hline $\begin{array}{l}\text { Support for the coherent development of } \\
\text { research \& innovation policies }\end{array}$ & 66.7 & & & & 33.3 & 3 \\
\hline Support for the coordination of activities & 84.2 & 5.3 & & 10.5 & & 19 \\
\hline Total & 69.2 & 5.0 & 6.4 & 16.6 & 2.7 & 559 \\
\hline Impact on marine/maritime sector & 59.5 & 9.9 & 2.5 & 24.0 & 4.1 & 121 \\
\hline
\end{tabular}

Even when only 6 per cent of the FP6 projects are reported to be extensions of nationally financed projects, 48 per cent of the projects are closely related to research for which the Norwegian participant has obtained Norwegian public funding during the last 5 years. For FP7, 44 per cent of the applications are closely linked to research for which Norwegian public funding has been obtained during the last 2 years (Table 4.17). In other words, the larger part of both the FP6 participations and the FP7 applications are not closely related to nationally financed research, and very few of the projects are extensions of nationally financed projects (there are differences between the thematic priorities, see Section 4.4).

The links to nationally financed research is closest in the higher education sector, and considerably lower among the enterprises. Among the higher education institution 
respondents, as much as 59 per cent in FP6 and 52 per cent in FP7 have obtained national funding for closely related research. Among the enterprises, 34 per cent in FP6 and 31 per cent in FP7 have such funding (Table 4.17).

Table 4.17 Links to other projects: Funding of thematically related projects. Per cent FP6 and FP7.

\begin{tabular}{|c|c|c|c|c|c|c|}
\hline \multirow{2}{*}{$\begin{array}{l}\text { Was the EU project closely related to research for } \\
\text { which you received Norwegian public funding? }\end{array}$} & \multicolumn{3}{|c|}{$\begin{array}{c}\text { FP6 } \\
\text { Norwegian public } \\
\text { funding last } 5 \text { years }\end{array}$} & \multicolumn{3}{|c|}{$\begin{array}{c}\text { FP7 } \\
\text { Norwegian public } \\
\text { funding last } 2 \text { years }\end{array}$} \\
\hline & Yes & No & $\mathrm{N}$ & Yes & No & $\mathrm{N}$ \\
\hline a) Research Institute & 53.0 & 47.0 & 251 & 46.6 & 53.4 & 416 \\
\hline b) Higher Education Institution & 58.5 & 41.5 & 135 & 52.0 & 48.0 & 273 \\
\hline \multirow{4}{*}{$\begin{array}{l}\text { c) Enterprise } \\
\begin{array}{l}\text { Large enterprise } \\
\text { Medium enterprise } \\
\text { Small enterprise }\end{array}\end{array}$} & 34.3 & 65.7 & 99 & 31.0 & 69.0 & 203 \\
\hline & & & & 25.7 & 74.3 & 74 \\
\hline & & & & 29.2 & 70.8 & 24 \\
\hline & & & & 35.2 & 64.8 & 105 \\
\hline d) Other & 18.8 & 81.3 & 48 & 16.7 & 83.3 & 42 \\
\hline Total & 47.8 & 52.2 & 533 & 43.5 & 56.5 & 934 \\
\hline
\end{tabular}

Of the FP6 respondents, 254 report national funding for closely related research (FP6), and several of them report more than one national funding source; 201 state that the EU project was closely linked to research funded by RCN research programmes, 22 closely linked to SFI or SFF funded by RCN, and 97 that it was closely linked to research funded by other national sources. Similar figures for FP7 are shown in Table 4.18, also showing the success rates in the various categories. The success rate for the FP7 applications with related RCN programme funding is about the same as applications without any national funding. Applications with related SFI or SFF funding, however, have a considerably higher success rate. Applications linked to national funding other than by the RCN, on the other hand, have a somewhat lower success rate. There are notable differences between the thematic priorities and within Environment, applications with related RCN funding have a much higher success rate, see Section 4.4.

Table 4.18 FP7: proposal success by national funding.

\begin{tabular}{lrrrr}
\hline & & \multicolumn{3}{c}{ Application status } \\
\cline { 2 - 4 } $\begin{array}{l}\text { Was the EU project closely related to research for } \\
\text { which you received Norwegian public funding? }\end{array}$ & Rejected & Funded & Uncertain & N \\
\hline No & 66.8 & 28.7 & 4.6 & 527 \\
Yes, Research Council of Norway programme & 69.7 & 28.1 & 2.2 & 320 \\
SFI or SFF funded by the Research Council of Norway & 53.1 & 43.8 & 3.1 & 32 \\
Yes, other national funding & 71.0 & 24.2 & 4.8 & 124 \\
\hline \multirow{2}{*}{ Total } & $\mathbf{6 7 . 8}$ & $\mathbf{2 8 . 4}$ & $\mathbf{3 . 8}$ & $\mathbf{9 3 2}$ \\
\hline *Several applicants replied positive to more than one national funding source, totals are consequently not sums. \\
Sources: Survey to Norwegian applicants to FP7.
\end{tabular}




\subsubsection{The qualities of the EU projects}

To what extent does the research undertaken in the PF projects differ from other research undertaken at the participating institutions? In this section, PF projects are compared with other projects concerning a variety of different qualities: scientific quality, orientation towards basic and long-term research, scientifically/technologically risky research, multidisciplinarity, new scientific results from the projects, as well as the projects' strategic importance to the participating organisation.

In the participant survey all respondents were asked to compare the nature of their EU project with their other $R \& D$ projects. On all aspects they were asked to compare, the larger share reported that there was no difference. Fifty-nine per cent reported that their EU projects were as scientifically/technologically risky as their other R\&D projects; 58 per cent that they had the same scientific quality; 50 per cent that they provided the same amount of new scientific results, and were equally oriented towards basic research. Moreover, 45 per cent reported that they were equally multidisciplinary, 40 per cent that they were equally strategic important to their organisation and 39 per cent that they were equally long-term.

Of those reporting differences, a clear majority state that the EU projects are more multidisciplinary (43 versus 12 per cent), and long-term (36 versus 25 per cent). Moreover, a somewhat higher proportion reports that the EU projects were less oriented towards basic research (28 versus 22 per cent). These results confirm the overall orientation of the PFs aimed at multidisciplinary applied research. At least for the large amount of participants at higher education institutions, a description of PF research as somewhat more multidisciplinary and somewhat less basic that their other research, is as expected. Some informants expressed concerns about the required multidisciplinarity in FP research because it forces collaboration in studies where there is no scientific reason for collaboration. The consequence is disputes among scientists on the scientific strategy of projects and potential negative effect on the climate for collaboration. On the other hand, as more long-term than other projects, EU projects come out on the positive side. 
Table 4.19 Participants' assessments of the nature of the EU projects. Per cent.

\begin{tabular}{|l|r|r|r|r|}
\hline $\begin{array}{l}\text { Please compare the nature of your EU project(s) with } \\
\text { your other R\&D projects and indicate which projects }\end{array}$ & $\begin{array}{r}\text { The EU } \\
\text { projects }\end{array}$ & $\begin{array}{r}\text { Oifference } \\
\text { difl }\end{array}$ & $\begin{array}{r}\text { Our other } \\
\text { projects }\end{array}$ & N \\
\hline All project types & & & & \\
\hline a) are most strategically important to your organisation? & 32.8 & 39.5 & 27.7 & 491 \\
\hline b) are most oriented towards basic research? & 22.2 & 49.8 & 28.0 & 490 \\
\hline c) provide most new scientific results? & 22.0 & 50.3 & 27.7 & 491 \\
\hline d) are most scientifically/technologically risky? & 22.7 & 59.0 & 18.2 & 488 \\
\hline e) have the highest scientific quality? & 23.2 & 58.0 & 18.7 & 491 \\
\hline f) are most long-term? & 36.1 & 39.2 & 24.7 & 490 \\
\hline g) are most multidisciplinary? & 43.2 & 44.6 & 12.2 & 491 \\
\hline Research oriented project types* & & & & \\
\hline a) are most strategically important to your organisation? & 31.3 & 42.2 & 26.5 & 313 \\
\hline b) are most oriented towards basic research? & 23.4 & 49.4 & 27.2 & 312 \\
\hline c) provide most new scientific results? & 25.3 & 49.4 & 25.3 & 312 \\
\hline d) are most scientifically/technologically risky? & 25.5 & 58.1 & 16.5 & 310 \\
\hline e) have the highest scientific quality? & 27.6 & 54.5 & 17.9 & 312 \\
\hline f) are most long-term? & 40.2 & 39.5 & 20.3 & 311 \\
\hline g) are most multidisciplinary? & 48.4 & 42.0 & 9.6 & 312 \\
\hline
\end{tabular}

*Includes Collective Research Projects (CLR), Co-operative Research Projects (CRAFT), Integrated Projects (IP) and Specific Targeted Research Projects (STREP).

Source: Survey to Norwegian participants in FP6. ERA-net participants were not posed the questions in this table.

Interpreting the results, especially regarding which projects provide most new scientific results, there is a need to differentiate between the various kinds of FP6 projects. Some project types are aimed at networking activities, infrastructures or support, whereas others provide funding for research activities. Overall, a somewhat higher proportion (28 per cent) report that their other projects provide more scientific results than their EU projects (22 per cent, item c, upper part of Table 4.19). When including only the FP6 project types most clearly oriented towards research activities, one quarter of the participants report that their EU projects provide most new scientific results, and another quarter report that their other projects provide most new scientific results. The remaining half states that there is no difference (lower part of Table 4.19). There are however substantial differences between the research project types. Whereas the Collective Research Projects (CLR), the Cooperative Research Projects (CRAFT), and the Specific Targeted Research Projects (STREP) are more frequently considered to provide more new scientific results than participants' non-EU projects, the Integrated Projects (IPs, i.e. the larger EU projects) are given lower scores on providing new scientific results (Table A 15).

The nature of the EU projects versus participants other projects also varies somewhat by programme/priority (see Table A 10 in Appendix 1). The participants in the SME activities find the EU project to be more strategically important to their organisation (39 per cent); providing more new scientific results (31 per cent); being more scientifically/technologically risky, having higher scientific quality (42 per cent); and being more longterm (40 per cent) and multidisciplinary (50 per cent) than their other projects. Somewhat surprisingly, the participants in the SME activities do not find the EU projects more oriented towards basic research; 16 per cent state that the EU project is most oriented towards basic research; 29 per cent that their other projects are most oriented towards basic research. 
Within Information society technologies (IST) a substantially higher proportion of Norwegian participants finds the EU project more oriented towards basic research (37 per cent); providing more new scientific results (35 per cent); being more scientifically/technologically risky (36 per cent) and long term (51 per cent); and multidisciplinary (44 per cent), than their other projects.

Within Nanotechnologies and nanosciences (NMP) a higher proportion finds that the EU project is more oriented towards basic research (32 per cent); providing more new scientific results (26 per cent) being more scientifically/technologically risky (37 per cent); having higher scientific quality (32 per cent); long term (42 per cent); and multidisciplinary (58 per cent), than their other projects. No one here finds their other project to have higher scientific quality (68 per cent answer that the EU project and their other project have the same quality).

At the other end we find Life sciences, genomics and biotechnology for health (LIFE) and Sustainable development, global change and ecosystems (SUST) where a higher proportion finds that their other projects provide more new scientific results (22 and 34 per cent), and have higher scientific quality (26 per cent). Respondents in the LIFE programme also find their other projects to be more long-term (41 per cent), whereas the SUSTrespondents find the EU project to be more long-term (44 per cent). It should be noted that the number of respondents is small both for the NMP- and LIFE programmes (covering 19 of 57 Norwegian participations for NMP and 23 of 55 Norwegian participations for LIFE).

Summing up the comparison, the larger proportion of Norwegian participants in EU projects reports that there is no difference between their EU project and their other R\&D projects. There are some differences between the dimensions compared, for example a high proportion finds the EU more multidisciplinary than their other projects (43 per cent). With respect to scientific quality the figures are 5 percentage points more in favour of the EU projects than the other projects. Moreover, the nature of the EU projects versus participants other projects varies substantially between the different FP6 priorities.

\subsubsection{Proposal costs, obstacles and strengths}

Participants' application costs are substantial. According to the FP6 participant survey, each participating organisation typically spends 1 work month on an FP application (1 month is both the median value and the most frequent reply). Several respondents report putting down much more than one work month in the application, and the average reported application workload is 3.3 months per participation (Table 4.20). As the reason for some of the high values might be that the respondents have misread the question and answered for the project as such, not only the proposal, the median value may be a better indicator of 
the than the mean. Likewise, for the reported direct costs. The average costs reported amount to NOK 50,000, while the median value is NOK $10,000 .{ }^{47}$

Co-operative Research Projects and Integrated Projects have the highest applications costs, respectively 3 and 2 months (median, Table 4.20).

Table 4.20 FP6: Average proposal costs

\begin{tabular}{|c|c|c|c|}
\hline Project type & & $\begin{array}{r}\text { Total months } \\
\text { work }^{*}\end{array}$ & $\begin{array}{r}\text { Direct costs } \\
\text { (travel etc.) in NOK }\end{array}$ \\
\hline \multirow[t]{2}{*}{ CA } & Mean & 1.5 & 14167 \\
\hline & Median & 1.0 & 5000 \\
\hline Coordination Actions & $\mathrm{N}$ & 55 & 48 \\
\hline \multirow{2}{*}{ CLR } & Mean & 4.8 & 199351 \\
\hline & Median & 0.8 & 10000 \\
\hline Collective Research Projects & $\mathrm{N}$ & 14 & 14 \\
\hline \multirow[t]{2}{*}{ CRAFT } & Mean & 11.6 & 286638 \\
\hline & Median & 3.0 & 50000 \\
\hline Co-operative Research Projects & $\mathrm{N}$ & 31 & 28 \\
\hline II & Mean & 3.0 & 28500 \\
\hline \multirow{2}{*}{$\begin{array}{l}\text { Specific Actions to Promote Research } \\
\text { Infrastructures (I3) }\end{array}$} & Median & 1.5 & 2501 \\
\hline & $\mathrm{N}$ & 6 & 6 \\
\hline \multirow[t]{2}{*}{ IP } & Mean & 3.7 & 42173 \\
\hline & Median & 2.0 & 15000 \\
\hline Integrated Projects & $\mathrm{N}$ & 125 & 116 \\
\hline \multirow[t]{2}{*}{ MCA } & Mean & 1.2 & 23140 \\
\hline & Median & 1.0 & 5000 \\
\hline Marie Curie Actions & $\mathrm{N}$ & 41 & 41 \\
\hline \multirow[t]{2}{*}{ NOE } & Mean & 1.9 & 15444 \\
\hline & Median & 1.0 & 5000 \\
\hline Networks of Excellence & $\mathrm{N}$ & 49 & 47 \\
\hline \multirow[t]{2}{*}{ SSA } & Mean & 3.3 & 25115 \\
\hline & Median & 1.0 & 10000 \\
\hline Specific Support Actions & $\mathrm{N}$ & 51 & 47 \\
\hline \multirow{2}{*}{ STREP } & Mean & 2.7 & 34286 \\
\hline & Median & 1.0 & 10000 \\
\hline \multirow[t]{3}{*}{ Specific Targeted Research Projects } & $\mathrm{N}$ & 132 & 123 \\
\hline & Mean & 3.3 & 50281 \\
\hline & Median & 1.0 & 10000 \\
\hline Total & $\mathbf{N}$ & 504 & 470 \\
\hline
\end{tabular}

*One respondent reported using 200000 months on the proposal. This reply is not included in the calculations. Another 30 respondents reported using more than 12 months (up to 63 months). Some of these might have misread the question and answered for the project as such, not only the proposal. These replies are still included in the calculations, which imply that the estimated average time for the proposals, and especially the CRAFT-proposals might be too high.

Source: Survey to Norwegian participants in FP6.

Table 4.21 show that the FP7 applicants also typically spend 1 work month per application (that is; per participation in applications). Funded applications have a slightly higher average (3 versus 2.8 work months), but for both the median value is 1 work month.

47 The most frequent answer is NOK 0 , while the second most frequent value is NOK 20.000, and 8 respondents report above NOK 1 million. 
Table 4.21 Proposal costs FP7, average total months work for proposals

\begin{tabular}{lrrrrrr}
\hline Application status & Mean & Median & N & Minimum & Maximum & $\begin{array}{r}\text { Std. } \\
\text { Deviation }\end{array}$ \\
\hline Rejected & 2.8 & 1.0 & 591 & 0.0 & 300.0 & 15.5 \\
Funded & 3.0 & 1.0 & 252 & 0.0 & 48.0 & 5.4 \\
Uncertain & 1.6 & 1.0 & 25 & 0.1 & 5.7 & 1.5 \\
\hline Total & $\mathbf{2 . 8}$ & $\mathbf{1 . 0}$ & $\mathbf{8 6 8}$ & $\mathbf{0 . 0}$ & $\mathbf{3 0 0 . 0}$ & $\mathbf{1 3 . 1}$ \\
\hline
\end{tabular}

Source: Survey to Norwegian applicants to FP7.

In most cases, the larger share of the application costs is covered by the applicants, but the average proportion covered by the participating organisations is reduced from FP6 to FP7. On average, 86 per cent of the proposal costs in FP6 and 75 per cent in FP7 were covered by the participating organisation. The proportion covered by the Project Establishment Support Scheme (PES) from the RCN was almost doubled from FP6 to FP7 (from 11 to 20 per cent). There was also a small increase in the proportion covered by other external sources. Compared to other sectors, a larger share of the application costs of the institute sector is covered by PES, both in FP6 and FP7 (13 per cent in FP6 and 26 per cent in FP7, Table 4.22). Interviews with research managers confirm that PES has been a major incentive in the increase in number of proposals submitted.

Table 4.22 Proposal funding FP6 and FP7, average percentages from different funding sources, by sector.

\begin{tabular}{|c|c|c|c|c|c|c|c|c|c|c|}
\hline \multirow[b]{2}{*}{ Funding source } & \multicolumn{2}{|c|}{$\begin{array}{l}\text { Research } \\
\text { Institute }\end{array}$} & \multicolumn{2}{|c|}{$\begin{array}{c}\text { Higher } \\
\text { Education } \\
\text { Institution }\end{array}$} & \multicolumn{2}{|c|}{ Enterprise } & \multicolumn{2}{|c|}{ Other } & \multicolumn{2}{|c|}{ Total } \\
\hline & FP6 & FP7 & FP6 & FP7 & FP6 & FP7 & FP6 & FP7 & FP6 & FP7 \\
\hline Own organisation \% & 83.3 & 70.7 & 85.7 & 76.2 & 89.1 & 81.4 & 92.5 & 85.3 & 85.9 & 75.2 \\
\hline \begin{tabular}{|l|} 
Project Establishment Support \\
Scheme from RCN (PES) \% \\
\end{tabular} & 13.0 & 25.9 & 9.9 & 17.4 & 8.9 & 14.0 & 4.0 & 5.3 & 10.6 & 20.1 \\
\hline Other external sources \% & 3.6 & 3.5 & 4.4 & 6.4 & 2.0 & 4.7 & 3.5 & 9.4 & 3.5 & 4.8 \\
\hline Total $(100 \%)$ & 100 & 100 & 100 & 100 & 100 & 100 & 100 & 100 & 100 & 100 \\
\hline N (applicants) & 218 & 361 & 110 & 230 & 76 & 167 & 50 & 32 & 454 & 790 \\
\hline
\end{tabular}

Sources: Survey to Norwegian participants in FP6 and to Norwegian applicants to FP7. Only replies from respondents whose answers total 100 per cent are included in the calculations.

Table 4.23 shows funding sources for successful and rejected proposal. Successful proposals have a slightly higher proportion of pre-project funds and other external funding, whereas rejected proposals to a somewhat higher extent are funded by own organisation. 
Table 4.23 Proposal funding, means by proposal success FP7.

\begin{tabular}{|c|c|c|c|c|c|}
\hline $\begin{array}{l}\text { Application } \\
\text { status }\end{array}$ & & $\begin{array}{r}\text { Own } \\
\text { organisation } \\
\% \\
\end{array}$ & $\begin{array}{r}\text { Project } \\
\text { Establishment } \\
\text { Support RCN } \\
\text { (PES) \% } \\
\end{array}$ & $\begin{array}{r}\text { Other } \\
\text { external sources } \\
\% \\
\end{array}$ & $\begin{array}{r}\text { Total } \\
(100 \%) \\
\end{array}$ \\
\hline \multirow[t]{2}{*}{ Rejected } & Mean & 75.8 & 19.3 & 4.9 & 100.0 \\
\hline & $\mathrm{N}$ & 537 & 537 & 537 & 537 \\
\hline \multirow[t]{2}{*}{ Funded } & Mean & 72.5 & 22.3 & 5.2 & 100.0 \\
\hline & $\mathrm{N}$ & 229 & 229 & 229 & 229 \\
\hline \multirow[t]{2}{*}{ Uncertain } & Mean & 86.8 & 13.2 & 0.0 & 100.0 \\
\hline & $\mathrm{N}$ & 23 & 23 & 23 & 23 \\
\hline \multirow[t]{2}{*}{ Total } & Mean & 75.2 & 20.0 & 4.8 & 100.0 \\
\hline & $\mathrm{N}$ & 789 & 789 & 789 & 789 \\
\hline
\end{tabular}

Obstacles and strengths in proposals and projects

According to the FP6 participant survey, the major strengths in the proposal phase relate to finding relevant partners, access to scientific personnel for developing a good proposal and including interesting research questions in the proposal. A majority define these factors as strengths for their proposal, and very few report weaknesses regarding these issues. As perceived by the participants, the major weaknesses relate to administrative support from their own organisation, as well as support in coordination and management of the proposal phase and coping with proposal formalities. But also on these issues, there is a slightly higher proportion defining them as strengths rather than weaknesses (Table 4.24). In the interviews some informants emphasised the problems related to coordinating a proposal. Coordinating a large proposal is considered very demanding. While scientists normally had few problems when writing the scientific part, they had little experience in preparing the administrative, dissemination and impact part of proposals, often resulting in low score on this. Several informants stressed the need for professionalising the handling of proposals, including increasing local administrative resources as well as using external experts. 
Table 4.24 Strengths and weaknesses in the applications process, FP6. Per cent.

\begin{tabular}{|c|c|c|c|c|c|}
\hline $\begin{array}{l}\text { Please evaluate the significance of the following as } \\
\text { strengths or weaknesses in the application phase of } \\
\text { the project (i.e. the abilities of your group/your } \\
\text { organisation/the consortium): }\end{array}$ & Strength & $\begin{array}{r}\text { No } \\
\text { particular } \\
\text { strength } \\
\text { or } \\
\text { weakness }\end{array}$ & Weakness & $\begin{array}{l}\text { Don't } \\
\text { know }\end{array}$ & $\mathbf{N}$ \\
\hline a) Ability to find relevant partners & 59.8 & 24.6 & 2.5 & 13.1 & 525 \\
\hline $\begin{array}{l}\text { b) Ability to include research questions of our immediate } \\
\text { interest in the proposal }\end{array}$ & 57.2 & 30.7 & 2.1 & 10.0 & 521 \\
\hline $\begin{array}{l}\text { c) Access to scientific personnel for developing a good } \\
\text { proposal }\end{array}$ & 56.6 & 28.6 & 3.6 & 11.1 & 521 \\
\hline $\begin{array}{l}\text { d) Ability to agree on resource distribution (in the } \\
\text { consortium) }\end{array}$ & 35.8 & 45.8 & 6.2 & 12.3 & 520 \\
\hline e) Ability to agree about intellectual property rights & 20.0 & 51.2 & 5.2 & 23.6 & 516 \\
\hline f) Administrative support from own organisation & 24.2 & 45.0 & 22.3 & 8.5 & 520 \\
\hline $\begin{array}{l}\text { g) Support in your organisation regarding } \\
\text { coordination/management of the proposal phase }\end{array}$ & 24.6 & 41.9 & 23.5 & 10.0 & 520 \\
\hline $\begin{array}{l}\text { h) Moral support from the management of your } \\
\text { organisation }\end{array}$ & 36.9 & 42.7 & 11.0 & 9.4 & 520 \\
\hline $\begin{array}{l}\text { i) Ability to understand the full scope of the call topic and its } \\
\text { objectives }\end{array}$ & 47.3 & 35.2 & 6.7 & 10.7 & 522 \\
\hline j) Planning of the time needed for developing the proposal & 22.0 & 55.5 & 11.4 & 11.2 & 519 \\
\hline k) Coping with proposal formalities & 27.5 & 43.1 & 18.2 & 11.2 & 517 \\
\hline
\end{tabular}

Source: Survey to Norwegian participants in FP6.

There are no large differences between coordinators and other respondents in the definition of strengths and weaknesses. There are however, differences between sectors.

Administrative support and proposal formalities are more frequently reported to be a weakness in higher education institutions than in the other sectors. Thirty-three per cent of respondents at higher education institutions report administrative support from own organisation to be a weakness in the application phase, 35 per cent report support in own organisation regarding coordination/management of the proposal phase to be a weakness, and 24 per cent report coping with application formalities to be a weakness. In the enterprises, on the other hand, 18 per cent report administrative support from their own organisation to be a weakness in the application phase; 16 per cent report support in own organisation regarding coordination/management of the proposal phase to be a weakness; and 17 per cent report coping with proposal formalities to be a weakness. Ability to agree about intellectual property rights is somewhat more frequently reported a problem by respondents in enterprises. 10 per cent here report it as a weakness, whereas only 5 per cent in higher education institutions and research institutes report it as a weakness (all statistics from FP6 participant survey, no table).

Table 4.25 shows success rates by proposal strengths and weaknesses in FP7. The success rate is considerably higher for those applicants who define strengths in their access to scientific personnel for developing a good proposal and ability to find relevant partners. 35 per cent of those defining these factors as strengths made a successful application, whereas of those defining them as weaknesses, a far lower per cent succeeded (10 per cent of those with problems in finding relevant partners, and 15 per cent of those with problems in access to scientific personnel). Another important factor is time for preparing the proposal. Of those defining planning the time needed for the proposal as a strength, 38 per cent made 
a successful application, whereas only 17 per cent of those defining time as weakness succeeded. Other factors that also seem to affect success rates, albeit to a lower extent, are ability to include interesting research questions in the proposal, to agree on resource distribution, support from own organisation in coordinating/managing the proposal phase, and understanding the full scope of the call topic and its objectives. On the other hand, strengths in administrative support from own organisation seem to have marginal impact on proposal success. Administrative support with the applications still appears to be a major frustration for the Norwegian participants (Table 4.24), indicating that the researchers themselves spend much time on administrative work, unless other partners in the consortium are able to take care of such matters.

One factor appears to have an opposite effect. Applicants with problems in agreeing about intellectual property rights have a somewhat higher success rate (37 per cent success) than those defining agreeing on intellectual property rights as a strength (30 per cent success). This may indicate that those with such problems more often have proposals which score well in the review process (e.g. on novelty or economic impacts). 
Table 4.25 Proposal success by strengths and weaknesses in the applications process, FP7. Per cent.

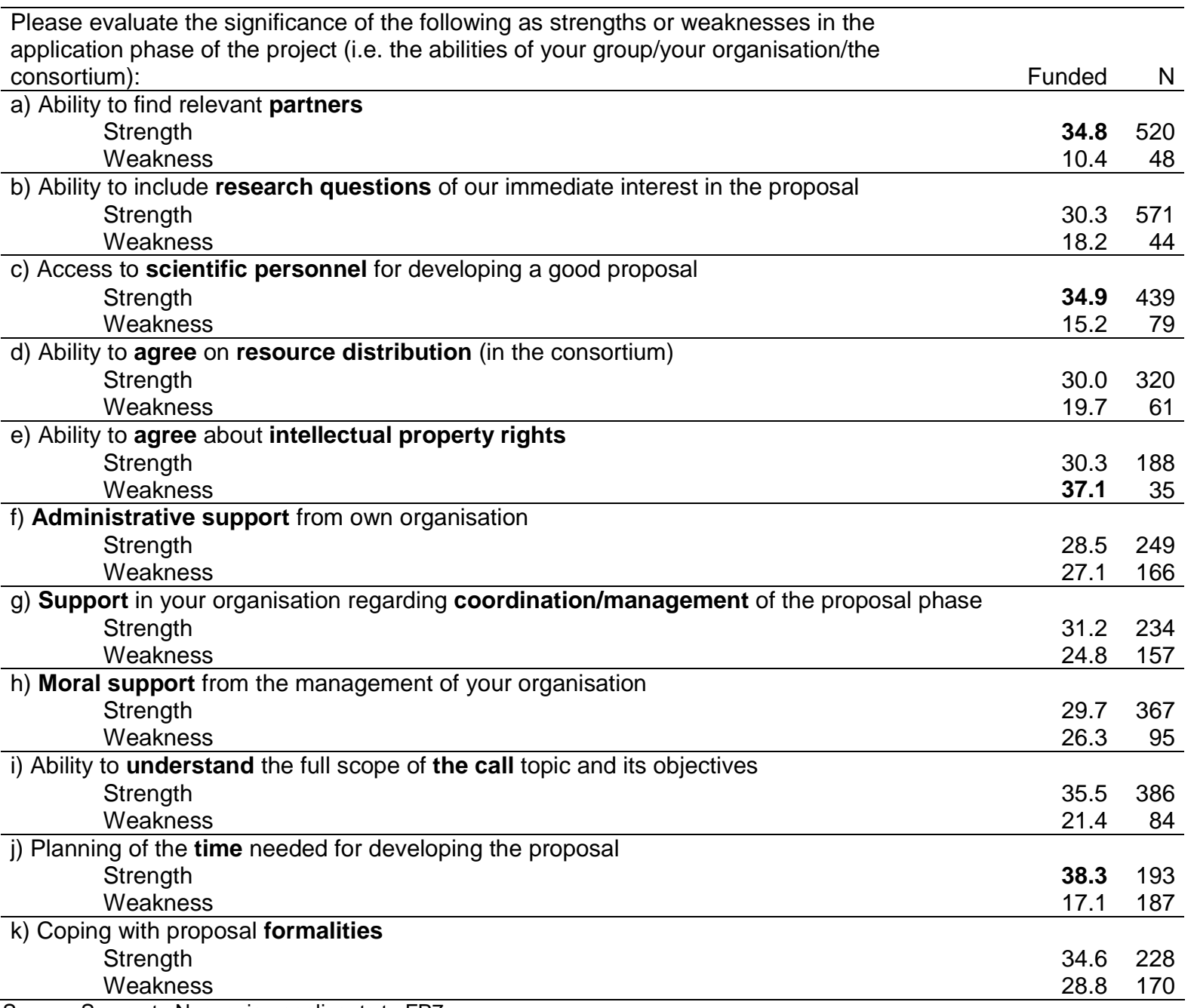

Source: Survey to Norwegian applicants to FP7.

FP6 participants were also asked about strengths and weaknesses in the project execution. The most frequent strengths relate to the project goals and the coordinator's leadership abilities, whereas the most frequent weaknesses - or negative factors - relate to EU reporting requirements, the partners' respect of deadlines and delivery of results as well as the number of partners in the consortium (Table 4.26). Concerning the latter, a general conclusion from the evaluation of FP6 is that small-scale efforts tend to be more successful than the large-scale efforts (Rietschel et al. 2009:59). 


\begin{tabular}{|c|c|c|c|c|c|}
\hline $\begin{array}{l}\text { Please evaluate the significance of the following as } \\
\text { strengths or weaknesses in the execution phase of the } \\
\text { project: }\end{array}$ & $\begin{array}{r}\text { Strength/ } \\
\text { positive } \\
\text { factor }\end{array}$ & $\begin{array}{r}\text { No } \\
\text { particular } \\
\text { strength } \\
\text { or } \\
\text { weakness } \\
\end{array}$ & $\begin{array}{r}\text { Weakness/ } \\
\text { negative } \\
\text { factor }\end{array}$ & $\begin{array}{l}\text { Don't } \\
\text { know }\end{array}$ & $\mathbf{N}$ \\
\hline a) The project goals & 65.2 & 28.8 & 3.9 & 2.1 & 532 \\
\hline b) Coordinator's leadership abilities & 53.9 & 31.8 & 12.4 & 1.9 & 532 \\
\hline c) The number of partners in the consortium & 33.4 & 40.2 & 23.0 & 3.4 & 530 \\
\hline d) The distribution of resources among partners & 23.1 & 55.2 & 17.6 & 4.2 & 529 \\
\hline e) The partners' skills/expertise in carrying out the project & 56.8 & 32.8 & 7.9 & 2.5 & 530 \\
\hline $\begin{array}{l}\text { f) The balance between the competence and the influence } \\
\text { of the various partners in the consortium }\end{array}$ & 34.3 & 46.7 & 13.5 & 5.5 & 527 \\
\hline $\begin{array}{l}\text { g) The individual partners' respect of deadlines/delivery of } \\
\text { results }\end{array}$ & 22.7 & 47.1 & 25.1 & 5.1 & 529 \\
\hline h) Management of confidential information & 19.6 & 60.6 & 1.7 & 18.1 & 530 \\
\hline i) EU reporting requirements & 16.6 & 47.8 & 30.1 & 5.5 & 529 \\
\hline $\begin{array}{l}\text { j) National audit requirements and/or other financial control } \\
\text { routines and rules }\end{array}$ & 11.4 & 59.2 & 18.6 & 10.8 & 527 \\
\hline k) Administrative support from own organisation & 31.6 & 46.0 & 20.0 & 2.4 & 531 \\
\hline
\end{tabular}

Source: Survey to Norwegian participants in FP6.

There are some notable differences between the sectors in reported weaknesses. As many as 31 per cent of respondents in higher education institutions report administrative support from own organisation to be a weakness/negative factor in the project execution, whereas only 11 per cent of respondents in enterprises find this to be a negative factor. Higher education is the only sector where the number of respondents replying that this is a negative factor outweighs the number who finds it a positive factor (31 per cent negative and 21 per cent positive). In the institute sector 19 per cent answer that administrative support from own organisation was a weakness/negative factor in the project execution, 40 per cent report is as a positive factor.

The number of partners in the consortium is reported as a negative factor in large consortiums. Fifty-one per cent of respondents in projects with more than 40 partners report the number of partners as a weakness in the project execution. ${ }^{48}$ Concerning EU reporting requirements, a somewhat larger proportion of coordinators report these requirements as a negative factor. At the same time a larger proportion state the reporting requirements to be a positive factor. As many as 37 per cent of respondents with coordinator responsibility report the EU reporting requirements as a negative factor in the project execution, and 20 per cent of the coordinator report the EU reporting requirements as a positive factor (similar percentages for all respondents are 30 and 17 respectively, Table 4.26).

4832 per cent of them report number of partners as no particular strength or weakness, and 15 per cent as a strength. 


\subsubsection{Benefits for participants: Collaboration and networks}

Most FP6 projects included a large number of partners and a high potential for network building. According to the participant survey, the impact on network building and longterm collaboration may be characterised as clearly successful.

In nearly all the FP project consortiums there are partners with whom the Norwegians have not previously cooperated (94 per cent of the 535 respondents replying to the question reported new partners in the FP6 project, Table 4.27).

Table 4.27 New collaborations by total number of partners in the project. Per cent

\begin{tabular}{|c|c|c|c|c|c|c|}
\hline \multirow{2}{*}{$\begin{array}{l}\text { Number of } \\
\text { partners }\end{array}$} & \multicolumn{5}{|c|}{ Number of new partners in the project } & \multirow[b]{2}{*}{$\mathrm{N}$} \\
\hline & 0 & $1-2$ & $3-9$ & $10-19$ & $20-90$ & \\
\hline $1-9$ & 17.4 & 18.8 & 63.8 & & & 149 \\
\hline $10-19$ & 3.2 & 4.8 & 55.6 & 36.5 & & 189 \\
\hline $20-39$ & 1.7 & 3.3 & 11.7 & 39.2 & 44.2 & 120 \\
\hline $40-95$ & & 5.2 & 6.5 & 6.5 & 81.8 & 77 \\
\hline Total & 6.4 & 8.4 & 40.9 & 22.6 & 21.7 & 535 \\
\hline
\end{tabular}

Inconsistencies in replies and corrections: In some cases the reported number of new partners exceeded the reported number of total partners in the project (presumably because the respondent reported number of researchers instead of number of partners). In these cases the number of new partners was moderated to be consistent with the number of total partners (e.g. the reply 800 new partners in a project with 88 partners were moderated to 80 new partners, and for all projects with one partner (accounting for 11 of the participations/respondents), the number of new partners were set to zero. Source: Survey to Norwegian participants in FP6.

There is also extensive communication between the participants. Fifty-five per cent have email communication with other participants at least once a week; 86 per cent at least once a month; 96 per cent have face-to-face meetings with other participants at least once a year (Table 4.28).

Table 4.28 In your EU project, how do/did you communicate with the other participants? Respondents' replies. Per cent.

\begin{tabular}{|c|c|c|c|c|c|c|c|c|}
\hline Mode of communication & Daily & $\begin{array}{r}\text { Once a } \\
\text { week }\end{array}$ & $\begin{array}{c}\text { Once a } \\
\text { month }\end{array}$ & $\begin{array}{r}4-8 \\
\text { times a } \\
\text { year }\end{array}$ & $\begin{array}{r}1-3 \\
\text { times } \\
\text { per year }\end{array}$ & $\begin{array}{l}\text { At start- } \\
\text { up and } \\
\text { end of } \\
\text { project }\end{array}$ & None & ${ }^{*} \mathbf{N}$ \\
\hline Face- to- face meetings & 0.7 & 2.0 & 4.6 & 23.4 & 65.0 & 3.2 & 1.1 & 560 \\
\hline Tele-conferencing & 0.2 & 2.8 & 13.1 & 13.3 & 15.9 & 2.1 & 52.5 & 533 \\
\hline Telephone (voice) & 0.7 & 16.7 & 25.5 & 20.6 & 20.4 & 2.0 & 14.1 & 545 \\
\hline e-mail & 19.3 & 35.8 & 30.8 & 10.9 & 2.5 & & 0.7 & 561 \\
\hline Fax and postal mail & 0.2 & 1.5 & 4.7 & 8.6 & 28.2 & 17.4 & 39.6 & 536 \\
\hline Virtual work space and labs & 3.9 & 3.9 & 4.9 & 3.0 & 7.3 & 3.2 & 73.7 & 532 \\
\hline Project home page \& data base & 5.5 & 11.6 & 18.9 & 17.0 & 17.2 & 4.1 & 25.7 & 541 \\
\hline Blogs \& wikis & 0.9 & 2.1 & 2.8 & 1.5 & 2.8 & & 89.9 & 536 \\
\hline
\end{tabular}

*Lower $\mathrm{N}$ imply that several respondents has not answering the question, probably indicating that the communication form is not in use and that the "none" category is larger than the figures in the table.

Source: Survey to Norwegian participants in FP6.

The large majority (87 per cent) of Norwegian participants assess the network building in their FP project as being mostly successful (39 per cent) or very successful (47 per cent). Only 6 per cent assess the project as unsuccessful in terms of network building ( 2.5 per cent very unsuccessful and 3.7 per cent mostly unsuccessful, Table 4.29). 
Table 4.29 Participants' assessments of the success of network building in the project, by project type. Per cent.

\begin{tabular}{|c|c|c|c|c|c|c|}
\hline Project type & $\begin{array}{r}\text { Very } \\
\text { unsuccessful } \\
\end{array}$ & $\begin{array}{r}\text { Mostly } \\
\text { unsuccessful } \\
\end{array}$ & Uncertain & $\begin{array}{r}\text { Mostly } \\
\text { successful } \\
\end{array}$ & $\begin{array}{r}\text { Very } \\
\text { successful } \\
\end{array}$ & $\mathbf{N}$ \\
\hline Coordination Actions (CA) & 3.4 & & & 32.2 & 64.4 & 59 \\
\hline $\begin{array}{l}\text { Collective Research Projects } \\
\text { (CLR) }\end{array}$ & & & 21.4 & 42.9 & 35.7 & 14 \\
\hline $\begin{array}{l}\text { Co-operative Research } \\
\text { Projects (CRAFT) }\end{array}$ & 3.2 & 16.1 & 19.4 & 48.4 & 12.9 & 31 \\
\hline $\begin{array}{l}\text { Specific Actions to Promote } \\
\text { Research Infrastructures } \\
(\mathrm{II} / \mathrm{I})\end{array}$ & & & & 33.3 & 66.7 & 6 \\
\hline Integrated Projects (IP) & 1.5 & 2.3 & 7.6 & 42.7 & 45.8 & 131 \\
\hline Marie Curie Actions (MCA) & 2.5 & 2.5 & 12.5 & 32.5 & 50.0 & 40 \\
\hline $\begin{array}{l}\text { Networks of Excellence } \\
\text { (NOE) }\end{array}$ & 6.5 & 4.3 & & 30.4 & 58.7 & 46 \\
\hline $\begin{array}{l}\text { Specific Support Actions } \\
\text { (SSA) }\end{array}$ & & 3.9 & 3.9 & 39.2 & 52.9 & 51 \\
\hline $\begin{array}{l}\text { Specific Targeted Research } \\
\text { Projects (STREP) }\end{array}$ & 2.9 & 4.4 & 8.0 & 41.6 & 43.1 & 137 \\
\hline Total & 2.5 & 3.7 & 7.2 & 39.2 & 47.4 & 515 \\
\hline
\end{tabular}

Source: Survey to Norwegian participants in FP6. (Q 26: To what extent would you say that the following elements have been unsuccessful/successful within the project?)

There are some differences between the project types (Table 4.29). For most project types, more than 80 per cent assess the network building in their FP project as successful (including both "mostly successful” and "very successful”). CRAFT projects, however, seem considerably less successful in terms of network building. Sixty-one per cent of CRAFT-respondents assess the network building as successful, and 19 per cent as unsuccessful.

In addition to the network building in the project, participants were asked about long-term cooperation relations resulting from the projects and with what kind of organisations they had established such relations. A majority of the participants established long-term cooperation with universities/colleges in Europe as a result of the project (10 per cent to a very high extent, 26 per cent to a high extent and 34 per cent to some extent). Moreover, a large share has established long-term cooperation with $\mathrm{R} \& \mathrm{D}$ organisations/research institutes in Europe (6 per cent to a very high extent, 16 per cent to a high extent and 26 per cent to some extent, Table 4.30). The proportion having established long-term cooperation with foreign firms is somewhat higher than the proportion which had established long-term cooperation with Norwegian firms (13 versus 9 per cent "high extent”/“very high extent”, and 19 versus 14 per cent “to some extent”, Table 4.30).

For all kinds of organisations, participation has resulted in more long-term collaboration with European partners than with other Norwegian partners. Nevertheless, the Framework Programme entails a considerable extent of long-term collaboration between Norwegian organisations, especially for universities and colleges. Ten per cent report that their participation "to a high or very high extent" has resulted in long-term cooperation with 
universities/colleges in Norway, and 22 per cent report that their participation has resulted in long-term cooperation with universities/colleges in Norway to some extent (Table 4.30).

Table 4.30 Long-term cooperation relations resulting from the projects. Respondents' replies. Per cent.

\begin{tabular}{|c|c|c|c|c|c|c|}
\hline $\begin{array}{l}\text { Please indicate whether the project has } \\
\text { resulted in long-term cooperation } \\
\text { relations involving: }\end{array}$ & Not at all & $\begin{array}{r}\text { To a } \\
\text { limited } \\
\text { extent }\end{array}$ & $\begin{array}{r}\text { To } \\
\text { some } \\
\text { extent }\end{array}$ & $\begin{array}{r}\text { To a } \\
\text { high } \\
\text { extent }\end{array}$ & $\begin{array}{r}\text { To a } \\
\text { very high } \\
\text { extent }\end{array}$ & $\mathbf{N}$ \\
\hline Universities and colleges in Norway & 46.4 & 22.3 & 21.5 & 8.5 & 1.2 & 506 \\
\hline Universities and colleges in Europe & 12.6 & 17.1 & 34.4 & 26.2 & 9.6 & 508 \\
\hline $\begin{array}{l}\text { Public or private non-profit R\&D } \\
\text { organisation in Norway }\end{array}$ & 56.2 & 17.1 & 18.3 & 6.6 & 1.8 & 502 \\
\hline $\begin{array}{l}\text { Public or private non-profit R\&D } \\
\text { organisation in Europe }\end{array}$ & 35.6 & 17.3 & 25.8 & 15.7 & 5.5 & 508 \\
\hline Norwegian firms & 61.8 & 15.4 & 13.7 & 6.9 & 2.2 & 505 \\
\hline Foreign firms & 52.8 & 15.8 & 18.6 & 9.7 & 3.2 & 506 \\
\hline The public sector in Norway & 51.8 & 23.9 & 17.1 & 6.2 & 1.0 & 502 \\
\hline $\begin{array}{l}\text { The public sector in one or more European } \\
\text { countries (incl. The European Commission) }\end{array}$ & 44.4 & 22.6 & 20.6 & 8.1 & 4.2 & 504 \\
\hline Actors outside Europe & 56.2 & 16.3 & 19.5 & 6.2 & 1.8 & 502 \\
\hline
\end{tabular}

The different sectors report somewhat different kinds of long-term cooperation resulting from the EU project, indicating a tendency towards "within-sector-cooperation". Higher education is the sector reporting most long-term cooperation with universities and colleges in Europe. The institute sector is the sector that reports most cooperation with non-profit R\&D organisations in Europe. The enterprises report most cooperation with actors outside Europe, with foreign firms as well as with universities, colleges and non-profit R\&D organisations in Norway. "Others” (including many ERA-NET projects) report most cooperation with public sector in European countries and in Norway as well as with Norwegian firms (same question as table above, no separate table for figures by sector).

\subsection{Impacts of the Norwegian participation}

What kind of impacts and effects do FP participation have on the Norwegian research community and society? Below impacts are analysed based on participants' survey replies concerning economic benefits, new knowledge and innovation resulting from the projects and long-term effects on knowledge production. The long-term effect analysis is supplemented by a bibliometric study. Focus is on impacts at the research community that may benefit the society at large.

\subsubsection{Economic benefits}

To what degree do the participating enterprises expect economic benefits from their FP6 projects? In the survey, 38 per cent of respondents stated that they expect economic benefits associated with the project in the form of increased sales or reduced costs. The remaining 62 per cent do not expect such benefits (Table 4.31). 
Table 4.31 Expected direct economic benefits from the project, replies from enterprises. Per cent.

\begin{tabular}{lrrr}
\hline $\begin{array}{l}\text { Are direct economic benefits expected in the form of increased sales } \\
\text { or reduced costs which can be associated with the project? }\end{array}$ & Yes & No & N \\
\hline Direct economic benefits expected & 37.9 & 62.1 & 87 \\
Increase in turnover expected & 26.4 & 73.6 & 87 \\
Reduction in costs expected & 11.5 & 88.5 & 87 \\
\hline Source: Survey to Norwegian participants in FP6. Only enterprise participants were posed the questions in this table.
\end{tabular}

The respondents who replied that they expected direct economic benefits were asked to specify the kind of benefits expected. Twenty-six per cent (of the total 87 enterprise respondents) replied "increase in turnover" and 12 per cent replied "reduction in costs". Other specifications included new products, new markets, new potential partners and reduction of lead time.

The data indicate that having a leading responsibility in the project increased chances of economic benefits. Whereas 42 per cent of participants with a leading responsibility report expected economic benefits, only 26 per cent of participants without such responsibilities expect economic benefits from the project (Table 4.32).

Table 4.32 Expected direct economic benefits from the project, replies from enterprises by participant role. Per cent.

\begin{tabular}{|c|c|c|c|c|}
\hline \multirow{2}{*}{ Participant role } & & \multicolumn{2}{|c|}{ Direct economic benefits expected } & \multirow[b]{2}{*}{$\mathbf{N}$} \\
\hline & & No & Yes & \\
\hline $\begin{array}{l}\text { Has your organisation had a leading } \\
\text { responsibility (a work package for }\end{array}$ & Yes & 57.8 & 42.2 & 45 \\
\hline example) in the project? & No & 73.7 & 26.3 & 38 \\
\hline
\end{tabular}

Source: Survey to Norwegian participants in FP6. Only enterprise participants were posed the questions in this table. As 4 of these respondents did not reply to the question of leading responsibilities, figures in this table are based only on 83 respondents, not 87 as in the table above.

\subsubsection{New knowledge and innovation: Expected and achieved project results}

Many different kinds of results are achieved or expected to be achieved in the projects. 68 per cent report having developed new expertise or skills, and another 23 per cent report that they expect to develop it. Sixty-two per cent report new scientific results and another 26 per cent that they expect to achieve it. Fifty-six per cent report scientific publications and another 29 per cent that they expect to achieve it. There is also a substantial proportion that has developed new scientific methods (42 per cent), developed new technology, processes, products or services (34 per cent), developed prototype (28 per cent), implemented new technology, processes, products or services (24 per cent, and another 34 per cent that expect to implement it), established standards or norms (17), and obtained doctoral degrees (16 per cent, Table 4.33). These results are quite similar to those found in the evaluation of the Norwegian participation in the $5^{\text {th }}$ Framework Programme (NIFU, STEP and Technopolis 2004, page 103). 
Table 4.33 Participants' reports on project results. Per cent.

\begin{tabular}{|c|c|c|c|c|c|}
\hline Type of results: & $\begin{array}{r}\text { Not expected } \\
\text { to be achieved }\end{array}$ & Achieved & $\begin{array}{r}\text { Expected to be } \\
\text { achieved in the } \\
\text { course of the } \\
\text { project }\end{array}$ & $\begin{array}{r}\text { Expected to be } \\
\text { achieved within } 3 \\
\text { years after } \\
\text { project period } \\
\text { ends }\end{array}$ & $\mathbf{N}$ \\
\hline New scientific results/knowledge & 12.5 & 61.6 & 20.4 & 5.5 & 511 \\
\hline $\begin{array}{l}\text { Development of new } \\
\text { expertise/skills }\end{array}$ & 8.6 & 68.2 & 19.8 & 3.3 & 509 \\
\hline $\begin{array}{l}\text { Development of new scientific } \\
\text { methods }\end{array}$ & 36.8 & 41.7 & 17.1 & 4.4 & 503 \\
\hline $\begin{array}{l}\text { Development of new } \\
\text { technology/new processes/new } \\
\text { products/new services }\end{array}$ & 39.5 & 34.0 & 15.0 & 11.5 & 506 \\
\hline $\begin{array}{l}\text { Implementation of new } \\
\text { technology/new processes/new } \\
\text { products/new services }\end{array}$ & 41.7 & 24.3 & 13.8 & 20.2 & 506 \\
\hline Sale of know-how or licenses & 80.2 & 4.0 & 4.2 & 11.6 & 500 \\
\hline Application for patent & 83.7 & 6.4 & 4.2 & 5.8 & 502 \\
\hline Development of prototype & 60.8 & 27.6 & 6.6 & 5.0 & 503 \\
\hline $\begin{array}{l}\text { Establishment of standards, } \\
\text { norms }\end{array}$ & 62.8 & 16.7 & 10.3 & 10.1 & 503 \\
\hline Scientific publications & 14.8 & 56.2 & 17.4 & 11.6 & 507 \\
\hline Doctorate degrees & 61.6 & 15.9 & 13.1 & 9.5 & 497 \\
\hline
\end{tabular}

Source: Survey to Norwegian participants in FP6. ERA-net participants were not posed the questions in this table.

\subsubsection{Long-term effects on knowledge production}

In interviews with key informants in the Norwegian R\&D community they stated that participation in EU FPs has contributed to a change in the way they organise and plan R\&D. This aspect was emphasised as significant at universities and colleges; some informants depicted this as a "radical shift" in terms of academic culture. For private sector participants, this aspect was not so pronounced. Instead, they emphasised that FP participation provided them with broader research opportunities and networks because the projects in which they participate are considered as "neutral ground" for doing important industrial $\mathrm{R} \& \mathrm{D}$. This type of $\mathrm{R} \& \mathrm{D}$ is often considered as being too risky for the firm to undertake alone. Some informants also pointed to a generation factor, implying that this type of international R\&D collaboration is more attractive for younger researchers because they are intellectually and culturally more open-minded in their outlook - and have a more cosmopolitan orientation.

Norway's participation in EU FPs have evolved in tandem as higher education institutions and research institutes have become more systematic in terms of R\&D planning and priority-setting. The earlier ideals of "academic freedom" and adherent notions of autonomy for the individual researcher have gradually been substituted with a more strategic approach and management, with priority setting and coordination, because doing research has increasingly become complex, expensive - and, ultimately, highly dependent on being associated with the international R\&D community. 
Bibliometric analysis: Significant increase in co-authorship with EU-countries

Does participation in the Framework Programme impact the collaborations profile of Norwegian researchers? This question has been addressed by analysing the distribution of co-authorships. Figure 4.1 shows the changes in the co-authorships profile during the period 1988-2007. In 1988, 15 per cent of the Norwegian publications incorporated coauthors from EU countries, whereas in 2007 as much as 37 per cent were co-authored with EU countries. Collaboration with the North America and Nordic countries ${ }^{49}$ also increased during the period, but at a much slower pace than for the EU region. Thus, the relative importance of EU collaboration has increased, while the relative importance of collaboration with North America and the Nordic countries has decreased.

The approach undertaken in this study does not permit an examination of the reasons for the change in the geographical collaboration profile. Nevertheless, Norwegian participation in the EU Framework Programmes and the associated research cooperation with European partners has without doubt had an impact in this respect. In fact, during the years following Norwegian participation in the Framework Programme (1995-1998) growth was particularly strong and the proportion increased by 7 points, from 22 to 29 per cent. It should be noted that the proportion of collaborative articles with EU partners has increased gradually and that a significant rise can be observed also in the years prior to Norway joining the Framework Programme in 1994. This indicates that the trend towards increased Europeisation is part of the broader internationalisation trend which could have occurred also without a Norwegian participation the Framework Programmes - albeit at a slower pace. More detailed results from the bibliometric study are given in Appendix 5.

49 The three Nordic EU member states are also included in the EU-category. 
Figure 4.1 The proportion of the Norwegian publications involving international coauthorship, by region (EU 27, North America and Nordic* countries) 19882007

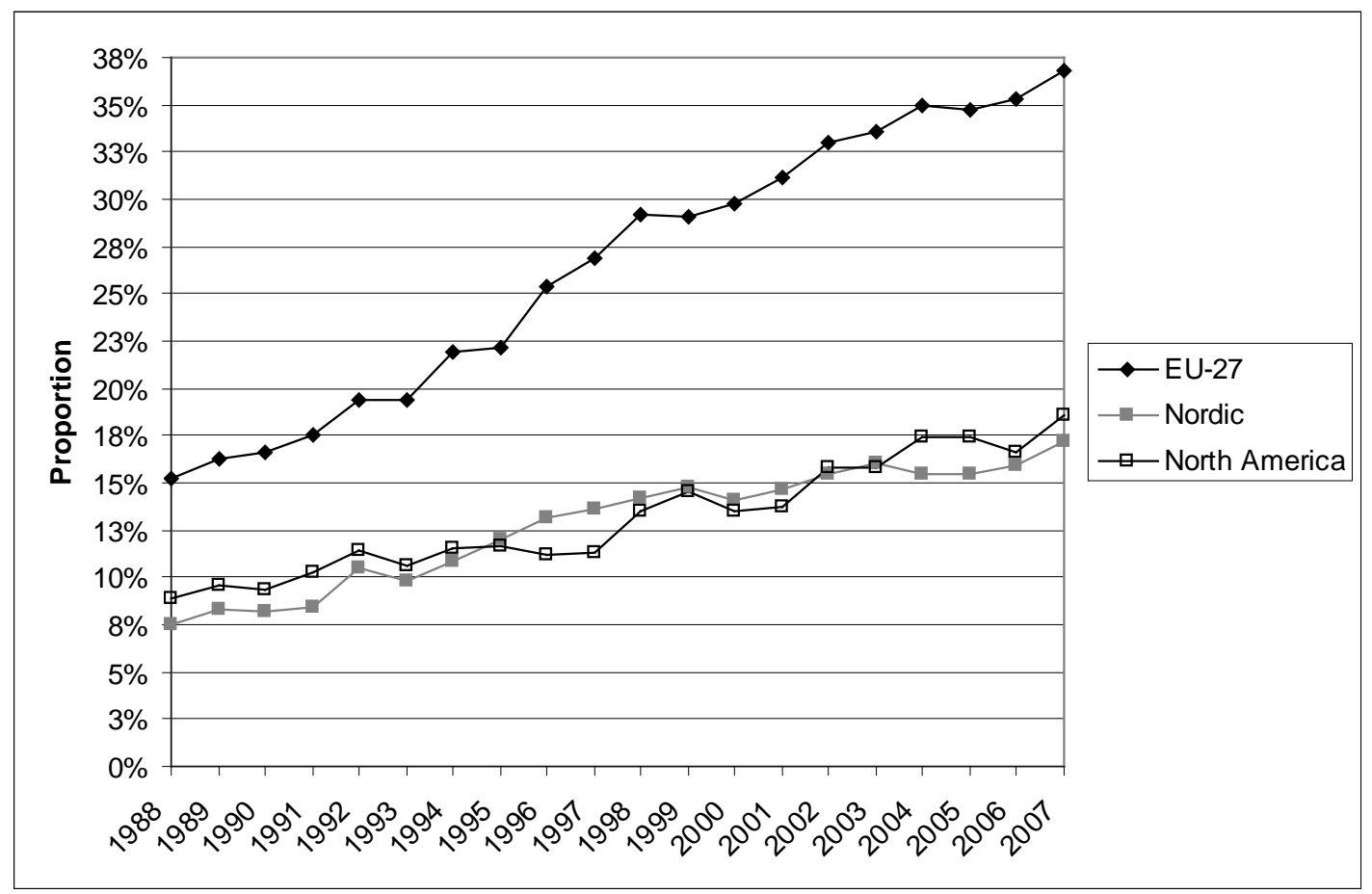

*) The three Nordic EU member states are also included in the EU category.

Impact on R\&D capabilities and activities and long-term effects for participants

In addition to producing results, the Framework Programme projects have had an impact on participants’ R\&D capabilities and activities. Seventy-eight per cent report that their long-term international cooperation links have been extended (fully or partly agree that these links have been considerably extended); 66 per cent report that their overall research capabilities have been improved; and 50 per cent report that their overall innovation capabilities have been improved (fully or partly agree that is has been significantly improved). Twenty-two per cent fully agree that the EU project has explored new research areas of significant importance for their future research/innovation activities; another 38 per cent partly agree. Thirteen per cent fully agree that the EU project has significantly increased their publication output, while a further 30 per cent partly agree. Moreover, 55 per cent report that their research and innovation management skills have been improved as a result of the EU project (fully or partly agree that is has been significantly improved). Fifty-two per cent fully or partly agree that the project contributes to innovation, 34 per cent that it has increased their knowledge on new $R \& D$ markets, and 13 per cent that it has increased their knowledge on patenting or protection of intellectual property. Five per cent fully agree that the project has changed their way of doing research and innovation, and 22 per cent partly agree (Table 4.34). 
Table 4.34 Participants' assessments of effects on research and innovation capacities. Per cent.

\begin{tabular}{|c|c|c|c|c|c|c|c|}
\hline $\begin{array}{l}\text { Estimate the extent to which you agree or } \\
\text { disagree with the following statements } \\
\text { about this particular EU project: }\end{array}$ & $\begin{array}{r}\text { Fully } \\
\text { disagree }\end{array}$ & $\begin{array}{r}\text { Partly } \\
\text { disagree }\end{array}$ & Uncertain & $\begin{array}{l}\text { Partly } \\
\text { agree }\end{array}$ & $\begin{array}{r}\text { Fully } \\
\text { agree }\end{array}$ & $\begin{array}{r}\text { Not } \\
\text { relevant }\end{array}$ & $\mathbf{N}$ \\
\hline $\begin{array}{l}\text { Our overall research capabilities have been } \\
\text { significantly improved as a result of the EU } \\
\text { project }\end{array}$ & 6.8 & 5.6 & 12.2 & 39.2 & 27.0 & 9.2 & 500 \\
\hline $\begin{array}{l}\text { Our overall innovation capabilities have been } \\
\text { significantly improved as a result of the EU } \\
\text { project }\end{array}$ & 6.3 & 7.1 & 21.5 & 36.0 & 13.6 & 15.6 & 494 \\
\hline $\begin{array}{l}\text { Research and innovation management skills } \\
\text { have been significantly improved as a result } \\
\text { of the EU project }\end{array}$ & 7.2 & 8.2 & 21.3 & 37.3 & 17.9 & 8.0 & 498 \\
\hline $\begin{array}{l}\text { The EU project has changed our way of doing } \\
\text { research and innovation in the organisation } \\
\text { /project unit }\end{array}$ & 21.6 & 18.1 & 24.4 & 22.0 & 4.6 & 9.3 & 496 \\
\hline $\begin{array}{l}\text { Long term international cooperation links } \\
\text { have been considerably extended as a result } \\
\text { of the EU project }\end{array}$ & 4.4 & 4.4 & 9.7 & 34.8 & 43.5 & 3.2 & 497 \\
\hline $\begin{array}{l}\text { The EU project lead to significantly increased } \\
\text { publication output in my unit }\end{array}$ & 12.9 & 16.5 & 19.3 & 30.2 & 12.5 & 8.7 & 497 \\
\hline $\begin{array}{l}\text { Through the EU project we have increased } \\
\text { our knowledge on patenting/protection of } \\
\text { intellectual property }\end{array}$ & 26.4 & 13.3 & 16.1 & 10.5 & 2.8 & 31.0 & 497 \\
\hline $\begin{array}{l}\text { Through the EU project we have increased } \\
\text { our knowledge on new R\&D-markets }\end{array}$ & 16.4 & 10.5 & 18.0 & 27.3 & 6.9 & 20.9 & 494 \\
\hline $\begin{array}{l}\text { Through the EU project new research areas } \\
\text { of significant importance for our future } \\
\text { research/innovation activities have been } \\
\text { explored }\end{array}$ & 9.7 & 7.3 & 13.7 & 38.2 & 21.8 & 9.3 & 495 \\
\hline $\begin{array}{l}\text { The EU project leads/contributes to } \\
\text { innovation }\end{array}$ & 9.3 & 5.9 & 16.2 & 30.4 & 21.5 & 16.6 & 493 \\
\hline
\end{tabular}

Source: Survey to Norwegian participants in FP6. ERA-net participants were not posed the questions in this table.

The impact on overall research capabilities is slightly higher in higher education institutions than in research institutes. Thirty-three per cent of higher education institutions fully agree, and 43 per cent partly agree, that their overall research capabilities have been significantly improved as a result of the EU project. In research institutes 29 per cent fully agree and 40 per cent partly agree.

Studying the enterprises' replies to the impact questions specifically relevant for this sector we find some (although not large) differences from the overall figures reported in the table above. Most notably, a larger proportion of enterprises report that the project contributes to innovation, and at the same time a larger proportion disagree. Thirty-four per cent of enterprises fully agree, 35 per cent partly agree, and 14 per cent of enterprises fully disagree, that the EU project contributes to innovation. The higher scores on both agree and disagree relate to a lower share of "not relevant" replies among the enterprises. On other issues relevant to the sector there are small differences from the overall figures in Table 4.34: per cent of enterprises fully agree and 42 per cent partly agree their overall innovation capabilities have been significantly improved as a result of the EU project. Five per cent of enterprises fully agree and 44 per cent partly agree that the EU project has increased their knowledge on new R\&D-markets. 
To what extent does participation in the EU Framework Programme have a more lasting impact on the participants' research activities, position and capabilities? As reported above, a large proportion of participations had positive effects on research and innovation capabilities and long-term cooperation links, and also changed the participating organisations' way of doing research. Substantial and positive long-term effects were also found when enquiring into the general effects of the EU Framework Programme on participating organisations' research activities (Table 4.35). A large part (41 per cent) of FP6 respondents report that participation has enabled them to generate international projects, also outside the EU Framework Programme. Moreover, 33 per cent report that taking part in EU projects has resulted in larger collaborative projects, also outside the Framework Programme. Twenty-one per cent also report that the participation has changed the nature of their research activities in general, and the majority of these characterise the change as positive (Table 4.35). In sum, the participants' research activities are becoming more collaborative, international and organised in larger projects.

Table 4.35 Participants' assessments of effects on other research activities. Per cent.

\begin{tabular}{|c|c|c|c|c|}
\hline $\begin{array}{l}\text { My organisation's participation in the EU Framework Programme } \\
\text { has: }\end{array}$ & Yes & No & $\begin{array}{r}\text { No } \\
\text { opinion } \\
\end{array}$ & $\mathbf{N}$ \\
\hline $\begin{array}{l}\text { a) enabled us to generate international projects also outside the EU } \\
\text { Framework Programme }\end{array}$ & 40.6 & 37.7 & 21.7 & 493 \\
\hline $\begin{array}{l}\text { b) changed our research activities - also in non-EU projects - towards } \\
\text { larger collaborative projects }\end{array}$ & 33.0 & 48.9 & 18.1 & 491 \\
\hline c) changed the nature of our research activities in general & 20.7 & 60.2 & 19.1 & 493 \\
\hline $\begin{array}{l}\text { If yes on c) please indicate if the change is positive (yes) or negative } \\
\text { (no) }\end{array}$ & 57.2 & 6.1 & 36.7 & 180 \\
\hline
\end{tabular}

Source: Survey to Norwegian participants in FP6. ERA-net participants were not posed the questions in this table.

There are no large differences between sectors in the proportion reporting changed nature of research activities (Table 4.36).

Table 4.36 Participants' assessments of effects on other research activities: Changed the nature of our research activities in general by sector. Per cent.

\begin{tabular}{|l|r|r|r|r|}
\hline Sector & Yes & No & No opinion & N \\
\hline a) Research Institute & 21.9 & 62.0 & 16.0 & 237 \\
\hline b) Higher Education Institution & 20.0 & 61.6 & 18.4 & 125 \\
\hline c) Enterprise & 22.4 & 49.4 & $\mathbf{2 8 . 2}$ & 85 \\
\hline d) Other & 13.6 & 65.9 & 20.5 & 44 \\
\hline Total & 20.8 & 60.1 & 19.1 & 491 \\
\hline
\end{tabular}

Source: Survey to Norwegian participants in FP6. ERA-net participants were not posed the questions in this table.

Participants in some of the FP6 priorities seem more exposed to changing the nature of their research activities. Especially participants within Nanotechnologies and nanosciences but also those participating in Food quality and safety and in SME activities report changed nature of research activities as a result of the participation in the EU Framework Programme. On the other hand, we see that some of the priorities with many Norwegian 
participations, Sustainable development and Information society technologies, have a somewhat lower impact on the nature of the participants research activities (Table 4.37).

Table 4.37 Participants' assessments of effects on other research activities: "Changed the nature of our research activities in general". Per cent by programme.

\begin{tabular}{|l|r|r|r|r|}
\hline Programme/priority & Yes & No & $\begin{array}{r}\text { No } \\
\text { opinion }\end{array}$ & N \\
\hline 1. Life sciences, genomics and biotechnology for health & 21.7 & 69.6 & 8.7 & 23 \\
\hline 2. Information society technologies & 16.2 & 59.5 & 24.3 & 74 \\
\hline 3. Nanotechnologies and nanosciences & 31.6 & 47.4 & 21.1 & 19 \\
\hline 5. Food quality and safety & 27.9 & 60.5 & 11.6 & 43 \\
\hline 6. Sustainable development, global change and ecosystems & 16.5 & 64.3 & 19.1 & 115 \\
\hline 7. Citizens and governance in a knowledge-based society & 22.2 & 63.9 & 13.9 & 36 \\
\hline Horizontal research activities involving SMEs & 24.4 & 48.9 & 26.7 & 45 \\
\hline Human resources and mobility & 17.5 & 67.5 & 15.0 & 40 \\
\hline Policy support and anticipating scientific and technological needs & 21.6 & 60.8 & 17.6 & 51 \\
\hline Research and innovation & 7.1 & 71.4 & 21.4 & 14 \\
\hline Remaining priorities (5 priorities with less than 15 cases each) & 30.3 & 45.5 & 24.2 & 33 \\
\hline Total & 20.7 & 60.2 & 19.1 & 493 \\
\hline Source: Survey to Norwegian participants in FP6. & & & &
\end{tabular}

Participants were also asked about the expected future changes in the position of their organisation (Table 4.38). Twenty-four per cent report that to a high or very high degree the project will strengthen their position vis-à-vis competitors; 22 per cent that to a high or very high degree the project will contribute to securing their established customers; 18 per cent state that to a high or very high degree the project represents a gateway to new customers; and 10 per cent state that to a high or very high degree the project represents a gateway to new suppliers.

Table 4.38 Expected changes in the positions of the participating organisation. Per cent.

\begin{tabular}{|l|r|r|r|r|r|r|r|}
\hline $\begin{array}{l}\text { Please indicate expected future changes } \\
\text { in your organisation's position as a } \\
\text { result of the EU project }\end{array}$ & $\begin{array}{r}\text { To a } \\
\text { very } \\
\text { small } \\
\text { extent }\end{array}$ & $\begin{array}{r}\text { To a } \\
\text { small } \\
\text { extent }\end{array}$ & $\begin{array}{r}\text { To } \\
\text { some } \\
\text { extent }\end{array}$ & $\begin{array}{r}\text { To a } \\
\text { high } \\
\text { extent }\end{array}$ & $\begin{array}{r}\text { To a } \\
\text { very } \\
\text { high } \\
\text { extent }\end{array}$ & $\begin{array}{r}\text { Not } \\
\text { relevant }\end{array}$ & N \\
\hline $\begin{array}{l}\text { a) The project will strengthen our position in } \\
\text { relation to our competitors }\end{array}$ & 9.7 & 11.8 & 40.7 & 17.6 & 6.8 & 13.4 & 516 \\
\hline $\begin{array}{l}\text { b) The project contributes to securing our } \\
\text { position in respect of established customers }\end{array}$ & 11.9 & 7.8 & 28.9 & 17.0 & 5.3 & 29.1 & 512 \\
\hline $\begin{array}{l}\text { c) The project represents a gateway to new } \\
\text { customers }\end{array}$ & 15.6 & 11.3 & 22.3 & 11.5 & 6.6 & 32.6 & 512 \\
\hline $\begin{array}{l}\text { d) The project represents a gateway to new } \\
\text { suppliers }\end{array}$ & 21.2 & 8.4 & 15.5 & 7.3 & 2.8 & 44.8 & 509 \\
\hline
\end{tabular}

Source: Survey to Norwegian participants in FP6. Table A 9 in Appendix 1 provides figures by sector.

Enterprises, to which these questions are more relevant, report more expected changes than respondents from other sectors. Twenty four per cent of enterprises state that to a high or very high degree the project represents a gateway to new suppliers; 31 per cent that to a 
high or very high degree the project will strengthen their position vis-à-vis competitors; 36 per cent state that to a high or very high degree the project contributes to securing their established customers; and as much as 43 per cent indicate that to a high or very high degree the project represents a gateway to new customers (Table A 9). These results are on the same level as the results from the survey to the Norwegian participants in FP5, but the FP6 results are slightly lower on two of the issues (NIFU, STEP and Technopolis 2004, page 111).

\subsection{Differences by focus areas}

This Section addresses four selected thematic areas, the "focus areas" for the evaluation Health; ICT; Nanoscience, nanotechnologies, materials; Environment - and differences prevailing from the survey data. The thematic areas are presented and further discussed in Chapter 6.

\section{Success, quality and impact on other research activities}

Participants' overall assessments of the success of their FP6 projects vary considerably by thematic area. Participants in health and nano-related projects seem particularly satisfied with their projects. As many as 37 per cent of the respondents within "Nanotechnologies and nanosciences" (NMP) and 30 per cent within "Life” characterise their projects as "very successful”. The similar figures for the two other focus areas are substantially lower: 17 per cent very successful within ICT and 16 per cent within Sustainable environment (Table 4.39). Moreover, few respondents within NMP and "Life" are uncertain about the success of their projects and no one characterises them as unsuccessful, whereas within ICT and Sustainable environment far more respondents are uncertain about success and there are also 2 to 4 respondents characterising their projects as unsuccessful. 
Table 4.39 Overall assessment of the EU project: What is your total impression of the project (so far)? Participants' assessments by priority/programme. Per cent.

\begin{tabular}{|c|c|c|c|c|c|c|}
\hline Priority/programme & $\begin{array}{l}\text { Very } \\
\text { unsuccessful }\end{array}$ & Unsuccessful & Uncertain & Successful & $\begin{array}{l}\text { Very } \\
\text { successful }\end{array}$ & Total \\
\hline \multicolumn{7}{|l|}{ 1. Focusing and intergrating community research } \\
\hline \multicolumn{7}{|l|}{$\begin{array}{l}\text { A. Thematic priorities } \\
\text { - Life sciences, genomics and biotechnology for } \\
\text { health }\end{array}$} \\
\hline \multirow{2}{*}{$\begin{array}{l}\text { - Information society technologies } \\
\text { Nanotechnologies and nanosciences, } \\
\text { knowledge-based multifunctional materials and } \\
\text { new production processes and devices }\end{array}$} & 0.0 & 2.7 & 20.0 & 60.0 & 17.3 & 75 \\
\hline & 0.0 & 0.0 & 10.5 & 52.6 & 36.8 & 19 \\
\hline \multirow{4}{*}{$\begin{array}{ll}\text { - } & \text { Aeronautics and space } \\
\text { - } & \text { Food quality and safety } \\
\text { - } & \text { Sustainable development, global change and } \\
\text { ecosystems } \\
\text { - } \quad \text { Citizens and governance in a knowledge-based } \\
\text { society }\end{array}$} & 0.0 & 0.0 & 30.8 & 61.5 & 7.7 & 13 \\
\hline & 0.0 & 0.0 & 20.9 & 67.4 & 11.6 & 43 \\
\hline & 0.9 & 2.6 & 23.7 & 57.0 & 15.8 & 114 \\
\hline & 0.0 & 2.7 & 8.1 & 75.7 & 13.5 & 37 \\
\hline B. Specific activities covering a wider field of research & 3.0 & 5.0 & 15.8 & 58.4 & 17.8 & 101 \\
\hline 2. Structuring the European Research Area & 1.5 & 1.5 & 16.4 & 58.2 & 22.4 & 67 \\
\hline 3. Strengthening the foundations of ERA & 4.3 & 4.3 & 34.8 & 43.5 & 13.0 & 23 \\
\hline Total & 1.2 & 2.5 & 18.8 & 59.6 & 17.9 & 515 \\
\hline
\end{tabular}

As described in Section 4.2.2, the thematic areas also vary regarding the nature of the EU projects compared to participants' other projects. These findings only partly mirror the above overall assessments of success. Compared to other projects the ICT and the NMP projects are often characterised as providing more new scientific results, and having higher scientific quality, whereas the Life and Sustainable environment projects less often end up on the positive side when compared to participants' non-EU projects (Table A 10). In other words, NMP projects emerge well on both issues (overall success and better than participants other projects), Sustainable environment projects come out less well on both, and the results for the ICT and Life projects are mixed. The ICT projects are often characterised as better than participants' other projects, but not as successful as NMP and Life projects. The Life projects, on the other hand, are not characterised as better than participants' other projects, but still more successful than the ICT projects.

Respondents' statements on the effects of Framework Programme participation on their other research activities seem to be related to their overall assessments of success of their projects. The areas with the most successful projects (Life and NMP) are also those areas where respondents report clearest effects on their research activities in general. More precisely, participants in Life, and especially participants in NMP, report effects on the nature of participants' general research activities more frequently than the participants in ICT and Sustainable environment (Table 4.37). Moreover, they report that their organisations' participation in the EU Framework Programme has changed their research activities - also in non-EU projects - towards larger collaborative projects (Life 44 per cent and NMP 37 per cent, versus ICT 28 per cent and Sustainable development 32 per 
cent, Table A 17). On the other hand, all four areas report quite high effects on the ability to generate international projects also outside the EU Framework (Table A 16).

\section{Links to other projects and success rates}

Figures for FP6 show that the Norwegian participations are seldom extensions or followups of nationally financed projects, but that Life projects, more so than the projects within the three other focus areas, are extensions of nationally financed projects (24 per cent extensions for Life versus 3 to 11 per cent for the others, Table 4.16). ${ }^{50}$ Enquiring into close relations to nationally financed research (and not only about extension/follow-up), figures are higher and differences between the focus areas are less obvious. In FP6, Life has the highest proportion of participations that are closely related to nationally funded research (68 per cent), but the FP7 equivalent Health has a lower proportion of applicants closely related to nationally funded research, and is furthermore exceeded by Environment where 51 per cent of the applications are closely related to nationally funded research (Table 4.40).

Table 4.40 Links to other projects: Funding of thematically related projects by priority/programme, FP6 and FP7. Per cent.

\begin{tabular}{|c|c|c|c|c|c|c|}
\hline \multirow[t]{2}{*}{$\begin{array}{l}\text { Was the EU project closely related to research for } \\
\text { which you received Norwegian public funding? }\end{array}$} & \multicolumn{3}{|c|}{$\begin{array}{c}\text { FP6 } \\
\text { Norwegian public } \\
\text { funding last } 5 \text { years }\end{array}$} & \multicolumn{3}{|c|}{$\begin{array}{c}\text { FP7 } \\
\text { Norwegian public } \\
\text { funding last } 2 \text { years }\end{array}$} \\
\hline & Yes & No & $\mathrm{N}$ & Yes & No & $\mathrm{N}$ \\
\hline Life/Health & 68.0 & 32.0 & 25 & 47.1 & 52.9 & 70 \\
\hline IST/ICT & 41.5 & 58.5 & 82 & 34.2 & 65.8 & 161 \\
\hline NMP & 38.1 & 61.9 & 21 & 41.5 & 58.5 & 41 \\
\hline Sustainable environment/Environment & 50.0 & 50.0 & 128 & 51.3 & 48.7 & 115 \\
\hline *Total & 47.8 & 52.2 & 533 & 43.5 & 56.5 & 934 \\
\hline
\end{tabular}

Higher success rates could be expected for Framework Programme proposals related to research for which the applicant has received national funding, but as explained in Section 4.2.1 this is not the case (except for SFI and SFF funding). There are however, notable differences between the focus areas. Norwegian participants with related national funding have a substantially higher success rate in Environment proposals (FP7), and also a somewhat higher success rate in ICT proposals than Norwegian participants without such funding (39 versus 27 per cent for Environment. and 22 versus 19 per cent for ICT). For

50 Life projects are more often an extension/follow up of nationally financed projects and of previous EU projects (24 per cent each), than projects within the three other priorities are. The NMP projects are more often an extension/follow up of internally financed projects (25 per cent), and sometimes of other internationally financed projects (10 per cent), and seldom of nationally financed projects (5 per cent). The Sustainable environment projects are even more seldom an extension/follow up of nationally financed projects (3 per cent), whereas 11 per cent of the ICT projects are extension/follow up of nationally financed projects (all figures from Table 4.16). 
the two other focus areas, Health and NMP, the relation is negative: participants with related national funding have a lower success rate in FP7 (Table 4.41).

Table 4.41 FP7: proposal success by national funding. Per cent of proposals funded (success rate).

\begin{tabular}{|c|c|c|c|c|c|c|c|c|c|}
\hline \multirow{3}{*}{$\begin{array}{l}\text { Prioritylprogramme } \\
\text { Health }\end{array}$} & \multicolumn{8}{|c|}{$\begin{array}{l}\text { Was the EU project closely related to research for which you received } \\
\text { Norwegian public funding last } 2 \text { years? (success rates within groups) }\end{array}$} & \multirow{3}{*}{$\begin{array}{r}\text { Tota } \\
\text { success } \\
\text { rate }\end{array}$} \\
\hline & \multicolumn{2}{|l|}{ No } & \multicolumn{2}{|c|}{ Yes, RCN } & \multicolumn{2}{|c|}{${ }^{*}$ Yes, SFI/SFF } & \multicolumn{2}{|c|}{${ }^{* \star}$ Yes, other national } & \\
\hline & $(N=37)$ & 32.4 & $(\mathrm{~N}=25)$ & 28.0 & $(\mathrm{~N}=0)$ & - & $(\mathrm{N}=17)$ & 41.2 & \\
\hline ICT & $(N=106)$ & 18.9 & $(\mathrm{~N}=41)$ & 22.0 & $(\mathrm{~N}=7)$ & 14.3 & $(\mathrm{~N}=16)$ & 18.8 & 19.0 \\
\hline NMP & $(N=24)$ & 33.9 & $(\mathrm{~N}=16)$ & 18.8 & $(\mathrm{~N}=2)$ & 0.0 & $(\mathrm{~N}=4)$ & 50.0 & 28.6 \\
\hline Environment & $(N=56)$ & 26.8 & $(\mathrm{~N}=49)$ & 38.8 & $(\mathrm{~N}=9)$ & 66.7 & $(\mathrm{~N}=13)$ & 30.8 & 32.8 \\
\hline *Total & $(N=527)$ & 28.7 & $(\mathrm{~N}=320)$ & 28.1 & $(\mathrm{~N}=32)$ & 43.8 & $(\mathrm{~N}=124)$ & 24.2 & 28.4 \\
\hline
\end{tabular}

*Includes survey replies within all programmes priorities, not only the four in the table, cf. Table 4.18

${ }^{* *}$ Numbers too low for analysis within priorities.

Sources: Survey to Norwegian applicants to FP7.

Overall figures for FP7 so far show a lower success rate for Norwegian coordinators (5.5 percentage points lower success rate than non-coordinators, Section 4.2.1 and Table 4.15). There are however large differences between the focus areas. Within Health, Norwegian coordinators have a much higher success rate than non-coordinators (39 versus 18 per cent). The coordinator success rate is also slightly higher within Environment and ICT. Within NMP, on the other hand, no proposal with a Norwegian coordinator is funded so far (Table A 14).

Summing up, the data give no basis for stating that projects linked to nationally funded research in general have a higher chance of EU funding than projects without such links. It should, however, be noted that within Environment, projects linked to nationally funded research have a substantially higher success rate than projects without such links. Moreover, within Health we find that a large part of FP6 projects are closely related to nationally funded research, and that Norwegian coordinators have a much higher success rate than non-coordinators in FP7. Notably, this is also the focus area with the highest proportion of participations which are extensions of previous EU projects (Life FP6, Table 4.16). Taken together, these findings may indicate that a good integration between national funding and EU funding in FP6 has given Norwegian participants a good basis for coordinating projects in FP7.

\subsection{Overall discussion of main findings}

Judging from the high number of Norwegian researchers involved in the Framework Programmes (about 5000), the potential impact on Norwegian research can be 
substantial. ${ }^{51}$ Close to one fifth (18 per cent) of the involved researchers at Norwegian organisations are $\mathrm{PhD}$ students, indicating potential for long-term synergies with and impact on Norwegian research.

What are the Norwegian experiences with FP participation and what are the results and impacts of the participation? Below major findings of Chapter 4 are discussed according to the relevant issues in the Terms of reference for the evaluation (Appendix 4).

\section{Participation costs and success factors}

How much resources are spent on the FP projects and how are expenses covered? The EU financial support does not cover all FP project costs, and participants need additional funding to cover costs. On average 62 per cent of Norwegian participants' project costs are covered by the EU financial support, 19 per cent by the participating organisation and the rest by other sources (Chapter 5, Table 5.4).

The applications costs are also substantial. Both in FP6 and FP7 each participating organisation typically spent one work month on the application (median value). In most cases, the larger share of the application costs is covered by the applicants, but the average proportion covered by the participating organisations was reduced from FP6 to FP7 (from 86 per cent in FP6 to 75 per cent in FP7). The proportion covered by the Project Establishment Support Scheme (PES) from the RCN was nearly doubled from FP6 to FP7 (from 11 to 20 per cent).

The survey results indicate that time planning is important for application success. Of those defining planning the application time as a strength of their applications, 38 per cent succeeded, whereas only 17 per cent of those defining time as a weakness succeeded (FP7). Moreover, economic resources have some impact on application success. Successful applicants have a slightly higher proportion of Project Establishment Support (PES) and other external funding, whereas rejected proposals are funded by their own organisation to a somewhat higher extent.

The choice of partners is decisive for the outcome. The data indicate that finding strong partners with experience in coordinating and writing EU proposals is a successful strategy (FP7):

- Norwegian applicants without coordinator or a leading responsibility in the project have higher success rates than Norwegian applicants with such responsibilities.

- The success rate is considerably higher for the applicants who define strengths in their access to scientific personnel for developing a good application and ability to find relevant partners.

51 The 536 Norwegian FP6 participations for which we have survey replies (accounting for 42 percent of the participations), report a total of 2499 researchers involved in their organisations. 


\section{Strategies and synergies}

What are the participants' strategies and priorities for their FP-participation? A large part of FP7 applicants report that the project was an integrated part of their organisation's internationalisation strategy, indicating some synergy between FP research and participants' research and research strategy. Access to research networks, expertise, scientific excellence and funding are the most important motivations for the Norwegian participants in the Framework Programme. Access to economic resources and scientific excellence is more important for the FP7 than the FP6 participants, which may be explained by the introduction of the ERC.

Even if a large part report that the project was an integrated part of their organisation's internationalisation strategy, much of the FP6 projects, as well as the FP7 applications, are not closely related to nationally financed research, and very few of the projects are extensions of nationally financed projects. The financial synergies between Norwegian and EU financed research consequently seem limited:

- 52 per cent of the FP6 projects are not closely related to research for which the Norwegian participant has obtained Norwegian public funding during the last 5 years; 57 per cent of the FP7 applications are not closely linked to research for which the Norwegian public funding is obtained during the last 2 years.

- 69 per cent of the FP6 projects are not an extension/follow up of another R\&D project (vs. 65 per cent in the FP5 survey); 17 per cent are extensions of previous EU projects, whereas only 6 per cent are extensions of nationally financed projects.

The data give no basis for stating that projects linked to nationally funded research in general have a higher chance of EU funding than projects without such links (except for applications closely related to SFI/SFF funding). Within Environment, however, projects linked to nationally funded research have a substantially higher success rate than projects without such links. Moreover, within Health we find that a large part of the FP6 projects was closely related to nationally funded research, and some indications that good integration between national funding and EU funding in FP6 has given Norwegian participants a good basis for coordinating projects in FP7.

The qualities of the EU projects

What characterises PF projects with Norwegian participation, and how does the FP research compare with research outside the FP? A large proportion of Norwegian participants in FP6 report that there is no difference in the nature of their EU project and their other R\&D projects. EU projects are generally perceived as having the same scientific quality, being equally scientifically/technologically risky and providing the same amount of new scientific results as participants’ other R\&D projects. 
There is, however, a high proportion (43 per cent) that finds the EU project more multidisciplinary than their other projects. Some (22 per cent) also find that the EU projects were less oriented towards basic research. This is in line with the overall orientation of the FPs towards applied and multidisciplinary research.

\section{Benefits for participants}

To what extent and in what ways do the participants profit from their FP projects? The large majority of respondents characterises their FP6 projects as successful (60 per cent) or very successful (17 per cent), and only 4 per cent consider that it was unsuccessful or very unsuccessful. Especially participants within Life and NMP report high success. Not surprisingly, participants with coordinator responsibility are more positive than participants without coordinator responsibility. This indicates that coordinators have been better able to achieve their aims for the project.

Overall, the high proportion of successful projects indicates that the large majority of participants profit from their FP participation. The participants characterise the projects as particularly successful in terms of impact on network building and long-term collaboration. The projects are also assessed as successful in terms of research performance, achieving project objectives, and as basis for acquiring new R\&D projects. Looking more closely at research performance, nearly half of FP6 respondents (43 per cent) report that the EU project has increased their publication output, of which a smaller share (13 per cent) report significantly increased output.

Concerning economic results of the projects, more respondents answer positive than negative. 38 per cent of the participating Norwegian enterprises expect direct economic benefits in the form of increased sales or reduced costs which can be associated with the FP6 project. The remaining 62 per cent do not expect any such economic benefits.

Notably, the figures above relate to FP6 project. It is too early to assess benefits from FP7 projects. One positive indication of FP7 benefit may still be noted. Comparing FP6 and FP7, a considerable increase is observed in participants at Norwegian higher education institutions who have a leading responsibility in the projects (for example work package responsibility). ${ }^{52}$ Project involvement is a key criterion for participation benefits and more leading responsibilities in the FP7 than the FP6 projects indicate increased ability to profit from the FP participation.

52 In FP6, 58 per cent of the participations from Norwegian higher education institutions included a leading responsibility, in FP7, 78 per cent have such a responsibility. 


\section{Ability to create innovation and added value}

To what extent do the Framework programme improve participants' abilities to create innovation and added value? FP6 participants report extensive impacts on their R\&D capabilities and activities. Close to 70 per cent have developed new expertise or skills from the project, and most of the remaining participants expect such project benefits the in the future. Moreover, a majority have developed, or expect to develop, new technology, processes, products or services. There is also a majority who have implemented, or plan to implement, new technology, processes, products or services.

The projects also impact participants' future opportunities. 60 per cent report that the EU project has explored new research areas of significant importance for their future research and innovation activities. Reporting on expected future changes in the position of their organisation, as much as 43 per cent of the enterprises state that to a high or very high degree the FP6 project represents a gateway to new customers. Moreover, 31 per cent report that to a high or very high degree the project is expected to strengthen their position vis-à-vis competitors and 24 per cent that to a high or very high degree the project represents a gateway to new suppliers.

In conclusion, the FP6 participations have had substantial impact on Norwegian research and innovations capabilities. Added value of the participation is further elaborated in Chapter 5.4.

\section{Long-term impacts}

In the longer perspective, what impacts of the Norwegian FP participation can be expected? Substantial long-term effects are reported in the participant survey. A substantial proportion report positive effects on long-term cooperation links, as well as changes in the participating organisations' way of doing research - also outside the Framework Programme. The FP6 participants’ research activities are becoming more collaborative, more international and organised within larger projects. This indicates longterm behavioural impacts of the Framework Programmes on the Norwegian research community. Especially participants within Nanotechnologies and nanosciences, but also those participating in Food quality and safety and in SME activities, report a changed nature of research activities as a result of the participation.

Moreover, analyses of co-author links with researchers in other countries show that a fundamental structural change of Norwegian science towards more European collaboration has taken place. Even when research collaboration with all parts of the world increase, the data indicate a relatively higher increase in European collaboration, also outside the Framework Programme. 


\subsection{Issues to be improved}

As evident from the analysis above, the Norwegian participation in the Framework Programme is successful in terms of generating benefits for Norwegian research and innovation. Concerning benefits at the participant level, no major issue needing improvement appear from the analysis. Concerning the framework conditions for participations there are, however, some issues needing improvement. The Norwegian participants are concerned about the economic and administrative burden of participating in the Framework, including complying with reporting demands, reviews and audits, and covering the non-EU financed part of the projects. Several respondents used the open reply box at the end of the survey to amplify such issues. These issues were also central in the interviews in participant organisations.

\section{Heavy administrative burden}

A large part of the informants' suggestions for improvements concerns the EU bureaucracy - the formal demands regarding the applications, reporting, auditing, etc. Expressions such as "extensively burdensome administrative requirements”, "overwhelming, irrational bureaucracy”, "massive waste of time”, “confusing and frustrating nightmare”, and "EU funding is yet another burden on scientist who are supposed to be creative", are numerous in the open reply boxes. The rules and requirements are not easily accessible and much time is used on interpreting and understanding them. Coordinators in particular report that administrative work takes time and resources - something which could be better used in research activity. There is a need to hire people only to take care of the administrative requirements.

Informants have different suggestions on how to deal with this. Several would like the RCN to arrange video/web-based information seminars and courses. They expect the information seminars arranged by RCN to be useful to them, but find it difficult to take the time for travelling to Oslo for a two hour event. Web-seminars and courses would be a nocost, easily accessible alternative. Several also suggest arranging meetings for exchanging experiences, including those of successful applicants, learning from mistakes, how to handle administrative and economic requirements and so forth. Another suggestion was for courses for first-time coordinators, focusing on both the administrative requirements and the social aspects of leading a large international research group. Another suggestion was to distribute successful applications as templates for new applicants, and yet another to establish a professional not-for-profit organisation to assist smaller institutions in handling administration of proposals and larger projects.

In general, there seems to be a need for more assistance in handling the administrative requirements for which some have found a solution. Whereas a large number of informants report on the time and frustration they had in coping with the administrative requirements, others report on the crucial assistance they received. Some acquired the help through 
working with colleagues/partners with extensive experience in administrating Framework Programme projects. Others received good administrative support from their organisation or from external experts on the Framework Programme (including professional consultants).

In addition to those that call for more help to cope with administrative requirements, there are some who oppose the administrative requirements. They see them as unnecessarily complex and taking large resources away from the research activity, claiming that there should not be a need for extensive professional help for writing applications and administering research projects. Moreover, some are concerned that the Commission needs to clarify, improve and simplify rules and requirements, and suggest that the RCN should have a role in advocating this need.

\section{Large consortia, little research content and little basic research}

Several informants (mostly FP6 participants, but also some FP7 participants) comment on the project size, reporting that projects with a high number of partners are less efficient and that excessive resources and time are spent on administering the projects, leaving less time and resources for research activities. Moreover, cross-disciplinary and international research cooperation is challenging and time-consuming, and only to a limited extent the Framework Programme provides funding for long-term basic research activities. Funds are mainly directed for network activities and more limited research activities, and additional funds are needed to cover research activities.

\section{Research institutes: Economic deficit}

Underfinanced projects, unclear cost models for EU projects and economic deficit are common complaints in the open reply boxes. First of all, the EU funding does not cover all project costs, and when there is no additional funding from other sources this implies an economic loss for the participant. Especially research institutes with low basic funding are concerned about this. Moreover, the rules are unclear. The result of the Commission's audits of FP6 projects is that the project costs of several Norwegian participants are not accepted as eligible costs. ${ }^{53}$ This relates to the calculation of productive hours, rules of depreciation and VAT. In sum, the participants find it very difficult to cover both their project expenses (find extra funding) and to separate between eligible and non-eligible costs when trying to comply with the economic rules and guidelines for the EU projects.

\section{SMEs' experiences: Need external support}

The small enterprises are especially concerned about the administrative and economic burden of taking part in EU projects. They report a need for extensive help in "solving the paper work", both in writing proposals and reporting. They find it irritating that small

53 Relates FP6 and research institutes and enterprises using the full cost model with actual indirect costs. 
enterprises must fulfil the same administrative requirements as large enterprises which have far more resources to handle such requirements. Moreover, they find the funding insufficient and that too many resources go to the larger partners or to external assistance administrating the project.

\section{Large firms' experiences: Lack of matching research interests}

Several of the large firms interviewed commented on the thematic focus of the Framework Programme. The match between the FP7 calls and their research interests is far from optimal. The EU projects are valuable in terms of long-term training and network building, and give access to knowledge from important European actors, but as calls do not match their current research interests, their participation is limited. Some have simply not been able to find a proper niche in FP7 for their kind of industry, but still hope for calls that match their interests. Other reasons for limited participation include lack of relevant European partners for projects on their most relevant topics, that they do not need the EU funding, and unsuccessful applications (partly because their topics are not given priority in the FP). Some informants also point to the enterprise's internal attitude/culture and approach to research as a partial explanation.

\section{Lacking coordination with national priorities and funding}

Some of the informants ask for more agreement between Norwegian programme calls and the priorities in the Framework Programme. This would facilitate parallel funding of projects - making it easier to do substantial research on the topic, creating synergies between EU funding and national funding and, of course, better coverage of project costs. Another effect would be that national projects prepare for international projects later. Getting such parallel projects is said to be difficult and some also claim that the RCN does not give priority to international projects, nor to co-funding EU research. Some give examples of parallel project applications not funded by the RCN and report that there is no Norwegian funding for the topic of their EU project. Both more agreement with EU calls and more open calls are suggested to facilitate Norwegian co-funding of EU research.

It is also said that Norway does not offer the same kind of national prestigious funding schemes (i.e. open call basic research schemes as in Germany and the Netherlands) giving Norwegian scholars the proper track record to compete with researchers from other countries in the ERC schemes.

On the other hand, there are informants who emphasise that Norwegian research resources seem too oriented towards the EU, and that other international cooperation schemes exist which are more important than the Framework Programme. Some maintain that there are specific national issues which have to be covered by national funding schemes, and that important non-national research issues are not covered by the FPs and need to be funded from elsewhere. 


\section{The role of the Framework Programmes in the Norwegian research and innovation system}

The topic of this chapter is the role played by the Framework Programmes in the Norwegian research system. In the first section of the chapter, statistics establishing the relative size of the Norwegian participation in the FPs compared to the overall size of the national R\&D system are presented. This includes a comparison of the national financial contribution to FPs, compared to Norwegian contributions to other international R\&D international research activities.

In Section 5.2, the focus is on the structuring effects the new R\&D policy instruments introduced in the FP6 and FP7 such as the European Research Council (ERC), Joint Technology Initiatives (JTIs), new agreements for building new Research Infrastructures related to the European Strategy Forum for Research Infrastructures roadmap (ESFRI), Marie Curie schemes and ERA-NETs, have on the Norwegian research system and how they contribute to further integrate it into the ERA. We also investigate the structuring effects large research projects (IPs) and Network of Excellence have on the participants as opposed to traditional instruments, such as STREPS, SSAs, etc.

Based on the analysis in the first two sections, Section 5.3 provides a forward-looking assessment of the Norwegian participation in the FP7 and provides an assessment of the competitiveness of the Norwegian research system in the FP7 arena. Finally, Section 5.4 investigates four key aspects of the Norwegian participation in the FP6 and FP7:

- $\quad$ The degree of additionality of the Norwegian FP projects

- Administrative capacities and administrative costs of the Norwegian participation in the FPs.

- How well Norwegian research organisations deal with the issue of intellectual property rights in their participation in FP projects and whether their knowledge on this issue is satisfactory.

- The capacity the Norwegian research system has to absorb and appropriate knowledge produced in FP projects where Norwegian researchers participate.

Section 5.5 summarises the main findings of previous sections. 


\subsection{The significance of the Norwegian participation in the Framework Programmes compared to national research activities}

According to the latest statistics (data from 2007), the total funding of R\&D in Norway in 2007 was NOK 37.4 billion. Of this, 3.1 billion NOK was funding from sources outside Norway (“abroad”), i.e. approximately 8 per cent of the total, (see Figure 5.1). In 2007, funding from FPs amounted to NOK 482 million, or 1.3 per cent of Norway’s total R\&D expenditure.

R\&D expenditure in Norway by source of funds and sector of performance: 2007

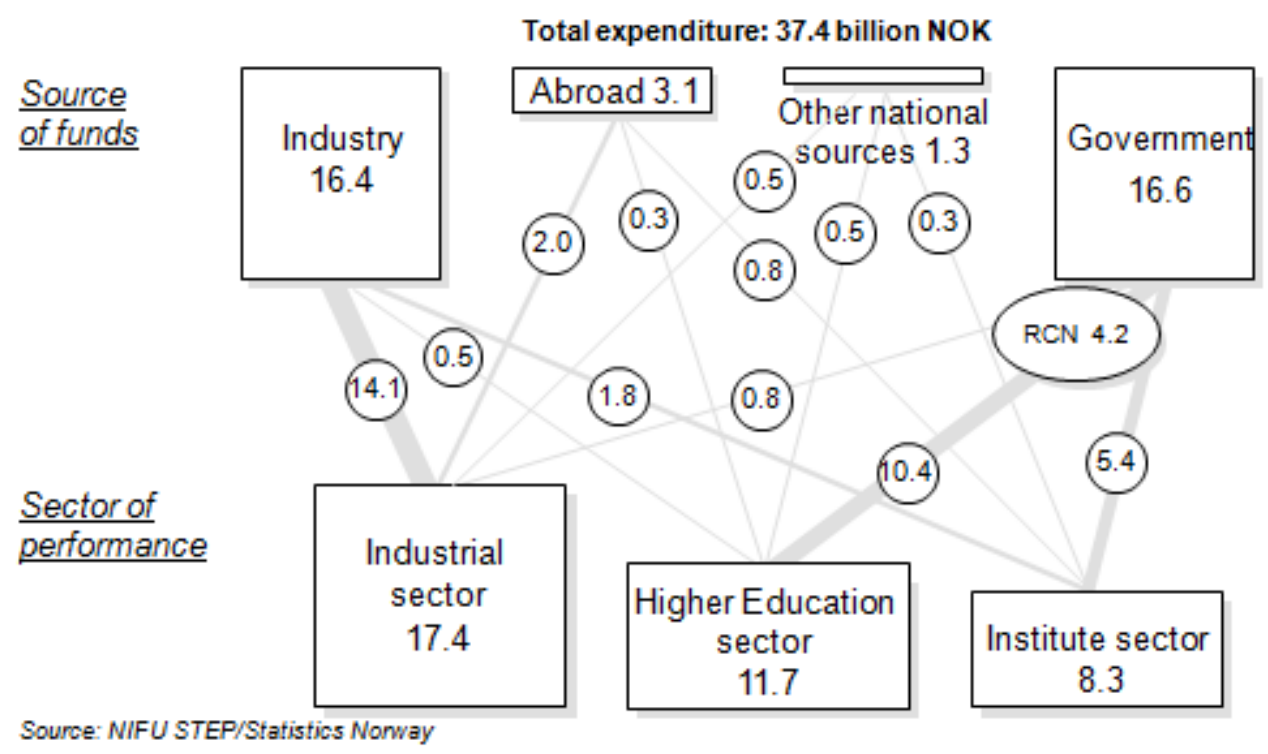

Figure $5.1 \quad R \& D$ expenditure (in NOK billion) in Norway by source of funds and sector of performance in 2007

In this perspective, Norway's participation in EU FP seemingly plays a marginal role.

Although there has been an increase in EU funding of Norwegian participation from 2001 to 2007, as shown in Table 5.1, from a narrow economic perspective the role of EU funding of Norwegian research activities is small. Furthermore, even if Norway achieved "juste retour" (i.e. break even between the participation contribution that Norway pays to FPs and EU contribution to Norwegian participations), this would only have an incremental impact. The share of EU funding from the FP6 would increase from 1.3 per cent to approximately 1.55 per cent. 
Table $5.1 \quad R \& D$ expenditure funded by the EU Commission by sector of performance in Norway: 2001 - 2007. Million NOK

\begin{tabular}{|l|c|c|c|c|}
\hline Year & $\begin{array}{c}\text { Higher } \\
\text { education } \\
\text { sector }\end{array}$ & $\begin{array}{c}\text { Institute } \\
\text { sector }\end{array}$ & $\begin{array}{c}\text { Business } \\
\text { sector }\end{array}$ & Total \\
\hline 2001 & 105,0 & 159,6 & 101,7 & 366,3 \\
\hline 2003 & 137,7 & 217,7 & 106,8 & 462,2 \\
\hline 2005 & 166,3 & 217,8 & 95,4 & 479,5 \\
\hline 2007 & 171,8 & 253,7 & 56,6 & 482,0 \\
\hline
\end{tabular}

Figure 5.2 and Figure 5.3 show funding from EU Commission as a share of total external funding in the Higher Education Sector (Figure 5.2) and as a share of non-pubic external funding (i.e. excluding funding of research by RCN, the Ministries and other governmental organisations). Both figures show that funding from the EU Commission is less important source of external funding than the RCN, Ministries, Industry and other sources of national R\&D-funding. About 30 per cent of non-public external funding of the University of Oslo derives from EU Commission, while for the University hospitals EU Commission funds represent less than three per cent. Note that compared to all other Higher education institutions, funding from ministries is by far the most important source of external funding for university hospitals.

Figure 5.4 and Figure 5.5 show that funding from EU Commission as a share of total external funding in 2007 varied from 7 per cent for Engineering and Technology to 3 per cent for Agricultural sciences, Medical and health sciences and Humanities. Note that in Humanities other foreign funding sources consists 32 per cent of the total non-public external funding of R\&D expenditures in Higher Education sector compared to 11 per cent for EU Commission funding (Figure 5.5).

Figure 5.6 and Figure 5.5 compare funding from EU Commission with other sources of external funding in the Research institute sector (Government institutions and a large number of private non-profit research organisations receiving basic allowances from the RCN) in 2007. Funding from EU Commission is in general a minor source of external funding for the Norwegian institutes with shares varying from four per cent for the group of National Social Science research institutes to three per cent for all the others. 


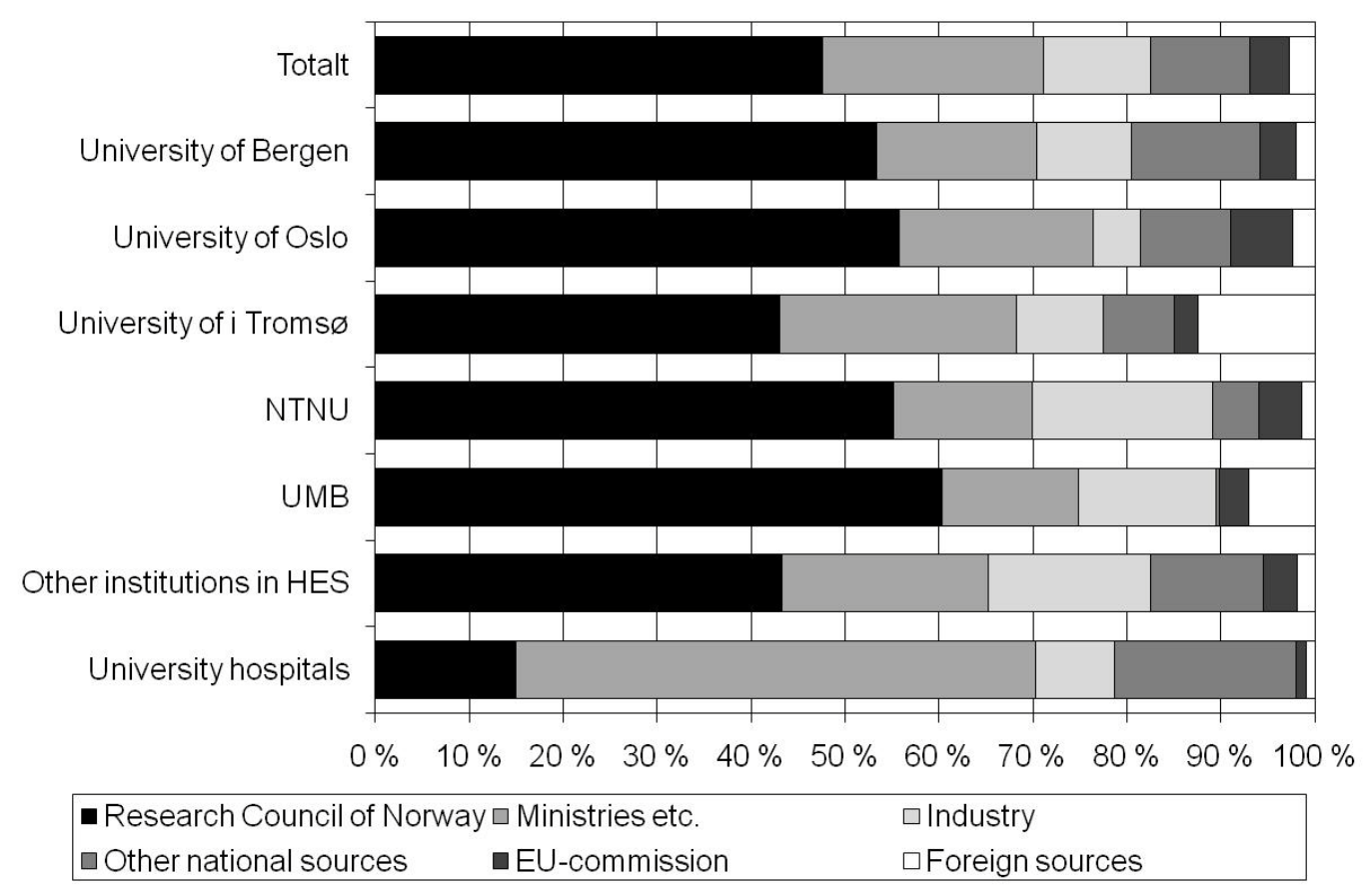

Source: NIFU STEP/R\&D statistics

Figure 5.2 External funding of R\&D in the Higher education sector in Norway by institution and source of fund. 2007.

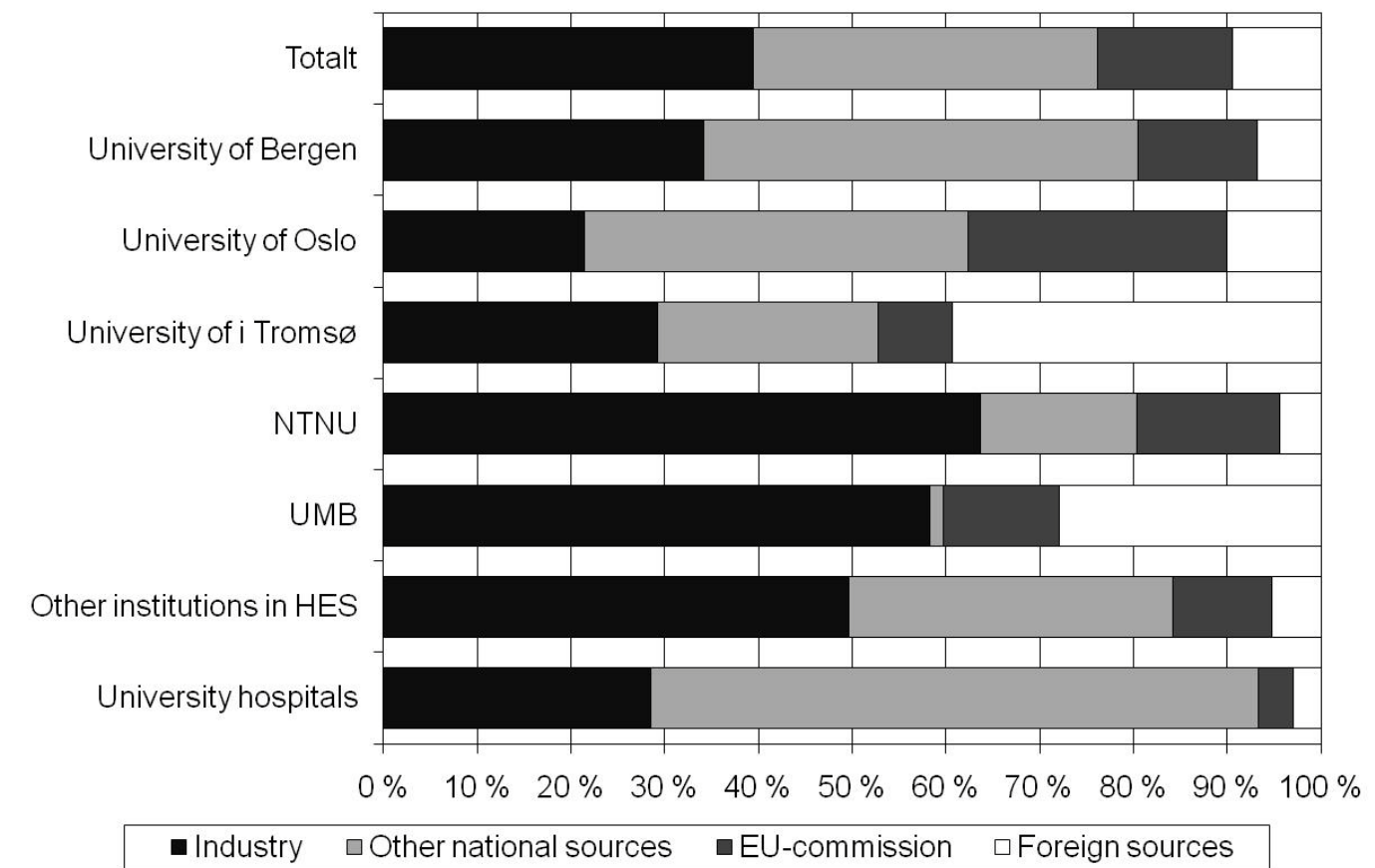

Source: NIFU STEP/R\&D statistics

Figure 5.3 Non-public external funding of R\&D in the Higher education sector in Norway by institution and source of fund. 2007. 


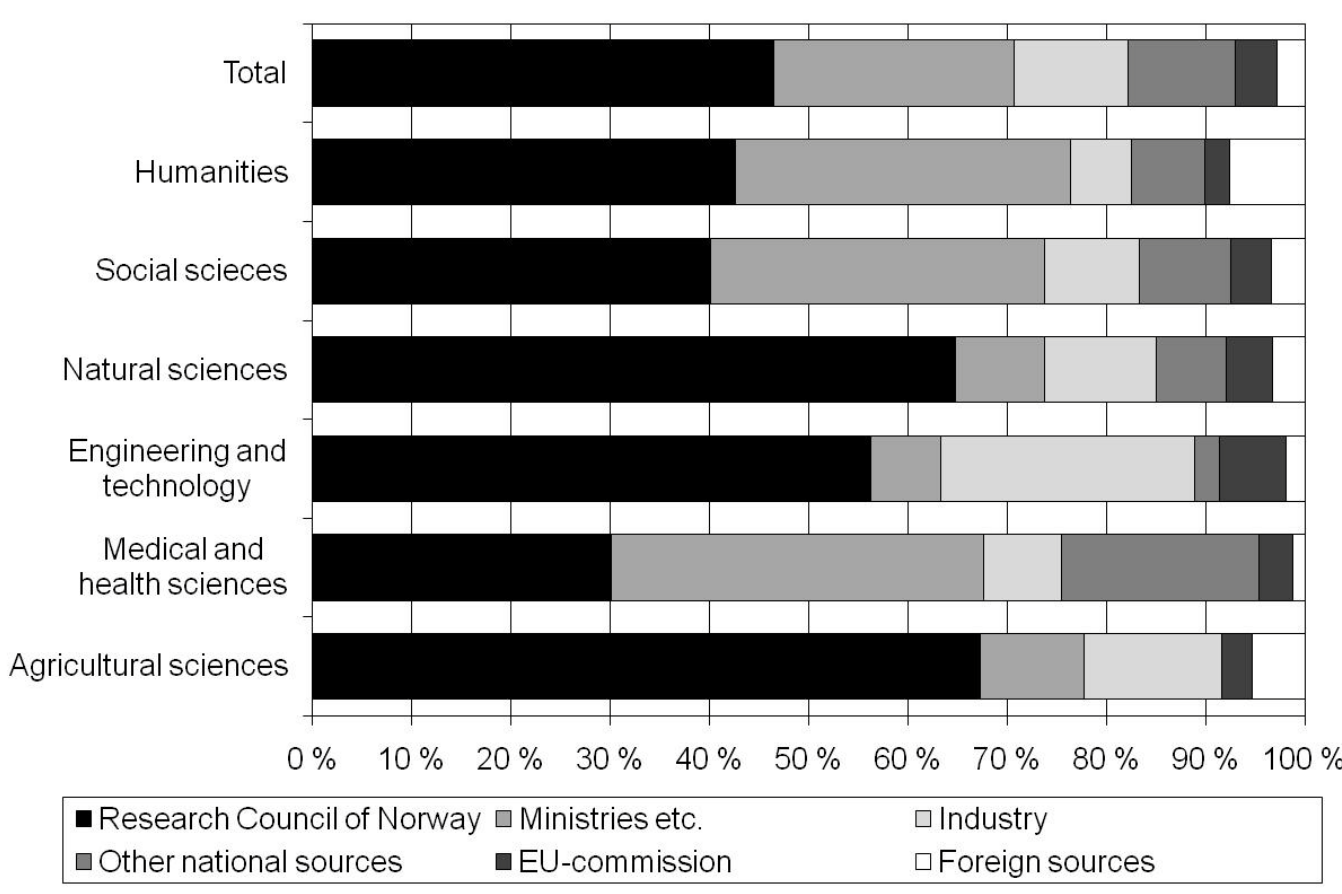

Source: NIFU STEP/R\&D statistics

Figure 5.4 External funding of R\&D in the Higher education sector in Norway by field of science and source of fund. 2007

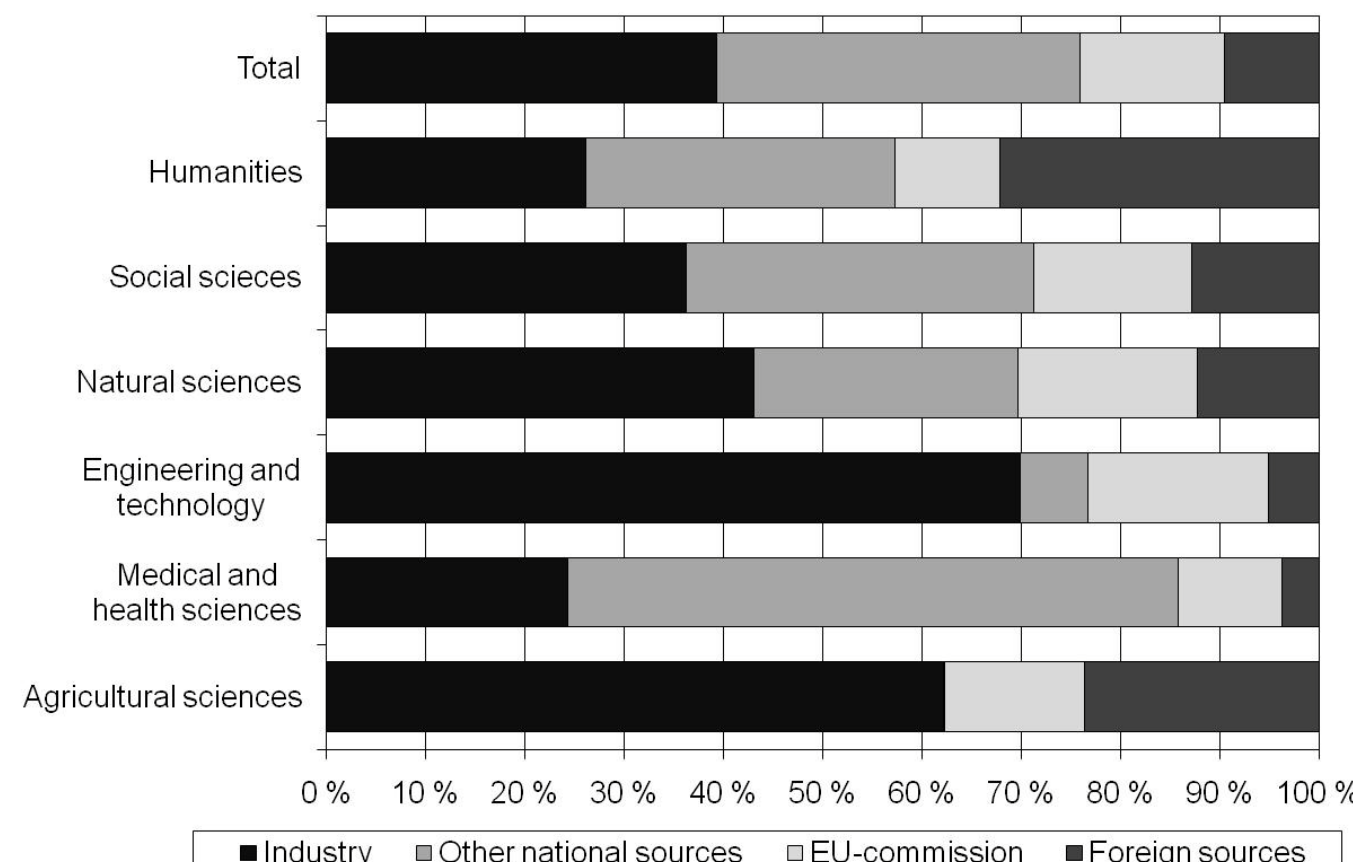

Source: NIFU STEP/R\&D statistics

Figure 5.5 Non-public external funding of R\&D in the Higher education sector in Norway by field of science and source of fund. 2007 


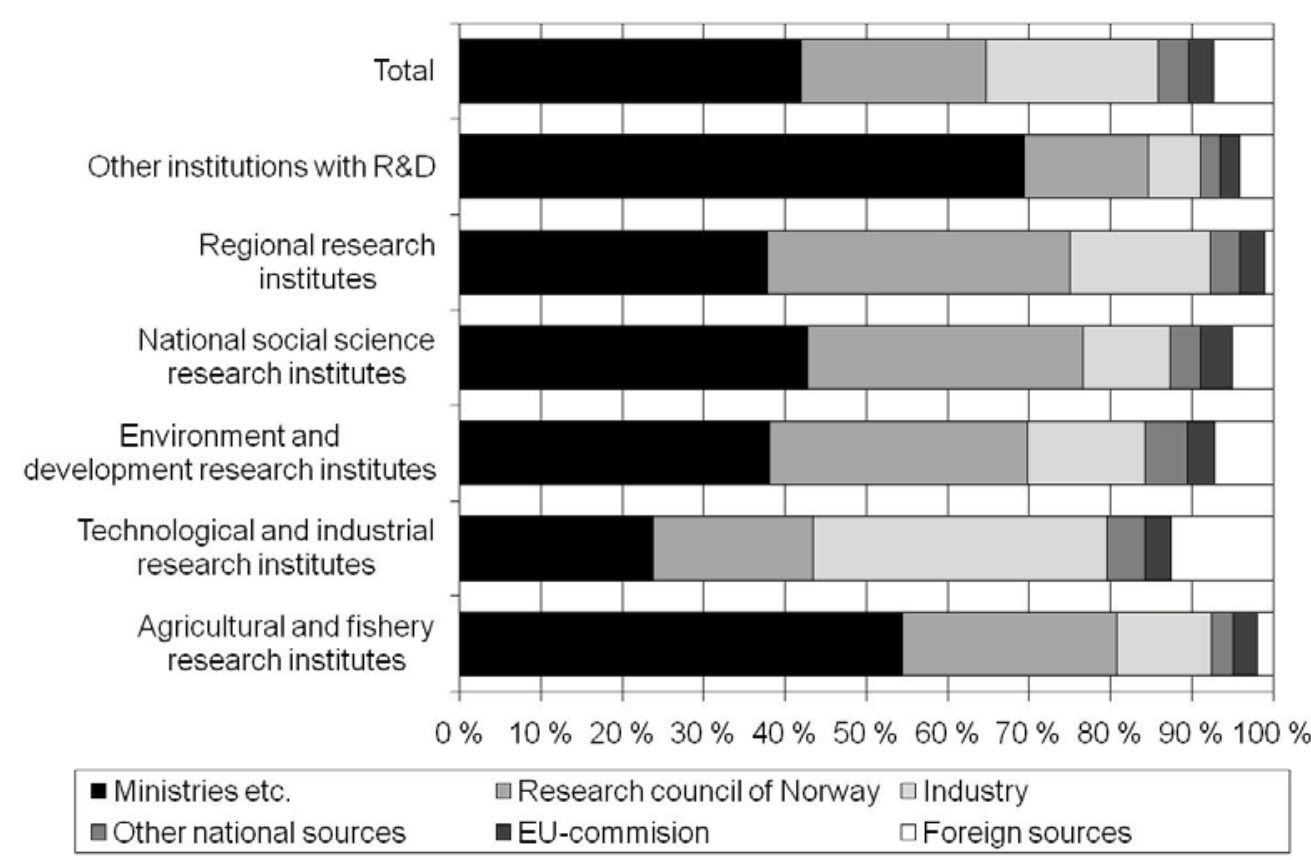

Source: NIFU STEP/R\&D statistics

Figure 5.6 External funding of R\&D in the Institute sector in Norway by type of institution and source of fund. 2007

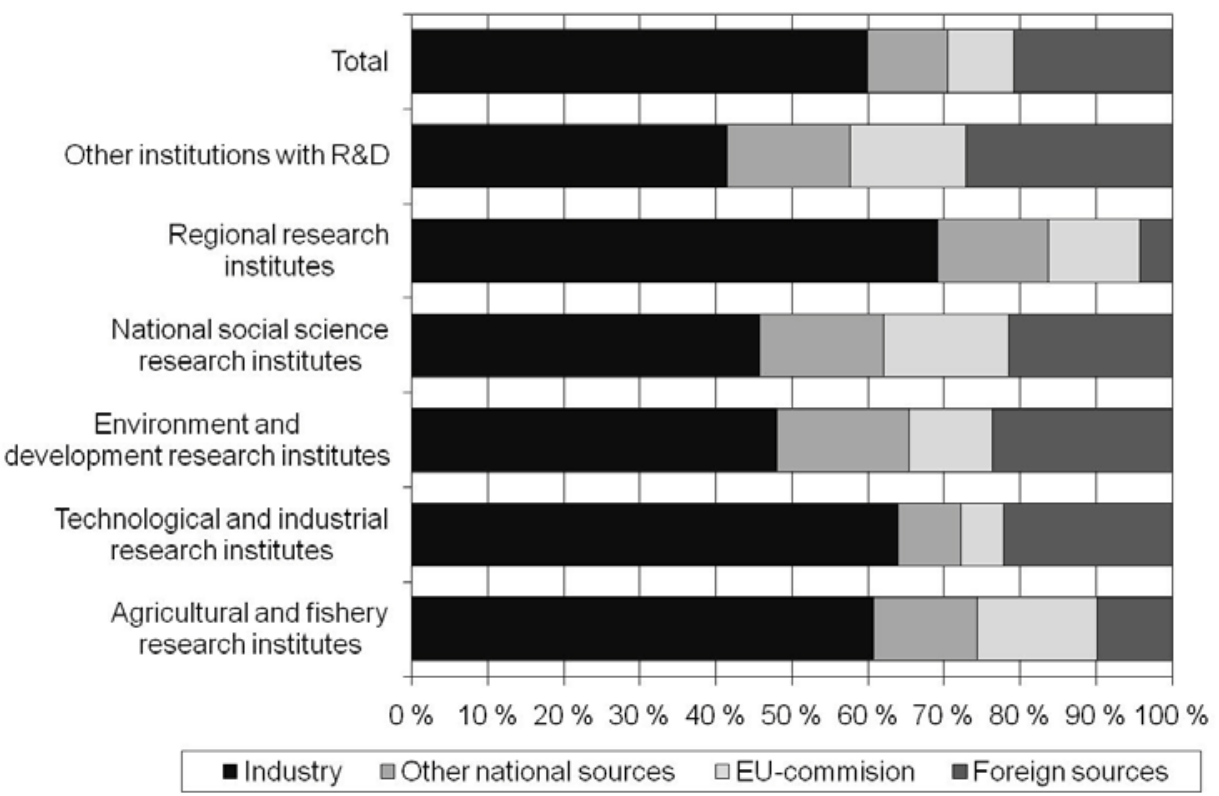

Source: NIFU STEP/R\&D statistics

Figure 5.7 Non-public external funding of R\&D in the Institute sector in Norway by type of institution and source of fund. 2007.

From the Table 5.1 and Figures 5.1-5.7 we conclude that as a source of funding the FPs play a minor role in the Norwegian research system as a whole and for all three R\&Dperforming sectors. 
However, "following the money" does not pay attention to the fact that the total eligible costs of all FP6 projects where Norwegian researchers participate was approximately 40 billion NOK, a figure larger than the total R\&D expenditure in 2007 in Norway. This indicates the magnitude and the potential significance of the knowledge production which is taken place in the FPs for the Norwegian research system.

Further to that, one should also note that probably a large part of the category "Other foreign sources” in the R\&D statistics may be related to FP-research as payments from foreign coordinators of FP projects could be included in this category. If this is true (see also Figure 5.9 below), than up to 40 per cent of non-public external funding for the research institute sector and up to 23 per cent for the Higher Education sector represents funding associated to FP activities. Of course, one should also take into consideration the so-called EU-SAM funds - utilised by the RCN for co-funding up to 25 per cent of total eligible costs of the Norwegian research institutes in FP6. With EU-SAM funds one could claim that maximum up to 15 per cent (most probably close to 7 per cent) of the total external funding in the research institute sector is associated with FP activities in 2007. For the Higher Education sector this share is maximum seven per cent (most probably close to five per cent). International comparative statistics on university external funding does not exist, but we expect that the FPs as an external funding source play greater role in the Higher education sector in other countries.

We know also that national FP participation is concentrated on a small number of university departments, research institutes and businesses in Norway. This means that there is an uneven dispersion of EU contribution to Norwegian organisations which by and large reflects the international orientation of the research teams in these R\&D organisations and the thematic content and priorities of the FPs. Hence, from the point of view of the participating organisations, this unevenness implies that a small number of university departments and other R\&D organisations are more involved in FP research activities while others are barely active. This is particularly true for almost all 19 Norwegian State University colleges and for many of the university hospitals in the country (see also Figure 5.3).

This uneven distribution raises also another issue, namely, that some $R \& D$ organisations may be so heavily involved that they experience "participation barriers" - mainly caused by the heavy administrative burdens associated with FP project participation and the cofunding of the participation - while other $R \& D$ organisations remain almost totally detached from FP activities.

We believe that there is need for policy action with the objective to involve a greater number of Norwegian R\&D organisations in FP research. This can be done partly by rewarding financially EU inactive R\&D organisations (at the research department/group level) for applying and hopefully succeeding to participate in FP projects, and partly by 
stimulating $R \& D$ organisations with participation experience to include non-participating Norwegian organisations in their FP projects could be allocated in FP7 to mobilise a greater number of relevant research groups.

Having said that, we repeat that the key question for policy decisions is how much of the knowledge output from the FPs in which Norway participates is absorbed and further exploited by the Norwegian research system, and how much of this knowledge contributes (or may contribute) to the advancement of the economic competitiveness and social welfare of the nation. Although this question is discussed in Section 5.4.5 in a greater detail, we mention here that increasing the absorptive capacity of the Norwegian research system necessitates strategies of utilisation and articulation of FP research in the national research system. By utilisation strategies, we mean strategies for how to better utilise the FP research activities for the advancement of the competitiveness of the Norwegian research and innovation system. Numerous interviews indicate that there is an increasing need to reflect upon the issue of the potential value and utilisation of the Norwegian FP participation profiles at all levels, as the attention of the policy actors to this issue is very small, also within the EU Commission.

Our assessment is that the strategic thinking and strategic positioning of Norwegian researchers in FP projects with the utilisation of results and outcomes as a main objective could have been more explicit in the majority if not all Norwegian organisations, including the business sector and other participants such as the Research Council of Norway. The latter is not only a key organisation in the designing and implementation of the research policy in Norway, but it is also one of the most significant Norwegian participants in the FP6 and FP7, due to its participation in ERA-NETs (cf. 5.2).

\subsubsection{The significance of FPs as a vehicle of internationalisation of the Norwegian research}

Table 5.2 shows that the Norwegian contribution to FPs in 2009 represents more than 60 per cent of total State funding of international R\&D activities in the national budget.

Table $5.2 \quad$ Funding of international R\&D commitments through the state budget. 2000-2009. Million NOK

\begin{tabular}{lrrrr}
\hline & 2000 & 2003 & 2006 & 2009 \\
\hline Nordic Minister Council ${ }^{1)}$ & $20 \%$ & $23 \%$ & $18 \%$ & $13 \%$ \\
CERN & $9 \%$ & $13 \%$ & $7 \%$ & $8 \%$ \\
EMBL & $1 \%$ & $1 \%$ & $1 \%$ & $1 \%$ \\
EMBC /ESRF/IARC & $1 \%$ & $1 \%$ & $1 \%$ & $1 \%$ \\
EU Framework Programmes & $49 \%$ & $37 \%$ & $58 \%$ & $59 \%$ \\
ESA & $21 \%$ & $25 \%$ & $16 \%$ & $19 \%$ \\
\hline Total (in MNOK) & 964 & 838 & 1327 & 1913 \\
\hline
\end{tabular}

${ }^{1}$ ) Only a smaller share of this amount is spent on R\&D.

Source: NIFU STEP/Statsbudsjettanalysen 


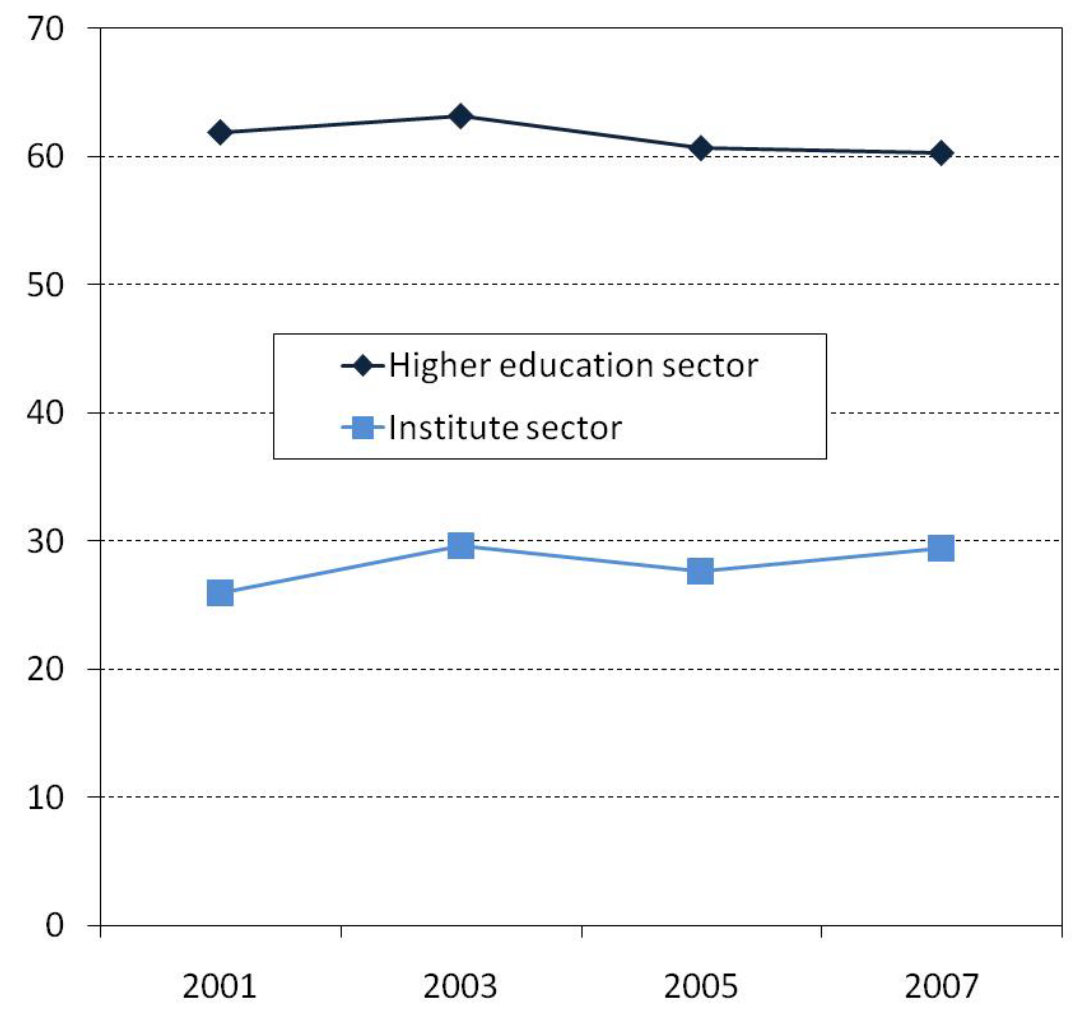

Source: NIFU STEP

Figure 5.8 Funds from the EU Commission as a share of national R\&D funds from abroad: 2001 - 2007. Per cent

This share is even higher, considering that expenses following national commitments to FP7 related activities, such as State co-funding of national participation in JTIs, ERANETs, ESFRI-projects other R\&D activities under articles 169 and 171 must be added to that.

From the perspective of R\&D-performing organisations, Figure 5.8 shows that funds from the EU Commission accounted for the major part of the funding from abroad in the Higher education sector in 2007, about 60 per cent. Thus, the FPs is the most important international funding source for the Norwegian universities. The Research institute sector receives a larger part of the funding from abroad from other sources than the EU Commission, only one third of the funding from abroad comes from the EU Commission in this sector. These shares have been relatively stable for both sectors from 2001 to 2007.

At the Norwegian University of Science and Technology (NTNU), the funding from the EU Commission amounted to 77 per cent of total funding from abroad in 2007, while at the University of Tromsø this share was only 18 per cent. At the University of Bergen and the University of Oslo the share was 65 and 71 per cent, respectively (se also Figure 5.3). According to the national R\&D statistics, the EU Commission funded R\&D at the 
University of Oslo for 72,9 million NOK in 2007, NTNU received 36,7 million NOK, the University of Bergen 30,5 million NOK and the University of Tromsø 8,0 million NOK.

In the Institute sector, the Regional research institutes had the highest share of funding from the EU Commission as a share of funding from abroad in 2007, 74 per cent, while the Technical and industrial research institutes had the lowest share, 20 per cent. At the Social science research institutes the share was 43 per cent, at the Agriculture and fishery research institutes 62 per cent and at the Environment and development research institutes 32 per cent. The Technical industrial research institutes received funding of $R \& D$ activities from the EU Commission that amounted to 110,0 million NOK, while the Agriculture and fishery research institutes received 54,7 million NOK and the Regional research institutes 7,1 million NOK.

Figure 5-9 presents a more detailed analysis of R\&D funding sources from abroad in the Norwegian Higher education institutions and Research institutes. As mentioned above, some of the sources of foreign R\&D-funding may in fact be related to FP activities as they may reflect transfers effectuated by coordinators of EU projects having Norwegian partners. Unfortunately, it is not possible to estimate the precise volume of these "hidden" EU-funds, but Figure 5-9 provide some indications. In the research institute sector, EU Commission is the most important funding source from abroad, with EU Commission funding as second most important.

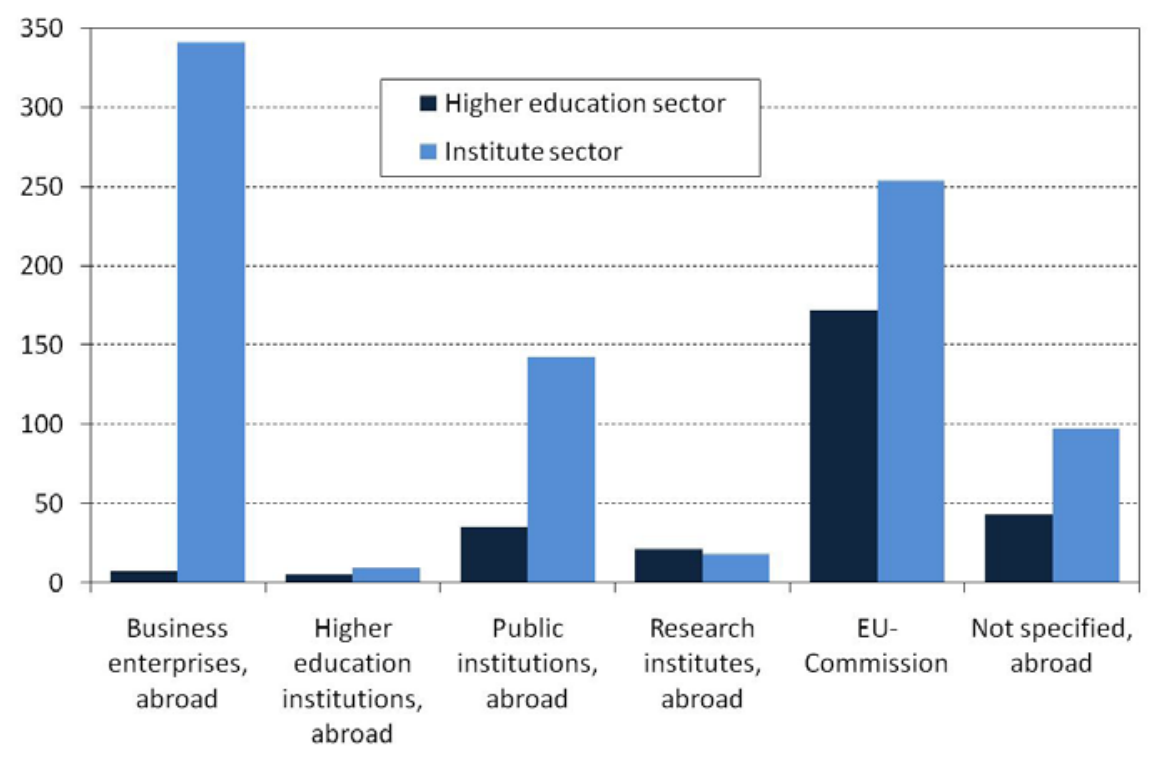

Source: NIFU STEP

Figure $5.9 \quad R \& D$ expenditure by type of funding from abroad and by sector of performance. 2007. Million NOK. 


\subsubsection{Geographical range of internationalisation activities}

Some critical voices point to the dominance of EU research in Norway's international R\&D budget and to the fact that R\&D collaboration with USA, Russia, China, Japan, India, etc. could have been higher considering the position of these countries in the global research system. A detailed examination of the resources allocated to the large number of bilateral R\&D agreements between Norway and other countries was not possible in this evaluation exercise. Yet, it is certain that bilateral R\&D agreements represent only a very small proportion of the total funding of Norwegian international R\&D commitments.

Furthermore, the bibliometric analysis (see Appendix 5) suggests that the accession of Norway as a full member in the FP4 in 1994 coincides with a clear trend showing a steep increase of the number of scientific publications involving co-authorships between Norwegian and EU researchers. As a comparison, co-authorships of Norwegian and US researchers increased at a significantly slower pace than the co-authorships with EU Member States in the same time period.

The issue of an optimal balance of bilateral or multilateral R\&D collaboration activities with other countries, in particular, USA, Japan, China, India, Canada and Russia is outside the scope of this evaluation. It is noteworthy, however, that the Ministry of Foreign Affairs published a White Paper (St. meld. Nr. 15 (2008-2009)) which provides a state of the art analysis of the main priorities of the Norwegian foreign policy. Though the term "research" is mentioned numerous times in this document it is far from clear how Norway could implement a research policy consistent with national foreign policy priorities. It is even more difficult to figure out what the role of the research policy collaboration with other Nordic countries is supposed to be in this respect.

The Nordic dimension and the future role of Nordic R\&D collaboration - both within and outside the scope of FPs - in the internationalisation of the Norwegian research system is an interesting question which require more policy attention and policy analysis in the future.

Concurrently, EU R\&D policy is aware of the fact that a greater share of the FPs should fund collaborative research with third countries. The ex post evaluation of FP6 Framework Programme pointed to this deficiency and the FP7 has already opened for the possibility to include researchers from third countries in ordinary cooperation activities. The Norwegian participation in specific measures in support of international collaboration (INCO) in FP6 and FP7 has, however, been low. An investigation should be made to see whether this is due to the particular profile and priorities under the INCO priority area, or if this is an indication that international collaboration with third countries is in general a weak point in the Norwegian research. 


\subsubsection{Norwegian national thematic and technology priorities ${ }^{54}$}

The Norwegian R\&D surveys 2007 and 2005 allow us to measure R\&D expenditure on thematic and technology priorities as defined in the white papers of the Ministry of Education and Research. ${ }^{55}$ The R\&D units participating in the survey were asked to estimate the proportion of their R\&D expenditures in three technology areas (Information and communication technologies (ICT), Biotechnology, Nanotechnology and New materials) and four thematic priorities: Energy and environment, Marine and Maritime, Food safety and security, and Health. In 2007 the priority area "Welfare" - basically applied research within Social Sciences and Humanities - was included for the Higher education sector and the Institute sector only. The three technology priority areas are not defined as mutually exclusive categories, and therefore some double counting may occur.

Energy and environment was clearly the thematic priority area that had the largest share of Norwegian R\&D expenditure, amounting to 7.7 billion NOK in 2007. The business sector dominated, accounting for 60 per cent of the total national R\&D expenditure in this thematic priority area. In comparison, from the 19 €million total EU-contribution to Norwegian participants in the first two years of ENERGY theme in FP7, 26 per cent went to participants from the business sector, 50 per cent to research institutes and 16 per cent to universities.

Health was the second largest thematic priority with 5.6 billion NOK, with the Higher Education sector accounting for 60 per cent of the total national effort, half of this spent within university hospitals. In comparison, from the 15.5 €million total EU-contribution to Norwegian participants in the first two years of HEALTH theme in FP7, 54 per cent went to universities, 13 per cent to university hospitals, 15 per cent to the business sector and 10 per cent to the Norwegian Institute of Public Health. In addition to the fact that, Norwegian participation is generally low in HEALTH, university hospitals have only four participations so far in this FP7 theme which clearly is a low number compared with the volume of R\&D performed.

Marine and Maritime and Food accounted for approximately the same amount of R\&D expenditure in 2007 with 2.0 and 1.8 billion NOK respectively. The research institutes performed the largest share of R\&D in these two thematic areas. About 60 per cent of the total EU contribution to Norwegian participants in the "Food, Agriculture, fisheries and Biotechnology - BIO” theme in FP7 so far are allocated to research institutes.

54 This subsection draws heavily from the analysis in Gunnes H, T. Sandven (2007): Tematiske prioriteringer og teknologiområder i det norske forsknings- og innovasjonssystemet. NIFU STEP report 22/2007.

55 St meld. Nr. 30 (2008-2009) Klima for forskning; St. meld nr. 20 (2004-2005) Vilje til forskning. There are but minor changes in the definition of national thematic R\&D priorities between these two documents. Obviously the R\&D surveys 2007 and 2005 focused on thematic and technology priority areas as defined in St. meld. Nr. 20 (2004-2005). 
MATFORSK is here a key actor. The number of participations from the Norwegian business sector is low in this programme. Further, since Marine and Maritime are themes appearing as topics in the working programmes of several priority areas in FP6 and FP7, it is not straightforward to assess Norwegian participation in this thematic priority. According to the RCN (the portfolio analysis conducted by the RCN in 2008) it seems that a large number of FP6 and FP7 projects with Norwegian participants deal with Marine and Maritime research issues.

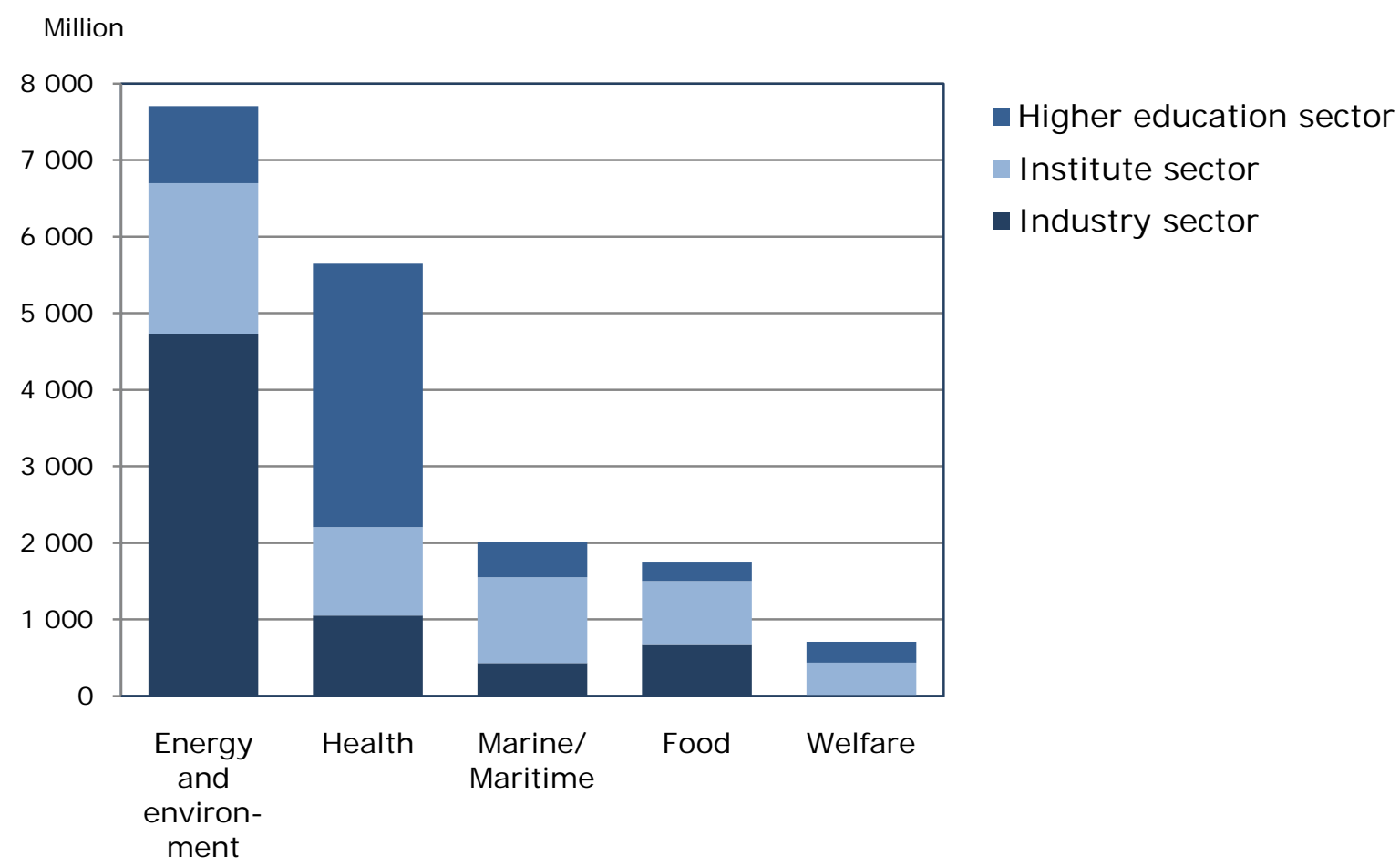

Figure 5.10 Current R\&D expenditure (in NOK billion) by thematic priority and sector of performance. 2007. Million NOK

Source: NIFU STEP/Statistics Norway

National R\&D expenditure on Information and communication technologies (ICT) amounted to 7.9 billion NOK in 2007. More than 80 per cent of this was spent in the business sector, with the technical-industrial research institutes as the second largest R\&Dperforming sector. In comparison, from the 22 €million (about 176 million NOK) total EU-contribution to Norwegian participants in the first two years of ICT theme in FP7, 24 per cent went to participants from the business sector, 54 per cent to research institutes and 18 per cent to universities. Thus, Norwegian ICT firms participate little in the FP7 compared to the considerable volume of their overall R\&D expenditures.

National R\&D expenditure on Biotechnology amounted to 2.4 billion NOK in 2007. Higher Education was the main performing sector in this technological activity, with 46 per cent of total R\&D expenditures, followed by the business sector with 41 per cent. 
Within New materials, Norwegian R\&D expenditure was 2.1 billion NOK in 2007, of which Nanotechnology accounted for 0.5 billion NOK. Eighty per cent of the effort within New materials took place in the business sector. The business sector also accounted for half of the total R\&D expenditure within Nanotechnology. The Higher Education sector was the second largest performing sector in Nanotechnology, with approximately 25 per cent of the current R\&D expenditure. In comparison, from the 17 €million total EUcontribution to Norwegian participants in the first two years of "Nanosciences, nanotechnologies, Materials - NMP” theme in FP7, 24 per cent went to participants from the business sector, 60 per cent to research institutes (SINTEF in particular) and only 13 per cent to universities. Based on the national research profile, we can conclude that universities and the business sector could have higher participations in FP7 than the realised.

\section{Million NOK}

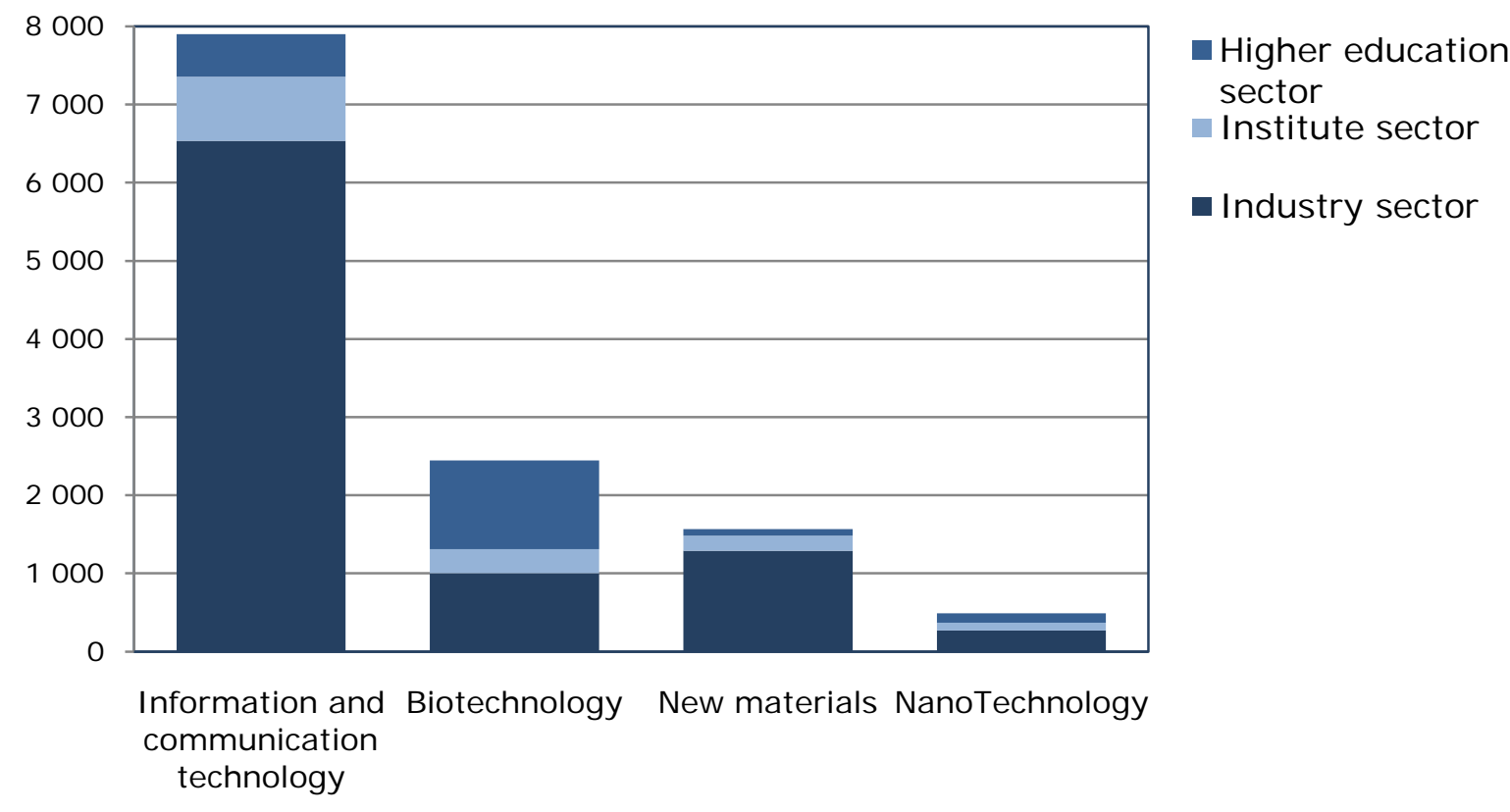

Figure 5.11 Current R\&D expenditure by technology priority area and sector of performance. 2007. Million NOK.

Source: NIFU STEP/Statistics Norway

\subsubsection{Assessment of the role of FPs in the national research system}

As a funding source, the FPs play a minor role in the national research system. It is the overall size (total project costs) of the FPs activities Norwegians are involved in which really demonstrates the significance of EU research. In FP6, the total costs of all research projects with Norwegian participation surpass Norway's total gross R\&D expenditure (GERD) in 2007. 
The thematic priorities in the FP6 and FP7 corresponds also quite well with the national thematic and technology priorities. All Norwegian thematic and technological priorities are addressed by the FPs either as a separate theme or as activities under several themes. For example, Marine and Maritime research is a key thematic priority for Norway. The FP7 addresses Marine and Maritime research topics under the themes BIO, TRANSPORT and ICT.

Also the mix of thematic priorities in the FP6 and FP7 corresponds relatively well with the national mix of thematic priorities, measured as shares of total Norwegian R\&D expenditures in 2007. For example, 23 per cent of total R\&D expenditures in Norway in 2007 addressed ICT-themes. The share of ICT theme in the total FP7 budget is 18 per cent. Health as a thematic priority represents 16 per cent of Norway's GERD, the share of HEALTH theme in the FP7 is 12 per cent. Research in Food as a thematic priority together with Biotechnology as technological priority constitute about 10 per cent of GERD in Norway, BIO has a four per cent share in the budget of FP7. Research in Materials and nanotechnology as a technological priority constitutes six per cent of Norway's GERD while the NMP theme gets seven per cent of the FP7 budget.

On the other hand, 18 per cent of Norway's GERD is spent on Energy and Environment research while these themes receive only 8 per cent of the budget in the FP7. Also, about seven per cent of GERD in Norway is spent on Marine and Maritime themes, while the share of the FP7s budget allocated to these marine and maritime themes is difficult to determine, but probably lower than the equivalent share in Norwegian research. Finally, applied social science research receives considerable more funding in Norway compared to many other countries, while the share of social science research in the budget of FP7 is between 5-8 per cent (i.e. SSH 1.2\%, Regions of Knowledge 0.2\%, Research Potential 0.7, Science in Society 0.7, as well as, components of social science research in the cooperation part and 14 per cent of the total ERC funds).

With this and with the analysis in Chapter 3 in mind, we conclude that:

- The FPs have been so far a minor funding source in the Norwegian research system. However, based on the sheer volume (total project costs) of the R\&D activities within the FPs where Norwegians are involved in, the FPs consist the most important internationalisation channel for the Norwegian research system.

- The thematic structure of the FPs corresponds fairly well with the thematic profile of the Norwegian research system. However, in terms of R\&D expenditures, the themes Energy and Environment, Marine and Maritime and Social science research are higher prioritised in Norway compared to FP7. Further, the IDEAS and PEOPLE programs are examples of activities addressing fundamental research issues. About 15 per cent of the FP7 budget is reserved for bottom-up frontier research. Also, the large and increasing number of co-publications with EU suggests that FP participation has a positive impact on the quality of national research. Hence, national participation in the 
FP7 can be justified as the main strategy for internationalisation in all thematic and technology priorities in Norway and as an instrument for enhancing the quality of research.

- Considering the quality of Norwegian frontier research, the low participation in the IDEAS so far is worrying and calls for careful monitoring of the participation in this program as well as studies investigating in more depth the reasons behind the low number of Norwegian proposals.

- Given the total size of R\&D expenditure in 2007, Norwegian participation in the IST priority area in FP6 and in ICT theme in FP7 seems to be below the national potential. In particular, the business sector shows low levels of ICT participation in FP6 and FP7 despite the fact that it is by far the largest $\mathrm{R} \& \mathrm{D}$ performing sector in this priority area of technology.

- Norwegian participation in HEALTH (FP7) and LIFE (FP6) lies below the national potential. Therefore, the low number of participations of university hospitals should be of concern.

- There is a large number of scientific areas, ranging from humanities, to nursing that are not addressed by the FPs. It is unclear whether there is any internationalisation strategy for these areas in Norway. This is an important issue, in particular for the Norwegian state university colleges. For many of these, the FPs is not an internationalisation option.

- For the departments in the Norwegian state university colleges that could participate in the FPs but they do not apply, there is a need to investigate in detail the reasons for their inactivity.

- Participation in FP and other ERA activities attracts the main attention of Norwegian policy makers and represents the lion's share of funding of Norway's international research collaboration. It is unclear whether participation in the FPs is "crowding out" collaboration opportunities with countries which do not participate in the FPs, in particular USA, Japan, China, India, Russia, etc., for this there is a need to conduct a separate focused study.

- The role of Nordic collaboration as a strategic alliance aiming at a better representation of Norwegian interests in the FPs, as a platform for various types of alliances in the shaping of ERA and as an alternative and independent sphere of international collaboration activities is not properly addressed in the present Norwegian policy making.

\subsection{Structuring effects and ERA}

The objective in the section is to assess the extent to which participation in FPs enables Norway to take part in the ongoing structuring of ERA, and what structural effects this has on the Norwegian research system. By structural effects we mean the following:

- Integration of national research funding schemes, in particular national R\&D programs. By integration we mean a) multi-country contributions to a common pot 
of funds for consortiums consisted by researchers from these countries; b) opening national R\&D programmes to non-national researchers; c) joint-programming.

- National participation and contribution to funding the construction of new research infrastructures.

- National co-funding of initiatives involving the business sectors from different countries as an attempt to identify areas of common interest.

- Increased collaboration among the participants in the FP through larger research projects and networks than in previous FPs as an attempt to achieve critical mass in specific research topics.

- Increased international researcher mobility and, more generally, lowering the barriers of knowledge circulation within ERA.

The ERA idea fuelled a set of activities exceeding the realm of the Framework Programmes. However, it is FP6 and FP7 which provided the necessary political, economic and legal platform for the implementation of many of these activities.

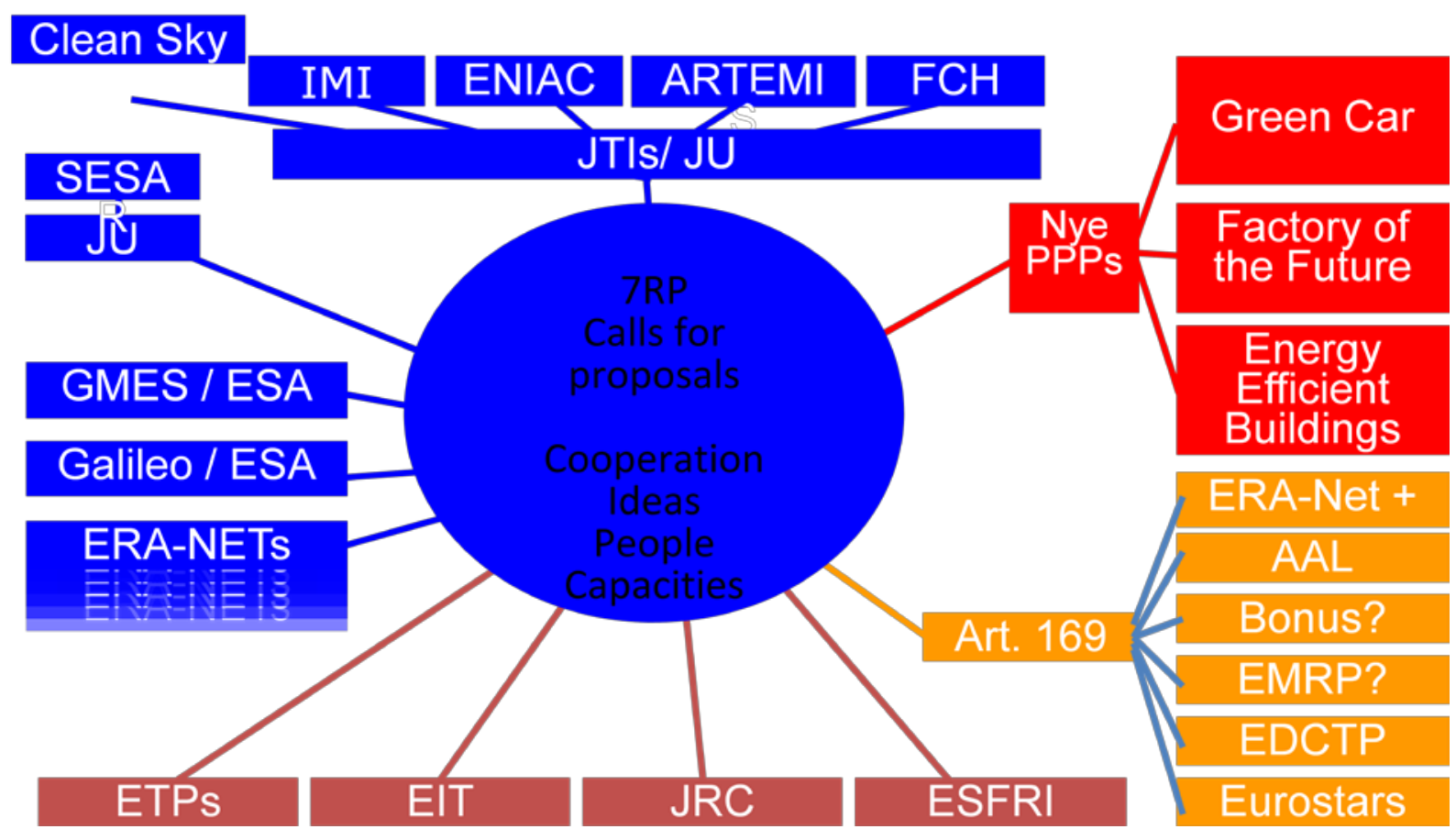

Figure 5.12 New Public-private partnerships associated with FP7 activities.

Source: Research Council of Norway

Figure 5.4 depicts the various types of new activities associated with FP7. There has been a gradual increase of organisational complexity from FP5 to FP7 and it is difficult to comment on all types of measures introduced in FP6 and FP7. In this section we examine structuring effects stemming from a limited set of measures shown in Figure 5.4, that is, only those which in one way or another are new compared to FP5 and funded by the FP6 and/or FP7. These are: 


\section{ERA-NETs}

2. Integrated projects and Network of excellence

3. European Research Council (ERC)

4. Research infrastructure programme in FP6 and FP7, including ESFRI-initiative

5. Human Resources and Mobility Schemes

6. Joint Technology Initiatives (JTI) and European Technology Platforms (ETP)

7. Participation of Small and Medium Enterprises - SME-programme

\subsubsection{ERA-NETS}

First introduced under the FP6, the ERA-NETs aim at a bottom-up coordination of national R\&D programme funding, and function as learning arenas which may ultimately result in joint multinational programmes involving several Member States although not necessarily all. ERA-NETs are an effective tool for reducing fragmentation in the research funding schemes in Europe and to increase coordination between them. The recent evaluation of the FP6 by the Rietschel-group of experts (European Commission 2009) concludes that the ERA-NETs "should continue [to exist] in order to encourage greater use of true common pots, detaching funding from the national level and developing common strategic issues".

With 47 participations, the RCN was one of the national research agencies with the largest number of ERA-NET participations in FP6. Twenty-eight of these ERA-NETs launched common calls. By May 2009, the RCN had used in total 204 million NOK for funding common-call proposals. These funds were taken from several national $R \& D$ programmes managed by the RCN, in particular from FUGE, RENERGI, NANOMAT and NISE. Usually, in these common calls the participating national agencies committed themselves to only fund researchers from their own countries, thus ensuring “juste retour".

There is no doubt, that many of the RCNs staff, through their participation in ERA-NETprojects, gained considerable experience and knowledge on how research policies and activities are organised in other Member States. The large number of ERA-NET participations can also be justified by the sheer fact that Norway has to broaden and strengthen RCN policy-influence channels within the EU as a non-EU member. Through the ERA-NETS, the RCN staff created networks and collaborative platforms with their counterparts in many other Member States. This multiplies and amplifies the channels of communication and information for policy making. For a non EU member these channels are of great importance for the design of future research policies within and outside the FPs.

On the other hand, decisions to participate in many ERA-NETs have been seemingly taken ad hoc, without a common strategy and without a realistic consideration of the administrative burdens associated with all these ERA-NET participations. 
It is important that the RCN draws lessons from the 45 ERA-NETs it participated so far. A study with the objective to assess good practices of policy design and effective collaboration platforms could contribute to a more coherent and strategic approach towards ERA-NETs in the future. In particular, it would be interesting to know how the RCN assesses experiences and outcomes from the launched common-calls. Such an assessment could be helpful in designing national strategy aimed at future "joint programming initiatives”. Finally, the high number of RCNs participations in the ERA-NET scheme may be considered as policy experience and experience with strategic and organisational aspects of joint programming. It is important that the RCN assesses and draws lessons from this participation. This assessment exercise could be also helpful for the Ministry of Education and Research in its future work with joint programming issues in the new CREST/GPC-committee dealing with this.

\subsubsection{Integrated projects and Network of Excellence}

Large research and network projects such as Integrated projects (IP) and Network of excellence (NoE) were to play an important structuring role in the FP6 by integrating cooperation activities in fewer but considerably larger collaborative projects. The idea with larger projects was primarily to increase the interconnectivity of research networks and to enhance self-regulated management mechanisms within these large projects such that they end up as independent and self-sustained entities. NoEs have been evaluated by an independed group of experts (Bonaccorsi et al. 2008) which, by and large, recommends the discontinuance of the NoE scheme. IPs in the FP6 have so far not been submitted to an independed evaluation, despite the fact that they attracted 40 per cent of the overall FP6 funding. However, the overall evidence suggests that the IPs were a considerably more successful instrument than NoEs.

The share of Norwegian participations and the FP6 contribution to Norwegian participations in NoEs and IPs were almost exactly the same as the overall FP6 shares of IPs and NoEs. This means that Norwegian researchers encountered no above-average difficulties in participating in this type of project. On the other hand, survey results show that participants in IP and NoE projects seem to be less satisfied than participants in STREPs (see Table A8, Appendix 1). Also several interviewees, in particular those from the business sector, mentioned that the success of very large R\&D projects depends greatly on the management skills of the project leaders. IPs may have greater impact prospects than smaller projects, but the risk of failure and opportunity costs due to suboptimal utilisation of results are also greater. Interviewees from the business sector also mentioned that IPR ownership issues are more difficult to settle in large projects than in smaller ones.

As a conclusion, Norwegian participants seem to prefer collaborative projects of small and medium size. Consequently, Norwegian authorities should attempt to influence future FPs in this direction. 


\subsubsection{European research Council (ERC)}

The experience with the NEST programme in FP6, a bottom-up blue-sky research programme with ex-ante evaluation of proposals organised by the researcher community, provided an example and an organisational model for the creation of the European Research Council in the FP7. It is still too early to evaluate the organisational model and the research activities of ERC, which is funded by the IDEAS programme. The main share of the IDEAS budget open to competition has not yet been spent and therefore, it is rather premature to evaluate the effects of the ERCs activities. We only note that the Rietschel evaluation report of FP6 mentions that the collaborative aspect in blue-sky NEST projects is missing. This is also absent in the present activities of ERC.

Only three Norwegian participations were registered in the NEST-programme under FP6. Of 27 proposals to ERC for Advanced Investigators Grants forwarded by Norwegian research organisations four so far have been selected for funding in the IDEAS programme, three in Life Sciences and one in Physical and mathematical Sciences. Norwegian Starting grant applications have been far less successful. Hence, in total, Norwegian participation in ERC so far has been quite low and this should be a matter of national concern.

Three of the four Advanced Investigators grants went to investigators working in research groups which already receive funds from the Norwegian Centres of Excellence Scheme (SFF) of the RCN. Given the fierce competition for ERC funding we argue that the Norwegian Centres of Excellence seem to represent a competitive part of the Norwegian fundamental research activities.

In the immediate future (2010-2012), the challenge for the Norwegian universities and in particular for the SFFs and the Norwegian Centres of Innovation Excellence (SFIs), is to mobilise resources for preparing well-designed and original project proposals in the next phase of calls for grants by the ERC. Norwegian universities will probably profit considerably from paying more attention to the reputational effects stemming from ERC grants as these grants are seen as indicators measuring academic quality and scientific competitiveness worldwide. In an environment of increasing competition for students and research funds among European universities, the indirect long-term structural effects of ERC grants can be substantial.

At present there is no Norwegian national expert serving the ERC administration despite the efforts of the Norwegian authorities to support politically and financially such a position in ERC. 


\subsubsection{Research Infrastructures (RI)}

The Research Infrastructure (RI) programmes of FP6 and FP7 are probably the most conspicuous contributions of FPs to the integration process within ERA alongside Marie Curie schemes. RI funding implies that national research facilities of high quality is upgraded and made available to a large numbers of European researchers. This way they also contribute to boosting researcher mobility in Europe. Norwegian participation in the RI programme was lower than expected in FP6 (see Table 3.2).

ESFRI aims to integrate national research resources into a common, pan-European effort, but this is formally not a part of the FPs. However, FP6 - and in particular FP7 - funds the preparatory phases of such projects. By now there are some 44 ESFRI projects aiming at building new research facilities in Europe. Further, the Partnership for Advanced Computing in Europe (PRACE) is the first example of an ESFRI research facility where operational costs are directly co-funded by FP7. Thus, co-funding of a greater number of ESFRI research infrastructures is likely to occur in FP7, even more so in FP8. Currently, Norway will probably host two ESFRI-projects - SIOS and ECCSEL - and might also cofund the construction of other ESFRI research facility projects. About 200 million NOK from the Norwegian Research Fund (Forskningsfondet) are earmarked annually for the development and maintenance of national research infrastructures (scientific equipment), some of which might fund Norwegian ESFRI-commitments.

\subsubsection{European Technology Platforms (ETP), Joint Technology Initiatives (JTI), Article 169}

European Technology Platforms (ETPs) were to bring together self-organising groups of stakeholders, usually led by industry, with the aim of preparing a long-term strategic R\&D plan, to obtain the needed public and private investments and to identify relevant skill and education needs within specific technologies involving major economic or societal challenges. They would ensure synergy between public authorities, users, regulators, industry, consumers and poles of excellence viewed as places where basic research and technology are closely linked ${ }^{56}$. Although some of the ETPs received some funding through FP6, they cannot be viewed as an integral part of FP6 as such. Rather, they are key policy complements to FP6.

By the end of 2008 there were 36 ETPs, spanning a wide range of technologies. ${ }^{57}$ According to information from the RCN, 31 of the 36 ETPs involved Norwegian potential. June 2009, Directorate General for Research. EUR 23729. 
participations. Most if not all of these 31 ETPs are clearly relevant to vital sectors of the Norwegian economy including oil and gas ${ }^{58}$.

However, the recent evaluation of the European Technology Platform schemes (see Idea Consult 2008) suggest that they have not been effective so far in raising new funds or coordinating research polices at regional, national and EU levels in support of ETP activities. Further, it is almost certain that the current financial crisis worsened the prospects for a successful implementation of the strategic plans for many ETPs. It is consequently too early to assess the structural effects Norwegian participation in ETPs may have on the Norwegian industry.

Joint Technology Initiatives (JTIs) are new policy instruments introduced in FP7 with the aim of developing public-private partnerships set up at European level in order to leverage more R\&D investments from Member States, Associated Countries and industry and ultimately to boost European competitiveness. JTIs raison d'être is to play an important role in shaping the European research landscape by stimulating research investment, building critical mass by uniting fragmented efforts and accelerating the process of converting the results of European research into marketable goods and services.

A JTI is a legally established Joint Undertaking, set up on the basis of Article 171 of the EC Treaty. Each JTI includes one or more decision-making bodies, an executive director and staff. It is co-funded with means from FP7 co-operation activities; it organizes calls for proposals, oversees selection procedures and puts in place contractual arrangements for projects. The following five JTIs have been adopted so far in FP7: Innovative Medicines (IMI), Embedded Computing Systems (ARTEMIS), Clean Sky in the field of aeronautics, ENIAC (nanoelectronics), Fuel Cells \& Hydrogen (FCH). The total sum allocated to these five JTIs is €8.6 billion, part of which will be funded by FP7 but with additional substantial contributions from national and industry sources.

By March 2009 five projects with Norwegian participation have been selected out of 5 proposals in ARTEMIS and ENIAC. Given this success rate (100\%) we may assume that JTI-activities are a suitable instrument for Norwegian researchers. On the other hand, none of the interviewees from the business sector mentioned JTIs as an important or even emerging activity for their R\&D strategies.

The responsibility for generating national co-funding of Norwegian participation in JTIs is placed to that ministry closest to the thematic priorities of each JTI. The Ministry of Trade and Industry co-funds Norwegian participation in both ARTEMIS and ENIAC together with the RCN. National participation decisions in JTIs (and in Article 169 activities) seem to be taken ad hoc so far and without a clear or long-term strategic perspective. This is

58 See for example “Zero Emission Fossil Fuel Power Plants Technology Platform” with Bellona represented by Fredrik Hauge of Bellona and Statoil as members of the Advisory Council. 
understandable given the current rapid expansion of the number and complexity of publicprivate partnership R\&D activities. In the future, however, a more coherent budgetary approach and ministerial coordination for participation decisions in future public private partnerships (PPPs) will be needed. Such decisions should be based on a broader set of stakeholder consultations, including the RCN, the business sector and the researcher community and must be linked to broader strategic policy goals.

Article 169 initiatives are also public-public partnerships set up at European level. They bring together national R\&D programmes to define common objectives and to combine funding and knowledge in order to fulfil these objectives. The first two Article 169 initiatives under the FP7, EUROSTARS addressing research and development performing SMEs, and AAL, which aims to use intelligent products and provide remote services to elderly people, have been launched. Two more initiatives under Article 169 were advanced in 2008: EMPR, a European Metrology Joint Research Programme, and BONUS, a Joint Research Programme on Baltic Sea Research. The latter is still under preparation. The EDCTP (European \& Developing Countries Clinical Trials Partnership), launched in 2003 under FP6 as the first Article 169 initiative, has been evaluated and further activities remain to be decided.

By March 2009, EUROSTARS had attracted 21 proposals with Norwegian participation of which 6 have been accepted; AAL attracted 11 proposals with Norwegian participation of which 4 have been accepted.

\subsubsection{Participation of Small and Medium Enterprises (SMEs)}

EUROSTARS seems to be a popular measure among Norwegian SMEs. High participation in Article 169 initiative coincides with the high Norwegian participation rates in the Research for Benefit of SMEs programme under the FP7 and the Specific measures in support for SMEs under the FP6. Thus, SME-oriented activities in FPs seem to attract many Norwegian companies linking them to other national and European research organisations and businesses. In this respect, Teknologisk institutt (TI), Nor-Tek Teknologisenter (a branch of the PERA-group) and SINTEF play an important role in attracting Norwegian SME-firms to participate in projects lead by them. On the other hand, we observe relatively few Norwegian SME participations in the co-operation parts of the FP7 (the COOPERATION specific programme) and FP6.

Reflecting upon the structural effects of FP participation on the Norwegian SMEs, we are left with the impression that much more could be done in order to augment the economic outcomes of their participation, both by the companies themselves but also and chiefly by Innovation Norway. We return to this point in 5.4.5. 


\subsection{Prospects of Norwegian participation in FP7 and national research competitiveness}

As argued earlier, "juste retour" may be used as a yardstick to identify strengths and weaknesses of the national research system, i.e. as an indicator of revealed strengths and weaknesses within the competitive environment of the Framework Programmes. This ultimately renders possible policy actions based on rational analysis. These analyses may lead to policies for the enhancement of national research activities within research fields with "low participation” and/or reinforcing national research activities in fields with "strong" participation.

\subsubsection{Prospective of Norwegian participation in FP7}

In Kaloudis (2006) we find forecasts for the EU contribution to Norwegian participants in FP6 by priority area. This study provides also three possible scenarios for the Norwegian participation in the first four years of the FP7 (2007-2010). The forecast for the overall EU contribution to Norwegian in FP6 in Kaloudis (2006) was five per cent lower than realised, amounting to $€ 284$ million. Thus we believe it is useful to apply the same methodology for a prospective analysis of the Norwegian participation in FP7.

Using RCN data on Norwegian participation in FP7 and data on FP7 from the Second FP7 Monitoring Report and by applying more or less the same methodology as in Kaloudis (2006) we estimated an expected EU contribution to Norwegian participants after the first four years of the FP7 of $€ 353$ million. Given an error margin of five per cent the expected range of the EU contribution to Norway in the first four years is €335-370 million; that is, an 18-35 per cent increase compared to EU contribution to Norwegian participants in FP6. If one considers that in the FP7 the EC funds up to $75 \%$ of eligible costs of many types of beneficiary groups (for example research institutes and SMEs) compared to only $50 \%$ in FP6, the realised EU contribution to Norway in FP6 and the four-year estimate for FP7 cannot be compared directly. In fact, an increase of EU contribution from the FP7 of about 18 per cent (the lower range in our estimate) compared to FP6 would in reality mean a slight decrease of the real volume of the Norwegian participation in FP7 compared to FP6.

Because of these new, higher funding practices (75\%) and because of the new activities under IDEAS (consuming 15 per cent of the budget for competitive funds in FP7) as well as the introduction of new PPPs, JTIs and Article 169 initiatives, the overall volume of ordinary collaborative research projects under the Co-operation part of FP7 is about the same or even smaller than in FP6. This actually happens despite the fact that the FP7 budget is about 30 per cent larger than that of FP6. One may conclude that the competition for funds open for collaborative projects has in reality increased in FP7. Subsequently, in FP7 there is a moderate but clearly visible shift away from traditional collaborative project research and towards other types of policy intervention, in particular towards fundamental research projects led by individual research teams and towards the new ERA-structuring 
activities. For a number of reasons which we develop below, it appears that the Norwegian research system is not entirely prepared to meet these new challenges.

Table 5.3 shows estimates of EU contributions to all participants (column A) and to Norwegian researchers in FP7 (column B) in the period 2007-2008 by thematic activity. Dividing column B by column A we get the share of FP7EU contributions made to Norwegians. Shares of EU contribution in the range of 2.1-2.3 per cent correspond to the contributions from the Norwegian government to FP7 (contingent) and, thus, constitute a "juste retour" level of participation.

Table 5.3 shows that the overall Norwegian share of EU contribution in FP7 in 2007-2008 is significantly lower than a "juste retour" level. It is clearly lower than that in FP5 and slightly lower than the Norwegian share of EU contribution in FP6.

Table 5.3 FP7's overall budget, estimates of total EU contributions in retained proposals in 2007 and 2008, EU contribution to Norwegian participants in 2007 and 2008, and shares of EU contribution to Norwegian participants of overall EU contribution in FP7 in 2007 and 2008 by theme activity. Emillion.

\begin{tabular}{|c|c|c|c|c|}
\hline Theme & $\begin{array}{l}\text { FP7 Budget } \\
\text { (2007-2013) }\end{array}$ & $\begin{array}{l}\text { EU contribution to } \\
\text { all participants in } \\
2007 \text { and } 2008 . \\
\text { (Estimates) } \\
\text { (A) }\end{array}$ & $\begin{array}{l}\text { EU contribution to } \\
\text { Norwegian } \\
\text { participants in } \\
\text { FP7 in } 2007 \text { and } \\
2008 \\
\text { (B) }\end{array}$ & $\begin{array}{c}\text { Shares of } \\
\text { EU } \\
\text { contribution to } \\
\text { Norwegian } \\
\text { researchers } \\
\text { (B/A) }\end{array}$ \\
\hline HEALTH & 6100 & 1248 & 15,5 & $1,2 \%$ \\
\hline $\mathrm{BIO}$ & 1935 & 401 & 9,6 & $2,4 \%$ \\
\hline $\mathrm{ICT}$ & 9050 & 2140 & 21,7 & $1,0 \%$ \\
\hline NMP & 3475 & 1113 & 16,7 & $1,5 \%$ \\
\hline ENERGY & 2350 & 490 & 18,8 & $3,8 \%$ \\
\hline ENVIRONMENT & 1890 & 435 & 23,2 & $5,3 \%$ \\
\hline TRANSPORT/AERO & 4160 & 1153 & 14,8 & $1,3 \%$ \\
\hline $\mathrm{SSH}$ & 623 & 138 & 2,0 & $1,4 \%$ \\
\hline SPACE & 1430 & 161,5 & 5,3 & $3,3 \%$ \\
\hline SECURITY & 1400 & 304 & 6,2 & $2,0 \%$ \\
\hline ERA-NET & 70 & 63 & 1,1 & $1,8 \%$ \\
\hline IDEAS & 7510 & 868 & 6,9 & $0,8 \%$ \\
\hline PEOPLE (1) & 4750 & 950 & 8,7 & $0,1 \%$ \\
\hline $\mathrm{RI}$ & 1715 & 890,5 & 5,3 & $0,6 \%$ \\
\hline SME & 1336 & 271 & 16,6 & $6,1 \%$ \\
\hline POTENTIAL & 340 & 65 & 0,3 & $0,4 \%$ \\
\hline SIS & 330 & 58 & 3,6 & $6,1 \%$ \\
\hline INCO & 180 & 37 & 0,5 & $1,3 \%$ \\
\hline REGIONS & 126 & 22 & 0,0 & $0,0 \%$ \\
\hline Total (ex. JRC/EURATOM) & 48770 & 10808 & 176,8 & $1,6 \%$ \\
\hline
\end{tabular}

1)Estimates of EU contribution in the People programme are based on numbers of applicants as reported in the Second Monitoring report and on the share of PEOPLE-programme in the budget of FP7.

Source: EC, RCN, Second FP7 Monitoring report, estimates calculated by NIFU STEP.

The following thematic activities show a significantly higher than expected Norwegian participation: Environment, ERA-NETs (i.e. Coherent development of research policies), the SME-programme, ENERGY and Science in Society. Thus the strong Norwegian presence in Environmental and Energy research of FPs is a stable feature from FP4 to FP7. 
The following thematic activities show a significantly lower than expected Norwegian participation: IDEAS, INCO, PEOPLE, RI (Research infrastructures), HEALTH, ICT and $S S H$ (Social Sciences and humanities). REGIONS (Regions of Knowledge) and POTENTIAL (Research Potential of convergent regions) are two small thematic activities with less relevance for Norwegian participants.

The surprising aspects of this (estimated) participation pattern are the low levels of participation in SSH-programme in FP7 compared with much higher participation levels in FP6 and FP5 and the low participation in the IDEAS-programme. PEOPLE, INCO, RI, HEALTH and ICT showed low Norwegian participation levels also in previous FPs.

Norwegian participation on the NMP (Nanosciences, Nanotechnologies and Materials) in FP7 seems to be higher than in FP6 and approaches the levels of fair return. The SECURITY, which is a new area of research in the FPs and for first time introduced in FP7, mobilised a quite large number of Norwegian participations (but still below the expected "juste retour" levels).

Unless the RCN and the ministry do not increase the scale, the scope and the quality of their mobilisation policies and incentives, we expect that Norwegian participation will remain at the same low levels throughout the entire FP7. The critical programmes for the overall Norwegian participation in the FP7 are (in order): 1) IDEAS, 2) ICT, 3) HEALTH. Norwegian participation in ICT and HEALTH is further analysed in Chapter 6.

As regards the IDEAS programme, we ask whether the low participation in this programme is a reflection of weaknesses in basic Norwegian research or just a consequence of the fact that Norwegian researchers who have the potential do not generate a sufficiently large number of good project proposals. For example, it is peculiar that the SIMULA centre is not more visible in the FP arenas. The same could also be said for a number of Norwegian Centres of Excellence (SFF). Unfortunately, we did not have the required resources to investigate Norwegian spearheads of basic research such as the SFFs, approach the FP arenas and how active they are. It is, however, decisive that the RCN and the ministry prioritise this monitoring task in the immediate future.

\subsubsection{Competitiveness of the Norwegian research system in FPs}

Success rates may be used as indicators for competitiveness of the Norwegian research in the various thematic areas of FPs. The overall success rate of Norwegian proposals in FP6 was 25 per cent, well above the average for the entire FP6 (18 per cent) and higher than the overall success rates of Denmark, Finland and Sweden. Further, Norwegian success rates in proposals with Norwegian coordinators achieved a rate of success of 22 per cent. We observe more or less the same picture in the FP7 but with the low success rate in IDEAS (i.e. applications to the European Research Council) as Norway’s "weak spot” so far. 
Hence, there is nothing wrong with the overall ability of Norwegian researchers to write good proposals and to compete in the FPs. The challenge is rather to encourage, and by other means stimulate, increased activity in submitting project proposals, in particular, within ICT and HEALTH programmes. In other words, the policy analysis challenge is to understand the reasons why Norwegian researchers are reluctant to get involved in the FP research within certain research fields. Three factors seem to play an important role in this respect: 1) access to networks; 2) co-funding; 3) administrative support of high quality. The latter is discussed in 5.4.2.

\section{Quality of Networks}

Because of "the rule of the game" and the way R\&D is organized in EU FPs, the rate of success for Norwegian participants in the FPs is in reality an indicator of the success of the consortia in which they participate. EU requires that consortia should be composed of participants (i.e. researchers) from many different nations, and that the R\&D has to address issues with relevance for the European dimension and perspective set in the programmes. In the evaluation of proposals for projects, these are assessed and ranked according to their scientific merit or similar criteria in terms of the goals set in the programme, and the extent to which the project plan has the potential to fulfil EU goals. Hence, low or high rate of success in obtaining EU funding is the result of successful international collaboration from the very start. A number of factors influence this. According to informants, participants who are members of strong international academic, scientific or professional networks are more successful than those that are not.

The topic of how these international networks are constituted and maintained, how they evolve and recruit or exclude members, is of course relevant in this context, but according to informants, the elusive notion of reputation of individual researchers and organisations seem to play a significant role in how proposals are made and how consortia that forward these are composed. Ultimately, the likelihood of obtaining funding increases if the participant has a strong reputation. In turn, this is an important criteria for "membership" in a network that has the ability to put forward proposals that obtain favourable evaluations. These qualitative aspects related to the importance of networks are to some extent (indirectly) supported by the answers given to the evaluation in the surveys, as explained in Section 4.2.1. The "ability to find relevant partners" was identified as the most important factor in the application phase of the project. In Section 4.2.4, the impact of network was emphasized.

Although international networks play a crucial role in establishing consortia and for submitting proposals for funding projects in the FPs, this in turn depends on the motivation for participation. According to the responses given in the surveys (cf. Section 4.2.1), a number of apparently interrelated factors are involved in this. Of these, the highest emphasis was put on access to research networks closely followed by factors such as expertise and scientific excellence. Hence, one may observe a loop of causality. Ability to 
compete depends on "membership" in competitive international research networks. However, motivation for participation is an expectation of obtaining access to research networks - both factors seem to reinforce each other.

Table 5.4 FP6 project funding, Average percentages from different funding sources, by sector.

\begin{tabular}{|l|r|r|r|r|r|}
\hline & \multicolumn{3}{|c|}{ Participant/respondents sector } & \\
\cline { 2 - 6 } Funding source & $\begin{array}{r}\text { Research } \\
\text { Institute }\end{array}$ & $\begin{array}{r}\text { Higher Educ. } \\
\text { Institution }\end{array}$ & $\begin{array}{r}\text { Enterprise } \\
\text { Other }\end{array}$ & Total \\
\hline EU funding \% & 60,8 & 67,8 & 52,7 & 63,7 & 61,5 \\
\hline RCN Co-funding for EU projects \% & 11,5 & 2,2 & 1,5 & 5,4 & 6,7 \\
\hline National programmes/other RCN-funding \% & 3,0 & 6,5 & 1,3 & 5,0 & 3,8 \\
\hline Other Norwegian external funding \% & 4,1 & 3,5 & 2,1 & 0,2 & 3,1 \\
\hline International funding other than EU \% & 1,5 & 0,2 & 0,0 & 4,6 & 1,3 \\
\hline Budgeted funding by my & & & & & \\
organisation/institutional core funding \% & 15,0 & 17,4 & 33,7 & 16,5 & 19,0 \\
\hline Not covered/non-budgeted deficit \% & 4,0 & 2,5 & 8,8 & 8,1 & 5,0 \\
\hline Total (100\%) & 100,0 & 100,0 & 100,0 & 100,0 & 100,0 \\
N (number of respondents) & 239 & 129 & 92 & 65 & 525 \\
\hline
\end{tabular}

Source: Survey to Norwegian participants in FP6. Only replies from respondents whose answers sum up to 100 per cent are included in the survey.

\section{Co-funding of costs of participation}

In addition to networks, ability to compete is also related to funding, or more specifically, having financial means for participation in the proposal process, and more importantly, obtaining funding for the eligible project costs that are not funded by the EU. As shown earlier, the median proposal cost for Norwegian participants was about one month of work and about NOK 10,000 in direct costs. Eighty-six per cent of these costs were covered by the organisation of the applicant; only 10 per cent came from the RCN. ${ }^{59}$

Two fundamental issues are illustrated in Table 5.4. First, on average only seven per cent of overall eligible costs are co-funded by national R\&D programmes and additional three per cent by other national funding sources. These show how poorly national research policy measures support participation in the FPs. Second, several participants reported that their EU projects turned to be "economic disasters". It is remarkable that, on average, nine per cent of the overall costs for the participating firms were not-covered/non-budgeted. This underlines the severity of obstacles to participation (in particular for firms) presented by the administrative and financial routines of FPs.

59 Figures for FP6. The FP7 survey indicates a reduction of the costs covered by the organisation of the applicant (75 per cent) and that on average 20 per cent came from RCN. 


\subsection{Strategic aspects of the Norwegian participation in FPs}

\subsubsection{Additionality}

In an evaluation of public research policy measures, the concept of additionality is often used to discuss and analyze whether the economic support of R\&D contributes to the promotion of goals set for a national research policy or strategy. The basic idea of additionality is counterfactual, i.e. the question asked is: "Would the type of R\&D supported by the public (e.g. EU) have been undertaken if there had been no public support?” The underlying assumption is that public support of R\&D only has a legitimate role in so far as this is a countermeasure for market failure or structural imperfections. Hence, the answer is: "If for some reason R\&D is not done, even if this is in the interests of society and stakeholders, then this is a case for public support of $\mathrm{R} \& \mathrm{D}$ because a market or structural failure represents a barrier for creating the potential benefits of R\&D.” In the use of the concept of additionality, this often is further distinguished in three levels:

- Input additionality, i.e. if public support stimulates actors to increase their R\&D effort, e.g. if 1 NOK of R\&D support from public sources stimulates the firm or the organisation to also spends 1 NOK of their own for the same purpose. There is no additionality if public R\&D support is used as a substitute for the firm's own R\&D spending (potentially increasing the firm's net profit).

- Output additionality, i.e. if public support has contributed to increase the R\&D output of the firm or the organisation such as patents, scientific articles, prototypes, business plans, etc. - and in the absence of this public support these output would not have been made.

- Behavioural additionality, if public support of R\&D stimulates actors to change the way they think and plan R\&D permanently, so that they become more innovation and R\&D-oriented in their way of work, or in the case of EU FPs, that they "think Europe” and collaboration with partners in EU in terms of their R\&D strategy.

In evaluating Norway's participation in FP6, we asked participants for their opinion on this topic. Table 5.5 shows that 62.5 per cent of the participants fully agree to the statement that "Our organisation would not have participated in this project or a similar project without the EU contribution" - and only 5.5 per cent fully disagree. Hence, according to the respondents' perception, the additionality of EU FP6 may be considered as significant. Table 5.6 shows that there is some variety at the level of programmes in terms of this perception. In general, this does not contradict the observation that participants consider that additionality has been made by participation in the EU FP. The evidence from the bibliometric analyses (cf. Section 4.3.3.on long-term effects and Appendix 5) supports this perception in at least two dimensions. The volume of publications co-authored with Europeans has increased (output additionality) significantly during Norway's participation in the EU FP. Although there is a time-lag for scientific publications, this pattern of increase in output has been maintained throughout EU FP6 and FP7. Secondly, this reflects the fact that the Norwegian R\&D community has reoriented itself towards Europe, and 
which may also be considered as evidence of behavioural additionality. In interviews with decision-makers and managers in the Norwegian R\&D community this aspect was emphasized: Participation in the EU FP has changed their way of thinking, planning and doing R\&D. This is perhaps most significant for universities and other higher education institutions because participation in EU FPs has stimulated them to reorganize and "reengineer" their way of doing research. This change is not only due to requirements of participation in EU FPs, but also at national level and other types of international R\&D collaboration. R\&D is increasingly undertaken in large consortia; there has been a shift in R\&D away from "one man shows” (e.g. the professor and his assistant or PhD-student) to participation in larger, inter-organisational and international R\&D projects and programmes. In this picture, the findings from the survey on Norway's participation in EU FP6 and other evidence suggest that the additionality of FP project has been significant.

Table 5.5 The importance of the EU financial contribution and the international collaboration. Participants' assessments. Per cent.

\begin{tabular}{|l|r|r|r|r|r|r|}
\hline Additionality: & $\begin{array}{l}\text { Fully } \\
\text { disagree }\end{array}$ & $\begin{array}{l}\text { Partly } \\
\text { disagree }\end{array}$ & Uncertain & $\begin{array}{l}\text { Partly } \\
\text { agree }\end{array}$ & $\begin{array}{l}\text { Fully } \\
\text { agree }\end{array}$ & $\mathrm{N}$ \\
\hline $\begin{array}{l}\text { a) Our organisation would not have participated in } \\
\text { this project or a similar project without the EU's } \\
\text { financial contribution }\end{array}$ & 5,5 & 4,9 & 9,4 & 17,8 & 62,5 & 512 \\
\hline $\begin{array}{l}\text { b) We could have carried out such a project even } \\
\text { without the EU's financial contribution }\end{array}$ & 58,4 & 17,2 & 12,1 & 8,0 & 4,3 & 512 \\
\hline $\begin{array}{l}\text { c) We could have achieved the same } \\
\text { scientific/technological results without the } \\
\text { international collaboration involved in this project }\end{array}$ & & & & & & \\
\hline
\end{tabular}

Source: FP6 survey 
The importance of the EU financial contribution and the international collaboration. Participants' assessments by FP7 priority/programme. Per cent.

\begin{tabular}{|c|c|c|c|c|c|c|}
\hline $\begin{array}{l}\text { Our organisation would not have } \\
\text { participated in this project or a } \\
\text { similar project without the EU's } \\
\text { financial contribution }\end{array}$ & $\begin{array}{l}\text { Fully } \\
\text { disagree }\end{array}$ & $\begin{array}{l}\text { Partly } \\
\text { disagree }\end{array}$ & Uncertain & $\begin{array}{l}\text { Partly } \\
\text { agree }\end{array}$ & $\begin{array}{l}\text { Fully } \\
\text { agree }\end{array}$ & $\mathrm{N}$ \\
\hline $\begin{array}{l}\text { 1. Life sciences, genomics and } \\
\text { biotechnology for health }\end{array}$ & 4,3 & 13,0 & 21,7 & 26,1 & 34,8 & 23 \\
\hline 2. Information society technologies & 2,6 & 6,6 & 9,2 & 13,2 & 68,4 & 76 \\
\hline $\begin{array}{l}\text { 3. Nanotechnologies and } \\
\text { nanosciences }\end{array}$ & & 5,3 & 5,3 & 31,6 & 57,9 & 19 \\
\hline 5. Food quality and safety & 4,7 & 7,0 & 9,3 & 25,6 & 53,5 & 43 \\
\hline $\begin{array}{l}\text { 6. Sustainable development, global } \\
\text { change and ecosystems }\end{array}$ & 5,2 & 2,6 & 4,3 & 20,0 & 67,8 & 115 \\
\hline $\begin{array}{l}\text { 7. Citizens and governance in a } \\
\text { knowledge-based society }\end{array}$ & 13,9 & 8,3 & 8,3 & 19,4 & 50,0 & 36 \\
\hline $\begin{array}{l}\text { Horizontal research activities } \\
\text { involving SMEs }\end{array}$ & 4,8 & 4,8 & 9,5 & 11,9 & 69,0 & 42 \\
\hline Human resources and mobility & 2,5 & 5,0 & 15,0 & 17,5 & 60,0 & 40 \\
\hline $\begin{array}{l}\text { Policy support and anticipating } \\
\text { scientific and technological needs }\end{array}$ & 7,8 & 3,9 & 9,8 & 19,6 & 58,8 & 51 \\
\hline Research and innovation & 13,3 & & & 6,7 & 80,0 & 15 \\
\hline $\begin{array}{l}\text { Support for the coordination of } \\
\text { activities }\end{array}$ & 5,3 & & 21,1 & 10,5 & 63,2 & 19 \\
\hline $\begin{array}{l}\text { Remaining priorities ( } 5 \text { priorities with } \\
\text { less than } 15 \text { cases each) }\end{array}$ & 6,1 & 3,0 & 12,1 & 9,1 & 69,7 & 33 \\
\hline Total & 5,5 & 4,9 & 9,4 & 17,8 & 62,5 & 512 \\
\hline
\end{tabular}

Source: FP6 survey

\subsubsection{Strengthening national administrative infrastructures}

Simplification processes are progressing slowly in the EC. ${ }^{60}$ The evaluation report of FP6 (Rietschel Report) assesses that the protracted and bureaucratic nature of FP administrative procedures constitute a "powerful disincentive to apply”. In support of this statement, there is solid evidence from the Norwegian case that an increasing number of financial audits, increased time consumed in plain project administration and unreasonably high administrative burdens for the participating organisations, is a serious problem. This is probably the primary cause of increased reluctance by the business sector to participate than all the other hindrances taken together. For example, one large Norwegian firm reported that it allocates 1.5 man-years dedicated entirely to administrative support of the firm's FP7 projects. This firm was also forced to adopt separate internal financial routines for its EU projects, different from all other national R\&D-projects, due to consistently late payments from the EC.

The situation is worse for many SMEs and for many small or medium size research institutes, in particular those having a low number of FP participations. These simply cannot afford to recruit project administrators with international experience and they find

60 See European Commission 2009. Second FP7 Monitoring report: Monitoring report 2008. 1 October 2009, in particular Section 3.2. 
themselves having to cope as best they can with what administrative infrastructures they may have (if they have). Right or wrong, "rumours” or own-experiences with never-ending administrative and financial processes are clearly disincentives to apply for funds, in particular for the following two groups: a) Research groups receiving generous R\&D funds from national sources; and b) Research groups with little or no international $R \& D$ collaboration experience.

In FP7 the situation has become even more difficult for many Norwegian R\&D organisations. As mentioned earlier, the financial rules of participation may vary between and even within instruments, with some JTIs and CSAs as examples. An even more serious problem is the uncertainty and confusion among many Norwegian research institutes, including the largest one, as to how to calculate their personnel costs in FP projects. In practice this uncertainty means that many of these research institutes participate in the FP7 without knowing what the precise budgetary consequences of their participation are.

Though the Directorate General for Research it is not the only responsible in the EC for this, there is no doubt that ultimately this little flattering situation is becoming a serious threat for the FPs and ultimately for the ERA project. The moment a critical mass of European researchers - or their research organisations - decides that it has had enough with the bureaucratic procedures of FPs ,that will be the end of Framework Programmes as we know them. Fortunately, we are far from this situation, but gloomy warnings are already there.

Be that as it may, the important question in this context is what Norwegian actors can do unilaterally for minimising the damages administration demands may cause on the volume and quality of the Norwegian participation in the FP7.

On this point, the EU office of the RCN is surprisingly reluctant and inactive. Compared to the generous and smoothly functioning support measures by the RCN for writing FP proposals, there is little done in guiding and advising research organisations in administrative matters. Admittedly, it is not possible for RCN to provide assistance to all administrative issues that Norwegian participants struggle with, but it does little in providing advice as to what type administrative skills a participating organisation needs to have. It does little in disseminating information of good examples and good problemsolving (for example, how to prepare for an external ex-post audit). It does little to stimulate inter-organisational collaboration aiming at building common administrative solutions (even common facilities) so that a specialised and smaller number of administrative staff can serve a (much) larger pool of EU projects from different research organisations.

Our main argument here is that national authorities ought to pay attention to the quality and effectiveness of the national research administrative infrastructures as a means to 
remove barriers and ultimately to augment the volume of Norwegian participation. For example, it is not possible to successfully co-ordinate an FP project unless one has solid assistance of an experienced administration staff to fall back on. There are a number of firms and research institutes which decline the coordinator role in FP projects because of the heavy administration responsibilities this would imply.

Therefore, we suggest that the RCN starts to work more strategically along this direction. For example, it could organise consultations with Norwegian research organisations, both those with large participation experience and those with limited or no participation experience, in order to assess how costly the administrative aspects of participation really are and to what extent they constitute a hampering factor for participation. It could also organise targeted lessons learnt seminars with the aim of building administrative capacities associated with Norwegian participation in FPs. In doing this, large companies should also be included.

Finally, the RCN alone cannot do much. The Norwegian research organisations ought to recognise the strategic importance of having an experienced administrative staff in the competition for FP funds (and not only here).

\subsubsection{Intellectual property rights (IPR)}

Intellectual property rights (IPR) is important in terms of apropriability of results of knowledge production and research. However, in the context of EU FPs, this is generally not an important issue. There are a number of reasons for this. Most fundamental, the nature of R\&D in FPs is basically generic; the terms pre-competitive and pre-normative are often used to emphasize this aspect, which implies that the topic of property rights to the knowledge and outcomes of the R\&D is not so relevant. This aspect is reflected in the responses made in the survey, cf. Table 5.7, where a large majority of the respondents (60 per cent) said that IPR-protection does not apply. The reason for this is that results from the projects are made public or because these are published, which supports the interpretation that for this type of knowledge production, IPR is not an issue.

However, as shown in table 5.6, 40 per cent of the respondents said that IPR is enacted, either at the level of the participants' mother organisations (11.4 per cent), or at the level of the consortia in which they participate (31.1 per cent). Furthermore, 10.8 per cent of the respondents answered that patenting was used as an IPR strategy. However, secrecy (20.7 per cent) was more common. 
Table 5.7 Protection of intellectual rights from EU project. Per cent.

\begin{tabular}{|c|c|c|}
\hline $\begin{array}{l}\text { Please state if the intellectual rights stemming from } \\
\text { the results of the EU project are protected }\end{array}$ & Yes & $\mathbf{N}$ \\
\hline Protection does not apply* & 59,5 & 511 \\
\hline Project results are protected at the consortium level ${ }^{\star \star}$ & 31,1 & 511 \\
\hline Project results from my organisation are protected ${ }^{\star \star}$ & 11,4 & 511 \\
\hline \multicolumn{3}{|l|}{ **If 'protected', then how? } \\
\hline Patent & 10,8 & 511 \\
\hline Secrecy & 20,7 & 511 \\
\hline Other (Trademarks, copyrights, etc,) & 11,5 & 511 \\
\hline \multicolumn{3}{|l|}{ *If protection does not apply, why? } \\
\hline Too early & 7,0 & 511 \\
\hline Cannot be protected & 15,3 & 511 \\
\hline More important that results are made & & \\
\hline known/published & 45,0 & 511 \\
\hline
\end{tabular}

In interviews with R\&D stakeholders, the topic of IPR, although recognized as important, is not considered a risk, barrier or source of conflict in the participation. In general, IPR is not considered an item of importance in the R\&D strategy of the organisation in their participation in FPs; IPR is seen as a contractual or legal issue that needs professional management attention, on a par with other legal aspects related to contracts. Hence, coordinators of technology or life science-oriented R\&D projects bring in and use IPR experts at various stages of a project. However, the initial consortium agreement is essential. This, according to an informant, is also the most difficult part because of the size of the consortia: a large number of participants (partners) with sometimes divergent interests make agreement on ownership of future ("Foreground", i.e. unknown) results difficult. In this context, EU standard contract template covering IPR is considered rigid because neither of the two options are able to serve the interests of all participants.

Most of the large Norwegian participating organisations in the EU FP have access to inhouse expertise on IPR. At universities, this may be the technology transfer office (TTO) or an entity in the university's administration. For these, according to informants, if IPR becomes an issue, they are capable of attending to these challenges. Conversely, IPRs issues are more demanding for SMEs. The innovation agency, Innovation Norway, funds a number of activities aiming at the strengthening of IPR skills among Norwegian SMEs. We were not able to clarify whether some of these IPR activities addressed the issue of IPRs in international collaboration projects, in particular FP projects.

\subsubsection{National absorptive capacity}

The concept of absorptive capacity points to an nation's ability to systematically utilize, advance and apply its knowledge creation activities, such as R\&D, in its production of goods and services. For an entire nation or an economic sector, measuring "absorptive capacity” is difficult. In this section, we assess national absorptive capacity related to national participation in FPs. In this, we apply evidence extracted from our surveys, key interviews and desk research. Our main conclusion is that there is a clear scope for policies to improve the absorptive capacity of participating research organisations and through 
them to further increase the national absorptive capacity of national R\&D-activities in general.

In the FP6 survey we asked participants about topics relevant for the absorptive capacity issue, such as, “Do you expect spin-offs from your FP6 project?”. As shown in Table 5.8, the categories "improved services and products to end-users" and "increase in European competitiveness" were given highest scores in terms of expected spin-off effects from participation in FP6. In contrast, the expectations were lower in terms of commercial potential ("transfer of knowledge/commercialisation via Technology Transfer Office"), and even lower in terms of "transfer of technology to Norwegian firms that had not participated in the EU project”.

Table $5.8 \quad$ Expected spin off effects from the FP6 project. Per cent.

\begin{tabular}{|c|c|c|c|}
\hline Do you expect that this EU project will have spin off effects such as...? & \#Yes & \%Yes* & $\mathbf{N}$ \\
\hline $\begin{array}{l}\text { a) Transfer of knowledge/commercialisation via Technology Transfer Office in own } \\
\text { organisation }\end{array}$ & 98 & 16,1 & 610 \\
\hline b) Transfer of knowledge to Norwegian firms not participating in the EU project & 155 & 25,4 & 610 \\
\hline c) Transfer of technology to Norwegian firms not participating in the EU project & 79 & 13,0 & 610 \\
\hline d) Improved services and products for the end-user & 207 & 33,9 & 610 \\
\hline f) Increased competitiveness in Norway & 196 & 32,1 & 610 \\
\hline g) Increased European competitiveness & 261 & 42,8 & 610 \\
\hline
\end{tabular}

Source: Survey to Norwegian participants in FP6.

In terms of expected impacts, the respondents placed high scores on the category "policy development” and “environment/climate” as positive impacts for recipients of their research, as shown in Table 5.9.

Table 5.9 The project's expected impact sector/area. Per cent.

\begin{tabular}{|l|r|r|}
\hline $\begin{array}{l}\text { Do you expect that this EU project will } \\
\text { have a positive impact on one or more of } \\
\text { the following? }\end{array}$ & \#Yes & $\begin{array}{r}\text { Per cent of } \\
\text { respondents }\end{array}$ \\
\hline a) Laws, regulations, standards & 162 & 26,5 \\
\hline b) Policy development & 231 & 37,8 \\
\hline c) Environment/Climate & 211 & 34,5 \\
\hline d Aid/third world development & 47 & 7,7 \\
\hline e) Improved use of resources and energy & 143 & 23,4 \\
\hline f) Transport & 79 & 12,9 \\
\hline g) Health & 135 & 22,1 \\
\hline h) Food safety and/or food security & 87 & 14,2 \\
\hline i) Marine/maritime sector & 126 & 20,6 \\
\hline Total & *461 & (N) \\
\hline $\begin{array}{l}\text { *Number of respondents who answered yes to at least one of the questions. } \\
\text { Source: Survey to Norwegian participants in FP6. }\end{array}$ &
\end{tabular}

A fundamental aspect of national absorptive capacities is the development of organisational skills and expertise. Thus, how participation in FP6 contributed to that is a 
pertinent issue. In the survey, question related to this topic was posed, as already presented in Section 4.1. About 18 per cent of the Norwegian participants were Ph.D. students. The share of Ph.D. students was highest from higher education institutions, but also high for research institutes. The implication of this is that many (presumably) young persons are trained in international collaboration in advanced research projects. Furthermore, in FP6, 12 per cent of the Norwegians participations were coordinators (i.e. the Norwegian partner coordinated the project), ${ }^{61}$ and about 60 per cent had leadership responsibilities (for example being in charge of a work package). ${ }^{62}$ Apart from the status and influence that a leadership role carries, a coordinator is a central node in a project. Being a coordinator (or work-package leader) facilitates access and enables deeper insight to all aspects of an R\&D-project. It thus facilitates the exploitation of the results by the coordinating organisation. The coordinator is also normally closer to stakeholders. Hence, the combination of Ph.D. student participation and the central role many Norwegian participants had in their FP6 projects may be interpreted as indications of high absorptive potential. The interesting policy question is whether this potential is actually materialised in terms of innovative capacities and/or enhanced economic competitiveness by Norwegians, in particular by Norwegian firms.

According to diffusion theory (Rogers, 1996), diffusion of new knowledge and innovation is most efficient and rapid in social networks, particularly among peers. For knowledge production from research, this type of diffusion is important for groups of potential users (e.g. firms) that have a weak absorptive capacity because their links with the research community is weak and because they do not have the type of skills needed for absorption. Yet the potential benefits for them in acquiring new knowledge may be high.

In the context of FPs, a relevant recipient group is SMEs. The national innovation agency, Innovation Norway, runs a number of programmes and educational activities designed to strengthen Norwegian SMEs. Evidence from key interviews suggests that business participation in FPs, in particular SME participation, receives little or no attention in ongoing national innovation policy measures. This is highly surprising as one would expect that those SMEs which participate in FPs are the spearheads of the Norwegian innovation system in many advanced and traditional technology sectors. Either Innovation Norway does not consider this set of business as a relevant target group (they are already advanced and internationalised and therefore they do not need any further support), or it fails to see that assisting these companies to reap the economic benefits from their participation will strengthen the overall national absorptive capacity. This gap of policy coherence between national innovation policy measures and national business participation in FPs is even more serious given that Norway is highly successful in mobilising SMEs to

61 Including only those who answered to the survey, shows 20 per cent coordinators as this respondent group has a higher response rate.

6260 per cent might be somewhat overestimated as participants without leadership responsibilities are likely to have a lower response rate. 
participate in FPs support for SME-measures. Therefore, it is crucial to get a deeper understanding of what innovation opportunities there are embedded in national SME participations and think how ongoing or new policy measures could best assist the realisation of this potential. If, after a thorough examination of the quality of Norwegian SME -participation, the conclusion is that there is little to gain by supporting these firms (or these projects) nationally financially or otherwise, this too is vital information for policy-makers in Norway ${ }^{63}$ and in Brussels.

Our key point here is that one cannot expect from the FPs alone to unilaterally assume the responsibility for the economic utilisation of EU research. This should be mainly the responsibility of the participating organisations (TTOs in universities and research institutes and companies) and of the national innovation agencies which should do everything they can to develop appropriate down-stream policy measures to reap national benefits from participations linked to their countries.

As a final comment, Innovation Norway is also the responsible agency for the Norwegian participation in the Competitiveness and Innovation Framework Programme (CIP). There are clear synergies between national participation in the FPs and CIP. These synergies must be identified and integrated in an overall national innovation strategy where participation in FP and CIP is an integral part of national innovation policies and not separate worlds.

\subsection{Chapter conclusions}

From the analysis above we conclude the following:

1. The potential value of the Norwegian participation in FPs is illustrated by the total eligible costs of all FP projects where Norwegian researchers participate - and which may be considered as the value of developing a common good for Europe. In FP6 the total eligible costs of projects with Norwegian participation amounted to 40 billion NOK.

2. In particular, SME participation in FPs does not get much attention in national innovation policy measures, in spite of the important policy goal of internationalisation of SMEs. Innovation Norway and the Division for Innovation in the RCN clearly have a policy responsibility in this respect, in addition to Ministry of Trade and Industry and Ministry of Education and Research.

3. The thematic relevance of the FPs for the Norwegian research system is intact. All national thematic priorities but one (as defined in several White papers on

63 In particular, for the Norwegian part of the European Enterprise Network (EEN) coordinated by Innovation Norway and the EU-office at the RCN. Upstream activities, that is, activities to enhance mobilization for national participation in FPs are more coherent and better co-ordinated between EEN, Innovation Norway and RCN than downstream activities (that is, support measures for exploitation of results from FP participation). 
Norwegian research) are directly addressed by large thematic programmes in the FPs.

4. With the IDEAS programme in the FP7 and with all new ERA activities (ERANETs, ESFRIs, JTIs, ETPs etc.) the relevance of the FPs is only increasing and the potential long-term structural effects of these activities on the national research system will be large.

5. It is of paramount importance to adopt a robust and coherent research policy for the overall national participation in all these new areas of ERA-activities, where decisions on future commitments should be part of a well-designed strategic plan for all national international commitments (not only EU), and reflecting national strengths and national policy priorities. Participation in the ERA should not be the result of a series of isolated ad hoc responses, though ad hoc decisions will not be easy to avoid entirely. Such a strategic approach will demand a higher degree of policy coordination between responsible ministries on the one hand and between the Ministry of Education and Research and the RCN on the other. The RCN should strengthen its role as a strategic advisory body. It should prepare analytical notes with up-to-date information on a regular basis advising the Ministry of Education and Research on possible future options and policy alternatives. The Counsellor of Research in the Norway Mission to the EU and the new Office of Research in Brussels are already contributing to such activities. The Ministry should concentrate more on the national decision-making processes and on the coordination of activities between the responsible ministries and on overall decision-making processes.

6. Although the potential value of Norwegian FP projects is large, the FPs as such constitutes only a marginal source of funding in all R\&D performing sectors in Norway. This means that the Norwegian research system can afford to increase its exposure to FP research considerably in the future.

7. Heavy administrative and financial practices constitute a critical barrier for participation. Researchers need to have the support of experienced and effective administrative staff, especially if they are leading FP projects. We believe that administrative staff with good knowledge of the FPs is a scarce resource in the Norwegian research system. We also believe that this scarcity is not recognised as a problem either by Norwegian policy makers or by the participating organisations themselves. On this point, the RCN has a number of policy options for alleviating and improving the quality of administrative support in the Norwegian participating organisations (see 5.4.2).

8. Overall national participation in the FP7 so far is relatively lower than national participation in FP5 and slightly lower than FP6. The following thematic activities show a significantly high Norwegian participation in the first two years of FP7: Environment, ERA-NETs (i.e. Coherent development of research policies), the SME-programme, ENERGY and Science in Society. Thus the strong Norwegian presence in Environmental and Energy research of FPs is a stable feature from FP4- 
FP7. The following thematic activities show a low Norwegian participation:

IDEAS, INCO, PEOPLE, RI (Research infrastructures), HEALTH, ICT and SSH (Social Sciences and humanities).

9. New policy approaches are needed for increasing national participation in IDEAS, ICT and HEALTH thematic programmes. Regarding IDEAS, the RCN should assess whether Norwegian Centres of Excellence and other relevant Norwegian research groups in basic research are sufficiently responsive to calls for proposals from this programme. 


\section{$6 \quad$ In-depth analysis of Norway's participation in four important thematic priorities in EU Cooperation}

As shown in chapter 5, in the success rates and other indicators, the performance of Norway has been uneven both in FP6 and FP7, raising a number of questions as to why. Does this unevenness reflect poor quality of research in relevant Norwegian research communities, specifically Norway's comparatively low rate of participation in some thematic areas? Does it reflect a mismatch of research interests at the level of researchers and their specialized fields of interests? Or, does it reflect the fact that these communities are more interested in international research collaboration elsewhere outside the EU, for example with countries such as the USA, Japan or China? Or does this reflect general low priority of R\&D within their organisation? Are there structural factors that may explain patterns of participation such as a mismatch between research agendas in Norwegian research institutions with those of the EU FP? Although this topic of unevenness may raise a number of questions, what is important in the context of the evaluation is to provide explanations that may be converted into strategic measures and interventions that are more effective, if there is reason to believe that such potential exists.

In the terms of reference for this evaluation, looking into these questions employing an indepth analysis of Norway's participation has been specified. In the following, the evaluation will present analyses of Norway's participation in four thematic areas:

1. Health in FP7 and its predecessor in FP6: Life sciences, Genomics and Biotechnology for Health (LIFE),

2. ICT - Information and communication technologies in FP7 and its predecessor in FP6: Information Society Technologies (IST),

3. Nanoscience, nanotechnologies, materials and new production technologies in FP7, and its predecessor in FP6: Nanosciences, Materials, New Processes (NMP),

4. Environment (including climate change) in FP7 and its predecessor in FP6: Sustainable Development, Global Change and Ecosystems (Only GLOBAL) 
Participants' Norwegian participation and success rates in four thematic areas.

\begin{tabular}{|c|c|c|c|c|}
\hline Health & \multicolumn{3}{|c|}{ Success rate FP7 (per cent) } & Environment \\
\hline Norway & 20 & 13 & 25 & 24 \\
\hline EU-average & 18 & 15 & 11 & 14 \\
\hline \multicolumn{5}{|c|}{ Total Norwegian participations and major institutions (number of participations in parenthesis) } \\
\hline & Health & ICT & Nano & Environment \\
\hline \multirow[t]{15}{*}{ FP6 } & Total 55 & Total 176 & Total 56 & Total 126 \\
\hline & UiO(11), & SINTEF(27), & SINTEF(17), & UiO(18), \\
\hline & RRHF(11), & Telenor(23), & $\operatorname{NTNU}(7)$ & NILU(12), \\
\hline & $\operatorname{UiB}(9)$ & $\mathrm{UiO}(17)$ & Statoil(3) & NIVA(8), \\
\hline & NTNU(4), & NTNU(10), & & UiT(7), \\
\hline & NIPH(3) & FAST(5), & & UiB(7), \\
\hline & & Q-Free(4), & & NERSC(7), \\
\hline & & NERA(4), & & MET.no(7), \\
\hline & & SensoNor(3), & & NTNU(6), \\
\hline & & Computas(3), & & CICERO(6), \\
\hline & & $\mathrm{RCN}(3)$ & & $\operatorname{IMR}(6)$ \\
\hline & & NERSC(3) & & NPI(5), \\
\hline & & & & NGI(5), \\
\hline & & & & SWECO(4), \\
\hline & & & & $\operatorname{UMB}(3)$ \\
\hline \multirow[t]{12}{*}{ FP7 } & Total 34 & Total 50 & Total 41 & Total 64 \\
\hline & UiB (8), & SINTEF (15), & SINTEF(14), & NILU(9), \\
\hline & $\mathrm{UiO}(4)$ & NTNU(3), & DNV(3), & $\mathrm{UiB}(6)$ \\
\hline & NIPH(3), & SensoNor(3), & RCN(3), & IMR(5), \\
\hline & RRHF(3) & Telenor(3) & & NINA(5), \\
\hline & & & & $\mathrm{UiO}(5)$ \\
\hline & & & & UiT(4), \\
\hline & & & & Bioforsk(3), \\
\hline & & & & NERSC(3), \\
\hline & & & & $\operatorname{NIVA(3),~}$ \\
\hline & & & & SINTEF(3), \\
\hline & & & & NTNU(3) \\
\hline
\end{tabular}

As shown in Table 6.1, Nano has the highest rate of success in Norwegian participation in FP7 as measured by the distance from the EU average, closely followed by Environment. At the other end of the scale, Norway's performance in ICT, as measured by the rate of success so far in FP7, is somewhat lower than the EU average. This was also the case in FP6 with the IST thematic priority. More significant, the level of participation seems to have decreased, possibly plausibly because of a higher rate of rejection of applications with Norwegian participations. However, because ICT/IST in terms of budget and activity is the largest thematic priority in FP6 and FP7, this apparent decline may have contributed to an increase in the "deficit" in the funding balance between EU and Norway. As will be shown, the rate of success in Health is higher in FP7 compared to its predecessor in FP6 (Life), and is now above the EU average. However, key informants believe that in this thematic priority there is a potential for increasing both the level of participation - and, hopefully, the rate of success.

\subsection{The approach of the in-depth study}

The four topics of the in-depth study have all been given high priority in the national research policy and strategy. They have also corresponding topics in the thematic priorities 
of FP6 and FP7, i.e. there is a considerable overlap and commonality in terms of priority and research questions. In a strategic perspective, one could expect, given the high priority of these topics in the national research policy and strategy and combined with their high degree of commonality with their counterparts in the FPs, that this would be reflected in high effects as measured by a high level of participation in the FPs for a number of reasons. But as indicated in Table 6.1, this is not the case. The purpose of the in-depth study is to probe into this so as to provide explanations that may be used for designing or adjusting strategic measures and instruments. In this, the focus will be set on the Research Council of Norway because this agency has a number of important strategic roles and responsibilities in Norwegian R\&D, and, specifically, for Norway's participation in EU FPs.

In 2004, the Research Council of Norway reorganized itself and established the Division for Strategic Priorities in order to focus on national research priorities and in order to respond to explicit policy signals in White Papers on research policy, as explained in Chapter 2. In this new entity, the RCN established a special instrument called "Large-scale Programmes” 64 in order to serve these policy goals. The purpose of this was to concentrate research funding and strategy specifically on thematic areas that had high priority in the national research policy in order to "..deal with national research policy priorities and ...build long-term knowledge aimed at encouraging innovation and enhance value creation, as well as to help find solutions to important challenges facing society”. The programmes were:

- Functional Genomics (FUGE) - which may be considered as complementary to some of the activities in LIFE and its successor Health

- Aquaculture - An Industry in Growth (HAVBRUK) - which may be considered as complementary to some of the activities in Food Quality and Safety in FP6 and Food, agriculture and fisheries, and biotechnology in FP7

- Nanotechnology and New Materials (NANOMAT) - which may be considered as a counterpart to most of the activities in Nanotechnologies and nanosciences, knowledge-based multifuncitional materials, new production processes and devices of FP6 and Nanosciences, nanotechnologies materials and new production technologies in FP7,

- Climate Change and its Impacts in Norway (NORKLIMA) - relevant to Norway's participation in Environment and its predecessor in FP6

- Optimal Management of Petroleum Resources (PETROMAKS), which does not have a counterpart as a thematic area in FP, although some of the projects in PETROMAKS have participation in FPs.

64 Cf. "SATS på forandring - Midtveisevaluering av Store programmer”, (Evaluation report in Norwegian) published by the Research Council of Norway in March 2009. 
- Clean Energy for Future (RENERGI) - relevant for Norway's participation in Environment and its predecessor in FP6

- Core Competence and Growth in ICT (VERDIKT) - which corresponds to IST in FP6 and ICT in FP7.

Many of these programmes are complementary, almost identical in terms of topics with many of the same thematic priorities in FPs. For this purpose, the evaluation examined the relationship between the four thematic priorities specified for the in-depth analysis in the terms of reference and their national counterparts in the Research Council of Norway's "Large-scale programmes". Although the research done in these programs do not cover all R\&D within these fields, they have nevertheless been established in order to concentrate and boost R\&D which has high national priority. Because of their central role in Norwegian R\&D policy and strategy, the evaluation decided to investigate the extent to which these national priorities interact with Norway's participation in FPs - and to what extent these are able to create the synergies and other benefits that are expected in Norway's internationalisation of its R\&D. This approach may be graphically illustrated (Figure 6.1). One important source of information in this context has been the report from the evaluation of "Large-scale programmes" as a strategy instrument and measure published in 2009, together with the material this was based on. Using this as a starting point, the evaluation included a series of interviews of key informants relevant for providing insight and information for the in-depth study of the relationship between these important national research programmes and their counterparts in FPs. In addition to this, desk research of documents relevant for this study was undertaken.

In 2009, in a mid-term evaluation of Large-scale Programmes, the report suggests that the "...full potential of this instrument has not been achieved...due to the relatively complex and partly conflicting overall goals...”. More specifically and relevant for this evaluation, the report observes that although the programme committees, in their terms of reference, were instructed to make international research collaboration high priority in their decisions, "Clear strategies, such as coordination with EU Framework Programmes, seem to be lacking”. ${ }^{65}$ With some notable exceptions that contradict this, the evaluation of Norway's participation in FPs gives support to this as will be shown in the analyses of thematic areas presented below. By analyzing these four thematic priorities one may obtain insights that may answer some of the questions asked initially in this chapter on why the Norwegian participation is EU FPs is uneven.

65 Cf. "SATS på forandring - Midtveisevaluering av Store programmer”, Norges forskningsråd, mars 2009, p. 39, translated from Norwegian by the author. 


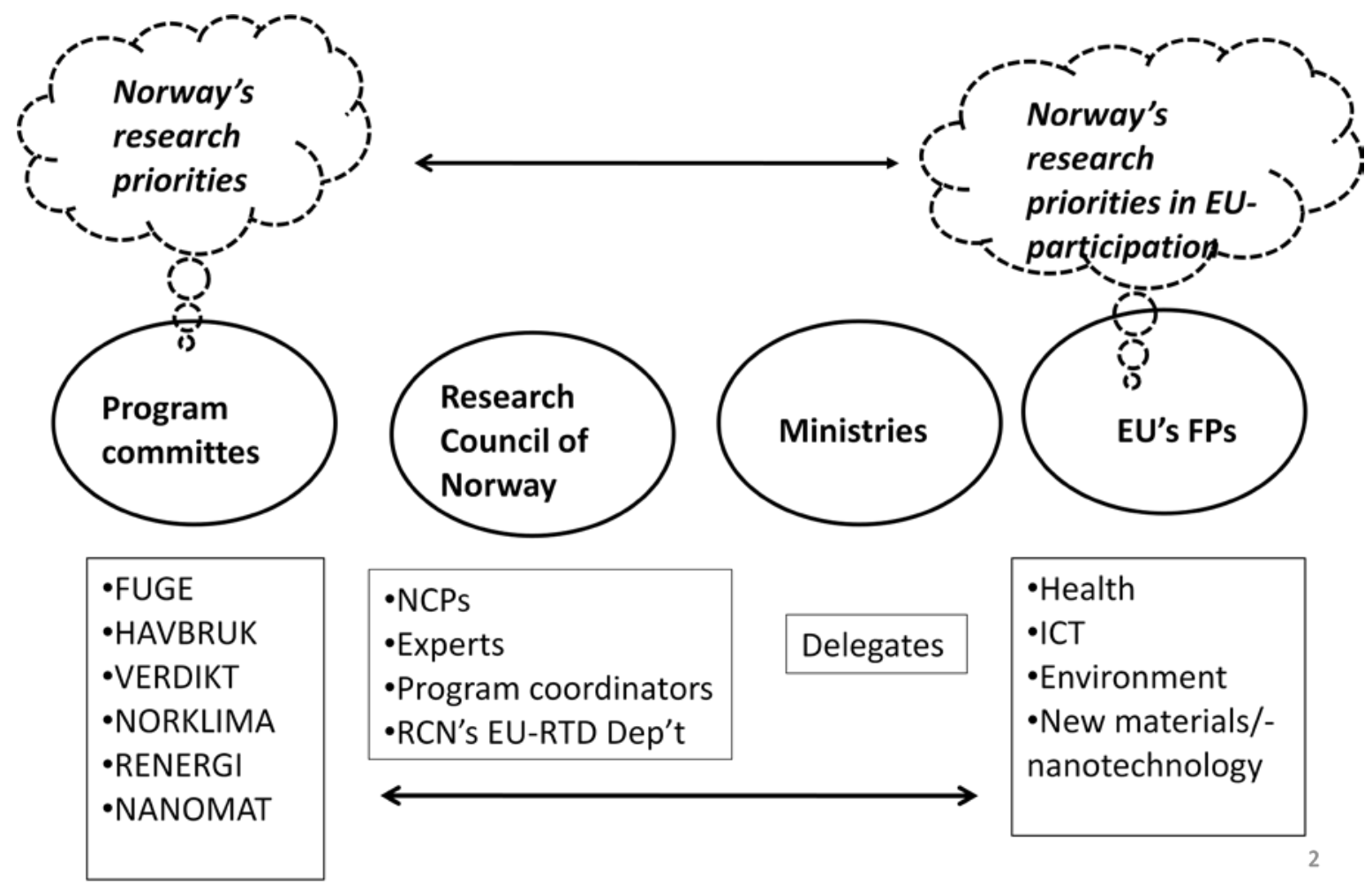

Figure 6.1 Approach for studying Norwegian research priorities' interaction with participation in EU FPS

\subsection{Health}

In FP7, Health is one of the ten thematic priorities within the specific programme Cooperation. In terms of topics, rationale and activities, this programme has many similarities with the thematic priority of Life sciences, Genomics and Biotechnology for Health (LIFE) in FP6. As with many other thematic priorities in FP7, Health, with some adjustments, is considered an extension of the LIFE programme of FP6.

In Norwegian research policy, the topic of health has one of the highest priorities, as expressed in the white papers on research policy in 2005 and 2009. The 2005 White Paper ${ }^{66}$ states that research in health should aim at improving national assets in terms of medical and public health research. The research should contribute to alleviate deficiencies and weaknesses pointed out in an international evaluation on medical research in Norway, in particular conditions for doing clinical research: Competence in doing clinical research is fundamental for knowledge based care of patients. An efficient and high quality public health service will also require research in health economics and organisational studies. Furthermore, Norway's participation in global medical and public health research must be strengthened. This prioritizing must also contribute to building competence on health related to ethnic minorities. In the 2009 white paper on research, the priorities from 2005 
were reconfirmed. The welfare dimension was particularly emphasized: Research in health should contribute to "..good health, decrease social inequalities related to health, and develop high quality public health services”. ${ }^{67}$ In a white paper on innovation from 2009, the government confirmed the high priority on research related to health and welfare, in particular research that will develop new medical equipment, new medical therapies and methods, new drugs and by this contribute to improving health and care service provisions. ${ }^{68}$ However, in describing and justifying this (and other priorities), the strategic role of participating in FPs is not prominent, in spite of the strong emphasis put on the importance of internationalisation as a general research strategy. As outlined earlier, for example that national priorities in research policy must be amplified by international research collaboration, and for this reason, more clear priorities for the total international collaboration must be made.

The aim of the FP6 thematic priority LIFE (Life sciences, Genomics and Biotechnology for Health) is research related to advanced genomics and its application for health, and combating major diseases ${ }^{69}$. According to the evaluation of $\mathrm{FP}^{70}$, the most important achievement of LIFE was the development of methods in high throughput genomics. The programme has also increased understanding of the possibilities of stem cells and various genomes and how they might be used to address widespread diseases such as diabetes, cancer and heart disease, in addition to some rare diseases. In FP7, the thematic priority Health covers three topics: a) Biotechnology, generic tools and medical technologies for human health, b) Translating research for human health and c) Optimising the delivery of healthcare to European citizens. The last topic on healthcare is new in FP7.

According to RCN, the Norwegian rate of success in LIFE in FP6 was 22.3 per cent (number of successful applications/total number of applications with Norwegian participants) which was 4 per cent lower than the EU average. Norwegian researchers participated in 9 per cent of the projects that were funded. These indicators may be interpreted as a comparatively weak performance. In FP7, in Health, Norway's rate of success so far has been 20 per cent, which is above EU average of 18.2 per cent and for this reason may be interpreted as an improved rate of performance, but still below comparable figures from Nordic neighbours. This higher rate of success may be due to the new topic of healthcare in Health, a topic which should be of interest to research communities in public health institutions. However, the Norwegian performance in terms

67 St meld nr 30 (2008-2009) ”Klima for forskning”, p. 16

68 St meld nr 7 (2008-2009) ”Et nyskapende og bærekraftig Norge”, p. 120

69 For more information, see: http://www.europarl.europa.eu/sides/getDoc.do?pubRef=//EP//TEXT+TA+P6-TA-2006-0513+0+DOC+XML+V0//EN

70 "Evaluation of the Sixth Framework Programmes for Research and Technological Development 20022006”, Report of the Expert Group, Chair: Ernst Th. Rietschel, cf: http://ec.europa.eu/research/reports/2009/pdf/fp6_evaluation_final_report_en.pdf and the EU Commissions response to this, COM (2009) 210 final. 
of participation and rates of success in LIFE and Health is interesting for a number of reasons, one being that these topics belong to a sector of Norwegian society that has had a large growth during the past decades in terms of resources allocated.

Although precise explanations may be difficult, the general impression obtained from interviews of knowledgeable informants is that Norway's performance in LIFE and Health reflects a low interest in the relevant research communities for doing international $R \& D$ collaboration in general. ${ }^{71}$ Some of these communities are, of course, truly international and world class, and hence, balances this impression. Nevertheless, according to key informants the interest for carrying out international research collaboration is low. One explanation for this is that these research communities have few incentives for obtaining funding from participation in international research, i.e. that their traditional sources of national research funding are considered adequate for their ambitions. They point to the funding provided by “affluent” NGOs and charitable funds such as the Norwegian Cancer Society. However, this accounts for 11 per cent of the funding of Norwegian health and medical research, that is, only a small share. According to an analysis done by NIFU STEP based on data from comprehensive surveys of R\&D-spending in all public and private hospitals in Norway (Wiig 2007 ${ }^{72}$; Brofoss and Wiig 2009), the Research Council of Norway only funds 4 per cent of this research in Norway ${ }^{73}$. The lion's share of research funding (70 per cent) is part of the "basic funding" from the Ministry of Health and Care Services to institutions, mainly "regional health authorities" [regionale helseforetak] undertaking health and medical research, and another 15 per cent is "targeted funding" from the same source. Hence some informants suggest that "they are not hungry", implying that they have little need for obtaining new sources of funding; they are adequately funded and the Ministry of Health and Care Services, which is the main funding mechanism (85 per cent of the funding) and is not part of the national system under the aegis of the Research Council of Norway. Another reason may be that recruiting young medical researchers has been considered a problem for many years due to lack of interest (poor pay) among potential candidates. A third, more structural reason given is that EU priority of genomics and biotechnology in LIFE and Health are areas of research were the number of researchers in Norway is low, hence the national capability is low, which translates into low interest for participation. The inclusion of healthcare as a topic in FP7 Health has broadened the scope of this thematic priority, so the potential for increasing the participation should be present because there are a number of public health institutions

71 One informant illustrated this by referring to a conversation with a NIH (National Institute of Health in USA) research director, who observed that at their labs in USA, all kinds of strange languages are spoken because this is a truly international organization that attracts people and collaboration all over the world. Of these languages spoken, even Swedish and Danish may be spoken, but not Norwegian implying the weak presence (or even absence) of Norwegians at $\mathrm{NIH}$.

72 Cf. p. 35 and figure 4.3 in this report

73 In the funding of research at university hospitals, the Research Council of Norway's share of the funding is larger, but still small compared to the total funding from the Ministry of Health and Care Services. 
such as nursing colleges which are doing research in this area. The challenge for these is that their capability for doing research is generally low, i.e. the number of researchers is low and they have little experience in doing research, far less with international research collaboration as evident in their publication profiles, etc.

Although a number of plausible reasons may be given for Norway's pattern of participation and rate of success in LIFE and Health, this situation should be a matter of concern. In many ways this diverges from Norway's national research ambitions, specifically those related to the particular emphasis on increasing the quality of research in health and healthcare - and the policy admonitions that the research community in Norway should increase their international collaboration for this purpose. If the factor of complacency represents a barrier for increasing the interest and mobilization of researchers for doing international research, policy instruments and incentives that counterbalance these should be developed. These should be directed to the relevant institutions, because, as our analysis suggests, the challenges are with the research communities and their interests, not with the RCN and its system, because RCN, as indicated, plays a minor role in the funding and national strategy of health and medical research in Norway.

In fact, the RCN and the network of relevant civil servants in the ministries responsible for the governance of Norway's participation in LIFE and Health are very active in providing information and promoting the attractiveness and potentials of participation in EU research. The potential for increasing international $\mathrm{R} \& \mathrm{D}$ collaboration - and in particular participation in EU FP's research - is within the power of the Ministry of Health and Care Services. Hence, this should become a matter of attention in the national research strategy and leadership role in this sector.

\section{$6.3 \quad$ ICT}

The latest Norwegian white paper on research policy (2009) states that ICT, together with food, biotechnology and new materials, will be given high priority because these are strategically important fields of industrial research. The white paper states that RCN's "Large-scale programmes" are important for implementing these priorities and that these may potentially “..strongly contribute to the development of high-tech industry”. ${ }^{74}$ Giving high priority to ICT research has been on the agenda of Norwegian research policy since the 1980s. The latest white paper does not elaborate much on why or what kind of ICT research is important, as in the case of health, but points to previous white papers on research policy and to the inauguration declaration ${ }^{75}$ made by the present "Red-Green"coalition government in 2005.

74 http://www.regjeringen.no/upload/kilde/smk/rap/2005/0001/ddd/pdfv/260512-regjeringsplatform.pdf 
In EU FPs, research in information and communication technologies has become the largest thematic area in Cooperation. EU own evaluation of IST-FP6 ${ }^{76}$ (the "Aho panel”) suggests that "the research investment [4 billion Euro] has been well managed and has been effective in reaching its goals. However, improvements can be made in the flexibility and simplification of the funding mechanism, and in strengthening the global impact of European research in this area”. (p. 1) In the FP7 successor, ICT, the focus has shifted towards more long-term, fundamental research on ICT technology and service development aimed at market roll-out during the latter part for the next decennium, i.e. in 2015-2020. Although this ambitious goal is laudable, it poses a challenge for Norwegian R\&D which has a much shorter time-horizon in its research, in particular in industry. Hence, the profile of ICT is more favourable to the type of research done at universities and research institutes and their perspectives - and less interesting to industrial firms for the same reason.

In the "Large-scale programmes" scheme within the RCN, ICT is the topic of the large programme VERDIKT. VERDIKT has a general similarity, i.e. considerable overlap, with IST and ICT, but is much smaller and more focused in some areas. According to the strategy $\operatorname{plan}^{77}$ of the RCN EU RTD Department, VERDIKT’s “....strategy development, thematic priorities and schedule for proposals must cater to the needs of coordination with [FP7] ICT programme, in order to create synergies with Norwegian ICT-research” (p. 23).

In the mid-period evaluation of VERDIKT of 2009, on the topic of internationalisation, informants in the programme emphasized the importance of international research collaboration for VERDIKT, and that they had projects in their portfolio which were active participants in the Nordic collaborative programme NORDITE and in EUREKA. They also stated that the topic of internationalisation is on the agenda of programme committee meetings as an item of discussion, however, "Verdict's relationship to ICT [FP7] needs to be clarified" - but this has been postponed due to other, more urgent items on the agenda, such as allocations and prioritization of national proposals. One call for proposals to VERDIKT in 2008 was actually postponed in order to avoid a "conflict of schedule" with a call for proposals from the EU IST-programme that had a deadline close to VERDIKT's first deadline. This postponement was made in order not to overburden the R\&D community with too much work with applications

None of the people working for VERDIKT in RCN have roles as NCPs or experts in EU IST or ICT. However, those who serve in these capacities hold regular briefings and

76 Cf. ”Information Society Research and Innovation: Delivering results with sustained impact Evaluation of the effectiveness of Information Society Research in the $6^{\text {th }}$ Framework Programme $2003-$ 2006”, May 2008.

77 Norges forskningsråd, EU-kontoret, ”Forskningsrådets EU-prosjekt for 7. rammeprogram 2007-2013”, English title translated from Norwegian by the authors. 
information meetings with the "VERDIKT people" in the RCN's administration and the Norwegian research community in general. In RCN's organisation, which is large, these experts and NCPs belong to the Innovation Division and conduct ICT research management work related to other ICT projects and programmes. Hence, the liaison role of NCPs and RCN experts to VERDIKT is indirect. To some extent this may explain why VERDIKT's relationship to EU IST and ICT seems detached and somewhat loosely coupled.

According to some of the informants, Norway's performance in EU IST and ICT reflects two factors: that the ICT R\&D community in Norway is small and that EU research agenda in IST and ICT has been tailored to the needs and interests of large national equipment manufacturers such as Siemens, Alcatel, Nokia and Ericsson and their national systems of innovation in ICT. As with health and medical research, some informants point to the factor of complacency because they observe that research organisations that have acquired status as "Centers of excellence" such as the SIMULA research institute in Oslo. These seem to have a low level of participation in EU FPs, possibly an indication of low interest in doing EU research. However, this does not accord well with the opportunities for longterm research in FP7 ICT, nor does this accord with the high priority given to ICT in national research policy. One may also point to the fact that ICT is the sector responsibility of a number of ministries and that a unified research strategy between these ministries on ICT does not exist. Neither does the Ministry of Education and Research have a strong role in coordinating this thematic priority. Finally, the development of ERA and emergence of relevant JTIs on ICT such as the large JTI “Artemis” are outside the FP. These initiatives may be of greater interest for industrial R\&D, which so far in FP7 has a lower rate of participation compared to FP6.

\subsection{Environment}

In FP7, Environment is one of the ten thematic priorities within the specific programme Cooperation. In terms of topics, rationale and activities, this programme has many similarities with the thematic priority of Sustainable Development in FP6. As many other thematic priorities in FP7, Environment, with some adjustments, is considered an extension of the Sustainable Development programme of FP6. The latter programme consisted of three parts: sustainable energy, surface transport and sustainable change and ecosystems. In FP7, surface transport has been taken out. Environment still consists of three parts: Climate change, Sustainable resource management and Environmental technologies.

In Norwegian research policy, as in more general policy, the environment has been a top priority for decades (c.f. "Brundtland Commission” of 1987), but its priority has been amplified by increased emphasis on issues related to climate change. The latest White Paper on research policy makes a blunt allusion to this in its title, "Climate for research" [Klima for forskning]. This states that - as an aspect of global challenge - this will require 
improved coordination of international research collaboration and research policy (p. 12). This priority is important because of global issues related to poverty, demand for energy, climate change, loss of biological diversity and increasing pressure on natural resources for production of food. More specifically, the government puts emphasis on research relevant for climate research, in particular research on renewable energy and carbon sequestration. This priority has been sanctioned by a large majority of the political parties in the parliament (Storting) in January 2008, in the reading of a White Paper on Norwegian climate policy, ${ }^{78}$ in what was subsequently called the "Climate compromise". ${ }^{79}$ In this, agreement was made on the strategy of how research on development of renewable energy and carbon sequestration will be intensified in the forthcoming years.

Within the RCN “Large-scale programmes” scheme, research relevant to Environment and its predecessor in FP6 is the topic of the large programme NORKLIMA - and to some extent RENERGI. According to the strategy plan ${ }^{80}$ of RCN's EU RTD Department, there is a “...considerable overlap between EU and Norway's prioritization in research related to environment and climate change" (p. 35) and the research agenda of Environment. Furthermore, the document suggests that the rate of success of Norwegian participation in FPs has been highest within topics that have a high national priority, such as in NORKLIMA, but also in some other closely related programmes in RCN's portfolio.

On the topic of international research collaboration, NORKLIMA, in its self-evaluation in 2008 evaluation states that research on climate is very international and that NORKLIMA will continue to give this high priority and strengthen this dimension. For this reason, international research collaboration is a strategic goal for NORKLIMA. In calls for proposals and in assessment of proposals, international research collaboration has been given high priority. In addition to the international research collaboration of researchers in projects funded by NORKLIMA, the programme itself participates in two ERA-NET initiatives, CIRCLE ${ }^{81}$ and Europolar ${ }^{82}$ - and a number of other research related boards and initiatives on a more international scale.

As pointed out earlier on the Norwegian participation in Sustainable development in FP6 and in Environment in FP7, Norway has a high number of participations in these. Although this participation profile may be due to a number of factors, this is also congruent with the strategy of the Norwegian large-scale research programme NORKLIMA, which puts high

78 Cf. St meld nr 34 (2006-2007), ”Norsk klimapolitikk”.

79 http://www.regjeringen.no/Upload/MD/Vedlegg/Klima/avtale_klimameldingen.pdf, see Chapter 4 on research.

80 Norges forskningsråd, EU-kontoret, ”Forskningsrådets EU-prosjekt for 7. rammeprogram 2007-2013”, English title translated from Norwegian by the authors.

81 Climate Impact Research Coordination for a Larger Europe.

82 The European Polar Consortium: Strategic Coordination and Networking of European Polar RTD Programmes 
emphasis on international research collaboration in its decisions and priorities. In contrast with the other programmes within the "Large-scale"-programme scheme, NORKLIMA is distinct in so far as it is explicit in implementing a strategy of internationalisation and in integration of international research collaboration in its work. This is reinforced at the operational level - the NCP and experts to the relevant EU programmes are also employees in the Division for Strategic Priorities, that is, they are close to the research administration of the large-scale programmes. As seen in Norway's participation in Environment, a number of factors act in concert in an apparent optimal way. However, the role of strategy, i.e. having clear strategic goals in terms of internationalisation of R\&D collaboration - and participation in EU FPs, and integration of these in the programme's prioritisation, seem fundamental.

\subsection{Nanoscience, nanotechnology and new materials}

In FP7, "Nanoscience, nanotechnologies, materials and new production technologies” is one of the ten thematic priorities within the specific programme Cooperation. In terms of topics, rationale and activities, this programme has many similarities with the thematic priority of "Nanosciences, Materials, New Processes (NMP)" in FP6. The latter programme consisted of three parts: Nano-technologies and nano-sciences, knowledgebased multifunctional materials, and new production processes and devices. The main aim of these programmes improvement of the knowledge base and capacity for innovation, i.e. to support the capacity and competence building that European industry needs, specifically, to build a knowledge base for European process based industries and manufacturing. In this, nano-technology and nano-science are considered as having significant potential. In FP7, this aspect is amplified by the introduction of a new activity: "Integration of technologies for industrial applications". Otherwise, this thematic priority is similar to its predecessor in FP6.

The latest Norwegian White Paper on research policy states that nanotechnology and new materials, together with ICT, food and biotechnology, are to be given high priority because these are strategically important fields of industrial research. The 2009 white paper states that the RCN "Large-scale programmes" are important for implementing these priorities and that these may potentially “...strongly contribute to the development of high-tech industry”. ${ }^{83}$ Giving high priority to nanotechnological research has been on the agenda of Norwegian research policy since the 1990s. The latest White Paper does not elaborate much on why or what kind of research in nanotechnology and new materials is important, as in the case of health, but points to previous white papers on research policy and to the inauguration declaration ${ }^{84}$ made by the present "Red-Green” coalition government in 2005.

83 http://www.regjeringen.no/upload/kilde/smk/rap/2005/0001/ddd/pdfv/260512-regjeringsplatform.pdf 
In the RCN “Large-scale programmes” scheme, research relevant for nano-science and nano-technologies is the topic of the programme NANOMAT. This evolved from the research group FUNMAT, which finished its work in 2002. According to the strategy plan $^{85}$ of RCN's EU RTD Department, NANOMAT is within the domain of EU FPs on nano-technologies and nano-science (p. 28). Hence, an analysis of NANOMAT is interesting in terms of participation in EU FP because of its high priority in the national research policy, although the NANOMAT is much smaller in size compared to its counterpart in FP. In the evaluation of NANOMAT, informants from the programme emphasize the importance of international research collaboration for the aims of NANOMAT by stimulating participation for Norwegian researchers to participate in EU FPs, including the ERA-Net project MATERA. In addition, the evaluation states that that 20 per cent of the projects financed by NANOMAT have some type of international collaboration because this is evident in the accounts of the projects. NANOMAT also funds a programme for international post-doctorates for 3 years where the recipients are required to work more than half of this period outside Norway. The steering committee of NANOMAT has held two "dialogue meetings" with high-level officials of DG RTD, which, according to participants, were successful and contributed to their perception of having a voice in strategic matters in EU FP. FP7 programme committee in nanotechnologies, nano-science and new materials is also considered as being open and active, i.e. that Norwegian participants feel that they (in spite of Norway's status as non-member) are welcome and that they are able to make an impact, although this is not essentially due to Norway's diminutive size.

According to informants, Norway's pattern of participation reflects the size of the relevant research community in Norway. This is small and comparatively young - and characterized as having a "sub-critical" size. Although increased funding is always welcome, the main problem is that there are too few researchers doing research in nanotechnology and nano-science in Norway. This explains why the proportion of nonNorwegian researchers holding a Ph.D degree and post-doctoral scholarships have increased rapidly in Norway in recent years. Of course this may be beneficial for Norway should these researchers decide to become permanent residents. Hence, in Norway's participation in FP research on nanotechnology and nanoscience, which in terms of success rates is high, the main obstacle for increasing participation seems to be the small size of the Norwegian research community in this field of science and technology. In terms of strategy, NANOMAT is clear on the importance of internationalisation and has implemented this in the strategy. One may also observe that NANOMAT, together with BIA, maintains a close relationship with the expert and NCP affiliated with the NMP programme committee. Hence, as with Norway's participation in Environment, one may

85 Norges forskningsråd, EU-kontoret, ”Forskningsrådets EU-prosjekt for 7. rammeprogram 2007-2013”, English title translated from Norwegian by the authors. 
observe that national programmes that have made and implemented a strategy of internationalisation are also successful in terms of high rates of success in EU FPs.

\subsection{Survey data}

The surveys undertaken by the evaluation of participants provided data on how researchers who had participated in the four thematic priorities covered by this in-depth analysis assessed the success of their participation, cf. Chapter 4.4. As explained, participants' overall assessment of the success of their FP6 projects varied considerably by thematic area. Whereas participants in Health and NMP-related projects seem particularly satisfied with their projects, participants in ICT and Sustainable environment were much less satisfied (Table 4.39). Furthermore, the data indicate that respondents within NMP and Life (FP6) felt that their projects were successful. In contrast, within ICT and Sustainable Environment many respondents were uncertain about success. What is interesting with these findings is that researchers' own assessment of their projects in terms of success does not correlate with the overall success rate of the national participation because ICT has a low rate of success and Sustainable Environment has a high rate of success. One interpretation of this observation is that these measure different phenomena.

In terms of national funding to thematically related projects in EU FPs, the survey indicates that the Norwegian participations are seldom extensions or a follow-up of nationally financed projects. This supports the interpretation of weak alignment of national research funding with EU funding. For this reason, there were few cases that show the effect of a close alignment. Hence, the survey data neither supports nor contradicts that projects linked to nationally funded research in general have a higher chance of obtaining EU funding than projects without such links. Still, the data indicate that a good integration between national funding and EU funding in FP6 has given Norwegian participants a good basis for coordinating projects in FP7.

\subsection{General observations and discussion}

The in-depth study of the four cases - which were all high priority topics in the national research policy and strategy - show variety in terms of participation in FPs and rates of success. The mid-period evaluation of 2009 of the RCN “Large-scale programmes” states that although these have contributed substantially to the priorities set in the national research policy, they suffer from the fact that in terms of budgets they only provide funding for 38 per cent of the activities in the areas that have been designated as high priority. The rest is covered by other research funding mechanisms which are beyond the control and strategic decisions of the Large-scale programmes. This, the evaluation suggests, may explain why the contribution from the "Large-scale programmes" has not been as significant as expected. However, in terms of the present evaluation of Norway's 
participation in FPs, this, together with other data sources, provides an interesting insight into internationalisation of Norwegian research and the different patterns of participation one may observe.

The analyses of the four cases have shown that the degree to which the different programmes have international collaboration as part of their strategy varies. Although all the programmes state that internationalisation and international research collaboration is important, the reflection of this in priority setting and decision-making differs. One may observe, as in the large-scale programme NORKLIMA and NANOMAT, a high degree of dedication towards internationalisation and a pattern of successful participation in the FPs. However, NANOMAT's pattern of participation in the FPs differs from that of NORKLIMA. One interpretation of this is structural, i.e. characteristics of the research communities that are relevant for participation both in the national "Large-scale programmes" and their counterparts in EU FPs. This point is made by some informants who suggest that Norway's success in FP7 Environment and its predecessor in FP6 reflect a strong and comparatively large and well-established national research community in this domain. In contrast, in the field of nano-science and nano-technology, the national research community is comparatively small and still young as this is an emerging field of science and technology. In the two other thematic topics presented above, Health and ICT, the research communities are comparatively large, particularly in Health. Hence, this aspect does not necessarily provide a satisfactory general explanation, although size of a national research community sets a limit as to the potential of participation.

In the mid-period evaluation of 2009 of the "Large-scale programmes" as an instrument and strategy measure, on the topic of internationalisation, the evaluators point to the mandate of the programmes which require the programmes to internationalize although the mandate does not specify or define this requirement. ${ }^{86}$ In assessing this, the evaluation observes, as shown above, that some of the programmes have developed and implemented strategies for internationalisation. In general, they seem to lack clear strategies for internationalisation, such as coordination of activities with EU FPs. In following up this issue in the present evaluation, this emerged as a more general aspect related to prioritysetting and decision-making in the RCN. Most of the decisions on which projects and programmes to fund are made in various types of committees and boards in what may be termed as the RCN system. Specific decisions are made according to criteria such as scientific excellence (often based on peer-review assessments), relevance and some policy and strategy considerations spelt out in policy documents or decisions made at top levels of the system. Although terms such as "international standard", "international research frontier" or "world class" are used in this context, these do not seem to imply requirement for doing international research collaboration. According to informants, in the discussions

86 Cf. "SATS på forandring - Midtveisevaluering av Store programmer”, Norges forskningsråd, mars 2009, p. 39, translated from Norwegian by the author. 
and negotiations in committees and boards on funding and other allocations of resources, the aspect of international collaboration is not an important criteria when decisions are made, nor in more general strategic discussions. Their main focus is on the national research arena, which in many ways is natural, because in most boards and committees, the members represent national stakeholders and have a mindset that is focused on the national scene. In some boards and committees, the topic of internationalisation seems to be an "exterior factor" to which some type of recognition should be made, but is not really a core matter or criterion for making decisions. One of the large-scale programmes evaluated, informants said that they would attend to this matter once they had completed allocations of funds to projects subsequent to a national call for proposals, and that due to this "urgent matter”, the question of internationalisation and participation in EU RPs had been postponed, although they recognized the need for clarifying this issue. The general absence or weakness of internationalisation and participation in EU RPs in the decision-making and priority-setting in the governing bodies of the RCN seems to reflect four factors:

- Lack of explicit strategy and instructions to the governing bodies on internationalisation as a criterion for their decision-making, research agenda-setting and priority-making. Hence, governing bodies should be required to give priority to projects, or make allocations otherwise, that create synergies between national research activities in international collaborative research, according to national research priorities. In the evaluation, it became clear that the RCN has recognized these weaknesses and has introduced measures to amend these in its governance and management. Some of these measures may imply total "reengineering", which is relevant for the next point.

- When on average 31 per cent of Norwegian FP6 participants say that substantial improvements are needed in the information on how to combine national and FP funding, this is an indication that EU research does not sit comfortably in the national research funding landscape.

- The Research Council of Norway should develop and strengthen its portfolio analysis capability in order to serve the needs of the type of priority setting and decision-making needed for creating synergies between national research and international research. Deciding on what type of international research collaboration to participate in requires in-depth knowledge of the available options world-wide - and a capability of analyzing this in a national strategic perspective within a specific field of research. Hence, in some fields this type of analysis could conclude that collaboration and participation in the EU FP may be less interesting for Norway than developing research collaboration with research communities, for example in USA, Japan, or elsewhere. Alternatively, one may envisage that, for strategic reasons, one project proposal which is academically second to the best one should, in spite of this, be supported if this is done in tandem with participation with a project in the EU FP, because this will serve as an avenue for obtaining knowledge or technological opportunities that Norway does not have. 
- The high symbolism attached to international research cooperation at political level may lead to myriads of internationalisation initiatives for the research council. This may take management attention and focus away from long-term goals set in research strategy plans. Once priorities are made, these should be executed and implemented and adjustments, if necessary, should be made according to goals in the national research policy.

These four points and the discussion make numerous direct and indirect references to national policy, policy measures and related issues of governance. This will be the topic of the next chapter. 


\section{$7 \quad$ National policy measures and the governance of EU research}

The purpose of this chapter on Norway's policy measures and the governance of EU research is to describe, analyze and discuss issues that are relevant for national research policy and strategy. Following the terms of reference for the evaluation, this is done by addressing the three topics:

- Analyses of effects of the national system for information and counselling and related economic incentives.

- Norway's influence on EU research and participation in programme committees in EU FP,

- National governance processes and coordination of Norway's participation in the FPs.

A summary of the findings and implications is be presented and discussed at the end of the chapter.

\subsection{Analyses of effects of the national system for information and counselling and related economic incentives}

As explained in Chapter 2, an important goal in Norwegian research policy is to increase Norwegian participation in EU FPs as part of Norway's effort to increase internationalisation of its research. For this purpose an element in the national strategy has been development of a system designed to increase Norwegian participation in EU FPs and to improve the Norwegian R\&D community's ability to compete successfully in these contexts. Although Norway has a fair performance record generally in terms of rates of success which is comfortably higher than the EU average (as shown in Chapter 5), Norwegian rates of success are lower than other Nordic countries. In addition, the rate of return of EU funding has a "deficit”, which has increased from FP5, indicating that the level of participation should be increased, primarily because this may contribute to the goals of internationalisation of Norwegian research - and associated knowledge benefits and innovation opportunities. For these and other reasons, the national system for information and counselling has an important mission. Hence, evaluating the effects of this system may provide insight and explanations relevant for the strategy of increasing Norwegian participation in EU FPs. In the following, this topic will be approached first by describing Norway's system for information and counselling. Analyses of the effects of this system, based on evidence provided by the surveys of Norwegian FP participants are then presented. This is followed by analyses and discussion of instruments and incentives. 


\subsubsection{The national system for information and counselling}

As explained in Chapter 2, the Research Council of Norway has the main operational responsibility for promotion, information and counselling related to Norway's participation in EU FPs. The activities associated with these tasks are organized in the EU RTD Department, an entity within the unit for international affairs affiliated to the Director General of the Research Council of Norway. In May 2007, the strategy of this entity was spelt out in a document presented in Chapter 2. This document will be revised every second year. As a general comment, this document shows that Research Council of Norway now has introduced a systematic approach to portfolio management of Norway's participation in EU research. The director of the EU RTD Department is a member of the board of directors of the Research Council of Norway, a fact that reflects the importance attached to Norway's participation in EU's research in the Research Council of Norway. Furthermore, this is amplified by a new policy stating that at every board meeting of the Research Council of Norway, both the "Main Board" [Hovedstyret] and the boards of its divisions, the topic of Norway's participation in EU FPs and related matters should be a permanent item on every meeting agenda. The director of EU RTD Department is usually invited to address these issues at such meetings. The effect of the activities and instruments managed by the EU RTD Department has been measured in the surveys of the evaluation and the results of these are presented below, cf. Section 7.1.2.

The EU RTD Department has an important mission in terms of dissemination of information on EU FPs and general counselling services to the Norwegian R\&D community. This is done through a number of different channels, such as the web, distribution of documents and other information material, a home page, newsletters, "help desk function”, and so forth. In addition, the EU RTD Department arranges a large number of information meetings, both general and more specialized, throughout Norway, for example meetings on a particular thematic priority, or calls for proposals. For providing expert information, the personnel who serve as National Contact Point (NCP) have an important function in providing expert, up-to-date information and advice to the Norwegian research community because they monitor the activities in the various programs. In addition, many of the NPCs also serve as experts in various Norwegian programme committee delegations in the FP.

In addition to the roles and functions described above, the EU RTD Department manages a funding mechanism for supporting Norwegian applicants, i.e. the Project Establishment Support (PES) scheme, in which all potential applicants (except universities) are given 50 per cent refunding of the costs incurred during work undertaken in developing an EU project proposal. Universities are given a lump sum grant for the same purpose. In 2008, the budget of PES was NOK 47 million and this provided support to more than 550 proposals. According to informants, this instrument has been highly popular as evident in the size of this funding. Notably, the share of PES funding has been doubled from FP6 to 
FP7 (Table 4.22). This topic of financial instruments and incentives is analyzed further below, cf. Section 7.1.3.

The EU RTD Department is responsible for the Research Council of Norway's liaison office in Brussels, established in 2005. This office is considered as a success by informants because of its ability to network with the EU Commission - and by this to exert influence. The Brussels office also has close relationships with similar national liaison offices in Brussels, in the IGLO network; in fact, many of these are located in the same office building in Brussels. This is thus an important step towards pooling Norway's administrative resources with those of the Member States. Although this office maintains relationships with Norway's mission to the EU in Brussels, it presents itself as a representative of the Research Council of Norway and should be seen as a way of effectively linking to networks of national funding agencies. It has also been important for establishing a more effective division of labour vis-à-vis the Norwegian Mission to the EU and its Counsellor for Research. The main responsibility of the latter is management of the EEA-treaty in matters related to Norway's national interests in the participation in EU FPs, such as Norway's economic contribution to EU for its participation in the FPs. Although the Counsellor of Research is formally an employee of the Norwegian Ministry of Foreign Affairs, this person may be considered as a person who represents the interests of the Ministry of Education and Research vis a vis the EU Commission.

The Brussels liaison office of the Research Council of Norway is instrumental in arranging “dialogue meetings” where Norwegian R\&D stakeholders meet relevant high-level executives and experts in the EU Commission who they consider to be important in influencing the EU research agenda and promoting Norway's interests and, reciprocally, to obtain a better understanding of EU's thinking and plans. In these meetings, Norwegian stakeholders are organized as "national teams" according to their field of research interest and institutional affiliation. This type of targeted influencing efforts began during the FP5, but has been intensified after the establishment of the Brussels liaison office. In 2009, the Brussels liaison office organized a series of dialogue meetings between high level representatives of DG RTD and various Norwegian national teams such as those representing the Norwegian R\&D community in fields of environmental research, medical and health research, liberal arts and humanities, material sciences, and food and bioproduction research. A similar dialogue meeting was organized for the programme committee from the Norwegian Large Scale Programme "RENERGI" and complementary high level officials for renewable energy research in DG RTD. One dialogue meeting which the Research Council of Norway characterizes as successful was arranged in August 2009, in Tromsø and Lofoten in northern Norway. The purpose of this meeting was to present arguments for a concerted European research effort in the field of marine bioproduction in FP7 to the high level representatives of DG RTD - and to present Norway's positions in the cross-cutting thematic priority of "The Oceans". 
In the 2008 annual report from the EU RTD Department, the Brussels liaison officer is described as the most important person in terms of network building vis a vis the EU Commission, in particular DG RTD. This is done by a number of different ways, as described above. According to the annual report of 2008, the Brussels office handled more than 500 contacts and visitors, arranged 35 seminars and meetings, held more than 70 bilateral meetings with the EU Commission - all of which indicates a high level of activity and energy considering this is done mainly by one officer.

Another important mechanism related to the EU RTD Department is the arrangement of "secondment" of national experts for work in offices relevant to R\&D in the EU Commission. This scheme is part of the general arrangement by which national experts are seconded to the Commission and other EU institutions from the EU Member States and the EEA countries. The purpose of this arrangement is to supply EU institutions, in particular the Commission and EU agencies, with expertise that is not available internally. It is also a tool for the EU to increase and disseminate knowledge of the European institutions and decision-making processes. For the national institutions which send their officers as national experts, this is an opportunity for international training and hands on experience in important policy areas of the European Union for their staff. ${ }^{87}$ In 2009 there were approximately 50 Norwegians taking part in the scheme, fewer than 10 of these in areas related to research ${ }^{88}$. Despite this modest number, this is an important element in keeping alive the interaction between Norway and the Commission also in the area of research policies. The actors are, however, well aware that the terms of the seconded national experts are such that they cannot be used by national authorities to promote Norwegian interests directly. This corresponds with what studies of seconded national experts observe: National experts tend operate first and foremost as "ordinary" DG officers. "Back home", their national employers seem to consider them "out of sight out of mind", i.e. "forgotten" by Oslo once in Brussels. Still, they are important for lowering the barriers for getting in touch directly with the DG, and for the expertise they carry with them when they return to the mother institution (Trondal, Van den Berg and Suvarierol 2008). Since the seconded national experts generally operate on the same terms as other SNEs and DG officers, national experts, when located at the right place, may be part of important policy development processes. Norwegians seconded to the DG Research are there through a bilateral agreement and as such, this arrangement is in an more uncertain position than that of the "in-kind" payment to the administrative costs of participating in EU programmes. Also, there are overall developments that place such arrangements under a potential stress, such as the more recent narrowing down of the rules concerning the detachment of experts

87 There are two kinds of arrangements for National experts seconded from Norway: 1) national experts to the European Commission that are in kind contribution to the running costs of the programmes in which they participate. 2) bilateral agreements between the European Commission and the EFTA States on a voluntary basis. Such bilateral agreements are used in particular for secondments to the Research programme.

88 Cf. http://www.efta.int/content/eea/national-experts. 
from the private sector, and questions raised about what kind of tasks national experts may participate in when they are assigned to in Brussels. These caveats notwithstanding, all informants seem to consider these a valuable asset and they represent a resource that could be used much more.

The role of the EU RTD Department as the pinnacle of the national information system includes also the responsibility for running a number of information meetings of various types, both within the Research Council of Norway and with external partners in various forums. Two of these were the "Norwegian ERA Forum". According to the 2008 annual report of the EU RTD Department, the EU RTD Department altogether arranged 42 meetings of this type ${ }^{89}$.

Although the Research Council of Norway and its EU RTD Department is the largest actor in Norway in terms of providing information and counselling services related to FPs, there are others who also serve this function, often in close collaboration with the Research Council of Norway:

- Innovation Norway, which has responsibility for administration of the European Entreprise Network (EEN) in Norway. The purpose of this is to mobilize the SMEsector and to increase their participation in the FPs and in CIP (Competitiveness and Innovation Programme), as described earlier in Chapter 5 . The actual work is done in close collaboration with four other research organisations in Norway: IRIS, NOFIMA, NORUT and SINTEF.

- Most of the universities and some of the larger university colleges in Norway, as a staff function related to the office or entity for international research cooperation, have one or two officials who are responsible for this, either full-time or part-time. This is the case of the University of Oslo, University of Bergen, Norwegian University of Science and Technology (NTNU), University of Tromsø, Norwegian University of Life Science (UMB), University College of Oslo, University of Stavanger and University of Agder. These people often organize information meetings, arrange courses (tutorials) on how to write applications, or provide advice and services related to contracts and IPR-issues.

- Many of the large research institutes with many participations in the FPs have an organisational entity or staff people who serve as advisors on EU FP, such as the SINTEF group, NILU, NIVA, Matforsk, etc. These also provide legal advice on contracts, and if necessary, on legal matters related to IPR.

- Many of the large companies that participate in FPs also have staff who serve as advisors on EU FPs, such as Den norske Veritas (DnV), Telenor, Statoil-Hydro, etc. The staff here also provide legal advice on contracts, and if necessary, on legal matters related to IPR. 
In general, most of the large institutions, firms and agencies that are involved in EU research now have more than a decade of experience with this. They have a close relationship with the Research Council of Norway, in particular the EU RTD Department. With the latter, they cooperate on organizing information services and a number of other initiatives, such as “dialogue meetings” with DG RTD. The EU RTD Department has also organized a system and network of National Contact Persons (KP) ${ }^{90}$ at universities (20 persons), research institutes (40 persons) and private sector firms (20 persons). This liaison function is important for providing information to relevant R\&D organisations and firms in Norway that participate in EU FPs. In 2008, the topic of EU's new cost model was important for this network. In addition, the EU RTD Department has arranged meetings with leaders of universities and university colleges in order to promote their interest in participation in EU FPs. Hence, many of the participating institutions and firms have established systems and routines that make them capable of participation in EU FPs. However, SMEs are not part of this picture - and the role of IN is important for these. In addition, the challenges related to the strategic aspects of Norway's research policy have created new types of challenges that will increase the demand for the functions provided by the national information and counselling system, i.e. the role of the Research Council of Norway will become more important in the future, in terms of the emerging ERA. Awareness of this aspect is high, as evident in documents and statements made by officials from EU RTD Department, however, making assessment of this is outside the scope of this evaluation.

\section{The role of expert reviewers}

A number of Norwegians serve as expert reviewers for undertaking ex-ante evaluations of project proposals to the FPs. DG RTD organizes and maintains this pool of reviewers. According to one knowledgeable Norwegian reviewer who has participated in this for many years, Norwegian proposals have gradually "lagged behind" while the general quality of proposals has increased over the years. Be this as it may, the point is that the insights of these people used by the Norwegian research system. Apparently, this is not the case now. A side issue in this is the poor payment given to these reviewers making this strategic role less attractive for Norwegians, and for experts from other countries in Northern Europe. Some type of remuneration scheme may encourage more people to serve as experts - and some type of mechanism should be designed to leverage the insights and competence of these people for improving Norwegian proposals.

\subsubsection{Effects of national information and consultation services and financial incentives}

In order to measure the effects of national information and counselling services, the evaluation posed a number of questions on this topic in the two surveys that were

90 This is different from National Contact Points. 
undertaken in the evaluation; cf. questionnaires in Appendix 6, Part 7, for the questions that were used to map this topic. The rationale for asking the researchers is that we consider them as being the best source of information on this topic. The most interesting in this context is what respondents state in terms of weaknesses, i.e. which areas of the Norwegian information and consultation services need "substantial improvements" because this may be interpreted as an indicator of limited effect. The responses to this topic are shown in Table 7.1. These are also distributed according to thematic priority of participation of the respondents. This table is interesting because the respondents were experienced, i.e. they had participated in FP6 projects, and were involved in FP7. The FP6 participant survey and the FP7 applicant survey both confirm the same two issues most in need of improvement: 31 per cent of FP6 participants and 34 per cent of FP7 applicants required better advice on how to combine national $R \& D$ funding with Framework Programme activities. Moreover, 26 per cent of FP6 participants and 23 per cent of FP7 applicants required more assistance with financial rules and regulations, audits and financial reporting. In summary, substantial improvements are needed. A large part of the remaining respondents stated that some improvements are needed, whereas few replied that no improvements are needed (Appendix 1, Table A 11).

As shown, the need for "substantial improvements" on general information has the highest score for participants in SMEs, followed by LIFE (the predecessor to Health in FP7). This pattern, i.e. the highest score for SMEs followed by LIFE, is seen in almost all the other categories of information, except for the categories "Financial rules/reporting" and "How to combine national funding and FP”. One may also interpret this response as a measurement of the effect of NCP function although the survey did not specifically ask respondents about their assessment of the NCPs. In these, many other categories of participants also give relatively high scores for "substantial improvements needed". An interesting case in this context is participants from IST who gave low scores for general information but high scores on "How to combine national funding and FP6" as a category of "substantial improvements needed". This may be interpreted as an indicator of a disincentive to participate. However, similar scores may also be observed for FOOD. 
Table 7.1 Participants in FP6: Effects of Norwegian information and consultation services for the 7th Framework Programme. Per cent within programme/priority answering "Substantial improvements needed".

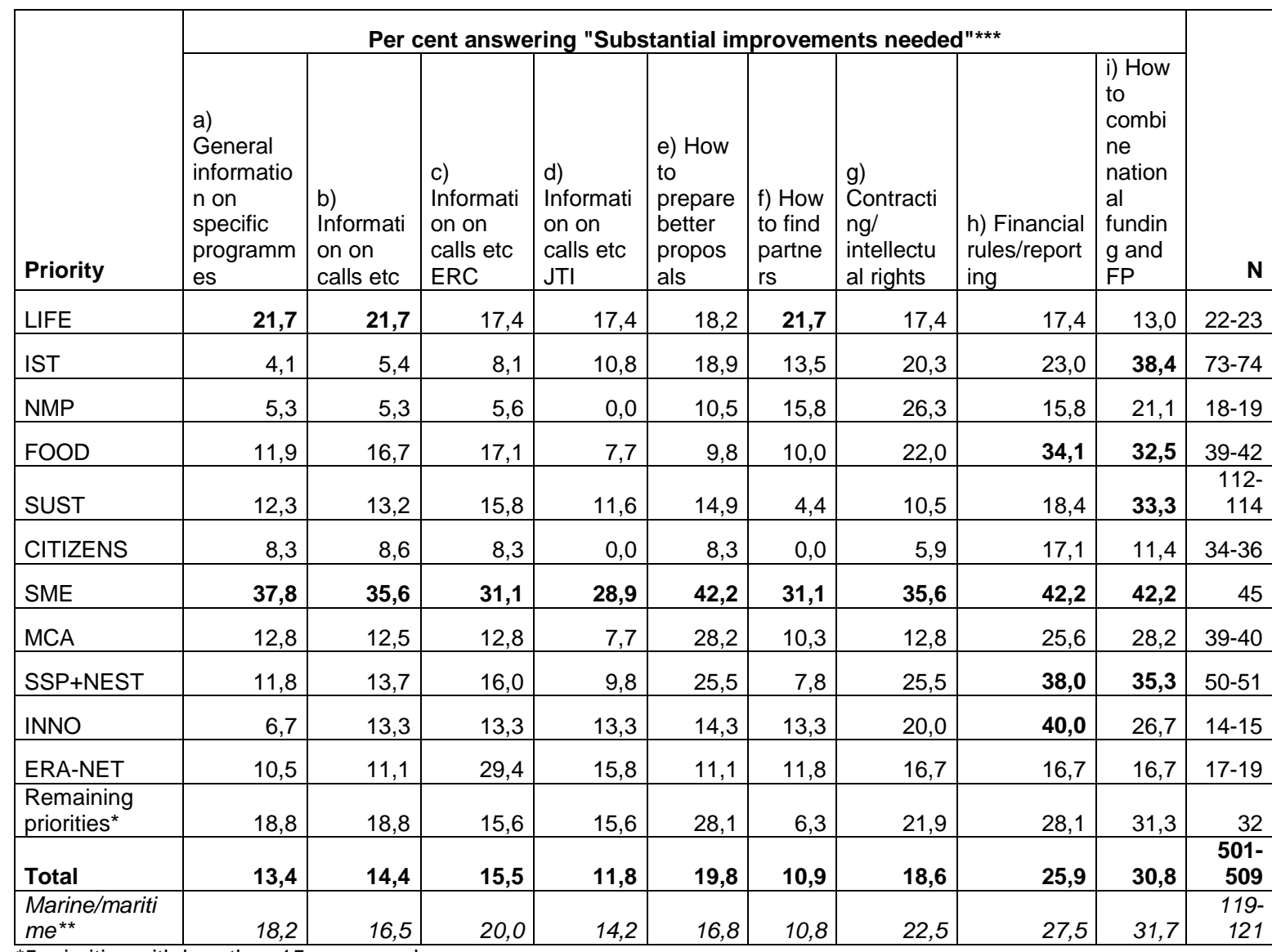

*5 priorities with less than 15 cases each.

**Projects with impact on marine/maritime sector according to respondents' replies, include projects in various priorities.

*** See Table 7.2 for the concise question formulations.

Source: Survey to Norwegian participants in FP6.

Furthermore, three more issues are given equal relative importance by the two groups of respondents. Twenty per cent of FP6 participants and 22 per cent of FP7 applicants ask for better advice on how to prepare proposals. Nineteen per cent of FP6 participants and FP7 applicants ask for better advice and legal support to contracting and management of intellectual rights. Sixteen per cent of FP6 participants and 17 per cent of FP7 applicants ask for better information on calls and research activities of the European Research Council. Lowest scores were given concerning how to find and connect to partners (FP6 participants) and general information on the various specific programmes of the Framework Programmes (FP7 applicants).

The data shown in Table 7.1 indicate that there is a general need for increasing the effects of the information and counselling. However, for some categories of participants, this may be urgent. For SMEs, this seems to be the case and which reflects on the role of Innovation Norway, but this may also reflect that SMEs have limited capacity to develop their own information and counselling services at the organisational level - as has been done by the major universities and main FP players in the research institute sector and industry. In any 
case, the data also indicate the need for developing a differentiated strategy in order to increase the effects of information and counselling services, depending on the type of participation and category of information and counselling services.

In some interviews of stakeholders, informants suggested that the information and counselling services of the Research Council of Norway are "too much Oslo-oriented" and for them "Norway outside Oslo does not exist". In order to provide measurement for these types of statements, the responses were distributed according to the geographical location of the respondents.

There are significant regional differences in the demands for more assistance. Among the FP6 participants, the clearest need for improvements on all issues is found in Northern Norway. The exception is advice on how to find and connect to partners, where the clearest need is found in the south (Adger and Rogaland, Table 7.2). Among the FP7 applicants regional differences vary more. The capital region (Oslo and Akershus) has the highest demand for advice and legal support to contracting, management of intellectual rights as well as financial rules and regulations, audits, financial reporting (Table 7.3). For this reason, a strategy for increasing the effects of information and counselling services needs to be designed and targeted in order to cater for the needs of the R\&D community in Northern Norway in addition to Agder and Rogaland. 
Table 7.2 Participants in FP6: Effects of Norwegian information and consultation services for the 7th Framework Programme. Per cent "Substantial improvements needed" by region.

\begin{tabular}{|c|c|c|c|c|c|c|c|}
\hline \multirow{2}{*}{$\begin{array}{l}\text { Is there a need for improvements in the } \\
\text { Norwegian information and consultation } \\
\text { services concerning the following aspects of } \\
\text { the 7th Framework Programme? }\end{array}$} & \multicolumn{7}{|c|}{ Per cent answering "Substantial improvements needed" } \\
\hline & $\begin{array}{r}\text { Agder } \\
\text { and } \\
\text { Rogaland } \\
\end{array}$ & $\begin{array}{r}\text { Northern } \\
\text { Norway }\end{array}$ & $\begin{array}{r}\text { Oslo and } \\
\text { Akershus }\end{array}$ & $\begin{array}{l}\text { Rest of } \\
\text { Eastern } \\
\text { Norway }\end{array}$ & Trøndelag & $\begin{array}{r}\text { Western } \\
\text { Norway }\end{array}$ & Total \\
\hline $\begin{array}{l}\text { a) General information on the various specific } \\
\text { programmes of the Framework Programmes }\end{array}$ & 11,1 & 27,6 & 15,3 & 10,0 & 7,0 & 9,1 & 13,4 \\
\hline $\begin{array}{l}\text { b) Information on calls and upcoming } \\
\text { deadlines for submitting proposals }\end{array}$ & 5,6 & 20,7 & 17,1 & 5,0 & 9,3 & 12,1 & 14,5 \\
\hline $\begin{array}{l}\text { c) Information on calls and research } \\
\text { activities of the European Research Council } \\
\text { ERC) }\end{array}$ & 11,1 & 24,1 & 17,3 & 10,0 & 11,6 & 12,3 & 15,6 \\
\hline $\begin{array}{l}\text { d) Information on calls and other related } \\
\text { research and innovation activities of Joint } \\
\text { Technology Initiatives (JTI) }\end{array}$ & 11,1 & 17,9 & 11,8 & 10,0 & 11,6 & 10,6 & 11,8 \\
\hline e) Advice on how to prepare better proposals & 27,8 & 31,0 & 20,1 & 20,0 & 15,1 & 18,5 & 19,9 \\
\hline f) How to find and connect to other partners & 16,7 & 6,9 & 12,5 & 10,0 & 8,1 & 7,6 & 10,8 \\
\hline $\begin{array}{l}\text { g) Advice and legal support to contracting, } \\
\text { management of intellectual rights }\end{array}$ & 5,6 & 27,6 & 20,8 & 10,0 & 14,0 & 18,2 & 18,7 \\
\hline $\begin{array}{l}\text { h) Financial rules and regulations, audits, } \\
\text { financial reporting }\end{array}$ & 22,2 & 37,9 & 29,2 & 15,0 & 16,3 & 24,6 & 26,1 \\
\hline $\begin{array}{l}\text { i) Advice on how to combine/connect national } \\
\text { R\&D-funding with FP project activities }\end{array}$ & 33,3 & 41,4 & 30,0 & 15,0 & 34,9 & 27,7 & 30,7 \\
\hline $\mathrm{N}$ & 18 & 28-29 & 280-287 & 20 & 86 & $65-66$ & $\begin{array}{r}498- \\
506 \\
\end{array}$ \\
\hline
\end{tabular}

Source: Survey to Norwegian participants in FP6.

As indicated earlier, there are also significant differences between the Framework Programme priorities. Table 7.1 shows that participants in SME activities in particular and in the Life-programme think there is a substantial need for improvement in the Norwegian information and consultation services. As reported in Section 4.5, small enterprises are in particular need of assistance. The Life-programme is among those programmes with low Norwegian participation, and the figures indicate that the participants in this programme have had more problems in finding information and relevant partners than the participant in other programmes. 
Applicants to FP7: Effects of Norwegian information and consultation services for the 7th Framework Programme. Per cent "Substantial improvements needed" by region.

\begin{tabular}{|c|c|c|c|c|c|c|c|}
\hline \multirow{2}{*}{$\begin{array}{l}\text { Is there a need for improvements in the } \\
\text { Norwegian information and consultation } \\
\text { services concerning the following aspects of } \\
\text { the } 7 \text { th Framework Programme? }\end{array}$} & \multicolumn{7}{|c|}{ Per cent answering "Substantial improvements needed" } \\
\hline & $\begin{array}{r}\text { Agder } \\
\text { and } \\
\text { Rogaland }\end{array}$ & $\begin{array}{r}\text { Northern } \\
\text { Norway }\end{array}$ & $\begin{array}{l}\text { Oslo and } \\
\text { Akershus }\end{array}$ & $\begin{array}{l}\text { Rest of } \\
\text { Eastern } \\
\text { Norway }\end{array}$ & Trøndelag & \begin{tabular}{|c|} 
Western \\
Norway
\end{tabular} & Total \\
\hline $\begin{array}{l}\text { a) General information on the various } \\
\text { specific programmes of the Framework } \\
\text { Programmes }\end{array}$ & 7,5 & 13,0 & 11,5 & 7,5 & 8,7 & 9,6 & 10,2 \\
\hline $\begin{array}{l}\text { b) Information on calls and upcoming } \\
\text { deadlines for submitting proposals }\end{array}$ & 2,4 & 16,7 & 14,0 & 2,5 & 9,2 & 9,6 & 11,2 \\
\hline $\begin{array}{l}\text { c) Information on calls and research } \\
\text { activities of the European Research Council } \\
\text { ERC) }\end{array}$ & 4,9 & 20,8 & 18,0 & 12,5 & 15,8 & 20,4 & 17,0 \\
\hline $\begin{array}{l}\text { d) Information on calls and other related } \\
\text { research and innovation activities of Joint } \\
\text { Technology Initiatives (JTI) }\end{array}$ & 2,4 & 9,4 & 17,2 & 15,4 & 17,2 & 16,1 & 15,7 \\
\hline $\begin{array}{l}\text { e) Advice on how to prepare better } \\
\text { proposals }\end{array}$ & 7,3 & 22,2 & 25,1 & 10,0 & 19,8 & 27,0 & 22,2 \\
\hline f) How to find and connect to other partners & 17,1 & 13,0 & 14,5 & 5,0 & 9,3 & 15,7 & 12,8 \\
\hline $\begin{array}{l}\text { g) Advice and legal support to contracting, } \\
\text { management of intellectual rights }\end{array}$ & 2,5 & 18,9 & 22,9 & 7,5 & 18,0 & 16,7 & 18,8 \\
\hline $\begin{array}{l}\text { h) Financial rules and regulations, audits, } \\
\text { financial reporting }\end{array}$ & 2,5 & 20,4 & 28,1 & 12,5 & 22,7 & 17,1 & 22,7 \\
\hline $\begin{array}{l}\text { i) Advice on how to combine/connect } \\
\text { national R\&D-funding with FP project } \\
\text { activities }\end{array}$ & 9,8 & 33,3 & 36,3 & 15,0 & 36,8 & 32,8 & 33,5 \\
\hline $\mathrm{N}$ & $40-41$ & $53-54$ & $367-373$ & $39-40$ & $227-231$ & $112-117$ & $\begin{array}{r}839- \\
853\end{array}$ \\
\hline
\end{tabular}

\subsubsection{Instruments and incentives for increasing participation}

In FP6, the Research Council of Norway co-funded 25 per cent of the costs of the research institutes participation in IP and STREP projects (the so-called SAM-EU funding) as well as up to 50 per cent of costs related to the preparation of proposals (Project establishment support, or PES). Because the funding regime of EU was changed in FP7 (EU now funds 75 per cent of project costs), the SAM-EU funding scheme is no longer in use.

In 2009, the Research Council of Norway changed its funding policy of PES for FP7. The main participating organisations are now eligible for an annual lump-sum grant for funding up to 50 per cent of the costs related to work with EU proposals. All organisations receiving such funding must report at the end of the year how their PES funding has been used. Norwegian PES funding could be considered as generous since Norway seems to be the only country, apart from Ireland, having such a funding/support of the pre-competitive phase among all ERA-countries. PES funding amounts to 45-50 million NOK annually.

Compared to FP6, the new PES-funding policy in the FP7 has reduced to a minimum the transactions costs for a large number of applications. However, applications to PESfunding from Norwegian private companies are still processed by the RCN on a case-bycase basis. The PES co-funding mechanisms do not differentiate between thematic areas 
or type of instruments. There are no plans for any kind of differentiation of PES funding in order to stimulate application activity in those thematic priorities in FP7 where there is manifestly a relative low Norwegian participation.

In general, and compared to other countries, one may consider this type of Norwegian support scheme as attractive. This raises the question of the effect of the other instruments because, in spite of its attractiveness, the level of participation in Norway is lower than other Nordic countries. Hence, one may suggest that other, more effective incentives are needed. However, this topic should be analyzed by considering the effects of other types of funding mechanisms as presented below.

\section{Effects of financial support schemes}

In order to provide a measurement of the effects of financial support schemes, the evaluation posed a number of questions on this topic in the two surveys which were undertaken in the evaluation; cf. questionnaire in Appendix 6, Part 7, for the questions that were used to map this topic. A large part of the respondents indicated that there is a need for improvement in the Norwegian financial support schemes for participation in the 7th Framework Programme. Among FP6 participants, 35 per cent stated that there is a need for substantial improvements in the national direct co-funding of EU projects. Another 40 per cent believe that there is need for some improvement, and only 8 per cent think that there is no need for improvement (Table 7.4). Although critics may suggest that posing these types of questions are leading in the sense that researchers instinctively always want more funding, regardless of their real need, implying that this does not measure effects, but the "greed" of researchers. However, if this assumption is valid, one would expect a uniform pattern of response - which is not the case. As may be observed, the distribution of institutional affiliation of the respondents shows variety in the responses. This indicates that the effects of financial support schemes vary according to type of institution, and that this needs to be taken into consideration when instruments are designed or adjusted. 


\begin{tabular}{|c|c|c|c|c|c|}
\hline $\begin{array}{l}\text { Is there a need for improvements in the financial } \\
\text { support schemes provided by the national authorities } \\
\text { responsible for the Norwegian participation in the } 7 \text { th } \\
\text { Framework Programme? }\end{array}$ & $\begin{array}{r}\text { Substantial } \\
\text { improvements } \\
\text { needed }\end{array}$ & $\begin{array}{r}\text { Some } \\
\text { improvements } \\
\text { needed }\end{array}$ & $\begin{array}{r}\text { No } \\
\text { improvements } \\
\text { needed } \\
\end{array}$ & $\begin{array}{r}\text { No } \\
\text { opinion } \\
\end{array}$ & $\mathrm{N}$ \\
\hline a) Financial support for preparing proposals & 26,1 & 41,4 & 14,7 & 17,8 & 505 \\
\hline $\begin{array}{l}\text { b) National direct co-funding (medfinansiering fra } \\
\text { Norges forskningsråd) of participation in the EU } \\
\text { projects }\end{array}$ & 34,8 & 40,2 & 7,6 & 17,5 & 503 \\
\hline $\begin{array}{l}\text { c) National financial support (medfinansiering fra } \\
\text { Norges forskningsråd) of participation in activities } \\
\text { organized and managed by the European } \\
\text { Technology Platforms (ETPs), Joint Technology } \\
\text { Initiatives (JTIs), ESFRI, EIT, European Research } \\
\text { Council (ERC) }\end{array}$ & 24,5 & 27,0 & 3,2 & 45,3 & 503 \\
\hline $\begin{array}{l}\text { d) Co-ordination of funding between Framework } \\
\text { Programme activities and relevant national R\&D and } \\
\text { innovation support schemes/programmes (Research } \\
\text { Council of Norway and/or Innovation Norway) }\end{array}$ & 25,2 & 37,7 & 6,5 & 30,6 & 504 \\
\hline $\begin{array}{l}\text { e) Financial support for long-term positioning in } \\
\text { Framework Programme-selected areas of National } \\
\text { strategic importance }\end{array}$ & 31,2 & 32,9 & 4,0 & 31,9 & 504 \\
\hline
\end{tabular}

Source: Survey to Norwegian participants in FP6.

Studying difference between organisation types, we find that the research institutes (counting both FP6 participants and FP7 applicants) express the highest need for substantial improvements in financial support schemes. On all issues the highest proportion of respondents indicating the need for substantial improvements in funding is found at the research institutes. There is one exception. FP6 participants at higher education institutions express the clearest need for better national direct co-funding ( 43 per cent state that substantial improvements are needed). It should also be noted that better national direct cofunding is the issue most of the respondents seem concerned about, regardless of organisation type (and similar for FP6 participants and FP7 applicants, Table 7.5 and Table 7.6).

There is also a high proportion who believe there is a need for better financial support of long-term positioning Framework Programme-selected areas of "National strategic importance“ (31 per cent state "substantial improvements"; 33 per cent state "some improvements”). The majority would also like better financial support for preparing proposals, better co-ordination of funding between Framework Programme activities and relevant national R\&D and innovation support schemes/programmes, and support for of participation in activities organized and managed by the European Technology Platforms (ETPs), by Joint Technology Initiatives (JTIs), ESFRI, EIT, and by the European Research Council (Table 7.4). As shown, 45 per cent of the respondents do not have an opinion on the new initiatives outside Cooperation. This could be an indication of little knowledge about these new instruments, i.e. that they do not know the rules and arrangements in these and are not aware of - and hence not in a position to assess the need for financial support schemes. 
These results may be interpreted as indication of "once bitten twice shy”: Among respondents from the higher education sector, the need for improvement of co-funding is higher than when the respondents include applicants. In contrast, in the institute sector this is obviously a factor that is a concern for the applicants more so than among those who have participated.

Table 7.5 FP6 participants: Effects of Norwegian financial support schemes for the 7th Framework Programme. Per cent that find substantial improvements needed, by respondent's sector.

\begin{tabular}{|c|c|c|c|c|c|c|c|c|}
\hline \multirow{2}{*}{$\begin{array}{l}\text { Is there a need for improvement } \\
\text { in the financial support schemes } \\
\text { provided by the national } \\
\text { authorities responsible for the } \\
\text { Norwegian participation in FP7? }\end{array}$} & \multicolumn{2}{|c|}{ Research Institute } & \multicolumn{2}{|c|}{$\begin{array}{l}\text { Higher Education } \\
\text { Institution }\end{array}$} & \multicolumn{2}{|l|}{ Enterprise } & \multicolumn{2}{|l|}{ Other } \\
\hline & $\begin{array}{r}\text { Substantial } \\
\text { improvements } \\
\text { needed } \\
\end{array}$ & $\mathrm{N}$ & $\begin{array}{r}\text { Substantial } \\
\text { improvements } \\
\text { needed } \\
\end{array}$ & $\mathrm{N}$ & $\begin{array}{r}\text { Substantial } \\
\text { improvements } \\
\text { needed } \\
\end{array}$ & $\mathrm{N}$ & $\begin{array}{r}\text { Substantial } \\
\text { improvements } \\
\text { needed }\end{array}$ & $\mathrm{N}$ \\
\hline $\begin{array}{l}\text { a) Financial support for preparing } \\
\text { proposals }\end{array}$ & 31,5 & 232 & 23,4 & 124 & 22,6 & 84 & 17,5 & 63 \\
\hline $\begin{array}{l}\text { b) National direct co-funding } \\
\text { (medfinansiering fra Norges } \\
\text { forskningsråd) of participation in } \\
\text { the EU projects }\end{array}$ & 37,0 & 230 & 43,2 & 125 & 27,7 & 83 & 20,6 & 63 \\
\hline $\begin{array}{l}\text { c) National financial support } \\
\text { (medfinansiering fra Norges } \\
\text { forskningsråd) of participation in } \\
\text { activities organized and managed } \\
\text { by the European Technology } \\
\text { Platforms (ETPs), Joint } \\
\text { Technology Initiatives (JTIs), } \\
\text { ESFRI, EIT, European Research } \\
\text { Council (ERC) }\end{array}$ & 29,1 & 230 & 27,6 & 123 & 17,6 & 85 & 11,1 & 63 \\
\hline $\begin{array}{l}\text { d) Co-ordination of funding } \\
\text { between Framework Programme } \\
\text { activities and relevant national } \\
\text { R\&D and innovation support } \\
\text { schemes/programmes }\end{array}$ & 28,8 & 229 & 25,6 & 125 & 20,0 & 85 & 19,0 & 63 \\
\hline $\begin{array}{l}\text { e) Financial support for long-term } \\
\text { positioning in Framework } \\
\text { Programme-selected areas of } \\
\text { National strategic importance }\end{array}$ & 35,7 & 230 & 32,0 & 125 & 25,9 & 85 & 21,0 & 62 \\
\hline
\end{tabular}

Source: Survey to Norwegian participants in FP6. 
FP7 applicants: Effects of Norwegian financial support schemes for the 7th Framework Programme. Per cent that find substantial improvements needed, by respondent's sector.

\begin{tabular}{|c|c|c|c|c|c|c|c|c|}
\hline \multirow{2}{*}{$\begin{array}{l}\text { Is there a need for improvement } \\
\text { in the financial support schemes } \\
\text { provided by the national } \\
\text { authorities responsible for the } \\
\text { Norwegian participation in FP7? }\end{array}$} & \multicolumn{2}{|c|}{ Research Institute } & \multicolumn{2}{|c|}{$\begin{array}{l}\text { Higher Education } \\
\text { Institution }\end{array}$} & \multicolumn{2}{|l|}{ Enterprise } & \multicolumn{2}{|l|}{ Other } \\
\hline & $\begin{array}{r}\text { Substantial } \\
\text { improvements } \\
\text { needed }\end{array}$ & $\mathrm{N}$ & $\begin{array}{r}\text { Substantial } \\
\text { improvements } \\
\text { needed }\end{array}$ & $\mathrm{N}$ & $\begin{array}{r}\text { Substantial } \\
\text { improvements } \\
\text { needed }\end{array}$ & $\mathrm{N}$ & $\begin{array}{r}\text { Substantial } \\
\text { improvements } \\
\text { needed }\end{array}$ & $\mathrm{N}$ \\
\hline $\begin{array}{l}\text { a) Financial support for preparing } \\
\text { proposals }\end{array}$ & 33,4 & 380 & 20,4 & 255 & 23,8 & 181 & 2,7 & 37 \\
\hline $\begin{array}{l}\text { b) National direct co-funding } \\
\text { (medfinansiering fra Norges } \\
\text { forskningsråd) of participation in } \\
\text { the EU projects }\end{array}$ & 48,5 & 377 & 32,0 & 253 & 29,2 & 178 & 18,9 & 37 \\
\hline $\begin{array}{l}\text { c) National financial support } \\
\text { (medfinansiering fra Norges } \\
\text { forskningsråd) of participation in } \\
\text { activities organized and managed } \\
\text { by the European Technology } \\
\text { Platforms (ETPs), Joint } \\
\text { Technology Initiatives (JTIs), } \\
\text { ESFRI, EIT, European Research } \\
\text { Council (ERC) }\end{array}$ & 33,5 & 376 & 21,5 & 251 & 21,5 & 181 & 10,8 & 37 \\
\hline $\begin{array}{l}\text { d) Co-ordination of funding } \\
\text { between Framework Programme } \\
\text { activities and relevant national } \\
\text { R\&D and innovation support } \\
\text { schemes/programmes }\end{array}$ & 34,9 & 375 & 24,5 & 249 & 25,0 & 180 & 22,2 & 36 \\
\hline $\begin{array}{l}\text { e) Financial support for long-term } \\
\text { positioning in Framework } \\
\text { Programme-selected areas of } \\
\text { National strategic importance }\end{array}$ & 36,9 & 377 & 29,9 & 251 & 24,0 & 179 & 16,2 & 37 \\
\hline
\end{tabular}

Source: Survey to Norwegian applicants in FP7.

\section{Effects of performance based budgeting and incentives to participate in the Framework Programmes}

Part of the basic state funding of Norwegian higher education institutions and research institutes is based on performance indicators. The survey provides data on how the participants perceive the Norwegian performance-based budgeting in terms of incentives to participate in the Framework Programme. Overall, 26 per cent of FP6 participants and 28 per cent of FP7 applicants perceive the performance-based budgeting to give incentive to increased participation: a minority find to the contrary. The larger part has no opinion. Somewhat surprisingly, the rejected FP7 applicants, more often than the funded applicants, find performance-based budgeting an incentive to participate (30 versus 22 per cent, Table 7.8).

A notable difference is found between the perceptions of the FP6 and FP7 participants from the higher education institutions (HEI). Whereas only 10 per cent of the FP6 participants at HEIs perceive performance-based budgeting as an incentive to decrease participation in EU research (Table 7.7), as much as 23 per cent of the FP7 applicants perceive the performance-based budgeting as an incentive to decrease participation (funded applicants, Table 7.8).

This is hard to explain, but may be linked to incomplete information on the details of the performance-based budgeting, as well as different local distribution models. Several 
respondents commented on the performance-based budgeting in the open comment box in the questionnaire. Some commented on the publication scores of performance-based budgeting and seemed unaware of the EU funding part of the performance scores. Respondents from some higher education institutions commented that performance-based budgeting at their institution provided no incentive for researchers or the research group, as they did not see the money, but that other institutions had models giving the active researchers proper credit. It was, moreover, commented that the incentives given by performance-based budgeting for the research institutes are miniscule. It was also noted that performance-based budgeting favours publications with few authors and gives no incentive to participating in large consortia, and that collaboration and networking activities are not given any credits.

These results and comments clearly underline how participation in the FPs are linked to a very broad spectre of factors that affects the research activities in Norwegian universities, colleges and research institutes. This also implies that the direct incentive based measures have mixed direct effects. Similarly it can be argued that FP funding and choice to engage in FPs is not directly "all about the money". The FPs also contributes to reputation and status that indirectly may also affect the internal distribution of resources. But such effects vary locally, and as suggested by informants EU funding might be more valued as a sign of research quality and standing at the research strategic level than on the "laboratory floor".

Table 7.7 Effects of FP6 participants on result-based funding and incentives to participate in the Framework Programmes. Per cent.

\begin{tabular}{lrrrrr}
\hline $\begin{array}{l}\text { To what extent does the new result-based } \\
\text { funding system for higher education institutions } \\
\text { and research institutes provide incentives to } \\
\text { participate in the Framework Programmes }\end{array}$ & $\begin{array}{r}\text { Incentive to } \\
\text { decrease } \\
\text { participation }\end{array}$ & $\begin{array}{r}\text { ro } \\
\text { changed } \\
\text { incentives }\end{array}$ & $\begin{array}{r}\text { Incentive to } \\
\text { increase } \\
\text { participation }\end{array}$ & No opinion & N \\
\hline Research Institute & 3,5 & 17,6 & 21,1 & 57,7 & 227 \\
Higher Education Institution & 9,6 & 22,4 & 42,4 & 25,6 & 125 \\
Enterprise & 7,1 & 6,0 & 20,2 & 66,7 & 84 \\
Other & 1,6 & 3,2 & 16,1 & 79,0 & 62 \\
\hline Total & 5,4 & 15,1 & 25,7 & 53,8 & 498 \\
\hline Source: Survey to Norwegian participants in FP6. & & & & &
\end{tabular}


Table 7.8 To what extent does the new result-based funding system for higher education institutions and research institutes provide incentives to participate in the Framework Programmes? FP7 applicants' replies by applications status. Per cent.

\begin{tabular}{|c|c|c|c|c|c|c|c|c|c|c|}
\hline \multirow{2}{*}{$\begin{array}{l}\text { Organi- } \\
\text { sation } \\
\text { type }\end{array}$} & \multicolumn{2}{|c|}{$\begin{array}{l}\text { Incentive to } \\
\text { decrease } \\
\text { participation }\end{array}$} & \multicolumn{2}{|c|}{$\begin{array}{c}\text { No changed } \\
\text { incentives }\end{array}$} & \multicolumn{2}{|c|}{$\begin{array}{l}\text { Incentive to } \\
\text { increase } \\
\text { participation }\end{array}$} & \multicolumn{2}{|c|}{ No opinion } & \multicolumn{2}{|c|}{$\mathbf{N}$} \\
\hline & Funded & Rejected & Funded & Rejected & Funded & Rejected & Funded & Rejected & Funded & Rejected \\
\hline $\begin{array}{l}\text { Research } \\
\text { Institute } \\
\text { Higher } \\
\text { Education }\end{array}$ & 12,0 & 10,7 & 22,2 & 21,0 & 22,2 & 30,9 & 43,5 & 37,4 & 108 & 262 \\
\hline Institution & 22,6 & 10,1 & 20,8 & 31,2 & 30,2 & 36,2 & 26,4 & 22,6 & 53 & 199 \\
\hline Enterprise & 4,4 & 2,0 & 19,1 & 20,0 & 14,7 & 17,0 & 61,8 & 61,0 & 68 & 100 \\
\hline Other & 0,0 & 4,5 & 20,0 & 13,6 & 26,7 & 18,2 & 53,3 & 63,6 & 15 & 22 \\
\hline Total & 11,5 & 8,7 & 20,9 & 24,0 & 22,1 & 29,8 & 45,5 & 37,4 & 244 & 583 \\
\hline *All & 9 & 3 & 22 & & 27 & 7,5 & 40 &, 3 & 85 & 58 \\
\hline
\end{tabular}

*Also including 31 respondents for which information about application outcome is missing.

Source: Survey to Norwegian applicants in FP7.

\section{Other aspects related to instruments and incentives}

The change in the funding regime of EU from FP6 to FP7 has apparently not had an effect on the level of participation of Norwegian HEIs. Hence this change may be interpreted as having a beneficial effect on HEI participation and serve as an incentive for increasing future participation. For research institutes, on the other hand, these changes have not contributed to solving the financial problems related to their participation in the FPs. The problems seem to be related to the basic funding of research institutes, which roughly speaking works this way: Whereas universities (HEIs) are rewarded with approximately 2 NOK in basic funding for each 1 NOK they obtain in funding from the EU, the equivalent rewards for research institutes are minuscule, almost zero. In the long run, this may become a disincentive, although most research institutes attempt to compensate this by finding "creative solutions" such as relabeling other projects (which have funding) as their in-kind co-funding for their participation in FPs. This aspect needs to be taken into consideration in the criteria for basic funding of research institutes and is a specific responsibility of the Research Council of Norway.

Further, new financial rules regarding participation in certain types of projects in FP7, in particular coordination and support or supporting actions (CSAs), render it difficult for many, if not all research organisations in Norway, to participate. Though FP7 covers 100 per cent of actual personnel costs in these projects, it only accepts 7 per cent of actual personnel costs as refundable overhead costs. (In FP6 this threshold was 20 per cent for specific support action (SSAs)). In a high cost country such as Norway, R\&D overheads constitute a considerable part of overall costs for all research organisations, subsequently implying that it is more costly for high-cost country researchers to compete than those in low-cost countries. Furthermore, the fact that FP7 covers 100 per cent of actual personnel costs means that national authorities are not allowed to co-fund participation in these 
projects. Hence, participation in CSAs is often considerably more expensive for research organisations than ordinary collaborative projects. For Norwegians in particular, this is a clear disincentive to participate in these types of projects. Such projects are often of particular strategic research policy importance and participation in these projects should be better organized and tackled by Norwegian authorities, in particular by the Research Council of Norway.

This issue is of particular concern because CSAs are not the only instrument by which such unfavourable financial conditions for Norwegian participation are introduced. Many calls launched by the European Research Council, JTIs, as well as other framework programmes, such as the Lifelong Learning Programme (LLP) and the Competitiveness and Innovation Framework Programme (CIP) launch activities with the same or even less financially favourable conditions. In addition, different financial rules and standard renders it difficult for many research organisations to understand the actual economic implications of participation in these activities in their budgetary processes.

The observations above give us reason to suggest that the Research Council of Norway initiates a project with the objective of investigating how serious the disincentives are for participation, i.e. the low percentage of overheads cost coverage and other unfavourable financial rules in all relevant international schemes/programmes co-funded by the Norwegian state. The project should result in a set of recommendations concerning methods and strategies for making participation in these more attractive.

\subsection{Norway's influence on EU research priorities and participation in programme committees in FPs}

Although Norway is a small country and a non-member of EU, the main point of this section is that in spite of this, there are opportunities for exerting influence on EU's research priorities that are open for Norway, as for all others. However, participation in formal mechanisms such as program committees is not effective for these purposes, although this is important for many other reasons. As will be explained, the EU-system, in contrast to many other European bureaucracies, is at many points open and malleable, specifically at the early stages of processes that may eventually become a formal policy initiative or decision, such as the formation of a new FP. However, participation in program committees, which have formal status as Comitology Committtes, provides only incremental opportunities for influence for its participants.

In programme committees, Norway is represented by a delegate, one for each thematic programme in Cooperation, and one superior committee, in total eleven delegates. In addition, Norway is represented with delegates in Ideas, People, Capacities and its subcommittees, Joint Research Centre and the committees for the programs covered by the article 169. These delegates are usually mid-level officers from ministries that have "sector 
responsibility" for a particular field of research, such as an official from the Ministry of Environment who represents Norway as a delegate in the programme committee of FP7's Environment. In the ministries, the delegates are usually officials in the organisational entity responsible for research. In addition to delegates, employees from the RCN attend meetings as experts. The role of the expert is to support the delegate from the ministry as an advisor.

\section{Channels and instruments for influencing the FP}

The EEA (European Economic Area) Agreement came into force in 1994. This inaugurated a new policy regime for Norway in areas covered by the Agreement. Norway does not have access to formal ${ }^{91}$ Council meetings. EEA membership grants very limited access to the political process within the EU and Norway's participation is primarily restricted to membership in preparatory and implementation committees. For this reason, a central part of Norwegian policy for Europe, as evident in a recent White Paper on this ${ }^{92}$ states that Norway's attention and energy should be focused on the early, decision shaping stage, when the EU is preparing new policies and regulations: The strategic work for promoting Norwegian positions should be done prior to formal decision making processes in the EU institutions. Translated into the area of research policy, a core question concerns how to influence the shaping of the profile and the FPs in its decision-shaping stage and in the process where overall principles and priorities of the FPs are elaborated. This concern is reflected in the EU strategy elaborated by the Ministry of Education and Research (cf. Chapter 2). However, Norway's EEA membership status sets some parameters for Norway's ability to pursue such a strategy that needs to be pointed out, although policy documents and the informants also reflect these.

First, the overall development of the FP volume is, of course, outside of the possible area of Norwegian influence as decisions about the size of the FP budget are determined by the much larger budgetary process and deals struck in the EU long term financial perspective. The rules that apply make the EU budget for FPs dependent on negotiations between the member states on relative appropriations according to policy area. Since the total amount of the EU own resources cannot exceed 1.24 per cent of gross national income (GNI) of the EU, an increase in the FPs budgets has to be taken from other policy areas (in particular the funds for the Common Agricultural Policy). The considerable increase in the FP budget

91 The Norwegian Minister of Education and Research has, since the German chairmanship of the European Council in 2007, been invited to attend the informal meeting in the Council of fellow ministers of education and research. Although some interpret this as symbolic and inconsequential, others suggest that this is significant, because these meetings are often formative, with more open agendas than the formal meetings. They also suggest that Norway's non-membership does not really represent barriers in terms of obtaining high-level access and participation in important processes. Both way, this opportunity and point of access, combined with Norway's attendance in the CREST and its sub-committees, indicate that there are numerous points of interaction and influence with the EU policy making system relevant for research policy and strategy.

92 St.meld. nr.23 (2005-2006) Om gjennomføring av Europapolitikken. 
(see Chapter 2) does not increase the money the member states have to pay. For Norway, however, this is not the case; an increase in the FP budget implies an increase in the Norwegian contribution to the FP funds. On this point Norwegian policy-makers cannot do much more than pay close attention to the developments and make sure that budgetary shifts come to the attention of the domestic arena. Even though such larger decisions cannot be influenced, it is paramount for Norway's involvement in EU research that these developments are closely monitored and communicated to the domestic policy-making and stakeholder community. The latter is also the second a corner stone of the overall government EU strategy. Monitoring the developments in the EU is primarily a responsibility for the Norwegian mission to the EU.

Norway is formally not part of the Lisbon Strategy, and under no moral or other obligation to nationally organize and respond to the Lisbon agenda. Neither does it participate in the soft law processes such as activities organized under the Open Method of Coordination. Yet it is an official objective to "actively relate to the EU "Growth and Jobs"”(Lisbon strategy), and the Ministry of Industry and Trade have the coordinating role and the responsibility for the Norwegian "mirror" report on the developments in the areas encompassed by the Lisbon strategy. Given the relatively close link between the ERA and the EU Lisbon strategy (see Chapter 2), the overall monitoring of the broader context is relevant as a framework for Norway's participation in the FPs in so far as this may provide a basic understanding of the dynamics in EU's research policy and strategy. An assessment of Norway's interactions and response to the EU Growth and Jobs strategy is beyond the mandate of this evaluation, yet there are indications that the uses of such soft law processes have become more important. For issues related to research policy, this is covered by the Ministry of Education and Research, together with the Research Council of Norway. No other ministry is equally engaged in such processes as this Ministry (Gornitzka 2009).

The shaping of the FPs programme profile and internal distribution of funds to different activity areas and instruments is an extremely complex process and largely understudied (Muldur et al. 2006). In order to conduct an adequate assessment of the relative effectiveness of Norwegian strategies for influencing the shaping of FP decisions one would have to address the question of what goes into the position formation of the Commission and the inter-institutional relationships between Commission, the Council and the European Parliament beyond the formal description of the decision-making process that shapes the FP. Trying to understand, much less influence FP priority-setting, requires more detailed understanding of what can most charitably be described as an opaque, if not impenetrable, process. Of course, Norway should seek to have as much influence on setting FP priorities as possible, and to as quickly and effectively as possible disseminate information about priorities/programmes to national researchers; but that this is a necessary but minor facet of increasing national success in FP competitions. Several of the interviewees have, however, commented on the impediments and critical success factors 
for promoting the Norwegian points of view. The role of competence is important in this. This is discussed below.

\section{The role of competence}

What has emerged in the evaluation is that the main basis for influence in the EU system is competence - not only in the research projects, but also in the committees under the Commission in general. Competence in this context means individual expertise in a scientific field or techno-economic domain, including cultural and political ability and skills to apply this, and ability to obtain recognition as an authority or respected person on the relevant topic. The studies of Commission committees/expert groups (i.e. committees that the Commission establishes and consults in the preparatory stages) ${ }^{93}$ provide an important access point in the early stages of the process. Participants in these expert committees take part by virtue of their role as the national representative and their role as technical experts (Trondal and Veggeland 2003). The working methodology in these committees is more akin to arguing than bargaining over conflicting interests (Egeberg, Schaefer and Trondal 2006). DG Research is among the directorates general in Brussels that uses this type of consultation most frequently. More than the average expert groups in the EU, the expert groups under the DG Research are composed of a combination of national ministry and agency officials and various types of stakeholders from industry and research communities.

The FP's programme committees ${ }^{94}$ are part of the Comitology and follow the procedures of the Comitologty Commitees in general. They are venues for advising and controlling the Commission on the activities in the various thematic areas of the FP, and on matters relating to criteria for project support, and general issues on how the FPs are being implemented. Norwegian representatives have the right to be heard but no voting rights. Norway's treaty with the EU on participation in FPs stipulates that Norway may participate in the governing bodies of FPs, more specifically, in the activities of the programme committees. From the Norwegian side, participation in these governing bodies is

93 The participation of Norway in these settings can be made with reference to Article 99.1.of the EEA Agreement that states: "As soon as new legislation is being drawn up by the EC Commission in the field which is governed by this Agreement, the EC Commission shall informally seek advice from experts of the EFTA States in the same way as it seeks advice from experts of the EC Member States for the elaboration of its proposals”.

Currently the following Comitology Committees are operational in research policy: C14400 - Standing Committee for Agricultural Research (SCAR); 2. C32000 - The programme committee for the execution of the specific programme 'Co-operation' implementing FP7 C32001 Specific; C32002 Health; C32003 Food, Agriculture and Fisheries, Biotechnology; C32004 Nano-sciences, Nano-technologies, Materials and new Production Technologies; C32005 Energy; C32006 Environment; C32007 Transport (including Aeronautics); C32008 Socio-economic Sciences and Humanities; 3. C32100 The programme committee for 'Ideas'; 4. C32200 The programme committee for 'People'; 5. C32300 - The programme committee 'Capacities'; - C32301 - Research Infrastructures (DG RTD and DG INFSO); C32302 Research for the benefit of SMEs; C32303 - Regions of Knowledge, Research Potential and Support for the coherent development of research policies; C32304 Science in Society; C32305 Activities of International Co-operation. 
coordinated by the Ministry of Education and Research, which also represents Norway in the EU Scientific and Technical Research Committee - the CREST-committee. The various programme committees of FPs are chaired by civil servants in the European Commission, usually high-ranking officials from one of the fifteen Directorates within the European Commission's Directorate General for Research Technology Development (DG RTD) that is responsible for a particular thematic priority. Each participating nation is represented in these bodies by a delegate. However, the delegates of the associated nations to the FP (such as Norway) do not have voting rights. As pointed out by all informants, this is really inconsequential because of the modus operandi of these programme committees (they seldom vote anyway), but more significantly because of the dynamics and processes of how research agendas are set in the EU system.

The importance of these committees is linked just as much to what happens around them informally as within meetings. Interviewees that have participated in the FP committee structure, clearly voice similar concerns: Norwegian participation in these fora has to be anchored in issue competence and that is the basis for being heard. Direct promotion of Norwegian interests without solid general arguments does not stand much of a chance. Interviewees (especially those who have participated in the FP programme committees) commonly refer to how it has become "crowded around the table", especially since the enlargement and the full entry of the new Member States. Some also argue that the Norwegian non-membership status is an impediment in subtle more than overt ways, such as "not being heard". This implies that the Ministry of Education and Research's current strategic emphasis on selection of competent and experienced officials for participation in FP7 committees will continue to be a core issue. Participation in the committee structures is demanding on the Ministry of Education and Research, on the sector ministries that participate and on the Research Council of Norway, but nonetheless a core intake into being part of shaping the FPs. Several of the FP programme committee members interviewed in the evaluation emphasized the importance of investing resources in preparation, and in retaining venue competence. ${ }^{95}$

Committees are not only a site for interest promotion, but a site for learning where national officials familiarize themselves with the nature of the EU administrative system. They represent an important intake into the information on developments within European research policy in general. In connection with these committee meetings the officials can develop alliances with Member States' representatives in the committee in order for them to voice common concerns and opinions - although this is often difficult to achieve. Some of the informants also note that the role of the FP programme committees is changing in a sense that there is less leeway to influence the prioritization of projects to be funded, for

95 Venue competence is a type of proficiency with a high level of tacit knowledge that enables the holder of this to understand, interpret and maneuver goal oriented in the highly politicized research policy and strategy environment inside and surrounding the EU's FPs. 
example. Such changes in the longer turn may change the significance this part of the committee system in the FPs.

\section{A changing consultation regime for FPs?}

The importance of the committees discussed above for the purpose of influencing the shape of the FPs, together with active and competent participation in the expert groups and programme committees is important, but this is also part of a much larger system of consultation. As noted above, there is little systematic knowledge on the mechanisms that in practice is important for determining the shape of the FP. The size and complexity of the programme has grown and so we can assume that the complexity of the dynamics that shapes the makings of an FP has increased as well. Figure 7.1 attempts to model core elements that serve as input in the FP7 consultation system. This system is open and provides access opportunities beyond Norwegian participation in the Committee system of the FP and EU research policy domain in general. One of these is participation in FP online consultation system, as was used in connection with the "Expression of Interest" process at the start of FP6, writing of position papers, and visible participation in DG conferences and meetings.

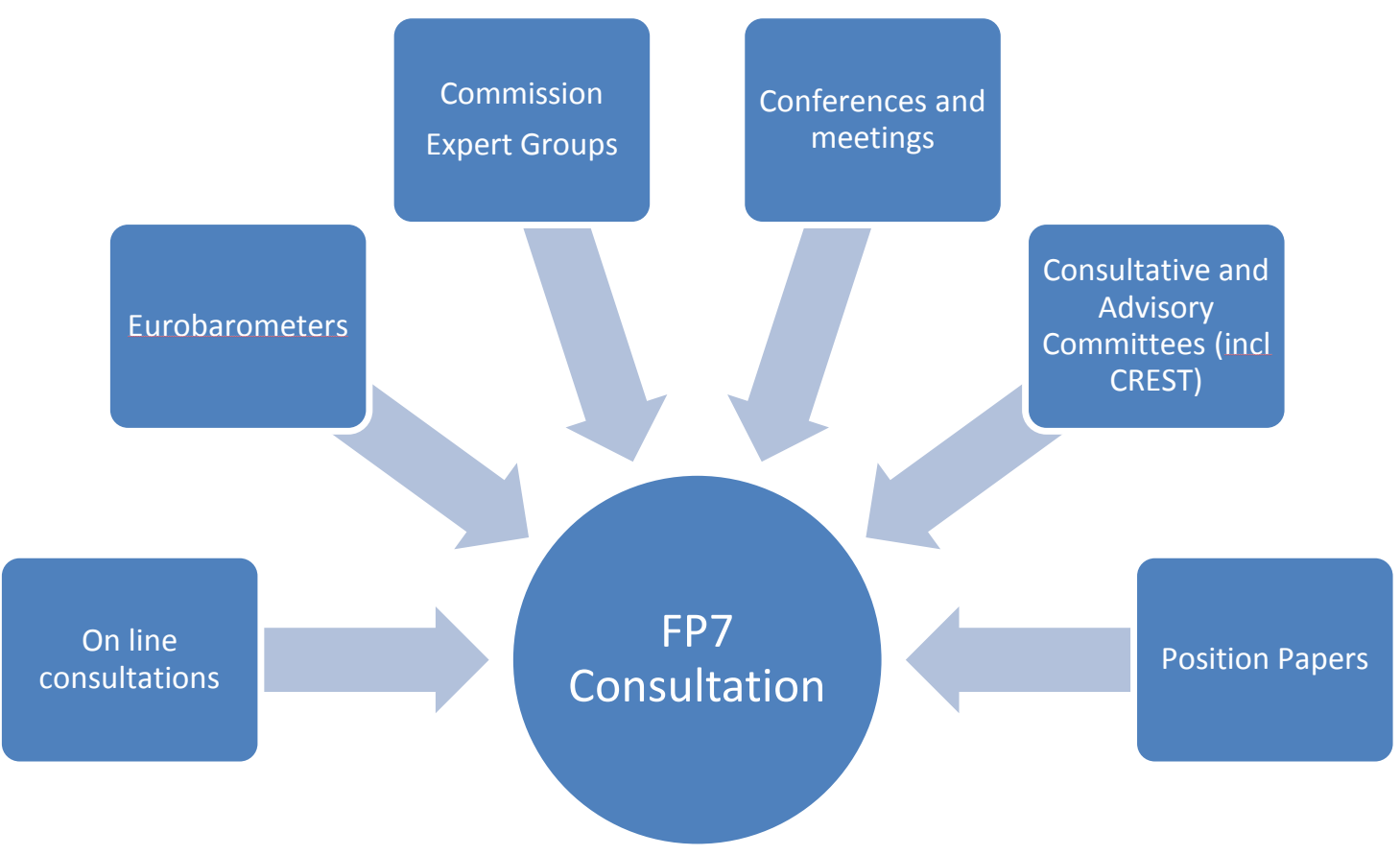

Figure 7.1 The structure of Framework Programme consultation. Adapted from Muldur et al. (2006, p. 150)

Although more official, the role of CREST and its sub-committees is also important. In this committee, Norway has a long tradition of participation and Brussels is a prioritized venue for Norwegian policy makers. This committee has changed its role somewhat over the 
years. In addition to the advisory capacity for the FPs, it has been central in orchestrating the application of the Open Method of Coordination (OMC) in the area of research, specifically in connection with the follow-up to the Barcelona target. Hence, Norway's participation in this group is an important piece in the mosaic that makes up the Norway's interface with the FPs and European research policy more widely. This is, for instance, a venue where new instruments such as ERA-NET and article 169 are being discussed and, for this reason, serves as a listening post for such developments. Current discussion in the EU on ERA governance may lead to a shift in the responsibilities of CREST.

In summary, a close look at the EU system shows that there is a broad range of access points where Norwegian participation outside the more formal participation in programme committees is possible and has also been prioritised to some extent. Although exact data on this is not available, the impression is that Norway should put much more emphasis on this aspect in its participation in EU research. There are at least two reasons for this. First is the potential for exerting influence and as surveillance and learning mechanism. This is recognized as significant by most nations. However, they all seem to struggle with how to do this. Secondly, this needs to be coupled with decision-making processes and prioritysetting in the national research community, and less with the ministries and official bureaucracies. But mastering these potentials and opportunities is demanding; it requires organized and persistent attention to such opportunities and considerable venue competence in combination with top level expertise ("knowing what you talk about"). The experiences reported by the interviewees are testimony to the complex web of processes involved in shaping the priorities and profile of the world's biggest research programme. These are processes intertwined with broader political processes outside the more narrow confines of the research policy priority-setting, as is illustrated in the Norwegian efforts to keep energy research in the FPs.

The multiple new instruments that are being developed are challenging (cf. Chapter 3). Some of these are changing with the evolution of the instruments and thematic emphasis: "Ideas” for example is very much organized at an arm's length from the Member States' influence: the new instruments referred to in Chapter 2 have different funding and decision-making procedures to the core the FPs. It demands attention be paid to even more arenas. This development also represents new actor constellations where research communities, national administrations, national funding agencies and industry are blended in new and demanding ways, for instance in relation to the concept of Joint Programming. In practice it is not only daunting for promoting the national interest but also a major challenge in developing the Norwegian position and priorities - and for development of national funding mechanisms. As emphasized earlier, successful participation in these requires a broad range of competencies - the types of competence that exist in research communities in Norway, but less so in ministries and research funding agencies. In a follow-up of the evaluation, careful analyses of this should be made in order to develop strategy and incentives that will develop these possibilities better. However, this needs to 
be approached with an understanding that the essential element in this is motivating highly competent people to do work in these systems. In order to motivate these people, a system of incentives needs to be developed that really remunerates the time, effort and energy that this requires. Remuneration by some abstract points in the funding scheme for the institution they work for will not do, nor will appeal to some type of national charity work either.

In general, one may observe that the relationship between the delegations that represent Norway in program committees and the governing bodies in the Research Council of Norway is weak: People who make decisions on research priorities in programme committees in the Research Council of Norway have indirect relationship with the people who are active in the governing bodies in the EU FP system - and, more general, with the EU Commission and DG RTD. In some of the Large-scale programmes presented in chapter 5 such as NANOMAT and NORKLIMA, the experts and NCPs seem to have close relationship with their programme committees. This may possibly have contributed to the high awareness and pattern of participation of NORKLIMA and NANOMAT in international research collaboration and in EU FP.

A systematic information asymmetry seems to exist; the people who make decisions on Norwegian research do not participate in, or are distant from, the discussions and processes in research priority setting in the EU system. There are mechanisms that counterbalance this information asymmetry, but they are vulnerable, based on informal communication networks and dependent on the personality and working style of the individuals involved. One way that this works is informal consultations prior to programme committee meetings in Brussels with knowledgeable members of the Norwegian research community. In the relationship between ministry delegates and the RCNs representative this is a flexible arrangement, but also somewhat vulnerable to changes in personnel. In general, delegates do not participate in relevant decision-making bodies in the RCN-system because they are not part of this, e.g. members of program committees in RCN. RCN's NCPs and experts seldom participate in these either, because they are part of the administration. The topics related to participation in EU research are not often on the agendas of these governing bodies, so their presence is not required in the meetings, although there are a few exceptions. These structural and organisational aspects may partly explain why internationalisation and participation in EU FPs so far play a minor role on the agendas of governing bodies in the RCN-system. 


\subsection{National governance processes and coordination of Norway's participation in the FPs}

In this section, the main topic is governance processes related to Norway's participation in FPs. More specifically, issues related to national goals as stated in the national research policy on Norway's participation will be addressed, (cf. Chapter 2) together with related "sector" goals in stakeholder ministries, i.e. to what extent these are clear, comprehensive and adequately coordinated. Furthermore, the section will identify and assess whether there are issues that need to be improved in terms of organisation, coordination and prioritysetting in the ministries and the RCN. To the extent data is available, the analyses will make comparisons of equivalent systems of governance and coordination in other countries that participate in FPs.

These topics are complex and difficult to penetrate in exhaustive way within the scope of the evaluation, and to some degree they are also sensitive and subject to numerous interpretations. However, the data collected and analyzed indicate that although the policy goals and related strategies are clear, have a sound rationale and high degree of endorsement (consensus) among all relevant stakeholders, their implementation is generally loose in terms of coordination and leadership. "Loose" is used to characterize that the fact that coordination is based on a distributed (in contrast to centralized) principle and subject to a soft leadership role by MER. This primarily reflects the strength of the "sector principle" in Norwegian research policy. The important question is whether or not this is satisfactory in terms of the goals in Norway's research policy and strategy related to internationalisation - and in terms of Norway's participation in EU FPs and the anticipated evolution of ERA. The brief answer is "yes". The status quo is adequate primarily because reforms or changes of the existing system, if feasible, will probably not contribute to solutions relevant to important challenges related to Norway's participation in EU FPs and ERA, i.e. increasing the participation of the Norwegian R\&D community and alignment of Norwegian research priority setting with international research and development. These challenges should be solved in the relevant institutions, organisations and communities, in particular within the system governed by the RCN, i.e. topics that are addressed in other parts of this chapter. In spite of this general comment, there are issues and areas that need attention and adjustments. These are presented in the following.

The Ministry of Education and Research (MER) has the general coordination responsibility for research and has, since 2004, also been reassigned constitutional responsibility for Norway's participation in EU FP and ERA. Prior to this, the Ministry of Trade and Industry had this responsibility for two years, partly because participation in EU FP at that time was considered most relevant for innovation policy and industrial development. Prior to this, the participation in EU FP had been the responsibility of the Ministry of Education and Church Affairs, i.e. the predecessor of MER today. The role of the MER in Norway's participation in the FPs and ERA is to develop Norway's research policy and strategy, as 
explained in Chapter 2. In addition, it has a role in coordinating the Norwegian government's relationship to the EU in matters related to Norway's participation in FPs and the ERA. The operational aspect of this is done by a small number of officials within the Department of Research in the MER. The ministry has no powers of authority over other ministries, however, it has a responsibility for coordination of other ministries on matters related to their relationship with the EU in matters of research. This encompasses formulation and communication of Norwegian priorities for European research cooperation through the mechanisms managed by the EU. The MER also manages the system of delegates to the programme committees described earlier. An official of MER is also head of the delegation to CREST. The MER also coordinates Norwegian participation in CREST's system of sub-committees. Hence, they are in close contact with an important research policy mechanism in EU. Formally, in the national budget, Norway's budget commitments and payments for participation in EU FPs are made through the budget of MER. However, responsibility for funding of activities and instruments in the Research Council of Norway related to strengthening Norwegian participation in EU FPs is shared with other ministries, but MER does not have powers of authority in this because at this is within the domain of the "sector principle". Although MER's role is primarily designated as "coordination", implementation of this is a type of leadership which is constrained by the boundaries set by the "sector principle”. MER's role in coordination is done primarily by means of three inter-ministerial mechanisms:

- The EEA special committee on research ${ }^{96}$, to which all ministries with a responsibility for EU-research participation are invited. The Research Council of Norway and the Research Counsellor at the Mission of Norway to the EU attend the meetings regularly.

- Delegate meetings, to which all delegates and experts to EU FP programme committees are invited. The main function of this is information and consultation no decisions are made. This committee is large, approximately 25 to 30 representatives from various ministries and the Research Council of Norway attend.

- The research committee of the ministries ${ }^{97}$, to which top-level officials responsible for research in "sector" ministries are invited. The committee mainly focuses on coordination related to national research policy and activities, including budget matters. According to informants, the main function of this body is also information and consultation - no decisions are made.

All committees are chaired by top officials responsible for research at MER. The agendas of the two first meetings consist mainly of presentations and discussions of relevant topics related to Norway's participation in the FPs and the ERA. These are often held by representatives from the Research Council of Norway or from Norway's Mission to the

\footnotetext{
96 Translated from its Norwegian name: ”EØS spesialutvalg for forskning”.

97 Translated from its Norwegian name: ”Departementenes forskningsutvalg”.
} 
EU. Participants are, of course, at liberty to make comments and discuss matters of interest, but no decisions are made apart from general recommendations or admonitions.

As explained in Chapter 2.3 on Norway's strategy for participation in the FPs, the MER has assigned much of the responsibility for implementation to the Research Council of Norway, as evident in the number of actions specified in the strategy. Action no. 16 is significant for MER's relationship to other ministries. This action states that the Research Council of Norway is responsible for formulating strategy documents for participation in each Framework Programme and that this document should state Norway's main priorities and suggest, if necessary, possible adjustments for improving the programme. For implementation, this action requires that the Research Council of Norway develops these in cooperation with the relevant R\&D institutions, and that the Research Council obtains endorsement of these from relevant "sector" ministries. Although this disregards the power asymmetry in the relationships between the ministries and RCN, the logic of this is sound, given the dominant position of the "sector principle" for research policy in Norway and the Research Council of Norway's role as the national research strategic agency and funding body. In the evaluation, obtaining data and understanding how this works was difficult. Hence the picture is somewhat opaque. Action no. 16 has been a topic on the agendas of the inter-ministerial committees mentioned above, but, according to one informant, implementation is not yet completed. The Research Council of Norway’s strategy document on participation in FPs does not discuss or make reference to processes that reflect the criteria set in MER's specification of action no. 16 in terms of obtaining endorsement from relevant "sector" ministries, nor from relevant R\&D institutions. No explicit trace of this shows up in the annual budget proposals of the "sector" ministries. A search for this in the national budget proposals for $2009^{98}$ showed that some ministries, such as the Ministry of Agriculture and Food, acknowledge that MER has the main responsibility for coordination of research and Norway's participation in EU FP. ${ }^{99}$ However, strategic issues related to EU FP are generally absent in the presentations of research policy and activities in the relevant "sector" ministries, save one, the Ministry of Trade and Industry. The Ministry of Health and Care Services, in their national budget proposals for 2008 and 2009 does not even mention participation in FPs apart from stating that Norway participates in radiation projects in Euratom ${ }^{100}$. In general, little attention is

98 The national budget documents for 2009 (St.prp. nr 1 (2008-2009)) were analyzed: Ministry of Agriculture and Food, Ministry of Fisheries and Costal Affairs, Ministry of Health and Care Services, Ministry of Trade and Industry, Ministry of Transport and Communications, and, Ministry of the Environment.

Cf. St.prp.nr.1 (2008-2009), pp-71-72.

In the national budget proposal for 2007 from this ministry, however, on p. 294, there are four sentences on the topic of international research cooperation, one of these state the importance of this and another that states that participation in EU FP7 is important in this context and that development of a strategy for this is needed. In the national budget proposal for 2010 (Prop. 1S (2009-2010)), there is one sentence (p. 222) that states that Norwegian research institutions participate in EU FP7. In addition, the participation in Euratom radiation projects is described. This is also mentioned in the national budget proposals for 2007, 2008, and 2009. 
given to international research cooperation in this document, an observation that does not accord well with the high priority of health in the national research policy, as explained earlier in this chapter and in Chapter 2.

Finding traces of implementation of action no. 16 may be difficult because this is fairly new as an explicit strategic goal. Based on information from informants in the Research Council of Norway, the existing budget processes may serve the same purpose, de facto, as stated in action no. 16, at least to some extent. The Research Council of Norway has instituted a three years budget cycle closely aligned with its research priority and planning process. Formally, obtaining endorsement from the relevant ministries is achieved by presenting them with annual budget proposal documents, which specify and provide the rationale for all the details in the proposals. This initiates a number of bilateral processes between the Research Council of Norway and the relevant "sector" ministry, i.e. negotiations and discussions in which MER apparently has no role. The final outcome of these processes is manifest in the annual national budget proposals, as described earlier: Participation in FPs in general has a modest role in these documents, although there are marked differences, such as the Ministry of Health and Care Services with no traces in the 2008 and 2009 national budget proposals, in contrast to the Ministry of Trade and Industry, in which the FPs and research is given much attention. Hence, given the asymmetric power relationship between RCN and the ministries, one may reasonably question RCN's capability of obtaining the type of endorsement that action no. 16 requires if this is not supported by some type of mandate or authority from top of Norway's political system.

\section{International comparison}

Surprisingly enough, we could not find references to academic work or other studies on how Member States organize their participation in the EU research policy decision bodies in general and in particular in FPs programme committees. In ERAWATCH national country reports and in the ERAWATCH research inventory as well as in ERAWATCH policy mix reports there is wealth of interesting information, but this is more focused on the description and analysis of the national research policy at the Ministerial and Agency levels and on national policies regarding ERA (see Chapter 5 in national Policy Mix reports) and less on how Member States organize their strategy and participation in the Framework Programmes.

Even more surprising is the fact that evaluation reports of national participation in FPs rarely discuss, analyze and reflect upon the issue on the effectiveness of their organisation in terms of the national research policy in shaping and implementing FPs through ministerial meetings at high level, CREST, programme committees, etc. Possibly this question is of a greater importance to Norway, as a participating country in FPs outside EU and hence with a non-member status in EU research policy decisionmaking bodies and processes. Yet this question has apparently not been seriously addressed in an international perspective. 
Nevertheless, the recent evaluation of the FP6 (the "Rietschel-report") points also to the need of a transparent consultation with stakeholder communities and a explicit "programme logic" for a robust and effective FP design. This indicates also that there is a need for a thorough analysis of how Member States and other participating countries organize politically and administratively their national participation in FPs from the phase of FP design to the phase of evaluation results and outcomes of an $\mathrm{FP}^{101}$.

Denmark, Switzerland, Sweden and Finland have published evaluations of their participation in FP6. The Swiss evaluation (SER, 2008) and the Danish evaluation (Forsknings- og Innovationsstyrelsen, 2008) are mostly a presentation of facts and figures, similar to the presentation and analyses made in Chapter 3 in this report.

The evaluation of Finland's participation in FP6 (Kuitunen et al. 2008) provides a brief overview of the Finnish system of organizing its strategy and participation in EU FPs. This system reflects the top-down, somewhat centralized governance of research policy and strategy in Finland, with the Ministerial Committee at the top of a chain. Below this, the EU Committee with an R\&D subdivision has responsibility for governance of Finland's participation in EU research. The Finnish Secretariat for EU R\&D is affiliated with Tekes, the Finnish funding agency for technology and innovation. However, the secretariat also serves the Academy of Finland, the Ministry of Trade and Industry and the Ministry of Transportation and communications. The evaluation of Finland's participation in FP6 presents observations and suggestions that seem similar to those been presented in this report on Norway. The following points are of special interest:

- In a survey of participants in FP6 projects, 21 per cent of respondents in Finland said that they were dissatisfied with the services of the Finnish Secretariat for EU $R \& D^{102}$ The equivalent in Norway, i.e. respondents who said that "substantial improvements were needed" in terms of information and advice from the EU Information Centre, was slightly lower, possibly indicating a stronger effect of the information and counselling services in Norway.

- As in Norway, there is no clear consensus on Finland's performance in the preparation and design of the FPs. According to the evaluation, some suggest that Finns should be more active, i.e. that they are not active enough. On the other hand, others suggest that the Finns already exercise considerable power in a hidden way,

Be this as it may, it is clearly a sign of openness and willingness to improve national participation and co-ordination structures routines from the part of the Norwegian Ministry of Education and Research since in its mandate for this evaluation it is explicitly asked for an international comparison of national policy practices and organisation of the participation policies. Admittedly it is little that we can contribute to this issue in this evaluation, since such a task requires both considerable amount of resources and more time. 
i.e. that they have much influence, in particular in shaping ICT-activities within the FPs This points to the difficulty of making clear assessments of this issue.

- The Finnish evaluation is clear on one point: “..that national interests cannot be promoted if the national priorities are unclear or are in contradiction with each other.” ${ }^{103}$ This is interesting because it accords well with the analyses presented earlier in this chapter.

- Furthermore, the evaluation recommended the following goals for Finland:

- More participation of Finns in EU R\&D decision-making

- More project participation in FP7

- Mobilize new participants

- Utilization of new elements e.g. ERC, JTI, ETP, ERA-NET+

- Involve more companies and more academy-industry cooperation

- More strategic participation - based on better quality analysis

- Better success rate for Finnish coordinators

In November 2008 VINNOVA published a report on the long term impacts of the FPs on the Swedish research system from 1990 to date (Arnold et al. 2008). This evaluation has its main focus on four industrial sectors: Sustainable energy, Life Science and Health, ICT and Vehicles, and five universities in Sweden. It does not make any assessment of the overall governance of the Swedish participation in EU FPs, but has several comments on the Swedish research strategy related to some of the sectors that were evaluated, such as Life Science and Health:

"Policy implementation is in principle fragmented and coordination is carried out informally and on an ad-hoc basis at the research funding level. No formal and obligatory fora for coordination exists in the area of research policy and operations, and it is a well-known fact that lack of comprehensive coordination at this level is a weakness of the Swedish system." (Arnold et al. 2008 p. 79)

Further on, the evaluation suggests that:

"This is a small country on the periphery of Europe with no real research strategy and a notoriously fragmented research community that undoubtedly will need further to specialise in order to survive. Some specialisation within the more applied areas of research is happening as a function of industrial relationships and needs. In more fundamental research, national instruments are only just beginning to appear that promote specialisation and scale.” (Arnold et al., 2008, p. 186)

In terms of policy implications, Technopolis states that the following may be important for Sweden: 
- An acute need to develop strategies for thematic and institutional concentration in the ERA.

- A need to communicate about strategy and needs to the Commission and with the research and industrial communities.

- A requirement to support increased Swedish participation in the Technology Platforms and other new structures such as the JTIs - not least because it is not clear that the FPs will continue in their present form.

- A need to maintain a fully independent set of national strategies and programmes tuned to national needs but more deliberately to consider how to use the complementary resources available from the FPs. A slavish reproduction of the FP priorities is in the interests neither of Sweden nor of Europe.

- A need to find policy mechanisms that can compensate or substitute for the Framework Programme's weakness as an instrument to tackle fragmented SMEand technology-based industries.

- A need for new mechanisms that can go beyond R\&D support to tackle some of the key innovation risks in radical technological change in areas like energy and climate change, where there is not necessarily time available to wait for a market solution to emerge but where risk-sharing between equipment supply and major users is a requirement for transition.

In summing up this brief side-glance to Switzerland, Denmark, Sweden and Finland, none of these have evaluated the governance of their participation in EU FPs. However, the evaluations of Swedish and Finnish participation point to the crucial factor of strategy. Observations on this seem similar to the observations made in the evaluation of Norway. This is interesting, because in a Nordic perspective these two countries had rates of success that were slightly higher than that of Norway so far in FP7. Nevertheless, they are similar to some degree,- and are all above the EU average in terms of success. However, their governance structure is different to Norway and to each other. This may indicate that the type of governance does not really make a big difference and as indicated by the evaluations, strategy seems to be paramount.

\section{National evaluations of research and strategy plans}

The Research Council of Norway organizes a number of evaluations of disciplines and research organisations in Norway. The purpose of this is to obtain information relevant for their work on national strategy development and for its advisory role to ministries that fund research. In the present evaluation, all the evaluations (13) of the Research Council of Norway undertaken after 2001 have been analyzed in the perspective of EU FP strategy. The most recent one, the evaluation of basic research in chemistry ${ }^{104}$ of 2009 , has a

104 Cf. http://www.forskningsradet.no/no/Artikkel/Fagevaluering+av+grunnleggende+forskning+i+kjemi/1236 $\underline{685253862}$ 
comment on EU FP; it observes (p.31) that EU FP is important in terms of researcher mobility, and that these opportunities are used by some institutions that are "well connected". A similar statement is found in the evaluation of engineering from $2004^{105}$ (p.21). Two other evaluations mention EU as a potential funding source (the evaluation on development research from $2007^{106}$ and the evaluation of economics research ${ }^{107}$, also from 2007). In the others, EU FPs is not mentioned, presumably because this has not been a topic in the evaluations. In other types of evaluations undertaken by the Research Council of Norway, such as the evaluation of Norwegian technical-industrial research institutes, primary sector research institutes and environmental and development research institutes were done prior to 2002, and may for this reason be considered as not so relevant for current research policy and strategy. Hence, the topic of EU research in these documents is almost absent in these documents. This observation is supported by an analysis done by Karl Erik Brofoss (2004) of all the evaluations that at that time (2004) had been done by the Research Council of Norway. This is also congruent with the impression obtained in the interviews done in the present evaluation and in an earlier study of Norway's participation in EU FP6 (Godø \& Slipersæter, 2006), i.e. that few Norwegian institutions that participate in EU FPs have explicit strategies or evaluations of their participation in EU research. However, there are some exceptions to this, as seen in the 2009 strategy document from the University of Oslo, in which the Faculty of Law (p. 20) as the only one, puts internationalisation and cross-disciplinary research high on its list of priorities. As shown, internationalisation and participation in EU FPs generally is not a high priority issue in Norwegian research strategy, as reflected in evaluations and strategy documents at the level of research institutions and organisations.

Summary of finding on national governance and coordination of Norway's participation in the FPs

In summing up, the following aspects seem salient:

- MER's role in coordination of Norway's participation in EU FPs is generally loose and indirect.

- MER's capacity for serving this role is also limited, which makes the division of labour and relationship with the Research Council of Norway crucial.

- MER has delegated and assigned much of the responsibility of coordination of Norway's research strategy on participation in EU FP to the Research Council of Norway.

105 Cf. http://www.forskningsradet.no/no/Artikkel/Evaluering+av+forskning+innen+ingeniorvitenskapelige+fa g+2004/1187748085642

Cf. http://www.forskningsradet.no/no/Artikkel/Evaluering+av+utviklingsforskning/1249538460855

107

http://www.forskningsradet.no/no/Artikkel/Evaluering+av+okonomifaglig+forskning+i+Norge/1187748 $\underline{085396}$ 
- MER's strategy on how strategies on participation in EU FPs should be developed is clear and has a sound logic, as evident in action no. 16 of its research strategy, however, RCN's relationship to ministries is clearly asymmetric in terms of power, which makes obtaining endorsement from them on Norway's FP-strategy challenging.

- In the research policy and strategy of "sector" ministries, participation in EU FP and ERA is generally given little attention, with the exception of the Ministry for Trade and Industry.

- The question is as indicated in the beginning of this section: Is this discrepancy unsatisfactory? More explicitly: Does this in any way represent barriers for achieving national policy and strategy goals in terms of internationalisation and, in particular, participation in EU FPs and the ERA? As pointed out by almost all informants, the "sector” principle in Norwegian research policy is fundamental and unassailable. Hence, a more centralized type of coordination with stronger leadership, more authority and power to one ministry is incompatible with deeply entrenched principles of governance in Norway. As many informants point out, this type of model will not necessarily achieve the goals of increasing internationalisation of Norwegian research. Moreover, there is little reason for making changes in the existing governance structures and processes for research. In any case, this is not necessary because this is the raison d'être for the Research Council of Norway.

However, there are some issues that the existing system needs to address and resolve:

- The need to develop decision-making mechanisms and routines for overall strategy, participation and funding of activities in the ERA in which Norway, for strategic reasons, should participate.

- The need to boost participation of Norwegian ICT research in FP7 where the "sector" principle does not seem capable of handling the complexity in an adequate way. ICT is a thematic priority shared with many ministries - and a comprehensive, coherent policy seems to be lacking. This multi-ministerial aspect may pose problems in other areas also,

- The need to align the Ministry of Health and Care Services' research prioritymaking process with that of the RCN - and more specifically, to align a strategy for internationalisation and participation in EU FP with the strategy of this ministry,

- The need to improve information flow among delegates participating in programme committees. Specifically, some informants suggest that the routines of writing reports from attendance of programme committee meetings is given low priority and that MER should enforce more discipline on this, because, as they express, they do not really know what is going on in the other programme committees. 


\subsection{Discussion and implication of findings}

As explained in Chapter 2, although FP7 in many ways resembles its predecessor FP6 in terms of thematic priorities, and for this reason may be characterized in terms of continuity, the introduction of the ERA and other dynamics have significantly altered and expanded EU RTD landscape outside the boundaries of its FPs. Although this development is beyond the scope of the evaluation, this expansion of the RTD system will amplify the urgency and necessity of Norway's research strategy towards EU. The need for this is clearly expressed in the latest White Paper (2009) on Norway's research policy for 2007$2010,{ }^{108}$ which states that Norway needs to develop an active policy for participation in the European Research Area, partly because the volume of research in this is expected to become so large that, due to limited resources, Norway will not be able to participate in all the progammes and projects, and must prioritize its participation.

The expected expansion of the RTD system will be in addition to the planned increase in annual budgets for FP7. These will nearly double in size by 2013 compared to the initial size of the FP7 budget in 2007. According to estimates made by the Norwegian delegation to the EU, Norway's funding obligation to the FPs will grow from approximately NOK 900 million NOK in 2007 to some 1,750 million NOK in 2013, as shown in Figure 7.2. This estimate is based on forecasts of the increase in the GNP of both Norway and the EU, and the formula in the EEA treaty on Norway's funding contribution for participation in the FPs. 


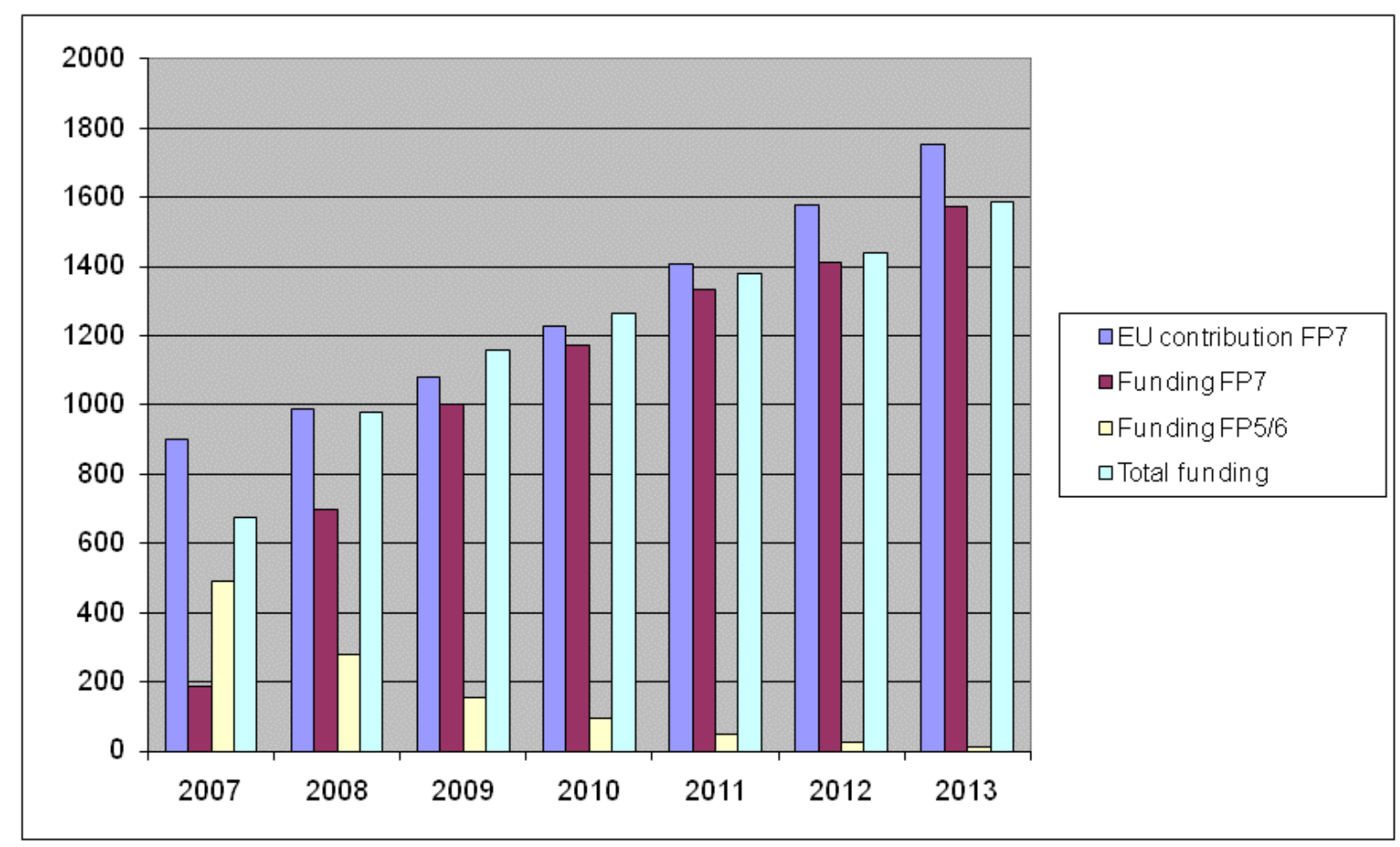

Figure 7.2 FP7 2007-2013: Forecast of Norwegian contribution to EU, in MNOK, rate of exchange: 1 Euro $=$ NOK 8.20). Source: Norwegian delegation to the EU.

The volume of Norwegian participation will have to increase substantially in the future. Because of the time lags involved in the application processes, this increase has to be made in the forthcoming period, i.e. in 2010-2011. If, in addition, Norway wishes to become an active participant in the development of the ERA, this will also require an expansion of capacity for participation, and inevitably new sources of funding. Many of these new initiatives are of interest to Norwegians, in particular some of the Joint Technology Initiatives. This will also have implications for Norway's research strategy, however, these types of decisions should be done by the actors in Norway's research system. In particular, the governing bodies and committees in the Research Council of Norway need to take an active role in this and develop a strategy for participation in ERA as part of their overall strategy for internationalisation.

This chapter has presented data and analyses on a broad range of topics related to national policy measures and the governance of EU research. In brief:

- The analyses of effects of the national system for information and counselling and related economic incentives show two issues in most need of improvement: Better advice on how to combine national R\&D funding with FP activities, and, second, more assistance with financial rules and regulations, audits and financial 
reporting. ${ }^{109}$ In addition, the need for "substantial improvements" on general information has the highest score for participants in SME, followed by LIFE. Research institutes express the highest need for substantial improvements in financial support schemes. Current support schemes are not sustainable and may serve as disincentives for participation. The role of research institutes is strategic in terms of Norway's general level of participation and for increasing private sector participation.

- Analysis of Norway's influence on EU research and participation in programme committees in EU FP showed that there is a broad range of access points where Norwegian participation outside the more formal participation in programme committees is possible and - to some extent - has also been prioritized. Norway should put much more emphasis on this aspect in its participation in EU research. There are at least two reasons for this: Potential for exerting influence and as surveillance and learning mechanism. Secondly, this needs to be coupled with decision making processes and priority setting in the national research community, less with the ministries and official bureaucracies.

- In the national governance processes and coordination of Norway's participation in the FPs, the Ministry of Education and Research's (MER) role in coordination of Norway's participation in EU FPs is generally loose and indirect. MER has delegated and assigned much of the responsibility of coordination of Norway's research strategy on participation in EU FP to the Research Council of Norway.

- MER's strategy on this is clear and has sound logic based on the principle of sector responsibility in Norwegian research policy. However, in the research policy and strategy of "sector" ministries, participation in FPs and the ERA is generally given little attention, with the exception of the Ministry for Trade and Industry.

\section{Implications for Norway's research strategy for EU research}

In general, those who are responsible for making decisions and allocations in Norwegian research policy, strategy and priority setting should have a stronger focus and dedication to the importance of internationalisation of R\&D, particularly the EU RTD because in the foreseeable future this will be Norway's most important and economically demanding way of participating in international R\&D. The Research Council of Norway, specifically the

One example of some of the challenges that potential participants encounter if they are contemplating submission of a proposal to FPs may be seen in the following statement copied from the front page of a call for proposals in CORDIS:

Audits of ongoing projects: The following paragraph should be inserted at the end of chapter 5 of the Guide for Applicants ("What happens next"):

Applicants are reminded that the Commission's Research DGs have adopted a new and reinforced audit strategy aimed at detecting and correcting errors in cost claims submitted in projects on the basis of professional auditing standards. As a result the number of audits and participants audited will increase significantly and the Commission's services will assure appropriate mutual exchange of information within its relevant internal departments in order to fully coordinate any corrective actions to be taken in a consistent way. More information can be found here:

http://cordis.europa.eu/audit-certification/home_en.html 
various boards and committees that make decisions on priorities and allocations on research, will play a key role in this. The RCN has recognized this and has taken measures for implementing new ways and means to adapt to these challenges throughout its organisation. At present, the following factors seem to play an important role:

- In a priority setting, the focus of decision makers is national; international R\&D does not get much attention. Furthermore, there should be a shift in attitudes among decision makers that serve these bodies. Instead of using the Research Council of Norway as a national redistribution mechanism, focus should be set on the international research and innovation arena and how to create synergies and become more competitive.

- The interest among the stakeholder ministries responsible for the sectors relevant for the research done in the EU FPs varies, but in general does not get the attention this deserves.

- The development of ERA should be given attention in terms of strategy and level of decision making.

- The relationship between the EU RTD-system, national delegations and research decision makers needs to become more coupled and strengthened.

- The system of NCP as liaison between the EU RTD-system and the Norwegian $\mathrm{R} \& \mathrm{D}$ community has a sound rationale, but the effect of this function seems opaque, and hence, this should be a topic of a more targeted, special evaluation or reengineering process, i.e. make the NCP function more specialized to the information needs of researchers (e.g. how to obtain funding, how to respond to EU red-tape, etc.)

- National delegates to programme committees in EU do not have much influence on EU agenda setting and priorities, and they are also decoupled from national decision making arenas. However, they are important for making Norway visible in the EU R\&D policy landscape and for informing policy-makers in the ministries that have sector responsibility of current research policy in the EU.

- Working with EU research is demanding in terms of human resources, attention and time needed for building influential relationship - Norway is not up to the mark in this respect.

As indicated above, in the evolution of ERA a large number of new initiatives, programmes and organisms have emerged, which will put new demands on:

- Norwegian agencies such as the Research Council of Norway and Innovation Norway,

- the Norwegian government, in particular ministries responsible for sectors for which relevant research is done in the context of ERA, e.g. various European Technology Platforms and JTIs - Joint Technology Initiatives - both in terms of research policy and strategy, but perhaps more in terms of providing funding,

- potential participants and stakeholder institutions for obtaining human and economic resources in order to participate. 
According to the informants in the Norwegian R\&D community, EU projects are not adequately funded and they are very demanding in terms of administration, i.e. the EU RTD system is highly bureaucratic and seen as inefficient by many of the respondents. This point should not come as a surprise because in almost all recent evaluations of FPs, also EU's own evaluations, this point has been made.

Decision-making, strategy and coordination of participation in EU RTD is primarily undertaken by the participating institutions. However, most of these, in particular higher education institutions, do not have the professional skills and competence needed for this type of work in terms of R\&D management, as indicated in the number of respondents who stated that "substantial improvements needed" in this matter. A related aspect is that many of these institutions have not developed clear strategies for their participation in international R\&D, such as EU FPs, this is usually done on the level of the individual researcher. In the future, institutions need to become more systematic and goals oriented in terms of their research strategy - and orient themselves towards international R\&D collaboration.

So far, many of the participants feel that FP7 is more challenging and demanding compared to its predecessors in terms of their rate of success for proposals, and so forth. As pointed out earlier, funding seems to be satisfactory for higher education institutions, but not for research institutes. In order to become more successful, a system of learning and skills development should be instituted in order to transfer knowledge and skills from those who have been successful to others (e.g. finding right partners, how to write applications, allocation of resources, etc.). The cooperation between NCR and Innovation Norway on encouraging and mobilizing firms seems to function well and more SMEs should be encouraged to apply for participation in the ordinary programmes in the FP, not just the SME programme.

Recommendations for future policy are elaborated in Chapter 8.4. 


\section{Overall assessments of Norwegian participation and future strategies}

From the perspective of Norwegian researchers, participation in FP6 and FP7 is a success in terms of network building, research performance, achieving project objectives and as a starting point for acquiring new R\&D projects. Participants also report extensive impacts of their projects on their R\&D capabilities and activities, and significant long-term effects. The EU projects explore new research areas of significant importance for the participants' future research/innovation activities. A substantial number of researchers state that the EU projects they participated in had positive effects on research and innovation capabilities, and long-term cooperation links. Because of this, research activities are becoming more collaborative, international and organised in larger projects.

These positive findings should really not come as a surprise because in general, research benefits from international collaboration. However, this fits well with the intentions expressed in Norwegian research policy on the high priority of internationalisation of Norwegian research. Although Norway's rate of success is slightly lower than its Nordic rivals, it is still above the EU average, which is also an indicator of success. For these reasons, it is in Norway's interest to continue participation in EU FPs - it should even be increased in order to obtain more benefits. This is the main recommendation of this evaluation.

However, there are some matters of concern: For the institutions and the Norwegian state that fund and support participation in FP6 and FP7, the participation represents burdens and costs that may threaten the long-term sustainability and legitimacy of Norway's participation in EU FPs. EU projects are not adequately funded and the EU FP administration is unnecessarily demanding and inefficient. Both factors make institutions less willing to participate in EU FPs because this drains money, energy and time away from research. This concern is not uniquely Norwegian; almost all evaluations of EU FPs point to the need of making the EU system more efficient. EU's payment to Norwegian participations as measured by its share of FP-budgets has decreased from approximately 2 per cent in FP5, to 1.7 per cent in FP6, and to 1.6 per cent so far in FP7. In this perspective, Norway's competitiveness has decreased, which is also a matter of concern insofar as this may be interpreted as an indicator of underperformance of Norwegian research. However, we think that this may be corrected by targeted measures designed to increase Norwegian participation in some areas of research that have high priority in Norwegian research policy.

This chapter will summarise our assessments of FP6 and FP7 in the Norwegian research system and other questions in the mandate of this evaluation. Section 8.4 will present recommendations. In that, it must be made clear that large parts of Norwegian involvement 
in ongoing and future ERA activities ${ }^{110}$ are, according to the mandate, not the subject of this evaluation.

\subsection{Norwegian participation and results versus resources spent}

\section{Overall participation results}

Although the Norwegian participation has increased in terms of funding from EU as measured in Euros from the FP5 to FP7, in relative terms, i.e. as shares of the overall participation in the FPs, it has decreased from approximately 2 per cent in FP5, to 1.7 per cent in FP6, and to 1.6 per cent so far in FP7. This is manifest in an increasing "deficit" for Norway, i.e. that for every 1 NOK sent to Brussels, Norwegian researchers were able to obtain NOK 0.84 in FP6 as compared to NOK 0.90 in FP5. In addition, the following features are salient in terms of Norway's participation in FPs:

- Norway's share of project contracts (excluding Marie Curie Actions) with at least one Norwegian participation increased from 8.5 per cent in FP5 to 15 per cent in FP6 and decreased slightly to 13 per cent so far in FP7,

- The share of contracts having a Norwegian coordinator is generally high; 19.4 per cent in FP5, decreasing slightly in FP6, however, with an increase to a share of 21 per cent so far in FP7,

- Norway's decrease in funding from EU is an effect of Norway's share of participations in projects have, which have also decreased: From 1.9 per cent in FP5, to 1.8 per cent in FP6, and further down to 1.6 per cent so far in FP7.

In terms of thematic activities within the FPs, the pattern of participation from the FP5 to FP7 has been generally stable, but there are also some noteworthy changes. Norwegian participation in thematic activities such as Environment, Energy, Food and the SMEprograms has been high since FP5 and in some of them it is still increasing. In particular, participation in the SME-program increased considerably from the FP5 to FP6 and it increased further from the FP6 to FP7.

Conversely, Norwegian participation in Health, ICT (IST), Research infrastructures (RI), Marie Curie Actions/People and INCO was rather low in FP5 and remains low in FP7, with the exception of Health, which has increased somewhat in FP7. Norway's participation in Ideas related to the new European Research Council is low.

EU-contribution to Norwegian participants in SSH and Transport programs in FP7 is lower than what it was in FP5 and FP6 and we have no a good explanation for this decrease.

\footnotetext{
110 That is, all ERA-activities which are not directly funded by the FPs, such as, joint-programming activities, the implementation of ESFRI-projects, European Technology Platforms, other recently established PPPs, etc.
} 
Participation in Space, Security (which was a new area of research in FP7) and SiS is high. Participation in NMP programme in the FP7 is higher compared to FP6.

In terms of types of beneficiaries, the EU contribution to Norwegian large firms is decreasing, while the EU-contribution to the research institute sector is levelling off. Participation from Norwegian state colleges and from Norwegian university hospitals is negligible. Only the universities seem to keep increasing their participation shares from the FP5 to FP7, a fact that may be associated with the economic incentive system for university participation in the FPs after the introduction of the new national result-based system.

In terms of rates of success as measured by the percentage of proposals that obtained funding (i.e. successful proposals) with at least one Norwegian participant (Norwegian proposals) of all project proposals, the figures show that so far in FP7, the overall Norwegian rate of success has been higher than the EU average in almost all thematic activities, except ICT. For example, the success rates in NMP, Energy, Environment, Transport and Space varied from 24 per cent to 40 per cent, In FP6, the rate of success was 25 per cent, which also was above the EU average (18 per cent). The share of all proposals submitted in Health, ICT, NMP, Ideas, People and to a lesser extend in Transport with a Norwegian participation is low. One interpretation of these low figures is that there is a potential for increased participation in EU FP, in particular in the above-mentioned activities which also constitute large parts of the budget in FP7. In ICT, the quality of the Norwegian proposals also needs improvements.

\section{Effectiveness of the Norwegian participation}

The large majority of respondents characterise their FP6 projects as successful. In particular, coordinators seem to have been able to achieve their aims for the project. The participants characterise the projects as particularly successful in terms of network building. The projects are also considered successful in terms of research performance, achieving project objectives and as establishing a basis for acquiring new R\&D projects. Far lower scores are obtained on economic results of the projects. The majority of enterprises participating in FP6 do not expect any direct economic benefits from the project (increased sales or reduced costs). However, a large part of the business participants still answer that the project represents a gateway to new customers and that their participation will strengthen their position vis-à-vis competitors, and 38 per cent $d o$ expect direct economic benefits.

The FP6 participants report extensive impacts of their projects on their R\&D capabilities and activities and significant long-term effects are found. The EU projects explore new research areas of significant importance for the participants' future research/innovation activities. A substantial number have had positive effects on research and innovation capabilities, and long-term cooperation links. The FP6 participants' research activities are 
becoming more collaborative, international and organised in larger projects. That is, the participating organisations' way of doing research has changed. Moreover, the bibliometric analysis shows that a fundamental structural change of Norwegian science towards more European collaboration has taken place without any sign of crowding-out R\&Dcollaboration with third countries, such as USA. In other words, the behavioural additionality of participation in EU FP is high.

Major factors of success seem to be:

- finding strong partners with experience in coordinating and writing EU proposals,

- sufficient time and external funding for developing the proposal.

\section{Limited synergies with national priorities}

Accounting for only 1.3 per cent of Norway's total R\&D expenditures, the Framework Programme cannot be expected to have large impact on Norwegian research as a funding mechanism. However, national and institutional co-funding of the Framework Programme co-opts substantially more research resources than the EU contribution to the FP projects. Further, the FPs constitute the largest source of external R\&D funding (competitive funds) next to RCN for Norwegian universities - and a potential funding source for university colleges. Moreover, the Norwegian research policy ${ }^{111}$ is that participation in international research should create synergies with national priorities. ${ }^{112}$

On the overall policy level there is a good match between the Framework Programme priorities and Norwegian research priorities, and seemingly a good foundation for synergies. It is, however, hard to discover these synergies at the research-performing level. The larger part of both the FP6 participations as well as the FP7 applications are not closely related to nationally financed research, and very few of the projects are extensions of nationally financed projects. The data indicate limited coordination with national priorities and funding and informants ask for a better alignment between Norwegian R\&D programme calls and the priorities in the Framework Programme.

However, there are many indications that show substantial impacts of the FPs on the national research system. For example, a high number of Norwegian researchers are involved in the framework programmes. The FP6 survey alone, accounting for 42 per cent of the Norwegian participations, reports 2499 involved researchers. About 18 per cent are PhD students, indicating that the FPs provide clear opportunities for training researchers in

111 St.meld. nr. 30 2008-2009 (White Paper on research).

112 There are two different views on coordination of national and EU-research: Some are most concerned about the need to ensure that there are good Norwegian research units ready to compete in the Framework Programme, and that the national framework conditions for participating are optimal. Other are more concerned that EU-priorities my bind up much national research resources, and give less room for other research. Among our interviewees and survey respondents, the latter category is a clear minority. 
an international environment. Moreover, a large part (72 per cent) of the FP7 applicants report that their project was an integrated part of their organisation's internationalisation strategy, and a large part of the FP7 participants (62 per cent) have a leading responsibility in the projects, indicating ability to impact the project content. Furthermore, there are indications of successful integration with national research within some thematic priorities (Health and Environment, see Section 4.4). However, other data suggest a potential for increasing the alignment of national research with participation in EU FPs, in particular in the thematic priorities of Health and ICT. Hence, the overall picture is mixed and suggests that here is a clear scope for a more careful design of national $R \& D$ policies acting both as leverage to participation in the FPs and as a vehicle for absorbing and further utilising new knowledge from the FPs projects in a national context.

\subsection{The role of the Framework Programme and the ERA in Norwegian research and innovation policy}

By joining the FP7, Norway has made commitments that are legally and politically binding until 2013. As Figure 7.2 in Section 7.4 shows, the budgets in FP7 will increase substantially and hence, Norway's financial commitment will increase accordingly. Given these commitments, the best approach should be that Norway considers this as an opportunity to amplify the internationalisation of its R\&D and innovation activities. Although this may prove to be a demanding challenge, the potential benefits from increasing the participation Norwegian research outweigh these. This will require focused strategic approaches and planning within the Norwegian R\&D system. In particular, the role and modus operandi of the Research Council of Norway will have to be adjusted or reengineered to meet these challenges. In addition, this may have implications for stakeholder ministries and other government agencies.

In Norwegian research policy and priorities, internationalisation and - as an extension of this - participation in EU FPs is important because this is perceived as beneficial for Norway. However, this need is not necessarily unconditional. One way to look at this is as illustrated in Figure 8.1, which represents a simple approach to this topic. The basic idea is to juxtapose thematic areas of priority in the FP research with the Norwegian degree of research competitiveness in the same thematic areas. This simple framework may be used then as a rough guide to what should be priorities in Norwegian internationalisation strategy within different research fields. Take for example quadrant II in Figure 8.1. The Norwegian participation in EU FPs ICT, Health and NMP is low, however, these areas are in the core of the thematic research priorities in the national research system and they are also high priorities in the FP7. In these thematic areas there is a need of a more targeted national support in order to increase the quality of national research within these fields, to amplify thematic affinities between national activities and FP-activities and to increase the incentives for FP-participation. In this quadrant we could also place the area of fundamental research which is now done through the Ideas of the European Research 
Council. The low participation in this programme so far should be a matter of concern and raises a number of questions as to the strategies of fundamental research in Norway. The Norwegian Centres of Excellence should be the spearhead of the Norwegian participation in the Ideas. Some of them have succeeded, but the low number of proposals in this area suggests that there is either a deficit of creativity and confidence which should be urgently addressed or a lack of interest.

Degree of priority in the FP framework

\begin{tabular}{|c|c|c|}
\hline \multirow{3}{*}{ 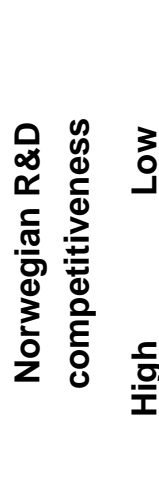 } & Low & High \\
\hline & $\begin{array}{l}\text { I. } \\
\text { Neglected areas? }\end{array}$ & $\begin{array}{l}\text { II. } \\
\text { Norway should intensify and } \\
\text { increase national efforts, e.g. in } \\
\text { ICT, Health, NMP }\end{array}$ \\
\hline & $\begin{array}{l}\text { III. } \\
\text { Research alliances outside EU or } \\
\text { outside the FPs, aligned to } \\
\text { Norwegian interests, e.g. } \\
\text { Petroleum, Marine }\end{array}$ & $\begin{array}{l}\text { IV. } \\
\text { Maintain national leadership and } \\
\text { increase participation }\end{array}$ \\
\hline
\end{tabular}

Figure 8.1 Approach to priorities in internationalisation of Norwegian research

In quadrant III, the situation is the opposite to quadrant II. Norway possesses research competitive advantages in thematic areas which have no priority in EU FPs. A typical example here is the area of oil and gas where Norway possesses a global leadership. In this case, national research policies could with advantage search for international alliances outside the FP-framework either through join-programming or through bilateral agreements. Another option is of course, to build alliances with other Member States with the purpose to influence and change the thematic structure of FPs to the advantage of Norwegian priorities. But this will require substantial diplomatic and political skills and efforts - other strategies of internationalisation may be more attractive and interesting for Norway and should be pursued for this reason.

Quadrant I helps us to think more about those thematic areas which receive relatively low attention both nationally and in the FPs. Take for example the area of law, or the area of humanities, or even the areas of education and teaching, tourism, arts, crafts, etc. What type of internationalisation strategies is relevant in these areas? Is there a need for internationalisation strategies in these areas?

Quadrant IV refers to the areas where Norway possesses a clear international competitive advantage and also has FP priority. These are for example the thematic areas of Energy and Environment (and to a lesser extend the area of Social Sciences), but also the areas of Space and Security which appear for first time as separate thematic activities in the FP7. In these areas, a national strategy could be to (carefully) open for increased international 
collaboration in national R\&D-programs and do what it is necessary for maintaining scientific leadership, if this, for strategic reasons (not prestige) is important for Norway.

\section{The role of ERA}

As discussed in Chapter 5, the development of the ERA, in particular the emergence of numerous initiatives and new types instruments such as the ERA-NETs, JTIs, ERC, the ESFRI-initiatives, etc., in the future may have profound and far-reaching structuring effects on the Norwegian research and innovation system. In the evaluation, it became clear that an important challenge related to the ERA is to observe, understand and "translate" the dynamics and direction of this development to Norwegian policy-makers and stakeholders. Although the ERA development is described as important and farreaching to outsiders, the ERA landscape is rapidly changing, it is complex and appears impenetrable to many actors in the Norwegian R\&D-system. However, the focus on the ERA-NET activities, which have been popular in Norway, should be maintained as a multilateral coordination mechanism because this is an efficient way for Norwegian actors to participate in and contribute to the creation of a network of people working with R\&D strategy and funding in Europe. This is important for a number of reasons, one being that this may develop more flexible and agile models for international R\&D collaboration in addition to those that have been implemented by the EU Commission.

he Ministry of Education and Research and the RCN follow closely the development ESFRI-projects. In the short run, these projects may represent a considerable investment. Decisions for national commitment to these require a careful analysis of the potential benefits for the national research system. In the long run, however, national access to new European research infrastructures may create substantial added-value because these enable advancement of science, technology and may open new horizons of knowledge.

In general, the development of the ERA should become a matter of greater attention and more careful analysis at all policy-making levels.

\subsection{National policy measures and the governance of EU research}

Norway's participation in EU research involves a number of organisations and measures that were analyzed in the evaluation, as elaborated in Chapter 7 of this report. For the Norwegian research community, two issues are considered critical for their participation and for this reason need to be improved: a) Better advice on how to combine national R\&D funding with FP activities; b) better administrative support providing assistance and high quality services and advice regarding financial rules and regulations, audits and financial reporting. In addition, there is a strong need for "substantial improvements” on general information for SMEs. 
Research institutes express the need for substantial improvements in financial support schemes. Current support schemes are not sustainable and may serve as a disincentive for participation. The role of research institutes is strategic in terms of Norway's general level of participation and for increasing private sector participation.

Furthermore, the analysis identified that alignment of the national research strategy with a clear strategy of internationalisation is important and may explain variety in the current pattern of participation in various thematic priorities. The RCN has a clear responsibility for implementing processes that will align national research priorities to a strategy of internationalisation. The role of various programme committees and governing bodies that determine priorities and decide on allocations are important in this context.

In the EU system, there is a broad range of access points where Norwegian participation outside the more formal participation in programme committees is possible and which, to some extent has also been prioritised. Norway, as a non-EU participant should put much more emphasis on this aspect in its participation in EU research. In this, it is important that people participate as experts with high competence, which points to higher involvement of the Norwegian research community in this type of work. Increasing the range of access points between the research community and the EC needs to be coupled with decisionmaking processes, priority-setting and better co-ordination within the national research community and less with the ministries. In this, we note that organisations, such as, the Norwegian Association of Higher Education Institutions, the Federation of Norwegian industries, ABELIA, etc, ought to play a more prominent role. The high ERA-Netparticipation of the RCN in the FP6 should be understood and evaluated in this context, even if ERA-Nets consumed considerable amount of scarce time, people and other resources in this organisation.

In the national governance processes and coordination of Norway's participation in the FPs, the role of the MER in coordinating Norway's participation in FPs is generally loose and indirect. The MER has delegated and assigned much of the responsibility of the implementation of the national participation in FPs to the RCN. The MER strategy on this is clear and has a sound logic based on the principle of sector responsibility in Norwegian research policy. However, in the research policy and strategy of sector ministries, participation in FPs and the ERA generally receives little attention with the exception of the Ministry for Trade and Industry.

\subsection{Recommendations}

The following recommendations are based on the analyses and findings presented in this report and as summarised above. 
Norwegian research decision makers and research institutions need to have a strong focus and dedication to the importance of internationalisation of $R \& D$, and in particular the Framework Programme. In the foreseeable future this will continue to be Norway's most important internationalisation channel of national R\&D activities. Decisions regarding national participation in new ERA instruments will in addition require better analysis of the rationale and the expected benefits from this participation. The Ministry of Education and Research has the main responsibility but the RCN will have an important role in implementing this.

At the institutional level there is a need to become more systematic and goal-oriented in terms of research strategy and orientation towards international R\&D collaboration. In particular, a mechanism for commercialisation and exploitation of results from research seem to be absent in most institutions. They might also profit from more explicit priorities concerning the kind of international research projects in which they participate as well as strategies for reducing the proportion of resources spent on administrating EU projects. According to the informants in higher education institutions, there is also a potential for improving the local incentive systems linked to participating in the Framework Programme.

For these reasons, we recommend the following actions:

- Decision makers that serve various boards and committees in the Research Council of Norway must be required to make priorities in terms of international research collaboration and innovation arenas. How to create synergies with national research and how to become more internationally competitive should guide their decisions.

- The relationship between the EU RTD-system, national delegations and research decision makers, in particular decision makers that serve the Research Council of Norway, needs to become more coupled and strengthened.

- Many stakeholder ministries responsible for the sectors relevant for the research done in the EU FPs should be required to work with the Research Council of Norway in developing strategies and goals for participation in EUs FP - and, increasingly, also participation in ERA-related activities.

- The development of ERA should be given attention in terms of strategy and level of decision making. This is a responsibility for

o the Ministry of Education and Research and agencies such as the Research Council of Norway and Innovation Norway,

o ministries responsible for sectors for which relevant research is done in the context of ERA, e.g. various European Technology Platforms and JTIs - Joint Technology Initiatives - both in terms of research policy and strategy, and also in terms of providing funding,

o potential participants and stakeholder institutions for obtaining human and economic resources in order to participate. 
- In order to influence and increase our understanding of EU's research system, the Ministry of Education and the Research Council of Norway should develop incentives and encourage experts from the Norwegian research community to participate in activities that are strategic for the planning and formation of EU FPs.

\section{Ease the administrative and economic burdens}

According to the informants in the Norwegian R\&D community, EU projects are not adequately funded and they are very demanding in terms of administration, i.e. the EU RTD system is considered as unnecessarily demanding and inefficient by many of the respondents. This point has been made in almost all evaluations of EU FPs. This situation is clearly unsustainable and may discourage future participation, in particular participation of the best researchers who may conclude that funding sources are more attractive than FPprojects for this reason. A number of specific actions related to these points should be taken:

- National co-funding: Because EU funding schemes for research projects cover as a maximum 75 per cent of the total cost, there is a need for better mechanisms for national co-funding. This is a major barrier for especially research organisations, for expanding their EU funded research activities. The Research Council of Norway should explore in an innovative manner possible ways of improving national co-funding.

- The maximum threshold of 7 per cent of actual personnel costs in claiming overhead expenses for Coordination and Support Actions (CSAs) represent for the majority of Norwegian participants a clear obstacle to participate in these types of projects. The Research Council of Norway should explore in an innovative manner possible ways of improving funding of CSAs.

- The definition and computation of "eligible costs" needs to be revised and harmonised with real costs of doing R\&D. In this, RCN should take an initiative and otherwise provide assistance and advice.

- Audits of costs statements is a major source of confusion among the Norwegian participants. When the largest and most experienced Norwegian research organisation reports difficulties in getting the ECs financial services to accept its financial statements it is clear that there is a need for radical reforms. The RCN should develop a plan and strategy for this, in cooperation with other national research funding agencies. This matter is also urgent.

- Norway should take initiatives for a reform of EU FP bureaucracy, which is increasingly recognized as inefficient and a drain on resources and human talent.

Although Norway, as a small country and non-Member of the Community, does not carry much weight, it should be possible to bring the topic of reforming EU FP administration on the agendas of other nations who also suffer from this. As already stated, this matter is so 
serious that the future and legitimacy of EU research is at stake. The Ministry of Education and Research should be able to take an initiative in this.

\section{Ensure increased participation of the large enterprises}

The major challenge for many of the large enterprises is to find Framework Programme calls that match their research interests. Ways should be found to improve communication opportunities to the large enterprises, as well as better promoting their interests when calls are formulated. This is a task for the NCPs of the Research Council of Norway. In addition, private firms doing R\&D are also discouraged by the bureaucracy of EU FPs. This has increasingly become a disincentive for their participation. This amplifies the urgency of the recommendation made above.

\section{Improving conditions and participation of SMEs - improve dissemination of results}

More SMEs should be encouraged to apply for participation in the ordinary programmes in the FP, not just the SME programme. Many are still not satisfied with the external support for applications and administration of projects, and demand more efficient assistance. Improving working conditions for SMEs in this context is primarily a responsibility of Innovation Norway. Innovation Norway should also improve its system for dissemination of results from the participations.

\section{Transferring the skills of successful participation and experts}

A system of learning and skills development should be instituted in order to transfer knowledge and skills from successful applicants to future applicants. Economic incentives, as well as strengthening the network of EU advisers in the higher education sector are relevant measures for skill transferring. Moreover, the insight of expert reviewers who work for the EU DG RTD in doing ex-ante assessments of research proposals to FPs should be used as advisors for the Norwegian research community. This may include meetings for exchanging experiences, including those of successful applicants and learning from mistakes; finding good partners, how to write applications, how to handle administrative and economic requirements and so forth. There is a particular need for courses for first-time coordinators, where both the administrative requirements and social aspects of leading a large international research group should be addressed. To reduce the time and costs of participating in RCN seminars and courses, web-based participation and tutorials should be developed and offered. This should be a responsibility of the EU RTD Department of the Research Council of Norway. The research performing institutions themselves are still responsible for strengthening their administrative support. 


\subsection{Looking forward for a better framework}

The degree of involvement of national policy makers in the implementation of FP7 is increasing constantly. The logical consequence of this is that in the future decision making processes regarding national participation in FP and other ERA-activities the Ministry of Education and Research and the Research Council of Norway must involve the researcher community (senior researchers, research managers and other competent stakeholders) in more direct ways, as explained in Chapter 7.

This becomes even more important, because the period from now until autumn 2010 signals the starting of the discussion on how to set priorities for the FP8 debate. The actual proposal for FP8 is expected to be presented late 2011 or beginning of 2012 at the latest. Based on the experience from previous FPs when the Commission has announced a Framework Programme, the major part of its thematic content is fixed. Hence, the critical period for shaping the thematic content of the next FP is the next 12-18 months and in this time period Norway must have a clear idea of what are the national priorities and preferences. Equally important is the number of access points to communicate national views to the Commission. The so-called research DGs (RTD, ENTR, TREN, INFSO and in principle JRC) are the key actors in the designing of FP8, but they are also influenced by policy DGs, such as environment, health, agriculture, maritime, fisheries within the Commission and other well-organized stakeholders.

According to a number of sources (Andreé (2009), Rietschel-report, L. Georgiou (2008) etc.) important thematic building blocks in the next FP could be: Cooperation (which will include activities such as Joint Programming, JTIs, Societal (or Grand) Challenges, Private Public Partnership, 'Pre-commercial Procurement), ERC, Mobility and Research Infrastructure and Capacity-building. There will also certainly be a discussion on the budgetary size and on the interrelations between them. In this discussion, Norway has to identify and defend positions which both are for the benefit of ERA and aligned with Norwegian interests.

In that one can draw lessons from the patterns of the Norwegian participation in FP6 and FP7. The strong participation in Environment, Energy, Space, SME, BIO (including Food) suggest that in these areas national R\&D efforts have been and remain successful. The weak participation in the ICT, Health and Ideas programs - which all represent national research priority areas - suggest that there is a need for more carefully designed national R\&D strategies in order to increase the quality and to enhance national and international competitiveness in these areas. In this, the responsible ministries and RCN have a key role to play. 


\section{Litterature}

Andrée D. (2009). Priority-setting in the European Research Framework Programmes Swedish Ministry for Education and Research. Vinnova Analysis VA 2009:17. ISBN: 978-91-85959-69-3

Arnold, E. et al. (2008). Impacts of the Framework Programme in Sweden. Stockholm, VINNOVA analysis VA 2008:11.

Bonaccorsi A., M. Horvat, T. Maimets, P. Papon (2008). Expert Group on the future of Network of Excellence. Final report. September 2008.

Brofoss, K. E. and Wiig, O. (2009). Forskningsrådet på sidelinjen? Forskningspolitikk, 32(3): 12-14.

Brofoss, K. E., (2004). En gjennomgang av Forskningsrådets fagevalueringer, Oslo, NIFU STEP Arbeidsnotat 7/2004.

Christiansen, T. and E. J. Kirchner (2000). Europe in Change. Committee Governance in the European Union, Manchester, Manchester University Press.

Egeberg, M., G. F. Schaefer and J. Trondal (2006). 'EU Committee Governance between Intergovernmental and Union Administration’, in Egeberg, M. (ed), Multilevel Union Administration. The Transformation of Executive Politics in Europe, Houndmills, Palgrave MacMillan, pp. 66-85.

European Commission (2009). Evaluation of the Sixth Framework Programmes for Research and Technological Development 2002-2006. Report of the Expert Group chaired by Ernst Th. Rietschel, February 2009.

European Commission (2009); Second FP7 Monitoring Report: Monitoring report 2008. 1 October 2009.

Forsknings- og Innovationsstyrelsen (2008). Tall om Danmarks deltagelse i EU's 6. rammeprogram for forskning og teknologisk udvikling. Copenhagen, Forsknings- og Innovationsstyrelsen.

Forskningsrådet (2009). EU-kontorets årsrapport for 2008. Oslo, Norges forskningsråd.

Georgiou L. (2008): Europe’s Research System Must Change, Nature, UK, vol. 452: 935936.

Godø, H., S. Slipersæter (2006). Universitets- og høgskolesektorens deltakelse i EUs 7. RP: Vurdering av strategi og organisering, Oslo, NIFU STEP Arbeidsnotat 30/2006.

Gornitzka, Å. (2009). How strong is EU soft law? Paper presented at ECPR general conference, September 2009. 
Gornitzka, Å. and L. Langfeldt (2008). 'The internationalisation of national knowledge policies’ in Å. Gornitzka and L. Langfeldt (Eds.) Understanding the "New" Internationalisation of Research and Higher Education in Norway. Dordrecht, Springer.

IDEA consult (2008). Evaluation of the European Technology Platforms (ETPs). Brussels, IDEA Consult.

Jacobsson, B. and G. Sundström (2006). Från Hemvävd til Invävd. Europeiseringen av svensk statsforvaltning och politik, Malmö, Liber.

Kaiser, R. and H. Prange (2004). 'Managing diversity in a system of multi-level governance: the open method of co-ordination in innovation policy', Journal of European Public Policy 11(2): 249-266.

Kaloudis (2006): Forskningspolitiske prioriteringer og muligheter i EUs 7. Rammeprogram: Overordnet vurdering av sannsynlig profil på den norske deltakelsen. NIFU STEP arbeidsnotat 33/2006.

Kaloudis A. and P. Koch (2004) (eds). The role of the business-oriented Norwegian Research Institutes in the national innovation system, Oslo, NIFU STEP Report.

Kaloudis A. and K. Rørstad (2006). Analysis of public R\&D funding in Norway. Oslo, NIFU STEP Working paper 51/2006.

Klitkou A. and A. Kaloudis (2007). Scientific versus economic specialization of Business R\&D - the case of Norway. Research Evaluation 16 (4):283-298.

Kuitunen, S. et al. (2008), Finns in the 6th Framework Programme. Evaluation of Participation and Networks. Helsinki, Tekes Programme Report 6/2008.

Kunnskapsdepartementet (2008). Strategi for Norges samarbeid med EU om forsking og utvikling. Oslo, Kunnskapsdepartementet.

Larédo, P. (2008) “Discussing the role of ERA in the Lisbon process”. Background paper for FP6 expert group. October 2008.

Muldur, U., F.Corvers, H. Delanghe, J. Dratwa, D. Heimberger, B. Sloan and S. Venslembrouck (2006). A New deal for an effective European research policy: the design and impacts of the 7th framework programme. Dordrecht, Springer.

NIFU, STEP and Technopolis (2004). Evaluation of Norway's participation in the EU's 5th Framework Programme. Oslo, NIFU.

OECD (2002). The Measurement of Scientific and Technological activities: Proposed Standard Practice for Surveys on Research and Experimental Development "Frascati Manual 2002”.

Rietschel E.T., et al. (2009), Evaluation of the sixth Framework Programmes for Research and Technological Development 2002-2006. Report of the Expert Group. Berlin and Brussels February 16, 2009. 
SER (2008), Switzerland's Participation in the 6th European Research Framework Programme. Facts and Figures. Bern, State Secretariat for Education and Research SER.

Trondal, J., C. Van den Berg and S. Suvarierol (2008). 'The compound machinery of government: The case of seconded officials in the European commission', Governance-an International Journal of Policy and Administration, 21(2): 253-274.

Trondal, J. and F. Veggeland (2003). 'Access, Voice and Loyalty: The representation of domestic civil servants in EU committees', Journal of European Public Policy, 10(1): 59-77.

Wicken O. (2009). The Layers of National Innovation Systems: The Historical Evolution of a national Innovation System in Norway. In Fagerberg J., D.C. Mowery, B. Verspagen (eds.) (2009) Innovation, Path Dependency, and Policy: The Norwegian Case. Oxford University Press.

Wiig, O. (2007). Ressursbruk til forsknings- og utviklingsarbeid (FoU) i helseforetakene i 2007 - Hovedresultater og dokumentasjon, Oslo, NIFU STEP rapport 50/2007. 


\section{Appendix 1 Tables}

Table A 1 Response rate FP6 survey by participant sector

\begin{tabular}{lrr}
\hline Sector & $\begin{array}{r}\text { Per cent completed } \\
\text { survey }\end{array}$ & $\mathrm{N}$ \\
\hline Higher Education Institution (HES) & 46,7 & 287 \\
Research Institute (REC) & 51,2 & 410 \\
Enterprise (IND) & 29,8 & 392 \\
Hospitals (HOS) & 50,0 & 20 \\
Other (OTH) & 37,2 & 137 \\
\hline Total & 41,9 & 1246 \\
\hline
\end{tabular}

*Obtained complete sample as percentage of requested sample (not the obtainable sample).

Table A 2 FP6 applicant survey, response rates

\begin{tabular}{lrr}
\hline Priority & ${ }^{*}$ Completed & $\mathrm{N}$ \\
\hline 1. Life sciences, genomics and biotechnology for health & 41,8 \\
2. Information society technologies & 45,3 & 170 \\
3. Nanotechnologies and nanosciences, knowledge-based multifunctional materials and new & 37,0 \\
production processes and devices & 41,9 & 31 \\
4. Aeronautics and space & 55,8 \\
5. Food quality and safety & 36,8 & 315 \\
6. Sustainable development, global change and ecosystems & 70,4 \\
7. Citizens and governance in a knowledge-based society & 54 \\
Horizontal research activities involving SMEs & 29,4 & 153 \\
Human resources and mobility & 41,2 & 97 \\
Policy support and anticipating scientific and technological needs & 51,0 & 100 \\
Research and innovation & 39,5 & 38 \\
Research infrastructures & 37,5 & 24 \\
Science and society & 30,0 & 10 \\
Specific measures in support of international cooperation & 29,4 & 17 \\
Support for the coherent development of research \& innovation policies & 50,0 & 6 \\
Support for the coordination of activities & 46,7 & 45 \\
\hline Total & 41,9 & 1246 \\
\hline
\end{tabular}

*Obtained complete sample as percentage of requested sample (not the obtainable sample).

Table A 3 Response rate FP7 survey by application success

\begin{tabular}{lrr}
\hline Application result & $\begin{array}{r}\text { Per cent completed } \\
\text { survey* }\end{array}$ & $\mathrm{N}$ \\
\hline Success (MAINLIST) & 52,9 & 452 \\
Rejected & 36,6 & 1605 \\
Reserve list & 45,6 & 204 \\
\hline Total & 40,6 & 2261 \\
\hline
\end{tabular}

${ }^{\star}$ Obtained complete sample as percentage of requested sample (not the obtainable sample). 
Table A 4 Response rate FP7 survey by application sector

\begin{tabular}{lrr}
\hline Sector & $\begin{array}{r}\text { Per cent completed } \\
\text { survey }\end{array}$ & $\mathrm{N}$ \\
\hline Higher Education Institution (HES) & 43,6 & 683 \\
Research Institute (REC) & 42,7 & 738 \\
Enterprise (PRC) & 30,9 & 488 \\
Public (PUB) & 43,0 & 93 \\
Other (OTH) & 39,3 & 168 \\
N/A & 53,8 & 91 \\
\hline Total & 40,6 & 2261 \\
\hline
\end{tabular}

*Obtained complete sample: as percentage of requested sample (not the obtainable sample).

Table A 5 Response rate FP7 survey by programme

\begin{tabular}{|c|c|c|}
\hline Programmes/priorities & $\begin{array}{r}\text { Per cent } \\
\text { completed } \\
\text { survey }\end{array}$ & $\mathbf{N}$ \\
\hline \multicolumn{3}{|l|}{ COOPERATION } \\
\hline Health & 41,0 & 166 \\
\hline Food, Agriculture and Fisheries, and Biotechnology & 46,1 & 180 \\
\hline Information and Communication Technologies & 39,5 & 405 \\
\hline \multicolumn{3}{|c|}{ Nanosciences, Nanotechnologies, Materials and new Production } \\
\hline Technologies & 48,8 & 84 \\
\hline Energy & 47,7 & 128 \\
\hline Environment (including Climate Change) & 41,6 & 267 \\
\hline Transport (including Aeronautics) & 42,7 & 75 \\
\hline Socio-economic Sciences and the Humanities & 54,2 & 118 \\
\hline Security and Space & 38,6 & 70 \\
\hline IDEAS - European Research Council & 55,8 & 95 \\
\hline PEOPLE - Marie Curie Actions & 36,6 & 174 \\
\hline \multicolumn{3}{|l|}{ CAPACITIES } \\
\hline Research Infrastructures & 50,7 & 73 \\
\hline Research for the benefit of SMEs & 24,7 & 364 \\
\hline Regions of Knowledge & 46,2 & 13 \\
\hline Research Potential & 100,0 & 1 \\
\hline Science in Society & 37,9 & 29 \\
\hline Coherent development of research policies & 66,7 & 9 \\
\hline Activities of International Co-operation & 37,5 & 8 \\
\hline Euratom/Fission & 50,0 & 2 \\
\hline Total & 40,6 & 2261 \\
\hline
\end{tabular}

*Obtained complete sample as percentage of requested sample (not the obtainable sample). 
Table A $6 \quad$ End year of projects FP6 survey

\begin{tabular}{lrr}
\hline Year & N & Per cent \\
\hline 2003 & 1 &, 2 \\
2004 & 6 & 1,0 \\
2005 & 10 & 1,7 \\
2006 & 24 & 4,0 \\
2007 & 70 & 11,7 \\
2008 & 141 & 23,5 \\
2009 & 188 & 31,4 \\
2010 & 124 & 20,7 \\
2011 or later & 35 & 5,8 \\
\hline Total & 599 & 100,0 \\
\hline Missing & 11 & \\
Total N & 610 & \\
\hline Source: Survey to Norwegian participants in FP6.
\end{tabular}

Table A 7 Proposal success FP7 by degree of involvement in the proposal, per cent

\begin{tabular}{|c|c|c|c|c|c|c|}
\hline $\begin{array}{l}\text { To what extent did you (or } \\
\text { your EU project unit) } \\
\text { participate in the following } \\
\text { activities? }\end{array}$ & $\begin{array}{r}1 \\
\text { To a very } \\
\text { small extent }\end{array}$ & $\begin{array}{r}2 \\
\text { To a small } \\
\text { extent }\end{array}$ & $\begin{array}{r}3 \\
\text { To some } \\
\text { extent }\end{array}$ & $\begin{array}{r}4 \\
\text { To a high } \\
\text { extent }\end{array}$ & $\begin{array}{r}5 \\
\text { To a very } \\
\text { high extent }\end{array}$ & Total \\
\hline \multicolumn{7}{|l|}{$\begin{array}{l}\text { Development of project } \\
\text { idea }\end{array}$} \\
\hline Proposal rejected & 71,8 & 61,1 & 68,8 & 66,7 & 70,5 & 68,1 \\
\hline Proposal funded & 22,9 & 36,1 & 27,3 & 31,4 & 26,9 & 28,7 \\
\hline Outcome uncertain & 5,3 & 2,8 & 3,9 & 1,9 & 2,7 & 3,2 \\
\hline $\mathrm{N}$ & 131 & 144 & 205 & 159 & 264 & 903 \\
\hline \multicolumn{7}{|l|}{ Project formulation } \\
\hline Proposal rejected & 64,0 & 65,2 & 66,4 & 67,9 & 72,9 & 68,0 \\
\hline Proposal funded & 30,3 & 29,6 & 31,0 & 31,0 & 24,2 & 28,9 \\
\hline Outcome uncertain & 5,6 & 5,2 & 2,6 & 1,2 & 2,9 & 3,1 \\
\hline $\mathrm{N}$ & 89 & 135 & 274 & 168 & 240 & 906 \\
\hline \multicolumn{7}{|l|}{ Formulation of application } \\
\hline Proposal rejected & 57,5 & 67,2 & 69,1 & 65,5 & 72,5 & 68,0 \\
\hline Proposal funded & 36,3 & 27,0 & 28,7 & 33,3 & 24,0 & 28,8 \\
\hline Outcome uncertain & 6,3 & 5,8 & 2,1 & 1,1 & 3,5 & 3,2 \\
\hline $\mathrm{N}$ & 80 & 137 & 282 & 174 & 229 & 902 \\
\hline
\end{tabular}

Source: Survey to Norwegian applicants to FP7. All kinds of applicants, also for ERC-grants, are included in the table. 
Table A 8 Participants' assessments of the success of the project, by project type, per cent.

\begin{tabular}{|c|c|c|c|c|c|c|c|}
\hline $\begin{array}{l}\text { To what extent would you say that the following } \\
\text { elements have been unsuccessful/ successful } \\
\text { within the project? }\end{array}$ & $\begin{array}{l}\text { Very } \\
\text { unsuccessful }\end{array}$ & $\begin{array}{l}\text { Mostly } \\
\text { unsuccessful }\end{array}$ & Uncertain & $\begin{array}{l}\text { Mostly } \\
\text { successful }\end{array}$ & $\begin{array}{l}\text { Very } \\
\text { successful }\end{array}$ & $\begin{array}{l}\text { Not } \\
\text { relevant }\end{array}$ & $\mathrm{N}$ \\
\hline \multicolumn{8}{|l|}{ a) Project objectives achieved } \\
\hline $\mathrm{CA}$ & 1,8 & 5,3 & 14,0 & 54,4 & 24,6 & & 57 \\
\hline CLR & & 7,1 & 28,6 & 35,7 & 28,6 & & 14 \\
\hline CRAFT & 3,2 & 16,1 & 19,4 & 38,7 & 22,6 & & 31 \\
\hline II & & & 16,7 & 66,7 & 16,7 & & 6 \\
\hline IP & & 3,0 & 19,7 & 55,3 & 22,0 & & 132 \\
\hline MCA & 2,5 & 2,5 & 10,0 & 52,5 & 32,5 & & 40 \\
\hline NOE & & 8,7 & 13,0 & 43,5 & 34,8 & & 46 \\
\hline SSA & & 5,9 & 9,8 & 47,1 & 37,3 & & 51 \\
\hline STREP & 2,2 & 4,4 & 13,2 & 52,2 & 27,9 & & 136 \\
\hline Total & 1,2 & 5,3 & 15,2 & 50,9 & 27,5 & & 513 \\
\hline \multicolumn{8}{|l|}{ c) Basis for acquiring new R\&D projects } \\
\hline $\mathrm{CA}$ & & 3,6 & 28,6 & 30,4 & 26,8 & 10,7 & 56 \\
\hline CLR & & 14,3 & 28,6 & 21,4 & 35,7 & & 14 \\
\hline CRAFT & 6,5 & 19,4 & 32,3 & 32,3 & 9,7 & & 31 \\
\hline II & 16,7 & & 33,3 & 33,3 & 16,7 & & 6 \\
\hline IP & 2,3 & 4,6 & 32,1 & 38,2 & 22,1 & 0,8 & 131 \\
\hline MCA & 2,5 & 7,5 & 25,0 & 32,5 & 17,5 & 15,0 & 40 \\
\hline NOE & 2,2 & 10,9 & 21,7 & 37,0 & 23,9 & 4,3 & 46 \\
\hline SSA & & 7,8 & 35,3 & 35,3 & 15,7 & 5,9 & 51 \\
\hline STREP & 0,7 & 5,9 & 29,6 & 29,6 & 25,9 & 8,1 & 135 \\
\hline Total & 1,8 & 7,1 & 29,8 & 33,3 & 22,4 & 5,7 & 510 \\
\hline \multicolumn{8}{|l|}{ d) Positive economic results for the organisation } \\
\hline $\mathrm{CA}$ & 5,4 & 8,9 & 32,1 & 7,1 & 3,6 & 42,9 & 56 \\
\hline CLR & 7,1 & 14,3 & 21,4 & 50,0 & 7,1 & & 14 \\
\hline CRAFT & 13,3 & 13,3 & 40,0 & 20,0 & 13,3 & & 30 \\
\hline II & & 33,3 & 16,7 & 33,3 & & 16,7 & 6 \\
\hline IP & 3,8 & 5,3 & 38,9 & 26,7 & 7,6 & 17,6 & 131 \\
\hline MCA & 5,0 & 12,5 & 30,0 & 27,5 & 2,5 & 22,5 & 40 \\
\hline NOE & 8,7 & 13,0 & 28,3 & 13,0 & 6,5 & 30,4 & 46 \\
\hline SSA & 11,8 & 9,8 & 31,4 & 21,6 & 2,0 & 23,5 & 51 \\
\hline STREP & 5,1 & 11,7 & 30,7 & 27,7 & 7,3 & 17,5 & 137 \\
\hline Total & 6,3 & 10,2 & 32,9 & 23,5 & 6,3 & 20,9 & 511 \\
\hline \multicolumn{8}{|l|}{$\begin{array}{l}\text { e) Enhance market position and/or develop } \\
\text { customer networks }\end{array}$} \\
\hline 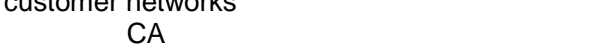 & 1,8 & 5,4 & 23,2 & 16,1 & 7,1 & 46,4 & 56 \\
\hline CLR & & 14,3 & 35,7 & 21,4 & 21,4 & 7,1 & 14 \\
\hline CRAFT & 12,9 & 9,7 & 25,8 & 25,8 & 16,1 & 9,7 & 31 \\
\hline II & 16,7 & 16,7 & 16,7 & & 16,7 & 33,3 & 6 \\
\hline IP & 4,6 & 6,9 & 17,6 & 25,2 & 11,5 & 34,4 & 131 \\
\hline MCA & & 2,5 & 27,5 & 10,0 & 5,0 & 55,0 & 40 \\
\hline NOE & 2,2 & 10,9 & 28,3 & 8,7 & 6,5 & 43,5 & 46 \\
\hline SSA & & & 17,6 & 39,2 & 7,8 & 35,3 & 51 \\
\hline STREP & 1,5 & 5,9 & 28,1 & 22,2 & 8,9 & 33,3 & 135 \\
\hline Total & 2,9 & 6,3 & 23,7 & 21,8 & 9,6 & 35,7 & 510 \\
\hline \multicolumn{8}{|l|}{ f) Research performance } \\
\hline $\mathrm{CA}$ & & 1,8 & 23,6 & 30,9 & 10,9 & 32,7 & 55 \\
\hline CLR & & 14,3 & 14,3 & 64,3 & 7,1 & & 14 \\
\hline CRAFT & 9,7 & 16,1 & 12,9 & 35,5 & 19,4 & 6,5 & 31 \\
\hline II & 20,0 & & 20,0 & 20,0 & 20,0 & 20,0 & 5 \\
\hline IP & 0,8 & 5,3 & 22,7 & 46,2 & 22,0 & 3,0 & 132 \\
\hline MCA & & 5,1 & 23,1 & 41,0 & 23,1 & 7,7 & 39 \\
\hline NOE & & 13,0 & 15,2 & 47,8 & 23,9 & & 46 \\
\hline SSA & & 5,9 & 17,6 & 31,4 & 13,7 & 31,4 & 51 \\
\hline STREP & 0,7 & 2,9 & 26,5 & 50,7 & 17,6 & 1,5 & 136 \\
\hline Total & 1,2 & 5,9 & 21,8 & 43,6 & 18,5 & 9,0 & 509 \\
\hline \multicolumn{8}{|l|}{ g) Access to research facilities abroad } \\
\hline $\mathrm{CA}$ & 1,8 & 3,6 & 12,5 & 33,9 & 12,5 & 35,7 & 56 \\
\hline CLR & & 7,1 & 42,9 & 28,6 & 21,4 & & 14 \\
\hline CRAFT & 6,5 & 12,9 & 32,3 & 32,3 & 6,5 & 9,7 & 31 \\
\hline II & 16,7 & & & 16,7 & 50,0 & 16,7 & 6 \\
\hline IP & 1,5 & 5,3 & 25,0 & 34,8 & 12,9 & 20,5 & 132 \\
\hline MCA & & 7,5 & 17,5 & 37,5 & 15,0 & 22,5 & 40 \\
\hline NOE & 2,2 & 6,5 & 15,2 & 32,6 & 21,7 & 21,7 & 46 \\
\hline SSA & & 5,9 & 15,7 & 25,5 & 7,8 & 45,1 & 51 \\
\hline STREP & 0,7 & 4,4 & 29,9 & 32,8 & 15,3 & 16,8 & 137 \\
\hline Total & 1,6 & 5,7 & 23,2 & 32,7 & 14,2 & 22,6 & 513 \\
\hline
\end{tabular}

h) Basis for new innovation activities in own 


\begin{tabular}{|c|c|c|c|c|c|c|c|}
\hline \multicolumn{8}{|l|}{ organisation } \\
\hline CA & 1,8 & 5,4 & 35,7 & 12,5 & 10,7 & 33,9 & 56 \\
\hline CLR & & 14,3 & 28,6 & 35,7 & 14,3 & 7,1 & 14 \\
\hline CRAFT & 9,7 & 3,2 & 25,8 & 35,5 & 19,4 & 6,5 & 31 \\
\hline II & 16,7 & 16,7 & & & 33,3 & 33,3 & 6 \\
\hline IP & 3,1 & 4,6 & 27,5 & 34,4 & 15,3 & 15,3 & 131 \\
\hline MCA & 2,6 & 10,3 & 17,9 & 25,6 & 12,8 & 30,8 & 39 \\
\hline NOE & 4,3 & 6,5 & 28,3 & 17,4 & 13,0 & 30,4 & 46 \\
\hline SSA & & & 23,5 & 35,3 & 5,9 & 35,3 & 51 \\
\hline STREP & 1,5 & 5,8 & 26,3 & 28,5 & 13,9 & 24,1 & 137 \\
\hline Total & 2,7 & 5,5 & 26,6 & 28,0 & 13,5 & 23,7 & 511 \\
\hline \multicolumn{8}{|c|}{ i) Basis for new innovation activities in Norway } \\
\hline CA & 7,1 & 1,8 & 32,1 & 14,3 & 8,9 & 35,7 & 56 \\
\hline CLR & & 21,4 & 28,6 & 21,4 & 21,4 & 7,1 & 14 \\
\hline CRAFT & 9,7 & 6,5 & 29,0 & 25,8 & 22,6 & 6,5 & 31 \\
\hline II & 16,7 & & 16,7 & 33,3 & & 33,3 & 6 \\
\hline IP & 3,8 & 5,3 & 32,6 & 32,6 & 7,6 & 18,2 & 132 \\
\hline MCA & 2,5 & 7,5 & 25,0 & 12,5 & 12,5 & 40,0 & 40 \\
\hline NOE & 6,5 & 8,7 & 28,3 & 17,4 & 10,9 & 28,3 & 46 \\
\hline SSA & 2,0 & 3,9 & 27,5 & 27,5 & 7,8 & 31,4 & 51 \\
\hline STREP & 2,2 & 6,7 & 33,3 & 21,5 & 11,1 & 25,2 & 135 \\
\hline Total & 4,1 & 6,1 & 30,7 & 23,5 & 10,6 & 25,0 & 511 \\
\hline
\end{tabular}

Table A 9 Expected changes in the positions of the participating organisation, by sector, per cent.

\begin{tabular}{lrrrrrrr}
\hline & To a & & & & To a & \\
& very & To a & To & To a & very & \\
small & small & some & high & high & Not & relevant & $N$ \\
\hline
\end{tabular}

a) The project will strengthen our position in relation to our competitors

\begin{tabular}{lrrrrrrr} 
Research Institute & 10,9 & 12,6 & 42,9 & 21,0 & 6,3 & 6,3 & 238 \\
Higher Education Institution & 5,6 & 11,1 & 43,7 & 15,9 & 5,6 & 18,3 & 126 \\
Enterprise & 11,5 & 12,6 & 37,9 & 17,2 & 13,8 & 6,9 & 87 \\
Other & 9,5 & 9,5 & 30,2 & 9,5 & 1,6 & 39,7 & 63 \\
\cline { 2 - 8 } & 9,5 & 11,9 & 40,7 & 17,7 & 6,8 & 13,4 & 514 \\
\hline
\end{tabular}

b) The project contributes to securing our position in respect of established customers

\begin{tabular}{lrrrrrrr} 
Research Institute & 12,3 & 8,5 & 36,2 & 18,3 & 6,0 & 18,7 & 235 \\
Higher Education Institution & 10,4 & 7,2 & 15,2 & 8,8 & 2,4 & 56,0 & 125 \\
Enterprise & 12,6 & 6,9 & 34,5 & 26,4 & 9,2 & 10,3 & 87 \\
Other & 11,1 & 7,9 & 20,6 & 15,9 & 3,2 & 41,3 & 63 \\
\cline { 2 - 7 } & 11,8 & 7,8 & 28,8 & 17,1 & 5,3 & 29,2 & 510 \\
\hline
\end{tabular}

c) The project represents a gateway to new customers

\begin{tabular}{lrrrrrrr} 
Research Institute & 16,9 & 13,6 & 30,1 & 12,3 & 3,8 & 23,3 & 236 \\
Higher Education Institution & 14,5 & 5,6 & 10,5 & 3,2 & 3,2 & 62,9 & 124 \\
Enterprise & 13,8 & 16,1 & 21,8 & 24,1 & 18,4 & 5,7 & 87 \\
Other & 12,7 & 7,9 & 17,5 & 7,9 & 7,9 & 46,0 & 63 \\
\cline { 2 - 7 } & 15,3 & 11,4 & 22,4 & 11,6 & 6,7 & 32,7 & 510 \\
\hline
\end{tabular}

d) The project represents a gateway to new suppliers

\begin{tabular}{lrrrrrrr} 
Research Institute & 24,0 & 11,6 & 16,3 & 7,7 & 0,9 & 39,5 & 233 \\
Higher Education Institution & 16,1 & 4,0 & 7,3 & 4,0 & 1,6 & 66,9 & 124 \\
Enterprise & 25,3 & 10,3 & 23,0 & 14,9 & 9,2 & 17,2 & 87 \\
Other & 12,7 & 3,2 & 19,0 & 1,6 & 3,2 & 60,3 & 63 \\
\cline { 2 - 7 } Total & 20,9 & 8,5 & 15,6 & 7,3 & 2,8 & 45,0 & 507 \\
\hline Source: Survey to
\end{tabular}


Table A 10 Participants' assessments of the nature of the EU projects, by FP6 priority, per cent.

\begin{tabular}{|c|c|c|c|c|}
\hline $\begin{array}{l}\text { Please compare the nature of your EU project(s) with your } \\
\text { other R\&D projects and indicate which projects: }\end{array}$ & $\begin{array}{r}\text { The EU } \\
\text { projects }\end{array}$ & $\begin{array}{r}\text { No } \\
\text { difference }\end{array}$ & $\begin{array}{r}\text { Our other } \\
\text { projects }\end{array}$ & $\mathbf{N}$ \\
\hline \multicolumn{5}{|l|}{ a) are most strategically important to your organisation? } \\
\hline 1. Life sciences, genomics and biotechnology for health & 30,4 & 52,2 & 17,4 & 23 \\
\hline 2. Information society technologies & 33,3 & 33,3 & 33,3 & 75 \\
\hline 3. Nanotechnologies and nanosciences & 31,6 & 36,8 & 31,6 & 19 \\
\hline 5. Food quality and safety & 33,3 & 33,3 & 33,3 & 42 \\
\hline 6. Sustainable development, global change and ecosystems & 26,3 & 46,5 & 27,2 & 114 \\
\hline 7. Citizens and governance in a knowledge-based society & 33,3 & 33,3 & 33,3 & 36 \\
\hline Horizontal research activities involving SMEs & 39,1 & 45,7 & 15,2 & 46 \\
\hline Human resources and mobility & 20,0 & 52,5 & 27,5 & 40 \\
\hline Policy support and anticipating scientific and technological needs & 39,2 & 33,3 & 27,5 & 51 \\
\hline Research and innovation & 38,5 & 23,1 & 38,5 & 13 \\
\hline Remaining priorities ( 5 priorities with less than 15 cases each) & 50,0 & 28,1 & 21,9 & 32 \\
\hline Total & 32,8 & 39,5 & 27,7 & 491 \\
\hline \multicolumn{5}{|l|}{ b) are most oriented towards basic research? } \\
\hline 1. Life sciences, genomics and biotechnology for health & 17,4 & 60,9 & 21,7 & 23 \\
\hline 2. Information society technologies & 37,3 & 38,7 & 24,0 & 75 \\
\hline 3. Nanotechnologies and nanosciences & 31,6 & 47,4 & 21,1 & 19 \\
\hline 5. Food quality and safety & 26,2 & 42,9 & 31,0 & 42 \\
\hline 6. Sustainable development, global change and ecosystems & 19,3 & 46,5 & 34,2 & 114 \\
\hline 7. Citizens and governance in a knowledge-based society & 20,0 & 48,6 & 31,4 & 35 \\
\hline Horizontal research activities involving SMEs & 15,6 & 55,6 & 28,9 & 45 \\
\hline Human resources and mobility & 7,5 & 67,5 & 25,0 & 40 \\
\hline Policy support and anticipating scientific and technological needs & 13,7 & 56,9 & 29,4 & 51 \\
\hline Research and innovation & 15,4 & 76,9 & 7,7 & 13 \\
\hline Remaining priorities (5 priorities with less than 15 cases each) & 36,4 & 39,4 & 24,2 & 33 \\
\hline Total & 22,2 & 49,8 & 28,0 & 490 \\
\hline \multicolumn{5}{|l|}{ c) provide most new scientific results? } \\
\hline 1. Life sciences, genomics and biotechnolo & 8,7 & 69,6 & 21,7 & 23 \\
\hline 2. Informatio & 34,7 & 42,7 & 22,7 & 75 \\
\hline 3. Nanotechnologies and nanosciences & 26,3 & 57,9 & 15,8 & 19 \\
\hline 5. Food quality and safety & 16,7 & 45,2 & 38,1 & 42 \\
\hline 6. Sustainable development, global change and ecosystems & 15,8 & 50,0 & 34,2 & 114 \\
\hline 7. Citizens and governance in a knowledge-based society & 31,4 & 37,1 & 31,4 & 35 \\
\hline Horizontal research activities involving SMEs & 31,1 & 53,3 & 15,6 & 45 \\
\hline Human resourc & 5,0 & 67,5 & 27,5 & 40 \\
\hline Policy support and anticipating scientific and technological needs & 23,5 & 45,1 & 31,4 & 51 \\
\hline Research and innovation & 14,3 & 57,1 & 28,6 & 14 \\
\hline Remaining priorities ( 5 priorities with less than 15 cases each) & 27,3 & 51,5 & 21,2 & 33 \\
\hline Total & 22,0 & 50,3 & 27,7 & 491 \\
\hline \multicolumn{5}{|l|}{ d) are most scientifically/technologically risky? } \\
\hline 1. Life sciences, genomics and biotechnology for $\mathrm{r}$ & 21,7 & 60,9 & 17,4 & 23 \\
\hline 2. Inform & 36,0 & 52,0 & 12,0 & 75 \\
\hline 3. Nanotechnologies and nanosciences & 36,8 & 52,6 & 10,5 & 19 \\
\hline 5. Food quality and safety & 14,6 & 58,5 & 26,8 & 41 \\
\hline hange and ecosystems & 17,7 & 54,9 & 27,4 & 113 \\
\hline in a knowledge-based society & 14,3 & 77,1 & 8,6 & 35 \\
\hline Horizontal research activities involving SMEs & 37,8 & 48,9 & 13,3 & 45 \\
\hline Human resources and mobility & 28,2 & 59,0 & 12,8 & 39 \\
\hline cipating scientific and technological needs & 13,7 & 68,6 & 17,6 & 51 \\
\hline Research and innovation & 35,7 & 50,0 & 14,3 & 14 \\
\hline Remaining priorities ( 5 priorities with less than 15 cases each) & 3,0 & 75,8 & 21,2 & 33 \\
\hline Total & 22,7 & 59,0 & 18,2 & 488 \\
\hline \multicolumn{5}{|l|}{ e) have the highest scientific quality? } \\
\hline biotechnology for health & 17,4 & 56,5 & 26,1 & 23 \\
\hline 2. Information society technologies & 26,7 & 57,3 & 16,0 & 75 \\
\hline 3. Nanotechnologies and nanosciences & 31,6 & 68,4 & & 19 \\
\hline 5. Food c & 23,8 & 52,4 & 23,8 & 42 \\
\hline 6. Sustainable development, global change and ecosystems & 21,1 & 52,6 & 26,3 & 114 \\
\hline 7. Citizens and governance in a knowledge-based society & 22,9 & 65,7 & 11,4 & 35 \\
\hline ctivities involving SMEs & 42,2 & 44,4 & 13,3 & 45 \\
\hline Human resources and mobility & 10,0 & 77,5 & 12,5 & 40 \\
\hline Policy support and anticipating scientific and technological needs & 21,6 & 54,9 & 23,5 & 51 \\
\hline Research and innovation & 21,4 & 57,1 & 21,4 & 14 \\
\hline Remaining priorities ( 5 priorities with less than 15 cases each) & 15,2 & 72,7 & 12,1 & 33 \\
\hline Total & 23,2 & 58,0 & 18,7 & 491 \\
\hline \multicolumn{5}{|l|}{ f) are most long-term? } \\
\hline 1. Life & 13,6 & 45,5 & 40,9 & 22 \\
\hline hnologies & 50,7 & 24,0 & 25,3 & 75 \\
\hline 3. Nanotechnologies and nanosciences & 42,1 & 52,6 & 5,3 & 19 \\
\hline 5. Food quality and safety & 28,6 & 50,0 & 21,4 & 42 \\
\hline
\end{tabular}


6. Sustainable development, global change and ecosystems

7. Citizens and governance in a knowledge-based society

Horizontal research activities involving SMEs

Human resources and mobility

Policy support and anticipating scientific and technological needs

Research and innovation Total

Remaining priorities (5 priorities with less than 15 cases each)

\section{g) are most multidisciplinary?}

1. Life sciences, genomics and biotechnology for health

2. Information society technologies

3. Nanotechnologies and nanosciences

5. Food quality and safety

6. Sustainable development, global change and ecosystems

7. Citizens and governance in a knowledge-based society

Horizontal research activities involving SMEs

Human resources and mobility

Policy support and anticipating scientific and technological needs

Research and innovation Total

Remaining priorities (5 priorities with less than 15 cases each)

Source: Survey to Norwegian participants in FP6. ERA-net participants were not posed the questions in this table.

\section{Table A 11 Participants in FP6: Opinions on Norwegian information and consultation} services for the 7th Framework Programme, per cent.

\begin{tabular}{|c|c|c|c|c|c|}
\hline $\begin{array}{l}\text { Is there a need for improvements in the } \\
\text { Norwegian information and consultation services } \\
\text { concerning the following aspects of the } 7 \text { th } \\
\text { Framework Programme? }\end{array}$ & $\begin{array}{r}\text { Substantial } \\
\text { improvements } \\
\text { needed }\end{array}$ & $\begin{array}{r}\text { Some } \\
\text { improvements } \\
\text { needed }\end{array}$ & $\begin{array}{r}\text { No } \\
\text { improvements } \\
\text { needed }\end{array}$ & $\begin{array}{r}\text { No } \\
\text { opinion }\end{array}$ & $\mathrm{N}$ \\
\hline $\begin{array}{l}\text { a) General information on the various specific } \\
\text { programmes of the Framework Programmes }\end{array}$ & 13,4 & 37,1 & 26,9 & 22,6 & 509 \\
\hline $\begin{array}{l}\text { b) Information on calls and upcoming deadlines } \\
\text { for submitting proposals }\end{array}$ & 14,4 & 36,8 & 27,8 & 21,1 & 508 \\
\hline $\begin{array}{l}\text { c) Information on calls and research activities } \\
\text { of the European Research Council ERC) }\end{array}$ & 15,5 & 37,7 & 20,8 & 26,0 & 504 \\
\hline $\begin{array}{l}\text { d) Information on calls and other related } \\
\text { research and innovation activities of Joint } \\
\text { Technology Initiatives (JTI) }\end{array}$ & 11,8 & 30,5 & 13,4 & 44,3 & 501 \\
\hline e) Advice on how to prepare better proposals & 19,8 & 40,6 & 19,6 & 20,0 & 505 \\
\hline f) How to find and connect to other partners & 10,9 & 33,6 & 33,2 & 22,3 & 503 \\
\hline $\begin{array}{l}\text { g) Advice and legal support to contracting, } \\
\text { management of intellectual rights' }\end{array}$ & 18,6 & 37,8 & 16,0 & 27,5 & 505 \\
\hline $\begin{array}{l}\text { h) Financial rules and regulations, audits, } \\
\text { financial reporting' }\end{array}$ & 25,9 & 37,4 & 14,5 & 22,2 & 505 \\
\hline $\begin{array}{l}\text { i) Advice on how to combine/connect national } \\
\text { R\&D-funding with FP project activities }\end{array}$ & 30,8 & 35,9 & 9,5 & 23,8 & 504 \\
\hline
\end{tabular}

Source: Survey to Norwegian participants in FP6. 
Table A 12 FP7 applicants: Opinions on Norwegian information and consultation services for the 7th Framework Programme, per cent "Substantial improvements needed" by application status.

\begin{tabular}{|c|c|c|c|c|}
\hline \multirow{2}{*}{$\begin{array}{l}\text { Is there a need for improvements in the Norwegian information and } \\
\text { consultation services concerning the following aspects of the } 7 \text { th } \\
\text { Framework Programme? }\end{array}$} & \multicolumn{3}{|c|}{$\begin{array}{c}\text { Per cent answering } \\
\text { "Substantial improvements } \\
\text { needed" } \\
\end{array}$} & \multirow[b]{2}{*}{ Total } \\
\hline & Rejected & Funded & Uncertain & \\
\hline $\begin{array}{l}\text { a) General information on the various specific programmes of the } \\
\text { Framework Programmes }\end{array}$ & 10,1 & 11,8 & 3,4 & 10,3 \\
\hline b) Information on calls and upcoming deadlines for submitting proposals & 12,3 & 9,4 & 10,3 & 11,4 \\
\hline $\begin{array}{l}\text { c) Information on calls and research activities of the European Research } \\
\text { Council ERC) }\end{array}$ & 18,2 & 14,6 & 17,9 & 17,2 \\
\hline $\begin{array}{l}\text { d) Information on calls and other related research and innovation activities } \\
\text { of Joint Technology Initiatives (JTI) }\end{array}$ & 17,2 & 12,7 & 17,2 & 15,9 \\
\hline e) Advice on how to prepare better proposals & 24,4 & 17,6 & 17,2 & 22,2 \\
\hline f) How to find and connect to other partners & 14,3 & 10,3 & 6,9 & 12,9 \\
\hline $\begin{array}{l}\text { g) Advice and legal support to contracting, management of intellectual } \\
\text { rights' }\end{array}$ & 19,0 & 19,8 & 7,1 & 18,8 \\
\hline h) Financial rules and regulations, audits, financial reporting' & 21,6 & 26,5 & 13,8 & 22,7 \\
\hline $\begin{array}{l}\text { i) Advice on how to combine/connect national R\&D-funding with FP project } \\
\text { activities }\end{array}$ & 33,7 & 33,9 & 27,6 & 33,6 \\
\hline $\mathrm{N}$ & $564-577$ & \begin{tabular}{r|r|}
$243-$ \\
246 \\
\end{tabular} & $28-29$ & $\begin{array}{r}837- \\
851 \\
\end{array}$ \\
\hline
\end{tabular}

Source: Survey to Norwegian applicants in FP7

Table A 13 Number of Norwegian participations in FP6 with impact on marine/maritime sector by programmes/priorities (respondent replies on impact of the project).

\begin{tabular}{|l|r|}
\hline Prioritylprogramme & $\begin{array}{r}\text { Number of participations } \\
\text { with positive impact on } \\
\text { marine/maritime sector }\end{array}$ \\
\hline 6. Sustainable development, global change and ecosystems & 51 \\
\hline Horizontal research activities involving SMEs & 16 \\
\hline Policy support and anticipating scientific and technological needs & 13 \\
\hline 5. Food quality and safety & 11 \\
\hline 4. Aeronautics and space & 7 \\
\hline Human resources and mobility & 6 \\
\hline Support for the coordination of activities & 6 \\
\hline 2. Information society technologies & 5 \\
\hline 3. Nanotechnologies and nanosciences & 4 \\
\hline Research and innovation & 4 \\
\hline 1. Life sciences, genomics and biotechnology for health & 1 \\
\hline Research infrastructures & 1 \\
\hline Specific measures in support of international cooperation & 1 \\
\hline Total & $\mathbf{1 2 6}$ \\
\hline
\end{tabular}


Table A 14 Success rates for Norwegian participations with and without coordinator responsibility in FP7 proposals, by programmes/priorities. Per cent.

\begin{tabular}{|c|c|c|c|c|}
\hline \multirow[b]{2}{*}{ FP7 Programme/priority } & & \multicolumn{2}{|c|}{ Coordinator } & \multirow[b]{2}{*}{ Total } \\
\hline & & Yes & No & \\
\hline \multicolumn{5}{|l|}{ COOPERATION } \\
\hline \multirow[t]{2}{*}{ Health } & Mainlist & 38,9 & 18,2 & 20,5 \\
\hline & & 18 & 148 & 166 \\
\hline \multirow[t]{2}{*}{ Food, Agriculture and Fisheries, and Biotechnology } & Mainlist & 11,8 & 16,4 & 15,9 \\
\hline & $\mathrm{N}$ & 17 & 165 & 182 \\
\hline \multirow[t]{2}{*}{ Information and Communication Technologies } & Mainlist & 13,3 & 11,9 & 12,1 \\
\hline & $\mathrm{N}$ & 45 & 360 & 405 \\
\hline Nanosciences, Nanotechnologies, Materials and new & Mainlist & 0,0 & 22,5 & 19,0 \\
\hline Production Technologies & $\mathrm{N}$ & 13 & 71 & 84 \\
\hline \multirow[t]{2}{*}{ Energy } & Mainlist & 33,3 & 24,1 & 25,4 \\
\hline & $\mathrm{N}$ & 18 & 112 & 130 \\
\hline \multirow[t]{2}{*}{ Environment (including Climate Change) } & Mainlist & 26,5 & 24,0 & 24,3 \\
\hline & $\mathrm{N}$ & 34 & 233 & 267 \\
\hline \multirow[t]{2}{*}{ Transport (including Aeronautics) } & Mainlist & 33,3 & 18,8 & 20,0 \\
\hline & $\mathrm{N}$ & 6 & 69 & 75 \\
\hline \multirow{2}{*}{ Socio-economic Sciences and the Humanities } & Mainlist & 3,0 & 14,1 & 11,0 \\
\hline & $\mathrm{N}$ & 33 & 85 & 118 \\
\hline \multirow[t]{2}{*}{ Security and Space } & Mainlist & 16,7 & 35,9 & 34,3 \\
\hline & $\mathrm{N}$ & 6 & 64 & 70 \\
\hline \multirow{2}{*}{ IDEAS - European Research Council } & Mainlist & 1,1 & 0,0 & 0,9 \\
\hline & $\mathrm{N}$ & 93 & 18 & 111 \\
\hline \multirow[t]{2}{*}{ PEOPLE - Marie Curie Actions } & Mainlist & 18,9 & 14,9 & 16,1 \\
\hline & $\mathrm{N}$ & 53 & 121 & 174 \\
\hline \multicolumn{5}{|l|}{ CAPACITIES } \\
\hline \multirow{2}{*}{ Research Infrastructures } & Mainlist & 12,5 & 43,1 & 39,7 \\
\hline & $\mathrm{N}$ & 8 & 65 & 73 \\
\hline \multirow[t]{2}{*}{ Research for the benefit of SMEs } & Mainlist & 23,7 & 25,3 & 24,9 \\
\hline & $\mathrm{N}$ & 76 & 289 & 365 \\
\hline \multirow[t]{2}{*}{ Science in Society } & Mainlist & 50,0 & 36,0 & 37,9 \\
\hline & $\mathrm{N}$ & 4 & 25 & 29 \\
\hline \multirow{2}{*}{$\begin{array}{l}\text { CAPACITIES - remaining programmes } \\
\text { (below } 20 \text { proposals per programme) }\end{array}$} & Mainlist & 0,0 & 51,7 & 45,5 \\
\hline & $\mathrm{N}$ & 4 & 29 & 33 \\
\hline \multirow[t]{4}{*}{ Total } & Mainlist & 15,4 & 20,9 & 19,9 \\
\hline & Reserve & 6,5 & 9,6 & 9,0 \\
\hline & Rejected & 78,0 & 69,5 & 71,1 \\
\hline & $\mathrm{N}$ & 428 & 1854 & 2282 \\
\hline
\end{tabular}

Source: Data from EC.

Table A 15 Please compare the nature of your EU project(s) with your other R\&D projects and indicate which projects provide most new scientific results? Per cent.

\begin{tabular}{|l|r|r|r|r|}
\hline Project type & $\begin{array}{r}\text { The EU } \\
\text { projects }\end{array}$ & $\begin{array}{r}\text { No } \\
\text { difference }\end{array}$ & $\begin{array}{r}\text { Our other } \\
\text { projects }\end{array}$ & $\mathbf{~ N}$ \\
\hline Coordination Actions (CA) & 27,5 & 40,0 & 32,5 & 40 \\
\hline Collective Research Projects (CLR) & 40,0 & 46,7 & 13,3 & 15 \\
\hline Co-operative Research Projects (CRAFT) & 26,7 & 56,7 & 16,7 & 30 \\
\hline Specific Actions to Promote Research Infrastructures (I3) & 16,7 & 66,7 & 16,7 & 6 \\
\hline Integrated Projects (IP) & 20,8 & 47,7 & 31,5 & 130 \\
\hline Marie Curie Actions (MCA) & 5,0 & 67,5 & 27,5 & 40 \\
\hline Networks of Excellence (NOE) & 24,4 & 35,6 & 40,0 & 45 \\
\hline Specific Support Actions (SSA) & 8,3 & 62,5 & 29,2 & 48 \\
\hline Specific Targeted Research Projects (STREP) & 27,7 & 49,6 & 22,6 & 137 \\
\hline Total & $\mathbf{2 2 , 0}$ & $\mathbf{5 0 , 3}$ & $\mathbf{2 7 , 7}$ & $\mathbf{4 9 1}$ \\
\hline
\end{tabular}

Source: Survey to Norwegian participants in FP6. ERA-net participants were not posed this question. 
Table A 16 Participants' assessments of effects on other research activities: "My organisations participation in the EU Framework Programme has enabled us to generate international projects also outside the EU Framework Programme", per cent by programme.

\begin{tabular}{|c|c|c|c|c|}
\hline Priority & Yes & No & $\begin{array}{r}\text { No } \\
\text { opinion } \\
\end{array}$ & $\mathrm{N}$ \\
\hline 1. Life sciences, genomics and biotechnology for health & 43,5 & 39,1 & 17,4 & 23 \\
\hline 2. Information society technologies & 43,2 & 44,6 & 12,2 & 74 \\
\hline $\begin{array}{l}\text { 3. Nanotechnologies and nanosciences, knowledge-based multifunctional } \\
\text { materials and new production processes and devices }\end{array}$ & 42,1 & 26,3 & 31,6 & 19 \\
\hline 4. Aeronautics and space & 46,2 & 30,8 & 23,1 & 13 \\
\hline 5. Food quality and safety & 44,2 & 30,2 & 25,6 & 43 \\
\hline 6. Sustainable development, global change and ecosystems & 46,1 & 39,1 & 14,8 & 115 \\
\hline 7. Citizens and governance in a knowledge-based society & 33,3 & 38,9 & 27,8 & 36 \\
\hline Horizontal research activities involving SMEs & 28,9 & 46,7 & 24,4 & 45 \\
\hline Human resources and mobility & 30,0 & 35,0 & 35,0 & 40 \\
\hline Policy support and anticipating scientific and technological needs & 31,4 & 39,2 & 29,4 & 51 \\
\hline Research and innovation & 50,0 & 35,7 & 14,3 & 14 \\
\hline Remaining priorities ( 5 priorities with less than 10 cases) & 60,0 & 15,0 & 25,0 & 20 \\
\hline Total & 40,6 & 37,7 & 21,7 & 493 \\
\hline
\end{tabular}

Source: Survey to Norwegian participants in FP6.

Table A 17 Participants' assessments of effects on other research activities: "My organisations participation in the EU Framework Programme has changed our research activities - also in non-EU projects - towards larger collaborative projects", per cent by programme.

\begin{tabular}{|c|c|c|c|c|}
\hline Priority & Yes & No & $\begin{array}{r}\text { No } \\
\text { opinion }\end{array}$ & $\mathrm{N}$ \\
\hline 1. Life sciences, genomics and biotechnology for health & 43,5 & 47,8 & 8,7 & 23 \\
\hline 2. Information society technologies & 28,4 & 48,6 & 23,0 & 74 \\
\hline $\begin{array}{l}\text { 3. Nanotechnologies and nanosciences, knowledge-based multifunctional } \\
\text { materials and new production processes and devices }\end{array}$ & 36,8 & 36,8 & 26,3 & 19 \\
\hline 4. Aeronautics and space & 30,8 & 46,2 & 23,1 & 13 \\
\hline 5. Food quality and safety & 27,9 & 58,1 & 14,0 & 43 \\
\hline 6. Sustainable development, global change and ecosystems & 32,2 & 53,0 & 14,8 & 115 \\
\hline 7. Citizens and governance in a knowledge-based society & 36,1 & 55,6 & 8,3 & 36 \\
\hline Horizontal research activities involving SMEs & 30,2 & 39,5 & 30,2 & 43 \\
\hline Human resources and mobility & 32,5 & 52,5 & 15,0 & 40 \\
\hline Policy support and anticipating scientific and technological needs & 37,3 & 41,2 & 21,6 & 51 \\
\hline Research and innovation & 28,6 & 57,1 & 14,3 & 14 \\
\hline Remaining priorities (5 priorities with less than 10 cases) & 45,0 & 35,0 & 20,0 & 20 \\
\hline Total & 33,0 & 48,9 & 18,1 & 491 \\
\hline
\end{tabular}




\section{Appendix 2 List of Abbreviations}

\begin{tabular}{|c|c|}
\hline AERO & Aeronautics and space \\
\hline ARTEMIS & Embedded Computing Systems Initiative \\
\hline BIA & Brukerstyrt innovasjonsarena \\
\hline $\mathrm{BIO}$ & Food, Agriculture and Fisheries, and Biotechnology \\
\hline BONUS & Joint Research Programme on Baltic Sea Research \\
\hline CA & Coordination Action \\
\hline CERN & European Organization for Nuclear Research \\
\hline CIP & Competitiveness and Innovation Programme \\
\hline CITIZEN & Citizens and governance in a knowledge-based society \\
\hline CLR & Collective Research Projects \\
\hline CRAFT & Co-operative Research Projects \\
\hline CREST & European Union Scientific and Technical Research Committee \\
\hline CSA & Coordination and Support Action \\
\hline DG & Directorate General \\
\hline DG RTD & Directorate General Research Technology and Development \\
\hline EIP & Entrepreneurship and Innovation Programme \\
\hline EIS & European Innovation Scoreboard \\
\hline EMBL & European Molecular Biology Laboratory \\
\hline EMPR & European Metrology Joint Research Programme \\
\hline ENIAC & European Nanoelectronics Initiative Advisory Council \\
\hline ERA & European Research Area \\
\hline ERANET & $\begin{array}{l}\text { Support for the coordination of activities/Instrument for cross-border joint } \\
\text { funding of R\&D }\end{array}$ \\
\hline ERC & European Research Council \\
\hline ESA & European Space Agency \\
\hline ESFRI & European Strategy Forum on Research Infrastructures \\
\hline ESRF & The European Synchrotron Radiation Facility \\
\hline EU & European Union \\
\hline EURATOM & European cooperation in nuclear energy \\
\hline EUREKA & Pan-European network for market-oriented, industrial R\&D. \\
\hline FOOD & Food quality and safety \\
\hline FP5 & $\begin{array}{l}\text { Fifth Framework Programme for Research and Technological Development } \\
\text { (1998-2002) }\end{array}$ \\
\hline FP6 & $\begin{array}{l}\text { Sixth Framework Programme for Research and Technological Development } \\
(2002-2006)\end{array}$ \\
\hline FP7 & $\begin{array}{l}\text { Seventh Framework Programme for Research and Technological } \\
\text { Development (2007-2013) }\end{array}$ \\
\hline GBOARD & Government Budget Appropriations or Outlays for R\&D \\
\hline GDP & Gross Domestic Product \\
\hline
\end{tabular}




\begin{tabular}{|c|c|}
\hline GERD & Gross Expenditure on R\&D \\
\hline GMES & Global Monitoring for Environment and Security \\
\hline HEI & Higher Education Institution \\
\hline I3 & Specific Actions to Promote Research Infrastructures \\
\hline ICT & Information and Communication Technologies \\
\hline IGLO & Informal Group of Liaison Offices \\
\hline IN & Innovasjon Norge \\
\hline INCO & $\begin{array}{l}\text { Activities of International Co-operation/Specific measures in support of } \\
\text { international cooperation }\end{array}$ \\
\hline INNO & Research and innovation \\
\hline IP & Integrated Project \\
\hline IPEG & Innovation Policy Expert Group \\
\hline IPR & Intellectual Property Rights \\
\hline IRC & Innovation Relay Centre \\
\hline IRE & Innovating Regions in Europe \\
\hline IST & Information society technologies \\
\hline JRC & Joint Research Centre \\
\hline JTI & Joint Technology Initiatives \\
\hline LIFE & Life sciences, genomics and biotechnology for health \\
\hline MCA & Human resources and mobility/Marie Curie Actions \\
\hline MER & Norwegian Ministry of Education and Research \\
\hline NCP & National Contact Points \\
\hline NMP & $\begin{array}{l}\text { Nanotechnologies and nanosciences, knowledge-based multifunctional } \\
\text { materials and new production processes }\end{array}$ \\
\hline NoE & Network of Excellence \\
\hline $\mathrm{OMC}$ & Open Method of Coordination \\
\hline PES & Project Establishment Support Scheme \\
\hline POTENTIAL & Research Potential \\
\hline PPPs & Public-Private Partnerships \\
\hline PRACE & Partnership for Advanced Computing in Europe \\
\hline $\mathrm{R} \& \mathrm{D}$ & Research and Development \\
\hline $\mathrm{RCN}$ & Research Council of Norway \\
\hline REGIONS & Regions of Knowledge \\
\hline RI & Research infrastructures \\
\hline RIS & Regional Innovation Strategy \\
\hline RIS-NAC & Regional Innovation Strategies in Newly Associated Countries \\
\hline S\&S & Science and society \\
\hline SAV & Strategic Added Value \\
\hline SFF & Norwegian Centres of Excellence \\
\hline SFI & Norwegian Centres of Innovation Excellence \\
\hline $\mathrm{SiS}$ & Science in Society \\
\hline SME & Small and medium enterprises \\
\hline
\end{tabular}


SNE Seconded National Expert

SSA Specific Support Action

SSH Socio-economic Sciences and the Humanities

SSP+NEST Policy support and anticipating scientific and technological needs

STREP Specific Targeted Research Project

SUST Sustainable development, global change and ecosystems

TTO Technology Transfer Office

\section{Norwegian R\&D institutions}

Bioforsk Norwegian Institute for Agricultural and Environmental Research

Cicero Senter for klimaforskning/Center for International Climate and Environmental Research Oslo

DNV Det Norske Veritas

IFE Institutt for energiteknikk/Institute for Energy Technology

IMR Havforskningsinstituttet/Institute of Marine Research

IRIS International Research Institute of Stavanger

Matforsk Now part of NOFIMA

MET.NO Norwegian Meteorological Institute

NIFU STEP Norsk institutt for studier av innovasjon, forskning og utdanning/ Norwegian Institute for Studies in Innovation, Research and Education

NILU Norsk institutt for luftforskning/Norwegian Institute for Air Research

NINA Norsk institutt for naturforskning

NIPH Folkehelseinstiuttet/The Norwegian Institute of Public Health

NIVA Norsk institutt for vannforskning/Norwegian Institute for Water Research

NGI Norges Geotekniske Institutt/Norwegian Geotechnical Institute

NOFIMA Norwegian Institute of Food, Fisheries and Aquaculture Research

NORUT Northern Research Institute

NPI Norsk Polarinstitutt/Norwegian Polar Instituteute

NTNU Norges teknisk-naturvitenskapelige universitet/Norwegian university of science and technology

RR-HF Rikshospitalet-Radiumhospitalet/Rikshospitalet University HospitalNorwegian Radium Hospital

SIMULA Simula Research Laboratory

SINTEF Stiftelsen for industriell og teknisk forskning ved Norges tekniske høgskole

TI Teknologisk institutt/National Institute of Technology

TØI Transportøkonomisk institutt/Institute of Transport Economics

UiA Universitetet i Agder/University of Agder

UiB Universitetet i Bergen/University of Bergen

$\mathrm{UiO} \quad$ Universitetet i Oslo/University of Oslo

UiS Universitetet i Stavanger/University of Stavanger

UiT Universitetet i Tromsø/University of Tomsø 
UMB Universitetet for miljø- og biovitenskap/Norwegian University of Life Sciences

\section{Enterprises}

Computas

FAST

NERA

NERSC

Nor-Tek

Q-Free

SensoNor

Statoil

SWCO

Telenor 


\section{Appendix 3 Informants in the evaluation}

Ministries in Norway

- Karen Nossum Bie, Ministry of Education and Research

- Maiken Engelstad, Ministry of Health and Care Services

- Pål Gretland, Ministry of Trade and Industry

- Tore Grønningsæter, Norwegian Delegation to the EU

- $\quad$ Tore Gunne, Ministry of Petroleum and Energy

- Dag Gustafson, Ministry of Trade and Industry

- Kyrre Lekve, Deputy minister, Ministry of Education and Research

- Viggo Lindahl, Ministry of Environment

- Jertrud Steinsli , Ministry of Fisheries and Coastal Affairs

- Erik Yssen, Ministry of Education and Research

- Karen Balke Øyseth, Ministry of Education and Research

Research Council of Norway

- Randi Aarekol Basmadjian, Division for Innovation

- Simen Ensby, Director, EU RTD office

- Arvid Hallen, CEO

- Anine Norgren Jahnsen, Division for Innovation

- Kari Kveseth, Director, International Unit

- Per Kommandantvold, International Unit

- Gudrun Langthaler, EU RTD, Brussels office

- Jon Børre Ørbæk, Division for Science

Innovation Norway

- Marthe Haugland, European Enterprise Network

- Helene Mørne, European Enterprise Network

\section{Participating institutions}

- Johanne Brendehaug, Tine

- Arne Flåøyen, Vetrinærinstituttet

- $\quad$ Tore Gunneriussen, Universitetet i Tromsø

- Anne Marie Haga, Universitetet i Bergen

- Elisabeth Harstad, DnV

- Rolf B. Haugen, Telenor R\&I

- Ragne Hildrum, Statkraft

- Monica Holthe, UMB

- Troels Jacobsen, Universitetet i Stavanger

- Helge Jansen, Norsk Hydro

- Collin Murphy, UMB 
- $\quad$ Einar Risvik, NOFIMA

- Nina Sindre, NTNU

- Ingrid Sogner, Universitetet i Oslo

- Jørund Sollid, Birkeland Innovasjon

- Aage Stangeland, Bellona

- $\quad$ Tore Andreas Torp, StatoilHydro

(SINTEF covered by member of the evaluation team)

Branch associations and other informants

- John Vigrestad, Norsk Industri

- $\quad$ Agne Nordbotten, FP5, FP6 and FP7 reviewer

Members and managers of national research programmes

- Astrid Brenna, NANOMAT

- Kari Fagernæs, NORKLIMA

- Dag Høivik, NANOMAT

- Hans Otto Haaland, RENERGI

- Ole Jan Iversen, chairperson, FUGE

- $\quad$ Tor Einar Johnsen, NANOMAT

- Steinar Kvitsand, IST/ICT

- $\quad$ Eliasbeth Baumann Ofstad, chairperson, RENERGI

- Torbjørn Svendsen, chairperson, VERDIKT

Observations from meetings

- $\quad$ RCN EU Research Contact Network, Gardermoen 6 March 2009

- $\quad$ EØS spesialutvalg for forskning, 17 March 2009

- $\quad$ RCN and Norwegian delegates to FP7 programme committees, 27 May 2009

- Innovation Norway’s European Enterprise Network, 31 March 2009 


\section{Appendix 4 Terms of Reference for the evaluation}

\section{Bilag 1 - Oppdragsspesifikasjon}

\section{Bakgrunn}

Kunnskapsdepartementet ønsker å inngå en avtale om gjennomføring av en evaluering av norsk deltakelse i EUs 6. rammeprogram og første del av det 7. rammeprogram..

EUs rammeprogrammer er det mest omfattende internasjonale forskningssamarbeid Norge deltar i. Norske deltakere i EUs rammeprogrammer deltar på bakgrunn av EØS-avtalen på lik linje med deltakere fra EUs medlemsland i programmet, det vil si med de samme rettigheter og plikter. Programmet er inndelt i sær- og delprogrammer innenfor disse igjen. Alle deler av programmet er åpent for norsk deltakelse.

Evalueringen skal styrke kunnskapsgrunnlaget for norsk forsknings- og innovasjonspolitikk generelt og politikk for internasjonalisering av norsk forskning spesielt. Evalueringen skal ikke minst bidra til styrket norsk evne til å møte morgendagens forsknings- og innovasjonspolitiske utfordringer knyttet til deltakelse i EU-forskningen, herunder i tiltak i rammeprogrammet for å bidra til utvikling av et europeisk forskningsområde - "European Research Area” (ERA).

Evalueringen skal herunder blant annet:

$>$ gi innspill til ny forskningsmelding i 2009

$>$ gi grunnlag for en videreutvikling av Kunnskapsdepartementets strategi for Norges samarbeid med EU om FoU med tanke på siste del av 7. rammeprogram, dvs. 2010-2013

$>$ være et innspill til arbeid med og strategier for EU-forskningen i departementer, Norges forskningsråd og de forskningsutøvende sektorene

$>$ inngå i et arbeid med å utvikle en mer aktiv politikk for norsk deltakelse i ERA

$>$ være en del av vurderingsgrunnlaget for norsk deltakelse i og norske prioriteringer for EUs fremtidige 8. rammeprogram, tentativt 2014-2020.

\section{Evalueringsoppdraget}

Evalueringen skal dekke norsk deltakelse i hele det 6. rammeprogrammet og i de første utlysningene i det 7. rammeprogrammet, det vil si perioden 2002-2008. Et vesentlig nytt element i evalueringen, sett i forhold til tidligere evalueringer av norsk deltakelse i EUs rammeprogrammer, vil være tiltak i det 6 . og det 7. rammeprogrammet med relevans for utvikling av ERA. Utvikling av ERA er nært knyttet til EUs høyt profilerte Lisboa-strategi.

En evaluering av norsk deltakelse i EUs rammeprogrammer i perioden 2002-2008 skal innebære en uavhengig analyse i tre deler av i) resultater og effekter av den norske deltakelsen, ii) rammeprogrammet og ERA som virkemidler i norsk forsknings- og innovasjonspolitikk og iii) nasjonale virkemidler for deltakelse i EU-forskningen og arbeidet i forvaltningen med denne, samt relevante målsettinger. Målsettinger omfatter de mål som er etablert for programmet og den norske deltakelsen, samt overordnede mål i norsk forsknings- og innovasjonspolitikk.

Evalueringen skal for alle delene foreta sammenligninger med: 
- tidligere evalueringer av norsk deltakelse i rammeprogram der dette er relevant for å se utviklingstrender.

- $\quad$ andre land både innenfor rammen av evalueringen og ved å ta i betraktning andre pågående evalueringer av 6. rammeprogram i medlemslandene og assosierte land til programmet, og særlig i de nordiske landene.

Evalueringen skal vurdere om resultater av deltakelsen i EU-forskningen står i forhold til de ressurser som legges inn i slik deltakelse både fra deltakernes og myndighetenes side.

Evalueringen skal så langt som mulig vurdere hvordan ressurser til kontingent til EUs rammeprogrammer står seg sett i forhold til utnyttelsen av offentlige forskningsbevilgninger til sammenlignbar nasjonal forskning og øvrig, sammenlignbart internasjonalt forskningssamarbeid, basert på tilgjengelige undersøkelser og data.

Det kan i forlengelsen av evalueringen være aktuelt å foreta nærmere vurderinger av enkelte forhold og legge til rette for en fordypning.

\section{Målsettinger}

De målsettinger evalueringen skal basere seg på er nedfelt i følgende dokumenter:

- St. meld. nr. 39 (1998-99) Forskning ved et tidsskille og innstilling fra Stortinget

- St. meld. nr. 20(2004-2005) Vilje til forskning og innstilling fra Stortinget

- St.prp. nr. 16(2002-2003) Om samtykke til godkjenning av EØS-komiteens beslutning nr. 154/2002 av 8. november 2002 om endring av artikkel 1 i protokoll 31 i EØS-avtalen om EFTA/EØS-statenes deltagelse i EUs 6. rammeprogram for forskning, teknologisk utvikling og demonstrasjonsaktiviteter

- St.prp. nr. 48(2006-2007) Om samtykke til deltakelse i en beslutning i EØSkomiteen om innlemmelse i EØS-avtalen av EUs sjuende rammeprogram for forskning, teknologisk utvikling og demonstrasjonsaktiviteter (2007-2013)

- Innstillinger fra Stortinget om St.prp. nr 16(2002-2003) og St.prp. nr. 48(20062007)

- Budsjettproposisjoner (St.prp. nr. 1) fra NHD og UFD/KD for perioden 2002-2008.

- Nasjonal helseplan 2007-2010

Evalueringen skal særlig legge vekt på de prioriterte strukturelle, tematiske og teknologiske FoU-områdene i norsk forskningspolitikk - jf. St. meld. nr. 20(2004-2005) Vilje til forskning ("Forskningsmeldingen") - og forskning relatert til klimautfordringene. Prioriterte norske FoU-områder som går på tvers av temaene i rammeprogrammet, som havforskning og havteknologi, skal ivaretas i evalueringen.

\section{Ncermere om de tre delene i evalueringen}

I gjennomføringen av evalueringens tre deler skal det legges vekt på de erfaringer som er gjort i tilknytning til norsk deltakelse i EUs 6. og 7. rammeprogrammer av forskningsinstitusjoner, bedrifter og andre norske deltakere i rammeprogrammene, Norges forskningsråd, Innovasjon Norge, departementer, norsk offisiell representasjon i Brussel og Kommisjonen.

\section{i) Del 1 - Resultater og virkninger for deltakere og samfunnet}

\section{Del 1 skal:}


i) gi en overordnet fremstilling og vurdering av omfang og profil på den norske deltakelsen i det 6 . rammeprogrammet og de første utlysningene i det 7. rammeprogrammet

ii) gi en fremstilling og vurdering av resultater for FoU-aktørene i rammeprogrammet i denne perioden (brukereffekter)

iii) gi en vurdering av overordnede samfunnseffekter av den norske deltakelsen i 6. og 7. rammeprogram, herunder kunnskapstilfang og innovasjon.

Denne delen skal gi en status- og resultatanalyse, og skal identifisere eventuelle forbedringspunkter for den norske deltakelsen i rammeprogrammet. Kontinuitet vs. endringer i den norske deltakelsen ved overgangen fra det 6 . til det 7 . rammeprogrammet skal belyses. Funn i denne delen skal sammenholdes med handlingsrettede analyser i de to neste delene.

Vedr. i), legges det til grunn at dette punktet i stor grad baseres på tilgjengelig statistikk fra Kommisjonen og Norges forskningsråd.

Blant problemstillingene evalueringen skal belyse i denne deler er:

- Utnyttelse, dvs. i hvilken grad norske forskere, institusjoner og norsk næringsliv nyttiggjør seg rammeprogrammet. Evalueringen skal vurdere om det er forskjeller mellom sektorer hva gjelder deltakelse og ikke-deltakelse og vurdere forklaringer på forskjeller.

- Utbytte for deltakerne, dvs. i hvilken grad deltakelsen bidrar til vitenskapelig og teknologisk utvikling, nye nettverk, utvikling av menneskelige ressurser, tilgang på forskningsinfrastruktur, nye kommersielle muligheter med mer.

- Avkastning, dvs. deltakelsens evne til å skape innovasjoner og økt verdiskaping.

- Forholdet mellom førstegangs- og tidligere deltakelse, dvs. i hvilken grad det kommer ny, norsk deltakelse til i rammeprogrammet.

- Kvaliteten på EU-prosjektene norske aktører deltar i.

- Langtidsvirkninger, dvs. effekter av deltakelsen i et mer langsiktig perspektiv.

- Strategier, dvs. i hvilken grad norske deltakere har uttrykte mål, prioriteringer og planer for deltakelsen.

- Fordeling av økonomisk støtte fra EU; hvordan EU-støtte til norske deltakere fordeler seg på delprogrammer i rammeprogrammet, aktørgrupper (universiteter og høyskoler, helseforetak, forskningsinstitutter, bedrifter/SMB og andre) og geografisk tilhørighet, og mulige forklaringer på den observerte fordelingen.

- Kostnader for deltakerne ved deltakelse og inndekning av disse.

- Kjønn; fordeling på kjønn i den norske deltakelsen.

\section{ii) Del 2 - Rammeprogrammet som virkemiddel i norsk forsknings- og innovasjonspolitikk}

Del 2 skal vurdere hvilken betydning rammeprogrammet har som forsknings- og innovasjonspolitisk virkemiddel, både sett i forhold til mål om økt kvalitet og relevans i norsk forskning gjennom internasjonalisering og styrking av øvrige nasjonale strukturelle, tematiske og teknologiske FoU-prioriteringer. Status og utvikling hva gjelder samspill og synergi med nasjonale FoU-satsinger skal stå sentralt, herunder vurderinger av nasjonal absorpsjonsevne knyttet til EU-forskningen og arbeidsdeling mellom den nasjonale forskningen og EU-forskningen. Forbedringspunkter skal klargjøres. 
Denne delen skal videre vurdere hvordan og i hvilken grad nasjonal forskning og nasjonale FoU-aktører omfattes og påvirkes av tiltak i rammeprogrammet for strukturering og integrasjon. Det 6. rammeprogrammet introduserte nye virkemidler (Integrated Projects, Networks of Excellence, ERA-NET) for å bidra til kritisk masse, strukturelle endringer og mer varig integrasjon i europeisk forskning, på bakgrunn av målet om å utvikle ERA. Tiltakene videreføres i det 7. rammeprogrammet, og det kommer til nye tiltak etter traktatens artikler 169 og 171, blant annet basert på ERA-NET og europeiske teknologiplattformer.

Evalueringen skal vurdere de forskningspolitiske innretninger Norge har gjort knyttet til åpning av nasjonale FoU-programmer og deltakelse i programsamarbeid, felles programmer og store teknologiløft, og sammenholde dette med framskrivninger i en handlingsrettet analyse som skisserer ulike handlingsvalg, dels basert på ulike finansieringsnivå, dels basert på alternative felter for innsats.

Del 2 skal også vurdere supplerende forskningspolitiske problemstillinger knyttet til:

- Addisjonalitet, dvs. deltakelsens evne til å utløse ytterligere FoU-innsats og endret FoU-atferd

- Konkurranseevne, $d v s$. norske deltakeres faglige og økonomiske evne til å delta i og nå opp i konkurransen i rammeprogrammet

- Intellektuelle rettigheter, dvs. norske deltakeres evne til å håndtere disse i EUprosjektene.

\section{iii) Del 3 - Nasjonale virkemidler og arbeidet i forvaltningen med EU-forskningen}

Del 3 skal vurdere tre temaer på ulike nivå i forvaltningen:

- Virkemidler for deltakelse i EU-forskningen

- Styringsdialog og koordinering

- Påvirkning av EU-forskningen og Norges deltakelse i programkomiteer i rammeprogrammet

Det skal foretas en effektanalyse av det nasjonale veilednings- og rådgivingsarbeidet og økonomiske incentiver for deltakelse i rammeprogrammet. Forholdet mellom ressursinnsats og resultater og effekter skal stå sentralt. Det skal legges vekt på sammenligninger av effekter av virkemidlene og effektivitet i disse hva gjelder norsk deltakelse i EU-forskningen med relevans for følgende nasjonale FoU-prioriteringer:

$$
\begin{array}{ll}
\text { o } & \text { Helse } \\
\text { o } & \text { IKT } \\
\text { o } & \text { Miljø } \\
\text { o } & \text { Nye materialer/nanoteknologi. }
\end{array}
$$

Evalueringen skal foreta en framskriving av virkemiddelbehov for siste del av det 7 . rammeprogrammet. Denne skal omfatte virkemidler i Norges forskningsråd og øvrige deler av virkemiddelapparatet, herunder Innovasjon Norge.

I tilknytning til styringsdialogen skal evalueringen vurdere om de nasjonale og sektorpolitiske målsettingene for deltakelse i EU-forskningen er klart definerte, tilstrekkelige og godt koordinerte, og vurdere eventuelle forbedringspunkter hva gjelder 
organisering, koordinering og prioritering av arbeidet med EU-forskningen i

departementene og Norges forskningsråd.

Evalueringen skal også vurdere gjennomføring av og gjennomslagskraft i det norske påvirkningsarbeidet overfor EU hva gjelder innholdet i EU-forskningen, herunder i programkomiteer, og ressursbruken knyttet til dette. Forbedringspunkter skal angis.

\section{Anbefalinger}

Evalueringen skal fremsette forskningspolitiske anbefalinger for bedre norsk deltakelse i og utbytte av EU-forskningen, optimal bruk av rammeprogrammet og ERA som forsknings- og innovasjonsstrategisk virkemiddel og bedre arbeid i forvaltningen med EUforskningen og mer effektiv virkemiddelbruk.

Evalueringen skal i sine anbefalinger ta i betraktning at budsjett for det 7 . rammeprogrammet og norske innbetalinger til EU øker i perioden 2010-2013. Evaluator skal i denne forbindelse gi en vurdering av hvilken plass og rolle rammeprogrammet og ERA bør ha som virkemiddel i norsk forsknings- og innovasjonspolitikk i tiden fremover.

Forslag til tiltak og endringer, blant annet hva gjelder fremtidig virkemiddelbruk, må være konkrete, spesifikke og godt begrunnede.

\section{Språk}

Evalueringsrapporten skal skrives på engelsk. Det skal skrives et sammendrag på norsk. Vedlegg kan være på norsk eller engelsk.

\section{Organisering og samarbeid}

\section{Underleverandører}

Evaluator vil ha det totale ansvaret for gjennomføring av evalueringen og være kontraktspartner. Det vil bli vurdert som en styrke ved tilbudet om evaluator også trekker inn andre fagmiljøer for å utføre deler av oppdraget, og dermed bidrar til en bredere faglig plattform knyttet til norsk deltakelse i EUs rammeprogrammer. Evaluator vil ha ansvaret overfor oppdragsgiver for at evalueringen skjer på en faglig tilfredsstillende måte og i henhold til konkurransegrunnlaget, og for fremdrift i deloppdragene. Det er evaluators ansvar å trekke konklusjoner av det samlede arbeidet.

\section{Referansegruppe}

Kunnskapsdepartementet vil oppnevne en referansegruppe for arbeidet. Kunnskapsdepartementet, Nærings- og handelsdepartementet, Helse- og omsorgsdepartementet og Norges forskningsråd vil være representert i referansegruppen i tillegg til representanter for de forskningsutøvende sektorene og/eller fagpersoner.

Detaljer skal avklares nærmere mellom evaluator og oppdragsgiver.

\section{Støtte og datagrunnlag}

Evaluator skal utføre sitt arbeid i en uavhengig og kunnskapsbasert prosess. Evaluator vil i sitt arbeid få bistand av Norges forskningsråd i den grad dette er ønskelig og aktuelt, blant annet hva gjelder fremskaffelse av data og relevante rapporter og studier utarbeidet i Norges forskningsråd og av andre, med sikte på en effektiv gjennomføring av evalueringen. 


\title{
Appendix 5 Bibliometric analysis of Norwegian R\&D
}

\author{
Dag W. Aksnes
}

\section{Introduction}

Publication and citation data have increasingly been applied as performance indicators in the context of science policy and research evaluation. The basis for the use of bibliometric indicators is that new knowledge - the principal objective of basic and applied research is disseminated to the research community through publications. Publications can thereby be used as indirect measures of knowledge production.

This report presents the results of a bibliometric study of collaboration patterns of the Norwegian research system. The report mainly focuses on a macro level, i.e. analyses of the entire national publication output as well as sectors and institutions.

The analysis is based on data provided by Thomson Reuters, the producer of the most important database for bibliometric purposes (formerly Institute for Scientific Information (ISI)).

The main findings from this bibliometric analysis are:

- During the 20 year period 1988-2007, Norwegian scientists published a total of almost 92,000 articles in international journals. The annual number of publications has been increasing significantly during the period, from 2,800 in 1988 to 7,300 in 2007. Even more striking is the rise in the international co-authorship during the period. In 1988, 25 per cent of the publications involved international coauthorship. This proportion has been increasing steadily over the period, rising to 55 per cent in 2007 (see Figure 1). Hence, more than every second paper published by Norwegian researchers now has foreign co-authors.

- In 1988, 15 per cent of the Norwegian publications had co-authors from EU countries. This proportion increased to 37 per cent in 2007.

\section{Data and methods}

The study has been based on the bibliometric database National Citation Report (NCR) for Norway. The database contains bibliometric data on individual journal articles for Norway (that is, publications with at least one Norwegian author address; in the study regular 
articles and reviews are included). The database covers a large number of specialised and multidisciplinary journals within the natural sciences, medicine, technology, the social sciences and the humanities. Even though coverage is not complete, the database includes all major journals within the natural sciences, medicine and technology and is generally regarded as constituting a satisfactory representation of international mainstream scientific research (Katz \& Hicks, 1998).

With respect to the social sciences and humanities, the coverage is more limited. It is important to emphasise that the practice of international journal publishing varies widely between the different sectors and disciplines. This means that the data are best suited to analyse collaboration in medicine and the natural sciences in which publication in international journals represents the main mode of communication. In technology, the social sciences and the humanities, other types of publication such as regional and domestic journals, books, reports are also important. However, we think it is reasonable to assume that the data in the latter cases cover the more internationally oriented part of the research - the research addressing national or local issues would usually not be published in international journals.

From a bibliometric perspective, a main advantage of the database applied is that it fully indexes the journals that are included. Moreover, all author names, author addresses and references are indexed. Through its construction it is also well adapted for bibliometric analysis. For example, country names and journal names are standardised, controlled terms. Of particular importance is that all author addresses are indexed, not just the first or reprint address for each paper. By definition, a publication is co-authored if it has more than one author, internationally co-authored if it has authors from more than one country. In this study this means that in addition to a Norwegian author address it has one or more foreign author addresses.

Compared to other methodologies, bibliometrics provides unique and systematic insight into the extent and structure of scientific collaboration. A main advantage is that the size of the sample that can be analysed using this technique can be very large and render results that are more reliable than those from case studies. Also, the technique captures nonformalised types of collaboration that can be difficult to identify with other methodologies.

There are nevertheless certain limitations. Research collaboration sometimes leads to other types of output than publications. Moreover, co-authorship can only be used as a measure of collaboration if the collaborators have put their names on a joint paper. Not all collaboration ends up in co-authorship and the writing of co-authored papers does not necessarily imply close collaboration (Katz \& Martin, 1997; Luukkonen, Persson, \& Sivertsen, 1992; Melin \& Persson, 1996). 
The fact that researchers co-author a scientific paper reflects collaboration, and coauthorship is commonly used as an indicator of such collaboration. Similarly, international co-authorship is used as an indicator of international collaboration, and co-authorship with persons from the EU countries as an indicator of EU collaboration.

The purpose of this study is to analyse the collaboration profiles of Norwegian research based on data on co-authorship. Questions that will be analyzed include:

- What are the most important EU-countries in terms of research collaboration with Norway?

- Which trends can be identified during the past decades?

- What differences can be identified at the levels of disciplines, sectors and institutions?

In addition we are not only focusing on collaboration with EU countries. We take a broader perspective and are also analysing international collaboration more generally. This is because collaboration among EU/EEA countries is part of a broader trend towards globalisation and more international cooperation.

Although the primary aim of the analysis is to provide background data for the evaluation of the Norwegian participation in 6th and 7th Framework Programmes, there are limitations to this approach. Through the bibliographic details, we can observe whether a publication has co-authors from another country (or more precisely, co-authors affiliated with foreign institutions). But we do not know anything about the reason behind this particular collaboration/co-authorship. The article may be the result of a project funded through the Framework Programme, or it may be the result of other formal or informal collaboration projects outside the scope of the Framework. Thus, in our study we only observe the net effect of the various types of collaboration.

In the study we have analysed the 20-year period 1988-2007, but the main focus is on the most recent five-year period 2003-2007, which is the most relevant period for the evaluation of the participation in the $6^{\text {th }} / 7^{\text {th }}$ Framework Programmes. The 20 -year period analysed also covers years prior to the first Norwegian participation in the Framework Programme in 1994 (1988-1993). In this way we are able to assess the situation before Norwegian researchers achieved access to the Framework Programme. It should be noted that there is a certain time lag in the publication data. It will usually last one or two years or more from when the research was carried out until the results are published as printed articles. This means publication data reflect the collaboration patterns a couple of years earlier or so. Even our most recent 2007 publication data are basically a reflection of the situation around 2005. Therefore we do not yet have publication data to assess the latest years of the $6^{\text {th }} / 7^{\text {th }}$ Framework participation. 
In the analyses we have included the current EU 27 Member States in the EU categories, even if some of these countries have not been a Member State throughout the entire period analysed.

\section{$3 \quad$ Results}

During the 20 year period 1988-2007, Norwegian scientists published a total of almost 92,000 articles in international journals. The annual number of publications has been increasing significantly during the period, from 2,800 in 1988 to 7,300 in 2007. Even more striking is the rise in the international co-authorship during the period. In 1988, 25 per cent of the publications involved international co-authorship. This proportion has been increasing steadily over the period, rising to 55 per cent in 2007 (see Figure A1). Hence, more than every second paper published by Norwegian researchers now has foreign coauthors.

The figures indicate that a fundamental structural change of Norwegian science towards more international collaboration has taken place during the period. This development is, of course, not unique for Norway. However, in 2003 "only” 20 per cent of all publications worldwide were internationally co-authored (National Science Board, 2006). Norway hence represents a country with a strong element of international collaboration in its publications. On the other hand, some countries have a higher proportion of internationally co-authored papers than Norway. Figures from the recent S\&T indicator report by the National Science Foundation (National Science Board, 2006) show that Norway ranks as $14^{\text {th }}$ of 46 countries in 2003 with a proportion of 50 per cent (only nations with at least 1,000 papers included). Among the countries ahead of Norway we find a few other WestEuropean nations, among these Switzerland (58 per cent), Belgium (56 per cent), Portugal (53 per cent), Austria (51 per cent), and Denmark (51 per cent). 
Figure A 1 The number and proportion of publications involving international coauthorship with a Norwegian co-author, 1988-2007.

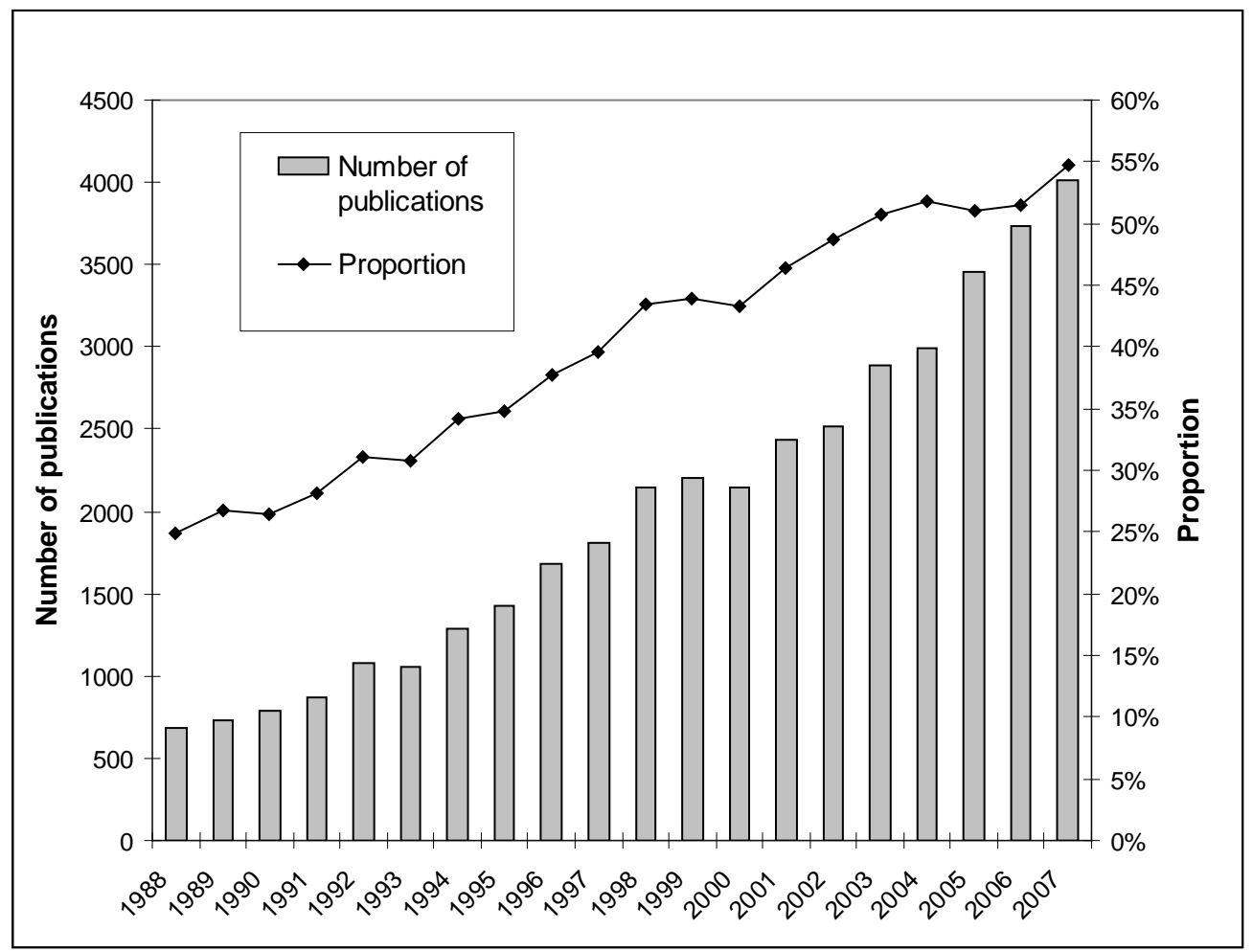

Which regions and countries are the most important collaborative partners for Norway and has the profile changed during the recent decades? This question has been addressed by analysing the distribution of co-authorships. Figure A2 shows the distribution of coauthorship for some main geographical regions for the period 1988-2007. As may be seen, the profile has changed during the period. In 1988, 15 per cent of Norwegian publications had co-authors from EU countries. This proportion increased to 37 per cent in 2007. Collaboration with the North America and Nordic countries ${ }^{113}$ also increased during the period but at a much slower pace than for the EU region. Thus, the relative importance of EU-collaboration has increased, while the relative importance of North American and Nordic collaboration has decreased.

Within the approach of this study, we cannot examine the reasons for this change in geographical collaboration profile. Nevertheless, the Norwegian participation in the EU Framework Programmes and the associated research cooperation with European partners has no doubt had a major impact in this respect. In fact, during the years following the Norwegian participation in the Framework Programme (1995-1998), the growth was particularly strong and the proportion increased by 7 percentage points from 22 to 29 per cent. On the other hand, it should be noted that the proportion of collaborative articles with the EU countries has increased gradually. A significant rise can be found also in the years prior to the Norwegian participation in the Framework Programme in 1994. This indicates

113 The three Nordic EU member states are also included in the EU-category. 
that the trend towards increased Europeanisation is part of the broader internationalisation trend which would have occurred also without a Norwegian participation the Framework Programmes - albeit at a slower pace.

Figure A 2 The proportion of the Norwegian publications involving international coauthorship, by region (EU-27, North America and Nordic* countries) 19882007

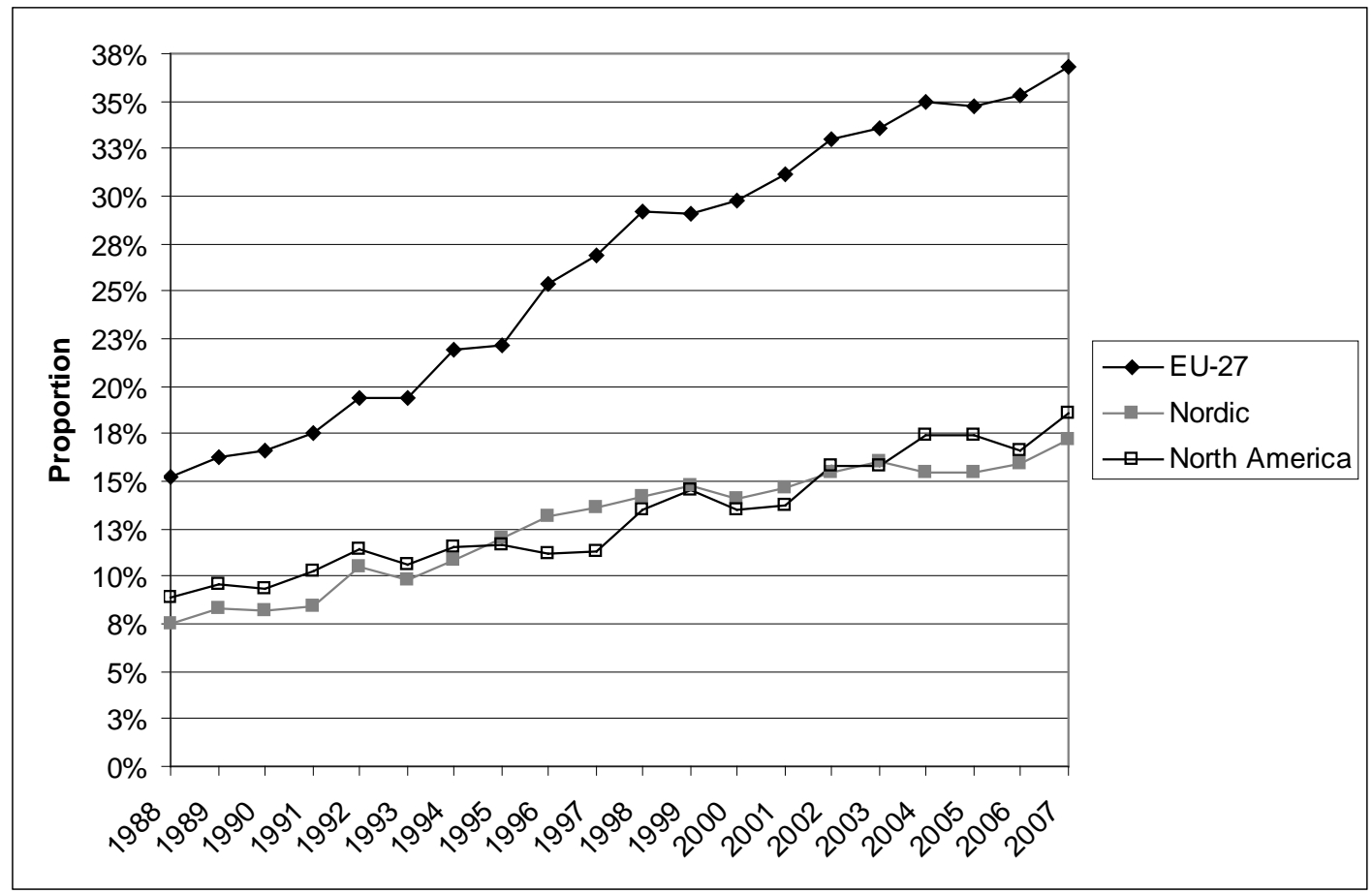

*) The three Nordic EU member states are also included in the EU-category

In Table B1 we have shown the proportion of the Norwegian publications involving international co-authorship by country for four periods: 1989-1993, 1994-1998, 19992002, and 2003-2007. The USA is by far the largest collaborative partner in all the periods. In 2003-2007, 15 per cent of publications had US co-authors compared to 9 per cent in 1989-1993. However, other countries have had a stronger growth, most notably the UK (from 4.2 per cent to 11.2 per cent), Germany (3.3 per cent to 8.0 per cent) and France (2.3 per cent to 6.4 per cent). 
Table B 1 The proportion of the Norwegian publications involving international coauthorship, by country*, 1989-1993, 1994-1998, 1999-2002, 2003-2007.

\begin{tabular}{|c|c|c|c|c|}
\hline COUNTRY & 1989-1993 & 1994-1998 & 1999-2002 & 2003-2007 \\
\hline USA & $9.2 \%$ & $10.6 \%$ & $12.6 \%$ & $15.1 \%$ \\
\hline UK & $4.2 \%$ & $6.5 \%$ & $8.9 \%$ & $11.2 \%$ \\
\hline SWEDEN & $6.1 \%$ & $8.5 \%$ & $9.5 \%$ & $9.7 \%$ \\
\hline GERMANY & $3.3 \%$ & $5.1 \%$ & $5.9 \%$ & $8.0 \%$ \\
\hline DENMARK & $3.4 \%$ & $4.8 \%$ & $5.6 \%$ & $6.4 \%$ \\
\hline FRANCE & $2.3 \%$ & $3.8 \%$ & $5.1 \%$ & $6.4 \%$ \\
\hline NETHERLANDS & $1.8 \%$ & $3.3 \%$ & $3.6 \%$ & $5.4 \%$ \\
\hline ITALY & $1.4 \%$ & $2.5 \%$ & $3.0 \%$ & $4.6 \%$ \\
\hline CANADA & $1.4 \%$ & $1.8 \%$ & $2.7 \%$ & $4.2 \%$ \\
\hline FINLAND & $1.7 \%$ & $3.0 \%$ & $3.6 \%$ & $3.9 \%$ \\
\hline SPAIN & $0.8 \%$ & $1.8 \%$ & $2.0 \%$ & $3.8 \%$ \\
\hline RUSSIA/USSR & $1.0 \%$ & $2.4 \%$ & $2.7 \%$ & $3.1 \%$ \\
\hline SWITZERLAND & $1.3 \%$ & $2.1 \%$ & $2.1 \%$ & $2.4 \%$ \\
\hline BELGIUM & $0.8 \%$ & $1.5 \%$ & $1.7 \%$ & $1.9 \%$ \\
\hline AUSTRALIA & $0.5 \%$ & $0.8 \%$ & $1.3 \%$ & $1.9 \%$ \\
\hline CHINA & $0.3 \%$ & $0.4 \%$ & $0.8 \%$ & $1.9 \%$ \\
\hline POLAND & $0.9 \%$ & $1.3 \%$ & $1.5 \%$ & $1.6 \%$ \\
\hline JAPAN & $0.7 \%$ & $1.3 \%$ & $1.5 \%$ & $1.5 \%$ \\
\hline AUSTRIA & $0.6 \%$ & $1.0 \%$ & $1.3 \%$ & $1.5 \%$ \\
\hline GREECE & $0.5 \%$ & $1.0 \%$ & $1.0 \%$ & $1.2 \%$ \\
\hline ICELAND & $0.4 \%$ & $0.5 \%$ & $0.8 \%$ & $1.0 \%$ \\
\hline PORTUGAL & $0.5 \%$ & $0.9 \%$ & $0.8 \%$ & $0.9 \%$ \\
\hline CZECH REPUBLIC & $0.0 \%$ & $0.8 \%$ & $1.0 \%$ & $0.9 \%$ \\
\hline ISRAEL & $0.4 \%$ & $0.5 \%$ & $0.6 \%$ & $0.9 \%$ \\
\hline BRAZIL & $0.3 \%$ & $0.8 \%$ & $0.7 \%$ & $0.7 \%$ \\
\hline IRELAND & $0.1 \%$ & $0.3 \%$ & $0.5 \%$ & $0.7 \%$ \\
\hline NEW ZEALAND & $0.1 \%$ & $0.3 \%$ & $0.3 \%$ & $0.6 \%$ \\
\hline SOUTH AFRICA & $0.0 \%$ & $0.1 \%$ & $0.3 \%$ & $0.6 \%$ \\
\hline SLOVENIA & $0.1 \%$ & $0.5 \%$ & $0.6 \%$ & $0.5 \%$ \\
\hline HUNGARY & $0.2 \%$ & $0.4 \%$ & $0.4 \%$ & $0.5 \%$ \\
\hline $\begin{array}{l}\text { TOTAL (number of } \\
\text { Norwegian articles) }\end{array}$ & 15,699 & 21,820 & 20,398 & 32,832 \\
\hline
\end{tabular}

*) Only countries with proportions of 0.5 or above in the most recent period (2003-2007) are included in the table.

For the most recent period (2003-2007) we identified all articles involving co-authorship between persons from Norway and one or more EU-27 countries (a total of more than 11,000 publications) and calculated the share of co-authorship by country. The results are given in Table 2. In contrast to the previous table we here used the sum of all collaborative links as denominator $(21,488)$. Thus, Table B2 shows the relative importance of the various EU-27 countries as collaborative partners in per cent. As can be seen, the UK, Sweden and Germany are the largest collaborative countries. For example, Norwegian researchers co-authored the 3,665 papers with UK colleagues during this period. At the other end, we find Malta with 6 co-authored publications. 
Table B 2 The relative importance of the various EU-27 countries as collaborative partners. Proportion* of the Norway-EU publications by countries, 20032007.

\begin{tabular}{|l|r|r|l|r|r|}
\hline COUNTRY & $\begin{array}{l}\text { NUMBER OF } \\
\text { ARTICLES }\end{array}$ & PROPORTION* & COUNTRY & $\begin{array}{l}\text { NUMBER OF } \\
\text { ARTICLES }\end{array}$ & PROPORTION* \\
\hline UK & 3665 & $15.8 \%$ & CZECH REP. & 300 & $1.3 \%$ \\
\hline SWEDEN & 3190 & $13.7 \%$ & IRELAND & 236 & $1.0 \%$ \\
\hline GERMANY & 2628 & $11.3 \%$ & HUNGARY & 170 & $0.7 \%$ \\
\hline DENMARK & 2114 & $9.1 \%$ & SLOVENIA & 151 & $0.6 \%$ \\
\hline FRANCE & 2094 & $9.0 \%$ & ESTONIA & 114 & $0.5 \%$ \\
\hline NETHERLANDS & 1782 & $7.7 \%$ & LITHUANIA & 108 & $0.5 \%$ \\
\hline ITALY & 1505 & $6.5 \%$ & ROMANIA & 97 & $0.4 \%$ \\
\hline FINLAND & 1277 & $5.5 \%$ & SLOVAKIA & 95 & $0.4 \%$ \\
\hline SPAIN & 1232 & $5.3 \%$ & BULGARIA & 57 & $0.2 \%$ \\
\hline BELGIUM & 631 & $2.7 \%$ & LUXEMBOURG & 31 & $0.1 \%$ \\
\hline POLAND & 535 & $2.3 \%$ & LATVIA & 26 & $0.1 \%$ \\
\hline AUSTRIA & 504 & $2.2 \%$ & CYPRUS & 9 & $0.0 \%$ \\
\hline GREECE & 384 & $1.7 \%$ & MALTA & 6 & $0.0 \%$ \\
\hline PORTUGAL & 303 & $1.3 \%$ & TOTAL & $21,844^{*}$ & $100 \%$ \\
\hline
\end{tabular}

*) Double/multiple counts occur when a publication is co-authored by persons from more than one country. The unique number of Norway-EU publications is 11,549.

We also analysed the extent to which a change from bi-national to multi-national collaboration patterns has occurred. Since part of the Framework funding requires collaboration between institutions in at least three different countries one would expect multi-national collaboration to have been more frequent. In Figure A3 we have shown how the EU collaboration pattern changed in the period 1988-2007. In 1988 almost 90 per cent of the papers Norwegian researchers co-authored with colleagues in the EU countries were binational; in other words, involving collaboration between researchers in Norway and one other country. This proportion decreased to 68 per cent in 2007. Although this is a significant reduction, binational collaboration is still by far the most common. 
Figure A 3 The number of EU-27 countries per paper. Proportion of all Norway-EU collaborative papers, 1988-2007.

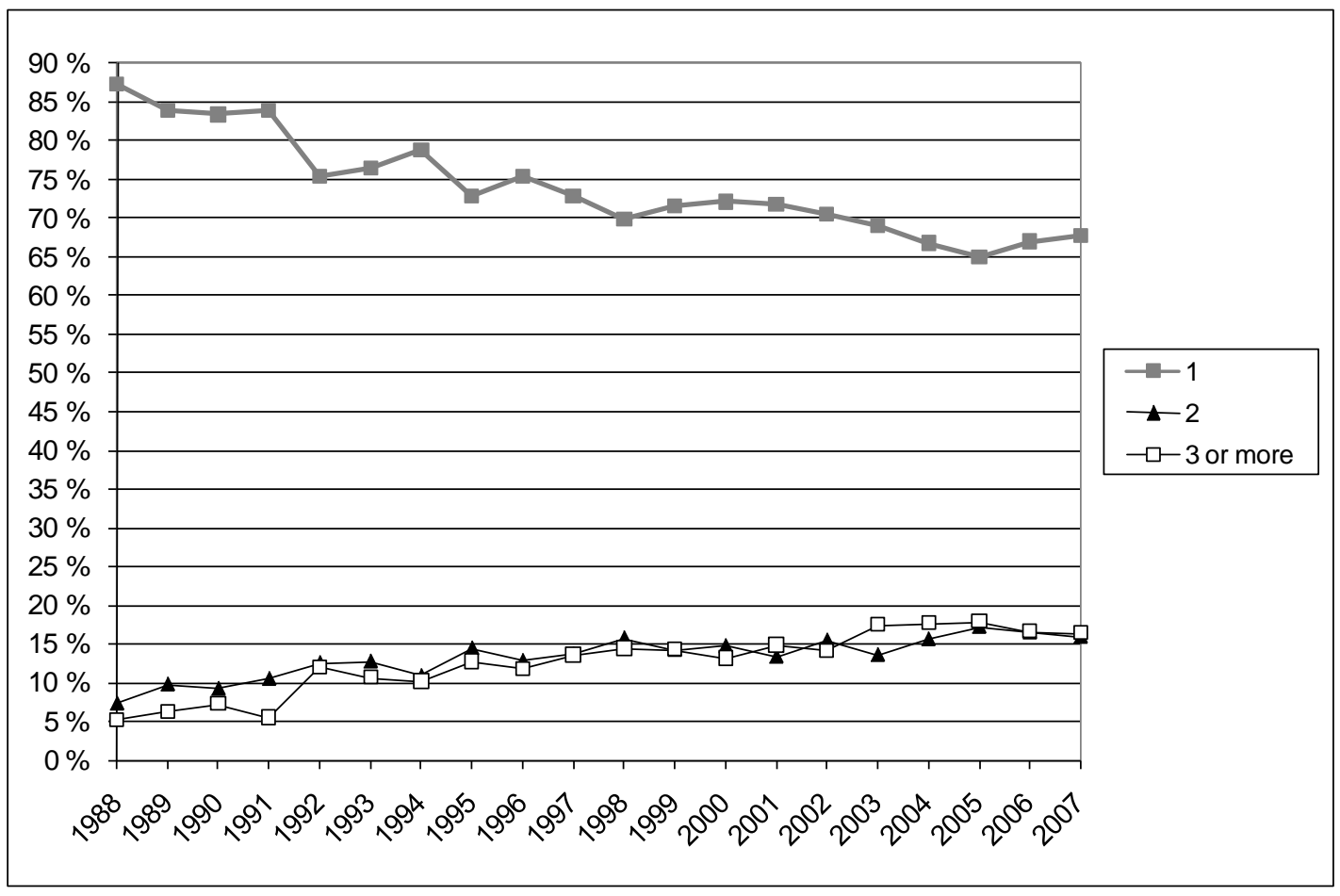

\subsection{Analyses of scientific fields: Disciplines}

Previous studies have shown that there are large differences between the various disciplines in terms of degree of international collaboration measured thorough coauthorship (Aksnes, Slipersater, Frolich 2008). We would expect to find a similar pattern in respect to the EU-collaboration. We analysed the proportion of international collaboration and EU collaboration for the four periods given above. In addition we identified the extent of Nordic collaboration, and collaboration more generally - i.e. the share of the articles that were authored by more than one author (regardless of nationality). The results are given in Tables B3 and B4.

A preliminary observation is that in the natural sciences, medicine and technology the large and increasing majority of the articles are collaborative. In biomedicine, for example, only 3 per cent of the publications in the most recent period (2003-2007) were singly authored. In the social sciences and the humanities the situation is different and in the latter domain the single-authored paper is still the norm. In 2003-07, 87 per cent of the papers had only one author compared to 98 per cent in the period 1989-1993. The social sciences used to have a profile characterised by very little collaboration but this has changed considerably. For example, in the category “Other social sciences”, 44 per cent of the papers had only one author in the most recent period, compared to 74 per cent in the period 1989-93. 
Tables B3 and B4 also show that there are major differences among the disciplines in terms of international collaboration. Physics and earth/space sciences have the highest proportion of international co-authorship, with 70 per cent of the articles involving international collaboration in the most recent period 2003-2007. These disciplines clearly rank above the others. Nevertheless, the proportion of international co-authorship is now around 50 per cent in mathematics, chemistry, biomedicine, biology, clinical medicine, engineering, and the agricultural sciences. There is a moderate level of international collaboration in psychology/psychiatry, economics and other social sciences. In these fields 30 to 40 per cent of the publications involved international co-authorship in 20032007. There is very little international collaboration as reflected in co-authorship in the humanities; 10 per cent in the most recent period.

In a recent article by Aksnes, Frolich and Slipersaeter (2008) showing similar results, the following explanations and comment was made: "This ranking pattern among the disciplines corresponds fairly well with those found in earlier studies (e.g. Frame and Carpenter, 1979; Luukkonen, Persson, Sivertsen, 1992). With regard to international collaboration, there seems to be a universal hierarchy among the disciplines that is not affected (or at least not strongly affected) by differences at the national level in terms of political, financial, and other factors related to research collaboration. There are, however, major differences in co-authorship among the countries also at the field level. In Norway, the share of international co-authorship has reached 70 per cent in some disciplines. If this development continues, almost all papers involving collaboration will involve international collaboration. If this is the case, national borders will have almost vanished in the process of scientific research.

Several attempts have been made to explain the marked variations among the disciplines in terms of international collaboration. One suggestion is that research addressing global or universal issues will have a much higher share of international collaboration than research of a domestic or local character. This explains why international collaboration is much more common in the natural sciences and medicine than in the social sciences and the humanities. Another important factor is access to research facilities. International collaboration has been shown to be particularly extensive in experimental research involving large-scale instrumentation such as telescopes or particle accelerators (Katz and Martin, 1997). Such facilities are often internationally maintained and bring together scientists from different countries. For areas of physics and the earth/space sciences, access to large-scale research facilities is essential, which likely contributes to the high share of international co-authorship found in these disciplines.”

It is interesting to note that in terms of EU-collaboration the ranking patterns are quite similar to the international collaboration patterns more generally. In physics and earth/space sciences, almost half of the publications (50 per cent and 47 per cent, respectively) in the period 2003-2007 involved collaboration with one or more EU 
countries. For the other natural sciences and medicine the corresponding proportions are in the range from 28 to 39 per cent. Moreover, in all disciplines the proportion of EUcollaboration has increased. For the two most recent periods (1999-2002 and 2003-2007) the increase was particularly strong in biology (7 percentage points) and clinical medicine, physics and other social sciences (6 percentage points).

We have also shown the proportion of articles involving collaboration among Norway and at least one other Nordic country. Apparently, Nordic collaboration is particularly important in clinical medicine and biomedicine, where approximately one fifth of the articles also had co-authors from another Nordic country in the most recent period. However, for all disciplines we find that Nordic collaboration loses its relative importance compared to other international collaboration. 
Table B 3 Co-authorship by discipline, 1989-2007. Share of articles involving international co-authorship, EU co-authorship, Nordic co-authorship and coauthorship generally. Per cent.

\begin{tabular}{|c|c|c|c|c|c|}
\hline Discipline & & 1989-1993 & 1994-1998 & 1999-2002 & 2003-2007 \\
\hline \multirow{5}{*}{ Mathematics } & Collaboration & $54 \%$ & $62 \%$ & $71 \%$ & $73 \%$ \\
\hline & International collab. & $44 \%$ & $44 \%$ & $52 \%$ & $52 \%$ \\
\hline & EU-collaboration & $18 \%$ & $24 \%$ & $29 \%$ & $33 \%$ \\
\hline & Nordic collaboration & $5 \%$ & $5 \%$ & $5 \%$ & $4 \%$ \\
\hline & $N$ & 314 & 383 & 425 & 641 \\
\hline \multirow{5}{*}{$\begin{array}{l}\text { Engineering/ } \\
\text { technology }\end{array}$} & Collaboration & $72 \%$ & $78 \%$ & $83 \%$ & $88 \%$ \\
\hline & International collab. & $28 \%$ & $33 \%$ & $42 \%$ & $46 \%$ \\
\hline & EU-collaboration & $15 \%$ & $19 \%$ & $25 \%$ & $28 \%$ \\
\hline & Nordic collaboration & $7 \%$ & $7 \%$ & $9 \%$ & $9 \%$ \\
\hline & $N$ & 1164 & 2077 & 1829 & 3547 \\
\hline \multirow{5}{*}{ Physics } & Collaboration & $83 \%$ & $88 \%$ & $92 \%$ & $94 \%$ \\
\hline & International collab. & $52 \%$ & $59 \%$ & $65 \%$ & $70 \%$ \\
\hline & EU-collaboration & $34 \%$ & $42 \%$ & $44 \%$ & $50 \%$ \\
\hline & Nordic collaboration & $15 \%$ & $23 \%$ & $22 \%$ & $18 \%$ \\
\hline & $N$ & 919 & 1480 & 1337 & 2132 \\
\hline \multirow{5}{*}{ Chemistry } & Collaboration & $87 \%$ & $93 \%$ & $94 \%$ & $95 \%$ \\
\hline & International collab. & $38 \%$ & $45 \%$ & $48 \%$ & $54 \%$ \\
\hline & EU-collaboration & $23 \%$ & $30 \%$ & $34 \%$ & $38 \%$ \\
\hline & Nordic collaboration & $8 \%$ & $11 \%$ & $13 \%$ & $13 \%$ \\
\hline & $N$ & 1224 & 1872 & 1424 & 2167 \\
\hline \multirow{5}{*}{$\begin{array}{c}\text { Earth/space } \\
\text { sciences }\end{array}$} & Collaboration & $78 \%$ & $86 \%$ & $89 \%$ & $92 \%$ \\
\hline & International collab. & $38 \%$ & $55 \%$ & $65 \%$ & $70 \%$ \\
\hline & EU-collaboration & $22 \%$ & $34 \%$ & $43 \%$ & $47 \%$ \\
\hline & Nordic collaboration & $7 \%$ & $12 \%$ & $15 \%$ & $16 \%$ \\
\hline & $N$ & 1152 & 1674 & 1763 & 2906 \\
\hline \multirow{5}{*}{ Biology } & Collaboration & $76 \%$ & $83 \%$ & $88 \%$ & $93 \%$ \\
\hline & International collab. & $27 \%$ & $36 \%$ & $45 \%$ & $55 \%$ \\
\hline & EU-collaboration & $17 \%$ & $23 \%$ & $30 \%$ & $37 \%$ \\
\hline & Nordic collaboration & $8 \%$ & $11 \%$ & $13 \%$ & $16 \%$ \\
\hline & $N$ & 2551 & 3709 & 3915 & 6016 \\
\hline
\end{tabular}


Table B $4 \quad$ Co-authorship by discipline, 1989-2007. Share of articles involving international co-authorship, EU co-authorship, Nordic co-authorship and coauthorship generally. Per cent.

\begin{tabular}{|c|c|c|c|c|c|}
\hline \multicolumn{2}{|l|}{ Discipline } & \multirow{2}{*}{$\begin{array}{r}1989-1993 \\
78 \%\end{array}$} & \multirow{2}{*}{$\begin{array}{r}\text { 1994-1998 } \\
87 \%\end{array}$} & \multirow{2}{*}{$\begin{array}{r}\text { 1999-2002 } \\
91 \%\end{array}$} & \multirow{2}{*}{$\begin{array}{r}2003-2007 \\
95 \%\end{array}$} \\
\hline \multirow{5}{*}{$\begin{array}{l}\text { Agricultural } \\
\text { sciences }\end{array}$} & Collaboration & & & & \\
\hline & International collab. & $18 \%$ & $29 \%$ & $41 \%$ & $47 \%$ \\
\hline & EU-collaboration & $11 \%$ & $19 \%$ & $26 \%$ & $29 \%$ \\
\hline & Nordic collaboration & $7 \%$ & $11 \%$ & $15 \%$ & $17 \%$ \\
\hline & $N$ & 472 & 653 & 752 & 1250 \\
\hline \multirow{5}{*}{ Biomedicine } & Collaboration & $91 \%$ & $94 \%$ & $95 \%$ & $97 \%$ \\
\hline & International collab. & $33 \%$ & $45 \%$ & $51 \%$ & $57 \%$ \\
\hline & EU-collaboration & $21 \%$ & $32 \%$ & $37 \%$ & $39 \%$ \\
\hline & Nordic collaboration & $11 \%$ & $17 \%$ & $18 \%$ & $19 \%$ \\
\hline & $N$ & 3357 & 3984 & 3576 & 5485 \\
\hline \multirow{5}{*}{ Clinical medicine } & Collaboration & $88 \%$ & $90 \%$ & $92 \%$ & $95 \%$ \\
\hline & International collab. & $22 \%$ & $33 \%$ & $40 \%$ & $49 \%$ \\
\hline & EU-collaboration & $16 \%$ & $25 \%$ & $30 \%$ & $36 \%$ \\
\hline & Nordic collaboration & $11 \%$ & $16 \%$ & $19 \%$ & $23 \%$ \\
\hline & $N$ & 4711 & 5963 & 5429 & 8551 \\
\hline \multirow{5}{*}{$\begin{array}{l}\text { Psychology/ } \\
\text { psychiatry }\end{array}$} & Collaboration & $74 \%$ & $75 \%$ & $82 \%$ & $89 \%$ \\
\hline & International collab. & $19 \%$ & $31 \%$ & $34 \%$ & $41 \%$ \\
\hline & EU-collaboration & $9 \%$ & $16 \%$ & $21 \%$ & $26 \%$ \\
\hline & Nordic collaboration & $6 \%$ & $10 \%$ & $13 \%$ & $15 \%$ \\
\hline & $N$ & 802 & 1019 & 876 & 1411 \\
\hline \multirow{5}{*}{ Economics } & Collaboration & $37 \%$ & $52 \%$ & $57 \%$ & $68 \%$ \\
\hline & International collab. & $24 \%$ & $27 \%$ & $31 \%$ & $36 \%$ \\
\hline & EU-collaboration & $14 \%$ & $16 \%$ & $19 \%$ & $21 \%$ \\
\hline & Nordic collaboration & $4 \%$ & $4 \%$ & $7 \%$ & $6 \%$ \\
\hline & $N$ & 163 & 305 & 331 & 606 \\
\hline \multirow{5}{*}{$\begin{array}{c}\text { Social sciences - } \\
\text { other }\end{array}$} & Collaboration & $26 \%$ & $32 \%$ & $44 \%$ & $56 \%$ \\
\hline & International collab. & $21 \%$ & $18 \%$ & $24 \%$ & $30 \%$ \\
\hline & EU-collaboration & $8 \%$ & $7 \%$ & $11 \%$ & $16 \%$ \\
\hline & Nordic collaboration & $4 \%$ & $3 \%$ & $4 \%$ & $7 \%$ \\
\hline & $N$ & 514 & 740 & 673 & 1277 \\
\hline \multirow{5}{*}{ Humanities } & Collaboration & $2 \%$ & $7 \%$ & $7 \%$ & $13 \%$ \\
\hline & International collab. & $3 \%$ & $5 \%$ & $4 \%$ & $10 \%$ \\
\hline & EU-collaboration & $2 \%$ & $3 \%$ & $3 \%$ & $6 \%$ \\
\hline & Nordic collaboration & $0 \%$ & $2 \%$ & $1 \%$ & $2 \%$ \\
\hline & $N$ & 251 & 308 & 272 & 412 \\
\hline
\end{tabular}

\subsection{Analyses of sectors and institutions}

In Figure A4, the proportion of EU co-authorship is shown for the Norwegian institute sector (research institutes) for the period 1991-2005. There has been a strong increase in the share of EU co-authorship. However, the research institutes have a slightly lower proportion of international co-authorship than the higher education institutions, on average about four points lower. 
Figure A 4 The proportion of EU co-authorship, 1991-2007, institute sector and national average.

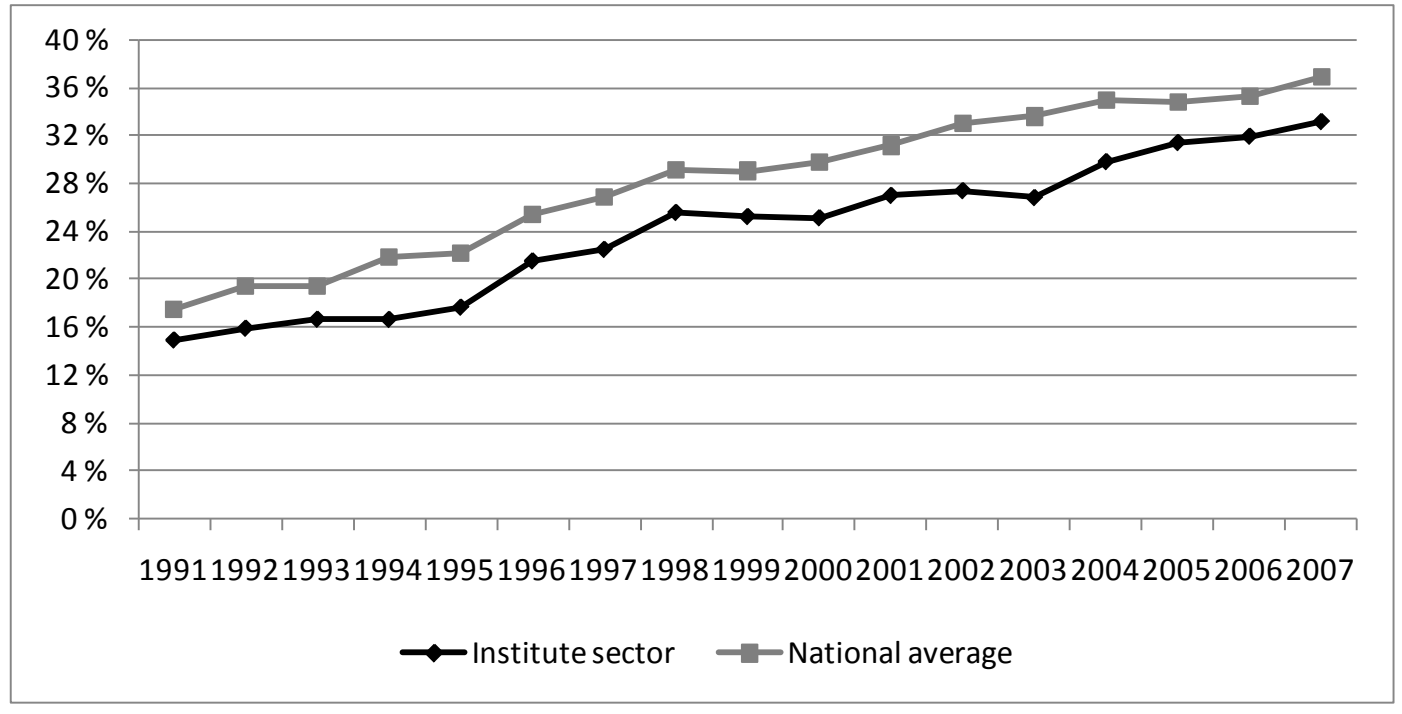

The proportion of international co-authorship has been shown to be lower than the national average in the institute sector (Aksnes, Frolich and Slipersater 2008). Moreover, it was found that in all disciplines the extent of international co-authorship was lower in the institute sector than in the higher education sector. The reason for this was expressed in the following way: “According to Frame and Carpenter (1979), the degree of collaboration can be explained by a basic/applied research dimension: the more basic the field, the greater the proportion of international co-authorships. This model may be appropriate for explaining the differences between the institute sector and the higher education sector. While the institute sector has a predominated applied research profile, the higher education sector is more heavily involved in basic research. Because applied research, more often than basic research, addresses problems of a local or domestic character this might affect the level of international collaboration.”

In an additional study we analysed three different university faculties at the four oldest universities in Norway: the natural sciences (including mathematics), medicine, and the social sciences. The differences at the faculty level are significant. On average, the proportion of papers involving EU co-authorship is twice as high in the natural sciences as in the social sciences, while medicine is positioned somewhere in between (see Figure A5). There are also variations among the different universities, with the University of Bergen appearing as the most collaborative university. 
Figure A 5 EU collaboration by faculty for the four traditional Norwegian universities, 2003-2007. Share of articles involving EU co-authorship.

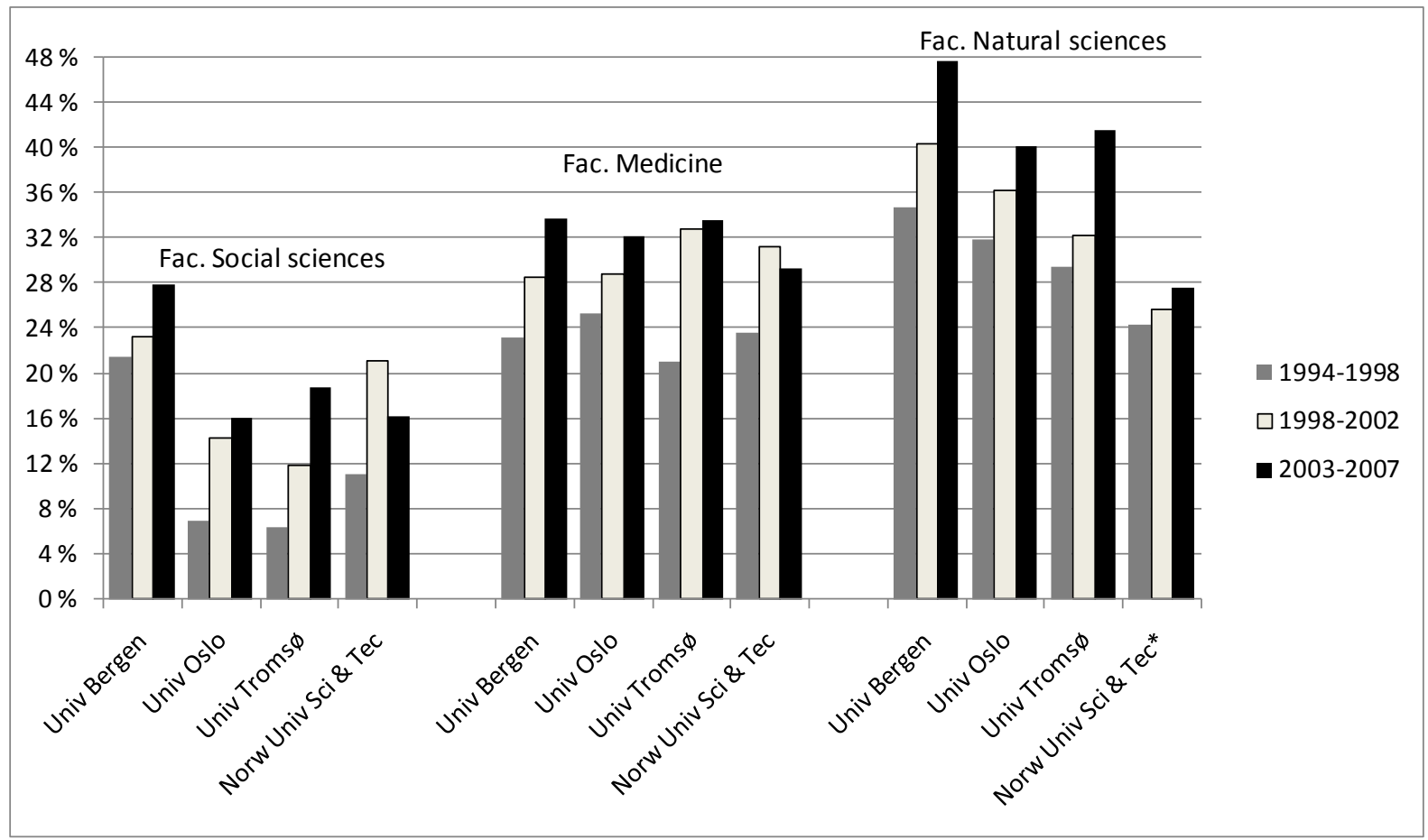

*) At this university, technology disciplines are included in the category for natural sciences.

In Table B5 we have shown the number and share of articles involving EU co-authorship for other units in the Higher Education sector and for the Industrial sector. Similarly, Table B6 gives the number and share of articles involving EU co-authorship for institutes in the Institute sector.

Table B 5 EU collaboration by other Higher education institutions* and the industrial sector, 2003-2007. Number and share of articles involving EU coauthorship.

\begin{tabular}{|c|c|c|c|}
\hline & $\begin{array}{l}\text { EU-collaboration - } \\
\text { number of articles }\end{array}$ & $\begin{array}{l}\text { EU-collaboration } \\
\text { - proportion }\end{array}$ & $\mathrm{N}$ \\
\hline THE NORWEGIAN UNIVERSITY OF LIFE SCIENCES & 398 & $25 \%$ & 1598 \\
\hline THE NORWEGIAN SCHOOL OF VETERINARY SCIENCE & 210 & $31 \%$ & 677 \\
\hline THE UNIVERSITY CENTER IN SVALBARD (UNIS) & 107 & $51 \%$ & 209 \\
\hline UNIVERSITY OF STAVANGER & 101 & $28 \%$ & 362 \\
\hline NORWEGIAN SCHOOL OF SPORT SCIENCES & 73 & $30 \%$ & 242 \\
\hline NORWEGIAN SCHOOL OF ECONOMICS AND BUSINESS ADM. & 54 & $24 \%$ & 227 \\
\hline UNIVERSITY OF AGDER & 54 & $24 \%$ & 224 \\
\hline INDUSTRAL SECTOR & 739 & $31 \%$ & 2406 \\
\hline
\end{tabular}

*) Only units with more than 50 EU articles during the period are included in the table. The numbers for each institution refer to the articles NIFU STEP has been able to allocate to the institutions (using information on listed author addresses) and has not involved a more comprehensive round of verification. 
As can be seen, there are large variations both in the number and proportion of articles involving collaboration with EU. The University of Life Sciences, The Norwegian School of Veterinary Science, Institute of Marine Research, The Norwegian Institute of Public Health and the SINTEF group are the largest contributors, all with more than 200 collaborative papers during the period. Within the framework of this report, we will not analyse these differences further. However, two factors seem to be important in explaining these differences. Firstly, the particular discipline profiles of the institutions/institutes. For example, units active within the natural sciences can be expected to have a much stronger international orientation than units within the social sciences; secondly, the degree of funding from the EU and participation in Framework Programmes. For example, the evaluation of the $5^{\text {th }}$ Framework Programme (NIFU, STEP and Technopolis 2004) showed that within the Institute sector, SINTEF, the Norwegian Institute for Air Research (NILU) and the Institute of Marie Research were the most active institutes in terms of participation.

Table B 6

EU collaboration by institutes in the Institute sector, 2003-2007. Number and share of articles involving EU co-authorship.

\begin{tabular}{|l|r|r|r|}
\hline & & & \\
& $\begin{array}{l}\text { EU-collaboration - } \\
\text { number of articles }\end{array}$ & $\begin{array}{l}\text { EU-collaboration - } \\
\text { proportion }\end{array}$ & $\mathbf{N}$ \\
\hline Institute of Marine Research & 248 & $36 \%$ & 698 \\
\hline The Norwegian Institute of Public Health & 229 & $28 \%$ & 814 \\
\hline SINTEF-group** & 213 & $22 \%$ & 968 \\
\hline Norwegian Institute for Air Research (NILU) & 186 & $63 \%$ & 295 \\
\hline Norwegian Institute for Nature Research (NINA) & 168 & $36 \%$ & 471 \\
\hline Geological Survey of Norway (NGU) & 149 & $44 \%$ & 340 \\
\hline Norwegian Polar Institute & 143 & $46 \%$ & 313 \\
\hline Cancer Registry of Norway & 134 & $48 \%$ & 280 \\
\hline The National Veterinary Institute & 108 & $26 \%$ & 416 \\
\hline Norwegian Institute for Water Research (NIVA) & 99 & $39 \%$ & 254 \\
\hline Institute for Energy Technology (IFE) & 93 & $35 \%$ & 265 \\
\hline Norwegian Food research Institute (MATFORSK) & 81 & $26 \%$ & 308 \\
\hline Norwegian Meteorological Institute & 52 & $42 \%$ & 146 \\
\hline Bioforsk - Norwegian Institute for Agricultural and & 52 & $23 \%$ & 238 \\
\hline Environmental Research & $23 \%$ & 229 \\
\hline National Institute of Nutrition and Seafood Research & & & 25 \\
\hline
\end{tabular}

*) Only units with more than 50 EU articles during the period are included in the table. The numbers for each institute refer to the articles NIFU STEP has been able to allocate to the institutes (using information on listed author addresses) and has not involved a more comprehensive round of verification.

**) Including associated limited companies. 
Appendix 6 Questionnaires used in the surveys of participants in EU FP6 and 7 FP 


\section{计 \\ NIFU}

\section{Evaluation of the Norwegian participation in the 6th Framework Programme}

\section{Part 1 Background information}

The project (please review the information below and edit as necessary)

a. Contract number

b. Project acronym

c. Special programme

d. Type of project

e. Number of partners in the project-consortium

\begin{tabular}{l|l|l|l|}
\hline f. Has your organisation had a coordinator responsibility in this project? & Yes \\
$\begin{array}{l}\text { g. Has your organisation had a leading responsibility (a work package for example) in the } \\
\text { project? }\end{array}$ & N
\end{tabular}

End year of project
[C. 2003
C 2004
C. 2005
[. 2006
C 2007
[ 2008
[. 2009
[ 2010
[. 2011 or later

Please indicate the type of your organisation
C a) Research Institute (including all private non-profit)
b) Higher Education Institution (HEI)
c) Enterprise
d) Other 


\section{Part 2 Key Information on EU-project}

Is this project an extension/follow up of another R\&D project?

a No

C Yes, extension of internally financed project

$B$

Yes, extension of nationally financed R\&D project

C

Yes, extension of previous EU-project

C

Yes, extension of another internationally financed R\&D project

How many researchers from your organisation were involved in this EU-project

a) Total number of researchers (not man-years)

b) How many were PhD students?

c) How many were women?

How many of your partners in the consortium had you not cooperated with previously?

Please estimate roughly how the costs of your participation have been funded (percent EU-contribution and percent from other sources).

Funding source

Approximate shares \%

a) EU-funding \%

b) The Research council of Norway (RCN):

Co-funding for EU projects \%

National programmes/other RCN-funding \%

c) Other Norwegian external funding \%

d) International funding other than EU \%

e) Budgeted funding by my organisation/institutional core funding $\%$

f) Not covered/non-budgeted deficit \%

Total $(100 \%)$

Was the EU-project closely related to research for which you received Norwegian public funding (during the last 5 years?)
C Yes
$B$ No 
If yes, please specify the funding source/programme

Check all sources that apply

Please specify

program

acronym/funding

source

Research Council of Norway Programme:

SFI or SFF (Senter for fremragende innovasjon / Senter for fremragende forskning) funded by the Research Council of Norway

Other national funding

To what extent did you/your organization participate in the following activities?

\begin{tabular}{|c|c|c|c|c|c|}
\hline & $\begin{array}{c}\text { To a } \\
\text { very } \\
\text { small } \\
\text { extent } \\
1\end{array}$ & $\begin{array}{c}\text { To a } \\
\text { small } \\
\text { extent } \\
2\end{array}$ & $\begin{array}{c}\text { To } \\
\text { some } \\
\text { extent } \\
3\end{array}$ & $\begin{array}{c}\text { To a } \\
\text { high } \\
\text { extent } \\
4\end{array}$ & $\begin{array}{c}\text { To a } \\
\text { very } \\
\text { high } \\
\text { extent } \\
\quad 5\end{array}$ \\
\hline a) Development of project idea & $G$ & $G$ & $G$ & $\mathrm{C}$ & $G$ \\
\hline b) Project formulation & E & E & E & $\mathrm{E}$ & C \\
\hline c) Formulation of application & $\mathrm{E}$ & C & E & $E$ & E \\
\hline d) Project execution & $B$ & $B$ & $B$ & $E$ & 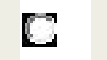 \\
\hline
\end{tabular}

In your EU-project, how do/did you communicate with the other participants?

Frequency (approximate)

\begin{tabular}{|c|c|c|c|c|c|c|c|}
\hline & Daily & $\begin{array}{c}\text { Once } \\
\mathbf{a} \\
\text { week }\end{array}$ & $\begin{array}{c}\text { Once } \\
a \\
\text { month }\end{array}$ & $\begin{array}{c}4-8 \\
\text { times } \\
a \\
\text { year }\end{array}$ & $\begin{array}{c}1-3 \\
\text { times } \\
\text { per } \\
\text { year }\end{array}$ & $\begin{array}{c}\text { At } \\
\text { start-up } \\
\text { and end } \\
\text { of } \\
\text { project }\end{array}$ & None \\
\hline Face- to- face meetings & $C$ & $E$ & $\mathbb{C}$ & $E$ & $C$ & $\square$ & C \\
\hline Tele-conferencing & $\mathrm{C}$ & $\mathrm{C}$ & C & $E$ & $\mathrm{C}$ & C & $E$ \\
\hline e-mail & 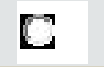 & $E$ & E & $a$ & C & C & $\mathbb{C}$ \\
\hline Telephone (voice) & $C$ & $\mathrm{C}$ & C & 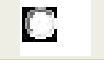 & $\mathrm{C}$ & E & $E$ \\
\hline Fax and postal mail & $\mathrm{C}$ & $\mathrm{C}$ & C & $E$ & $\mathrm{C}$ & $\mathbb{C}$ & $E$ \\
\hline Virtual work space and labs & $E$ & 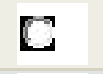 & $\mathrm{E}$ & $\mathrm{C}$ & $\mathrm{C}$ & 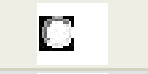 & $E$ \\
\hline Project home page \& data base & $\mathrm{C}$ & $\mathrm{C}$ & C & $E$ & $\mathrm{C}$ & C & $E$ \\
\hline Blogs \& wikis & $\mathrm{C}$ & $E$ & C & $E$ & $C$ & C & $\mathbb{E}$ \\
\hline
\end{tabular}




\section{Part 3 Funding, motivation and obstacles to participation}

Approximate resources utilised (in your organisation) for preparing the proposal for this EU-project

a) Total months work:

b) Direct costs (travel etc.) in NOK

c) Funding source for preparing proposal

Own organisation \%

Pre-project/positioning funds from Research Council (PES) \%

Other external sources \%

Total $(100 \%)$

Please evaluate the significance of the following as a motivation for your participation in the project?

\begin{tabular}{|c|c|c|c|c|c|}
\hline & $\begin{array}{c}\text { No } \\
\text { significance } \\
1\end{array}$ & $\begin{array}{c}\text { Small } \\
\text { significance } \\
2\end{array}$ & $\begin{array}{c}\text { Some } \\
\text { significance } \\
3\end{array}$ & $\begin{array}{c}\text { Large } \\
\text { significance } \\
4\end{array}$ & $\begin{array}{c}\text { Very } \\
\text { large } \\
\text { significance } \\
5\end{array}$ \\
\hline a) Access to technology & C & C & C & C & G \\
\hline b) Access to expertise & C & C & C & C & $\mathrm{C}$ \\
\hline c) Access to market contacts & E & C & C & C & C \\
\hline d) Access to research networks & G & C & E & C & $\mathbb{C}$ \\
\hline e) Access to financial sources & $E$ & $E$ & 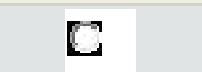 & $G$ & $\mathrm{E}$ \\
\hline f) Access to equipment and testing material & E & $E$ & 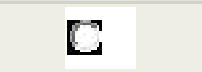 & 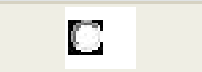 & E \\
\hline g) Access to scientific excellence & E & $\mathrm{E}$ & $\mathbb{B}$ & $\mathbb{E}$ & $\mathrm{E}$ \\
\hline $\begin{array}{l}\text { h) Access to promising/talented young } \\
\text { researchers }\end{array}$ & E & E & E & C & E \\
\hline i) Encouragement from your organisation & E & E & G & $\mathrm{E}$ & $\mathrm{E}$ \\
\hline j) Other, specify & E & G & $\mathbb{B}$ & $\mathbb{E}$ & $\mathrm{E}$ \\
\hline
\end{tabular}

Please specify "Other motivations" if this category is chosen in the table above. 
Proposal phase:

Please evaluate the significance of the following as strengths or weaknesses in the application phase of the project (i.e. the abilities of your group/your organisation/the consortium):

\section{No \\ particular strength}

or

Strength

a) Ability to find relevant partners

b) Ability to include research questions of our immediate interest in the proposal

c) Access to scientific personnel for developing a good proposal

d) Ability to agree on resource distribution (in the consortium)

C

C

C

Weakness

Don't

e) Ability to agree about intellectual property rights

f) Administrative support from own organisation

g) Support in your organisation regarding

coordination/management of the proposal phase

h) Moral support from the management of your organisation

i) Ability to understand the full scope of the call topic and its objectives

j) Planning of the time needed for developing the proposal

k) Coping with proposal formalities

a

C

know

\section{Project phase:}

Please evaluate the significance of the following as strengths or weaknesses in the execution phase of the project (postive or negative factor for the project):

\begin{tabular}{|l|c|c|c|c|}
\hline & $\begin{array}{c}\text { Songth/ } \\
\text { positive } \\
\text { factor } \\
\text { particular } \\
\text { or } \\
\text { weakness }\end{array}$ & $\begin{array}{c}\text { Weakness/ } \\
\text { negative } \\
\text { factor }\end{array}$ & $\begin{array}{c}\text { Don't } \\
\text { know }\end{array}$ \\
\hline $\begin{array}{l}\text { a) The project goals } \\
\text { b) Coordinator's leadership abilities }\end{array}$ & $\mathbf{C}$ & $\mathbf{C}$ & $\mathbf{C}$ & $\mathbf{C}$ \\
\hline \begin{tabular}{l} 
c) The number of partners in the consortium \\
\hline d) The distribution of resources among partners
\end{tabular} & $\mathbf{C}$ & $\mathbf{C}$ & $\mathbf{C}$ & $\mathbf{C}$ \\
\hline $\begin{array}{l}\text { e) The partners' skills/expertise in carrying out the project } \\
\text { f) The balance between the competence and the influence } \\
\text { of the various partners in the consortium }\end{array}$ & $\mathbf{C}$ & $\mathbf{C}$ & $\mathbf{C}$ & $\mathbf{C}$ \\
\hline $\begin{array}{l}\text { g) The individual partners' respect of deadlines/delivery of } \\
\text { results }\end{array}$ & $\mathbf{C}$ & $\mathbf{C}$ & $\mathbf{C}$ & $\mathbf{C}$ \\
\hline $\begin{array}{l}\text { h) Management of confidential information } \\
\text { i) EU reporting requirements }\end{array}$ & $\mathbf{C}$ & $\mathbf{C}$ & $\mathbf{C}$ & $\mathbf{C}$ \\
\hline $\begin{array}{l}\text { j) National audit requirements and/or other financial control } \\
\text { routines and rules }\end{array}$ & $\mathbf{C}$ & $\mathbf{C}$ & $\mathbf{C}$ & $\mathbf{C}$ \\
\hline \begin{tabular}{l} 
k) Administrative support from own organisation \\
\hline
\end{tabular} & $\mathbf{C}$ & $\mathbf{C}$ & $\mathbf{C}$ & $\mathbf{C}$ \\
\hline
\end{tabular}




\section{Part 4 Project results}

The following types of results are:

\begin{tabular}{|c|c|c|c|c|}
\hline 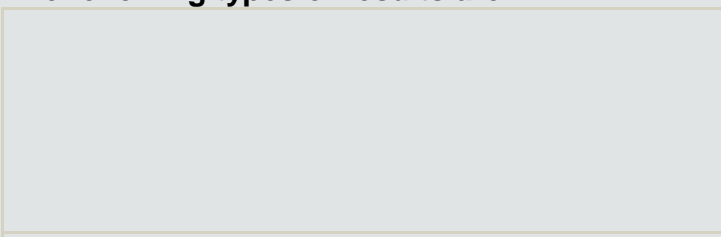 & $\begin{array}{c}\text { Not expected } \\
\text { to be } \\
\text { achieved }\end{array}$ & Achieved & $\begin{array}{c}\text { Expected to } \\
\text { be achieved } \\
\text { in the course } \\
\text { of } \\
\text { the project }\end{array}$ & $\begin{array}{c}\text { Expected to } \\
\text { be achieved } \\
\text { within } 3 \\
\text { years after } \\
\text { project } \\
\text { period ends }\end{array}$ \\
\hline a) New scientific results/knowledge & C & 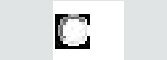 & C & C \\
\hline b) Development of new expertise/skills & B & $\mathbb{R}$ & E & 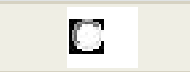 \\
\hline c) Development of new scientific methods & $\mathrm{E}$ & 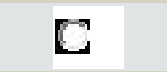 & E & G \\
\hline $\begin{array}{l}\text { d) Development of new technology/new processes/new } \\
\text { products/new services }\end{array}$ & C & G & C & C \\
\hline $\begin{array}{l}\text { e) Implementation of new technology/new processes/new } \\
\text { products/new services }\end{array}$ & C & C & C & G \\
\hline f) Sale of know-how or licenses & E & C & $E$ & E \\
\hline g) Application for patent & G & 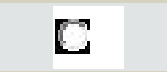 & E & $\mathrm{C}$ \\
\hline h) Development of prototype & 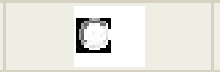 & G & C & $G$ \\
\hline i) Establishment of standards, norms & 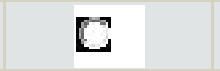 & $B$ & 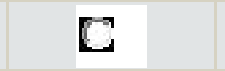 & 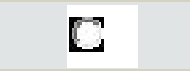 \\
\hline j) Scientific publications & $a$ & $G$ & 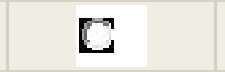 & $G$ \\
\hline k) Doctorate degrees & $G$ & 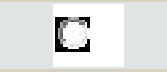 & 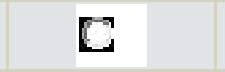 & $G$ \\
\hline
\end{tabular}

\section{Part 5 Effects on research and innovation capabilities}

Do you agree or disagree with the following statements about this particular EU project?

a) overall research capabilities have been significantly improved as a result of the EU project

b) Our overall innovation capabilities have been significantly improved as a result of the EU project

c) Research and innovation management skills have been significantly improved as a result of the EU project

\begin{tabular}{|c|c|c|c|c|c|}
\hline $\begin{array}{c}\text { Fully } \\
\text { disagree }\end{array}$ & $\begin{array}{c}\text { Partly } \\
\text { disagree }\end{array}$ & Uncertain & $\begin{array}{l}\text { Partly } \\
\text { agree }\end{array}$ & $\begin{array}{l}\text { Fully } \\
\text { agree }\end{array}$ & $\begin{array}{c}\text { Not } \\
\text { relevant }\end{array}$ \\
\hline $\mathbb{E}$ & C & $E$ & 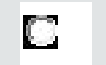 & $E$ & C \\
\hline $\mathbb{E}$ & C & 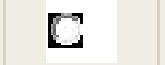 & $a$ & $a$ & $\mathbb{C}$ \\
\hline C & C & C & C & $\mathrm{C}$ & C \\
\hline 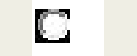 & C & 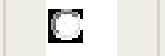 & $a$ & $a$ & C \\
\hline$E$ & C & $E$ & $a$ & 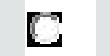 & $E$ \\
\hline C & C & C & $\mathrm{C}$ & $\mathrm{C}$ & $\mathrm{C}$ \\
\hline C & C & $C$ & 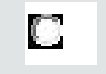 & $\square$ & 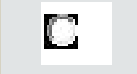 \\
\hline 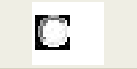 & C & 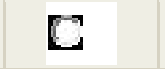 & C & $\mathrm{C}$ & C \\
\hline$E$ & $\mathrm{C}$ & $E$ & $E$ & $E$ & 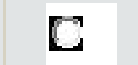 \\
\hline C & C & [ & & C & C \\
\hline
\end{tabular}

d) The EU-project has changed our way of doing research and innovation in the organisation /project unit

e) Long term international cooperation links have been considerably extended as a result of the EU project

f) The EU-project lead to significantly increased publication output in my unit

g) Through the EU-project we have increased our knowledge on patenting/protection of intellectual property

h) Through the EU-project we have increased our knowledge on new R\&D-markets

i) Through the EU-project new research areas of significant importance for our future

research/innovation activities have been explored

j) The EU-project leads/contributes to innovation*

*Definition: Innovation occurs when a company introduces a new or significantly improved product, process or organisational method. 
Please compare the nature of your EU project(s) with your other R\&D projects and indicate which projects The EU

No Our other projects difference projects
a) are most strategically important to your organisation?

b) are most oriented towards basic research?

c) provide most new scientific results?

d) are most scientifically/technologically risky?

e) have the highest scientific quality?

f) are most long-term?

C

C

g) are most multidisciplinary?

C

C

C

Impact of the project on other research activities: My organisation's participation in the EU Framework Programme has

a) enabled us to generate international projects also outside the EU Framework

Programme

\begin{tabular}{|c|c|c|}
\hline & No & No opinion \\
\hline & C & C \\
\hline & C & C \\
\hline & C & $\mathrm{C}$ \\
\hline & C & C \\
\hline
\end{tabular}

\section{Part 5 Effects on research and innovation capacities}

Please indicate whether the project has resulted in long-term cooperation relations involving:

collaborative projects

c) changed the nature of our research activities in general

If yes on c) please indicate if the change is positive (yes) or negative (no)

\begin{tabular}{|l|l|l|l|l|l|}
\hline & $\begin{array}{l}\text { Not } \\
\text { at } \\
\text { all }\end{array}$ & $\begin{array}{c}\text { To a } \\
\text { limited } \\
\text { extent }\end{array}$ & $\begin{array}{c}\text { To some } \\
\text { extent }\end{array}$ & $\begin{array}{c}\text { To a } \\
\text { high } \\
\text { extent }\end{array}$ & $\begin{array}{c}\text { To a } \\
\text { very high } \\
\text { extent }\end{array}$ \\
\hline a) Universities and colleges in Norway & $\mathbf{C}$ & $\mathbf{C}$ & $\mathbf{C}$ & $\mathbf{C}$ & $\mathbf{C}$ \\
\hline b) Universities and colleges in Europe & $\mathbf{C}$ & $\mathbf{C}$ & $\mathbf{C}$ & $\mathbf{C}$ & $\mathbf{C}$ \\
\hline $\begin{array}{l}\text { a) Public or private non-profit R\&D } \\
\text { organisation in Norway }\end{array}$ & $\mathbf{C}$ & $\mathbf{C}$ & $\mathbf{C}$ & $\mathbf{C}$ & $\mathbf{C}$ \\
\hline $\begin{array}{l}\text { b) Public or private non-profit R\&D } \\
\text { organisation in Europe }\end{array}$ & $\mathbf{C}$ & $\mathbf{C}$ & $\mathbf{C}$ & $\mathbf{C}$ & $\mathbf{C}$ \\
\hline c) Norwegian firms & $\mathbf{C}$ & $\mathbf{C}$ & $\mathbf{C}$ & $\mathbf{C}$ & $\mathbf{C}$ \\
\hline \begin{tabular}{l} 
d) Foreign firms \\
\hline e) The public sector in Norway
\end{tabular} & $\mathbf{C}$ & $\mathbf{C}$ & $\mathbf{C}$ & $\mathbf{C}$ & $\mathbf{C}$ \\
\hline $\begin{array}{l}\text { f) The public sector in one or more } \\
\text { European countries (incl. The European } \\
\text { Commission) }\end{array}$ & $\mathbf{C}$ & $\mathbf{C}$ & $\mathbf{C}$ & $\mathbf{C}$ & $\mathbf{C}$ \\
\hline g) Actors outside Europe & $\mathbf{C}$ & $\mathbf{C}$ & $\mathbf{C}$ & $\mathbf{C}$ & $\mathbf{C}$ \\
\hline
\end{tabular}

Please indicate expected changes in your organisation's position as a result of the EU project:

a) The project will strengthen our position in relation to our competitors

\begin{tabular}{c|c|}
\hline To a & To a \\
very small & small \\
extent & extent
\end{tabular}

To some extent

L
To a

high extent

E

C
To a very high

Not relevant

C

C 
b) The project contributes to

securing our position in respect of

established customers

\begin{tabular}{|c|c|c|c|c|}
\hline$E$ & $E$ & $a$ & $E$ & 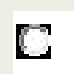 \\
\hline$E$ & $E$ & 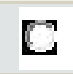 & $E$ & 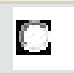 \\
\hline$E$ & $\mathbb{E}$ & C & 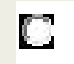 & C \\
\hline
\end{tabular}

Are direct economic benefits expected in the form of increased sales or reduced costs which can be associated with the project?

C No,- no direct economic effects

C Yes

If 'Yes', please specify (both may be indicated)

Increase in turnover

$\Gamma$ Reduction in costs

$\Gamma$ Other, please specify

Please state if the intellectual rights (IPR) from the EU project are protected

$\Gamma$ Project results are protected at the consortium level

Project results from my organisation are protected

$\Gamma$ Protection does not apply

If 'protected', then how?

Г Patent

$\Gamma$ Secrecy

Г Other (Trademarks, copyrights, etc,)

If protection does not apply, why?

ГToo early

$\Gamma$ Cannot be protected

$\Gamma$ More important that results are made known/published

Do you expect that this EU project will have a positive impact on one or more of the following? (Please check all that apply)

a) Laws, regulations, standards

b) Policy development

c) Environment/Climate

d Aid/third world development

e) Improved use of resources and energy

f) Transport

g) Health

h) Food safety and/or food security 
Do you expect that this EU project will have spin off effects such as...?

(Please check all that apply)

a) Transfer of knowledge/commercialisation via Technology Transfer Office in own organisation (TTO)

b) Transfer of knowledge to Norwegian firms not participating in the EU project

c) Transfer of technology to Norwegian firms not participating in the EU project

d) Improved services and products for the end-user

f) Increased competitiveness in Norway

g) Increased European competitiveness

\section{Part 6 Overall assessment of the EU-project}

What is your total impression of the project (so far)?
C Very unsuccessful
[ Unsuccessful
U. Uncertain
C. Successful
Very successful

To what extent would you say that the following elements have been unsuccessful/successful within the project?

\begin{tabular}{|c|c|c|c|c|c|}
\hline $\begin{array}{c}\text { Very } \\
\text { unsuccessful }\end{array}$ & $\begin{array}{c}\text { Mostly } \\
\text { unsuccessful }\end{array}$ & Uncertain & $\begin{array}{c}\text { Mostly } \\
\text { successful }\end{array}$ & $\begin{array}{c}\text { Very } \\
\text { successful }\end{array}$ & $\begin{array}{l}\text { Not } \\
\text { relevant }\end{array}$ \\
\hline $\mathrm{C}$ & 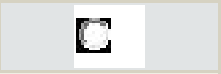 & $C$ & $E$ & $C$ & $\mathrm{C}$ \\
\hline$a$ & 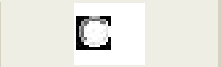 & C & $a$ & $a$ & 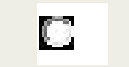 \\
\hline$C$ & $\mathrm{C}$ & 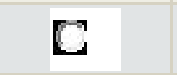 & C & C & $\mathrm{C}$ \\
\hline 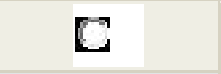 & 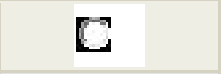 & 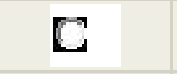 & 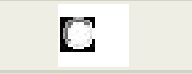 & $\mathrm{C}$ & $\mathbb{C}$ \\
\hline $\mathrm{C}$ & $\mathrm{C}$ & $\mathbb{C}$ & C & $\mathrm{C}$ & $\boldsymbol{C}$ \\
\hline$C$ & $C$ & $\square$ & $\mathrm{C}$ & $\mathrm{C}$ & 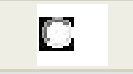 \\
\hline $\mathrm{C}$ & $\mathrm{C}$ & 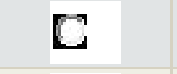 & $\mathrm{C}$ & $\mathrm{C}$ & 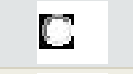 \\
\hline$C$ & $\mathrm{C}$ & 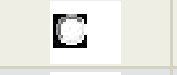 & C & 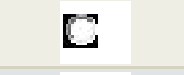 & $\mathrm{C}$ \\
\hline$C$ & 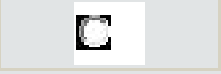 & $\square$ & 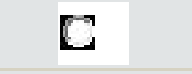 & $\mathrm{C}$ & $\boldsymbol{C}$ \\
\hline
\end{tabular}




\section{Additionality}

a) Our organisation would not have participated in this project or a similar project without the EU's financial contribution

b) We could have carried out such a project even without the EU's financial contribution

c) We could have achieved the same scientific/technological results without the international collaboration involved in this project

\begin{tabular}{|c|c|c|c|c|}
$\begin{array}{c}\text { Fully } \\
\text { disagree }\end{array}$ & $\begin{array}{c}\text { Partly } \\
\text { disagree }\end{array}$ & Uncertain & $\begin{array}{c}\text { Partly } \\
\text { agree }\end{array}$ & $\begin{array}{c}\text { Fully } \\
\text { agree }\end{array}$ \\
\hline$\square$ & $\square$ & $\square$ & $\square$ & $\square$ \\
\hline$\square$ & $\square$ & $\square$ & $\square$ & $\square$ \\
\hline$\square$ & $\square$ & $\square$ & $\square$ & $\square$ \\
\hline
\end{tabular}

\section{Part 7 National support schemes}

Is there a need for improvements in the Norwegian information and consultation services concerning the following aspects of the 7th Framework Programme?

\begin{tabular}{|c|c|c|c|}
\hline $\begin{array}{l}\text { Substantial } \\
\text { improvements } \\
\text { needed }\end{array}$ & $\begin{array}{c}\text { Some } \\
\text { improvements } \\
\text { needed }\end{array}$ & $\begin{array}{c}\text { No } \\
\text { improvements } \\
\text { needed }\end{array}$ & $\begin{array}{c}\text { No } \\
\text { opinion }\end{array}$ \\
\hline C & C & C & $\mathbb{C}$ \\
\hline $\mathrm{C}$ & $\mathrm{C}$ & $\mathrm{C}$ & $\mathrm{C}$ \\
\hline C & C & C & $\mathbb{C}$ \\
\hline $\mathrm{C}$ & $\mathrm{C}$ & $\mathrm{C}$ & C \\
\hline C & C & C & $\mathbb{C}$ \\
\hline 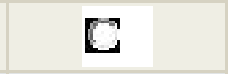 & $\mathrm{C}$ & 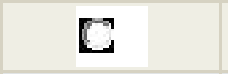 & 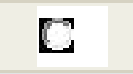 \\
\hline $\mathrm{C}$ & $\mathrm{C}$ & $\square$ & 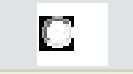 \\
\hline C & C & C & $\mathbb{C}$ \\
\hline $\mathrm{C}$ & $\mathrm{C}$ & $\mathrm{C}$ & $\mathrm{C}$ \\
\hline
\end{tabular}

a) General information on the various specific programmes of the Framework Programmes

b) Information on calls and upcoming deadlines for submitting proposals

c) Information on calls and research activities of the European Research Council (ERC)

d) Information on calls and other related research and innovation activities of Joint Technology Initiatives (JTI)

e) Advice on how to prepare better proposals

f) How to find and connect to other partners

g) Advice and legal support to contracting, management of intellectual rights

h) Financial rules and regulations, audits, financial reporting

i) Advice on how to combine/connect national R\&D-

funding with FP-project activities

Is there a need for improvements in the financial support schemes provided by the national authorities responsible for the Norwegian participation in the 7th Framework Programme?

\section{Substantial Some No}

improvements improvements improvements

No

needed

needed

needed

opinion

a) Financial support for preparing proposals

b) National direct co-funding (medfinansiering fra Norges forskningsråd) of participation in the EU-projects

c) National financial support (medfinansiering fra Norges forskningsråd) of participation in activities organized and managed by the European Technology Platforms (ETPS), Joint Technology Initiatives (JTIS), ESFRI, EIT, European Research Council (ERC)

d) Co-ordination of funding between Framework

Programme activities and relevant national R\&D and innovation support schemes/programmes (Research

Council of Norway and/or Innovation Norway)

e) Financial support for long-term positioning in

Framework Programme-selected areas of National strategic importance

C

C

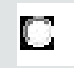

C

C

C

C

C

C

C

C
C

E

C 
To what extent does the new result-based funding system for higher education institutions and research institutes provide incentives to participate in the Framework Programmes?

Ca

Incentive to decrease participation

E No changed incentives

C Incentive for increase participation

No opinion

\section{Final comment}

Please take the time to comment on any aspect related to your EU-project or to the design, organization, and implementation of the Framework Programmes, you think important. (Gjerne på norsk!)

Of particular interest are your ideas and recommendations for improvements of national policies supporting Norwegian participation in the Framework Programmes and the subsequent exploitation of results in the 7 th Framework Programme. 


\section{NIFU 峉 Studier av innovasjon, forskning og utdanning}

\section{Evaluation of the Norwegian participation in the 7th Framework Programme}

\section{Part 1 Background information}

The project (please review the information below and edit as necessary)

a. Project acronym

b. Specific programme

c. Type of project

d. Number of partners in the project-consortium

\begin{tabular}{|c|c|c|}
\hline & Yes & No \\
\hline e. Has your organisation had a coordinator responsibility in this proposal/project? & $G$ & 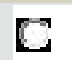 \\
\hline $\begin{array}{l}\text { f. Has your organisation had a leading responsibility (a work package for example) in the } \\
\text { proposal/project? }\end{array}$ & $\mathrm{C}$ & $\mathrm{E}$ \\
\hline
\end{tabular}

What is the current status for this proposal/project?

[. The proposal did not obtain EU funding (was rejected)

C. The proposal was successful, the project has not yet started up

C. The proposal was successful and the project has started up

We do not yet know the outcome of the application

Please indicate the type of your organisation

$[$ a) Research Institute (including all private non-profit)

b) Higher Education Institution (HEI)

C c) Large enterprise (more than 250 employees and/or a turnover exceeding 400 million NOK in 2007-2008)

d) Medium enterprise (between 100 and 250 employees and a turnover between 80 and 400 million NOK in 2007-2008)

[C. Small enterprise (less than 100 employees and/or a turnover less than 80 million NOK in 2007-2008)

f) Other

Was the proposal related to any of the following?

\begin{tabular}{l} 
Environment/Climate \\
$\square \quad$ Aid/third world development \\
\hline Improved use of resources and energy \\
$\square \quad$ Transport \\
$\square \quad$ Health \\
\hline$\quad$ Food safety and/or food security
\end{tabular}




\section{Part 2 The application process}

To what extent did you/your organization participate in the following activities?

\begin{tabular}{|c|c|c|c|c|c|}
$\begin{array}{c}\text { To a } \\
\text { very } \\
\text { small } \\
\text { extent } \\
1\end{array}$ & $\begin{array}{c}\text { To a } \\
\text { small } \\
\text { extent }\end{array}$ & $\begin{array}{c}\text { To } \\
\text { some } \\
\text { extent }\end{array}$ & $\begin{array}{c}\text { To a } \\
\text { high } \\
\text { extent }\end{array}$ & $\begin{array}{c}\text { To a } \\
\text { very } \\
\text { high } \\
\text { extent }\end{array}$ \\
\hline$\square$ & $\mathbf{C}$ & $\mathbf{3}$ & $\mathbf{4}$ & $\mathbf{5}$ \\
\hline$\square$ & $\square$ & $\square$ & $\square$ & $\square$ \\
\hline$\square$ & $\square$ & $\square$ & $\square$ & $\square$ \\
\hline
\end{tabular}

Approximate resources utilised (in your organisation) for preparing the proposal for this EU-project

a) Total months work:

b) Direct costs (travel etc.) in NOK

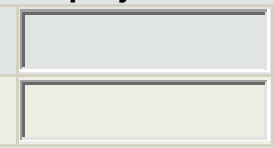

c) Funding source for preparing proposal

Own organisation \%

Pre-project/positioning funds from Research Council (PES) \%

Other external sources \%

Total $(100 \%)$

Please evaluate the significance of the following as a motivation for your participation in the proposal/project?

\begin{tabular}{|c|c|c|c|c|c|}
\hline & $\begin{array}{c}\text { No } \\
\text { significance } \\
1\end{array}$ & $\begin{array}{c}\text { Small } \\
\text { significance } \\
2\end{array}$ & $\begin{array}{c}\text { Some } \\
\text { significance } \\
3\end{array}$ & $\begin{array}{c}\text { Large } \\
\text { significance } \\
4\end{array}$ & $\begin{array}{c}\text { Very } \\
\text { large } \\
\text { significance } \\
5\end{array}$ \\
\hline a) Access to technology & C & $\mathrm{C}$ & $\mathrm{C}$ & $\mathrm{C}$ & $E$ \\
\hline b) Access to expertise & E & $E$ & E & E & $E$ \\
\hline c) Access to market contacts & C & C & C & C & E \\
\hline d) Access to research networks & C & C & $\boldsymbol{C}$ & C & C \\
\hline e) Access to financial sources & $\mathbb{C}$ & $\mathbb{C}$ & 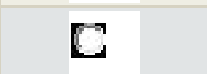 & C & C \\
\hline f) Access to equipment and testing material & $\mathrm{C}$ & C & C & C & $\mathrm{C}$ \\
\hline g) Access to scientific excellence & C & C & E & C & $\mathrm{C}$ \\
\hline $\begin{array}{l}\text { h) Access to promising/talented young } \\
\text { researchers }\end{array}$ & 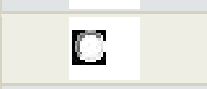 & C & $E$ & C & $E$ \\
\hline i) Encouragement from your organisation & $\boldsymbol{C}$ & 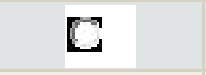 & 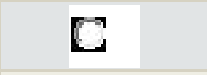 & 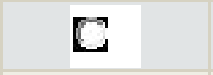 & $\boldsymbol{C}$ \\
\hline $\begin{array}{l}\text { j) The project is an integrated part of your } \\
\text { organisation's internationalisation strategy }\end{array}$ & $\mathbb{E}$ & $\mathbb{E}$ & $\mathbb{E}$ & $\boldsymbol{E}$ & $E$ \\
\hline k) Other, specify & $E$ & $\mathrm{C}$ & C & E & $E$ \\
\hline
\end{tabular}

Please specify "Other motivations" if this category is chosen in the table above. 
Please evaluate the significance of the following as strengths or weaknesses in the proposal phase of the project (i.e. the abilities of your group/your organisation/the consortium):

\begin{tabular}{|c|c|c|c|}
\hline & $\begin{array}{c}\text { No } \\
\text { particular } \\
\text { strength } \\
\text { or } \\
\text { weakness }\end{array}$ & Weakness & $\begin{array}{c}\text { Don't } \\
\text { know }\end{array}$ \\
\hline Strength & $C$ & $C$ & $C$ \\
\hline$C$ & $C$ & $C$ & $C$ \\
\hline$C$ & $C$ & $C$ & $C$ \\
\hline$C$ & $C$ & $C$ & $C$ \\
\hline$C$ & $C$ & $C$ & $C$ \\
\hline$C$ & $C$ & $C$ & $C$ \\
\hline$C$ & $C$ & $C$ & $C$ \\
\hline$C$ & $C$ & $C$ & $C$ \\
\hline$C$ & $C$ & $C$ & $C$ \\
\hline$C$ & $C$ & $C$ & $C$ \\
\hline & $C$ & $C$ & $C$ \\
\hline
\end{tabular}

Was the EU-proposal closely related to research for which you receive(d) Norwegian public funding (during the last 2 years)?
C
Yes
C No

If yes, please specify the funding source/programme. Check all sources that apply

$$
\begin{gathered}
\text { Please specify } \\
\text { program } \\
\text { acronym/funding } \\
\text { source }
\end{gathered}
$$

\section{Research Council of Norway Programme:}

SFI or SFF (Senter for fremragende innovasjon / Senter for fremragende forskning) funded by the Research Council of Norway

Other national funding

\section{Part 3 National support schemes for Framework Programme participation}

Is there a need for improvements in the Norwegian information and consultation services concerning the following aspects of the 7th Framework Programme?

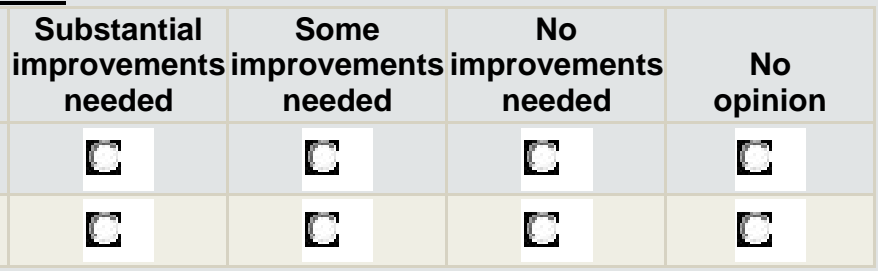


c) Information on calls and research activities of the European Research Council (ERC)

d) Information on calls and other related research and innovation activities of Joint Technology Initiatives (JTI)

e) Advice on how to prepare better proposals

f) How to find and connect to other partners

g) Advice and legal support to contracting, management of intellectual rights

h) Financial rules and regulations, audits, financial reporting

i) Advice on how to combine/connect national R\&Dfunding with FP-project activities

\begin{tabular}{|c|c|c|c|}
\hline 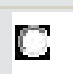 & $\mathrm{C}$ & 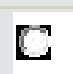 & $\mathrm{C}$ \\
\hline $\mathrm{C}$ & $\mathrm{C}$ & 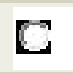 & C \\
\hline 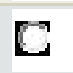 & $\mathrm{C}$ & $E$ & $\mathrm{C}$ \\
\hline$C$ & $\mathbb{C}$ & $E$ & $\mathrm{C}$ \\
\hline $\mathbb{C}$ & $\mathbf{C}$ & $\mathbb{E}$ & $\mathbb{C}$ \\
\hline $\mathrm{C}$ & $\mathbb{C}$ & $\mathbb{C}$ & $C$ \\
\hline$C$ & $\mathrm{C}$ & $\mathbb{C}$ & $\mathrm{C}$ \\
\hline
\end{tabular}

Is there a need for improvements in the financial support schemes provided by the national authorities responsible for the Norwegian participation in the 7th Framework Programme?

$\begin{array}{cccc}\begin{array}{c}\text { Substantial } \\ \text { improvements improvements improvements } \\ \text { needed }\end{array} & \begin{array}{c}\text { Some } \\ \text { needed }\end{array} & \begin{array}{c}\text { No } \\ \text { needed }\end{array} & \begin{array}{c}\text { No } \\ \text { opinion }\end{array}\end{array}$

a) Financial support for preparing proposals

b) National direct co-funding (medfinansiering fra Norges forskningsråd) of participation in the EU-projects

C

c) National financial support (medfinansiering fra Norges forskningsråd) of participation in activities organized and managed by the European Technology Platforms (ETPs), Joint Technology Initiatives (JTIS), ESFRI, EIT, European Research Council (ERC)

d) Co-ordination of funding between Framework Programme activities and relevant national R\&D and innovation support schemes/programmes (Research Council of Norway and/or Innovation Norway)

e) Financial support for long-term positioning in Framework Programme-selected areas of National strategic importance

C $\quad$ C

C

C

C

To what extent does the new Norwegian result-based funding system for higher education institutions and research institutes provide incentives to participate in the Framework Programmes?

C

Incentive to decrease participation

Ca No changed incentives

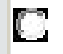
Incentive to increase participation

Ca No opinion

\section{Final comment}

Please take the time to comment on any aspect related to your EU-proposal or to the design, organization, and implementation of the Framework Programmes, you think important. (Gjerne på norsk!)

Of particular interest are your ideas and recommendations for improvements of national policies supporting Norwegian participation in the Framework Programmes and the subsequent exploitation of results in the 7 th Framework Programme. 